NUREG-0980

Vol. 1, No. 4

\title{
Nuclear Regulatory Legislation
}

\author{
104th Congress
}

Date Published: Decentber 1997

Office of the General Counsel

U.S. Nuclear Regulatory Commission

- Washington, DC 20555-0001

TI6TRFBUTION OF THIS DOCUMENT LS UNLMTTED

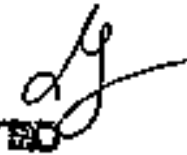

\section{MASTER}




\section{DISCLAIMER}

Portions of this document may be illegible electronic image products. Images are produced from the best available original document. 


\section{FOREWORD}

This compilation of statutes and material pertaisting to muclear regulatory legissation through the 104th Congress, 2nd Session, has been prepared by the Office of the General Counsel, U.S. Nuclear Regulatory Conmission, with the assistance of stafi, for use as an internal resource document. Persons using this document are placed on notice that it may not be used as an authoritative citation in beu of the primary legislative soures. Furthermore, while every effort has been mado to ensure the completeness and aceuracy of this material, neither the United States Government, the Nuclear Regulatory Commission, gor any of their employees makes any expressed or implited warranty or assumes liablity for the accuracy or completeness of the material presented in this compilation.

If you have any grestions concerning this compilation, please contact Cluristine Pierpoint, Legislative Specialist, Office of the General Counsel, U.S. Nuclear Regulatory Commission, Washington, DC 20555-0001. 



\section{TABLE OF CONMENTS}

VOLUME 1

1. Atomic Energy Act of 1954

2. Energy Reorganization Ast of 1974

- Reorganization Plan No. 3 of 1970 (EPA)

- Reorganization Plan No. 1 of 1980 (NRC)

- Executive Order No. 11834, Activation of the NRC

3. Low-Level Radioactive Waste Policy Amencments Act of 1985 (Title I)

('Ttle II-Compacts: SEE Volume II)

4. Nuclear Waste Policy Act of 1982, as Amended

5. Uranium Mill Tajlings

6. NRC User Foes

7. NRC Authortzations

8. Inspector Genetal Act of 1978, as Amended

9. Administrative Procedure Act

- Subchapter II - Administrative Procedure

- Subchapter III - Negotiated Rulemaking Procedure

- Subchapter IV - Altemative Means to Dispute Resolution in the Adnuinistrative Process

- Chapter 6--The Analysis of Regulatory Functions

- Chapter 7-Judicial Review

- Chapter 8-Congressional Review of Agency Rulenalking

Federal Advisory Committee Act

\section{VOLUME 2}

1. Commissioner Tenure

- Tenure of AEC Connuissioners

- Tenure of NRC Commissioners

2. NRC Appropriations

- Tabulation of NRC Appropriations by Fiscal Year

3. Chief Financial Officers Act of $\mathbf{1 9 9 0}$

4. Information Technology Management Reform

- Chief Information Officer

5. Foderal Critil Penalties .

$\mathbf{Y}$

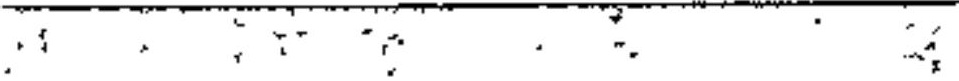


6. Paperwork Reduction Act of $\mathbf{1 9 9 5}$

7. Low-Levei Radioactive Waste Policy Amendments Act of 1985 (Title II-Compacts)

- Northwest Interstate Compact on Low-Level Radioactive Waste Management Compact

- Southerst Interstate Low-Level Radioactive Waste Managenent Compact

- Central Midwest Interstate Low-Level Radioactive Waste Compact,

- Midwest Interstate Low-Level Radioactive Waste Managernent Compact

- Rocky Mountain Low-Level'Radioactive Waste Management Compact

- Nortbeast Interstate Low-Level Radjoactive Waste Management Cornpact

8. Appalachian States Low-Level Radioactive Waste Compact Consent Act (P.L. 100-319)

9. Southwestern Low-Level Radioactive Waste Disposal Compact Consent Act (P.L. 100-712)

10. Clean Air Act of 1977, as Amended (Selected Sections)

11. Federal Water Pollution Control Act of 1972 (Sect. 511)

12. Netional Environmental Policy Act of 1969

13. Hazardous Materials Transportation Act, as antended

14. West Valley Demonseration Project Act

15. Nuclear Non-Proliferation and Export Licensing Statutes:

- Nuclear Non-Proliferation Alt of 1978 (P.L 95-242)

- International Atomic Energy Apency Participation Act of 1957 and the Statute of the International Atomic Energy Agency (P.L. 85-177)

- International Security Assistance and Arms Export Control Act of 1976 (P.L. 94-329)

- Intermational Security and Development Cooperation Act of 1980

- Intemational security and Development Cooperation Act of 1981 (P.L. 97-113)

- Convention on the Ptysical Protection of Nuclear Matertal Implementation (P.L. 97-351)

16. Miscenlareous: Selected Treaties, Agreements and Executive Orders

- Nuclear Non-Proliferation Treaty

- Convention on the Physical Protection of Nuclear Material

- Convention on Early Notification of a Nuckear Accjdent

- Convention on Assistance in the Case of a Nuclear Accident or Radiological Emergency

- Additional Protocol I to the Treaty for the Proujbition of Nuclear Weapons in Latin America

- United States List of Agreements for Peaceful Nuclear Cooperation 
- Agreements for Cooperation in the Use of Atomic Energy

- IAEA Supply Agreements

- Agreement between the United States and the International Atomic Energy Agency for the Application of Safeguards in the United States

- Convention of the Prezention of Marine Poltution by Dumping of Wastes and Other Matters

- Executive Order 10841 (re: International Atomic Energy Cooperation)

- Excentive Order 10956 (re: Amandt to E.O. 10841)

- Executive Order 12058 (re: Functions Relating to Nuclear Non-Proliferation)

- Executive Order 12658 (re: President's Commission on Catastrophic Nuclear Accidents)

- Executive order 12730 (re: Contintation of Export Control Regulations) 


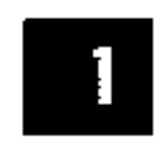

$$
\begin{aligned}
& . \\
& \cdot . \\
& \cdots \\
& =.
\end{aligned}
$$




\section{TITL'E I-ATOMIC ENERGY}

CHAPTER 1

\section{DECLARATION, FINDINGS, AND PURPOSE}

PAGE USC

\section{$42 \mathrm{USC}$}

Ser.

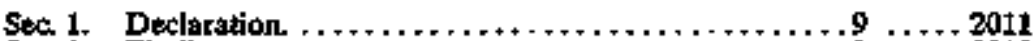

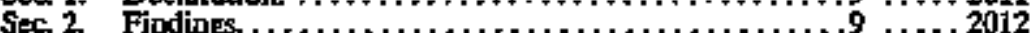

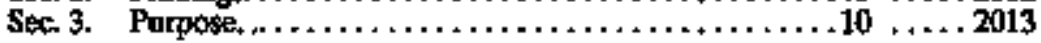

\section{'CHAPTER 2}

Sec. 11. Definitions.

\section{CHAPTER 3 \\ ORGANIZATION}

sec. 23. Office $\ldots \ldots \ldots \ldots \ldots+\ldots \ldots \ldots \ldots+\ldots+\ldots \ldots+\ldots+17 \ldots++2033$

Sec. 24. Genera Manager, Deputy and................17 ..... 2094

Assistant Geacral Managers.

Sec. 25. Divisions, Ofices, and Fositions ............... 18 . . 2035

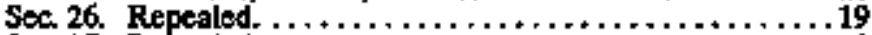

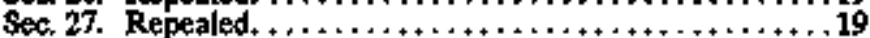

Sec. 28. Appointstent of Army, Navy, or Air Force Officer. . 19 .....2038

Sec. 29. Advisory Committes on Reactor Safieguards ...... $20 \ldots \ldots 2039$

\section{CHAPTER 4}

\section{RESEARCH}

Soc. 31. Research Assistance. . . . . . . . . . . . . . . . . 2051

Sec 32 Research by the Commission........................... 20552

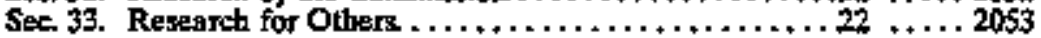

\section{CHAPTER 5}

PRODUCTION OF SPECIAL NUCLEAR MATERIAL

Sec. 41. Ornershtip and Operation of Production Facilties ...22 $\ldots \ldots 2061$

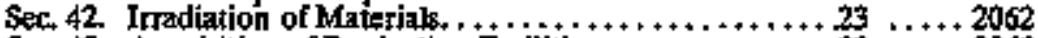

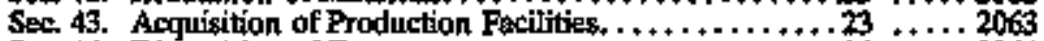

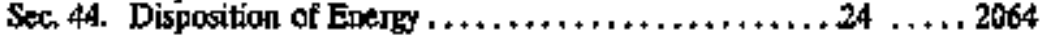




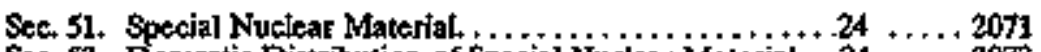

Sec. 53. Domestic Distribution of Speciaj Nuclear Materisl. . $24 \ldots \ldots 2075$

Sec. 54. Foreign Distribution of Special

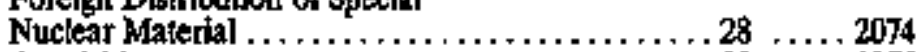

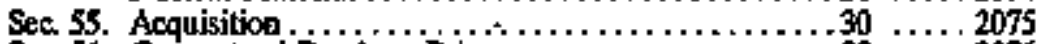

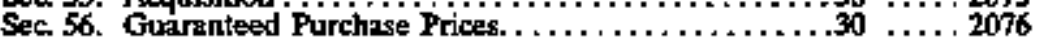

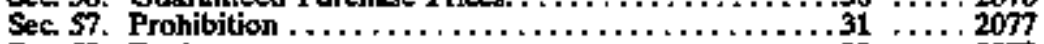

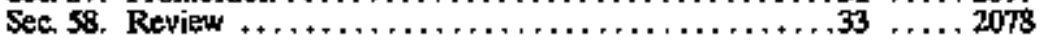

\section{CHAPTER 7 \\ SOURCE MATIERIAL}

Sec. 61. Source Material $\ldots \ldots \ldots \ldots \ldots \ldots \ldots \ldots \ldots \ldots \ldots \ldots 34 \ldots \ldots 2091$

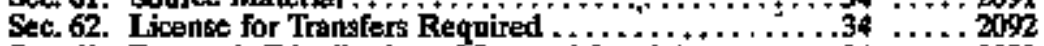

Sec. 63. Domestic Distribution of Source Materiat . . . . . . 34 . . . 2093

Sec. 64, Foreign Distribution of Souree Matertal. . . . . + + $+35 \ldots++, 2094$

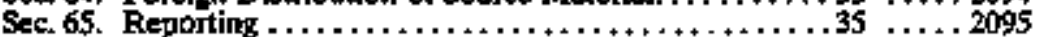

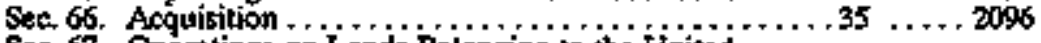

Sec. 67. Operations on Lands Belonging to the United

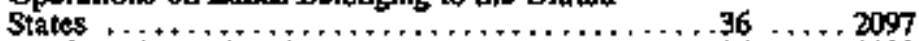

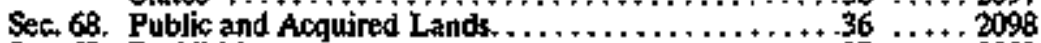

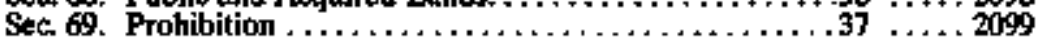

\section{CHAPTER 8 \\ BHPKODUCT MATERJAL}

Sec. 81. Domestic Distribution $\ldots \ldots \ldots+\ldots \ldots \ldots \ldots \ldots+37 \ldots+2111$

Sect 82 . Foreign Distribution of Byproduct Material......, $38 \ldots+, 2112$

Sec-83. Owarestip and Custody of Gertain Byproduct..... $39 \ldots \ldots .2113$ Material and Disposal Sites.

Sec. 84. Authonities of Commission Respecting Certain. . . . 41 . .+ 2714 Bypjoduct Matitial.

\section{CHAPTER 9 \\ MILITARY APPLICATION OF ATOMIC ENERGY}

Sec 91. Authority $\ldots \ldots \ldots \ldots \ldots \ldots \ldots \ldots \ldots \ldots \ldots \ldots \ldots \ldots, 42 \ldots, \ldots 121$

Sec. 92. Prohibition $\ldots \ldots+\ldots \ldots \ldots+\ldots \ldots \ldots \ldots \ldots \ldots \ldots \ldots 44 \ldots \ldots 2122$ 


\section{CHAPTER 10 \\ ATOMIC ENERGY LCENSES}

PAGE USC

42 USC Sec.

Sec101. License Required $\ldots \ldots \ldots \ldots \ldots \ldots \ldots \ldots \ldots \ldots \ldots \ldots$. $\ldots . \ldots 2131$

Sec.102. Utilization and Production Fucilities

for Industrial or Commercial Puposes. . . . . . . . $44 \ldots 2132$

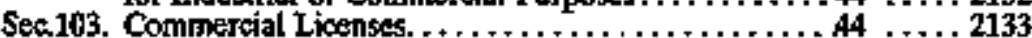

Sec.104. Medical Therapy and Research and Development . $45 \quad \ldots 2134$

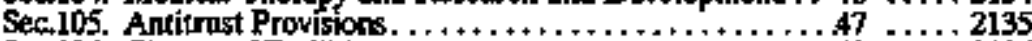

Sec 106. Classes of Facilities $+\ldots \ldots+\ldots+\ldots+\ldots+\ldots \ldots+\ldots+\ldots$ A9 $\ldots \ldots+2136$

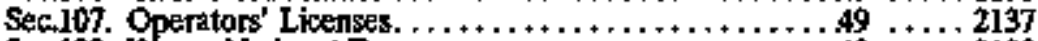

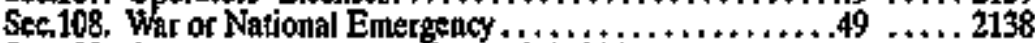

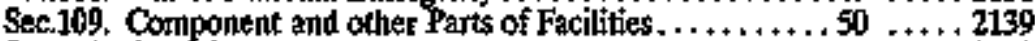

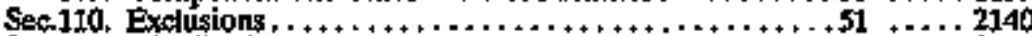

Sec.1II. Distribution by the Depardment of Energy ...... $51 \ldots \ldots 2141$

\section{CHAPTER II \\ INTERNATIONAL ACTIVTIES}

Sec.121. Effect of Intemational Arrangetrents .........51 ... 2151

Sec.122. Pollicies Contained in International Artangements . $51 \ldots \ldots 2152$

Sec.123. Coopstation with Otter Nations.................... 2152

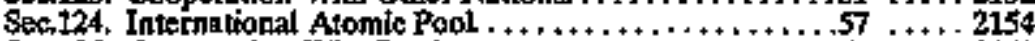

Sec 125, Cooperation With Berlin. $\ldots+\ldots+\ldots+\ldots+\cdots+\ldots++57+\ldots+2153$

Soc.126. Export Licensing Procedites . ...............57 .... 2155

Sec.127. Criteria Goweming United \$cates Nuclear Exporis . . 62 $\ldots+2156$

Sec 128. Additional Fxport Criterion and Procedures ...... $63 \ldots \ldots .2157$

Sec.129. Conduct Restuling in Termination of Nuctear

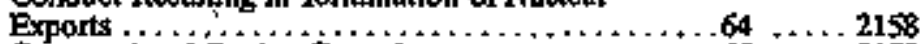

Sec.130. Contressiongl Revicw Procedures.

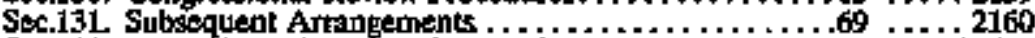

Sec.132. Authority to Suspend Nuclear Cooperation ........ $74 \ldots .21606$

Ser 133. Consultation with DOD. $\ldots \ldots \ldots+\ldots+\ldots \ldots+\ldots+\ldots 74 \ldots+2160 \mathrm{c}$

Sec.134. Further restrictions on exports.............

\section{CONTROL OF INFORMATION}

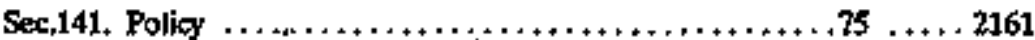

Sec.142. Classification and Declassification of $\ldots+\cdots+\cdots+\ldots 25 \ldots+\ldots$ 2161

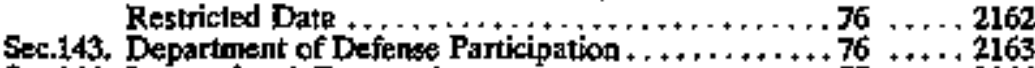

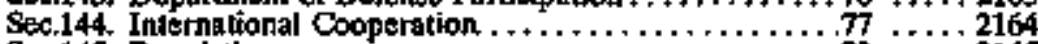

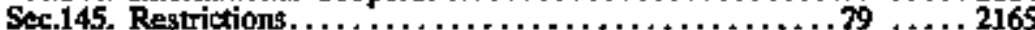

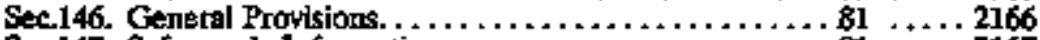

Sec.147. Safeguards J nformation....................... $81 \ldots+. .2167$

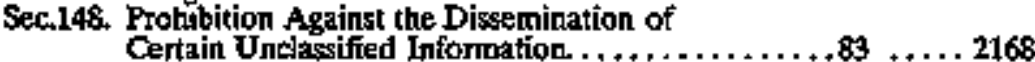

Sec.149. Fingerprinting For Criminal History Record Checks $85 \ldots . .2169$

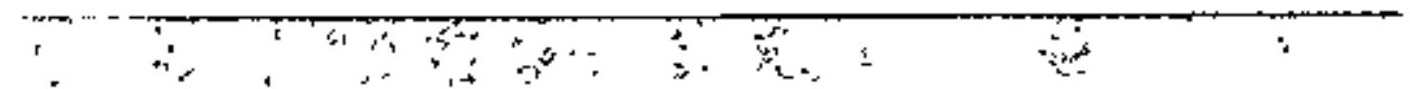




\section{CHAPTER 13 \\ PATENTS AND INVENTIONS}

PAGE USC

42 USC

Sec.

Sec.151. Irventions Relating to Atomit Weapons, and

Ftling of Roports ..................... $87 \ldots . .2181$

Sec.152. Inventions Made or Conceived Doring $\ldots \ldots 8182$

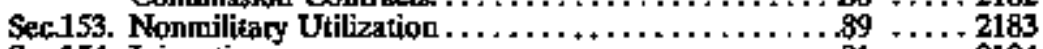

Sec.154. Injunctions $\ldots \ldots \ldots \ldots \ldots \ldots \ldots \ldots \ldots \ldots \ldots \ldots \ldots, 91 \ldots \ldots, 2184$

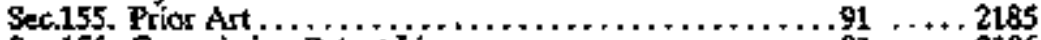

\$ec.156. Commission Patent Licenses ................

Sec.157. Compensation, Awards, and Royalties ..........92 . . . 2187

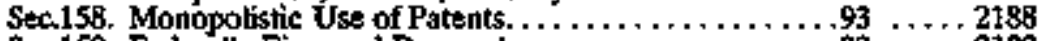

Sec.159. Federally Financed Research $\ldots \ldots+\ldots \ldots \ldots \ldots+\ldots+\ldots 93 \ldots \ldots 2199$

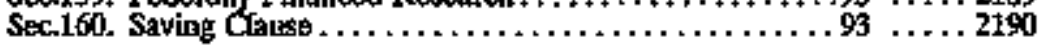

\section{CFAPTER 14 GENERAL AUTHORITY}

Sec.161. Genteral Prowisions..................93 ... 2201

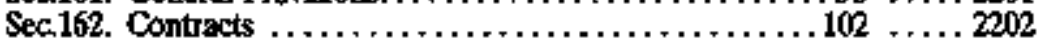

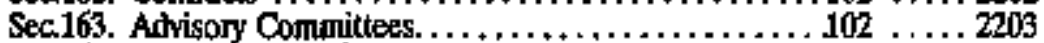

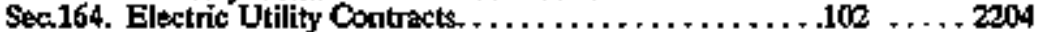

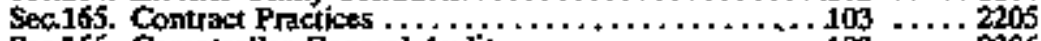

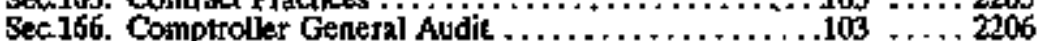

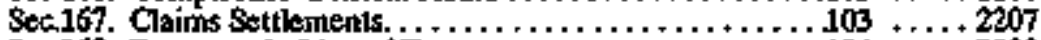

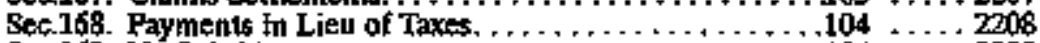

Sec169. No Subsidy ....................... $104 \ldots \ldots 2209$

Sec.170. Indemnification and Limitation of Liability $\ldots \ldots \ldots 104 \ldots 2210$

Sec.170A.Conftiets of Interest Relating to Contracts

and other Arrangements . . . . . . . . . . 2210.

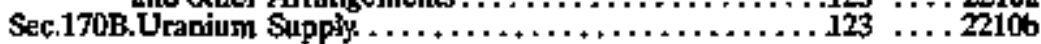

\section{CHAPTER 15 \\ COMPENSATION FOR PRIVATE PROPERTY ACQUIRED}

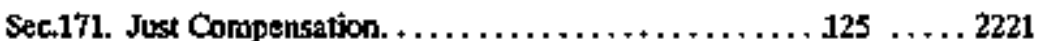

Sec.172. Condemmation of Real Property $+\ldots \ldots+\cdots \cdots \cdots \cdots+126 \ldots \ldots 222$

Sec.173. Fatent Application Disclosures................ $126 \ldots \ldots 223$

Sec.174. Attorney General Approval of Titb . . . . . . . $+126 \ldots \ldots 2224$

\section{CHAPTER 16 \\ JUDICIAL REVIEW AND ADMINISTRATTVE PROCEDURE}

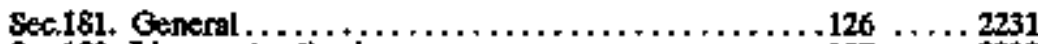

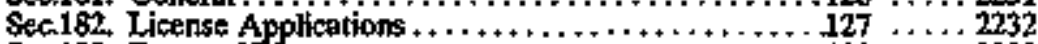

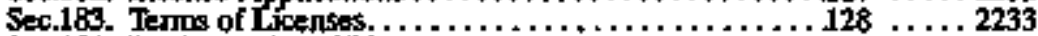

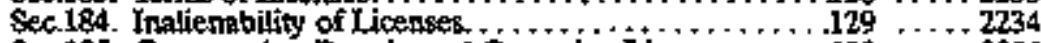

\$ec185. Constnuction Permits and Operating Licenses $\ldots+129 \ldots+2035$

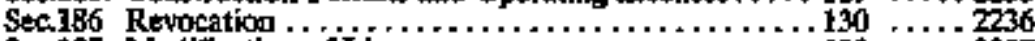

Sec.187. Moditication of License. $\ldots \ldots+\ldots+\ldots+\ldots+\cdots+130 \ldots+2237$

Sec.188. Contimed Operntion of Facilities $\ldots \ldots \ldots \ldots, \ldots+$ t30 $\ldots \ldots, 2238$

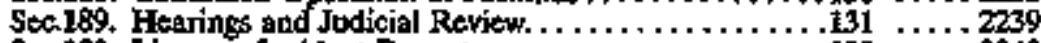

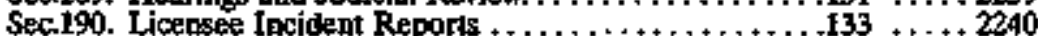

Sec.191. Atomic Safety and Licensing Board. . . . . . . . $333 \ldots \ldots$ 2241

Sec.192. Temporany Operating License $\ldots \ldots \ldots \ldots \ldots \ldots \ldots \ldots .134 \ldots \ldots .2242$

Sec.193. Licensing of Uranium Earichment

Facilities 


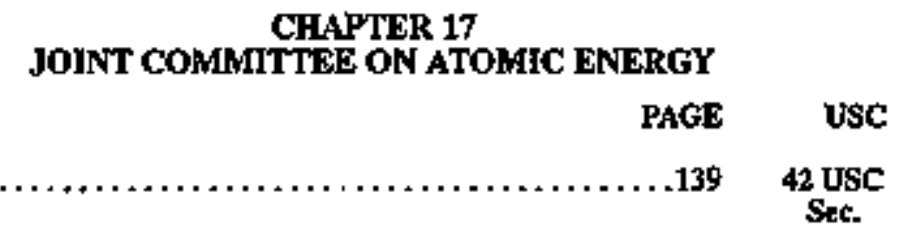

\section{CHAPTER I8 \\ ENEORCEMENT}

Sec. 221. General Provisions. . . . . . . . . . . . . . . 140 . . 2271

Sec. 222 Violation of Specitic Sections.............

Sec. 223. Violation of Sections Generally .............. 140 . . . 2273

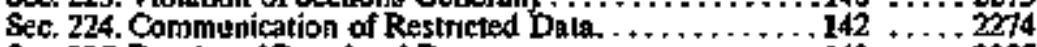

Sec. 225. Receipt of Restricled Data $\ldots \ldots \ldots+\ldots \ldots \ldots+\ldots 142+\ldots 2275$

Sec. 226. Tampering with Restricted Data ...........

Sec. 227. Disclosure of Restricted Data $\ldots \ldots \ldots \ldots \ldots \ldots \ldots \ldots .142 \ldots \ldots .2277$

\$ec. 228. Stafule of Limitations $\ldots+\ldots+\ldots+\ldots+\ldots++\ldots \ldots+143 \ldots+2278$

Sec. 229. Trespass Upon Commission Installations . . . . . . . $143 \quad \ldots \ldots .2278$ a

sec. 230. Photographing, stc, of Commission

Installations $\ldots \ldots+\ldots \ldots \ldots+\ldots \ldots \ldots+\ldots \ldots+\ldots, 143 \ldots+22786$

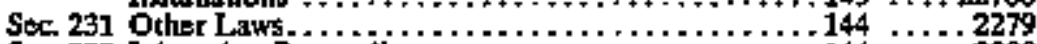

Sec. 232 Injunction Proceedings $\ldots \ldots \ldots \ldots \ldots \ldots \ldots+\ldots \ldots, 144 \ldots \ldots, 2280$

Sec. 233 Contempt Proceedings. . ................ $144 \ldots \ldots 2281$

Sec. 234 Civil Monetary Penalties for Vokations of

Licensing Requirements . ..................... $144 \ldots . .2282$

Sec. 234ACivit Monetary Penalties for Violations of

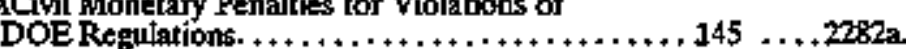

Sec 235. Protection of Nuckear Inspectors $\ldots+\ldots+\ldots+\ldots \ldots+147 \ldots \ldots 283$

Sec $\mathbf{2 3 6}$. sabolage of Nudear Facilities or Fuel $\ldots \ldots \ldots \ldots \ldots 147 \ldots \ldots 2284$

\section{CHAPTER 19 \\ MISCELLANEOUS}

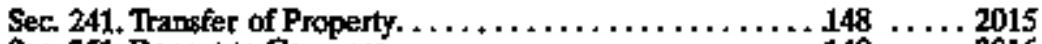

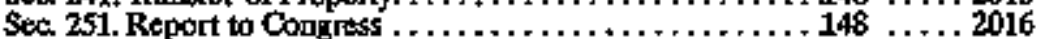

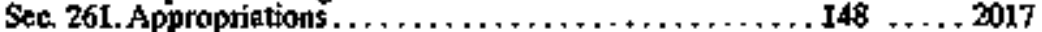

Sec 271 . A gency Jurisdiction $\ldots \ldots+\ldots \ldots \ldots \ldots \ldots \ldots \ldots \ldots .449 \ldots \ldots 2018$

Sec. 272, Applicability of Federal Power Acx . . . . . . . . . . 149 . . . 2019

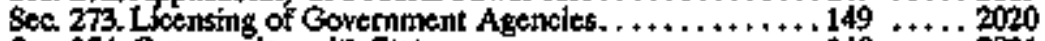

Sec. 274, Cooperation with States . ...............149 . . 2021

Sec 275, Health and Environmental Standards

for Uranifum Mall Tailings . $\ldots \ldots \ldots \ldots \ldots \ldots+\ldots+156+\ldots 2022$

Sec 276. Strte authority to regulate rediation below

level of regulatory comacern of Nuclear

Regulatory Commission.

$159+\ldots 2023=$

Sec. 28I. Separabilíty $\ldots+\ldots+\ldots \ldots \ldots+\ldots+\ldots+\ldots+\ldots+\ldots, \mathbf{1 6 0}+2011$ Note

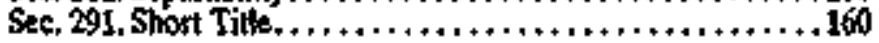

P.L. 102-486 (106 Stat 3122) 


\section{CHAPTER 20 \\ JOINT COMMITTEE ON ATOMIC ENERGY ABOLSSED: KUNCTIONS AND RESPONSIBILITIES REASSIGNED}

PAGE USC

42 DSC

Sec.

Sec. 301. Joint Comutittee on Atomic Enerigy

Abolished. ....................... 160

Sec. 302. Transter of Certain Functions of the Joint

Committee on Atomic Energy and Conforming

Amendments to Certain Other Laws. .......... 160

Sec 303. Information and Assistance to Congressional

Committees

161

\section{DEFENSE NUCLEAR FACILITIES SAFETY BOARD}

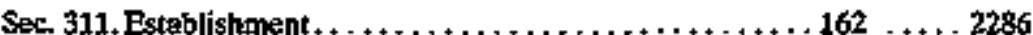

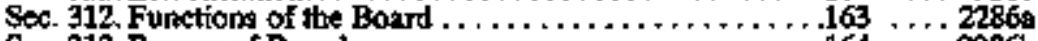

Sec. 313. Powers of Board. .........................164 $\ldots \ldots 2286 \mathrm{~b}$

Soc. 314. Respossibilithtes of the Secretary of

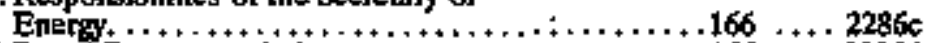

Soc. 315. Borti Recommendations ....................166 $\ldots . .2286 \mathrm{~d}$

Sec. 316. Reports $\ldots \ldots \ldots \ldots \ldots \ldots \ldots \ldots \ldots \ldots \ldots, \ldots \ldots, 169 \ldots \ldots 2286 t$

Sec. 317. Jndicial Review.................................

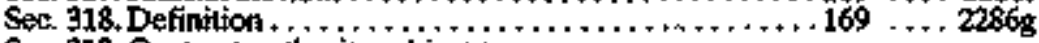

Sec. 319, Contract authority subject to

apptopriations..................

Sec. 320 Transmittal of $C$ ertain information to Congress. . . 170 $.2286 \mathrm{~h}-1$

Sec. 321 Annual Authorization of Appropriations ......... 170 .... 2286i

\section{TITLE II-UNITED STATES ENRICHMENT CORPORATION}

\section{CHAPTER 22*;* \\ GENERAL PROVISIONS}

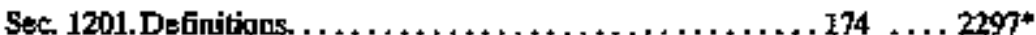

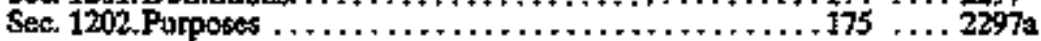

"Added by P.L. 102-486 (106 Stat. 2924)

"Sectlon will be repealed an privatization dale. Act April 26, 1996, P.L. 104-134, Tide III, CD 1, Subch A \$ 3116(a), I10 Stat. 1321-349, provides: "Chapters 22 through 26 of the Atomic Energy Aet of 1954 (42 U.S.C. $2297--2297 e-7$ ) are repealed as of the privatization date.". (The "priwatization date" is defined at 42 USCS $\$ 2297 \mathrm{~h}(9)$ as the date on which 100 percent of the ownership of the United States Envichment Corpbration has been transferred to private investors.) 


\section{CHAPTER 23* \\ ESTABLISHMENT, POWERS, AND ORGANIZATION OF CORPORATION"*}

PAGE USC

42 usc

See.

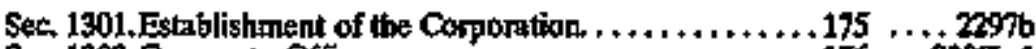

Sec 1302 . Corporte Oftices........................... 176 .. 22970-1

Sec 1303. Powers of the Corporation....................176 .. 2297b-2

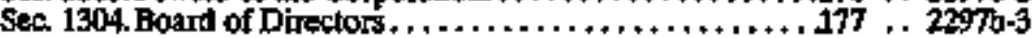

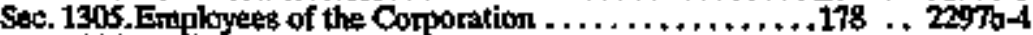

Sec. 1306.Audits $\ldots \ldots \ldots \ldots \ldots \ldots \ldots \ldots \ldots \ldots \ldots \ldots \ldots \ldots \ldots 179, \ldots \ldots+2297 \mathrm{~b}-5$

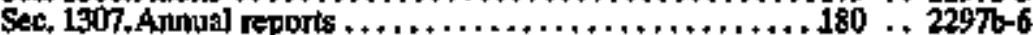

Sec. 1308. Acocounts ............................180 .. 2297 b.7

Sec. 1309.Objigations ........................... $180 \ldots$ 2297b-8

Sec. 1310. Exemption from taxation and payments

in tee of taxes.............................. 182 .. 22976-9

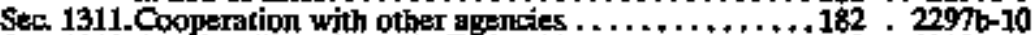

Sec 1312.Applicability of costato Federal laws ...........182 . 2297b-11

Sec. 1313. Security $\ldots \ldots \ldots \ldots \ldots \ldots \ldots \ldots \ldots \ldots \ldots \ldots \ldots .184 ; 2297 \mathrm{~b}-12$

Soc 1314.Contro of information. . . . . . . . . . . 184. 22975-13

Sec 1315. Transtton ...

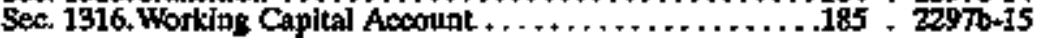

\section{RIGHTS, PRTVLEGES, AND ASSETS OF THE CORPORATION**}

Sec. 1401.Marketing and contracting authority $\ldots+\ldots+\ldots \ldots 185 \ldots+\ldots 2297 \mathrm{c}$

Sea 1402. Prieing ...............................186 ...22970-1

Sec, 1403. Leasing of paseous diffusion tacilities

of department ............................. $186 \ldots 2297 \mathrm{c} 2$

Sec 1404.Capital structure of Copporation ................187 ...2297c-3

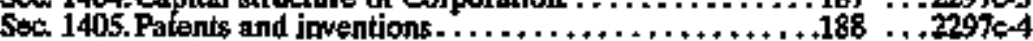

Sec. 1406.Labdilties ...........................188 ...22970-5

Sec. 1407. Iransfer of uranium ioventories.................188 ...22397c-6

Soc. 1408. Purchase of highly epriched uraniurn

from former Soviet Union. $\ldots \ldots+\ldots \ldots \ldots \ldots . .188 \ldots .23970-7$

\section{CHAPTER 25*, ** \\ PRIVATIZATION OF THE CORPORATION**}

Sec. 1501. Strategic plan for privatization $\ldots \ldots \ldots \ldots \ldots \ldots+189 \ldots .2297 \mathrm{~d}$

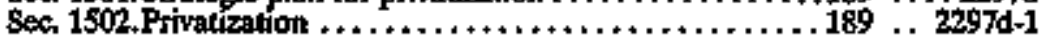

"Added by P.L. 102-486; 106 Stat. 2925; 106 Stat. 2934; and 106 Stat. 2937

**Section will be repealed on miritizolion dele. Act Aprit 26, 1996, P.L. 104-134, Title III, Ch 1, Subch A, \$ 3116(a), 110 stet, 1321-349, provjdes: "Chapters 22 thuough 26 of the Atomic Energy Act of 1954 (42 U.S.C. $2297-2297 \mathrm{e}-7$ ) are repealed as of the privatizalion date". (The "pifvatization date" is defined at 42 USC $\$ 2297$ h (9) as the date on whith 100 percent of the owentrship of the United States Enrichunent Corporation has been iransfiersed to private iavestors.) 


\section{AVLIS AND ALTERNATTVE TECHANOLOGIES FOR $\$$ URANIUM ENRICHMENT**}

Sec. 1601. Assessmeat by United States Enriehment Corporation............................

Sec. 1602.Transfer of riphts and property to '

United States Encichunent Corporation. ........ $191 \ldots$ 2297t-1

Sec. 1603.Predeployment sctivities by

Unted States Entichument Corporation $++\ldots+\ldots 192 \ldots$ 2297e-2

Sec. 1604. Unitied States Enrichment Corporation " sponsorshig of private for-profit corporation to construct AVLIS and afternative technologies for uranium enfichment ... . . . . . . . . . 192 .. 2297e-3

Sec. 1605. AVLIS Commercialization Fund within United States Bnrichment Corporation............ 194 .. 2297e-4

Sec. 1606.Department vestearch and development

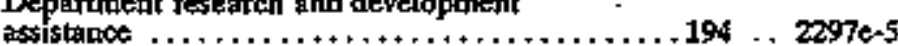

Sec. 1607 Site selection.............................194 . 2297e-6

Soc. 1608. Exchusion from Price-Anderson coverage ........ 194 .. 2297e-7

\section{CHAPTER 27*, ** \\ HCENSING AND REGULATION OF URANIUM ENRICHMENT FACILIJES}

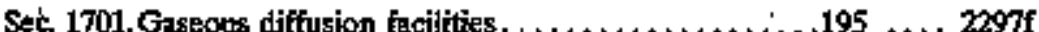

Set. 1702. Licensing of other technologies . . . . . . . . . . 2297f-1

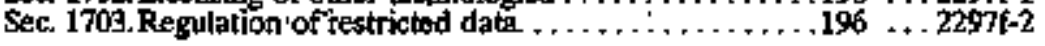

\section{CHAPTER 28*}

\section{DECONTAMINATION AND DECOMMISSIONING}

Sec. 1801. Uranium Enrichment Decontamiation

and Decommissioning Fund . ..............196 ... 22978

Sec. 1802 . Deposits $\ldots+\ldots \ldots \ldots \ldots \ldots \ldots+\ldots \ldots+\ldots+\ldots \ldots \ldots 197 \ldots$ 2297g-1

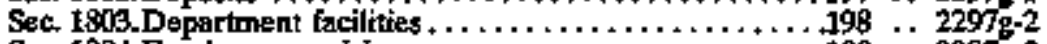

Sec. 1804.Employee provisions ....................198 .. 22978

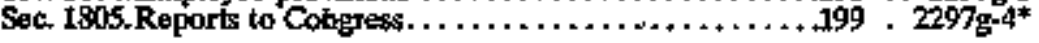

TITLE III**** , , , ,

$200 \ldots .2297 \mathrm{~h}$

*Added by PL 102-486 (106 Stat. 2939)

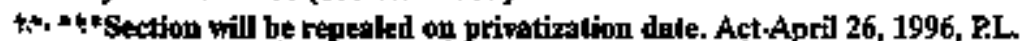
104-134, Title III, Ch 1, Subt A \& 3116(2), 110 Stat ' 331 -349, prowides: "Chapters 22 through 26 of the Atomic Energy Act of 1954 (42 U.S.C. $2297--2297 e-7$ ) are repealed as of the privatization date:". (The "privatization date is defined at 42.USCS $\$ 2297 \mathrm{k}$ (9) as the date on which 100 percent of the ownership of the United States Enrichment Corporation has been transferred to pivate investors.) 


\section{TTTLE I-ATOMIC ENERGY*}

Declaration.

42 USC sec, 2011

Funcỉngs-

42 USC sec. 2012

\section{CHAPTER 1-DECLARATION, RINDINGS, AND PURPOSE}

Sec. 1. Declaration-Atomic energy is capable of application for peaceful as well as military purposes. It is therefore declared to be the policy of the United States that-

a. the development, use, and control of atomic energy shall be directed so as to make the maximum contribution to the general welfare, subject at all times to the paramount objective of making the maximum contribution to the common defense and security; and

"b. the development, use, and control of atomic energy sthall be directed so as to promote world peace, inprove the general welfare, increase the standard of living, and strengthen free competition in private enterprise.

Sec. 2. Findings. ${ }^{2}$-The Congress of the United States bereby makes the following findings concerning the development, use and control of atomic energy:

"a. The development, utilization, and control of atomite energy for military and for all other purposes are vital to the common definse and security.

${ }^{*} \mathrm{c},{ }^{3}$ The ptocessing and utilization of source, byproduct, and special nuclear materiat affect interstate and foreign commerce and must be regulated in the national interest.

"d. The processing and utilization of source, byproduct, and special nuclear material muse be regulated in the national interest and in order to provide for the common defense and security and to protect the heslth and safety of the public.

"e. Source and special nuclear material, production facilities, and utflization facilities are affected with the public interest, and regulation by the United States of the production and utilization of atopic energy and of the facilities used in connection therewith is necessary in the national interest to assure the common defense and security and to protect the health and safety of the public.

"E. The necessity for protection against possible interstate damage opcurring from the operation of facilities for production or utilization of source or special miclear material places the operation of those facilities in interstate commerce for the purposes of this Act.

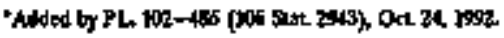
ilolos:

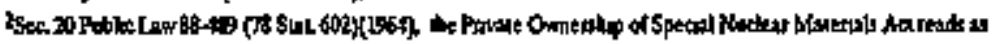

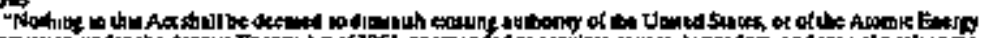

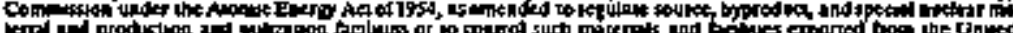

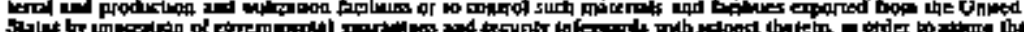

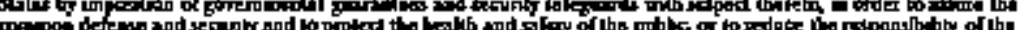

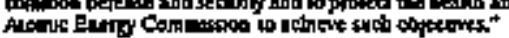

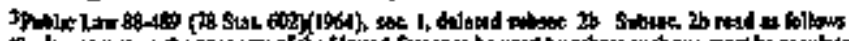

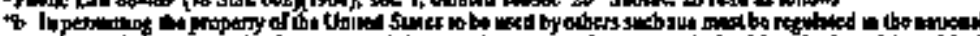

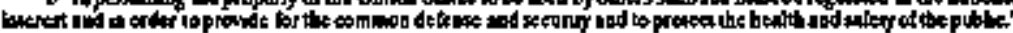

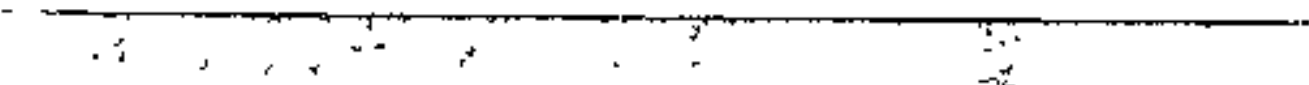


Purpose $42 \mathrm{USC} \mathrm{Sec}, 2013$

"g. Funds of the United Sates may be provided for the development and use of atomic energy under conditions which will provide for the common deferse and security and promote the gentral welfare.

${ }^{4} \mathrm{i} .{ }^{4}$ In order to protect the publić and to encourage the development of the atomic energy, industry, in the interest of the general welfaxe and of the common defense and security, the United States may make funds available for a portion of the damages suffered by the public from nuclear incidents, and may limit the liability of those persons liable for such lasses. 5

"Sec. 3. Purpose.-It is the purpose of this Act to effectuate the policies set forth aborte by providiog for

a. a program of conducting, assisting, and fostering research and development in order to encourage maximum scientific and industrial progress;

"b. a prograrn for the dissemination of unclassified scientific and technical information and for the control, dissemination, and declassification of Rescricted Data, subject to appropriate safeguards, so as to excourage scientific and industrial progress;

"c. a program for Government control of the possession, use, and production of atomic energy and special nuclear material, whether owned by the Government or others, so directed as to make the maximum contribution to the corrmon defense and security and the rational weifare, and to prowide continued assurance of the Goweminent's ability to enter into and enforce agree. monts with nations or groups of nations for the control of spectal nuclear materiats and atomic weapons. ${ }^{6}$

*d. a program to encovirage widespread participation in the development and utilization of atomic energy for peaceful putroses to the maximum extent consistent with the common defense and security and with the health and safecty of the public;

"e. a program of international cooperation to promole the common defense and security and to make available to cooperating nations the benefits of peaceful applications of atonaic energy as widely as expanding technology and considerations of the common defense and security will pernith and

"f. a progran of administration which will be consistent with the foregoing policies and prograns, with international arrangements, and with agreements for cooperation, which will enable the Congress, to be currently informed so as to take further legislative action as rnay be appropjate.

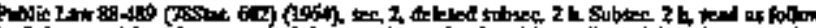

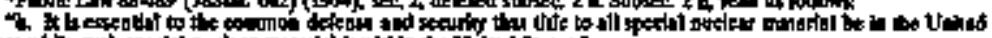

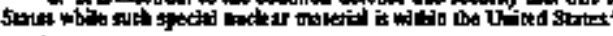

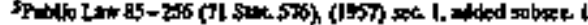

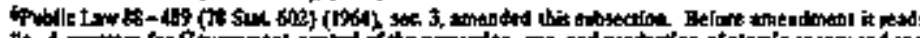

t $1 \mathrm{c}$ A f

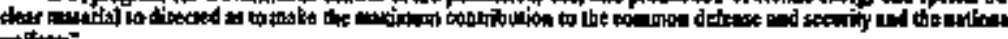

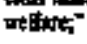


Definitions.

42 USC sec.2014

Agency of the

U.S.

Agreement for exoperation.

Alonic chergy.

Atomic weapon

Byproduct material.

Commission.

Common deferase and security.

Defense

information.

Design.

Exaraordiany nuclear occuristece.

\section{"CHAPTER 2-DEFINITIONS}

"Sec. 11. Definitions,-The intent of Congress in the definitions as given in this section should be construed from the words or phrases used in the definitions. As used in this Act:

"a. The term 'agency of the Uniteri States' ineans the executive branch of the United States, or any Government agency, or the legislative branch of the United States, or any agency, committec, commission, office, or other establishment in the legislative brancti, or the judicial branch of the United States, or any office, agency, committee, comisission, or other establishment in the judicial branch.

'b. The term 'agreeroent for cocperation' means any agreement with another nation or regional defense organization authorized or permitted by sections $54,57,64,82,91 \mathrm{c}, 103,104$, or 144, and made pursuant to section 123 .

"c. The term 'atomic energy' means all forms of energy released in the course of muclear fission or nuclear transformation.

"d. The term 'atonic weapon' means any device bttltzing atomic energy, exclusive of the means for transporting or propeling the device (where such means is a separable and divisible part of the device), the principal purpose of which is for use ab, or for development of, a weapon prototype, or a weapon test device.

"e. The term 'byproduct material' means (1) any radioactive materiel (except special nuclear matertaly yielded in or made radioactive by exposure to the radiation incident to the process of producing or utilizing special nuclear material, and (2) the tailings or wastes produced by the extraction or concentration of uranium or thorium from any ore processed primarily for its source meterial contert.

"f. The tern 'Commission' means the Atomic Energy Commission.

"g. The term 'common defense and security' mears the common defense and security of the United States.

"h. The term 'defense information' means any tuformation in any category determined by any Govermyent agency authorized to classify information, as being information respecting, relating to, or affectiog the national defense.

"i. The terti 'design' means (1) specifications, plans drawizgs, blueprints, and other itents of like nature; (2) the information contained therein; or (3) the research and development data pertinent to the information contained therein.

"j. The term 'extraordinary nuclear occurrence' means any event causing a discharge or dispersal of source, special nuclear, or byprochset material from its intended place of confinement in anounts off-site, or causing radiation levels off-site, which the

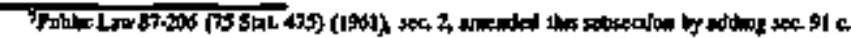

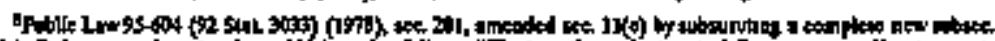

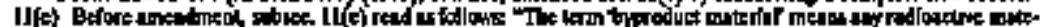

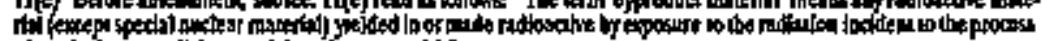

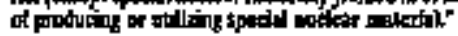


Financiel protection.

Government azency.

Indemaitor.

InternationaI

arrapgement.

Joint Conmittes.

Licensed activity.

Nuclear inciđent.
Nuclear Regulatory Commission or the Secretary of Energy, as appropriate, determines to be substantial, and which the Nuclear Regutatory Cornuission or the Secretary of Energy, as appropriate determines has restlted or will probably result in substantial darnages to persons off-site or property off-site. Any determination by the Nuclear Regulatory Commission or the Sectetary of Energy, as appropriate, that stuch as event bas, or has not, occurred shall be funal and conclusive, and no other official or any court shall have power or jurisdiction to review any such determination. The Nuclear Regulatory Commission or the Secretary of Energy, as appropriate, shall establish criteria in writing setting forth the basis tipon which such determatiotion shall be made. As used in this subsection, 'off-site' means away from 'the focation' or the contract location" as defined in the applicable Nuclear Regulatory Commission or the Secretary of Energy, as appropriate, indemnity agjeetment, entered into pursuant to section $170 .^{9}$

“k. The term 'financial protection' means the ability to respond in darnages for public ljability and to meet the costs of investigating and defending claims and settling suits for such damages. 10

" $\mathrm{l}$. The term 'Government agency' means any executive department, commission, independent establishment, corporation, wholly of partly owned by the United States of America which is an instrumentality of the United States, or any board, bureau, division, service, office, officer, authotity, administration, or other es. tablishrnent in the exectutive branch of the Gowermment.

$\mathrm{m}$. The term 'indemritor' means ( 1 ) any insurer with respect to his obligations under a policy of insurance furrished as proof of financial protection; (2) any licensee, contractor or ather person who is obligated under any other form of financial protection, with respect to such obligations; and (3) the Nuclear Regulatory Comnmission or the Secretary of Energy, as approprizte, with sespect to any obligation undertaken by it in an indemnity agreercent entered into pursuant to section 170.11

" $\mathrm{t}$. The tern 'international arrangemtent' means any international agreement bereaftes approved by the Congress or any treaty during the time such agreement or treaty is in full force and effect, but does not include any agreement for cooperation.

“o. The term 'Joint Cormuittee' means the Joint Committee on Atontic Enetgy.

"p. The term 'licensed activity' means an activity licensed pursuant to this Act and covered by the provisions of section 170a.12

"q. The term 'nuclear incident" means any occurrence, including an extraordinary nuclear occurrence, ${ }^{13}$ within the United States causing, withtr or outside the United States, bodily injury, sickaess, disease, or death, or loss of or damage to property, or loss of use of property, arising out of or resulting from the radioactive,

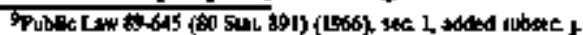

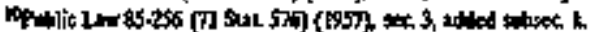

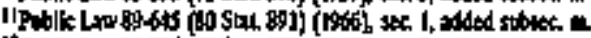

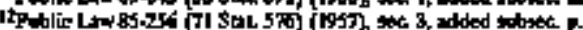

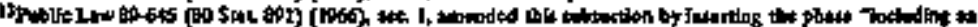

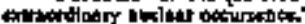


$\$ 2$ USC 2091, 2111, 2121,2151

Operator.

Perton.

Person ideranified. toxic, explosive, or other hazardous properties of sousce, special nuclear, or byproduct material: Provided however, That as the term is used in section $\mathbf{1 7 0} 1$., it shall include any such occurrence outside of the United States: And provided further, That as the term is used in section $170 \mathrm{~d}$., it shall include any such ocurrerce outside the United States if such occurrence involves source, special nuclear, or byproduct material owned by, and used by or under contract with, the United States: And provided further, That as the term is used in section $170 \mathrm{c}$, it shall indude any strch occurronce outside both the United Skates and any other nation if such occurreuce arises out of or results from the radioactive, toxic, explosive, or other hezardous properties of source, special nuclear, or byproduct material licensed pursuant to chapters $6,7,8$, and 10 of this Act, which is used in connection with the operation of a licensed stationary production utilization facility or which noves outside the territorial jimits of the United States in transit from one persor licensed by the Nuclear Regulatory Combission to another person liceased by the Nuclear Regulatory Commis. sion. 14

"r. The term 'operator' means any individusl who manipulates the controls of a utilization or production facility.

"s. The term 'person' means (1) any individual, corporation, partnership, firm, association, trust, estate, public or private institution, group, Gowermment agency other than the Commission, any State or any political subdivision of, or any political entity within a State, any foreign government or nation or any political subdivision of any such government or nation, or other entity; and (2) any legal sucoessor, representative, agent, or agency of the foregoing.

“t. The term 'person indemnified” means (1) with respect to a nuclear incident occurring within the United States or outside the United States as the terrin is used in section $170 \mathrm{c}$, and with respect to any nuclear inctient in connection with the designs, developmonit, constntetion, operation, repair, maintenance, or use of the nuclear ship Savannah, the person with whom an indemnity agreoment is executed or who is requited to maintain financjal protection, and any other person who may be liable for pubtic liability or (2) with respect to any other nuclear incident occurring outside the United States, the person with whom an indemnity agreement is executed and any other person who may be jable for public liability by reason of his activities turder any contract with the Sectetary of Energy or any project to which indemanfication under the provisions of section $170 \mathrm{~d}$. has been extended or under any stob-

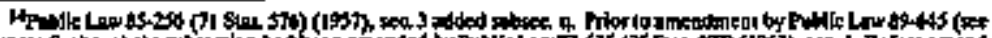

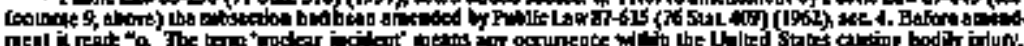

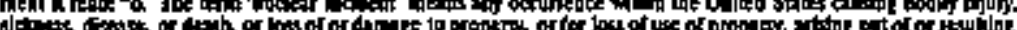

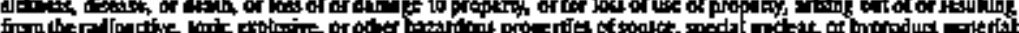

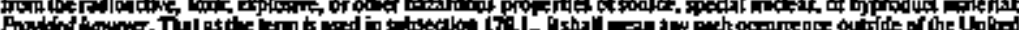

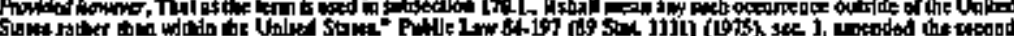

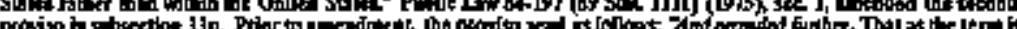

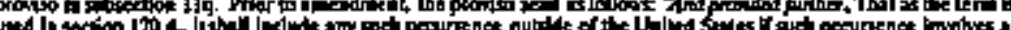

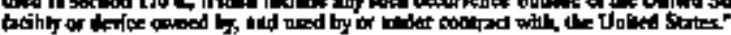


Production facility.

contract, purchase order or other agreenent, of any tier, under any such contract or project. ${ }^{15}$

"i. The term 'produce', when used in relation to special muclear mlaterjal, means (1) to manufacture, make, produce, or refine special nuclear material; (2) to separate special nuciear materiat from other substances in which suchnaterial may be contatoed; or (3) to make or to produce, new special nuclear material.

"v. The term 'production facility' means (1) any equipment or device determined by rule of the Commission to be capable of the production of special nuclear material is such quantity as to be of significance to the common defense and security, or in such manner as to affect the health and safety of the public or (2) any important component,part especially designed for suci equipment or device as determined by the Commission. Except with respect to the export of a urapium emrichment production facility, ${ }^{162}$, 16b such term as used in stibchapters IX and XV of this division shatl nat include any equipment or device (or jmportant component part especially designed for such equipment or device) capable of separating the isotopes of uranium or entriching uranium in the isotope $235 .=16 \mathrm{c}$

Public liability.

"w. The term 'pubtic liability' 17 means any legal liability arising out of or resulting from a nuclear ircident or precautionary evacuation (including all reasonab]e additional costs incurred by a \$tate, or political subdivision of a State, in the course of responding to a nuctear ineident or precautionary evacuation) except: (i) daims untier State or Federal workmen's compensation acts of employes or persons indemnified who are employed at the site of and in connection with the activity where the nuclear incident $\infty$ curs; (ii) claims arising out of an act of war; and (iii) whenever used in subsections $a, c_{\text {, }}$ and $k$, of section 170 , claims for loss of, or dannage to property which is located at the site of and used in contnection with licenses activity where the pucleas incident occurs. "Public liability" also includes damage to property of persons indemnified, Provided, That such property is covered under the

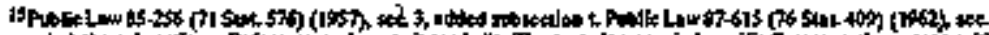

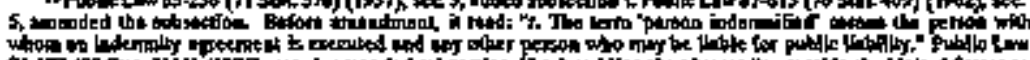

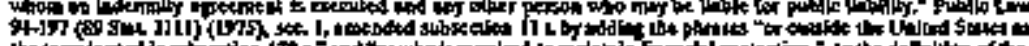

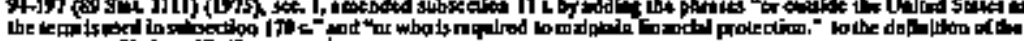

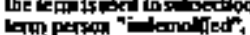

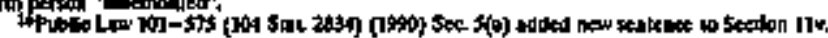

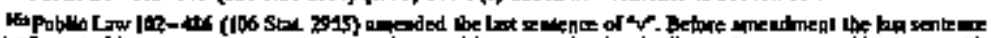

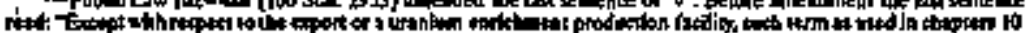

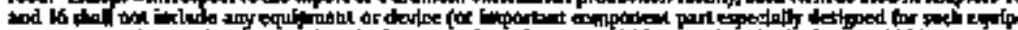

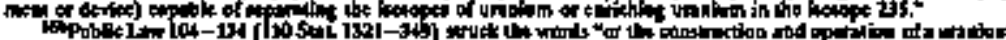

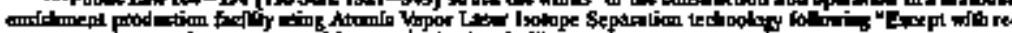

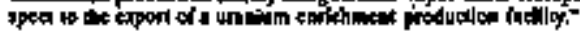

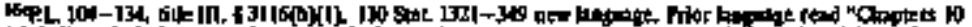

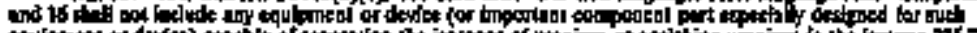

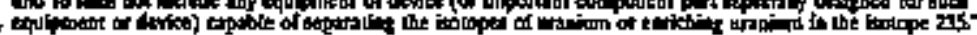

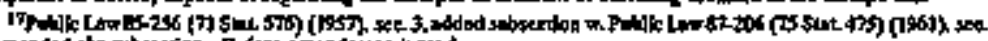

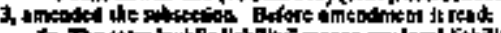

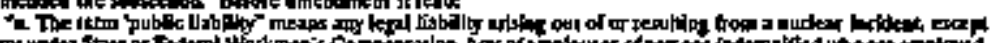

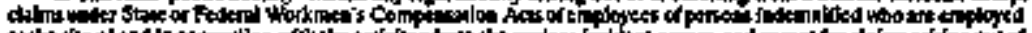

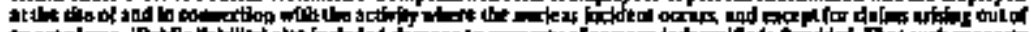

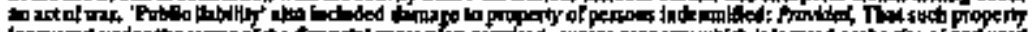

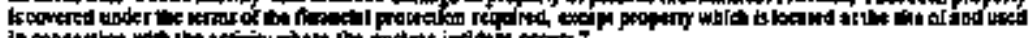

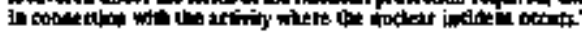


Resezarch and development.

\section{Restricted Data.}

Source material.

Special nuckear material.

United States.

Utilimation facility. terns of the financial protection required, except property which is located at the site of and used in connection with the activity where the nuclear incident ociurs.

" $x$. The term 'research and development' means (1) theoretical anajysis, exploration, or experimentation; or (2) the extension of investigative findings and theories of a scientific or technical na. ture into practical application for experimental and demonstration purposes, incluofing the experimental production and testing of models, devices, equipment, materials, and processes.

" $y$. The term 'Restricted Data' means al] data concerning (1) design, manufacture, or utilization of atomic weapons; (2) the production of special nuclear material; or (3) the use of special nuclear material in the production of energy, but shall not include data declassified or removed from the Restricted Data category purstuant to section 142.

" 2 . The term 'source material' means (1) urasuium, thorium, or aby other material which is determined by the Commission pirfsuant to the provisions of section 61 to be source material; or (2) ores containing one or more of the foregoing materials, in such concentration as the Commission may by regulation determine from time to tije.

"ar. The tem 'special nuclear material' means (1) plutonium, uranium enricted in the isotope 233 or in the isotope 235, and any other material which the Commission, pursuant to the provisions of section 51 , determines to be special nuclear material, but does not inchude sourse material; or (2) any material artificially entriched by any of the foregoing, but does not include source material.

“bb. The term 'United States' when used in a geographical sense includes all Territories and possessions of the United States, the Canal Zone and Puerto Rico. ${ }^{18}$

"cc. The term 'utilization factlity' means (1) any equipment or device, except an atomic weapon, determined by rule of the Commission to be capable of making use of special nuelear material in such quantity as to be of significance to the common defense and security, or in such manner as to affect the health and safety of the public, or peculiarly adapted for making use of atomic energy in such quantity as to be of significance to the common defense and security, or in such manner as to affect the health and safety of the public, or (2) any important component part especially designed for such equipment or device as determined by the Commission.

"dd. 18a The terms "high-level radioactive waste" and "spent nuclear fuel" have the meanings given such terms in section 2 of the Nuclear Waste Policy Act of 1982 (42 U.S.C. 10101).

"ee. The term "transuranic waste" mears material contaminated with elements that have an atomic number greater than 92, including neptunium, plutonium, americium, and curium, and that are in concentrations greater thas 10 nano-curies per gram, or

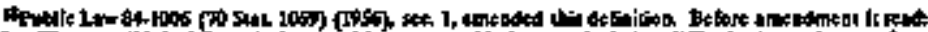

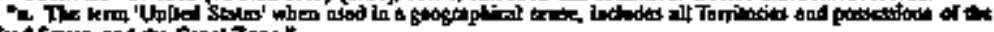

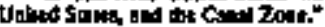

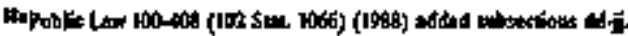


in sixch other concentrations as the Nuclear Regulatory Commission may prescribe to protect the public health and safery.

"ff. The terma "nuclear waste actrities", as used in section 170 , means activities subject to an agreement of indempification under subsection d. of such section, that the Secretary of Energy is authorized to undertake, under this Act $\mathrm{or}$ ary other low, involving the storage, handling, transportation, treatment, or disposal of, or research and development on, spent nutclear fuel, high-level radioactive waste, or transuranic waste, jncluding (but not limited to) activities authorized to be carried out under the Waste Isolation Pilot Project under section 213 of Public Law 96-164 (93 Stat. 1265).

"gg. The term "precautionary evacuation" means an evacuation of the public within a specified area rear a nuclear facility, or the transportation route in the case of an accident involving transportation of souree material, spectal nuclear matertal, byproduct material, high-level radioactive waste, spent nuclear fuel, or transuranic waste to or from a production or utilization facility, if the epracuation is-

(1) this result of any event that is not classified as a nuclear incident but that poses imminent danger of bodily ajury or property damage from the radiological properties of source material, special muclear material, byproctuet nuterial, higblevel radioactive waste, spent nuclear fuel, or transuranic waste, and causes an evacuation; and

(2) ipitiated by an official of a State or a political subdivision of a State, who is authorized by State jaw to initiate such an evacuation and who reasonably determined that such an evacuation was necessary to protect the pubijc health and safect.

bh. The tern "public liability action", as used in section 170, means any suit asserting public liabilíty. A public liability action - shall be deened to be an action arising under section 170 , and the substautive rules for decision in such action shall be derived frotn the law of the State in which the nuclear incident infolved occurs, uriess such law is inconsistent with the provisions of such section.

ji. Iegal Costs,-As used in section 170, the term "legal costs" thears the costs incurred by a plaintiff or a defendant in initiating, - prosecuting, investigating, settling, or defending clainas or suits for dannages arising under such section. 
Office.

42 USC

$\sec 2033$

General Manager,

Deputy and

Assistant General

Managers.

42 USC sec. 2034

\section{CHAPTER 3-ORGANIZATION}

"Sec. 23.19 Office--The principal office of the Commission shall be in or near the District of Columbia, but the Commission or any duly authorized representative may exercise any or all of its powers in any place; however, the Commission shall majutain an office for the service of process and papers within the District of Columbia.

"Sec. 24,20 General Manager, Deputy and Assistant General Managers.-There is hereby established within the Commission-

"a. a Geperal Manager, who shall be the chief executive officer of the Commission, and who shatl discharge such of the adninistrative and executive functions of the Commission as the Connmission may direct. The General Manager shall be appointed by the Commission, shall serve at the pleasure of the Commission, and shalt be removable by the Commission. 21

"b. a Deputy General Manager, who shall act in the stead of the General Manager during his absence when so directed by the General Manager, and who shall perform such other administra. tive and executive functions as the General Manager shalt direct.

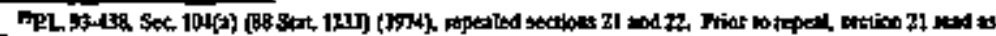
(1)

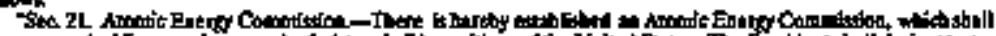

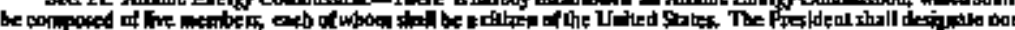

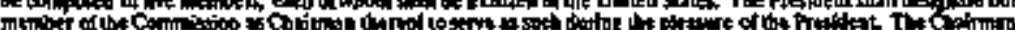
my best

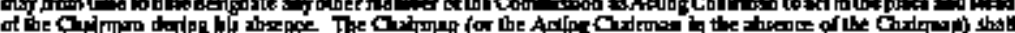

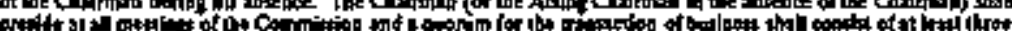

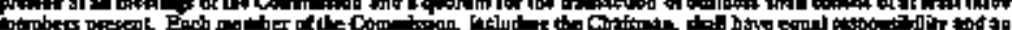

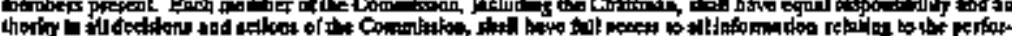

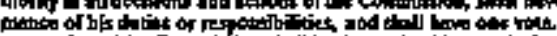

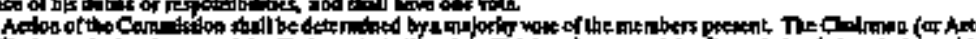

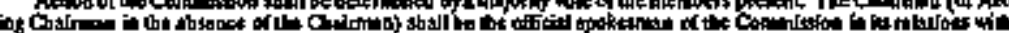

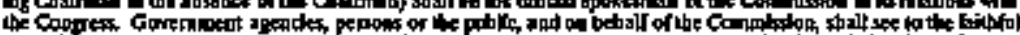

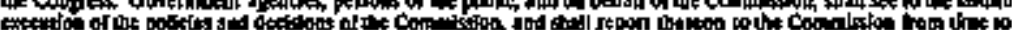

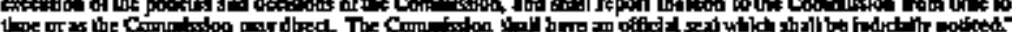

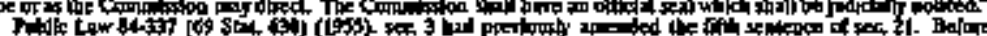

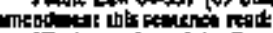

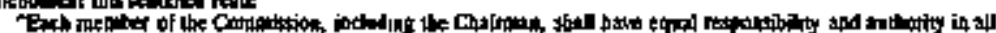

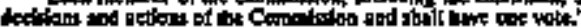

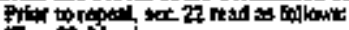

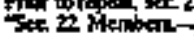

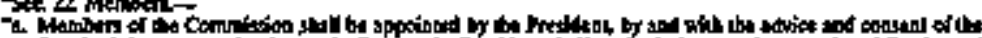
Stouts In the

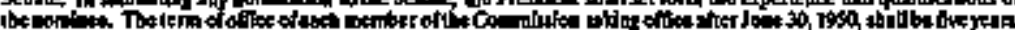

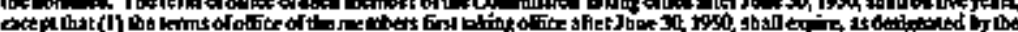

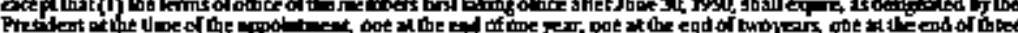

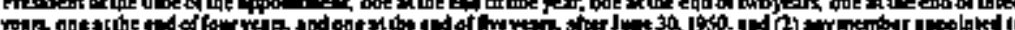

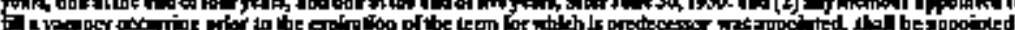

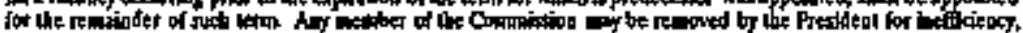

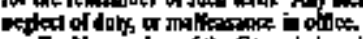

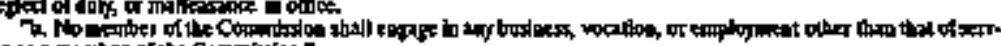

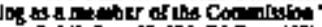

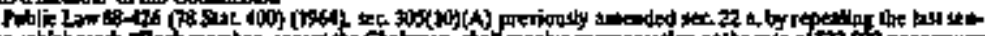

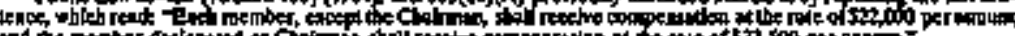

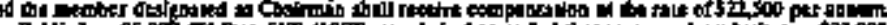

P.

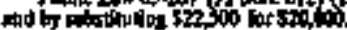

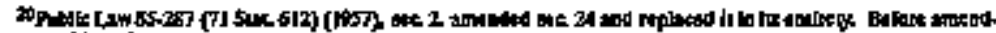

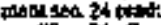

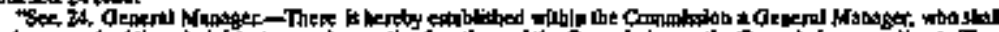

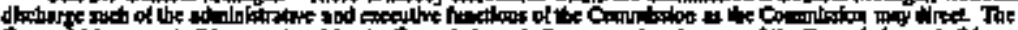

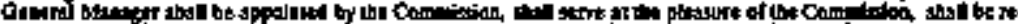

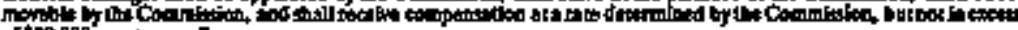

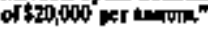

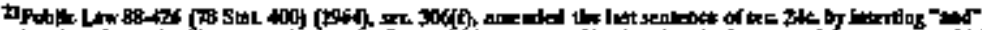

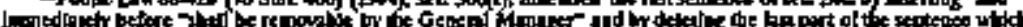

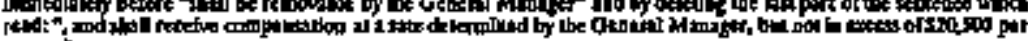
istiont 
Divisions ánd

offices.

42 USC sec, 2035.

Assistant General

Manager for

Military

Applitation.

Program divisions.

General Connsel.

The Deputy General Manager stall be appointed by the General Manager with the approval of the Comnission, shall serve at the pleasure of the General Manager, and shall be removable by the General Manager. 22

"..c. Assistant Oeneral Managers, or their equivalents (not to exceed a total of three positions), who shalt perform such administrative and executive functions as the General Manager shall direct. They shall be appointed by the Genteral Mantager with the approval of the Commisston, shall serve at the pleasure of the Geperal Manager, and shall be removabte by the General Mazagte. 23

"Sec. 25. Divisions, Offices, And Positions. ${ }^{24}$-There is hereby established within the Commission-

"a, A Division of Military Application and such other program divisions (not to exceed ten in number) as the Commission may determine to be necessary to the discharge of its responsibilities, including a division of divisions the primary responsibilities of which include the development and application of civilion uses of atomic energy. The Division of Military Application shall be under the direction of an Assistant General Manager for Military Application, who shall be appointed by the Commission and shal] be an active commissioned officer of the Armed Forces serving in general or flag officer rank or grade, as appropriate. Each other program division shall be under the direction of a Director who shall be appointed by the Conumission. The Commission shall require each such division to exercise stach of the Commission's administrative and executive powers as the Commission may determine:25

b. an Office of the General Counsel under the direction of the General Counsel who shall be appointed by the Comanissian; 26 and

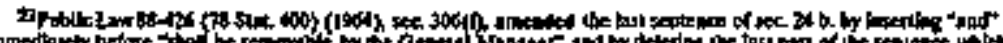

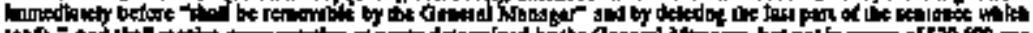

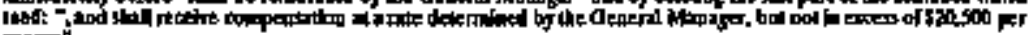
menpr".

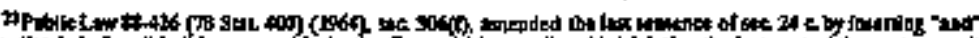

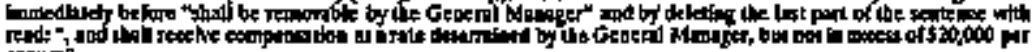
ancinn?

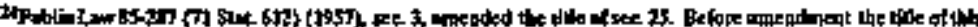

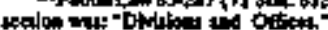

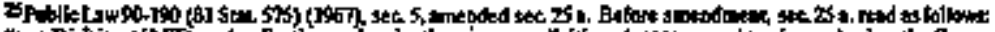

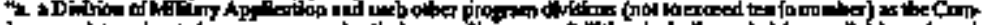

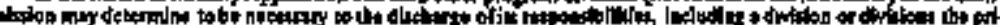

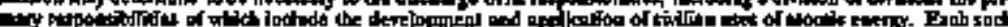

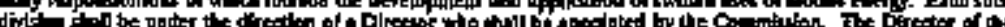

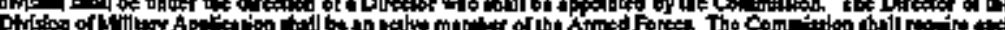
DWipe of the

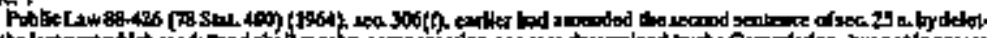

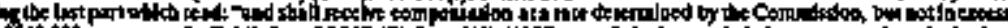

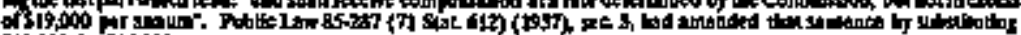

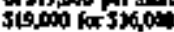

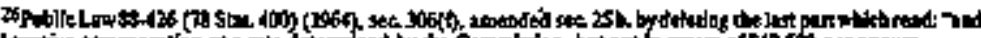

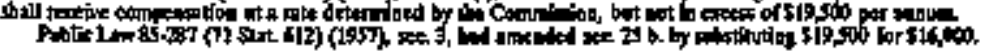


"c. an Inspection Division under the difecton of a Director who shall be appointed by the Commission 27 The Inspection Division shall be respomsible for gathering finformation to show whether or not the contractors, licensees, and officars and employees of the Commission are complying with the provisions of this Act (except those provisions for which the Federal Burean of Investigation is resporsible) and the appropriate rules and regulations of the Commission.

“d, such other executive management positions (not to exceed six in number) as tho Commission may determine to be necessary to the discharge of its responsibilities. Such positions shall be establisbed by the General Manager with the approral of the Commission. They shall be appointed by the General Manager with the approval of the Commission, shall serve at the pleasure of the Generaf Manager, and shall be remowable by the General Manager. 28

4Sec, 26.89

"Sec. 27.30

Appointment of Army, Navy or Air Force Officers.
"Sec. 28. Appointment Of Army, Navy, Or Air Force Ofiners-DNotwithstanding the provisions of any other law, the officer of the Army, Navy, or Air Force serving as Assistant Geueral Manzer for Mititary Application shall serve without prejudice to hits commissioned status as

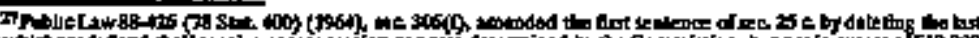

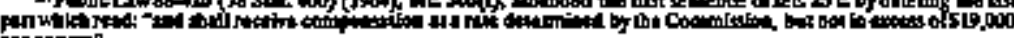
cr andim

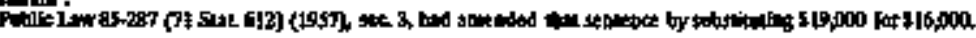

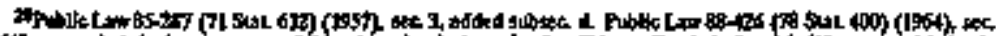

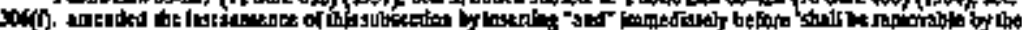

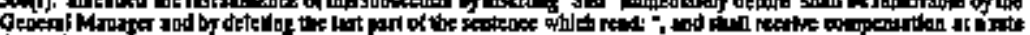

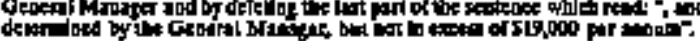

29 -

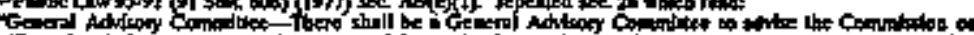

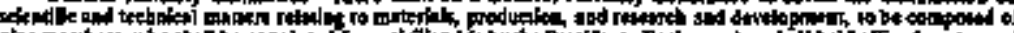

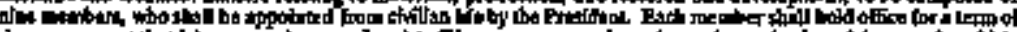

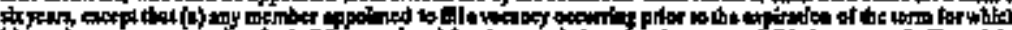

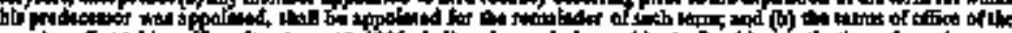

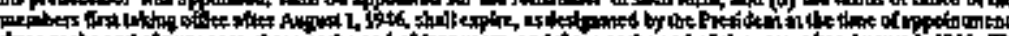

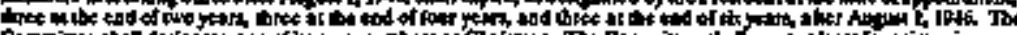

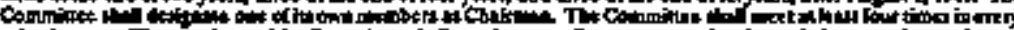

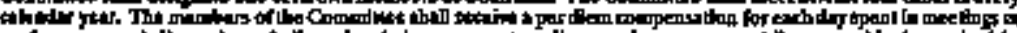

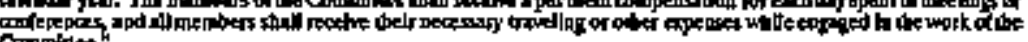
Convides

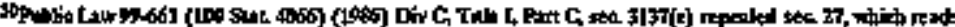

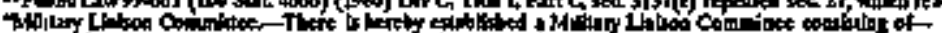

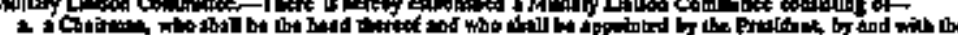

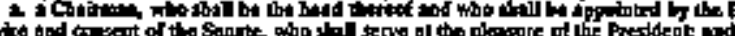

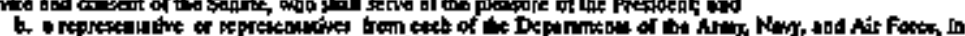

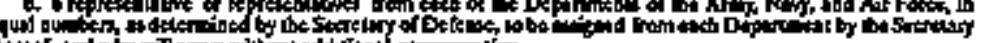

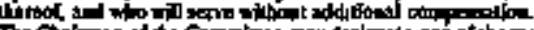

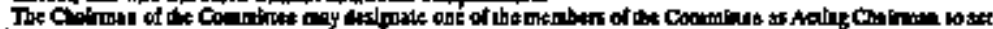

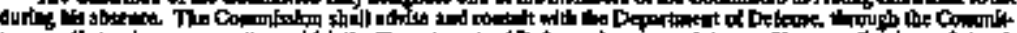

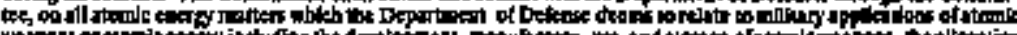

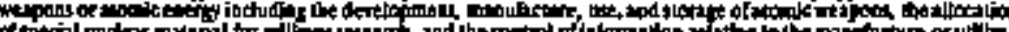

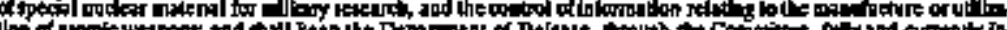

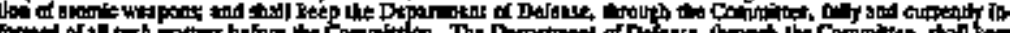

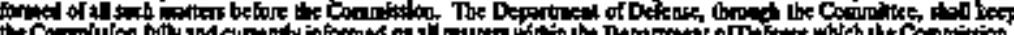

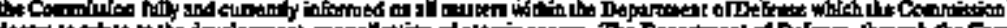

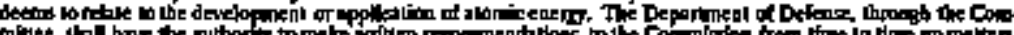

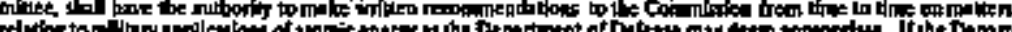

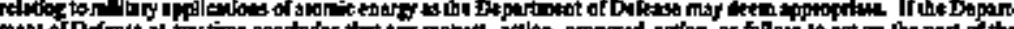

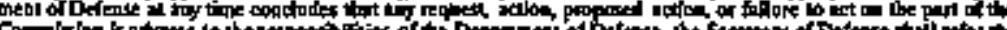

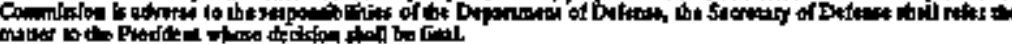


42 USC, $\sec 2038$

Chaiman, Military Liaison Committee.

Committee on Reactor Saftguards. 42 USC sec. 2039

Research assistance. such officer. Any such officer serving as Assistant General Manager for Military Application shall receive for addition to his pay and allowanoes, including special and incentive pays, for which pay and allowances the Commission shall reimburse his service, an amount equal to the difference benween such pay and allowances, including special and incentive pays, and the cormpensation established for this position ${ }^{31}$. Notwithstanding the movisions of any other Iaw, any active or retired otficer of the Amny, Navy, or Air Foroe may serve as Chaiman of the Military Liaison Committee without prejudice to his active or retired status as such officer. Any such officer serving as Chairman of the Military Liaison Conunittee shall receive, in addition to his pay and allowances, induding special and incentive pays, or in addition to his retired pay, an amount equal to the differerce between suck pay and alowances, including special and incentive pays, or between his retired pay, and the compensation prescribed for the Chairman of the Military Liaison Committee.

"Sec 29. Advisory Committee On Reactar Safeguards.There is hereby established an Aơvisory Committee onReactor Safeguards corsisting of a maximum of fifteen members appointed by.the Commission for terms of four years each. The Committee shall reviev. safety studies and facility license applications referred to it and shall make reports thereon, shall advise the Commission with regard to the hazards of proposed or existing reactor facilities and the adequacy of proposed reactor safety standards, and shall performs suct other duties as the Commission may request. One member shall be designated by the Committee as its Chairman. The members of the Committee shal] receive a per diem compensation for each day spent in meetings or conferences, or other work of the Committec, and all members shall receive their necessary traveling or other expenses while engaged in the work of the Committee. The provisions of section 163 shall be applicable to the Committee. ${ }^{32}$ In addition to its other duties under this section, the Committee, making use of all available sources, shall undertake a study of reactor safety research and prepare and submit anzually to the Congress a report containing the results of stich study. The first such report shall be stubmitted to the Congress not later than December 31, 1977.33 .

\section{"CHAPTER 4-RESEARCH}

"Sec. 31. Research Assistance.-

"a. The Commission is directed to exercise its porrers in such

31 P. mebl teac srowotis Fid of foilons

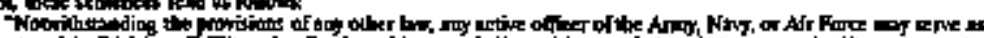

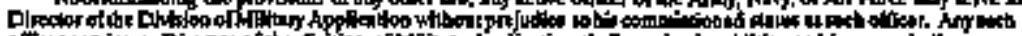

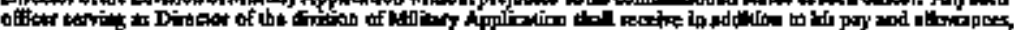

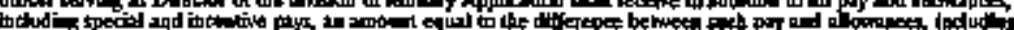

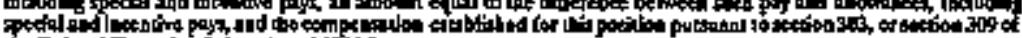

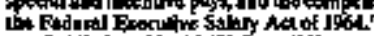

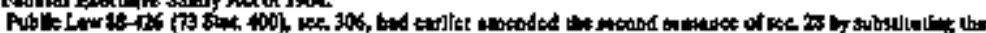

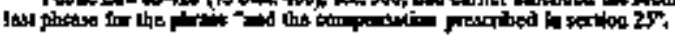

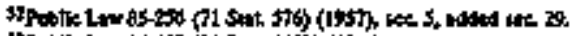

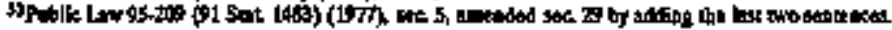


manner as to insure the continued conduct of research and deve]opment and training 34 activities in the fields specified below, by private or public institutions or persons, and to assist in the acquisition of an ever-expanding fund of theoretical and practical knowiledge in such fields. To this end the Connuission is authorized and directed to make arrangements (including contracts, agreements, and loaus) for the conduct of research and development activities relating to-

"(1) nuclear processes;

(2) the theory and profuction of atomic energy, including processes, materials, and devices related to such production;

"(3) utilization of special nuclear material and radiosctive material for Jeedical, biological, agricultural, health, or military purposes;

"(4) utilization of special nuclear material, atomic energy, and radioactive material and processes entailed in the utilization or production of atomic energy or such material for all other purposes, including indestrial or commercial uses, the generation of usable energy; and the denonstrition of ad. vances in the coromercial $\sigma \pi$ industrtal application of atonic energy, 35

"(5) the protection of health and the promotion of safety dirting reseasch and production activities, and

(6) the preservation and enhancement of a viable environment by developing gore efficient methods to meet the Nation's energy needs. 36

Grants for construction of reactors, etc.

41 USC 252(c). (See 41 USC $260 \mathrm{~b})$.)

"b. The Commission is further authotized to make grants and contributions to the cost af construction and operation of reactors and other facilities and other equiprnent to colleges, universities, hospitals, and eleenosynary or chatitable instítutions for the conduct of educational and training activities relating to the fields in subsection $\mathrm{a}^{37}$

"c. The Comunission may (1) make arrangernepts pursuant to this section, without regard to the provisions of section 3709 of the Revised Statutes, as amended, upon certification by the Commission that such action is necessary in the interest of the common defense and security, or upon a showing by the Commission that advertising is not reasonably practicable; (2) make partial and advance payments under such arrangements; and (3) make avallable for use in connection therewith such of its equipment and facilities as it may deem desirable.

"d. The arrangements made pursuant to this section shall contain such provisions (1) to protect health, (2) to mjnimize danger

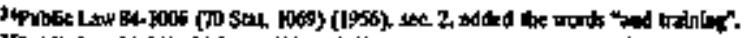

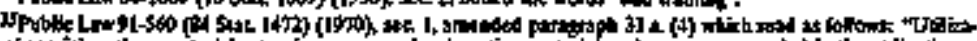

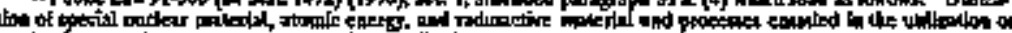

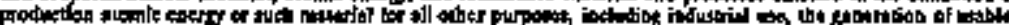

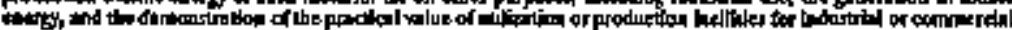
purpotis tor.

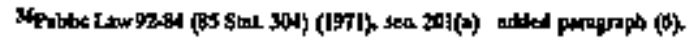

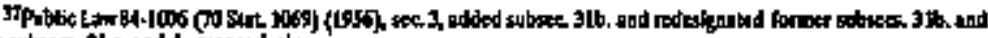

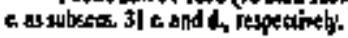


Research by the Commission.

42 USC

sec. $20 \$ 2$

Research for others. 42 USC

sec. 2053

Ownership and cperation of production facilities. 42 USC sec. 2061 to life or property, and (3) to require the reporting and to permit the inspection of work performed thoretander, as the Commission may dotermine. No such arsangentent shall contain any provisions or conditions which prevent the dissemination of scientific or technical information, except to the extent such dissesnination is prohibited by law.

"Sec, 32. Research by the Commisston,-The Commission is authorized and directed to conduct, through its own facilities, activities and studies of the types spectified in section 31.

"Sec- 33. Research For Others.-Where the Commission finds private facilities or laboratories are inadequate for the puspose, it is authorized to conduct for other persons, through its own facilities, stch of those activities and studies of the types specified in section 31 as it deems appropriate to the development of energy..$^{38}$ To the extent the Commission determines that private facilities or laboratories are inadequate to the purpose, and that the Commission's facilities, or scientific or technical resources have the potential of lending significant assistance to other persons in the fields of protection of public bealth and safety, the Connmisston may also assist other persons in these fields by conducting for such persons, through the Comrnission's own facilities, research and development or training activities and studies. The Commission is authorized to determine and make such charges as in its discretion may be desirabte for the conduct of the activities and studies referred to in this section. ${ }^{39}$

\section{"CHAPTER 5-PRODUCTION OF SPECIAL NUCLEAR MATERIAL}

"Sec. 41. Ownership and Operation of Ytoduction Facilities.-

"a. OWNERSHIP OF PRODUCTION FACHITIES-The

Commission, as agent of and on behalf of the United States, stall be the exclusive owner of all production facilities other than faciltties which (1) are usefenl in the condict of research and development activities in the fields specified in section 31, and do not, in the opinion of the Commission, bave a potential production rate adequate to enable the user of such factities to produce within a reasonable period of time a sufficient quantity of special nuclear material to produce an atomic weapon; (2) are licensed by the Commission pursuant under this title; or (3) are owned by the United States Enrichment Corporation. ${ }^{39}$

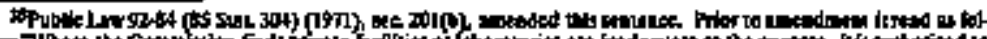

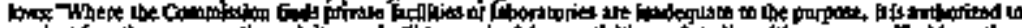

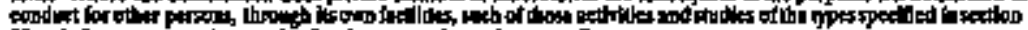

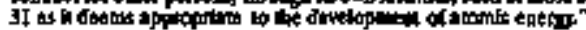
lom:

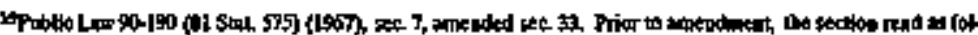

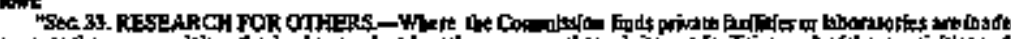

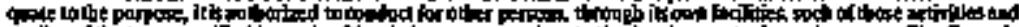

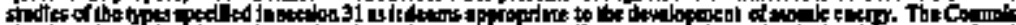

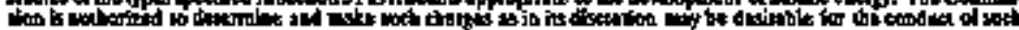
animites an shodlex"

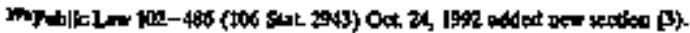


Operation of the Comrnission's production facilities.

41 USC 252(c)

(See 41 USC 260(b).)

Operation of otber puoduction facilities.

Irradistion of materials. 42 USC sec. 2062

Acyuisition of production facilities. 42 USC sec, 2063

44 USC 252(c) (See 41 USC 260(b). "b. OPERATION OFTHE COMMISSION'S PRODUCTION FACILITIES.-The Commission is authorized and directed to produce or to provide for the production of special nuctear materi* al in its own production facilities. To the extent deemed necessary, the Cormission is authorized to make, or to continue in effect, contracts witt persons obligating them to prodice special nuclear material in facilities owned by the Commission. The Commission is also atthorized to enter tuto research and development contracts authorizing the coptractor to produce special nuclear material in facilities owned by the Commission to the extent that the prodiction of such special nuclear material may be incident to the conduct of research and development activities under such contracts. Any contract entered into under this section shall contain provisions (1) probibiting the contractor from subcontracting any part of the work he is obligated to perform under the contract, except as authorized by the Commission; and (2) obligating the contractor $(A)$ to make such reports pertaining to activities under the contract to the Comjaission as the Commisston may require (B) to submit to inspection by employees of the Comentission of al such activities, and (C) to comply with all safery and stecurity ragulations which may be prescribed by the Conmission. Any contract made under the provisions of this paragraph may be made without regard to the prowisions of section 3079 of the Revised Statues, as amended, upon certification by the Commission that such action is necessary in the interest of the common defense and security, or upon a showing by the Commission that advertising is not reasonable practicable. Partial and advance payments may be made usder suef contracts. 40

"c. OPERATION OF OTHER PRODUCTION FACILJTIES. $\rightarrow$ Special nuclear material may be produced in the facilities which under this section are not required to be owned by the Commission.

"Sec. 42. Irradiation of Materials. - The Commission and persons lawfulby producing or utilizing special nuclear material are authorized to expose naterials of any kind to the radiation incident to the processes of producing or utilizing special nuclear material.

"Sec. 43. Acquistition of Production Facillttes,-The Commission is authorized to purchase any interest in facilities for the prochtetion of special nuclear materials, or in real property on which such facilities are located, without regard to the provisions of section 3709 of the Revised Statutes, as amended, upon certification by the Commission that such action is necessary in the interest of the common defense and security, of upon a showing by the Commission that advertising is not reasonabiy practicable. Partiol and advance payments may be made under contracts for such porposes. The Commission is further authorized to requisition, condemn, or otherwise acquire any interest in such production factilities, or to condemn or otherwise acquire stich real property, and just compensation shall be made therefor.

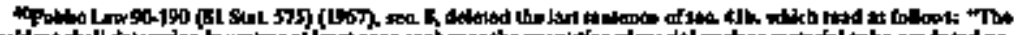

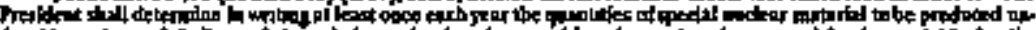

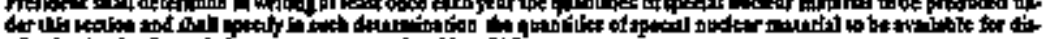

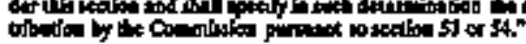


Disposition of energy. 42 U\$C set. 2064

pecial nuclear material.

42 USC sec. 2071

Nuclear material licenses 42 USC sec 2073
"Sec 44. Disposition of Energo-If energy is produced at: production facilities of the Conanission or is produced in experinantal utilization facilities of the Commission, such energy may be used by th: Comilnission, or transferred to other Govenment agencies, or sold to publicky, cooperatively, or privately owned utilities or users at reasonable and nondiscriminatory prices:if the energy produced is electric energy, the price shall be subject to regulation by the appropriate agency having jurisdiction. In contracting for the dispostal of such energy, the Commission shatl give preference and priosity to public bodies and oooperatives or to privately owned utilities providing electric utility services to high cost areas not being served by public bodies or cooperatives. Nothing in thits Act shall be construed to authorize the Commission to engage in the sale or distribution of energy for commercial use excopt sach entrgy as may be produced by the Commission incitent to the operation of research and development facilities of the Commission, or of production facilities of the Commission.

\section{CFLPTER 6- SPPCCLAL NUCLLAR MATERUL}

- “Sec. 51. Special'Nuciear Material-The Commission may determine from time to time that other material is special nuclear material in addition to that specified in the definition as special muctear material. Before unaking arry such detertmination, the Commission must find that such material is capable of relea'sing substantial quantities of atomic energy and toust find that the determination that such material is special muclear maferial is in the interest of the common defense and security, and the President must have' expressly assented in writing to the detemination. The Commission's deterimtmation, together with the assent of the President, shat be submitted to the Joint Conmitte** ard a perod of thithy days shall elapse while Contress is in session (in coinputing such thitty days, there shan be exchuded the days on which etther House is not in sestion because of an adjournment for more than thete days) befort the determination of the Commission may beicomp effective: Provided however, That the Joint Committee after having received such determination, may by resolution in writing, waive the conditions of or all or any portion of such thirty-day perjod.

"Sec. 53,41 Domestic Distribution of Special Naclear Material-

"a. The Commission is authorized (i) to issued licenses to trans-" fer or recotwe in interstate commerce, transfer, deliver, acọuire, posstss, own, receive possession of or title to, import, or export under the tems of an asgeement for cooperation arranged pur-

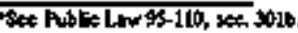

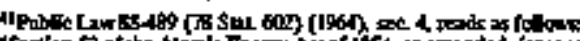

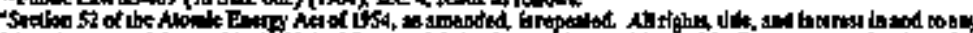

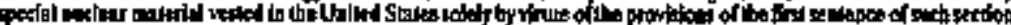

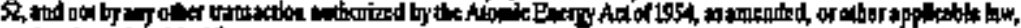

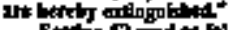

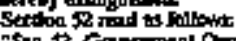

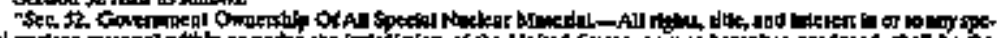

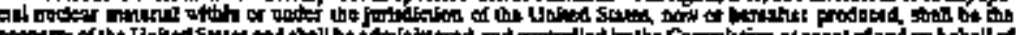

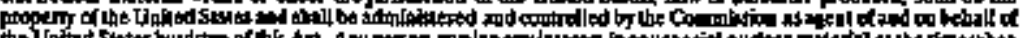

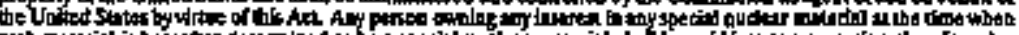

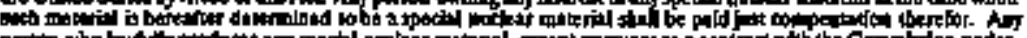

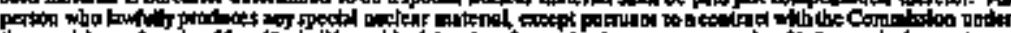

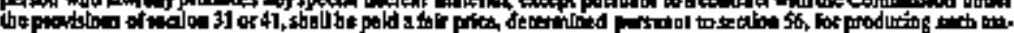
tor- 
suant to section 123, special nuclear materjal, (ii) to make special ntelear material available for the pertod of the license, and, (iij) to distribute special nuclear material within the United States to qualified applicants requesting such material-..42

"(1) for the conduct of research and development activities of the types spectified in section 31;

"(2) for use in the conduct of research and development activities or in redical therapy under a license issued pursuant to section 104;

"(3) for use under a license issued pursuant to section 103;

"(4) for suchs other uses as the Commission determines to be appropriate to carry out the purposes of this Act. ${ }^{43}$

"b. The Commisston shalt establish, by rule, minimum ctiteria for the issuance of specific or general licenses for the distribution of special nuclear naterial depending upon the degree of importance to the common defense and security or to the health and safety of the public of-

"(1) the pinysical characteristics of the special nuclear materjal to be distributed;

"(2) the quantities of spectial nuclear material to be distributed; and

"(3) the intended use of the special nuclear material to be distributed.

"c. (1) The Conmission may distribute special nuclear naterial licensed under this section by sale, lease, lease with option to buy, or grant. ${ }^{44}$ Provided however, That unless otherwise authorized by

Distribution. Jaw, the Commission shall not after December 31, 1970, distribute spectal nuclear material except by sale ${ }^{44 a}$ to any person who possesses or operates a utilization facility under a license pursuant to section 103 or $104 \mathrm{~b}$. for use in the course of activities under such license; nor shall the Commission perrit any such person after June 30, 1973, to continue leasing for use in the course of such activities special nuclear material previously leased to such person by the Comuission.

"(2) The Comntission shall establish reasonabie stajes prices for the special auclear material licensed and distributed by sale under this section. Such sales prices shall be established on a nondiscriminatory basis which, in the opirion of the Conmission, will provide reasonable compensation to the Govern. ment for such spectal nuclear material.

Agreements.

"(3) The Commission is authorized to enter into agreements with licensees for such pertod of time as the Commission may deem necessary or desirable todistribute to such licensees such

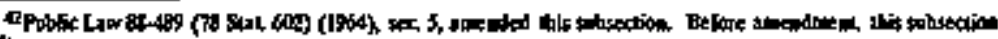

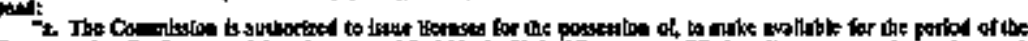

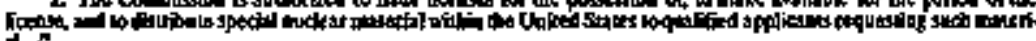

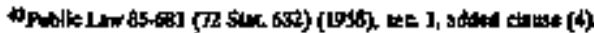

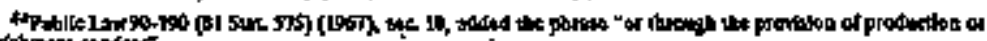
earichinster semiots.

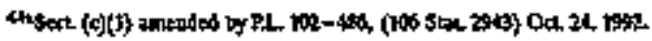


quantitites of spectial matedear materfal as nay be ntcessary for the conduct of the licensed activity. In such agreements, the Commission may agree to repurchase any special nuclear material licensed and distributed by sale which is not consumed in the course of the licensed activity, or any uranium remaining after irradiation of such special nuclear material, at a repurchase prico not to exceed the Commission's sale price for comparable special nuclear material or uranium in effect at the time of delivery of such material to the Commission.

"(4) The Commission may make a reasonable charge, determined pursuant to this section, for the use of special nuclear material licensed and distributed by lease under subsection 53 a.(1), (2) or $(4)^{45}$ and shall make a reasonable charge determined perrsuant to this section for the use of special nuclear material licensed and distributed by lease under subsection 53 a. (3). The Commission shall establish criteria in writing for the determination of whether special nuclear material will be dis, tributed by grant and for the deternination of whether a charge will be mode for the use of spectal nuclear material licensed and distributed by lease under subsection $53 \mathrm{a}$ (1), (2) or (4), corstidering, among other things, whether the licensee is a nonprofit or eleemosynary institution and the purposes for which the special nuclear material will be used. ${ }^{4}$

"di. In determining the reasonable charge to be made by the Commission for the use of special nuclear material distributed by lease ${ }^{47}$ to licensess of ubilization or prodaction facilities licensed pursuant to section 103 or 104, in addition to consideration of the cost therreof, the Commission shall take into consideration-

"(1) the use to be made of the spexial nucleas material;

"(2) the extent to which the use of the special nucleter naterial will,advance the development of the peaceful uses of atomic entrgy;

"(3) the energy value of the special nuclear nuaterial in the particular use for which the license is issued;

"(4) whether the special nuctear material is to be used in faeilitites licensed porsuant to section 109 or 104 . In tints respect, the Commission shall, insofar as practicable, make vniform, pondiscriminatory charges for the use of special nuclear material distributed to facilities licensed pursuant to section 103; and

"(5) with respect to special nuclear material consumed in a facility licensed pursuant to section 103 , the Commission shall

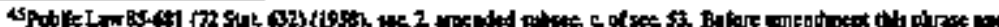

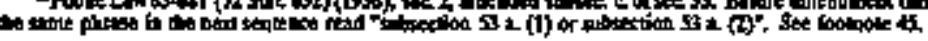

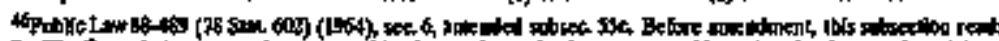

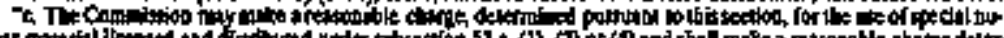

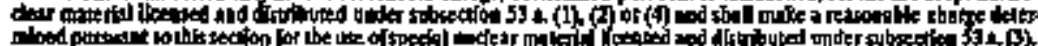

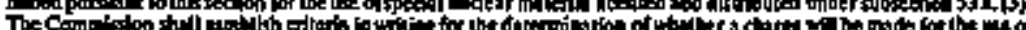
The Cor.

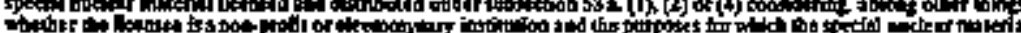
mitiod

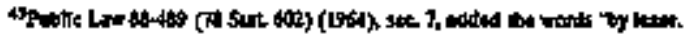


License condjtions.

Distribution for independent research, etc.
IIfake a further charge equivalent to the sale price for siunilar special ruckear material established by the Commission in accordance with subsection $53 \mathrm{cs}(2)$, and the Conmission may make such a charge with respect to such material consumed in a facility licensed pursuant to section 104.48

"e. Each license issued pursuant to this section shall contain and be stbject to the following conditions-

"(2) 49 no right to the special nuclear material shall be conferred by the license except as defined by the license;

"(3) neither the license nor any Iight tonder the license sball be assigned or otherwiss transferred in violation of the provisions of this Act:

"(4) all special nuclear material shall be subject to the right of recapture or control reserved by section 108 and to all other provisions of this Act;

"(5) no special nucloar material may be used in any utilization or production facility except to accordance with the provisions of this Act,

"(6) special nuclear material shall be distributed only on terins, as may be established by rule of the Commission, such that no user will be permitted to construet an atomic weapon;

"(7) special nuclear material shall be distributed only puIsuant to such safety standards as may be established by rule of the Commission to protect health and to minimize danger to life or property; and

"(8) except to the extent that the indemrification and bimita+ .tion of liability provisions of section 170 apply, the license will hold the United States and the Commission harmless from any damages resulting from the use or possession of special nuclear material by the licensee. 50

af. The Commission is directed to distribute within the United States sufficient special nuclear material to permit the conduct of widespread independent research and development activities to the maximum extent practicable. 51 In the event that applications for spectiol nuclear material exceed the amount available for distribution, preference shall be given to those activities which are most likely, in the opinion of the Commission, to contribute to basic research, to the development of peacetime uses of atomic energy, or to the economic and mititary strength of the Nation.

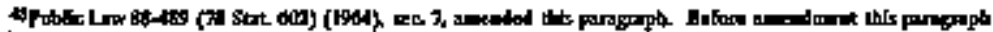
regits

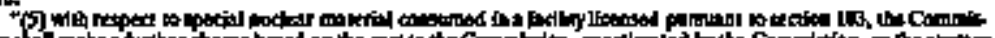

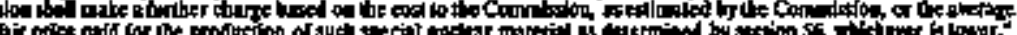
Dpatiel o f

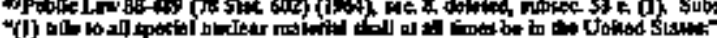

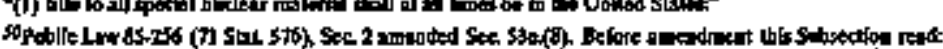

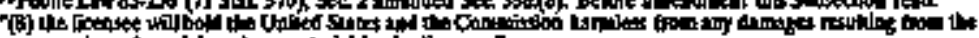

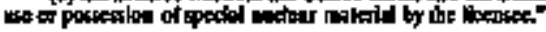

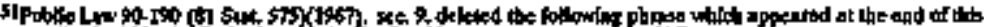

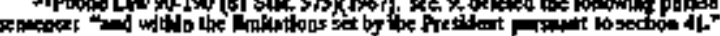

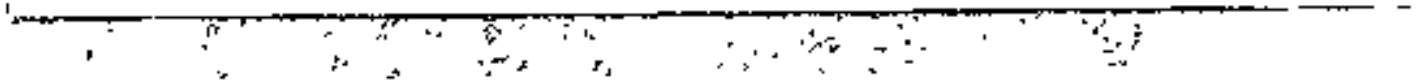


Foretign diștribution of special nuciear material, 42 USC sec. 2074.
"Sec. 54. Foreigen Distribution Of Special Nuclear Materkal,-a The Commission is authorized to cooperate with ary nation or group of notions by cistributing special nuclear material and to distribute such special nuclear material, pursuant to the terms of an agreement for cooperation to which such nation or group of nations is a party and which is niade in accordance with section 123 . Unless bereafter otherwise authorized by law the Commission shall be compensated for special nuclear material so distributed at not less than the Commission's published charges applicable to the domestec distribution of such material, except that the Commission to assist and encourage research on peaceful uses or for medical therapy may so distribute without charge during any calendar year only a quantity of suct matovial which at the time of transfer does not exceed in value $\$ 10,000$ in the case of one nation or $\$ 50,000$ in the case of ang group of gations. The Commission may Gistribute to the International Atomic Energy Agency, or to any group of nations, only such amounts of special muclear raterials and for such period of time as are authorized by Congress: Provided, however, That (i) notwithstandisg this provision, the Cormonission is herteby aulthorized, sutyject to the provisions of section 123, to distribute to the Agency, five thousand kilograms of contained uranium 235, five hundred grams of uranium-233, and three kilograms of plutonium, together with the amounts of special nuclear material which will match in amount the sum of all cquantities of specisl nuclear materials made available by all other members of the Agency to Jume 1, 1960; and (ii) rotwithstanding the foregoing provisions of this subsection, the Commission may distribute to the Internationel Atomic Energy Agency, or to any group of nations, stch other anounts of special nuclear materials and for such other periods of tome as are established in writing by the Cammission: Proulded, however, That before they ate established by the Coumission purstrant to this subdivision (ii), such proposed amounts and portiods shall bo submitted to the Congress and teferited to the Joint Committes ${ }^{\text {s2 }}$ and a period of sixty days shall elapos while Congress is in session (in cormputing such stxty days, there shall be excluded the days on which either House is not in session becatise of adjoumment of more than three days): And provlded further, That any sich proposed amounts and periods shall not become effective if during such sixty-day pertiod the Congress passes a concurrent resolution stating in substance that it does not favor the proposed action: And provided fur ther, That prior to the clapse of the first thirty days of any stech sixty-day perjod the Jotnt Committee shall stibmit a report to the Congress of its vieus and recommendations respecting the proposed amounts and periods and an accompanying proposed concurrent resolution stating in substance that the Conjress favors, or does not favor, as the case may be, the proposed amounts or periods. The Commission may agree to repurchase any special nuclear material distributed under a sale arrangement pirsuant to this subsection which is not consumed in the course of activities conducted jo atcordance with the agreement for cooperation, or any uraniure remaining after iradiation of such special nuclear material, at a repurchase

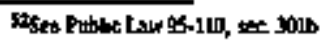


Foreigs distribution of certain materiak.

price not to exceed the Commission's sale price for comparable special nuclear material or uranium in effect at the time of delivery of such material to the Commission. The Conmission may also agree to purchase, consistent with and within the period of the agreement for conperation, special muctear material produced in a inciear reactor located outside the United Srates through the tase of special nuclear material which was leased or sold purstuant to this subsection. Under any stich agreement the Commission shall purchase only such material as is delivered to the Commisston dutisg any period when there is in effect a gataranteed purchase price for the same tiateriat produced in a suclear reactor by a person licensed under section 104, established by the Commission pursuant to section 56 , and the price to be paid shall be the price so established by the Commission and in effect for the same material delivered to the Cornmistion.

"b. Nowwithstanding the provisions of sections 123,124 , and 125 , the Commission is authorized to distribute to any person outside the United States (1) plutonium containing 80 percent centum or more by weight of plutonium-238, and (2) other special nuclear materat when it bas, in accordance with subsection $57 \mathrm{~d}$., exempted certain classes or quantities of such other special muclear material or kinds of uses or users there of from the requirements for a bicense set fortit in this chapter. Unless bezeafter otherwise autho. rized by law, the Commission shall be compensated for special nuclear material so distributed at not less than the Commisston's publistued charges applicable to the domestie distribution of such material. The Commission shall not distribute any plutoriun containing 80 per centum or more by weight of plutonum-238 to any person tuader this subsection if, in its opinjon, such distribution would be intuical to the cotmmon defense and security. The Conumisston may reguire such teports regarding the nse of material distributed pursuant to the provisions of this subsection as it deems necessary.

"c. The Commission is authorized to license or otherwise permit others to distribute special nuclear material to any person outside the United States under the same conditions, excepi as to charges, as would be applicable if the material were distributed by the Commission 55

"d. The atthority to distribute special muclear material under this section other than under an export license granted by the

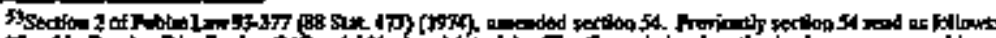

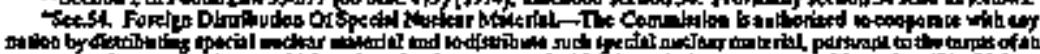

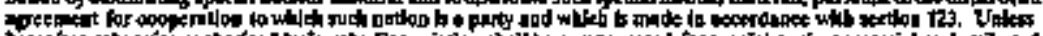

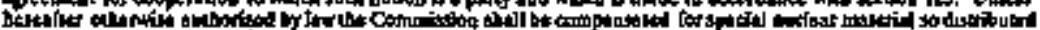

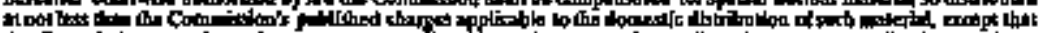

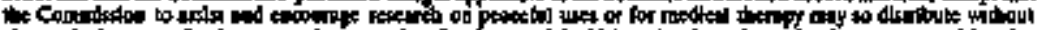
et.

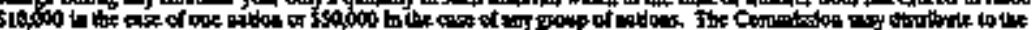

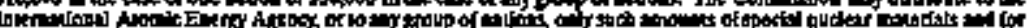

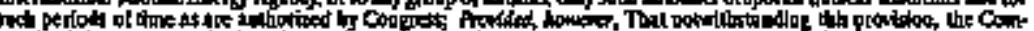

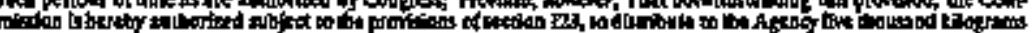

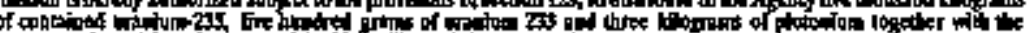

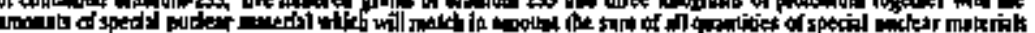

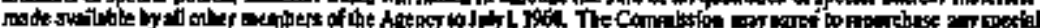

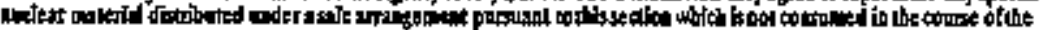

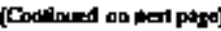


Acquísition

42 USC

sec. 20075 .

$41 \mathrm{JSC}$

252 (c)

(set 41 USC

260(b).)

Guaranted purchase prices.
Nuclear Regulatory Commission shall extend only to the followirg sroall quantitios of special nucleas material (jn no event more than five bundred grams per year of the uraniuar isotope 233, the uranium isotope 235, or plutoniain contáged in speciat nuclear material to any recipient):

"(l) which are contsined in laboratory samples, medical devices, or monitoring or other instuments; or

"(C) the distribution of which is needed to deal with an emergency situation in which tine is' of the essence.

ce. The authority in this stwction to connmit United States funds for any actuvities pursuant to any subsequent arrangement under section 131 a (2)(E) shall be subject to the requitements of section 131.54,

"Sec 55. Acqulstition.-The Commission is atuthorized, to the extent it deems necessary to effectuate the provisions of this Act, to purchase without regard to the limitations in section 54 or eny guaranteed pur. chase prices established pursuant to section 56 , and to take, requisition, condemn, or otherwise açuire any special nuclear material or any interest theswin. Any contract of purchase made under this section may be made without regard to the provisions of section 3709 of the Rovistd Statutes, as amended, upon certification by the Commission that such action is mecessary in the interest of the coraron defense and security, or upon a showing by the Commission that advertising is not reasonably practical. Partial and aovvance payments may be made under contracts for such purposes. Just compensation shall be made for any right, property, or interest in property taken, requisitioned, or con condemned under this section. ${ }^{55}$ Providing; That the authority in this section to commit United States funds for any activities purstuant to any subsequent arrangement under section 131 a.(2)(E) shall be subject to the requirements of section 131.5

"Sec. 56. Guaranteed Purchase Prices,-The Commission shall establish guaranteed purchase prices for plutonium produced in a nuclear reactor by a person licensed under section 104 and

\section{(Coolnma)}

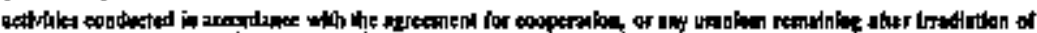

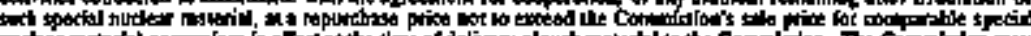

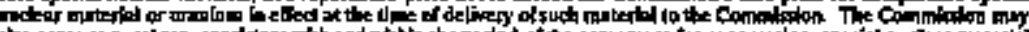

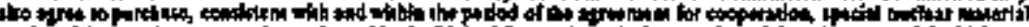

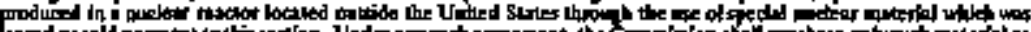

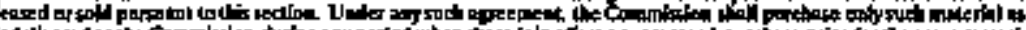

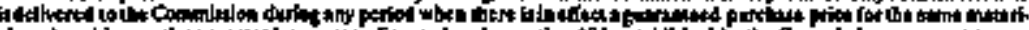

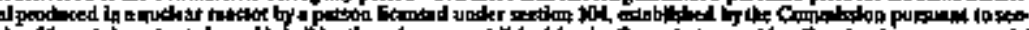

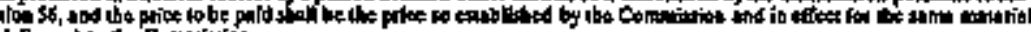

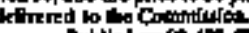

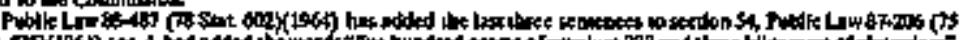

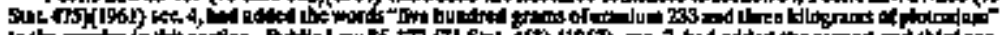

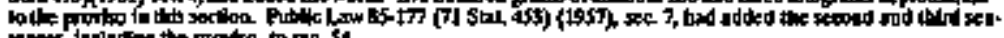

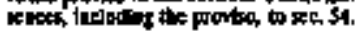

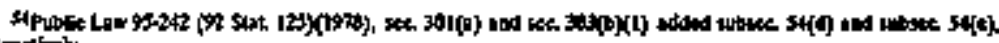
mosprationty

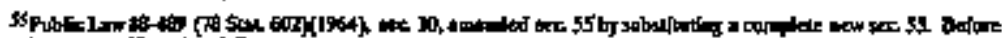

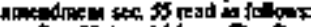

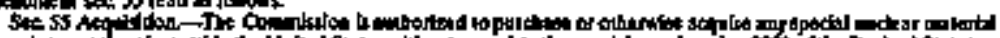

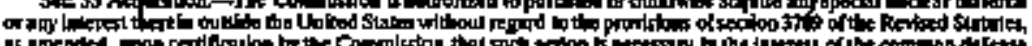

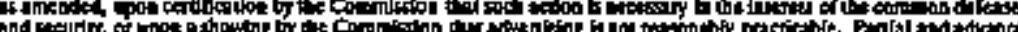

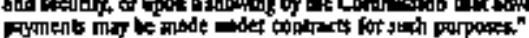

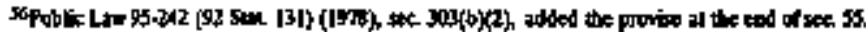


42 U.S.C. Sec. 2076 .

Unauthorized handling. 42 U.S.C. sec 2077 .

Special nuclear material production. Techrology transfers. 42 U.S.C. 2077

- Post, p. 142.

Post p. 127. delivered to the Commission before January 1,1971 . The Commission shall also establish for such periods of time as tt may deen necessary but not to exceed ten years as to any sucia period, guaranted ptirclase prices for uranium enricied in the isotope 233 produced in a juclear reactor by a person licensed under section 103 or section 104 and delivered to the Commission within the pertiod of the guarantec. ${ }^{57}$ Guaranteed purchase prices established under the authority of this section shall not exced the Commission's determination of the estimated value of plutonius or uranium enrictued in the tsotope 233 as fuel in nuclear reactors, and such prices sball be establisked on a non-discriminatory basis: Provided, That the Commission is authorized to establish such guaranteed putchase prices only for such plutonium or uranium enrictied in the isotope 233 as the Cotminission shall deternitioe is produred through the use of special nuclear material which was leased or sold by the Commission purguant to section 53.58

«sec. 57. Prohblition.--

"a. Unless autborized by a general or specific license issuked by the Commission, which the Commission is authotized to issute pursuant to section 53, no person may transfer or recejve in jiterstate commerce, transfer, deliver, accuire, own, possess, toceive possession of of title to, or jopport into of export from the United States any special nuclear material.

"b. It shall be unlawful for any person to directly or indirectly engage in the production of any special nuclear material outside of the United States except (1) as specifically authorized under an agreement for cooperation made pursuant to section 123, including a specific authorization in a subsequent arrangement under section 131 of this Act, or (2) upon althorization by the Sex-tary of Energy after a determination that such activity will not be inimical to the interest of the United States: Provided, That any suth determination by the Setretary of Energy shal] be made only with the conculretace of the Department of State and after consultation with the Arus Control and Disamment Agency, the Nuclear Regulatory Commission, the Department of Conutuerce, and the Departuent of Defense. The Secretary of Energy shall, within ninety days after the enactment of the Nuclear Non-Proliferation Act of 1978, establish ordetly and expeditious procedures, including provision for utcessary administrativs actions and intetagency mentoranda of understanding, which are rututually agree-

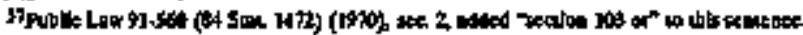

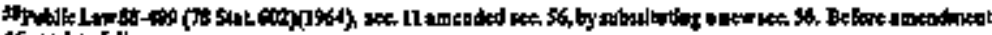

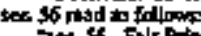

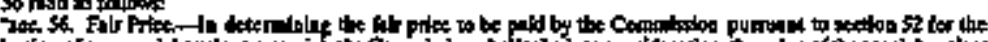

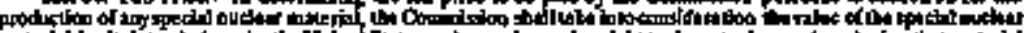

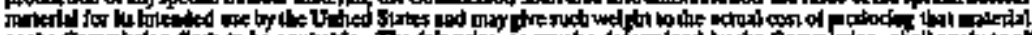

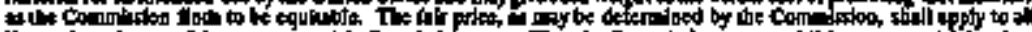
J[f

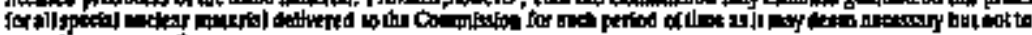
euted serat years. 
Authorization rexpuests, procedures.

Standerds and criteria.

Trede secrets, protection.

42 U.S.C. 2014. Pos, pp. 131, 141 .

42 U.S.C 7172

42 U.S.C. 2074 , 2094.

Anie, p. 125. able to the Secretaries of State, Defense, and Comunerce, the Director of the Arms Control and Dtsarmament Agency, and the Nuclear Rogulatory Commission for the consideration of requests for atthorization under this subsection. Such inocedures shall include, at a mintimum, explicit direction on the handing of ' such requests, express deadlines for the solicitation and collection of the views of the consulted agencies (with identified officials responsible for meeting strch deadlines), an inter-agency coordinating authority to mont tor the processing of such requests, predetermined procedures for the expeditious handling of intra.ggency

- and jnter-agency disagreements and appeals to hipher authorities, frequent meetings of inter-agency administrative coordinators to review the status of all pendìs requests, and similar administra-

tive mechanisms. To the extent practicable, an applicant should be advised of al the information requited of the applicant for the entire process for cvery agency's needs at the beginuing of the process.'Potentially controversial requests should be identified as quickly as possible so that any required poticy decisions or diplomatic consultajions can be initiated in a timely manner. An immediate effort should be' undertaken to establish quickly any recessary standards and witeria, jncluding the nature of only required assurances or evidentiary showings, for the decision required under this subsection. The processing of any requests proposed and filed as of the date of enactment of the Nuclear NonProliferation Act of 1978 shalt not be delayed pending the developipent and establishinent of procedures to implearent the requirements of this subsection. Any trade secrets or proprietary 'ruformation submitted by any person seeking an authorization uncer this' subsection shall be afforded the maximum degree of protection allowable by law: Provided fur ther That the export of component parts as defined in subsection 11 v. (2) or $11 \mathrm{cc}$. (2) shall be gowerned by sections 109 and 126 of this Act: Provided further, That notwithstanding subsection 402(d) of the Departatent of Energy Organtzation Act (Public Law 95-91), the Secretary of Energy and not the Federal Energy Regulatory Commission, shall bave sole jurisdiction within the Department of Energy over any matter arising from any function of the Secretary of Energy in this section, section 54 d., section 64 , or section 111 b. 59

"c. The Commission shall not-

"(l) distribute any special nuclear material to any person for a use which is not under the jurisdiction of the United States except pursuant to the provisions of section 54; or

"(2) distribute any speciad nuclear material or issue a license pursuant to section 53 to any person within the United States if the Compuission finds that the distribution of such special nuclear material or the jisuance of such license would be juinitical

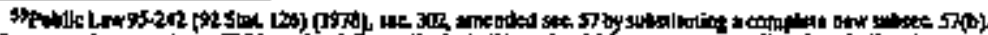

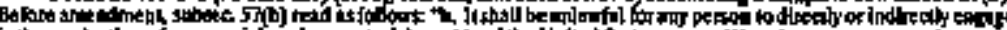

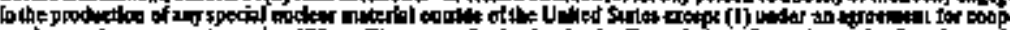

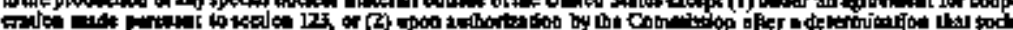

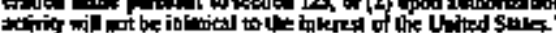


Certain exemptions.

Review

42 USC sec. 2078 to the common defense and steurity or would constitute an uareasonable risk to the health and safety of the public.

" $\mathrm{d}$. The Commission is authorized to establish classes of special nuclear material and to exempt certain classes or quantities of special nuclear material or kinds of uses or users from the requirements for a license set for th in this section when it makes a finding that the exerpition of such chasses or quantities of special nuclear material or such kinds of uses or users would not be injimical to the comutuon defense and security and woukd not constioute uneasonable risk to the bealth and safety of the public ${ }^{60}$

"e. Spewil nuclear material, as defined in section 11, produced in facilities licensed under section 103 or 104 may not be transferred, reprocessed, used, or otherwise made available by any instrumentality of the United States or any other person for nuclear explosive purposes." $" 61$

${ }^{4}$ Sec. 56. Review.-Before the Comnsission establishes ary guaranted

parchase price or guaranteed purchase price period in accordance with the provistons of section 56, or establishes any crittria for the waver of any charge for the use of special nuclear material lieensed and distributed under section \$3, the proposed guaranteed purchase price, guaranteed purchase price period, or criteria for the waiver of such charge shalt be submitted to the Joint Committes and a period of forty-five days shall elapse while Congress is in session (in computing such forty-five days there shall be excluded the days in which either House is not in session because of adjounnent for more than thet days): Provided however, That the Joint Comnittee, after having received the proposed guaranted purchase price, guaranted purchase price perjod, or criteria for the waiver of sikch charge, may by

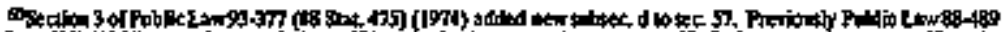

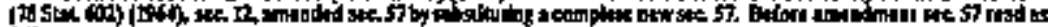
ollows.

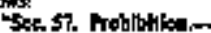

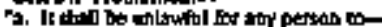

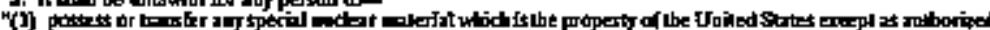

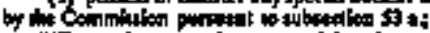

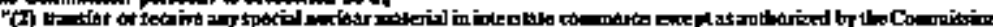

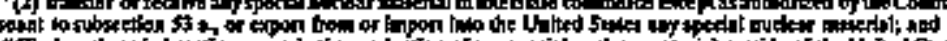

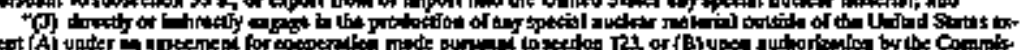

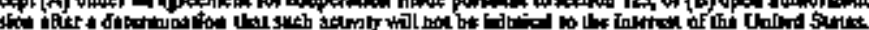

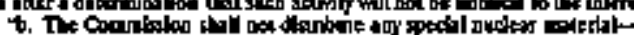

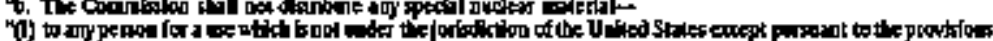
of

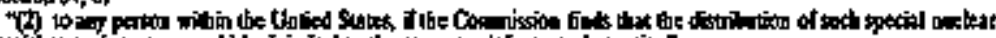

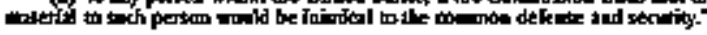

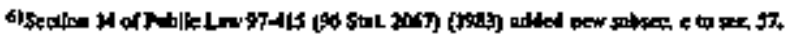


Iesolution in writing waive the conditions of, or all or any portion of, such forty-five day period. ${ }^{62,63}$

Source material 42. USC sec. 2091 .

Subrutttal of deternination to Joint Comumitles.

License for

transters requited 42 USC see 2092 .

Domestic distriturtion of souroe materiat. 42 USC sec. 2093.

Chages.

\section{"CHAPTER 7-SOURCE MATERIAL}

"Sec 61. Source Materlal.-The Comintssion may determine from tine to time that other material is source material in addition to those specified in the defirtition of source material. Before making such deteruiziation, the Commission must find that such material is essential to the production of special nucleat material and anust find that the determination that such material is source material is in the interest of the common defense and security, and the Président must kare expressly assented in writing to the determination. The Conmission's deter mination, together with the assent of the President, shall be submitted to the Joint Comnittee* and a greriod-of thirty days shall elapse while Congress is in session (in computiog such thirty days, there shall be encluded the days on which either House is not in sersion becaluse of an adjoutnment of more than three days) before the detertuination of the Commission aray become effective: Provided, however, That the Joint Committee, after having received such determination, way by resolution in writing warve the conditions of or all or any portion of such thirty-day period.

"Sec. 62. License For Transfers Required,-Unless authorized by a general or specific license issled by the Commission, which the Commission is hereby authorized to issue, no person may transfer or receive in interstate commerce, transfer, deliver, tecente possession of or title to, or import into or export from the United States any source material after removal from its place of deposit in nature, except that licenses shall not be required for quantities of source matterital which, in the opinion of the Commission, are umimportant.

"Sec 63. Domestic Distribution Of Sonrce Material-

*a. The Compuisston is authorized to issue licenses for and to distribute solvce material within the United \$tates to qualified applicants requesting such material-

(l) for the conduct of rosearch and development activities of the types specified in section 31 ;

"(2) for use in the conduct of research and development activities or in medical therapy under a license issued pursuant to section 104;

"(3) for use under license issued pursuant to section 103; or

"(4) for any other ust approved by the Commission as an atd to science or intustry.

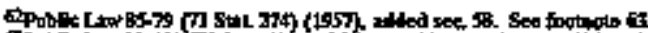

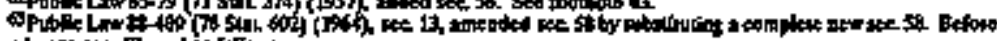

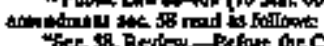

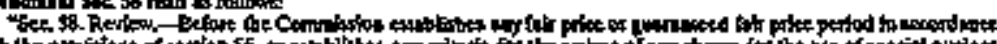

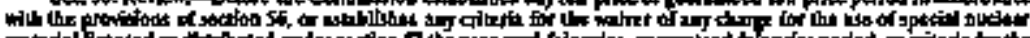

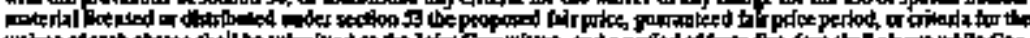

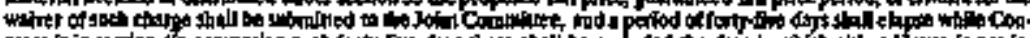

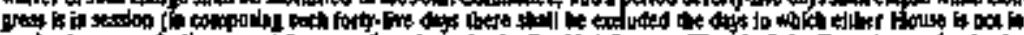

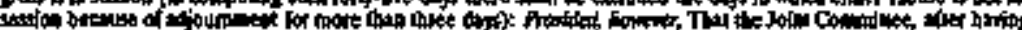

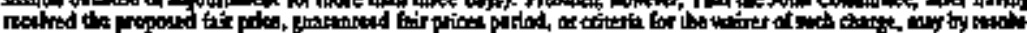

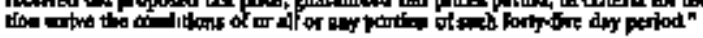

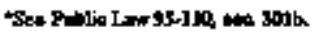


Foreign distribution of material. 42 USC sec. 2094.

42 USC 2094.

Reporting 42 USC sec. 2095 . 42 USC sec. 2096. "b. The Commission shall establish, by rule, minimum criteria for the issuance of specitic or general licenses for the distritbution of source naterial depending upon the degree of importance to the common defense and security or to the healtb and safety of the public of-

"(l) the physical characteristics of the source material to be distributed;

"(2) the quantities of source material to be distributed; and

"(3) the intended use of the source material to be distributed.

"c. Tbe Commission may make a reasonable charge deterutined pursuant to subsection $161 \mathrm{~m}$. for the source material licensed and distributed under subsection 63 a. (1), subsection 63 a. (2), or subsection 63 a. (4), and shall make a reasonable charge determined pursuant to subsection $161 \mathrm{~m}$., for the source material licensed and distributed under substection 63 a. (3). The Commission shall establish criteria in writing for the determination of whether a charge will be made for the source material licensed and distributed under subsection 63a. (1), subsection 63 a. (2), or subsection 63 a. (4), considering, among other things, whether the license is noiprofit or eleemosymary institution and the purposes for which the source material will be used.

Sec. 64. Foreign Distribution Of Source Material,-The Combission is authorized to cooperate with any nation by distributing source naterial and to distribute source material pursuant to the terms of an agrement for copperation to which such nation is a party and which is made in accordance with section 123. The Commission is also authorized to distribute source material outside of the United States upon a determination by the Commission that such activity will not be inimical to the interestr of the United. States. The authority to distribute source material under this section other than under an export license granted by the Nuclear Regulatory Commission shall in no case extend to quantities of source material in excess of three metric tons per year per recipient. ${ }^{64}$

Sec. 65. Reporting.-The Commission is authorized to issue such Ses, regulations, or orders recuiring reports of ownership, possession, extraction, refinting, shipment, or other handling of source material as it may deem necessary, except that such reports shall not be required with respect to (a) any source material prior to removal from its place of deposit in nature, or (b) quantitie of source material which in the opinion of the Commission ase animportant or the reporting of which will discourage independent prospecting for new deposits.

Sec. 66. Acquisition.-The Commission is authorized and directed, to the extent it deems necessary to effectuate the provisions of this Act-

a to purchase, take, requisition, condemn, or otherwise acquire supplies of source material;

b. to purchase, conflemn, or otherwise acquite any interest in real property containing deposits of source material; and 
41 USC 2S2(c). (See 41 USC $260(b)$.

Operations on lands belonging to the United States. 42 USC sec 2097

Public and acquired lands. 42 USC sec. 2098.

Reltase of reservation.

4. to purchase, condemn, or otherwise acquire rights to enter upon any real property deemed by the Commission to have possibilities of containing deposits of source matejial in order to conduct prospecting and exploratory operatons for such deposits.

Any purchase made under this section may be made without regard to the provisions of section 3709 of the Revised Statutes, as amended, upon certification by the Commission that such action is necessary in the interest of the coutuon defense and security, or upon a showing by the Commission that advertising is not reasonably practicable. Partial and advanced payments may be made under contracts for such purposes. The Commission may establish guaranteed prices for at source 'matertal delivered to it within a specified tutne. Just compensation sha!l be made for any sight, property, or interest in property taken, requisitioned, condemned, or otherwise acquired under this section.

"Sec, 67. Operations On Lands Belonging To The United States. The Commission is authorized, to the extent it deems nexessary to effectuate the provisions of this Act to issue leases or permits for prospecting for, exploration for, mining of, or removal of deposits of source material in lands belonging to the United States: Provided, however, That notwithstanding anty other trovisions of law, sucls leases or peruits ray be jssued for lands administered for dational park, montument, and wildtite purposes only when the Prestdent by Executive Order dexlares that the requirements of the common defense and secturity make such action necesstary.

"Sec. 68. Public And Aciuired Lamds. - os

"a. No individual, corporation, parmership, or association, which bad any part, directly or indirectly, in the development of the atomic energy program, may benefit by any location, entry, or settlement upon the public domain marle after such individual, corporation, partnership, or association took part in such project, if such individual, corporation, partnership, or association, by reason of having had such part in the development of the atomic energy program, acquired contidential official information as to the existence of deposits of such uranium, thorium, or other materials in the specific lands upon which suct location, entry, or settlement is made, and stabsequert to the date of the enactment of this Act made sucl location, entry, or settement or caused the same to be made for this,-or its, or their benest.

"b. Afry reservation of radioactive mineral substances, fissionable materials, or sourse materjal, together with the right to enter upon the land and prospect for, mine, and remove the sampe, inserted pursuant to Executive Order 9613 of September 13, 1945, Executive Order 9701 of March 4, 1946, the Atomic Energy Act of 1946, or Executive Ordier 9908 of December 5, 1947, in any patent, conveyance, lease, permit, or other authorization or instrument disposing of any interest in public or acquired lands of the United States, ts hereby released, remised, and quitcleimed to the person

65) ardos' 
or persons entitled upon the date of this Act under the grant from the United States or successive grants to the ownership, occupancy, or use of the land under applicable Federal or State laws: Pro. vided, however, That in cases where any such reservation on acquired land's of the United States has been heretofore released, remised, or quitclaimed subsequent to August 12,1954, in reliance upon authority deemed to save been contained in the Atomitc Energy Act of 1946, as arnended, or the AtomicEnergy Act of 1954, as heretofore amended, the same shall be valid and effective in ail respects to the samo extent as if public lands and not acquired lands had been involved. The foregoing release shall be subject to any rights which may have been granted by the United States pursuant to any such reservation, bat the releases shall be subrogated to the rights of the United States. ${ }^{66}$

60 STAT 775.

"c. Nowwithstanding the provisions of the Atomic Energy Act of 1946, as amended, and particularly section $5(b)(7)$ thereof, ${ }^{67}$ or the provisions of the Act of August 12, 1953 (67 Stat. 539), and particalarly section 3 thereof, any mining claim, heretofore located under the mining laws of the United States, for or based upon a discovery of a mineral deposit which is a source material and which, except for the possible contrary construction of stid Atomic Energy Act, would have been locatable under such mining laws, shall, insofar as adversely affected by such possible contrary construction, be valid and effective, in all respects to the same extent as if said mineral deposit were a locatable mineral deposit other than a source material.

Psobibition.

"Sec. 69. Prohibition.-The Comumission shall not license any person 42 USC sec. 2099. to transfer or deliver, receive possession of or title to, or iniport into or export from the United States any source material if, in the opinion of the Commission, the issuance of a license to such person for such purpose would be inimical to the commion defense and securtity or the health and safety of the public.

\section{"CHAPTER 8-_BYPRODUCT MATERIAL}

Dornestic

distribution.

42 USC

$\sec 2111$.

"Sec 81, Domestic Distribution.-No person may transfer or receive in interstate conmerce, mantfacture, produce, transfer, acquire, own, possess, import, or export any byproduct material, except to the extent authorized by this section, section $\$ 2$ or section 84.68 The Commission is authorized to issue general or specific licenses to applicants seeking to use byproduct material for research or development purposes, for medical therapy, industrial uses, agricultural uses, or such other useful

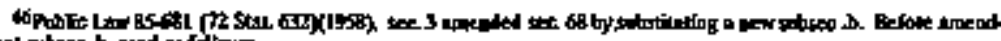

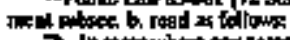

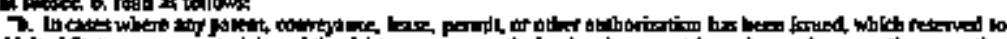

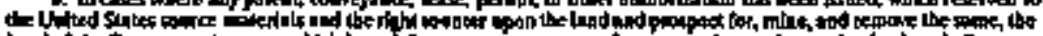

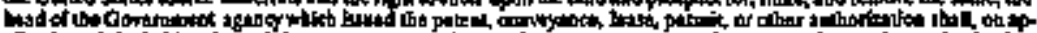

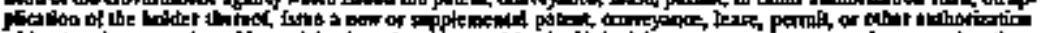

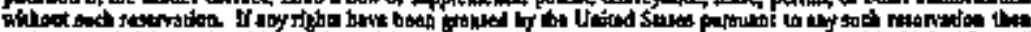

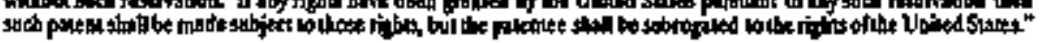

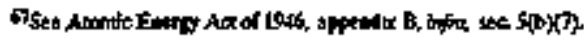

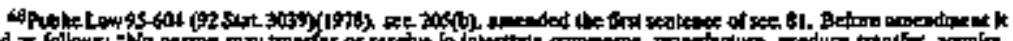

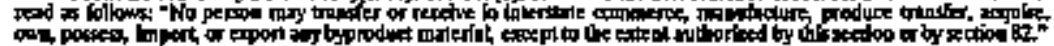


Foreign distris. bution of byproduct material. 42 USC sec. 2112.

applications as may be deweloped. The Commission may distribute, sell, loan, or lease such byproduct material as it owns to qualifted applicants ${ }^{6}$ with or without charge Provided, however, That, for byproduct material to be distributed by the Comsnission for a charge, the Commission shall establish prices on such equitable basis as, in the opinion of the Commission, (a) will provide reasonable compensation to the Govemment for such material, (b) will not discourage the use of such materiat or the development of sources of supply of such material independent of the Commission, and (c) will encourage research and development. In distributing such material, the Commission shall give preference to applicants proposing to use such material either in the conduct of research and development or in medical therapy. The Comraission shall not permit the fistribution of any byproduct material to any ticensee, and shall recall or order the recall of any distributed material from any licensee, who is not equipped to observe or who fails to observe such safety standards to protect health as may be established by the Cormission or who uses such material in violation of law or regtla. tion of the Comunission of in a manner other than as disclosed in the application therefor or approved by the Commission. The Commission is authorized to establish classes of byproduct material and to exempt certain classes or quantities of material or kinds of uses or users front the requirements for a license set forth in this section when it makes a finding that the exemption of such classes or quantities of such material or such kinds of uses or users will not constitute an unreasonable risk to the common defenst and security and to the health and safety of the public.

"Sec. 82. Foreign Dtstribation Of Byproduct Material.

. "a. The Commission is autharized to cooperate with any nation by distributing byproduct material, and to distribute byproduct material, pursuant to the terass of an agreernent for cooptration to which such nation is party and which is rrade $\mathrm{m}$ accordance with section 123.

"b. The Commission is also authorized to distribute byproduct material to any person outside the United States upon application therefor by such person and demand such charge for such material as would be charged for the material if $\mathrm{jt}$ were distributed within the United States: Provided, however, That the Comunission shal] not distribute any such material to any person under this section if, in its opintion, stch distribution would be joimical to the common defense and security: And provided further, That the Conumission may require such reports regarding the use of material distributed pursuant to the provisions of this section as it detus necessary.

"c. The Comrussion is authorized to license others to distribute byprochet material to any person outside the United States under tho same conditions, except as to charges, as would be applicable if the material were distributed by the Commission.

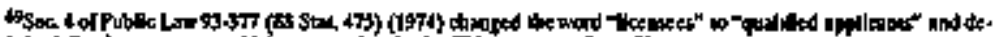

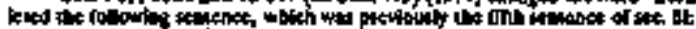

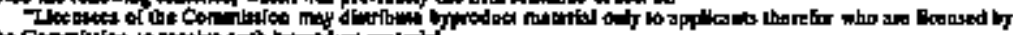

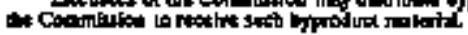


42 USC sec: 2119.

42 USC 2002, 2111. 42 USC 2014.

42 U.S.C. 2014

Rule, regutation of order.

"Sec. 83. Ownership And Custody Of Certain Byproduct Material And Disposable sites.-

*a. Any license issued or renewed after the effective date of this section under section 62 or section 81 of any activify which results in the production of any byproduct material, as defined in section 11e,(2), shall contain terms and conditions as the Commission de. termines to be necessary to assure that, prior to termination of such license-

"(I) the licensee will comply with decontamination, decommissioning, and reclamation standards prescribed by the Commisston for sites (A) at which ores were processed primarily for their source teaterial content and (B) at whith such byproduct material is deposited, and

"(2) ownership of any byproduct material, as defined in section $11 t$. (2), which resulted from such licensed activity shall be transferred to (A) the United States or (B) in the State in Which such activity ocenurred if such state exercises the option under subsection b. (1) to acquire land used for the disposal of byproduct material.

"Any license which is in effect on the effective date of this section and which is subsequently terminated witbout renewal shall comply witb paragraphs (1) and (2) upon termination." 70

(b)(1)(A) The Commission shall reguire by rule, regulation, or order that prior to the termination of any license which is issued after the effective date of this section, title to the land, including any interest therein (other than land owned by the United States or by a State) which is used for the disposal of any byproduct material, as defined by section $11 \mathrm{e}$. (2), pursuant to such license shall be transferted to-

(i) the United States or-

(ii) the State in which stich land is located, at the option of such State.

unless ${ }^{71}$ the Connmission determines prior to such termination that transfer of title to stech land and stich byproduct material is not necessary or desirable to protect the public health, safety, or welfare or to minimize or eliminate danger to hife or property. Such determination shall be made in accordance with section 181 of this Act. Notwithstanding any other provision of law or any such determination, such property and materials shall be maintained pursuant to a license issued by the Commission pursuant to section 81 of this Act ${ }^{72}$ in such manner as will protect the public health, safety, and the environment.

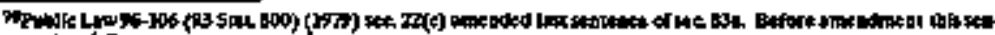
tenec xad os folloge

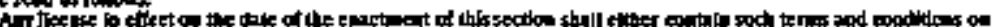

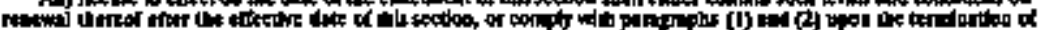

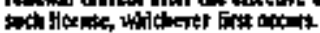

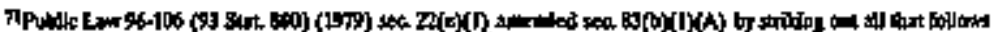

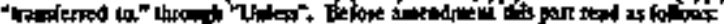

(A) lbe Unow suber, or

(2) Dints

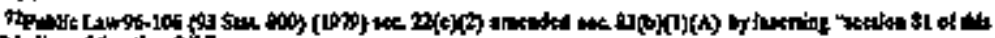

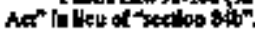


42 USC 2092.

Post, p. 3039.

"(B) If the Commission determines by order that use of the surface or subsurface estates, or both, of the land transferred to the United States or to a State under sub-paragraph (A) would not endanger the public health, safety, welfare, or exvironment, the Commission, pursulnt to such regulations as it may prescribe, shat permit the use of the surface or subsurface estates, of both, of ' such land in a marner consistent with the provisions of this section. If the Commission perrolts stich use of stcil land, it shaIl provide the person who transferred such land with the right of first refusal with respect to such use of such land.

"(2) If transfer to the United States of title to such byproduct material and such land is rexuired under this section, the Secretary of Energy or any Federal agency designated by the President shall, following the Commission's deteraination of couppliance under subsection $c_{\text {, }}$ assume title and custody of such byproduct material and land transferred as provided in this subsection Such Sexretary or Federal agency shall maintain such material and land in such manner as wilt protect the public health and safety and the environment. Such custody may be transferted to another officer or instontmentality of the United States only upon approwal of the President.

"(3) If transfer to a State of titte to such byproduct material is required in accordance with this snbsection, such State stall, following the Commission's determination of comptiance under stubsection d., assume titlé. and custocky of such byproduct material and land transferred as provided in this subsection. Such State shall maintain such material and land in such manner as will protect the public health, safety, and the emvironanent.

"(4) In the case of any stuch license under section 62, which was in effect on the effectire date of this section, the Cormmission may regurire, before the termination of stch license, such transfer of land and interest therein (as described in paragraph (1) of this subsection) to the United States or a State in which Jand is located, at the option of such State, as may be necessary to protect the public health, welfare, and the envinonment from any effects associated with such byptoduct material. In exercising the authority of this paragraph, the Commission shall take into consideration the status of the ownership of such land and interest therein and the ability of the licensee to trarsfer title and costody thereof to the United States or a State.

"(5) The Commission may, pursuant to a license, or by rule or order, require the Secretary or other Federal agency or State having custody of such property and materials to undertake such monitoring, maintenance, and emergency measures as are necessary to protect the public health ard safety and such other actions as the Commission deems necessary to comply with the standards promulgated pursuant to section 84 of this Act. The Secretary or stuch other Federal agency is atthorized to canry out mantenance, monitorting and emergency measures, but shall take no other botion pursuant to such license, rule or ordet, with respect to such 
property and materials unless expressly authorized by Congress after the date of enactment of this Act.

"(6) The transfer of title to land or byproduct materials, as defined in section 11 e. (2), to a State or the United States pur. stant to this subsection shall not relieve any licensee of liability for any fraudulent or negligent acts done prior to such transfer.

"(7) Material and land transferred to the Untited States or a State in acoordance with this stbsection shall be transferted without cost to the United States or a State (other than administrative and legal costs incurred in carrying out such transfer). Subject to the provisions of paragraph (I)(B) of this subsection, the United States or a State shall not transfer titie to material or property acquired under this subsection to any person, unless such transfer is in the sane manner as provided under section 104(b) of the Uranium Mill Tailings Ractiation Control Act of 1978.

"(8) The provisions of this subsection respecting transfer of title and custody to land aball not apply in the case of lands held in trust by the United States for any Indian tribe or lands owmed by such Indian tribe subject to a restriction agaimst alienation imposed by the United States. In the case of such lands which are used for the disposal of byproduct material, as defined in section 11 e. (2), the licensee shall be required to enter into stch arrangements with the Comrission as may be appropriate to assure the long-term maintenance and monitoring of such lands by the United States.

"c. Upon termination on any license to which this section applies, the Commission shall determine whether or not the licensee has complied with all applicable standards and requirements under such license. ${ }^{33}$

42 USC2114.

42 USC2014.

Infin.
"Sec. 84. Aulloorlties of Commissinn Respecting Certain Bypraduct Material.-

"a. The Commisston shall insure that the management of any byproduct material, as deffned in section 11 e. (2), is carried out in such manner as-..

"(1) the Commission deems appropriate to protect the public bealth and safefy and the environment from radjological and nonradiological hazards associated with the processing and with the possession and transfer of such material taking into accotint the risk to the public health, safety, and the enviromment, with due consideration of the economic costs and such other factors as the Conmission determines to be appropitiats, 74

"(2) conforms with applicable general standards promtulgated by the Administration of the Environmental Protection Agency under section 275, and

"(3) conforms to general requirements established by the Commission, with the concurrence of the Administrator, which are, to the maximum extent practicable, at lease comparable to requiements applicable to the possession, transfer, and disposal of similar hazardous

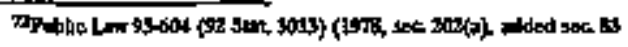

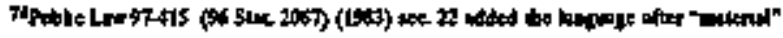


42 USC 6901.

note. .

Rule, regulatīon

of order.

42 USC 2112.

Civil penaly.

Anie, p. 3033.

42 USC 2282.

42 USC 2114.।

42 USC 2014.

42 USC 2022

Authority.

42 USC sec. 2121 material regulated by the Administrator under the Solid Waste DIsposal Act, as amended.

"b. In carrying out its authority under this section, the Comntission is authorized to-

"(1) by rule, regulation, or order reguire persons, officers, or instrumentalities, exenpted from licensing under section 81 of this Act to conduct monitoring, perfotm remedial work, and to comply with such other,measures as it may deem necessary or desirable to protect bealth or to minimize danger to life or property, and in connection with the dispostal or storage of such byproduct material; and

"(2) make such studies and inspections and to conduct such monitoring as may be necessary.

Any violation by any porson other than the United States or any officer ot ejuployes of the United States or a State of any rile, regulation, or order or licensing provision, of the Commmission established under this section or section 83 shall be subject to a civi] penalty in the same manner and in the same amount as violations subject to a civil penalty under section 234. Nothing in this section affects any authority of the Conmission under any other provisions of this Act 75

"c. In the case, of sites at which ores are processed primarily for their source material content or which are used for the disposal of byproduct material as dejined in section 11e. (2), a licensee may propose altermatives to speciñc requirements adopted and enforced by the Commission under this Act. Such alternative proposals may take into account local or regional conditions, including geolog, topography, hyctrology and meteorology. The Commission maytreat such altermatives as satisfyjng Commissiont requirements if the Commission determines that such alternatives will achieve a level of stabilization asd containment of the sites concerned, and a level of protection for public health, safety, and the environment from radiological and nonradiological hazards associated with such sites, which is equivalent to, to the extent practicable, or rtore strigent than the level which would be achieved by standards and requirements adopted and entorced by the Comunission for the stame purpose and any fural standarts promulgated by the Administrator of the Environnental Protection Agency in accordance with section 275. 176

\section{"CHAPTER 9-MILITARY APPLICATION OF ATOMIC ENERGY}

"Sicc. 91. Authority-

"a. The Commission is authorized to-

"(1) conduct experiments and do Jesearch and development work in the military application of atomic energy; and

"(2) engage' in the production of atomic weapons, or atomic weapon parts, except that such activities shall be carried on only to the extent thiat the express consent and direction of the President

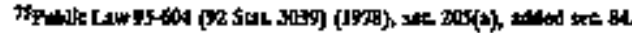

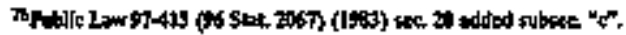


of the United States has been obtained, which consent and direction shall be obtained at least once esch year.

" $b$. The President from time to time nay direct the Commission (1) to deliver such quantities of special nuclear material or atomic weapons to the Department of Defense for such use as he deems pecessary in the interest of national defense, or (2) to authorize the Department of Defense to manufacture, produce, or accuire any atomic weapon or utilization facility for military purposes: Provided, however, That such authorization shall not extend to the production of special guclear material other than that incidental to the operation of such utilization facilities.

"c. The President may authortze the Commission or the Department of Defense, with the assistance of the other, to cooperate with another nation and, notwithstarding the provisions of section 37,62 , or 81 , to transfer by sale, lease, or loan to that nation, in accordance with terrns and conditions of a program approved by the President-

"(1) normuctear parts of atoric weapons provided that such gation has made substantal progress in the development of atomic weapons, and other nonmuclear parts of atomic weapons systerns involving Restricted Data prơfided that such transfer will not contribute significantly to that nation's atomic weapon design, development or fabrication capability; for the pupose of improv* ing that nation's state of training and operational readiness;

"(2) utilization facilities for military applications; and

"(3) source, byproduct, or special pnclear material for research on, development of, production of, or use in utilization facilities for military applications; and

"(4) source, byprodtuct, or special nuclear material for research on, development of, or use in atomic weapons: Provided, however, That the transfer of such material to that nation is necessaty to improwe its atomic weapon design, development, on fabrication capability: And provided futher, That stuch nation has made snbstantial progress in the development of atomic weapons, whenever the President deternines that the proposed cooperation and each proposed transter arrangement for the nonnvelear parts of atomic reapons and atomic weapons systems, utilization factitites or source, byproduct, or special nuclear material will promote and will not constitute an unreasonable risk to the common defense and security, thile such other nation is participating with the United States pursuant to an international arrangement by substantial and material contributions to the mutual defense and security: Provided, however, That the cooperation is urdertaken pursuant to an agreement entered into in accordance with section 123: And provided further, That if an agreement for cooperation arranged pursuant to this subsection provides for transfer of utilization factities for military applications the Commisstion, or the Department of Defense with respect to cooperation it has been autho. rized to undertake, may authorize any person to transfer such utilization facilities for military applications in accordance with the terms and conxitions of this subsection and of the agreement for cooperation 77 .

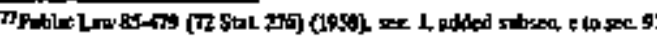

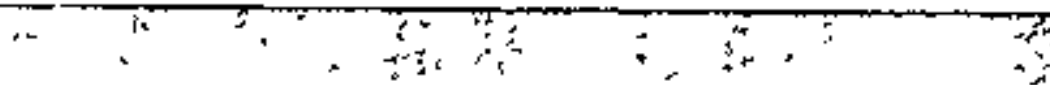


Prohibition. 42 USC sec. 2122

License required. 42 USC sec. 2131.

42 USC sec. 2132.

Commercial licenses. 42 ƯSC. sec. 2133.

"Sec. 92, Frohlbltion-It shal] be unlawful, except as provided in section 91, for any person to trunsfer or receive in interstate or foreign commerce, manufacture, produce, transfer, acquite, possess, import, or export any atomic weapon. Nothing in this section shall be deemed to modify the provisions of subsection 31 a. or section $101 .^{78}$

\section{- “CHAPTER 10-ATOMIC ENBRGY LICENSES}

"Sec. 101. Lcense Required.-It shall be unlawful, except as provided in section 91, for any person within the United States to transfer or receive in interstate commerce, manufacture, produce, transfer, acquire, possess, ase, ${ }^{9}$ inport, or export any utilization or production facility except under and in accordance with a ficense issued by the Cortmission pursuant to section 103 or 104.

"Sec. 102. Uttization And Production Facilltites For Industrial Or Conmmercial Purposes.-

"a. Except as provided in subsections $b$. and $c_{4}$, or otherwise specifically authorized by law, any licerse hereafter issued for a utilization or production facility for industrial or commercial purposes shall be issued pursuant to section 103.

"b. Any license hereafter isstred for a utilization or production facility for industrial or corrmercial purposes, the construction or operation of which was licensed pursuant to subsection $104 \mathrm{~b}$. prior to enactment into law of this subsection, shall be issued under subsection $104 \mathrm{~b}$.

"ce. Any license for a utilization or production facility for industial or commercíal purposes constructed or operated under an arrangement with the Commission entered into under the Cooperative Power Reactor Densonstration Program shall, except as otherwise specifically required by applicable law, be issued under subsection $104 \mathrm{~b}$. $\mathrm{BO}$

"Sec. 103, Commercial Licenses. -

$\mathrm{a}$. The Commission is authorized to issue licenses to persons applying therefor to transfer or receive in interstate commerce, manufachure, produce, transfer, acquire, p0scess, use ${ }^{81}$ import, or export under the terms of an agrésment for cooperation arranged purstant to section 123 , utilization or production faciltities for industrial or commercial purposes, ${ }^{82}$ Such likenses shall be isstued in

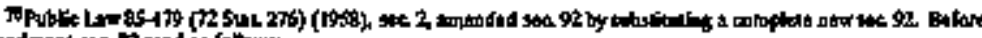

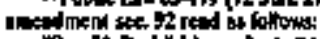

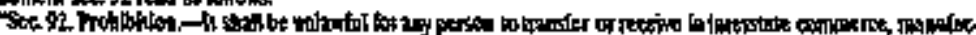

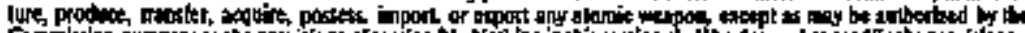

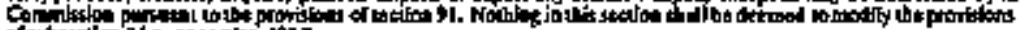

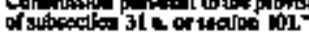

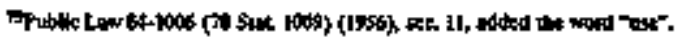

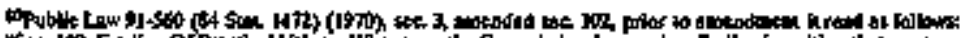

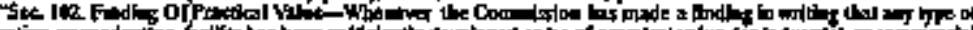

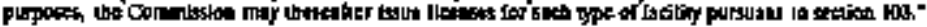

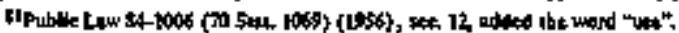

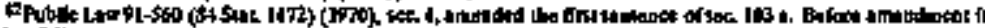
read a fod lowe

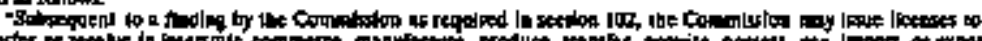

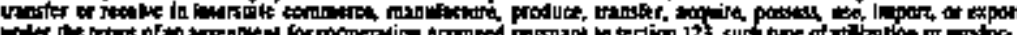
ibu fatilir."
} 
accordance with the provisions of chapter 16 and subject to such conditions as the Commisston may by rule or regulation establish to effectuate the purposes and provisions of this Act.

"b. The Commission shall issue such licenses on a nonexclusive basis to persons applying therefor (1) whose proposed activities will serve a useful purpose proportionate to the quantities of special nuclear material or source material to be utilized; (2) who are equipped to observe and who agree to observe such safety standards to protect health and to minimize danger to life or property as the Commission may by rule establish; and (3) who agree to make avalabile to the Commission such technical information and data conceming activities under sucti licenses as the Contuission may determine necessary to promote the common deferse and security and to protect the bealth and safety of the public. All such information may be used by the Commission orly for the purposes of the comtnon defense and security and to protect the bealth and safety of the public.

"c. Each such license shall be issued for a specified period, as detertmined by the Cormenission, depending on the type of activity to be licensed, but not exceeding forty years, and may be renetwed upon the expiration of such period

"d. No license under this section may be given to any person for activities which are not under or wittin the jurisdiction of the United States, except for the export of production or atilization facilities under terms of an agreement for cooperation arranged pursuant to section 123, or except under the provistions of section 109. No license may be issued to an alien or any ${ }^{83}$ corporation or other entity if the Commission knows or has reason to beliewe it is owned, controlled, or dominated by an alsen, a fortegrn corporation, or a foreign government. In any event, no license inay be issued to any person within the United States if, in the opinion of the Commission, the issuarce of a license to such person would be inimical to the common defense and security or to the health and safety of the public.

"E. Each license issued for a utilization facility under this section or section $104 \mathrm{~b}$. shall require as a condition thereof thet in case of any accident which could result in an unplanned release of quantities of fission products in excess of allowable limits for normal operation established by the Commission, the licensee shall immediately so notify the Commission. Violation of the condition prescribed by this subsection may, in the Commission's discretion, constitute grounds for license revocation. In accordance with section 187 of this Act, the Commission stall promptly amend each license for a utilization facility issued under thits section or section $104 \mathrm{~b}$. which is in effect on the date of enactraent of this subsection to include the provisions required under this subsection." "84

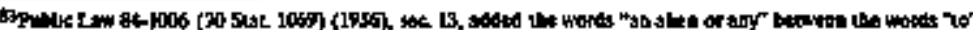

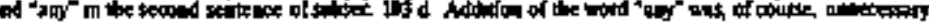

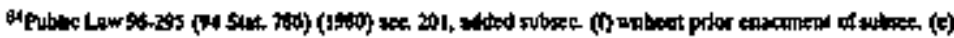


Medical therapy and research and development. 42 USC sec. 2134.

"Sec. 104. Medical Therapy And Research And Development.

"a. The Conunission is authorized to issue licenses to persons applying therefore for utilization facilities for use in medical therapy. In issuing such licenses the Commission is directed to permit the widest amount of effective medical therapy possible with the amount of special nuclear material avaihable for such purposes and to impose the minimum amourt of regulation corsistent with its chligations under this Act to promote the common defense and security and to protect the health and safety of the public.

"b. As provided for th substection $102 \mathrm{~b}$, or $102 \mathrm{c}$, or where specifjally authorized by law, the Commission is authorized to issue licenses under this subsection to persons applying therefor for utilization and production facilities for intustrial and commercial purposes. In issuing licenses under this subsection, the Commission shall impose the,minimum amount of such regulations and terms of license as wall permit the Commission to fulfill its obliga. tions under this Act. 85

"c. The Commission is authorized to issue licenses to persons applying therefor for utilization and production facilities useful in the conduct of research and deyelopment activities of the types specified in section $3 \mathrm{I}$ and which are not facilities of the type specified in subsection 104b. The Commission is directed to impose only such minimum amount of regulation of the licensee as the Commission finds will permit the Commission to fulfill its obligations under this Act to promote the common defense and security and to protect the health and safety of the public and will persit the conduct of widespread and diverse research and development.

"d. No license under this section Jaky be given to any person for activities which are not under or within the jurisdiction of the United States, except for the expont of production or utilization facilities under tenms of an agreement for cooperation arranged pursuant to section 123 or except under the provisions of sextion 109. No license may be issued to any corporation or other entity if the Commission knows or has reason to believe it is owned, con-

- tolled, or dominated by an alien, a foreign conporation, or a foreign government. In any event, no license may be issued to any person within the United States if, in the opinion of the Commisston, the issuance of a license to such person would be inimical to the common defense and secturity ot to the health and safety of the public.

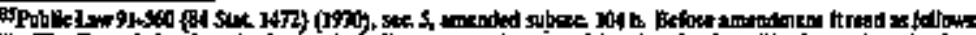
th. Co r o

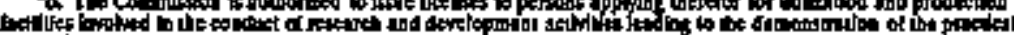

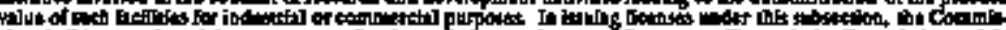

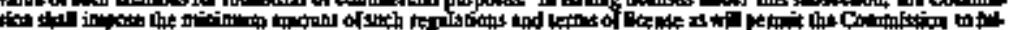

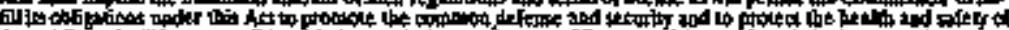

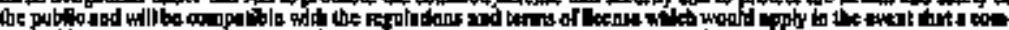

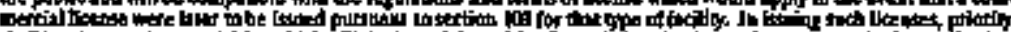

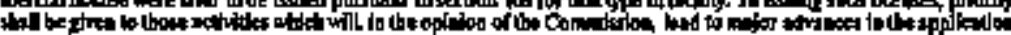

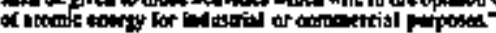


Antitrust provisions. 42 ứsc sec. 2135.
"Sec. 105. Antitrust Provisions.-.

"a. Nothing contained in this Act" ${ }^{\$ 6}$ shall relieve any person from the operation of the following Acts, as amended, An Act to protect trade and commerce against unlawful testraints and monopolies, approved July second, eighteen hundred and ninety; sections seventy-three to seventy-seven inclusive, of an Act entitled An Act to reduce taxation, to provide revenue for the Government, and for other purposes approved August twenty-seven, eighteen hundred and ninety-four; "An Act to supplement existing laws against unlawful restraints and monopolies, and for other purposes, approved October fifteen, nineteen hundred and fourteen; and As Act to create a Federal Trade Commission, to define its powers and duties, and for otber purpases, approved September twenty-six, nineteen hundred and fourteen. In the event a licensee is found by a court of competent jurisdiction, either in an original action in that court or in a proceeding to enforte or review the findings or orders of any Government agency having jurisdic. tion under the laws cited above, to have violated any of the provistons of such laws in the conduct of the licensed activity, the Commission may suspend, revoke, or take such other action as it may deen necessary with respect to any license isstred by the Commis. sion under the provisions of this Ant.

tb. The Commission shall report prompty to the Attorney General any information it may have with respect to any utilization of special nuclear material or atoujc energy which appears to violate or to tend toward the violation of any of the foregoing ACLs, of to restrict free competition is private enterprise.

"c. (1) The Commission shall promptly transmit to the Attomey General a copy of any license application provided for in paragraph (2) of this subsection, and a copy of any witten request provided for in paragraph (3) of this subsection; and the Attorney Geperal shall, within a reasonable time, but in no event to exceed 180 days after receiving a copy of such application or written request, render such advice to the Commission as be determines to be appropriate in regard to the fondtog to be made by the Commission pursuant to paragraph (5) of this subsection. Such advice shall include an explanatory statoment as to the reasons or basis therefor.

"2. Paragraph (1) of this subsection shall apply to an application for a license to construct or operate a utitization or production facility under section 103: Provided, however, That paragraph (1) shall not apply to an application for a license to operate a utilization or production facility for whish a construction permit was issued under section 103 unless tile Commisstan determines such review is advisable on the ground trat signififint changes in the licenses's activities or proposed activities have occunted subsequent to the previous review by the Aftornty General and the

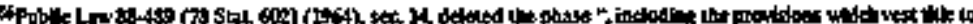

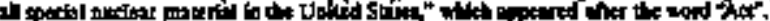


Coumpission under this subsection, in connection with the construction permit for the factlity.

"(3) With respect to any Commission perrmit for the construction of a utilization or production facility issued pursuant to subsection $104 \mathrm{~b}$. prior to the enactment into law of this subsection, any person who intervened of who sought by temely written notice to the Consnission to intervene in the construction permit proceeding for the facility to obtain a detemmination of antitust considerations or to advance a jurisdiction basis for such determination shall have the right, upon a written request to the Commission, to obtain an antitrust teview under this section of the - application-for an operating license. Such written request shall be made within 25 days after the date of initiol Commission publication in the Federal Register of notice of the filing of an application for an operating license for the facility or the date of enactment into law of this subsection, whichever is later.

“(4) Upon the request of the Attorney General, the Commission shall furrish or cause to be furnished such information as the Attorney General determines to be appropriate for the advice called for in paragraph (1) of this subsection.

“(5) Promptly upon receipt of the Attorney General's advice, the Commission shall publish the advioe in the Federat Register. Where the Attorney General advises that there may be adverse antitrust aspects and recomraends that there be a bearing, the Attorney General or his designee may participste as a party in the proceedings thereafter held by the Commission on such licensing matter in connection with the subject matter of his advice. The Commission shall give due consideration to the advice received from the Attorney Goneral and to such evidence as may be provided durting the prosetedings in connection with such subject matte $k$, and shail make a finding as to whether the activities under the license would create or maintain a situation jnconsistent with the antitrust laws as specified in subsection $105 \mathrm{a}$.

"(6) In the event the Commission's' finding under paragraph (5) is in the affirmative, the Comuission shall also consider, in determining whether the license should be issued or continued, such other factors, including the need for powser in the affected area, as the Commission in its judpment deeins'necessary to protect the public interest. On the basis of tits findings, the Commission shall have the authority to issue or continue a license as applied for, to refuse to issue a license, to rescind a license or amend it, and to issue a lioense with such conditions as it deems appropriate.

"(7) The commission, with the approval of the Attorney General, may except' from any of the requtrements of this subsection stech classes or types of licenses as the Contrission may determine would not significantly affect the applicant's activities under the antitrist laws as specified in subsection $105 \mathrm{a}$.

"(8) With respect to ary apptication for a construction permit on file at the time of enactment into law of this subsection, which permit would be for issuance under section 103, and with respect 
Classes of

facilities.

42 USC sec. 2136 .

Operatots'

licenses.

42 USC sec. 2137.

War or

netional

emergency.

42 USC sec. 2138 .

to any application for an operating license in connection with which a witten request for an antitrust review is made as provided for in paragraph (3), the Commission, after consultation with the Attorney General, may, upon determination that such action is necessary in the public interest to avoid unnecessary delay, establish by rule or order periods for Comrnission notification and receipt of advice differing from those set forth above and may issuc a construction permit or operating license in advance of consideration of and findings with respect to the matters covered in this subsection: Provided, That any constnuction permit or operating license so issued shall contain such conditions as the Commission deems appopopriate to assure that any subsequent findings and orders of the Commission with respect to such matters will be given fill! force and effect. ? $^{\text {? }}$

"Sec. I06. Classes Or Facilities-The Commisstion may-

“a. group the facilities licensed either under section 103 or under section 104 into classes which ntay include either production or utilization facilities or both, upon the basis of the similarity of operating and technical characteristics of the facilities;

"b. deffine the various adtivities to be carried on at each such class of facility; and

"c. designate the amounts of special nuclear material avalable for use by each such facility.

'Sec. 107. Operators' Licenses.-The Commission shall-

"a. prescribe uniform conditions for licensing mojividuals as operators of any of the various classes of production and utiliza. tion facilities licansed in this Act;

"b. determine the qualifications of such individuals;

"c. issure licenses to such individuals in such form as the commission may prescribe; and

"d. suspend such licenses for violations of any provision of this Act or any rule or regulation issued thereunder whenever the Commission deems such action desirable.

"Sec 108. War Or National Emergenoy.-Whenever the Congress declates that a state of war or national emergency exists, the Commission is authoized to suspend any licenses granted under this Act if in its judgntent such action ts necessary to the conmon defense and secturity. The Commission is authorized during such period, if the Cornmission finds it necessary to the common defense and secursty, to order the recapture of any special tuclear material ${ }^{83}$ or to order the operation of any facility licensed undor section 103 or 104 , and is authorized

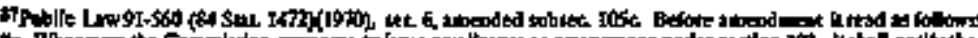

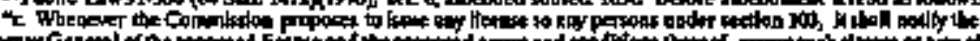

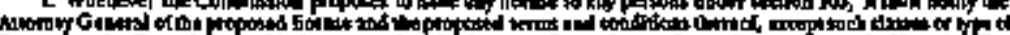

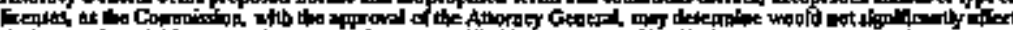

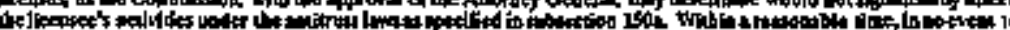

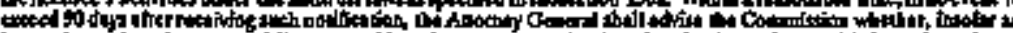

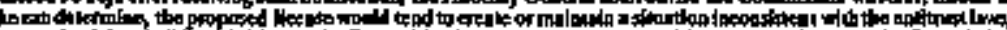

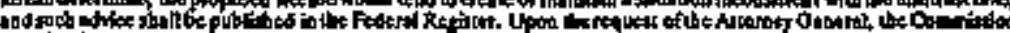

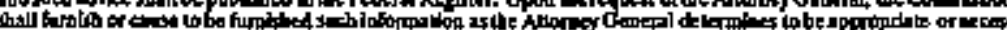

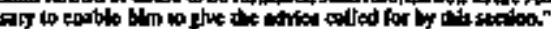

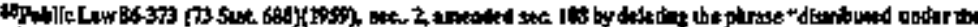

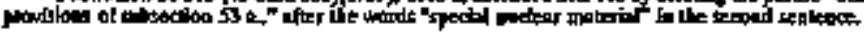



by, the operation of any such facility.

actrities I "a. With respect to those thilization and production facilities licenses, which are so determined by the Commission pursuant to subsecissuance, $\quad$ tion 11 v. (2) or $11 \propto$. (2) the Comuriosion may issue general licenses authorization. - for domestic activities required to be licensed under section 101, 42 USC 2139. if the.Commission determines in writing that such general licensExport bicenses.
"b. After consultigl with the Secretaries of State, Energy, and co. After consultigi with the Secretaries of State, Energy, and oirected to determine which component parts as defined in subsection 11 v. (2) or $11 \mathrm{cc}$ (2) and which other iterns or substances are especially relevant from the standpoint of export control because of their significance for nuclear explosive purposes. Except Ante, p. 131. as provided in section 126b. (2), no suct conponent, substance, or iten which is so determined by the Commission shall be exported unless the Commission issues a general or specific license for its export after finding, based on a reasonable judgment of the assurances provided and other information available to the Federal Government, including the Commission, that the following criteria or their equivalent are met: (1)IAEA safeguards as requited by Article III (2) of the Treaty will be applied with respect to such component, substance, or item; (2) no such component, substance; or item will be used for any nuselear explosive device or for research on or development of any puclear explosive device; and (3) no such component, substance, or item will be retransferred to the jurisdiction of any nation or group of nations unless the prior consent of the United \$tates is obtained for such retransfer; and after determining in writing that the issuance of each such zeneral or specific license or category of licenses will not beinimical to the common defense and sectrity; Provided, That a specific license

- shall not be recguired for an export-pursuant to this section if the

ir component, item or substance is covered by a facilty license issued pursuate to section 126 of this Act.

*c. The Commission shall not issue an export license under the suthority of subsection $b$. if it is advised by the executive branch, in accordance with the procedures established under subsection 126 a., that the export would be inimical to the connmon defense and security of the United States. ${ }^{89}$

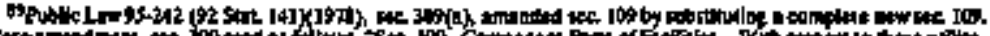

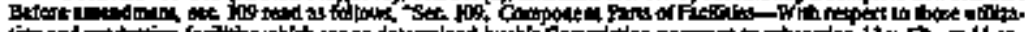

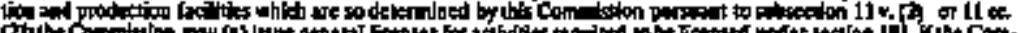

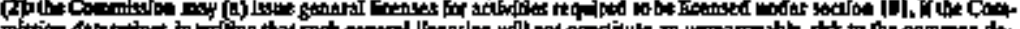

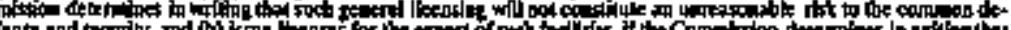

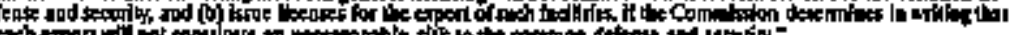

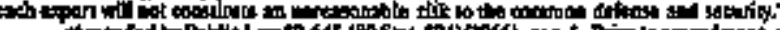

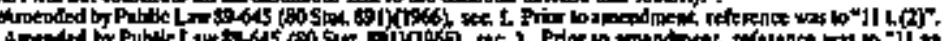

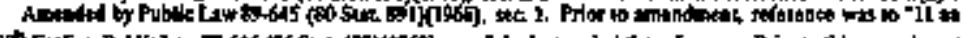

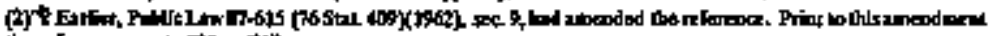
the refores w
} 
Exchusions.

42 USC sec 2140.

42 USC 2141.

Sppra.

42 USC 2312.

Past, p, 136.

Post p. 137.

Effect of international arraggements. 42 USC sec. 2151.

Policies contained in internalsonat arrangements. 42 USC sec. 2152.
"Sec. 110. Exdusions,-Nothing in this chapter shat be deemed *a. to require a license for (1) the processing, fabricating, or refining of special nuclear material, or the separation of special nuclear material, or the seperation of speciel nuclear material from other substances, under contract with and for the account of the Commission; or (2) the construction or operation of facilities under contract with and for the acsount of the Commission; or

"b. to require a license for the manufachure, production, or acquistition by the Department of Defense of any utilization facility authorized pursuant to section 91, or for the tise of such facility by the Departonent of Deferse or a contractor thereof.

"Sec. 111. Distribution By The Department OP Energy.-

*a. The Nuclear Regulatory Commission is authorized to license the distribution of special muclear material, some material, and byproduct material by the Department of Energy, pursuant to section 54,64 , and 82 of this Act, respectively, in accordance with the same procedures established by law for the export licensing of such material by any person: Provided, That nothing in this section shall require the licensing of the distribution of byproduct material by the Department of Energy under section 82 of this Act.

tb. The Department of Energy shall not distribute any special nuctear material or source material undet section 54 or 64 of this Act other than under an export license issued by the Nuclear Regulatory Commission until (1) the Department has obtaines the concurrence of the Departatent of State and has consulted with the Arms Control and Disarmament Agency, the Nuclear Regulatory Comutission, and the Department of Defense under mutually agreed procedures which shall be established within not more than ninety days after the date of enactraent of this provision and (2) the Department firds based on a reasonable juogment of the assurances provided and the information avajlable to the United States Gowermment, that the criteria is section 127 of this Act or theirequivalent and any applicable criteria in subsection 128 are met, and that the proposed distribution would not be inimical to the common defense and sectrity. ${ }^{90}$

\section{"CHAPTER 11- INTERNATIONAL ACTVITIES}

"Sec. 121. Effect Of International Arrangements, - Any provision of this Act or any action of the Commission to the extent and during the time that it conflicts with the provisions of any international arrangements made after the date of enactment of this Act shall be deemed to be of no force or effect.

"Sec. 122. Folicies Contained In International Arrangements--In the performance of its functions under this Aet, the Commission shall give Jaxoum effect to the policies contaiped in any international arrangement made after the date of enactment of this Act.

"Sec. 123. Cooperation With Other Nations, -"No cooperation with anty nation, group of nations or regional defense organization pursuant

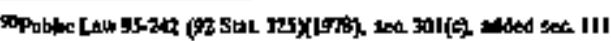


42 USC 2073 ,

2074,2077 .

2094, 2112

2121, 2133,

$2134,2164$.

Cooperative

agreements,

submittal to

President.

Contents. to section 53,54 a., $57,64,82,91,103,104$, of 144 shall be undertaken until-

"a. the proposed agreement for cooperation has been submitted to the President, which proposedragreement shall include the terms, conditions, duration, nature, and scope of the cooperation; and shall include the following requirements:

"(1) a guaranty by the cooperating party that safeguards as set

1. fotth in the agreenent for cooperation will be maintained with respect to all nuclear materials and equipment transferred pursuant thereto, and with respect to all special naclear material used in or produced through the use of such nuclear materials and equiponent, so long as the material or equipment remains under the jurisdiction or control of the cooperating party, irrespective of the duration of other provisions in the agreement or whether the agreement is terminated or suspended for any reason;

(2) in the case of non-nuclear-weapon states, a requireJent, as a condition of continted United States nuckear supply under the agreement for cooperation, that IAEA safeguards be maintained with respect to all nuclear materials in ail peaceful nuclear activities within the territory of such state, under its jurisdiction, or carried out under its control anywhere;

"(3) except in the case of those agreerments for cooperation arranged pursuant to subsection $91 \mathrm{c}$, a guaranty by the cooperating party that no nuclear materials and equipment or sensitive, nuclear technology to be transferred pursuant to such agreement, and no special nuclear material produced tirough the use of any nuclear materials and equipment or sensitive nuclear technology transferred pursstant to such agreement, will be used for any nuclear expiosive device, or for research on or development of any nuclear explosive device, or for any other military purpose;

." (4) except in the case of those egreements for cooperation artanged pursuant to subsection $91 \mathrm{c}$. and agreentents for cooperation with nuclear-weapon states, a stipulation that the United States shall have the right to require the retern of any nuciear materials and tquipment trassferred pursuant thereto and any special nuclear material produced through the use thereof if the conperating party detonates a nuclear explosive device or teminates or abrogates an agreement providing for IAEA safegnards;

(S) s guaranty by the cooperating party that any material or any Restricted Data transferred pursuant to the agreement for cooperation and, except in the case of agreements atranged pursuant to stbsection $91 c_{,}, 144 \mathrm{~b}, 144 \mathrm{c}_{\rightarrow}$, or $144 \mathrm{~d},{ }^{*}$ any production or utilization "facility transferted pursuant to the agreement for cooperation or any special nuclear material produced through the use of any such factity or throtigh the use of any material transferred pursuant to the agretment, will not te

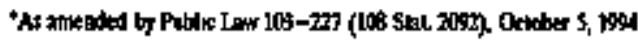


transferred to unatuthorized persons or beyond the jurisdiction or control of the cooperating party without the consent of the United States;

"(6) aguaranty by the cooperating party that adequate physieal security will be maintained with respect to any nuclear material transferred pursuant to such agreement and with respect to any special nuclear material used in or produced through the use of any materjal, production facility, or utilizatoon facilty transferred purstiant to such agreement;

" $(7)$ except in the case of agreements for cooperation arranged pursuant to subsection $91 \mathrm{c} ., 144 \mathrm{~b}, 144 \mathrm{c}$, or $144 \mathrm{d.}$ * a guaranty by the cooperating party that no material transferred pursuant to the agreement for cooperation and no material used in or produced through the use of any material, production facility, or utilization facility transferred pursuant to the agreement for cooperation will be reprocessed, enriched or (in the case of plutonium, uranium 233, or uranium enriched to greater than twenty percent in the isotope 235 , or other nuclear Inaterials which have been irradiated) otherwise altered in forn or content without the prior approval of the United States:

"(8) except in the case of agreeruents for conperation arranged pursuant to subsection $91 \mathrm{c.,} 144 \mathrm{~b} ., 144 \mathrm{c}$, or $144 \mathrm{~d}$.," a guaranty by the cooperating party that no plutonium, no uranium 233, and no uranium enriched to greater than twenty percent in the isotope 235 , transferred pursuant to the agreement for cooperation, or recovered from any source or special nuclear material so transferred or frosn any source or special nuclear material used in any production facility or utilization facility transferred pursuant to the agreement for cooperation, will be stored in any facility that has not been approved in advance by the United States and

"(9) except in the case of arreements for cooperation arranged pusstant to subsection $91 \mathrm{c}, 144$ b., $144 \mathrm{c}$, or $144 \mathrm{~d}$., " a guaranty by the cooperating party that any special nuclear material, production facility, or utilization factity produxed or constructed under the jurisdietion of the cooperation party by or through the tase of any sensitive nuchear technology transferred purstlant to such agreement for cooperation will be subject to all the requitements specified in this stubsection.

Agreement requirements Presidential exemptions.

Proposed cooperation agreements
The President may exempt a proposed agrement for cooperation (except an agreement arranged purstlant to subsection $91 \mathrm{c}, 144 \mathrm{~b}$, $144 \mathrm{c}$, or $144 \mathrm{d.}^{*}$ ) from any of the requirements of the foregoing sentence if he determines that inclusion of any such regutitement would be seriously prejudicial to the achievement of United States nonproliferation objectives or otherwise jeopardize the common defense and security. Except in the case of those agreenents for cooperation arranged pursuant to subsection $91 \mathrm{c}, 144 \mathrm{~b}, 144 \mathrm{c}$, or $144 \mathrm{~d}^{*}$ any proposed agreement for cooperation shall be negotiated by the Secre-

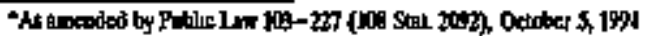


submittal to President. Nuclear Proliferation Assessment Statement, submitted to President. 42 USC 2121. 2164 .

Submittal to congigessional committees.

Ants p. 139. tary of State, with the techrical assistance and concurrence of the Secretary of Energy and in consultation with the Director of the Arms Control and Dișarnzantent Agency ('the Director'); and after consultation with the Commission shall be submitted to the President jointly by the Secretary of State and the Secretary of Energy accompanied by the views and recomnendations of the Secretary of State, the Secretary of Energy, the Nuclear Regulatory Commission, and the Director, who stiall also provide to the president an unctassified Nuclear Proliferation Assessment Statement (A) which shall anatyze the consistengy of the text of the proposed sgreement for cooperation with all the requirements of this Act, with specific attention to whether the proposed agteement is consistent with each of the criteria set forth in this subsection, and (B) ${ }^{90 \mathrm{e}}$ regarding the adequaty of the safeguards and other control mechanisms and the peaceful use assurances contained in the agreement for cooperation to ensure that any assistance furnished thereunder will not be used to further any miltary or nuclear explosive purpose. In the case of those agreements for cooperation arranged pursuant to subsection $\$ 1 \mathrm{c.} 144 \mathrm{~b} ., 144 \mathrm{c}$., or $144 \mathrm{~d}_{,}^{*}$ any proposed agreement for cooperation shall be submitted to the President by the Secretary of Energy or, in the case of those agreements for cooperation arranged pursuant to subsection $91 \mathrm{c}$, or 1446 ., which are to be implemented by the Department of Defense, by the Secretary of Deferse:

"b. the President has submitted text of the proposed agreenent for cooperation, except an agreement arranged pursuant to sec. tion $91 \mathrm{c}, 144 \mathrm{~b}, 144 \mathrm{c}$, or $144 \mathrm{~d}$. of section $144,{ }^{*}$ together with the accompanying unclassified Nuclear Proliftration Assessment Statement, to the Corratitee on Foreign Relations of the Senate and the Committee on Foreign Affairs of the Hotuse of Representatuves, the President has consulted with such Contmittees for a period of not less than thirty days of continuous session (as dofined in section $130 \mathrm{~g}$. of this Act) concerning the consistenty of the terms of the proposed agreentent with all the requirements of this Act, and $90 \mathrm{~b}$ the President has approved and authorized the execution of the proposed agreement for cooperation and has made a determination in writing that the performance of the proposed agreement will promote and will not constinte an unreasonable risk to, the common defense and security;

"c. the proposed agremment for $\infty 0$ peration (if not an abreement subject to stibsection d.), together with the approval and deteruination of the President, has been submitted to the Committee on International Relations of the House of Representatives and the Committee on Forreign Relations of the Senate for a period of thirby days of continuolus sussion (as defined in subsection $130 \mathrm{~g}$ ). Provided, however, That these committees, after having received such agreement for cocperation, may by resolution in writivg

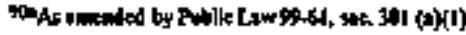

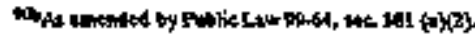


$42 \mathrm{USC} 2073$, $20 \% 4,2133,2134$.

Anit, p. 142.

Ante, p, 139.

Agency views to Congressional Committoes 42 USC 2121, 2164. waive the contitions of all or any portion of such thirty-day period; and

" $d$. the proposed agreement for cooperation (if arranged pursuant to subsection $91 c_{,}, 144 b_{1}, 144 c$, , or 144 d, or if entailing fmplementation of section $53,54 \mathrm{a}, 103$, or 104 in relation to a reactor that may be capable of producing more than five thermal mega. watts or special nuclear material for use in connection therewith) has been submitted to the Congress, together with the approval and determination of the President, for a period of sixty days of continuous session (as defined in subsection 130 g. of this Act) and referred to the Committee on International Rejations of the House of Representatives and the Committe on Foreign Relations of the Senate, and in addition, in the case of a proposed agreement for cooperation arranged pursuant to subsection $91 \mathrm{~cm}$ 144b., $144 \mathrm{cy}$, or 144 4, the Committee on Armed Services of the House of Representatives and the Committe on Armed Services of the Senate, but such proposed agreement for cooperation shall not become effective if during sucti sixty-day period the Congress adopts, and there is enacted, a joint resolution ${ }^{90 c}$ stating in sibstance that the Conzess does not thor the proposed agreement for copperation: Provided, That the sixty-day period shall not begin until a Nuclear Proliferation Assessment Statement prepared by the Director of the Arms control and Disarminnent Agency, when required by subsection 123 an, has been stibmitted to the Congress: Provided further, That an agreement for $\infty \%$ peration exempted bry the President purstsant to subsection a from any requirement contained in that subsection shall not become effective unless the Congress adopts, and there is enacted, a joint resolution stating that the Congress does favor such agreenent. ${ }^{90}$ During the sixtyday period the Committee on Forejgn Affairs of the House of Representatives and the Comunittee on Foreign Retations of the Senate shall each hold hearings on the proposed agreement for cooperation and subnit a report to their respective bodies recommending whether it should be approved or disapproved. 900 Any sucil proposed agreement for cooperation shall be considered pursuant to the procedures set forth in section 130 t. of this Act, 90:

"Following submission of a proposed agreement for copperation (except an agreement for cooperation arranged pursuant to stibsection $91 c_{1}, 144 b, 144 c$., or $144 \mathrm{~d}$.) to the Committee onInternational Rejations of the House of Representatives and the Committee on Foreign Relations of the Senate, the Nuclear Regulatory Commission, the Department of State, the Department of Energy, the Arms control and Disarmament Agency, and the Department of Defense shall, upon the request of either of those committeres, promptity furnish to those committess thetr views as

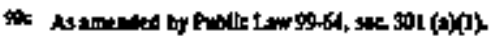

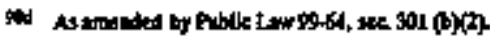

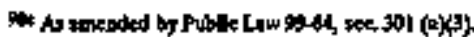

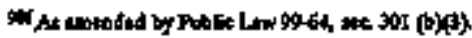


to whether the safeguards and other controls contained therein provide an adequate framewotk to ensure that any export as con. templated by such agrement wil not be inimical to or constitute an tintesorsable tisk to the common defense and security.

"If, after the date of enactment of the Nuctear Non-Probiferation 1 Act of 1978, the Congress fats to distapprove a pooposed agreement for cooperation which exempts the recipient nation fom the

Ante, p. 137.

Ants p. 131.

requitement set forth in subsection 123 a: (2), such failtire to act shall constitute a failure to adopt a resolution of disapproval pursuant to subsection 128 b. (3) For purposes of the Commission's consjideration of applications and requests under section 1262 , (2) and there shall be no congressionsl reviex pursuant to section 128 of any subseguent ficense or authorization with respect to that stato until the first such license of authorization which is issued af. - ter twelve months from the elapse of the sixty-day period in which the agreement for cooperation'in question is reviewed by the Congress. 91

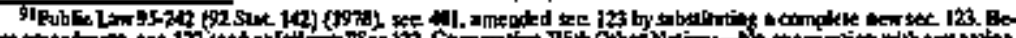

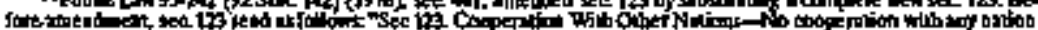

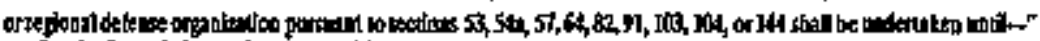

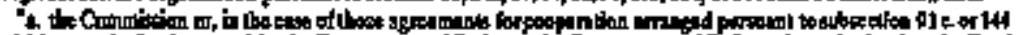

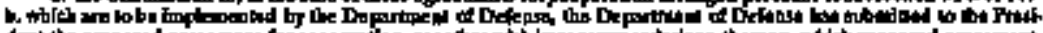

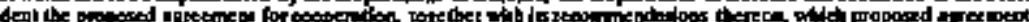

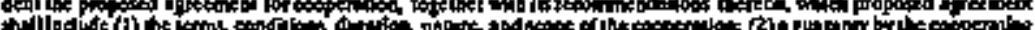

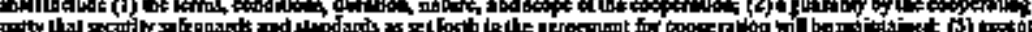

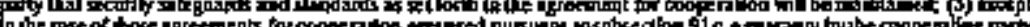

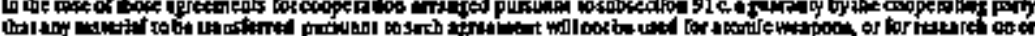

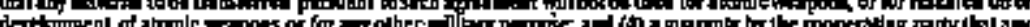

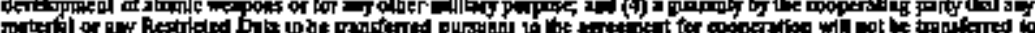

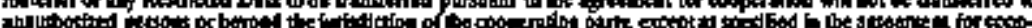
a리에

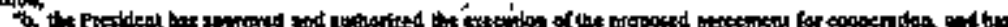

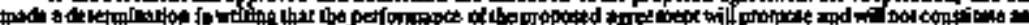

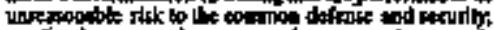

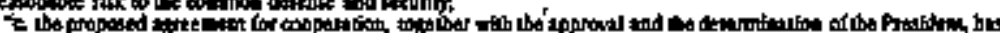

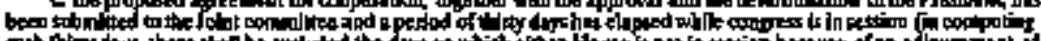

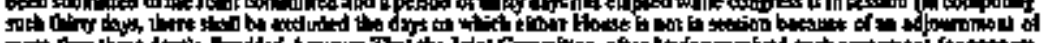

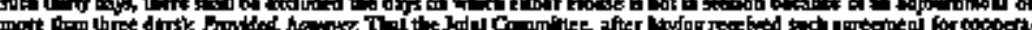

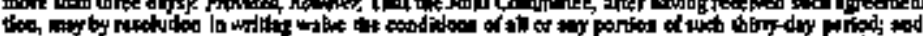

- The pothod la whe

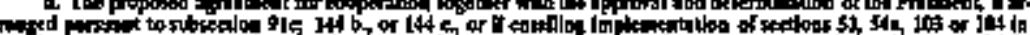

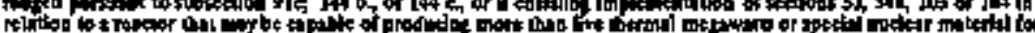

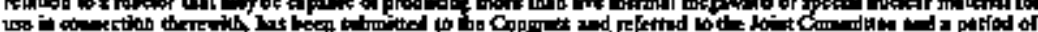

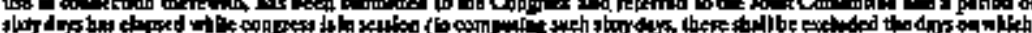

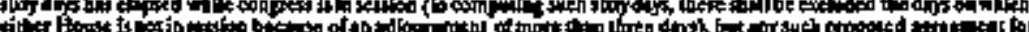

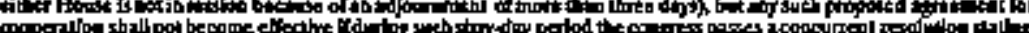

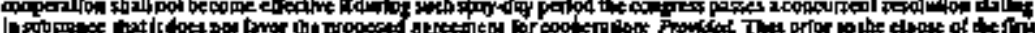

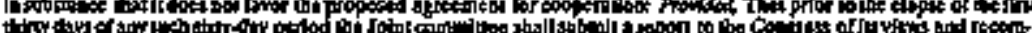

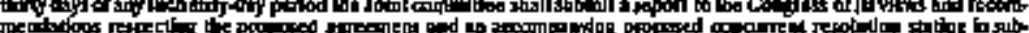

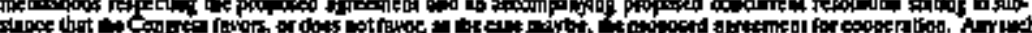

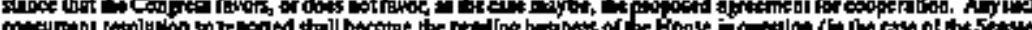

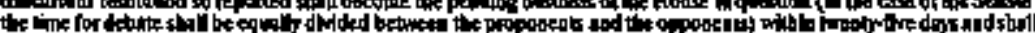

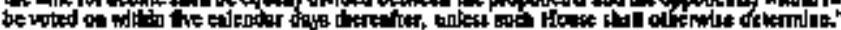

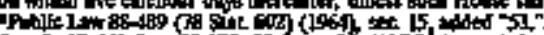

505 of

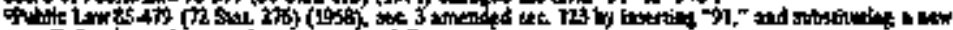

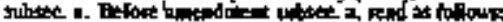

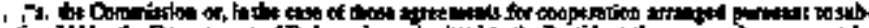

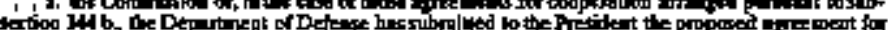

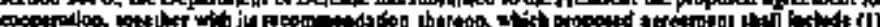
-

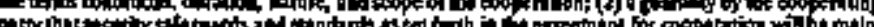

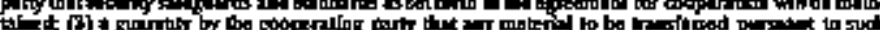
(a) (3) -

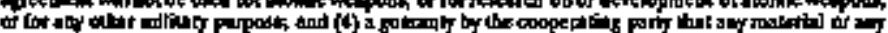

(Comatiof) 
International atomic pool. 42 USC sec. 2154.

Cocperation wtth Beritn. $42 \mathrm{USC}$ sec. 2453 (Nt).

42 USC 2155 Excmplion.

Anik, p. 125.

Supra. 42 USC 2112

Executive branch judgment notice to commission.

Procedures.

Condents.
"Sec 124. International Atomic Puol.-The President is authorized to enter into an jiternationd arrangerdent with a group of nations providing for interuational cooperation in the uanmilitary applications of atomic energy and he may thereanter cooperate with that group of nations pursuant to sections $54 a, 57,64,82,103,504$, of 144 a.. Provided however, That the cooperation is undertaken pursuant to an agreement for cooperation entered into in accordance with section 123 .

"Sec, 125. Coppenation Whth Berl|x.-The President may authorize the Commission to enter into agreements for cooperation with the Federal Republic of Germany in accordance with section 123, on behalf of Berlin, which for the purposes of this Act comprises those areas over which the Berlin Senate exercises jurisciction (the Inited States, and French sectors) and the Commission may thereafter cooperate with Berlin pursuant to sections $54 a_{3}{ }^{92} 57,64,82,103$, or 104; Provided That the graranties required by section 123 shall be made by Berlin with the approval of the allied commandants. ${ }^{3}$

"Sec. 126. Export Licensing Procedures.-

"a. No license may be issued by the Nuclear Regulatory Commis. sion (the "Commission') for the export of any production or ut:lization facility, or any source material or special nuclear material, including distributions of any material by the Department of Energy under section 54,64 , or 82, for which a license is requised or or Jequested, no exemption from any Jequiremient for such an export license may be granted by the Commission, as the case may be, until.-

"(1) the Commission has been notified by the Secretary of State that it is the judgment of the executive brancls that the proposed export or exemption will not be inimical to the common defense and security, or that any export in the category to which the proposed export belongs woutd not be inimical to the common defense and stoutity because it lacks significance for nuclear explosive purposes. The Secretary of State shall, within ninety days after the enactment of this seetion, establish orderly and expeditious procedures, including provision for necessary administrative actions and inter-agency memoranda of understanding, which are mutually agreeable to the Secre-

\footnotetext{
(Cantioned)

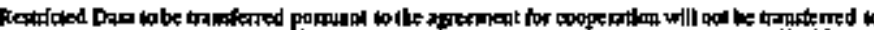

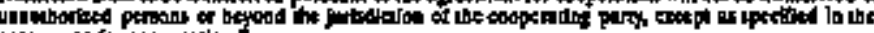

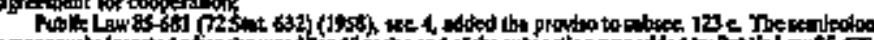

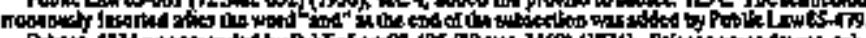
S

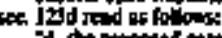

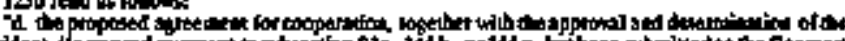
Pro.ideot if in

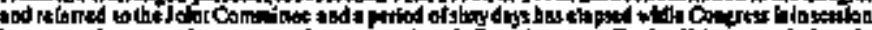

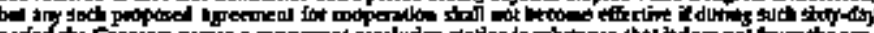

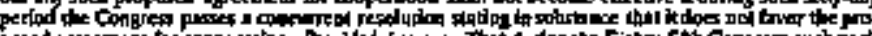

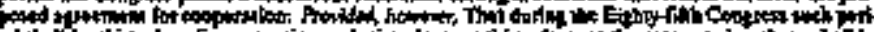

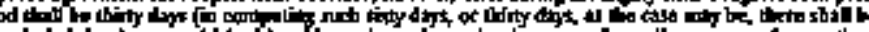

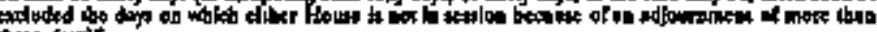
brex ofthit:

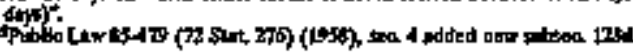

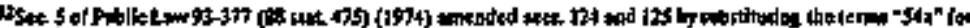
Lb $14 \mathrm{~m}$

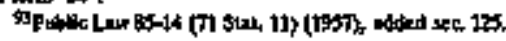


Standerds and criteria.

Notice to congressional conmititees. taries of Energy, Defense, and Commerce, the Director of the Arms Control and Disarmament Agency, and the Nuclear Regulatory Commission for the prepartation of the executive branch judgment on expart applications under this section. Such procedures shall include, at a minimun, explicit direction on the handling of stch applications, express deadlines for the solicitation and collection of the views of the consulted agencies (with identified officials responsible for meeting such deadlines), an mter-agency coordinatisg authotity to monitor the processing of such applications, predetermined procedures for the experditious handing of intra-agency and interagency disagreements and appeals to higher authorities, frequent meetings of inter-agency administrative coordinators to review the statos of all pending applications, and similar administrative mechanisms. To the extent practicable, an applicant should be advised of all the infontation reguired of the applicant for the entire process for wery agency's needs at the beginining of the process. Potentially controversial applications should be identified as quickly as possible so that any required poticy decisions or diplomatic consultations can be initiated in a timely manner. An immectiate effort should be undertaken to establish quickly any necessary standards and criteria, focluding the nature of any required assurances or evidentiary showing, for the decisions required under this section The processing of any export application proposed and filed as of the date of enactment of this section shail not be delayed pending the development and establishment of procedures to implement the requirements of thits section. The executive branch judgment shall be completed in not more than sixty days from recelpt of the applicalion of request, unless the Secretary of State in his discretion specifically authorizes additional time for consideration of the application or request because it is in the national interest to allow such additiona[ time. The Secretary shall notify the Committes on Foreigra Relations of the Senate and the Committee on International Relations of the House of Representatives of any such authorization. In stibmittotg any such judgritent, the Secretary of State shall specifically address the extent to which the export criteria then in effect are met and the extent to which the cooperating party has adiered to the provisions of the applicable agreement for cooperation. In the event he comsiders it warranted, the Secretary may also address the following additional factors, among others:

"(A) whether issuing the license or granting the exemp. - tion will materially actvance the non-proliferation polty of the Untited States by encouraging the recipjent nation to adtiere to the Treaty, or to participate in the undertakings contemplated by section 403 or $404(a)$ of the Nuctear Non-Proliferation Act of 1978; 
Posf, p. 136.

Data and recommendations.

Post, p. 136.

42 USC 2154.

Extension, notice to Congress.
"(B) whether failure to issue the license or grant the exemption would otherwise be seriously prejudictal to the non-proliferation objectives of the United States; and

"(C) whether the recipient nation or group of nations has agreed that ponditions substantially identical to the export criteria set forth in section 127 of this Act will be applied by another auclear supplier nation or group of thations to the proposed United States expont, and whether in the Sectetary's judgment those conditions will be implemented in a manner acceptable to the Unitect States.

The Secretary of State shall provide appropriate data and recommendations, subject to requests for additional data and recommendations, as required by the Commission or the SecJetary of Energy, as the case may be; and

(2) the Connmission finds, based on a reasonable judgment of the assurances provided and other information avaifable to the Federal Government, jncluding the Commission, that the criteria in section 127 of this Act or their equivalent, and any other applicable statutory requirements, are met Provided, That contintued cooperation under an agreement for cooperation as anthorized in bocordance with section 124 of this Act shall not be prevented by failure to meet the provisions of paragraph (4) or (5) of section 127 for a period of thirty days after enactment of this section, and for a period of twentythree months thereafter if the Secretary of State notifies the commission that the nation or group of nations bound by the relevant agreement has agreed to negotiations as called for in section 404(a) of the Nuctear Non-Proliferation act of 1978; however, nothing in this subsection shall be deemed to relinquish any rights which the United States may have under agreements for cooperation in force on the date of enactment of this section: Provided further, That if, upon the expiration of such twonty four moith period, the President determines that failure to continue cacperation with any group of nations which has been exemupted pursuant to the above proviso from the provisions of paragraph (4) or (5) of section 127 of this Act, but which has not yet agreed to cotmply with those provisions would be seriously prejudicial to the achievement of United States non-proliferation objectives or otherwise jeopardize the common defense and security, he may, after notifying the Congress of his determination, extend by Executive order the duration of the above proviso for a period of twelve months, and may further extend the duration of such proviso by one year increments anmually thereafter if he again makes such determination and so notifies the Congress. In the event that the Committee on International Relations of the House of Representatives or the Committee on Foreign Relations of the Senate reports a joint resolution to take any action with respect to any such extension, such joint resolution will be considered 
Post, p. 139.

Findings.

Judicial review, exception.

Presidential review.

Report to Congress and coreressional convinittees. Poort, p. 139. in the House or Senate, as the case may be, under procedures identical to thase provided far the consideration of resolutions pursuant to section 120 of this Act: And additionolly provided, That the Commission is suthorized to (A) make a single finding under this subsection for more than a single application or request, where the applications or requests involve exports to the saue country, in the same general time frame, of similar significance for nuclear explosive purposes and under reasonably similar circumstances and (B) make a finding under this subsextion that there is no material changed circumstance as. sociated with a new application or request from those existing at the time of the last application or request for an export to the same country, where the prior application or request was approved by the Commisston using all applicable procedures of this section, and such finting of no material changed circumstance stall be deemed to satisfy the requirement of this para. graph for findings of the Commission. The decision not to make any such fiading in lieu of the findings with would othetwise be required to be made under this paragraph shall not be subject to jucicial review: And provided further; That nothing contained in this section is intended to require the Commission independently to conduct or prohibit the Comasission from independently conducting country or site specifit visitations in the Commission's consideration of the applicstion of LAEA safeguards.

"b. (1) Timely consideration shall be given by the Commission to roquests for expout license and extmptions and such requests shall be granted upon a determination that all applicable statutory requirements have been met.

“(2) If, after receiving the executive branch judgment that the issuance of a proposed export license will not be inínical to the common defense and security, the Commission does not issue the proposed license on a timely basis because it is unable to make the stantory determinatons required under this Act, the Commission shall publitely issue its dectsion to that effect, and shall submit the license application to the President. The Commission's decision sball include as explanation of the basis for the decision and any dissenting or separate views. If, after recoiving the proposed ticense application and reviewing the Commision's decision, the President deternitaes that withholding the proposed export would be seriously prejudi. cial to the achievement of United States non-proliferation objectives, or would otherwise jeopardize the common fefense and security, the proposed export may be authoxized by Executive order; Provided, That prior to any stich export, the President shallsubmit the Executive order, together with his explanation of why, in light of the Commission's decision, the export should nonetheless be made, to the Congress for a period of sixty days of continurous session (as defined in subsection $130 \mathrm{~g}$.) and shall be referred to the Committee on Interna- 
Review.

Concerns and sequests, transsmittal to executive branch. tional Relations of the House of Representatives and the Cammittee on Foreign Relations of the Senate, but any sucit proposed export shall not occur if during such sixty-day period the Congress adopt a concurrent resolution stating in substance that it does not tavor the proposed export. Any such Executive order stall be considered pussuant to the procedures set forth in section 130 of this Act for the consideration of Presidential submissions: And provided further, That the pro. cedures established pursuant to subsection (b) of section 304 of the Nuclear Non-Proliferation Act of 1978 shall ptovide that the Commission shall inmediately initiate review of any application for a license under this section and to the maximum extent feasible shall expeditiously process the application concurrently with the executive branch seview while axpaiting the final executive branch judjanent. In inftating its review the Commission may identify a set of concerns and requests for Information associated with the projected issuance of such license and shall transinit such concerns and requests to the extcutive branch which shall address such concerns and requests in its written communications with the Commission. Such procedures shall also provide that if the Commission has not completed action on the application within sixty days after the receipt of an executive branch judgment that the proposed export or exemption is not imimical to the common defense and secunity or that any export in the category to which the proposed export belongs would not be inimical to the common defense and security because it lacks significance for nuclear explosive purposes, the Conimission shall inform the applicant in writing of the reason for delay and provide follow-up reports as appropriate. If the Commission has not completed action by the end of an additional sixty days (a total of one hundred and twenty days from receipt of the executfye branch judgment), the President may authortze the propased export by Erecutive order, opon a finding that further delay would be excessive and upon naking the fodings Itquired for such Presidential authorizations under this subsection, and subject to the Congressional review procedures set for th herein. However, if the Commission has commenced procedures for public partictpation regarding the proposed export under regulations promilgated pursuant to sibsection (b) of section 304 of the Nuclear Non-Proliferation Act of 1978, or-within sixty days after receipt of the executive branch judgment on the pfoposed export-the Comamission has jdentified and transmitted to the execultive branch a set of additional concertus or requests for information, the President may not authorize the proposed export until sixty days after public proseedings are completed of sixty days after a full executive branch response to the Commission's additional concerns or requests bas been made consistent with subsection a. (1) of this section: Prowlded further, That nothing in this 
Referral to confressional cosimittees.

42 USC 2156 section shall affect the right of the Commisșion to obtain data and recommendations from the Sexretary of State at any time as prowided in subsection a. (1) of this section.

${ }^{*} \mathrm{c}$. In the event that the House of Representatives or the Senate passes a joint resolution which would adopt one or more additional export criteria, or would modify any existing export criterla under this Act, any such joint resolution shall be referred is the other House to the Committee on Foreign Rela-

1. + tions of the Senate or the Committee on International Rela, tions of the House of Representatives, as the case may be, and $i$ shall be considered by the other House under applicable proceitures provided for the consideration of resolutions pursuant to section 130 of this Act, ${ }^{9 d}$

"Sec. 127. Crlteria Governing Unlted States Nuclear Exports,

"The United States adopts the following criteria which, in addition to other requtirements of law, will gowern exports for peaceful nuclear uses from the United States of source material, special muchesr material, production or utilization facilities, and any sensitive nuclear technology:

(1) JAEA safeguards as required by Article II (2) of the Treaty will be applied with respect to any such material or facilities proposed to be exported, to any such material or facilities previously exported and subject to the applicable agreement for copptration, and to any special nucleat matertal used in or produced through the ust thereof.

"(2) No such material, facilities, or sensitive muclear technology proposed to be exported or previously exported and subject to the applicable agreement for cooperation, and no special niclesar material produced through the use of such materiats, facilities, or sensitive nuclear technology, will be used for any nuclear explosive device or for research on or development of any nuclear explosive device.

"(3) Adequate phystcal secturity measures will bo maintained with respect to such material or facilities proposed to be exported and to any special nuclear material used in or proctuced through the tse thereof. Following the effective date of any regulations promulgated by the Commission pursuant to section 304 (d) of the Ntıctear Non-Proliferation Act of 1978, physical security meastures shall be deemed adequate if such measures provide a level of protection equivalent to that requited by the applicable regulations.

"(4) No such materials, facilities, or sensitive nuclear technology proposed to be exported, and no special nuclear material produced through the use of such material, will be retransferred to the jurisdiction of any other mation or group of nations unless the prior approval of the Unittd States is obtained for suchretransfer. In addition to other requirejuents of law, the United States may approve such retransfer only if the nation or group of nations

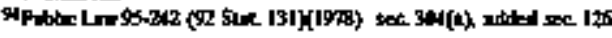


42 USC 2157.

Export applications, criterion entorcement.

Antes p. 131. Pass, p. 139. designated to receive such retransfer agrees that it shall be subject to the conditions requited by this section.

"(5) No such saterial proposed to be exported and no special puclear material produced through the use of such material will be reprocessed, and no irradiated fuel elements contaíning such material removed from a reactor shall be altered in form or content, unless the pritor apptoval of the United states is obtained for such reprocessing or alteration.

“(6) No such sensitive nuclear technology shall be exported unless the foregoing condjtions shall be applied to any nuclear maiterial or equipment which is produced or constructed under the jurisdiction of the recipient nation or group of nations by or through the use of any exported sensitive nuclear tectinology.95 "Sec. 128. Additional Export Criterion And Procedures-

"a. (1) As a condition of contimued United States export of source material, special nuclear material, production or utilization facilities, and any sensitive nuclear technology to non-puclear-weapon states, no stach export sholl be made unless IAEA safeguards are maintained with respect to all peaceful nuclear activities in, under the jurisdiction of, or carried out under the control of stch state at the time of the export.

"(2) The President shall seek to achieve adberence to the foregotng criterion by recipient non-nuclear weapon states.

"b. The criterion set forth in subsection a. shall be applied as an export criterion with respect to any application for the export of materials, factlities, or technology spectified in subsection a. which is filed after eighteen montis from the date of enactment of this section, or for any such application under which the first export would oscur at least twenty-four months after the date of enactment of this section, except as provided in the following paragraphs:

"(1) If the Commission or the Department of Energy, as the case may be, is notified that the President has determined that failure to approve an export to which this subsection applies because such criterion has notyet been metwould be seriously prejudicjal to the actitevement of United States non-proliferation objectives or otherwise jeopardize the comnon defense and security, the ticense or authorization may be issued subject to other applicable reguirements of law: Provided, That no such export of any produc. tion or utilization facility or of any source or special nuclear material (intended for tuse as fnel in any production or utilization facility) which has been licensed of authorized pursuant to this subsection stall be made to any non-nuclear-weapon state which has failed to meet such criterion until the first such license or authorization with respect to such state is submitted to the Congress (together with a detailed assessinent of the reasons underlying the President's determination, the judgentent of the executive brancth required under section 126 of this Act, and any Conmission opinionand views) for a period of sixty days of contimuous session (as defined in subsection $130 \mathrm{~g}$. of this Act) and referred to the Committee on International Relations of the House of Represen-

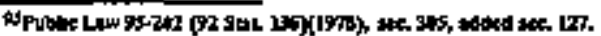


Congressional disapprowal, Iesolution. tatives and the Committe on For eign kelations of the Senate, but such export shall not occurif during such sixty-day period the Congress adopts a concurrent resolution stating in substance that the Congress does not favor the proposed export Any such license or

$\therefore$ authorization shall be consicered pursuant to the procedures set forth insection 130 of this Act for the consideration of Presidential submissions.

"(2) If the Congress adopts a resolution of disapproval pursuant to paragraph (1), no further export of materials, facilities, or technology specified in subsection a. shal] be permitted for the remainder of that Congress, unless such state meets the criterion or the President notifies the Congress that he has determined that significant progress has been made in achieving adberence to such criterion by such state or that United States foreign policy interestr dictate reconsideration and the Congress, pursuant to the procedure of paragraph (1), does not adopt a concurrent resolution stating in sulustance that it disagrees with the President's determination.

4(3) If the Congress does not adopt a tesolution of disapproval

Export asthorizations, congesstonal review.

Export termi. nations, criterion. 42 USC 2158. with respect to a license or authorization submitted pursuant to paragraph (1), the criterion set forth in subsection as shall not be applied as ar export criterion with respect to exports of materials, facilities and tectinology specified in substection a, to that state Provided, That the first license or authorization with respect to that state which is issued pursuant to this paragraph after twelve months fron the elapse of the sixty-day period specified in para. graph (1), and the first such license or authorization which is is swed after each twelve-month period thereafter, shall be submitted to the Congress for review pursuant to the procedires specified in paragraph (1): Provided further, That if the Congress adopts a resolution of disapprowal during atry review period provided for by this paragraph, the provisions of paragraph (2) shall apply with respect to further exports to stich state.\%

"Sec. 129. Conduct Resulting In Termination Ot Nuclear hxports"No nuclear materials and equipment or sensitive nuelear technology shail be exported to-

"(1) any non-nuclear-weapon state that is found by the President to have, at any time after the effective date of this section,

"(A) detonated a nuclear explosive devico; or

"(B) terminated or abrogated IAEA safeguards; or

(C) materially violated an IAEA safeguards agreement; or

"(D) engaged in activities involving source or special nuclear material and having direct significance for the manufacture or acauisition of nucleas explosive devices, and has fajled to take steps which, in the President's judgment, represent sufficient progress toward terminating suct activities; or

"(2) any nation or group of nations that is found by the President to have, at any tise after the effective date of this section,

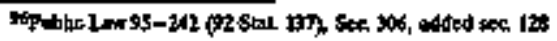


"(A) materialty violated an agreement for cooperation with the United States, or, with respect to material or equipment not supplied under an agreement for cooperation, materially violated the terms under which such material or equipment was supplied or the terms of any commitments obtained with respect thereto pursuant to section 402(a) of the Nuclear NonProliferation Act of 1978; or

"(B) assisted, encouraged, or indueed any non-nuclearweapon state to engage in activities involving source or special nuclear material and having direct significance for the manufacture or acquisition of nuclear explosive devices, and has failed to take steps which, in the President's judgment, represent sufficient progress toward terminating such assistance, encouragement, or jnducement; or

"(C) entered into an agreement after the date of enactment of this section for the transfer of reprocessing equipment, mitterials, or technology to the soverejgn contral of a non-puclearweapon state except in connection with an international fuel cycle evaluation in which the United States is a participant or pursuant to a subsequent international agreenient or understandiog to which the Untited States subsen ibes;

unless the President determines that cessation of such exports would bs seriously prejudicial to the achievement of United States non-proliferation objectives or otherwise jeopardize the common defense and sectrrity: Provided, That priot to the effective date of any such deternanation, the President's determination, together with a repott containing

Report Io. Congress.

Infra.

42 Usc 2159

Congressional committee reports.

Past. p. 142.

Ante pp. 131, $137,138,127$. the reasons for his determination, shall be submitted to the Congress and referred to the Committee on Intemational Relations of the Fouse of Representatives and the Committee on Foreign Relations of the Senate for a period of sixty days of continuous session (as defined in subsection $130 \mathrm{~g}$. of this act), but any stuch determination shall not become effective if during such sixty-day period the Congress adopts a concurrent resolution stating in stbstance that it does not favor the determination. Any such determination shall be considered pursuant to the procedures set forth in section 130 of this Act for the consideration of Presidential submissions. 97

"Sec. 130. Congresstonal Review Procedures.

"a. Not later than forty-five days of continuous session of Congress after the date of transmittal to the Congress of any submission of the President required by subsection $2 \% 126$ a. (2), 126 b. (2), 128 b., 129, 131 a. (3), or 131 f. (1)(A) of this Act, the Committee on Foreign Relations of the Senate and the Committee on Foreign Affairs of the Honse of Representatives. $9 \%$ shall each submit a report to its respective House on its views

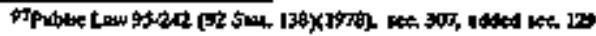

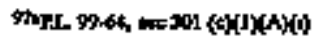

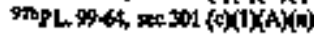

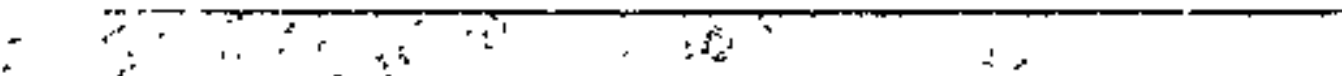


42 USC 2121 2164.

and recommendations respecting such Presidential submission together with a resolution, as defined in subsection f., stating in substance that the Conleress approves or disapproves such stibmission, as the case may be: Provided, That if any such committee has not reported such a resolution at the end of such forty-five day period, such comnittee shall be deemed to be discharged from further consideration of such submission. ${ }^{97 \varepsilon}$ If no auch resolution has been reported at the end of such period, the first resolution, as defined in subsection $f$, which is introduced within five days thereafter within such House shall be placed on the appropriate calendar of suct House.

"b. When the relevant conmittee or cornuittees have reported such a resolution (or bave been discharged from further consideration of such a resolution pursuant to subsection a.) or when a resolution has been introduced and placed on the appropsiate calendar pursuant to subsection a, as the case may be, it is at any time thereaftor in order (even though a previous motion to the starne effect has been disagreed to) for any Member of the respectrve House to move to proceed to the consideration of the resolution. The motion is highly privileged and is not debatable. The motion shall not be subject to amendment, or to a motion to postpone, of to a motion to proceed to the consideration of other business. A motion to reconsider the vote by whith the motion is agreed to or disagreed to shall not be in order. If a motion to proceed to the consideration of the resolution is agreed to, the resolution shall remain the unfinished business of the respective Hontse antil disposed of.

*c. Debate on the resolution, and on all debatable motions and appeals in connection therewith, shall be linited to not norte than ten hours, which shall be divided equally bëtween individuals favoring and fodividuals opposing the resolution. A motion further to linit debate is in order and not debratabte. An amendment to a motion to posteone, or a motion to recommit the resolution, or a motion to proceed to the consideration of pther business is not in order. A motion to reconsider the vote by which the resolution is agreed to of disagreed to shall not be in order. No amendment to any concurrent resolution pursuant to the procectures of this section is in order except as provided in subsection $d$.

"d. Immexliately following (1), the conclusion of the debate on such concurrent resolution, (2) a single quotum call at the copchtusion of debate if requested in accordance with the nules of the appropriate House, and (3) the considefation of an amendment introduced by the Majority Leader or his designee to insert the phrase, 'does not' in lieu of the word 'does' if the resolution under consideration is a concusrent resolution of approval, the vote on final approval of the resolution shall occur.

"e. Appeals from the decisions of the Chain relating to the application of the rules of the Senate or the House of Representatives, as the case may be, to the procedure relating to sueb a resolution shall be decided without debate.

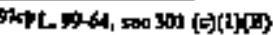


"Resolution."

Continuous sessions of Congress. Computation.

"f. For the purposes of subsections a. through e. of this section, the term 'resolution' means a concurrent resolution of the Congress, the roatter after the resolving clause of which is as follows: 'That the Congress (does or does not) fayor the transinitted to the Congress by the President on $\quad \therefore$, the blank spaces therein to be appropriately filled, and the affirmative or regative plurase within the parenthetical to be appropriately selected.

"g. (1) Except as provided in paragraph (2), for the purposes of this section-

"(A) contimuity of session is broken only by an adjournment of Congress sime die; and

"(B) the days on which either House is not in sessionbecause of an adjourmment of more than three days to s day certain are excluded in the computation of any period of time in which Congress is in continuous session.

(2) For purposes of this section insofar as it applies to section

(A) continutity of session is broken only by an adjournment of congress sine die at the end of a Congress; and

"(B) the days on which either House is not in session because of an adjournnent of more than three days are excluded in the computation of any period of time in which Congress is in contintous session.

"h. This section is enacted by Congress-

"(2) as an exercise of the rulernaking porter of the Senate and the House of Representatives, respectively, and as such they are deemed a part of the rules of each House, respectively, but applicable only with respect to the procedure to be followed in that House is the case of resolutions described by subsection $\mathrm{f}$ of this section; and thy supersede other rules only to the extent that they are inconsistent therewith; and

(2) With full recognition of the constitutional right of eitber House to change the rules (so far as relating to the procedure of that House) at any tone, in the same manner and to the sume extent as in the case of any other rule of that House.98

"i. (1) For the purposes of this subsection, the term 'joint resolution' means a joint resolution, the matter after the Jesolving clause of which is as follows: "That the Congress (does or does not) favor the proposed agreement for cooperation transwitred to the Congress by the President on with the date of the transmission of the proposed agrement for copperation inserted in the blank, and the affinmative or negative phrase within the parenthetical appropriately selected.

"(2) On the day on which a proposed agreement for cooperation is submitted to the House of Representatives and the Senate under section $123 \mathrm{~d}$., a joint resolution with respect to such agreement for cooperation shall be introtuced (by request) in the House by the chairman of the Comnittee on

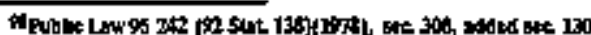


Foreign Affairs, for himsclf and the ranking minority member of the Committee, or by Members of the Hotse designated by the chairmas and ranking minority member; and shall be introduced (by request) in the Sinate by the majority leader of the Senate, for hiviself and the minority leader of the Serlate, or by Mfembers of the Senate designated by the majority leader and minority leader of the Senate. If either House is not in session on the day on which such an agreement for cooperation is submitted, the joint resolution stiall be introduced in that Fouse, as provided fon the preceding sentence, on the first day thereafter on which that House is in session.

"(3) All joint resolutions introduced in the House of Repre. sentatives shall be referred to the appropriate committee or committes, and all joint resolutions introduced in the Senate shall be referred to the Committee on Foreign Relations and in addition, to the case of a proposed agreement for cooperation arranged pursuant to section $91 \mathrm{~cm}, 144 \mathrm{~b}$., or $144 \mathrm{c}$, the Conmittee on Armed Services.

"(4) If the committee of either House to which a joint resolution has been referred has not reported it at the end of 45 days after its introduction, the committee shall be discharged from further consideration of the foint resolution or of any other joint resolution introduced with respect to the same matter, except that, in the case of a joint resolution which has been referred to more than one comnittee, if before the end of that 45-day period one such committee has reported the joint resolution, any committee to which the joint resolution was referred shall be disctarged fron: further consideration of the joint resolution or of any other joint resolution introduced with respect to the same matter.

(5) A joint resolution under this subsection shall be considered in the Senate in accordance with the provistons of section $601(b)(4)$ of the International Security Assistance and Ants Expont Control Act of 1976. For the purpose of expediting the consideration and passage of joint resolutions reported or discharged pursuant to the provisions of this subsection, it shall be in order for the committee on Rilles of the House of Representatives to present for consideration a resolution of the House of Representatives providing procedures for the immediate consideration of a joint resolution under this subsection which may be similar, if applicable, to the procedures set forth in section 601(b) (4) of the International Security Assistance and Arms Export Control Act of 1976.

(0) In the case of a joint resolution described in paragraph (1), if prior to the passage by one House of a joint resolution of that House, that House receives a joint resolution with respect to the mone matter from the other House, then-

(A) the procedure in that House shall be the same as if no joint resolution had been received from the other House; but 
42 USC 2160.

Consultation

42 USC 2121, 2164.

Notice putilication in the Federal

Register,

Nuctear

Proliferation

Assessment

Statement.

"Subsequont arringements."

Contracts.

Ante, p. 125.
(B) the vote on final passage shall be on the joint resolu. tion of the other House".

Sec, 131. Subsequent Arrangements.-

a (1) Prior to entering itto asly proposed subsequent arrange. ment under an agreement for cooperation (other than an agreement for cooperation arranged pursuant to subsection 91 c., 144 b., or $144 \mathrm{c}$ of this Act), the Secretary of Energy shall obtain the concurrence of the Secretary of State and sball consuit with the Director, the Commission, and the Secretary of Defense: Provided, That the Secretary of State shall tave the leading role in any negotiations of a policy nature pertaining to any proposed subse. quent arrangenent regarding arrangements for the storage or disposition of irradiated fuel elements or approvals for the transfer, for whitch prior approval is required under an agreement for cooperation, by a recipient of source or special nuclear matertal, pro. duction or atilization facilities, or nuclear technology. Notioe of any proposed subsequent arrangement shall the published in the Federal Register, together with the written determination of the Secretary of Energy that sucil arrangement will not be inimical to the common defense and security, and such proposed subseguent arrangement shall not take effect before fifteen days after pubjication. Whenewer the Director declares that he intenxds to prepare a Nuclear Proliferation Assessment Statement pursuant to paragraph (2) of this subsection, notice of the proposed subsequent arrangenent which is the subject of the Director's declaration shell not be published until after the receipt by the Secretary of Energy of such Statement or the expiration of the time authorized by subsection c. for the preparation of such Statement, whichever occurs iirst.

(2) If in the Dinector's view a proposed subsequent arrangement might signiticantly contribute to proliferation, he may prepare an unclassified Nuclear Proliferation Assessment Statement with Iegard to such proposed subseguent arrangement regarding the adequacy of the safeguards and other control mechanisins and the application of the peaceful use assurances of the relepant agreement to ensure that assistance to be furnished pursuant to the subsequent arrangement will not be used to further any military or nuclear explosive purpose. For the purposes of this section, the term 'subsequent arrangements' means arrangements entered into by any agency or department of the United States Government with respect to cooperation with any nation or group of nations (but not purely private or domestic arrangenents) inwolwing -

(A) contracts for the furnishing of nuclear materials and equipment;

(B) approvals for the transfer, for which prior approval is required under an agreenent for cooperation, by a recipient of any source or special ntacleas material, production of utilization facility, or nuclear tedhnology;

"(C) authorization for the distribution of nuclear materials and equipment pursuant to this Act which is not subject to the 
Post, pp. 131, 141 .

Post, p. 142.

Report to congressional commintees.

Post, p. 139 procecliats set forth in section $111 \mathrm{~b}$., section 126, of section 10\%.;

"(D) arrangements for physical security;

(E) arrangements for the storage or gisposition of irraciated fiel elements;

"(F) arrangements for the application of safeguards with respect to ancleas materials and equiprotent or

"(G) ang other arrangement which the President finds to be important from the standpoint of preventing proliferation.

“(3) The United States will give timely consideration to all requests for prior approval, when required by this Act, for the reprocessing of material proposed to be exported, previously exported and subject to the applicable agreement for cooperation, or special nuclear material prodiced through the use of stich material or a production or utilization facility transfiented pursuant to such agreement for conperation, or to the altering of inadiated fuel elements containing such material, and additionally, to the maxiJaum extent feasible, will attempt to expedite such constidefation when the terms and conditions for such actions set forth in such agreement for cooperation or in some other jotemational agreement executed by the United States and subject to congressionsl review procedhures comparable to those set forth in section 123 of this Act.

“(4) All óther statutory requirements under other sections of this Act for the approwal or conduct of any arrangement subject to this'subsection shall continue to apply and any other such requirements for prior approwal or conditions for entering such arrangements shall also be satisified before the arrangentent takes effect pursuant to subsection a. (1).

"b. With regard to any speciel nuclear materital exported by

the United States or produced through the use of any muckar materials and equipjuent on sensitive nuclear techrology oxported by the Uutted States-

"(1) the Secretary of Energy may not onter into any subsequent arrangement for the retransfer of any such material to a third country for reprocessing, for the reprocessing of any such material, or for the subsequent retransfer of any plutonium in quastities greater than 500 grams resulting from the reprocessing of any such material, until. he has provided the Committe on Intemational Relations of the House of Representatives and the Cornmittee on Foreign Relations of the Senate with a report containing his reasons for entering into such arrangement and a period of 15 days of continuous sesston (as defined in strbsection $130 \mathrm{~g}$. of this Act) has elapsed: Provided, however, That if in the view of the President an emergency exists due to unforeseen circumstances requiring fmmediat: entsy juto a subsequent arrangement, such period shall consist of fifteen calendar days; 
"(2) the Secretary of Energy may not enter toto any subsequent arrangement for the reprocessing of any such material in a facility which has not processed power reactor fuel assemblies or been the subject of a subsequent arrangetment therefor pritor to the date of enactment of the Nuclear Non-Proliferation Act of 1978 or for subsequent retrarsfer to a non-nuclear-weapon state of any plutcDium in quantities greater than 300 grams resulting from such reprocessing, unless in his judgment, and that of the Secretary of State, such reprocessing or retransfer will not result in a significant increase of the risk of proliferation beyond that which exists at the time that approwal is requested. Among all the factors in making this judgroent, foremost consideration will be given to whether or not the reprocessing or retransfer will take place under conditions that will ensture timely warning to the United States of any diversion well in advance of the time at which the non-nuclear-weapon state could transform the diverted material into a nuclear enplositue device and

"(3) the Secretary of Energy shail attempt to ensure, in entering into any subsequent arrangement for the reprocessing of any such - material in any facitity that has processed potser reactor fuel assemblies or been the subject of a subsequent arrangement therefor prior to the date of enactment of the Nuclear Non-Proliferation Ast of 1978, or for the subsequent tetransfer to any non-nuclear-weapon state of any plutonium in quantities greater than 500 grans resulting from such reprocessing, that sucis reprocessing or retransfer shail take place under conditions conoparable to those which in hisview, and that of the Secretary of State, satisfy the standards set forth in paragraph (2).

Nuclear materials, reprocessing or transfer procedures.

Controversial "c. The Secretary of Energy shall, within ninety days after the enactment of this section, establish orderly and expectitious procedures, including prowision for necessary administrative actions and inter-agency memoranda of understanding, which are mutually agreedble to the Secretaries of State, Defense, and Comunerce, the Director of the Aruls Control and DisarInarpent A genty, and the Nuclear Regulatory Commission for the consideration of requests for subsequent arrangements urder this section. Such procedures shall inchude, at a mimimum, explicit direction on the handling of such recuests, express deadlines for the solicitation and collection of the views of the contsulted aigencies (with identified officials responsible for meeting such deadlines); an inter*agency coordinating authority to monitor the processing of sich requests, predeter. mined procedures for the expeditious handling of intra-agency and inter-agency disagreements and appeals to higher authorities, frequent theetings of inter-agency administrative coordjnators to review the status of all pending requests, and similar administrative mechanisns. To the extent practicable, an applicant should be advised of all the information requited of the applicant for the entire process for every agency's needs at the beginning of the process. Potentially controwersial request

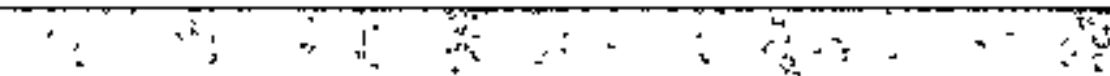


requests. identification.

Standards and criteria, Nuclear Proliferation

Assessment

Stattement.

Presidential

พ⿴aiver.

Notice to

congressional committees.

42 UsC 7132.

'

Presidential plan, submittal to Congress. shouxd be identified as quickly as possible so that any required policy detcions or diploutatic consultations can be initiated in a timely manner. An imnediate effort should be undertaken to establish quickly any necessary standards and criteria, including the nature of any required assurance or evidentiary showings, for the decisions required under this section. Further, such procedures shall specify that if he intends to prepare a Nuclear Proliferation Assessment Statement, the Director shall so dtclare in his response to the Department of Energy. If the Director declares that he intends to prepare such a Statement, he shall do so within sixty days of his recejpt of a copy of the proposed subsequent arrangement (đuring wlyich time the Sec-retary of Energy may not enter into the subsequent arrangement), unless pursuant to the Directors request, the President rwaives the sixty-day requirement and notises the Committee on International Relations of the House of Representatives and the Conumittee on Foreign Relations of the Sertate of such waiver and the justitication therefor. The processing of any subsequent arrangement proposed and filed as of the date of enactment of this section shall aot be delayed pending the developinent and establishment of procedures to jmplentent the regalirements of this section.

"d. Nothing in this section is intended to prohibit, permanently or unconditionally, the-reprocessing of spent fuef owned by a foreign nation which fuel has been sipplied by the United - States, to preclude the United States from full participation in the International Nuclear Fuel cycle Evaluation provided for in section 105 of the Nuclear Non-Proliferation Act of 1978; to in any way limit the presentation or consideration in that evaluation of any nuclear fuel cycle by the United States or any other participation; nor to prejudice open and objective con- sideration of the results of 'the' cvatuation.

"e. Notwithstanding subsection 402(d) of the Department of Energy Organizatton Adet (Public Law 95-91), the Secretary of Energy, and not the Federal Energy Regulatory Commission, shall have sole jurisdiction within the Department of Enersy over any matter arising from any function of the Secretary of energy in this section.

"t. (1) With regard to any substequent arangement under subsection a.,(2)(E) (for the storage or disposition of itradiated fuel elements), where such arrangement involves a dirext or indirect commitment of the United States for the storage or other disposition, interim or permanent, of any foreign spent nuclear fixel in the United States, the Secretary of Energy may not enter into any sirch subsequent arrangeraent, unless;

"(A)(i) Such commitment of the United States has been submitted to the Congress for a period of sixty days of continuous session (as defined in subsection $130 \mathrm{~g}$. of this act) and has been referred to the Committee on Internstional relations of the House of representatives and 
Ante, p. 125.

Post, p. 131.

Notice to congressional commititees.

Plan, tontents.

"Foreign spent tuclear fuel" the Conumitte on Foreigr Relations of the Senate, but any such coumbtitunent shall not becone offective tif dirizg such sixty-day period the Congress adopts a concurrent resolution stating in substance that it does not favor the commitment, auy such commitment to be considered pursuant to the procedures set forth in section 130 of this act for the consideration of Prosidential submission; or (ii) if the President has submitted a detajled generic plan for such disposition os storage in the Unjted States to the Congress for a period of sixty days of contimuous session (as deined in subsection $130 \mathrm{~g}$. of this Act), which plan has been referred to the Corminttes on International Relations of the House of Representatives and the Conmittee on Foreign Relations of the Senate and has not been adoption of a concurrent Jesolution stating in substance that Congress does not favor the plan; and the commitment is subject to the terms of an effective plan. any such plan shall be considered purstuatt to the procedures set forth in section $\mathbf{1 3 0}$ of this act for the consideration of Presidential submissions:

"(B) The Secretary of Energy has complied with subsection a.; and

"(C) The Secretary of Energy has complied, or in the arrangement will comply with all other statutory require. ments of this Act, under sections 54 and 55 and any other applicable sections, and any other requirements of law.

“(2) Subsection (1) shall not apply to the storage or other disposition in the United States of limited quantities of foreign spent nuclear fuel if the President determines that (A) a commit. mont under section $\mathbf{3 4}$ or $\mathbf{5 5}$ of this Act of the Uatit States for storage or other disposition of such limited quantities in the United States is required by an emergency situation, (B) it is in the national interest to take stich immediate action, and (C) he noti. fies the Comnittees on Interrational Relations and Science and Technology of the House of Representatives and the Committees on Foreign Relations and Energy and Nattural Resources of the Senate of the determination and action, with a detailed explanation and justification thereof, as soon as possible.

"(3) Amy plan submitted by the President under subsection f. (1) shall include a detailed disctussion, with detailed information, and any supporting documentation thereof, retating to policy objectives, technical description, geographic information, cost data and justifications, legal and regulatory considerations, environmental impact information and any refated international agreements, arrangements for understandings.

"(4) For the ptirposes of this subsection, the term foreign spent: nuclear fuel' shall include any nuclear fuel irradiated in any nu. clear power reactor located outside of the United States and operated by any foreign legal entity, government or nongovertument, regardless of the legal onnersitp or ather control of the fuel or the 
42 USC 21606.

President of U.S.

42 USC 2160

42 USC 2160

42 USC 2168d.

reactor and regardless of the origin or licensing of the futel or reactor, but not including fuel irtadiated in a research reactor. 99

4Sec 132. Authority To Suspend Nuctear Conperation With Nations Which Have Not Ratified The Convention Oa The Physical Security of Nudear Material.-

"The President may suspend nuclear cooperation under this Act with any nation or group of nations which has not ratified the Convention on the Plysical Security of Nuclear Material. ${ }^{n 9 a}$

4Sec. 133. Consultation With The Department Of Defonese Concernlag Certain Exports And Subsequent Arrangenents. -

"a. In addition to other applicable requirements-

"(1) a license may be issued by the Nuclear Regulatory Commiscion under this Act for the export of special muclear material described in subsections $b_{+}$; and

"(2) approvat may be granted by the Sectetary of Energy undet-section 131 of this Act for the transfer of special nuclear matertal described in subsection $b_{\text {; }}$;

only. after the Secretary of Defense has been consulted on whether the physical protection of that material during the export or transfer will be adequate to deter theft, sabotage, and other acts of international terrorism which would result in the diversion of thist material. If, in the view of the Secretary of Defense based on alI avatlable intelligence inforration, the export or transter might be subject to a genuine terrorist threat, the Secretary shall provide to the Nuclear Regulatory comimission or the Secretary of Enexgy, as approptiate, his written assessment of the risk and a description of the actions the Secretary of Defense considers necessary to uperade physical protection metasures.

4b. Subsection a. applies to the export or transfer of moke than 2 kilograms of plutonium or more than $5^{996}$ kilogratus of uranium entiched to thore than 20 percent in the isotope 233 or the isotopt 235 . 99

"Sec 134. Further Restrictions on Exports.-

"a. The Commission may issue a license for the export of highly enriched uranium to be used as a fuel or target in a nuclear research or tost reactor only if, in addition to any other requirement of this Act, the Commission detetmines that-

"(1) there is no alternatuve nuclear reactor fuel or target enriched in the isotope 235 to a lesser percent that the proposed export, that can' be used in that reactor;

"(2) the proposed recipient of that uranium has provided assurances that, whenever an alternative nuclear reactor fuel or target can be used in that reactor, it will use that alternative in lietu of highly enriched uranium; and

"(3) the United States Goverticuent is actively developing ar altemative nuclear reactor fuel or target than can be used in that reactor.

b. As toed int this section-

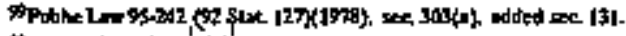

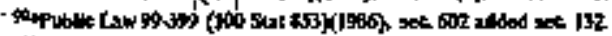

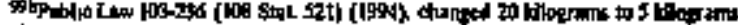

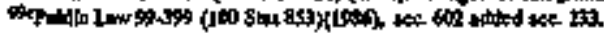


(1) the term "altemative nuclear reactor fuel or target" means a nuclear reactor fuel or target which is enriched to less than 20 percent in the isotope $U-235$;

"(2) the term 'highly clriched tuanium' means uranium enriched to 20 percent or more is the isotope $\mathrm{U}-235$; and

“(3) a fuel or target 'can be used' in a nuclear research or test reactor if-

(A) the fuel or target has been qualitied by the Reduced Enrichment Research and TestReactor Progran of the Depastanent of Energy, and

(B) use of the fuel or target witl pernit the large majority of ongoing and planned experiments and isotope production to conducted to the reactor without a large percentage increase in the total cost of operating the reactor.

"c. Report to Congress.

(1) INGENERAL-Not later than 90 days after the date of the enactment of this Act, the Chairman of the Nucltar Regulatory Commission, after consulting with other relevant agencies, shall submit to the Congress a report detailing the carrent disposition of previous United States exports of bighly enricbed uranium, including-

"(A) their location;

"(B) whether they are irradiated;

"(C) whether they have been used for the purpose stated in their export license; and

"(D) whether they have been used for an altermative purpose and, if so, whether such aiternative purpose has been explicitiy approved by the Conmission.

(2) EXPORTS TO EURATOM-To the maximum extent possible, the export required by paragraph (1) shall include"(A) exports of highly enriched uraniun to EURA. TOM; and

(B) subsequent retransfers of such material within EURATOM, without regard to the extent of United States control over such retransfers. ${ }^{95 e}$

\section{"CHAPTER 12-CONTROL OF INPORMATION}

"Sec. 141. Policy--It shan be the poltcy of the Commisston to control the dissepization and declassification of Restricted Data in such a manner as to assure the common defense and security. Consistent with suchpolicy, the Commisstion shall be guided by the following principles:

"a. Until effective and enforceable internatoonal safeguards agatinst the use of atomic energy for destructive purposes have been established by an international arrangement, there shall be no exchange of Restricted Data with other nations except as authorized by section 144; and

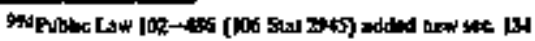

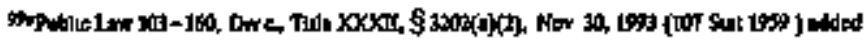


Classification ond declassification of restricted data. 42 USSC sec. 2162 .

61 STAT, 498 \$0 USC 403 (d)

Department
of Defense
participation.
42 USC
set. 2163.

"b. The dissemination of scientific and technical information relating to atomic energy should be permitted and encouraged so as to provide that free irterchange of ideas and crititisn which is essential to scientific and industrial progress and public understanding and to enlarge the fund of technical information.

"Sec. 142. Classification And Declassilication Of Restricted Data,-

4a. The Cormission shall from time to time determine the data, within the definition of Restricted Data, which can be pubtished without undue risk to the common deferse and security and shall thereupon cause stoch data to be dectassified and temoved from the category of Restricted Data.

"b. Tht commisston shall maintain a continuous review of Restricted Data and of any Classification guides jssued for the guidance of those in the atonic energy program with respect to the areas of Restricted Data which bave been declassified in order to determine which information may be declassified and tomoved from the icategory of Restricted Data without undue risk to the combon defonse and security.

"c. In the case of Restricted Data which the Commission and the Department of Deferse jointly determine to relate primarily to the military utilization of atomic weapons, the detentmination that such data may' be published without constitutiog an unceasonable risk to the common defense and security shall be made by the Commission and the Department of Defense jointly, and if the Commission and the Department of Defense do not agree, the determination shell be made by the Presidient.

"d. The Commission shal! remove from the Restricted Data category stuch data as the Commission and the Department of Defense jointly determine relates pitmarily to the military utilization of atomic weapons and whth the Commission and Department of Defonse jointly determine can be adequately safegnarded as defense jnformation: Provided, however, That no such data $\$$ removed from the Restricted Data category shall be transmitted or otherwisc made available to any nation or regional defense organization, while such dafa remains defense information, except purstant to an agreement for cooperation entered into in accordance with subsection b. or d. of section 144.100

"e. The Commission shall remove from the Restricted Data category such infomation concening the atomic energy programs of other nations as the Commission and the Director of Central Intelligence jointly deternine to be necessary to carry out the provisions of section 102(d) of the National Sectrity Act of 1947 , as amended, and can be adecisately safeguarded as defense information.

¿Sec. 143. Department Of Defense Partiefpation.-The Commission may authorize any of its employees, or employees of any contractor, prospective contractor, licensex or prospective licensee of the Commission or any other persoti authorized access to Restricted Data by the

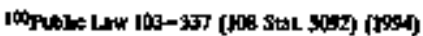


International cooperation. 42 USC

sec. 2164
Cooperation by Defense Department
Commission under sabsections $145 \mathrm{~b} .101$ and $145 \mathrm{a}^{302}$ to permit any employes of an agency of the Departanent of Defense or of jts contractors, or any member of the Armed Forces to have acoess to Restricted Data required in the performance of his duties and so certified by the head of the appropriate agency of the Department of Defense or his designee: Provided, however, That the head of the appropriate agency of the Department of Defense or his designee has deternoined, in accordance with the established persontnel securify procedures and stan. dards of such agency, that permitting the member or employee to have aceess to such Restricted Data will not ondanger the common defense and security: And provided further, That the Secretary of Deferise finds that the established personisel and other security procedures and stan. dards of such agency are adequate and in reasonable conformity to the standards established by the Commission under section 145.

"Sex. 144. Intermational Cooperation.-

"a. The President may authorize the Conimission to cooperate with another nation and to communicate to that nation Restricted Data on-

"(I) refining purifiction, and subsequent trotatment of source material;

"(2) civilian reactor clevelopment;

"(3) production of special nuclear material;

(4) health and safety;

(5) injustrial and other applications of atomic energy for peaceful purposes; and

"(o) research and development reiating to the foregoing:

Frovided, however, That no such cooperation shall involve the comnunication of Restricted Data relating to the design of fabrication of atomic weapons: And prourded further, That the cooperation is undertaken pursuant to an agreement for cooperation entered into in acoordance with section 123, or is undertaken purstant to an agreement existing on the effective date of this Act. ${ }^{102 a}$

"b. The President may authorize the Department of Defense, with the assistance of the Commission, to cooperate with another nation or with a regional defense organization to which the United States is a party, and to comrruunicate to that nation or organization stuch Restricted Data (induding desiga information) as is necessary to-

"(1) the development of defense plars;

"(2) the training of personnel in the employment of and deferse against atomic weapons and other military applications of atomic energy;

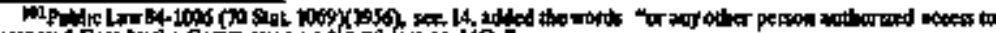

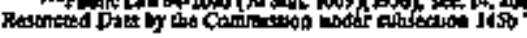

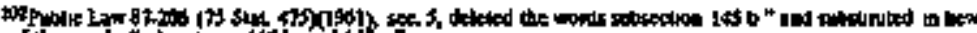

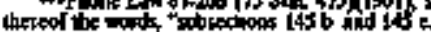

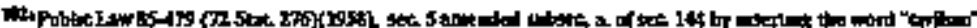

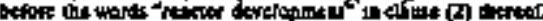

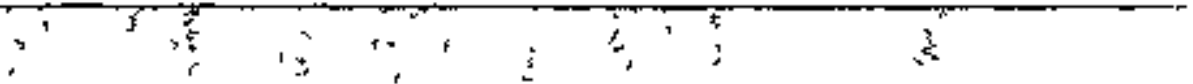


"(3) the evaluation of the capabilities of potential enemies in the eraployment of atomic weapons and oher military applications of atomic energy; and

$\Gamma$

"(4) the development of compatible delivery systems for atomic, preapons;

whenever the President determines that the proposed cooperation and the proposed communication of the Restricted Data will pronote and will not constitute an unreasonable risk to the common defense and security, while such other nation or organization is participating with the United Stases pursuant-to an international arrangement by substantial and material contributions to the mutual defense and security: Provided, however, That the cooperation is undertaken pursuant to an agreement entered into acoordance with section 123 . 103

" $\mathrm{c}$. In addition to the cooperation authorized in subsections 144 a. and $144 \mathrm{~b}$., the President may authorize the Commission, with the assistance of the Department of Defense, to caoperate with another nation and--

"(1) to exchange with that nation Restricted Data concern ing atomic weapons: Provided, That communication of such Restricted Data to that nation is necessary to improve its atortto weapon design, development, or fabrication capability and - provided that nation has made sulxstantial progress in the development of atoric weapons; and

*(2) to communicate or exchange with that nation Restricted

Data concerning research, development, or design, of military reactors,

whenever the President determines tist the proposed cooperation and the communication of the proposed Restricted Data will promote and will not constitute an unreasonable risk to the common defense and security, while such other nation is participating with the United States pursuant to an international arrangement by stbstantial and material contributions to the mutual defense and security: Provided, however, That the cooperation is undertaken pursuant to an agreement entered into is accordance with section 123.1032 .

"d. (1) In addition to the coperation authorized in subsections a., b., and c., the President may, upon maling a determination described in paragraph (2), authorize the Department of Energy, with the assistance of the Departurent of Defense, to cooperate with another nation to communicate to that nation such Re-

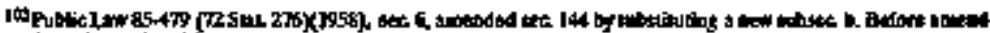

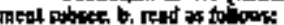

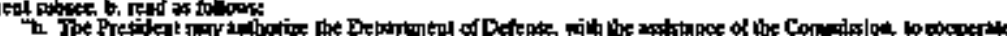

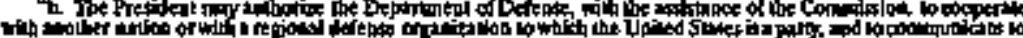

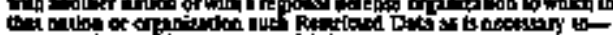

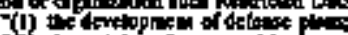

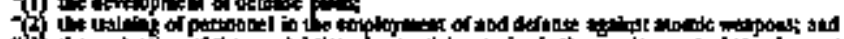

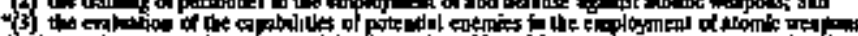

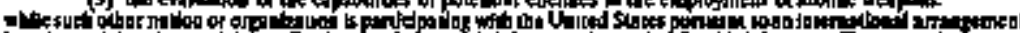

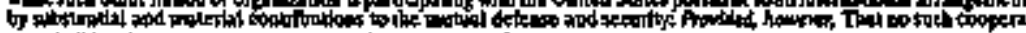

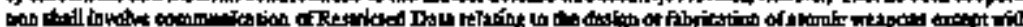

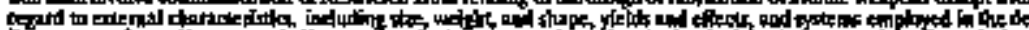

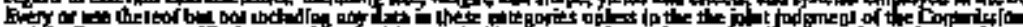

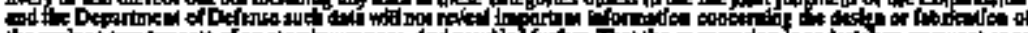

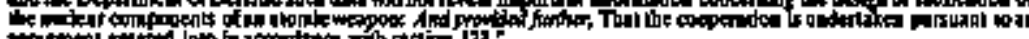

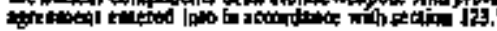

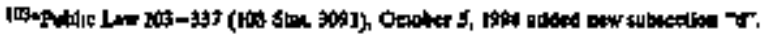


stricted Data, and the President may, upon making such determination, authorize the Departmerit of Defense, with the assistarce of the Department of Energy, to cooperate with another nation to communicate to that nation such data removed from the Restricted Data category under section 142, as is necessary for-

(A) the support of a program for the control of and accounting for fissile material and other weapons material;

(B) the support of the control of and accounting for atomic weapons;

(C) the verification of a treaty; and

(D) the establishonent of international standayds for the classification of date on atomic weapons, data on fissile material, and related data.

(2) A determination referred to in paragraph (1) is a deter. minstion that the proposed cooperation and proposed communicationt referred to in that paragraph-

(A) will promote the common defense and security intetests of the United States and the nation concerned; and

(B) will not constitnte an unreasonable risk to suxh common defense and secturity interests.

(3) Conperation under this subsection shall be undertaken purstant to an agreement for cooperation entered into in accordance with section 123.

"e. The President may authorize any agency of the United \$tates to connunicate in accordanse with the terms and conditions of an agreement for cooperation arranged pursuant to subsection 144 a, b., c., or d., such Restricted Data as is determined to be trans-

Restrictions. 42 USC $\sec 2165$.

Investigations by CSC. missabfe under the agreement for cooperation involved. ${ }^{\text {704 }}$

"Sec, 145. Restrtetions.-

"a. No arrangement shall be made under section 31, no contract shall be made or continued in effect under section 41 , and no license shall be issued under section 103 or 104, unless the person with whom such arrangoment is made, the contractor or prospective contractor, or the prospective liceasee agrees in writing not to permit any individenal to have access to Restricted Data until the Civit Service Commission shall have made an investigation and report to the Commission on the character, associations, and loyalty of such individeral, and the Commission shall have determined that permitting such person to have access to Restricted Data will not endanger the common defense and security.

"b. Except as authorized by the Commission or the General Manager upon a determination by the Commission or Gentral Marager that such action is ciearly consistent with the mational interest, no individual shall be employed by the Commission nor sball the Commission permit any individual to have access to Re. stricted Data until the Civil Service Coumtission shall have made an investigation and report to the Conmission on the character,

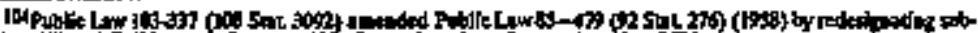

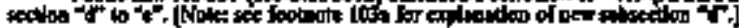


Investigations by FBI.

associations, and loyalty of such indjvidual, and the Comnission shall have determined that permitting such person to have access to Resticted Data will not endanger the combinon defense and secturity.

ce. In lieu of the investigation and report to be made by the Civl Service Commission purstuant to subsection b. of this section, the Comunission may accept an investigation and report on the character, associations, and loyalcy of an individual made by another Government agency which conducts personnel security investigations, provided that a securityclearance has been granted to such individual by another Goverament agency based on such investigation and report.

"d. In the event an investigation made purstuant to subsections a. and b. of this section develops any data reflecting that the ixtividual who is the subject of the investigation is of questionable loyalty, the Civil Service Commission shall refer the matter to the Federal Bureau of lnvestigation 'for the conduct of a full field investigation, the results of which shall be furnished to the Civil Service commission for its jnformation and appropriate action.

, "e. If the President deems it to be in the national interest he may from time to time determine that iwestigations of any group or class which are required by subsections a., $b_{\text {, and }}$. of this section be made by the Federal Bureau of Investigation.

"f. Notwithstending the provisions of subsections $a, b$, and c. of this section, a majority of the members of the Comnission stall certify those specific positions which are of a high degree of jinportance or senstivity, and upon such certification, the investigation ${ }^{105}$ and reports required by such provisions shall be made by the Federal Bureau of Imvestigation.

Fg. The commissions shall tstablish standards and specifications in writing as to tho scope and extent of itvestigations, the reports of which will be utilized by the Commission in making the determination, pursuant to subsections $a, b$, and $c$ of this section, that periuitting a person access to restricted date will not endanger the commion defense and security. Such stasidards and specifications shall be based on the location and class or kiad of work to be done, and shall, aroong other corsiderations, take into account the degree of importance to the conunon defense and security of the Restricted Data to which access will be permitted.

th. Whenever the Congress declares that a state of war eyists, or in the event of a national disaster due to enemy attack, the Commission is authorized during the state of war or period of national disaster due to eneruy attack to employ incividuals and to permit individuals access to Restricted Data pending the investigation report, and determination required by section $145 \mathrm{~b}$, to the extent that and so lopg as the Commission finds that such action is re-

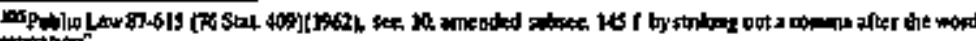

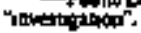


General provisions. 42 USC 站. 2166.

42 USC 2167. Regulations,

quired to prevent inpairuent of its activities in furtherance of the common defense and security. 106

"Sec. 146. General Provisjons.-

"a Secrions 141 to 145, inchusive, shatl tot exclude the applicable provisions of any other laws, except that no Government agency shall take any action under such other laws inconsistent with the provisions of those sections.

"b. The Conmission shall have no power to control or restrict the dissemination of jnformation other than as granted by thits or any other law.

"Sec. 147. Salieguards Information.-

"a. In addition to any other authority or requinement regarofing protection from disclosure of information, and subject to subsection (b)(3) of section 552 of title 5 of the United States Code, the Commission shall prescribe such regulations, after notice and opportunity for public comsnent, or issue stich orders, as necessary to probibit the unauthorized disclosure of safeguards information which specifically identifies a ticensee's or applicant's detailed"(1) control and accounting procedores or security measures (including security plans, procedures, and equipment) for the physical protection of special nuclear matertal, by whomever possessed, whether is transit or at fixed sites, in quantities determined by the Corranisston to be signiticant to the public heaith and safety or the common defense and security;

"(2) security meastres (including security plans, procedures, and equipment) for the physical protection of source material or byproduct Inaterial, by whomever possessed, whether in transit or at fixed sites, in quantities deterusisted by the Corn-

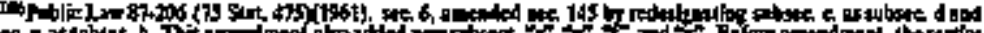

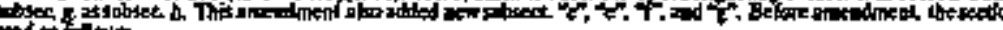

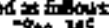

2. Nta

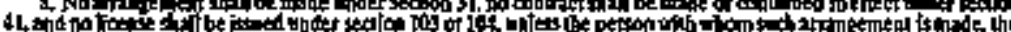
cor

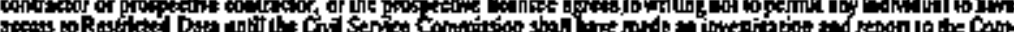

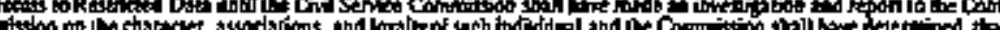

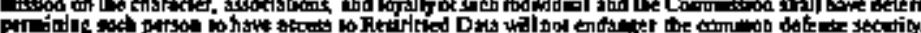

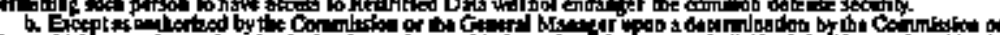

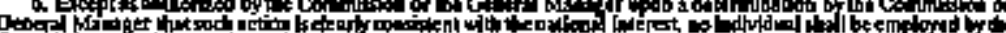

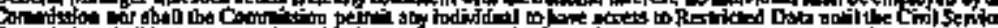

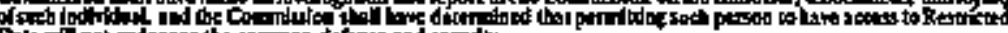

Dal

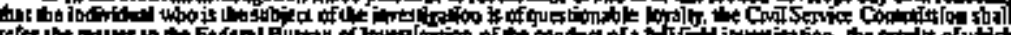

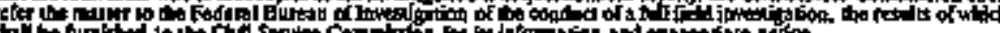

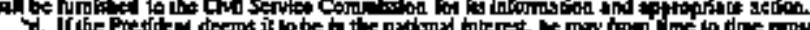

.

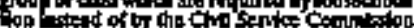

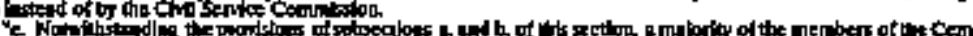

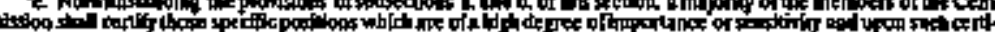

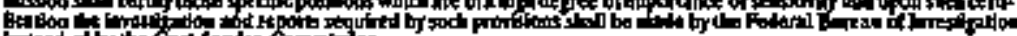

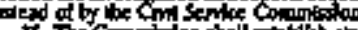

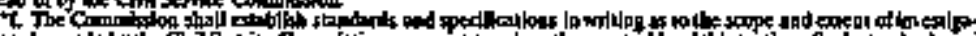

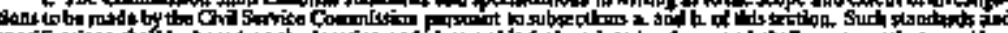

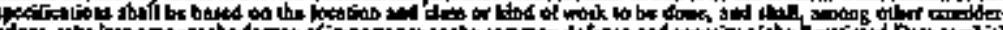

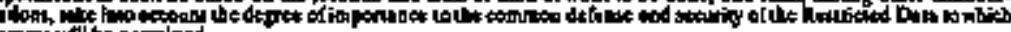

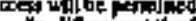

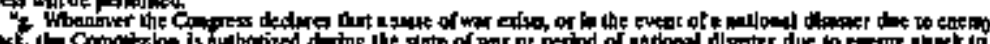

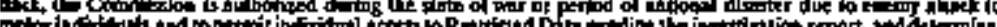

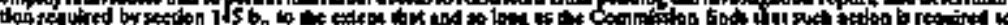

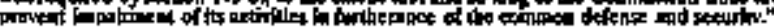
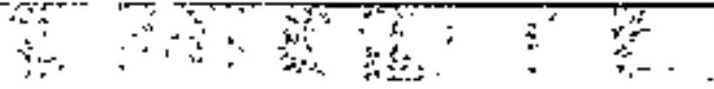

$\because$ 
dmission to be siprificant to the public health and safery or the common defense and security; or

"(3) secarity measures (including security plans, procedures, and equipment) for the physical protection of and the location

. of certain plant equipment vital to the safety of production or utilization facilities involving nuckear materials covered by paragraphs (1) and (2) if the unauthorized disclosure of suxch information coukd reasonably be expected to have a significant adverse effect on the bealth and safety of the public or the common defense and security significantly increasing the Jikelithood of theft, diversion, or sabotage of such material or such facility. The Comnuission shall exercise the authority of this subsection-2.

"(A) so as to apphy the mirimum restrictions peeded to protect the health and safety of the public or the common defense and secturity, and

"I* (B) upon a determination that the unauthorized disclosure of such information could reasonably be expected to have a significant adverse effect on the health and

safety of the public or the common defense and security by significantly increasing the likelibood of theft, diversion, or sabotage of such material or such facility.

Nothing in this Act shall authorize the Commission to prohibit the public disclosure of information pertaining to the routes and quantities of shipments of source material, by-product material, high jevel nucleas waste, or irraciated nuclear Jeactor fuel. Any person, whether or not a licensee of the Commission, 'who violates any regulations adopted under this section shall be subject to the civil nonetary penalties of section

42 USC 2282.

42 USC 2273. 234 af this Act. Nothing in this section shal! be construed to authorize the withiholding of information from the durly authorized committees of the Congress.

${ }^{t} \mathrm{~b}$. For the purpose of section 223 of this Act, any regulations or orders prescribed or issued by the Commission under this section shall also be deemed to be prescribed or issued under section 161 b. of this Act.

${ }^{\circ} c$. Ary determistation by the Commission concerning the applicability of this section shall be subject to judicial review pursuant to subsection (a)(4)(B) of section $\$ 52$ of title $S$ of the United States Code.

“d. Upon prescribing or tessuing any regulation or order under subsection a of thits section, the Commission shall submit to Congress a report that:

(1) spectifically identifies the type of information the Commission intends to protect from disclosure under the regulation or order;

'(2) specifically states the Commission's justification for determining that tunauthorized disclosure of the information to be protected from disclosure under the regulation or order could reasonabiy be expected to have a significant adverse effect on the health and safety of the public or the common 
defense and security by significantly increasing the likelikood of theft, diversion, or sabotage of such material or such facility, as specified under subsection (a) of this section; and

“(3) provides justification, including proposed alternative regulations or orders, that the regulation or arder applites only the minimus restrictions needed to protect the bealth and safety of the pubfic or the common defense and security.

"e. In addition to the reports required under subsection d. of this section, the Contrission shall submit to Congress on a quarterly basis a report detailing the Commission's application during that period of every regulation or order prescribed or issued under this section. In particular, the report shall:

"(1) identify any information protected from disclosure perr. suant to such regulation or order;

"(2) specitically state the Commission's justification for determuning that trauthonized disclosure of the intormation protected from disclosure under such regulation or order could reasonably be expected to have a significant adverse effect on the health and safety of the public or the common defense and security by significantly increasing the likelihood of theft, djversion or sabotage of such material or such facility, a specified under subsection a. of this section; and

(3) provide justifictation that the Connussion has applied such regulation or order so as to protect from disclosure only the 'minimum amount of information necessary to protect the health and safecy of the public or the common defense and stexurity. ${ }^{107}$

42 USC 2168.

"Sec 148. Prohibition Agalmst The Dissemination of Certaln Unclassified Information. - I08

Regulations.

"a. (1). In addition to any authority or requirement regarding protection from dissemination of information, and subject to section 5\$2(b)(3) of title 5, United States Code, the Secretary of Energy (hereinafter in this section referred to as the "Secretary" with respect to atomic emergy defense programs, ${ }^{109}$ ) shall prescribe such regulations, after notice and opportunity for public comment thereon, or issue suct orders as may be necessary to prohibit the unauthorized dissemination of unclassified information pertain + ing to-

"(A) the design of production facilities or utilization facilities

“(B) security , meeasures (Including security plans, procedures, and equipment) for the physical protection of (i) production or utilization facilities, (ii) puclear material contained in such facilities, or (iii) nuctear material in transit; or

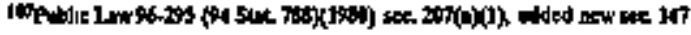

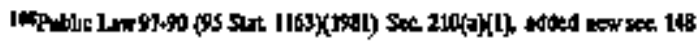

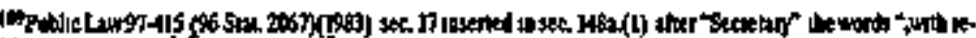

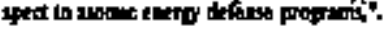


Penalties.

42 USC 2282
“(C) the design, manufachure, or utilization of any atomic weapon or component if the design, manufacture, or utilization of such weapoil or component was contained in any information declassified or removed from the Restricted Data category by the Secretary (or the head of the predecessor agency of the Department of Energy) purstant to section 142.

"(2) The Secretary may prescribe regulations or issue orders under paragraph (1) to prohibit the dissernination of any information described fin such paragtaph only if and to the extent that the Secretary determines that the unauthorized dissemination of such information could reasonably be expected to have a significent adverse effect on the health and safety of the public or the common defense and security by significantly increasing the likelihood of (A) illegal production of nuclear weapons, or (B) theft, diversion, or sabotage of nudetar materials, equipment, or facilities.

“(3) In toaking a deternjuation' uncter paragraph (2), the Secretary may consider what the tikelibood of an jllegal production, theft, diversion or sabotage referred to in stech paragraph would be if the information proposed to be probibited from dissemination under this section were at no time available for dissemination.

"(4) The Secretary shall exercise his authority under this subsection to prohibit the dissemination of any information described in subsection of (1)-

"(A) so as to apply the minimumn restrictions needed to protect the health and safety of the public or the cormmon defense and security; and

(B) upon a determination that the unauthorized dissemination of such information could reasonably be expected to result in a significant adverse effect on the health and safety, of the public or the conraon defense and security by significantly increasing the likelihood of (i) illeggl production of nuclear weapons, or (it) theft, diversion, or sabotage of nuclear materials, equipment, or facilities.

"(5) Nothing in this section shall be construed to authorize the Secretary to authortze the withtholding of information from the appropriate committees of the Congress.

b. (1) Ally person who violates any regulation or order of the Secretary issued under this section with respect to the unautho* rized dissemination of information shall be subject to a civil penalty, to be imposed by the Secretary, of not to exceed $\$ 100,000$ for each stch violation. The Secretary may conpromise, mittigate, or reuit any penalty imposed under this subsection.

"(2) The provisions of subsections b. and c. of section 234 of this Act shall be applicable with respect to the imposition of civil penalties by the Secretary under this section in the same manner that 
42 USC 2273.

Judfcial rewew.

Quarterly report.

42 USC 2169.

42 USC 2133, 2134.

42 USC 2168.

Health and medical care. suct provisions are applicalols to the inaposition of civil penalties by the Commission under subsection a. of such section.

"c. For the purposes of section 223 of this Act, any regulation prescribed or order issued by the Secretary under this section shal also be deemed to be prescribed or issued under section $161 \mathrm{~b}$. of this Act."

"d. Aly determination by the Secretary concerning the applicability of this section shall be subject to judicial review pursuant to section 552(a)(4)(B) of title 5, United States Code.

" $e$. The Secretary shall prepare on a quarterly basis a report to be made available upon the request of any interested person, detailing the Secretary's application during that period of each regulation or order prescribed or issued under this section. In particular, stteh report shall-

"(i) ideatify any information protected from disclosure purstunt to such regulation or order;

"(2) spectifically state the Secretary's justification for determining that unauthorized dissemination of the information protected from disclosure under such regulation or order could reasonably be expected to have a significant adverse effect on the health and safoty of the public or the common defense and security by significantly tatreasing the likelihood of illegal production of muclear weapons, or theft, diversion, or sabotage of nuclear riaterials, equipmentent, or facilities, as spectified under strbsection a.; and

"(3) provide justification that the Secretary has applied such regulation or order so as to protect from disclosure only the minimum amount of information necessary to protect the health and safety of the public or the common defense and security." 110

Sec. 149. Fingerprinting For Criminal Histery Record Checks.-

"a. The Nuclear Regulatory Commission (in this section re. ferred to as the 'Comunission') shall require each licensee or applicant for a license to operate a utilization facitity ander section 103 or $104 \mathrm{~b}$. to fingerprint each individual who is permitted unescorted access to the facility or is permitted access to safeguards informaton under section 147. All fingerprints obtained by a licensee or applicant as required in the preceding sentence shall be submitted to the Attorney General of the United States through the Commission for identífication and a criminal history records check The costs of any identification and recordis check conducted pursuant to the preceding sentence shall be patd by the licensee or applicant. Notwitistanding any other prowision of law, the Attortey General may provide all the results of the search to the Commission, and, in accordance with regulations prescribed under this section, the Conunission may provide such results to licensee or applicant subpuiting such fingerprints.

"b. The Commission, by nule, may relieve persons from the obligations imposed by this section, under specined terms,

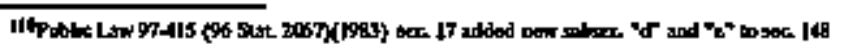


Safety.

Regulations.

42 USC 2168. conditions, and periods, if the Commission finds that such action is consistent with its obligations to promote the common defense and security and to protect the health and safety of the public.

"c. For purposes of adminustering this section, the Commission shatl prescribe, subject to public notice and comment, regulations-

"(1) to implement procedures for the taking of fingerprints; "(2) to establish the conditions for use of information received from the Attorney General, in order-

"(A) to limit the redissemination of such information;

"(B) to ensure that such information is used solely for the pupose of determining whether an individual shal] be permitted unescorted access to the facility of a licensee or applicant or shall be permitted access to safegluards inforIration under section 147 ;

"(C) to ensure that no fival determination may be made solely on the basis of information provided under this section involving-

"(i) an arrest more than 1 year old for which there is no information of the disposition of the case; or

"(ii) an arrest that resulted in disnissal of the charge or an acquittal; and

"(D) to protect individuals subject to fingerprinting nnder this section from misuse of the criminal history records; and

"(3) to provide each individual subject to fingerprinting under this section with the right to complete, correct, and explain information contained in the criminal history records prior to any jinal adverse deteruinitiotion.

"d. (1) The Commission may establish and collect fees to process fingerprints and crivinal history records under this section.

(2) Notwithstanding section 3302(b) of title 31, Unitted States

Code, and to the extent approved in appropriation Acts-

"(A) a portion of the amounts collected under this subsection in any fiscal year may be retained and used by the Commission to earry out this section; and

(B) the remaining portion of the amounts collected under this subsection on such fiscal year may be transferred periodically to the Attomcy General and used by the Attorney Generat to carry out this section.

(3) Ary amount made available for use under paragraph (2) shall remais available urtil enpended." 110a 
Inventions relationg to atomic weapons. 42 USC sec, 2381 . reports.

\section{"CHAPTER 13.-PATENTS AND INVENTIONS}

"Sec. 151. Inventions Rolating To Atomic Weapons, And Filing OP Reports.-111

"a. No patent shall hereafter be granted for any invention or discovery which is useful solely in the utitzation of special muclear material or atomic energy in an atomic weapon. Any patent granted for any such invention or discovery is hejeby revoked, and just compensation shall bo made therefor.

"b. No patent hereafter granted shall confier any rights with respect to any invertion or discovery to the extent that such inven. tion or discovery is used in the utilization of special nucleat material or atomic energy in atomic weapons. Any rights conferred by any patent heretofore granted for any invention or discovery are hereby revoked to the extent that such invention or discovery is so used, and just compensation shall be made therefor.

"c. Any person who has made or hereafter makes any invention or discovery useful in the production or utilization of special nuclear material or atomic energy, shall file with the Conmtssion a report containing a complete description thereof unless such invention or discovery is described in an application for a partent Filed with the Commjssioner of Patents by such person within the ine required for the filing of such report. The report covering any such invention or discovery shall be filed on or before the one hundred and eightieth day after such persont first discovers or first has reason to betieve that such invention or discovery is useful in such prodiction or utilization ${ }^{712}$

"d. The Commissioner of Patents shall notity the Commission of all applications for patents heretofore or befeafter filed which, in his opinion, disclose inventions or discoveries reguired to be reported under subsection 151c, and shall provide the Coramission access to alt such applications.

"e. Reports filed pursuant to subsection c. of this section, and application to which access is provided under subsection d, of this section, shall be kept in confidence by the Commission, and no information concerning the same given without authority of the inventor or croner unless necossary to canry out the provisions of any Act of Congress or in such spectial cirturnstances as ray be determined by the Commission. 113

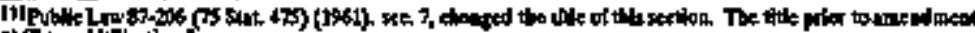

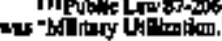

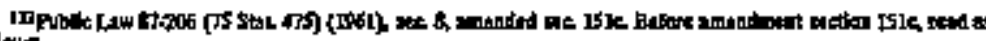

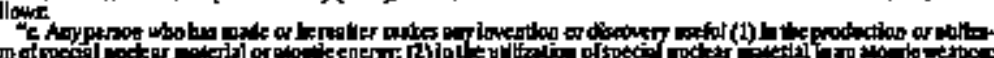

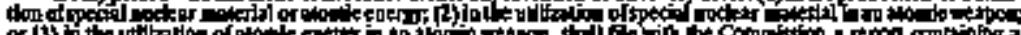

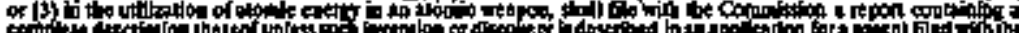

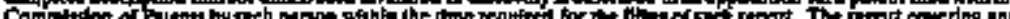

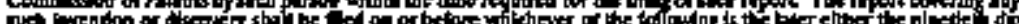

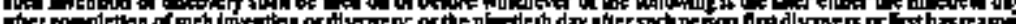

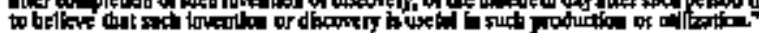

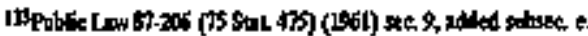


Imention conceived during Commistion contrack. 42 USC sec. 2182.
"Sec. 152. Inventfons Made Or Cońcelved Durbing Commisston Contracts-Any isvention or discovery, useful in the production or utilization of special nuclear material or atomic energy, made or conceived in the course of or under ang contract, subcontract, or - arrangemént entered into with or for the benefit of the Commission, regardless of whether the contract, subcontract, or arrangement involved the expenditure of funds by the Commission, stall be vested in, and be, the property of, the Commission, except that the Commission miay warive its claim to any, such invention or discovery under \$nch circumstazpes as the Conmission may deem appropriate, consistent with the policy of this section. No patent for aby invention or discorery, useful in the production or utilization of special nuclear materiai of atomic energy, shall be issued unless the appilicant files with the application, or within thirty days after request therefor by the Commissioner of Patents (un]ess the Commission advises the Comunissioner of Patents that its rights have been determined and that aceordingly no statement is necessary) a statement under oath setring forth the full facts strrounding the making or conception of the invention or discovery described in the application and whether the infention or discopery was made or concerved in the course of or under any contract, subcontract, or arrangement entered into with or for the benefit of the Commission, rebardless of whether the contract, subcontract, or arrangement juvolved the expenditure of funds by the Commission. The Commissioner, of Patents shall as soon as the application is otherwise in condtion for allowance ${ }^{114}$ forward copies of the application and the statement to the Comenission.

The Commissioner of Patents may proceed with the application and issule the patent to the applicant (if the thvention or discovery is otherwise patentable) uniess the Connission, within 90 dass after rectipt of coppies of the application and statement, directs the Commisstontr of Patents to issue the patents to the Commission (if the invention or discovery ts otherwise patentable) to be held by the Commission as the agent of and on behalf of the United States.

If the Commission files such a firection with the Commissioner of Patents, and if the applicant's statement alaims, and the applicant stil belteves, that the ixvertion or disconvery was not made or conceived in the course of or under any contract, subcontract or arrangement entered into with or for the benefit of the Commission entiting the Commission to the title to the applicant or the patent the applicant may, within 30 days affer notification of the filing of such a direstion, request a bearing before the Board of Patents Appeals and Interferences. The Board shall have the power to hear and determine whether the Commission was ontitied to the direction filed with the Commisstoner of Patents. The Board shall follow, the riles and procedures established for interference cases and an appeal may be taken by either the applicant or the Commission from the final order of the Board to the United States Coust of Appeals for the Federal Circuit in accordance with the

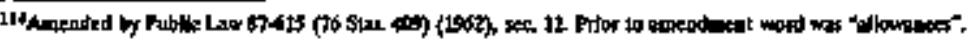


Nonmiltary utilization. 42 USC sec. 2183 .

procedures governing the appeals from the Board of Patent Appeals an Interferences.

If the statement filed by the applicant should thereafter be found to contain false material statements any notification by the Commission that it has no objections to the issuance of a patent to the applicant shall not be deemed in any respect to constitute a waiver of the provisions of this section or of ary applicable civil or criminal statute, and the Commission may have the titie to the patent transferred to the Cornmission on the records of the Commissioner of Patents in accordanee with the provisions of this section. A determination of rights by the Commission pursuant to a contractual provision or other arrangentent prior to the request of the Commissioner of Patents for the statement, shall be final in the absence of false material statements or nontisclosure of material facts by the applicant. 115

Sec. 153. Nonmilltary Uttiltzation.-

a. The Commission may, after giving the patent owner an opportunity for a hearing, declare arly patent to be affected with the public interest if (1) the invention of discovery covered by the patent is of primary importance in the funduction or utilization of special nuclear material or atomic energy; and (2) the licensing of such invention or discovery under this section is of primary importance to effectuate the policies and pturposes of this Act.

b. Whenever any patent has bent dectared affected with the public interest, purstiant to subsection 153 a.-

(1) the Commission is hereby licensed to use the tinvention or discovery covered by such patent in performing any of its powers under this Act;

(2) any person may apply to the Commission for a nonexcletsive patent license to use the intervention or discovery cowered by sucil patent, and the Combitission sball grant such patent

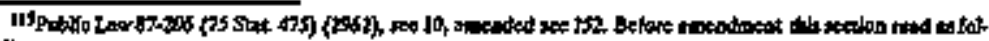
lond:

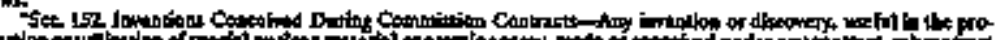

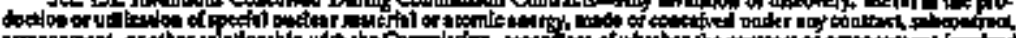

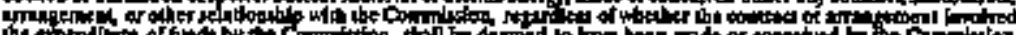

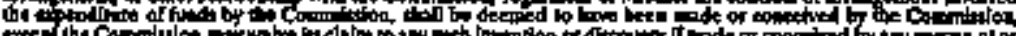

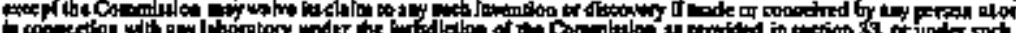

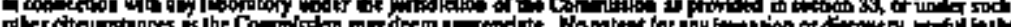

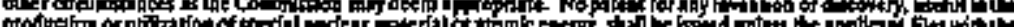

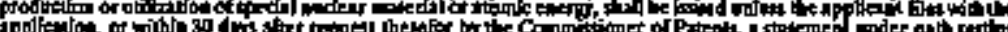

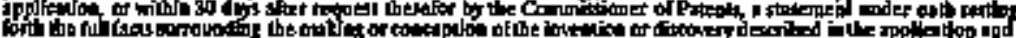

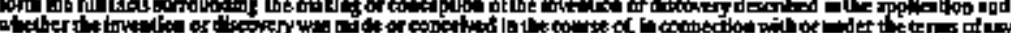

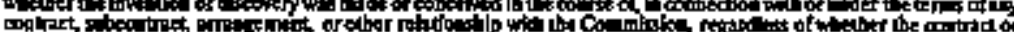

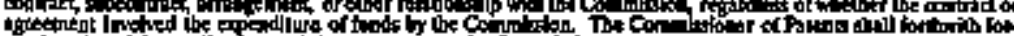

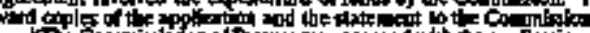

Tén of conof d]

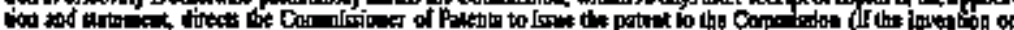

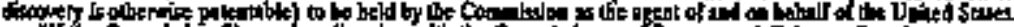

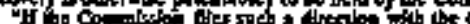

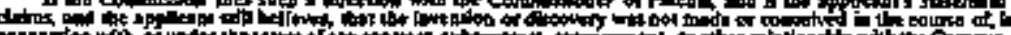

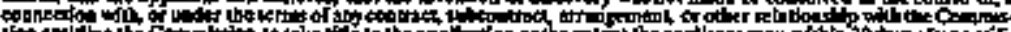

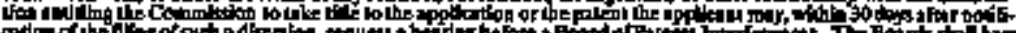

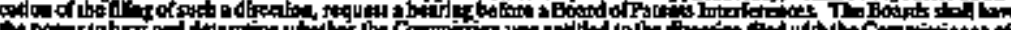

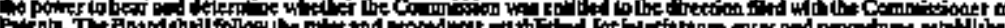

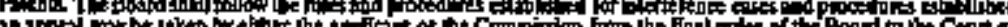

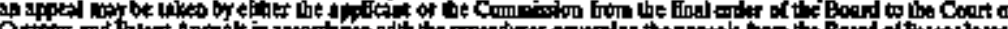

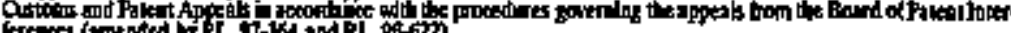

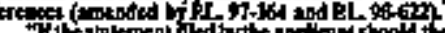

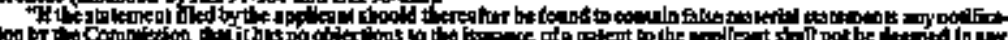

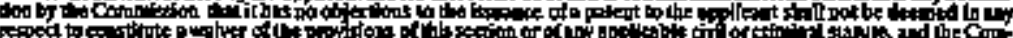

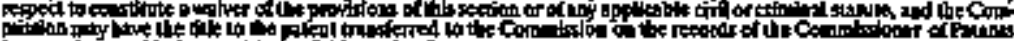

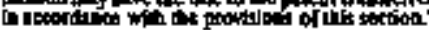

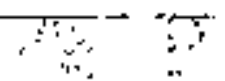

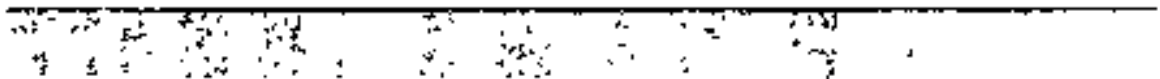


license to the extent that it finds that the use of the invention or discovery is of primary importanice to the conduct of an activity by such person authorized under this Act.

c. Any person-

(1) who has made application to the Commission for a license under sections $53,62,63,81,103$, or 104 , or a permit or lease under section 67 ;

(2) to whom such license, permit, or lease bas been issued by the Commission;

(3) who is authorized to conduct such activities as such applicant is conducting or proposed to conduct under a general license issued by the Commission under section 62 or 81 ; or

(4) whose activities or proposed activities are authorized under section 31,

may at any tilne make application to the Commission for a patent license for the use of an invention or discovery useful in the production or utilization of special nudear material or atomic energy covered by a patent. Each such application shall set forth the nature and purpose of the use which the applinuat intends to make of the patent license, the steps taken by the applicant to obtain a patent license from the owner of the patent, and a statement of the effects, as estimated by the applicant, on the authorzed activities which will result from failure to obtain such patent livense and which will result from the granting of such patent license.

"d. Whenever any person has made an application to the Commission for a patent licesse pursuant to sabsection $153 \mathrm{c}-$

"(1) the Commission, within 30 days after the filing of such application, shall make available to the owner of the patent all of the information contained in such application, and shal! notify the owher of the patent of the time and place at which a bearing will be held by the Commission;

"(2) the Commission shall hold a hearing within 60 days after the siling of such application at a time end place designated by the Commission; and

"(3) in the event an applicant applies for two or more patent licenses, the Commission may, in it discretion, order the consolidation of such applications, and if the patents are owraed by more than one owner, such owners may be made parties to one hearing.

"e. If, after amy hearing conducted pursuant to subsection $153 \mathrm{~d}$, the Commission finds that-

"(1) the invention or discovery covered by the patent is of primary importance in the prodtuction or utifization of spectal nuclear materlal atomtc energy;

" $(2)$ the licersing of such invention or discovery is of primary importance to the conduct of the activities of the applicant;

"(3) the activities to which the patent license are proposed to be applied by stch applicant are of primary importance to the furtherance of policies and putposes of this Act; and

“(4) suci applicant cannot otherrise obtain a patent license from the owner of the patent on terms which the Commission 
deems to be reasonable for the intended use of the patent to be made by such applicant, the Commission shall license the applicant to use the imvention or discowery covered by the patent for the purposes stated in such application on terms deemed equitable by the Comimission and generally not less fair than those granted by the patents or by the Commission to similar licensets forr comparable use.

"f. The Commission shall not grant any patent license pursuant to subsection $153 \mathrm{e}$. for any other purpose than that stated in the application. Nor shall the Conunission grant any patent license to any other applicant for a patent license on the same patent with. out an application being made by such applicant pursuant to subsection $153 \mathrm{G}$, and without separate notification and hearing as provided in subsection $153 \mathrm{~d}$., and without a seperate finding as provided in subsection $153 \mathrm{e}$.

"g. The owner of the patent affected by a declaration or a finding made by the Commission pursuant to subsection $153 \mathrm{~b}$. or $153 \mathrm{e}$. shall be entitled to a reasontable royalty fee from the licensee for any use of an invention or discovery licensed by the section. Such royalty fee may be agreed upon by such owier and the patent licensee, or in the absence of such agreement shall be determined for each patent license by the Commission persuant to subsection $157 \mathrm{c}$.

"h. The provisions of this section shall apply to any patent the application for which shall have been filed before September 1 , 1979.116

Injuactions. 42 USC sec. 2184 .

Prior art. 42 USC

sec. 2185 .

Commission patent licenses. 42 USC sec. 2186 .
“Sec. 154. Injunctions.-No court shall have jurisdiction or power to stay, restrain, or otherwise enjoin the use of any invention or fiscovery by a patent licensee, to the extent that sach use is licensed by subsection $153 \mathrm{~b}$. or $153 \mathrm{e}$. If, in any action against such patent licensee, the court shall determine that the defendant is exercising such license, the measure of damages shall be the royalty fee determined pursuant to subsection $157 \mathrm{c}$. If any such patent licensee shalt fail to pry such royalty fee, the patentee may bring an action in any court of competent jurisdiction for such royalty fee, togetier with such costs, interest, and reasonable attorney's fees as may be fixed by the court.

"Sec.15S. PrIor Art-In connection with appilications for patents covered by this Chapter, the fact that the invention or discorery was kown or used before siall be a bar to the patenting of such tinvertion or discowery even though such prior lonowledge or use was under secrecy within the atomic energy program of the United States.

"Sec, 156. Commission Patent Licentses,-The Commission shall establish standards specifications upon which it may grant a patent license to use any patent ${ }^{117}$ declazed to be affected with the public Interest pursuant to subsection 153 a. Such a patent license shall not waive any of the other provistions of this Axt.

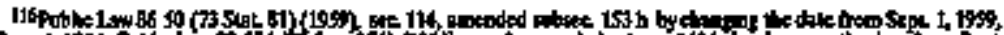

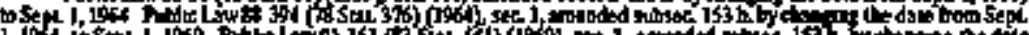

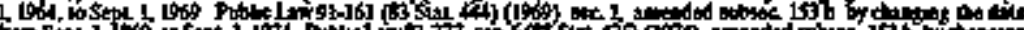

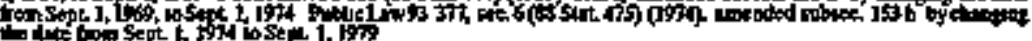

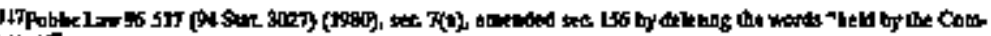
nomine of 
Compensation, awards, and royalties.

42 USC

sec. 2187 .

62 STAT 697.

Eligibility.

Standactls.

"Sec 157. Compensation, Awards, And Rogillies.

"a. Patent Compensation Board - The Commission shall desig- nate a patent Compensation Board to consicter applications under , this section. The members of the Board shall receive a per diem oompensation for each day spent in meetings of conferences, and all menbers shall receive their necessary traveling or other ex. penses while engaged in the work of the Board. The members of the Board may serve as suct without regard to the provisions of sections 281, 283, or 284 of Title 18 of the United States Code, except in so far as such sections may prohibit any such member from recetving compensaltion in respect of any particular matter which directly involves the Commission of in which the Commission is direstly interested.

b. Eligibility.-

"(1) Any owner of a patent licensed under section 158 or subsection $153 \mathrm{~b}$. or $153 \mathrm{e}$, or any patent licensed thereunder may make application to the Commission for the determination of a reasonable royalty fee in accordance with such procedutes as the Cotnmisston by regulation may establish.

"(2) Any person seekting to obtain the just compensation provided in section 151 shall make application therefor to the Commission in accordance with such procedures as the Commission may by regulation establish.

(3) Amy person making any tovention or discovery useful in the procustion or utitization of special nuclear miaterial or atomic energy, who is not entitled to compensation or a royalty therefor under this Act and who has complied with the provistons of section 151 c hereof may make application to the Commission for, and the Commission may grant, an award. The Commission may also, after consultation with ${ }^{116}$ the General Advisory Conmittee, and with the approval of the President, grant an award for any especially meritorious contribution to the development, use, or controd of atomic energy.

"c. Standards.

"(1) In determining a reasonabie royalty fee as provided for in subsection $153 \mathrm{~b}$., or $153 \mathrm{e}$., the Commission shall take into consideration (A) the advice of the Patent Compensation Board; (B) any defense, general or special, that might be pleaded by a defendant in an action for infringement; (C) the extent to which, if any, such patent was developed through federally financed research; and (D) the degree of utility, novelty, and importance of the irvention or discovery, and, may consider the cost to the owmer of the patent of developing stuch invention or discovery or acquiring such patent.

"(2)' In determining what constitutes just compensation as provided for in section 151, or in determining the amount of any award under subsection 157b.(3), the Commission shall take into account the considerations set forth in subsection 157

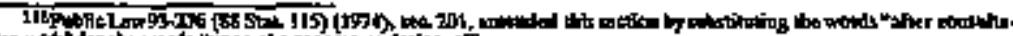

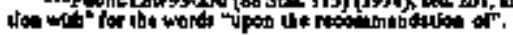


Monopolistic use of patents. $42 \mathrm{USC}$ sect 2188.

Federally fi. nanced research. 42 USC sec. 2189 .

Saving clause. 42 USC sec. 2190 .

c(1) and the actual use of such fivention or discowery. Such compensation may be pasd by the Commission in periodic payments or in a lump sum.

"d. Period Of Limitarions.-Every application under this section shall be barred unless filed within six years after the date on which first accrues the right of such reasonable royalty fee, just compensation, or award for which such application is filed. 11 y

"Bec. 158. Monopilistic Use Or Patents.-Whenever the ownet of ang patenet hereafter granter for any invention or discowery or primary use in the utilization or production of special nuclear material or atomic energy is found by a court of competent jurisdiction to have intentionally used such patent in a mantier so as to violate any of the antitrust laws specified in subsection 105a, thete may be inctuded in the fudgement of the court, in its discretion and in addition to any other lawful sanction, a requirement that such owner license such patent to any other licensee of the Commission who cientonstrates a geed therefor. If the court, at its distretion, deems that such licensee shall pay a reasonable royalty to the owner of the patent, the reasonable royalty shall be deternined in accordance with section 157.120

"Sec. 159. Federally Financed Research.- Nothing in thits Act shall affect the right of the Commission to require the patents granted on inventions made or conceived during the counse of federally inanced research or Operations, be assigried to the United States.

"Sec. 160. Saving Clauss,-Any patent apptication on which a patent was dentisd by the Unjted States Patent Office under section 11 (a) (I), 11 (a) (2), or 11 (b) of the Atomic Energy Act of 1946,121 and which is not prohibited by section 151 or section 155 of this Act may be reinstated upon application to the Commissioner of Patents withto one year after enactonent of this Act and shall then be deemed to have been contiuuously pending since its original filing date: Provided, however, That no patent issued upon any patent application sorejustated shall in any way furlish a basis of clajm against the Goverment of the United States.

\section{CHAPIER I4-GENERAL AUTHORITY}

\section{Gentral} provisions. 1 42 USC sec. 2201.

"Sec 161. General Provisions.-In the performance of jts functions the Commission is atthorized to-

"a. establish advisory boards to advise with and make recommendations to the Contmission on legislation, polictes, administration, reseatch, and otler matters, provided that the Cornuis. sion issues regilations setting forth the scope, procedure, and Jimitation of the authority of eacis such board;

"b. establish by rule, regulation, or order, such standards and instructions to govern the possession and use of special nucleas

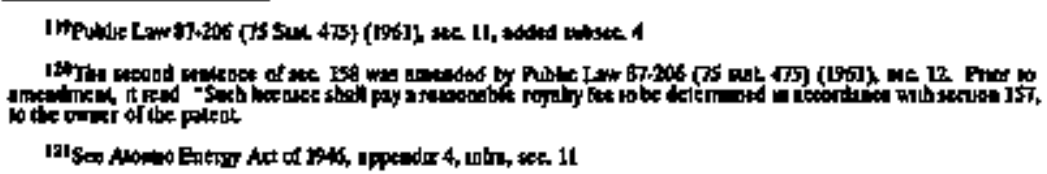


27 STAT 443. 49 USC 46.

SO STAT 443. 5 USC 5101.

'material, source material, and byproduct material as the Commission may deem necessary on desirable to promote the common defense and security or to protect heatth or to minimize danger to lifo ot property; in addition, the 'Commission shall prescribe such regulations or orders as-nay be recesstary or desirable to promote - the Nation's common defense and security with regard to control, ownership, or possession of aný equipment or device, or important component part especially designed for such equipment or device, capable of separating the ișotopes bf uranitum or enriching uranium in the isotope $235 ; 22$...

' "c. make such studies and investigations, obtain such jnformation, and bold such meetingsor heartugs as the Conunission may deem necessary or proper to assist it in exercising any authority provided in tits Act, or in the administration or enforcement of this Act, or any regulations or orders issued thereunder. For such pleposes the Commission is authorized to admintster oaths and affirmations, and by subpena to require any person to appear and testify or appear and produce documents, or both, at any designated place. Witnesses subpensed under this subsection shall be paid the same fees and mileage as are paid witnesses in th district courts of the United States; 123

"d. appoint and tix the compensation of such officers and employees as may be nocessary to carry out the functions of the Commission. Such officers and employees shall be appointed in accordance 'with the mivil-service laws and their compensation fixed in accordance with the Classification Act of 1949, as inmended, except that, to the extent the Compission deems such action necessary to the dischatge of jts responsibilities, personnel ntay be employed and their compensation fixed without regard to such laws: Provided, however, That go officer or employee (except such officers and employees whose compensetion is fixed by law, and scientific arxd technical personnel up'to a linit of the highest rate of grade 18 of the General Schedule of the Classification Act of 1949, as amended) ${ }^{124}$ whose position would be subject to the Classification Act of 1949, as amended, if such Act were applipable to such position, shall be paid asalary at a rate in excess of the rate payable under such Act for positions of equivalent difficulty or responsibility. Such rates of comperisation may be adopted by the Commission as may bo authorized by the Classification Act of 1949 , as amended, as of the same date such rates are authorized for positions subject to such Act.125 The Commission shatl make

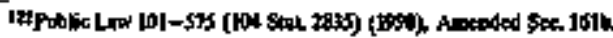

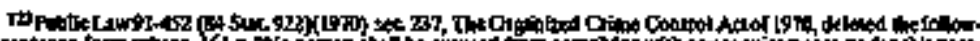

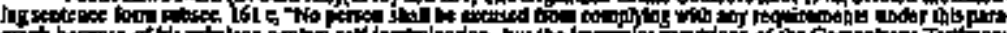

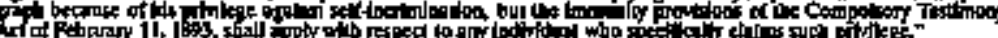

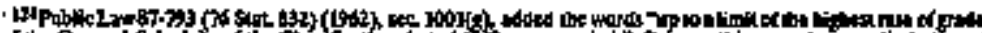

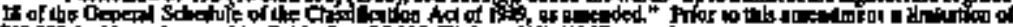

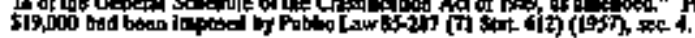

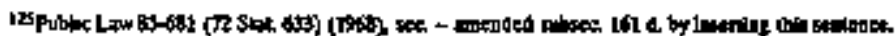


adequate provision for administrative review of any determinaton to distniss any employee;

“e, acquire such material, propery, equipment, and facilities, establish or construct such buildings and facilities, and modify such buildings and facilities from time to time, as it may deem necessary, and construct, acquire, provide, or arrange for such facilities and services (at project sites whiere such facilities and services are not available) for the housing, health, safety, welfare, and recreation of personnel employed by the Commission as it may deem necessary, subject to the provistons of section 174: Provided, however, That in the communities owned by the Commission, the Commission is authorized to grant privileges, leases and perrinits upon adjusted terms whjch (at the time of the initial grant of any privilege, grant, lease, or permit, or renewal thereof, or in order to avoid inequities or undite hardship prior to the sale by the United States of property affected by sucti grant) ${ }^{126}$ are fair and reasonable to responsible persons to operate commercial busisesses without advertising and without advertising (sic) and without securing cornpetitive bids, but taking into consideration, in addition to the price, and among other things (1) the quality and type of services required by the residents of the community, (2) the experience of tach concession applicant in the community and its surrounding area, (3) the ability of the concession applicent to meet the needs of the community, and (4) the contribution the concession applicant has made or witl make to the other activities and general welfare of the comnunity; ${ }^{127}$

f. with the consent of the agency concernec, utilize or employ the services or personnel of any Govermment agency or any State or local government, or volumtary or uncompensated persomnel, to perform snch functions on its behalf as may apptar desirable;

g. acquire, purchase, lease, and hold real and personal property, including patents, as agent of and on behalf of the United States, ${ }^{12}$ subject to the provistions of section 174 , and to sell, lease, grant, and dispose of such real and personal property as provided in this Act;

h. consider in a single apptication one or more of the activitits for which a license is required by this Act, combine in a single license one or more of such activities, and permit the applicant of licensese to incorporate by reference pertinent infortaltion alJeady filed with the Commission;

i. prescribe sucin regulations or order as it may deem nectssary (1) to protect Restricted Data received by any person in connection with any activity authorized pursuant to this Act, (2) to guard against the loss or diversion of any specjal nuclear material acquired by any person pursuant to section 53 or produced by any

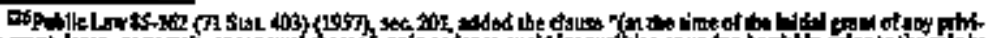

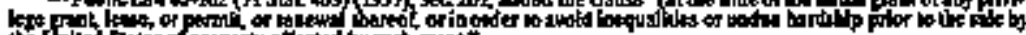

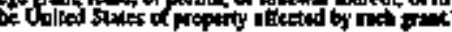

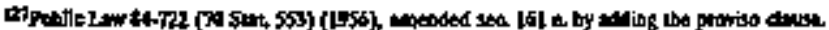

10 The 1 or of

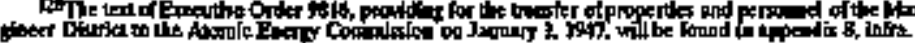


person in connection with any activity authorized pursuant to this Act, to prevent any use or disposition thereof which the Commis. sion may determine to be inimical to the common defense and security, including regulations or orders designating activities, involving quantities of special nuclear material which in the opinion of the Commission are important to the common defense and security, that may be conclucted only by persons whose character, associations, and ioyalty shall base been investigated under standards and specifications established by the Comritission and as to whom the Commission shall.have determined that permitting each sach person to conduct the activity will not be inimical to the common dofense and stcurity, ${ }^{129}$ and (3) to govern any activity authorized pursuzent to this Act, includiag standards and restrictions governing the desigth, location, and operation of facilities used in the conduct of sucti activity, in order to protect health and to minimize danger to life or property;".

69 STAT 377. 40 USC 471 note, 488.

j. without regard to the provisions of the Federal Property and Administrative Services Act of 1949,' as amerded, excepr section 207 of that Act, or any other law, make such disposition as it may deem desirable of (1) radioactive materials, and (2) any other property, the special disposition of which is, in the opinion of the Commission, in the interest of the national security: Provided, however, That the property farnished to licensees in accordance with the provisions of subsection $161 \mathrm{~m}$. shall not be deemed to be properly disposed of by the comunission pursuant to this subsec. tion:

k. authorize such of its members, officers, and employees as it deens mecessary in the interest of the common defense and security to carry firearms while in the discharge of their offictal duties. The Conmission thay also authortze such of those employees of its contractors and subeontractors (at any tier) engaged in the protec,tion of property under the jurisdiction of the United States located at facilties owned by or contracted to the United States or being transported to or from such facilities as it deems necessary in the interests of the common defense and security to carry firearns while in the disctarige of their official duties. A person authorized to carry firearns under this subsection snay, while in the perfors-

42 USC

$\sec 2201(\mathrm{~K})$ ance of, and in connection with, official duties, make arrests without warrant for any offense against the United States Corlmitted in that person's presence or for any felony cognizable under the laws of the Unuted States if that person has reasonabie gronnds to believe that the individual to be arrested has cornmitted or js committing such felony. An enaployes of a contractor or subeontractor authorized to carty tirearms under this substetion may make such arrests only whien the individual to be anrested is within, or in direct flight from, the area of such offense. A person granted authority to make anrests by this subsection may exercise that authority only in the enforcement of (1) laws regarding

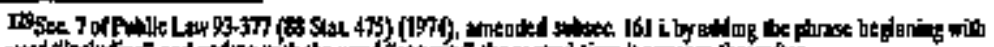

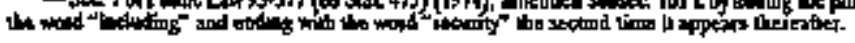


the property of the United States in the custody of the Departoxent of Energy, the Nuclear Regtlatory Contrission, or a contractor of the Department of Energy or Nuclear Regulatory Condmission, or (2) any provision of this Act that may subject an offender to a fine, imprisonment, or both. The arrest alithority conferred by this subsection is in addition to any arrest authority under otber laws. The Secretary, with the approval of the Attorney General, shall issne guidelines to implement this subsection; ${ }^{130}$ "m. ${ }^{13}$ epter into agreements with persons licensed under Section 103, 104, 53 a (4), or 63 a. (4) ${ }^{132}$ for sich periods of time as the Commission may deem necessaty or destrable ( 1 ) to provide for the processing, fabricating, separating, or refining in facilities owned by the Commission of source, byproduct, or other material or special nuclear material owned by or made avatlable to such licensees and which is utilized or produced in the conduct of the licensed activity, and (2) to sell, lease, or otherwise make available to stuch licensees such quantitics of source or byproduct matertial, and other material not defined as special nuclear material pursuant to this Act, as may be necessary for the conduct of the licensed activities; Provided however, That any such agreement may be canceled by the licensee at any time upon payment of such reasonable cancellation charges as may be agreed upon by the licensee and the Commissiont And provided, further, That the Commission shall establisb prices to be paid by licensees for material or services to be furnished by the Commission pursuant to this subsection, which prices shall be established on such a nondiscritrlinatory basis as, in the opinion of the Commission, will provide reasonable compensation to the Government for such material or services and will not discourage the development of sources of supply independent of the Commisston;

" ${ }^{+133}$ delegate to the General Manager or other officers of the Commission any of those functions assigned to it under this Act

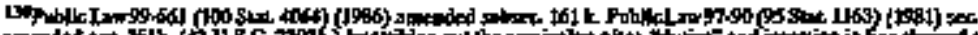

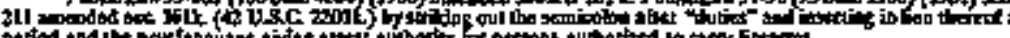

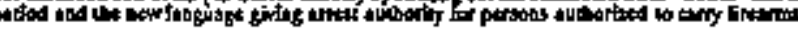

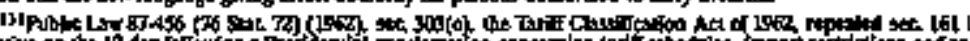

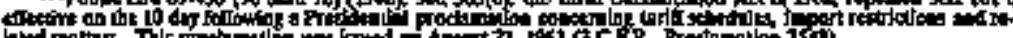

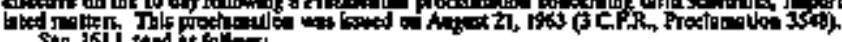

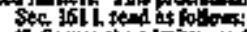

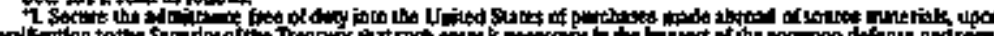

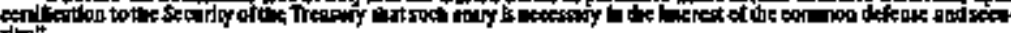
thent.

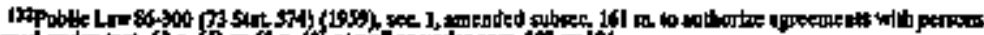

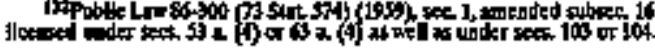

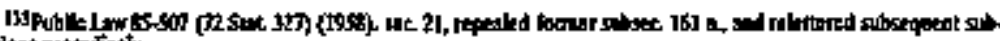

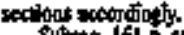

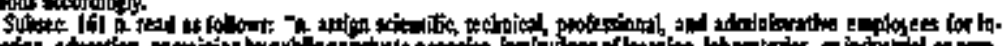

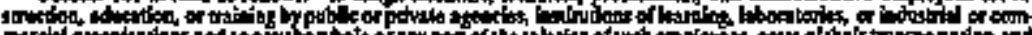

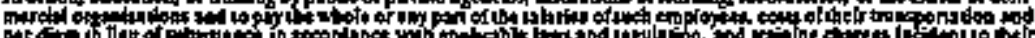

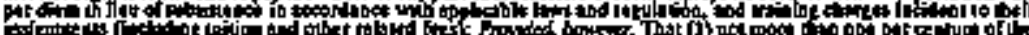

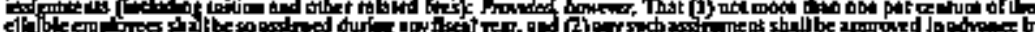

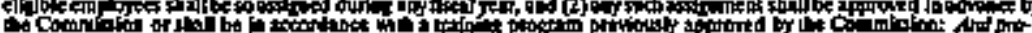

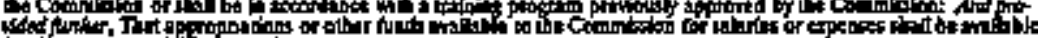

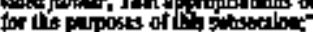


Eagements for rights-of way.

except those specified in section 51, 57b., ${ }^{134} 61,{ }^{133} 108,123,145 \mathrm{~b}$. (with respect to the determination of those persons to whom the Commission may reveal Restricted Data in the national interest), 145f., ${ }^{136}$ and $161 \mathrm{a}$;

"o. require by rule, regulation, or order, such reports, and the keeping of such records with respect to, and to provide for sucts inspections of, activties and stridies of types specified in section 31 and of activities under licenses issued pursuant to sections $\mathbf{5 3}$, $63,81,103$, and 104, as may be necessary to effectuate the purposes of this Act, including section 105; and

"p. make, promalgate, issue, rescind, and amend such rules and regulations as maty be necessary to carry out the purposes of this Act.

"q. The Commission is empoxered, under such terms and condtions as are deemed advisable by it, to grant easements for tights-of-way ower, across, in, and upon acpitired lands under its jurisdiction and control, and public lands permanently withdrawn or reserved for the use of the Commission, to any State, political subdivision thereof, or municipality, or to any indivicual, partnership, or corporation of any State, Territory, or passession of the United States, for (a) railroad tracks; (b) oil pipe lines; (c) stlbstations for electric power transmission lines, telephone lines, and telegraph tines, and pamping stations for gas, water, sewer, and oil pipe lines; (d) canals; (c) ditches; (f) flumes; (g) turnels; (h) dams and reservots in comection with fish and wildife programs, fish batcheries, and other fish-cultural inaproventents; (i) roads and sireet, and (j) for any other purpose or purposes deemed advisabile by the Commission: Provided, That such rights-of-way shall be granted only upon a finding by the Commission that the same will not be incompatible with the public interest: Provided further, That such nights-of-way shali not include any more land than is jeasonably ntcessary fot the purpose for which grented:And provided fur. ther, That all or any part of such right-of-way may be annulled and forfeited by the Commission for failure to comply with the terms and conditions of any grant hereunder or for nonuse for a period of two consecutive years or abandonment of rights granted under authority hereof. Copies of alI instruments granting easements over public lands pursugnt to this section shalj be furnished to the Secretary of the Interior. ${ }^{137}$

"r. Under such regulations and for such periods and at such prices the Commission may prescribe, the Coramission may sell or contract to sell to purchasers within Connission-owned communities or in the immediate vicinity of the Commission corarnunity, as the case may be, any of the following utilities and related ser-

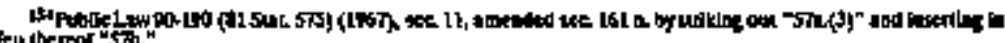

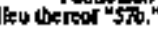

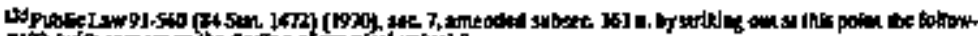

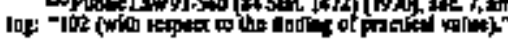

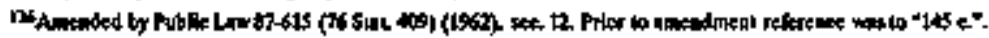

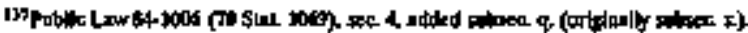


Succession of suthority.

Processing contracts.

Long term contract autbority. vices, if it is determined that they are not avajlable from anotber Jocal source and that the sale is in the interest of the glational defense or in the public interest:

(1) Electric power.

"(2) Steam.

(3) Compressed ait.

(4) Water.

(5) Sewage and garbage disposal.

“(6) Natural, mamufactured, or mixed gas.

"(T) Ice.

(8) Mechanical refrigeration.

"(9) Telephone service.

"Proceeds of sales under this subsection sbald be credited to the appropriation curreratly avajlable for the supply of that utitity of servict. To meet local needs the Comunission may make minor exparsions and extensions of any distributing system or facility within or in the immediate viciaity of a Commission-osiat community through which a utility or service is farnished under this subsection. 138

"s-establish a plan for a succession of authortty which will assure the community af direction of the Commission's operations in the event of a national disaster dite to enemy activity. Notwithstanding any other provision of this Act, the person or persons succeding to command in the event of disaster in accordance with the plan establisbed pursuant to this subsection shall be vested with all of the authority of the Commission: Provided, That any such succession to authority, and vesting of authonity shall be effective only in the event and as long as a quorum of three or more members of the Commission is unable to convene and exercise direction turing the disaster period: Provided further, That the disaster period iucludes the period when attack on the United States imminent and the post-attack period necessary to reestablish normal lises of command; 139

"t. enter into contracts for the processing, fabricating, separating, or refining in facilities owned by the Commission of source, byproduct or other material, or special nuctear material, in accordartce with and within the pertod of an agrement for cooperation while comparable services are available to persons licensed tnde section 103 or 104: Provided, That the prices for services under such contracts shall be go less tian the prices currently charged by the Commoisston plustrant to section $161 \mathrm{~m}$.;

"u. (1) enter into contracts for such periods of tine as the Connission may deem necessary or desirable, but not to exceed five years from the date of execution of the contract, for the purchase or acquisition of reactor services or services related to or required by the operation of reactors;

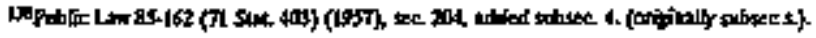

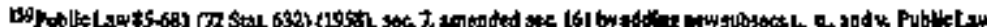

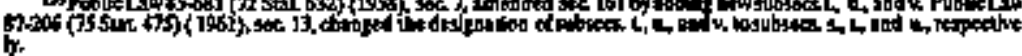


"(2) (A) enter into contracts for such periods of timet as the Comnission may deen necessary or destrable for the purchase or acquisition of axly supplies, equipjuent, materials, or services required by the Commission whenever the Conmission determines that: (i) it is advantageous to the Gowermment to make such purchase or acquisition from commercial sources; (ii) the furnishing of stch supplies, equipment, materisls, or services will requite the consefuction or acquisition of special facilitits by the vendors or supplies thereof; (iii) the amortization chargeable to the Commission constitutes an appreciable portion of the cost of contract performance, excluding cost of materizls; and (iv) the contract for such persod is more advantageous to the Government than a similar contract not executed under the authority of this subsection. Such contracts shall be entered into for periods not to exceed five years each from the date' of initial delivery of such supplies, equipment, materials, or services or ten years from the date of execution of the contracts excuuding periods of renewat under option.

"(B) In entering into such contratts the Commission shall be guided by the following principies: (i) the percentage of the total cost of special facilities devoted to contract performance and chargeable to the Commission should not exceed the ratio between the perjod of contract deliverits and the anticipated

- useful life of such spectial facilities; (ii) the desirability of obtaining options to renew the confract for reasonable periods at prices not to include charges for special facalities already amortized; and (iii) the desirability of Jeserving in the Commission the right to take title to the'spectal facilities under appropriate circuonstances; and

"(3) Indude fa contracts made under this subsection provisions which limit the obligation of funds to estimated anntal delivejies and services and the tmamor. tized balance of such amounts due for special facilities as the parties shall agree is chargeable to the performance of the contract. Any appropriation available at the time of iercuination or thereafter made available to the Cornusission for operating expenses shall be available for paymatent of suchoosts which may arise from termination as the conttract may provide. The term "special facilities" as used in this subsection mèns any land and any depreciable buildings, structures, utilities, machinery, equipplent, and fiktures necessary for the production or furnishing of such supplies, eqtuipment, materials, and services and not avalable to the ventiors or supptiers for the performance of the contract. 140

Contract authority. "v. provide services in support of the United States Exrichunent Corporation, except that the Secretary of Energy shall anmally collect payments and other charges from the Corporation sufficeint to ensure recovery of the costs (excluding deprecietion and 
42 USC 2231.

42 USC 2014. imputed interest on original plant investments in the Department's gaseous diffusion plants and costs under section 1403(d)) incurred by the Departuent of Energy sfter the date of the enactment of the Energy Policy Act of 1992 in performing such services;" $142+142 \mathrm{a}$

"w. prescribe and collect from any other Government agency, which applies for or is issued a license for a utilization facility designted to produce electrical or heat energy pursuant to section 103 or 104b, or which operates any faxility regulated or certfified under section 1701 or 1702 , ; and any fee, charge, os price which it may require, in accordance with the provisions of section 483a of titte 31 of the United States Code or any other law, of applicants for, or holders of, stch licerises or certificates. $143+143 \mathrm{a}$

" $x$. Establish by rule, regulation, or order, after public notice, and in accordance with the requirements of section 181 of this Act, such standards and instructions as the Commission may deem necessary or desirable to ensute-

"(1) that an adequale bond, surety, or other financial arrangement (as determined by the Commission) will be provided, before termination of any license for byproduct materials as defined in section 1le (2), by a licensee to permit the completion of all requirements established by the Commission for the decontamination, deconunissioning, and reclamation of sites, struchures, and equipment used in conjunction with byproduct material as so deFined, and

"(2) that-

"(A) in the case of any such license issued or renewed after the date of the enactonent of this subsection, the need for long-term maintenance and monitoring of such sites, structures and equipment after termination of such license will be minimized and, to the marimtum extent practicable, eliminated; and

"(B) in the case of each license for such material (whether in effect on the date of the enactment of this section or issued or renews thereafter), if the Conmission determines that any such long-rerm maintenance and monitoring is necessary, the ticensee, before termination of any license for byproduct material as defined in section 11 e. (2), will make available such bonding, surety, or other financtal arangements as may be necessary to assure stch long-term maintenance and monitoring.

Such standards and instructions promtulgated by the Commission pussuant to this subsection shall take into account, as determined by the Commission, so as to avoid unnecessary duplication and expense, performance bonds or other fijlancial arrangenents which are required by other Federal agencies or State agencies and/or other local governing bodies for such decommissioning, decontamination, and reclamation

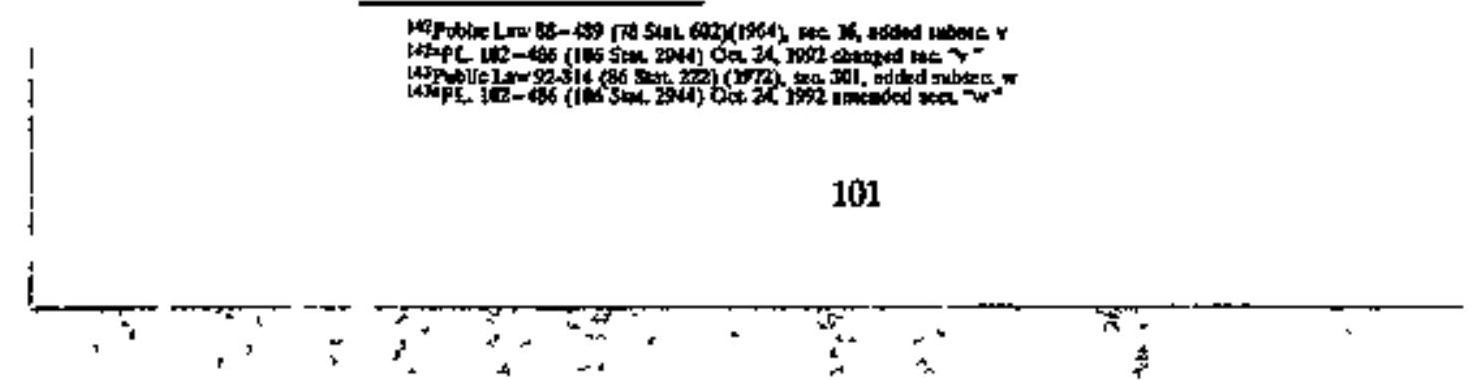


and lotag-term maintenance and monitoring except that nothing in this paragraph shall be constructed to require that the Commission accept such bonds of arrangements if the Commission determines that such bonds or arrangements are not adequate to carry out subparagraphs (1) and (2) of this subsection. 1 144

Contracts. $\quad$ "Sec. 162. Contracts.-The Presifient may, in advance, exempt any 42 USC sec. 2202. specific action of the Commission in a particula matter from the provisions of law relsting to contracts whenever he deteruines that such action is essential in the interest of the conmon defense and security.

Advisory , "Sec 163. Advisory Committees, The members of the General commities. Advisory Comnuittee established pursuant, to section 26 and the 42 USC sec, 2203. meernbers of advisory boards established pursuant to section 161 a. may serve as such without tegard to the provisions of sections 281,283 , or 284 of Title 18 of the United States Code, exoept insofar as suchl sections

62 STAT. 697. I, Jay prohibit any such member from rexeiving compensation from a source other than a nonprofit extucational instinution ${ }^{145}$ in respect of any particulas matter whith directly insolves the Commission or in ,which the Commission is directly interested. 146

Electric utility

"Sec 164. Electric Utility Contracts.-The Commission is authorized contracts. in connection with the construction or operations of the Oak Ridge, 42 USC sec 2204. Paducah, and Portsmouth tostallations of the Commisston, without regard to section 3679 of the Revised Statutes, as amended, to enter 31 USC 665. into new contracts or modify or confim existing contracts to provide for electric utility serves for periods not exceeding twenty-five years, and such contracts shall be subject to termination by the Commission upon payment of cancellation costs as provided in such contracts, and any appropriation presently, or herefafter made avallable to the Commission shall be available for the payment of such cancellation costs. Any stuch cancellation payments shall be taken into consideration in determination of the rate to be charged in the event the Commission or any other agency of the Federal Government shall purchase electric utility services from the contractors subsequent to the cancellation and during the life of the original contract. The authority of the Commission under this section to enter into new contracts or modify or confirm existing contracts to provide for electric utility services inchudes, in case such electric utility services are to be furnished to the Commission by the Tennessee Valley Authority, authority to contract with any person, to furnish electric utility services to the Tennessee Valtey Authority in replacement thereof. Any contract hereafter entered into by the Commission pursuent to this section shall be subraitted to the Joint Committee and a period of thirty days shall , elapse wiste Congress is is session (in computing such thirty days, there shalt be. excluded the days on which either House is not in session

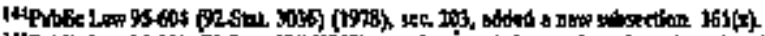

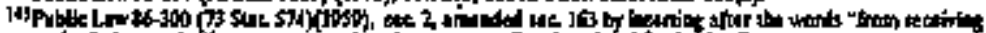

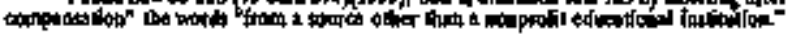

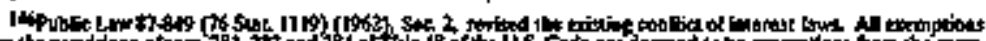

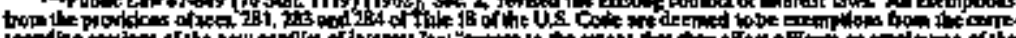

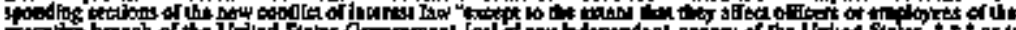

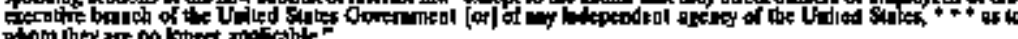

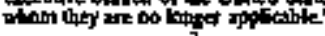


because of adjournment for more than three days) before the contract of the Conmission shall become effective: Provided, however, That the Joint Committee, after haring rectived the proposed contract, may by resolution in writing, waise the conditions of or all or any portion of such thirty-day period.

Contract practioss. 42 USC sect 2205.

60 STAT 755.

Comptrolier General audit,

42 USC sec. 2206.

$42 \mathrm{USC}$ sec. 2207.

"Sec. 165. Contract Practices.-

${ }_{a}$. In canrying out the purposes of this Act the Comminsion sinall not use the cost-plus-percentage-of-cost system of contracting.

${ }^{2} b$. No contract entered into under the authority of this Act shall provide, and no contract entered into under the authority of the Atomic Energy Act of 1946, as amended, shall be modified or amended after the date of enactiment of this Act to provide, for direct payntent or direct reimbursement by the Commission of any Federal income taxes on bebalf of any contractor performing such contract for profit.

"Sec. 166. Comptroller Genergl Andit.-No moneys appropriated for the purposes of this Act shall be available for pasments under any contract with the Commission, negotiated without advertising, except contracts with any foreign goversment or any agency thereof and contracts with forejgn producers, unless such contract inchudes a clause to the effect that the Comptroller General of the United States or any of his duly authorized representatives shail, until the expiration of three years after final payment, have access to and the right to examine any directly pertinent books, documents, papers, and records of the contractor or any of his subcontractors engaged in the performance of, and involving transactions related to such contracts or subcontracts: Provided, however, That no moneys so appropriated shall be avaílable for payment under such contract which includes any provision precluding an audit by the General Accounting Office of any transaction under such contract: And provided further, That nothing in this section shall prectude the earlier disposal of contractor and subcontractor records in accordance with records disposal schedules agreed upon between the Commission and the General Accounting Office, 147

"Sec. 167. Clajms Settlements-DTe Commission, axting on buhalf of the United States, is authorized to consider, ascertain, adjust, determine, settle, and pay, any claim for money damage of $\$ 5,000$ or less against the United States for bodily injury, death, or damage to or loss of real or personal property resulting from any detonation, explosion, or radiation produced in the conduct of any program undertaken by the Commission involving the defonation of an explosive device, where such claim is presented to the Commission in writing within one year after the accident or incident out of which the claim arises: Provided, however, That the damage to or loss of property, or bodily injury or death, shall not bave been caused in whole or in part by any negligence or wrongful act on the part of the claimant, his agents, or employees. Any such settlement under the authority of this section shall be final and conchusive for all purposes, notwithstanding any other

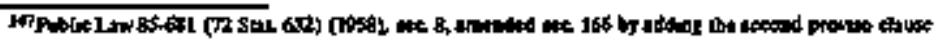


Pryments in Lieu of taxes. 42 USC sec. 2208 .

No subsidy.

42 USC

$\sec 2209$.

42 USC sec. 2210

Indemmitieation agreentent.

Waiver. provision of law to the contrary. If the Commission considers that a dain in excess of $\$ 5,000$ is meritorious and would otherwise be covered by this section, the Commission may report the facts and circumstances thereof to the Congress for its consideration. ${ }^{148}$

Sec 168. Payments In Lieu Of Taxes,-In order to render financial assistance to those States and localities.in which the activities of the Commission are carried on, and in which the Commission has acquired property previtously stoject to State and local taxation, the Commission is authorized to make payments to State and local governments in lieu of property taxes, Such payments may be in the amounts, at times, and upon, the terus the Commission deens appropiate, but the Commission shall be gujded by the policy of not making payments in excess of the taxes which would have boen payable for such property in the condition in which it was acquired, except in cases where special burdens bave been cast tpon the State or local government by actrvities of the Commission, the Manhattan Engineer District or theit agents. In ary stuch ceste, any benefit acenuing to the Stete or local government by reason of such activities shall be considered in determining the amount of the payinent:

Sec. 169. No Sulusidy-No funds of the Comunission siall be employed in the construction or operation of facilities licensed under section 103 or 104 except under contract or otiser arsangement erstered into pursuant to section 31.

Sec. 170. Indemnification Aad Lmitation of Liability_-149

a. Eact lisense issued unoer section 103 or 104 and tach construction permit issued under section 185 shall, and each $\mathrm{lj}$ cense issued under section 53,63 , or 81 may, for the public purposes cted it section $2 t$, have as a condition of the ljoense a tequirement that the licensee have and maintain financial protection of such type and in such amounts as the Nucleas Regulatory Commission (in this section referred to as the "Commission") in the exercise of its licensing and regulatory authority and responsibility shall require in accordance with subsection b. to cover public liability claims. Whenewer stuh financial protection is required, it may be a further condition of the license that the licensee execte and maintain'an inderinification agreement in accordance with subsection $c$. The Commission may require, as a fur-

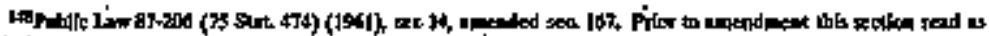
follonts

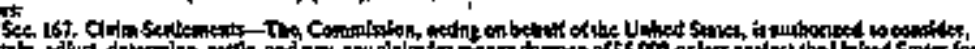

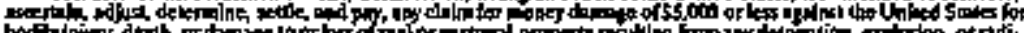

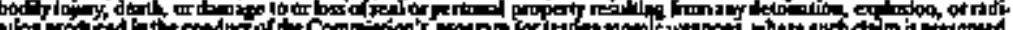
ton The

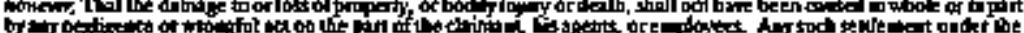

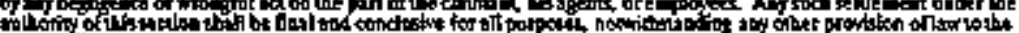
esming.

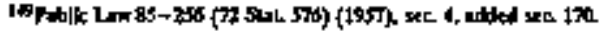


Lisbility insurance.

ther condition of issuing a license, that an applicant waive any immunity from public liability conferred by Federal or Stete law. 150

b. (1) The amount of primary financial protection required shall be the anount of liability irsuranes available from private sources, except that the Commission may establish a lesser amount on the basis of criteria set forth in writing, which it may revise from time to time, faking into consideration such factors as the following: (A) the cost and terms of private instrance, (B) the typt, size, and location of the licensed activity and other factors pertaining to the hazard, and (C) the nature and purpose of the licensed activity: Provided, That for facilities designed for producing substantial amounts of electricity and having a rated capacity of 100,000 electrical kilowatts or more, the amount of pritary financial protection required shall be the maximum amount available at reasonable cost and on reasonable terms from private sources (excluoting the amount of private liability insurance available under the industry retrospective rating plan required in this subsection). Such primary financial protection may include private insuranoe, privare contractual indemnities, self insurance, other proof of tinancial respensibility, or a combination of such Jueasures and shall be subject to such terms and conditions as the Commission may, be rule, regulation, or order, prescribe. The Commission shall require licensees that are required to have and maintain primary financial protection equal to the maximum annount of liability instrance available from private sources to maintain, in addition to such primary fimancial protection, private liability insurance avai]able under an industry retrospective ratist plan providing for premium charges deferred in whole of major part until public liability from anucleas incident exceeds or appears likely to exceed the level of the primary finaricial protection required of the licensee involved in the nuclear incident: Provided, That such insurance is available to, and required of, afl of the licenseets of such facilities without regard to the manner in which they obtain other types or aroounts of such primazy finaricial protection: And provided firther, That the maximum amount of the standard deferred premium that may be charged a licensee followitg any nucleas phcident under such a plan shall not be more than $\$ 63,000,000$ (subject to adjustment for inflation under subsection th) but not more than $\$ 10,000,000$ in any 1 year, for each factlity for which licensee is required to maintain the maximum arnount of primary financial protection: And provided further, That the amount which may be charged a licensee following any nuclear incident shall not exceed the licensee's pro rata share of the aegregate public liability ctaims

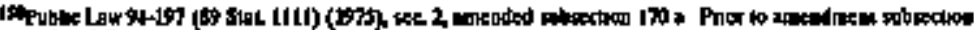

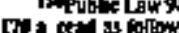

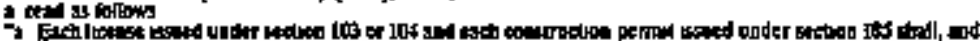

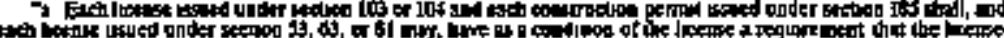

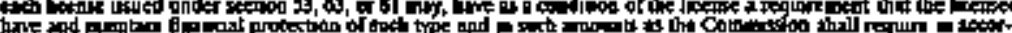

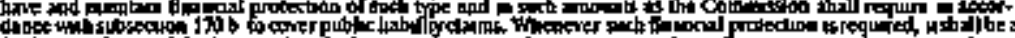

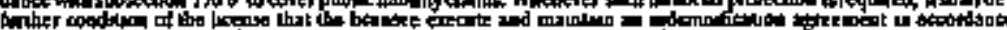

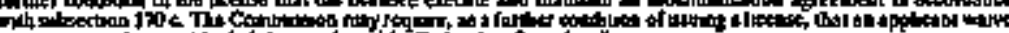

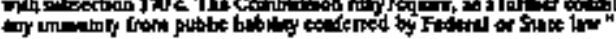

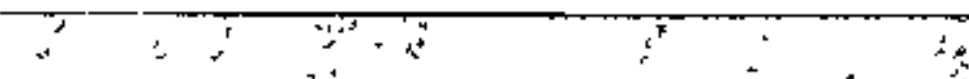


and costs (excluding legal costs subject to stibsection o.(1)(D), payment of which has not been authorzed under such subsection) arising ont of the nuclear incident. Payment of any State premium taxes which may be applicable to any deferred premint provjded for in this Act shall be the responsibility of the licensee and shail not be inchuded in the remospective preraing established by the Commission.

(2)(A) The Commission may, on a case by case basis, assess annual deferred pressium anounts less than the standard ansulal deferred premium amount assessed under paragrapb (1)-.-

(i) for any facility, if more than one nuclear incident occurs in any one calendar year; or

(ii) for any licensee licensed to operate more than one facility, if the Cotnmission determines that the financial impact of assessing the standard annual deferred premium amount under paragraph (1) would result in undue financial hardship to such licensee or the ratepayers of such licensee.

(B) Int the ovent that the Commission assesses a lesser arnntal deferred premium amount under subparagraph $(A)$, the Commission shall require payment of the difference between the standard annual deferred premium assessment under paragraph (1) and any such lesser annual deferred premium assessment within a reasonabie period of time, with interest at a rate determined by the Secretary of Treasury on the basis of the current average market yield on outstanding marketable obligations of the United States of comparable maturjies during the month preceding the date that the standasd annual deferred premium assessment under paragraph (I) would become dut.

(3) The Commission shall establish such requirements as are necessary to assure availability of funds to meet any assessment of deferred premiums within a reasonable time when due, and may provide reinsurance or shall otherwise guarantee the payment of such premíms in the event it appears that the amount of such premiutus will not be available on a timely basis through the resources of private tidiustry and fnsurance. Any agremement by the Commission with a ticenset or indempitor to guarante the payment of deferred premiums may contain such terms as the Commission deems appropriate to carry out the purposes of this section and to assure reimbursement to the Commission for its payments made due to the fathre of such licensee or indemnitor to meet any of its obtigations arising under or in connection with financial protection required under this subsection including without limitation terms creating liens upon the licensed facility and the revenues derived therefrom or any other property or revenues of such licensete to 
Ctaims.

Securities. secure such rejmbursenght and consent to the autonsatic terocation of any license. 151

(4)(A) In the event that the funds available to pay valid claims in any year are insuffictent as a result of the limitation on the amouns of deferred premitums that may be required of a licenste in any year under paragraph (1) or (2), or the Commisstion is required to make reinsurance or guaranteed payments under paragraph (3), the Commission shall, in order to advance the necessary fands-

(f) requirest the Congress to appropriate suffictent funds to satisfy such payments; or

(ii) to the extent approved in appropriation Acts, issue to the Secretary of the Treasiry obligations in such forms and denomtnations, bearing such maturities, and subject to such termas and conditions as may be agreed to by the Conmission and the Secretary of the Treasury.

(B) Except for finds appropriated for purposes of making reinsurance or guaranteed payments under paragraph (3), any funds appropinated under subparagraph (A)(i) shall be repaid to the beneral fund of the United States rireasury from amounts made available by standard deferred premitum assessments, with interest at a rate determined by the Secretary of Treasury on the basis of the current average market yield on cutstanding marketable obligations of the United States of comparable maturities ouring the month preceding the date that the funds appropriated under sticin subparagraph are made available.

(C) Except for funds appropriate for purposes of making reinsurance or guaranteed payments under paragraph (3), redemption of obligations issued under subparagraph (A)(in) shall be made by the Conmission from amounts made avajable by standard deferred premjum assessments. Such obligations shall bear interest at a rate determined by the Secretary of Treasury by taking into consideration the average market yield on outstanding marketable obligations to the United States of comparable maturities durfing the month preceding the issuarce of the obligations under this paragraph. The Secretary of the Treasury shall purchase any issued obligations, and for such purpose the Secretary of the Treasury may use as a public debt transaction the proceeds from the sale of any securities issued under chapter 31 of title 31, United States Code, and the purposes for which securities may be issued under such chapter are extended to include any purchase of suct obligations. The Secretary of the Treasury may at any tinte sell any of the obligations actiuired by the Secretary of the Treasury under this

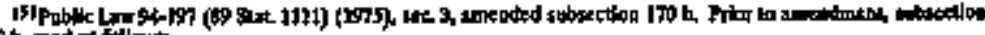
JW b. read a f fillowt

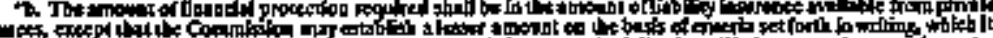

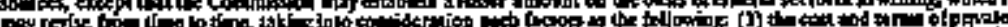

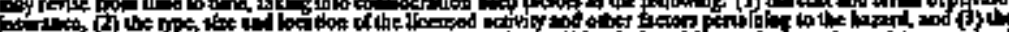

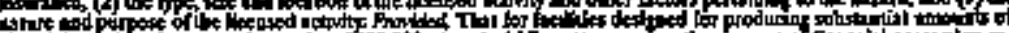

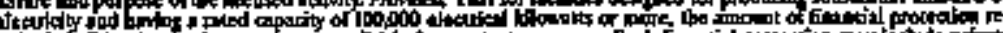

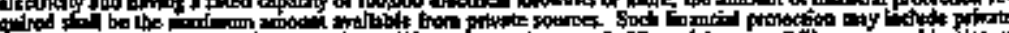

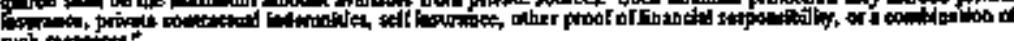

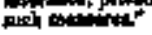


paragraph. All redemptions, purchases, and sales by the Secretary of the Treasury of obligations under this paragtaph shall be treated as public debt transactions of the United States.

c. The Commission shall, with respect to licenses issued between August 30, 1954, and August 1, 2002, for which it requires fintancial protection of less than $\$ 560,000,000$, agree to indernoify and hold harmless the licensee and other persons indempified, as their interest may appear, from pubìc liabjility arising from nuctear incidents which is in excess of the level of financial protection reguired of the licensee. The aggregate indemnity for all persons indemnified in connection with each muclear incident shall not exceed $\$ 500,000,000$ excluding costs of investigating and settling claims and defending suits for damage: Provided, however, That this amount of inderumity shall be reduced by the amount that the financial protection required stall exced $\$ 60,000,000$. Such a contract of indemnitication shall cover public liability arising out of or in connection with the licensed activity. With respect to any production or utilization factlity for which a construction permit is issued between Allgust 30, 1954, and August 1, 2002, 152 the requirements of this subsection shall apply to any license issued for such facility subsequent to August 1,2002.

d.(1)(A) In addition to any other authority the Secretary of Entrgy (in this section referred to as the "Secretary") may have, the Secretary shall, until August 1, 2002, enter into agreenents of indentuification under this subsection with any person who may condixet activities under a contract with the Department of Energy that involve the risk of public liabjlity and that are not subject to financial protection requitements tender subsection b. or agreements of indemnification under subsection c. or k. ${ }^{153}$

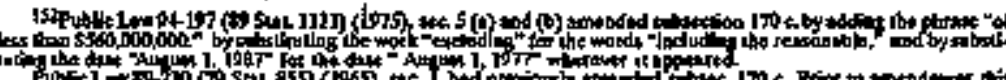

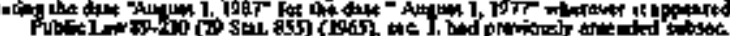

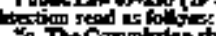

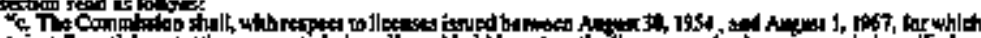

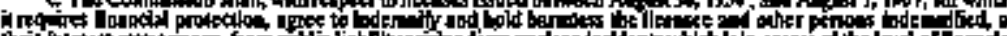

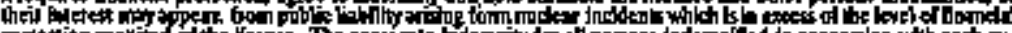

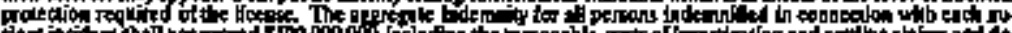

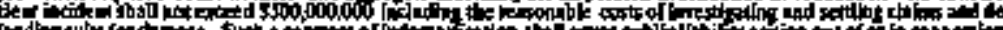

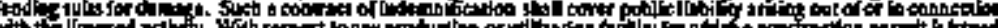

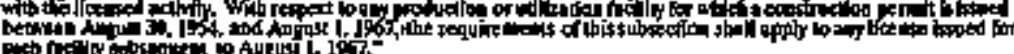

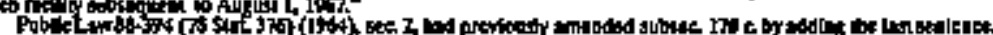

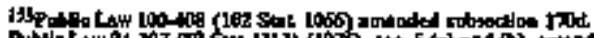

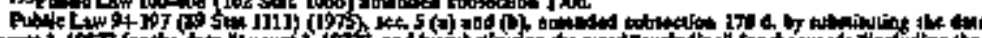

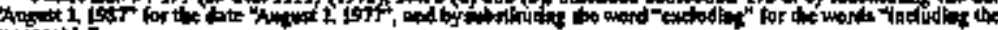

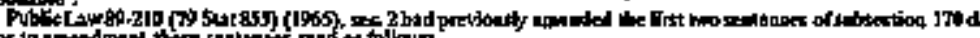

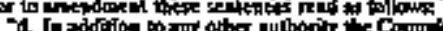

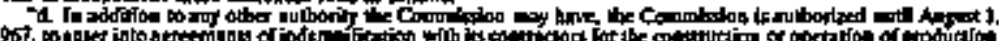

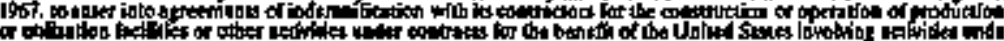

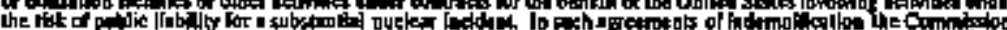

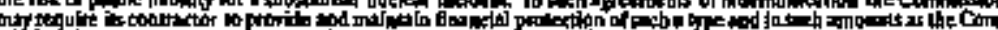

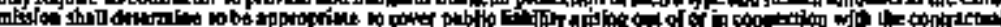

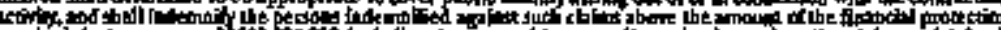

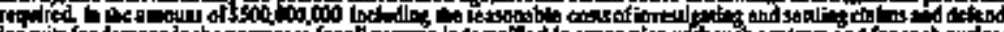

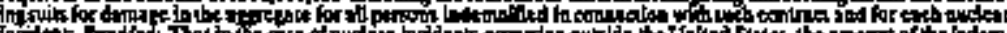

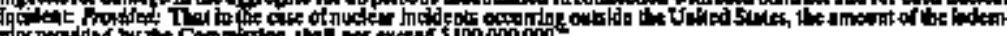
Ire proplad by

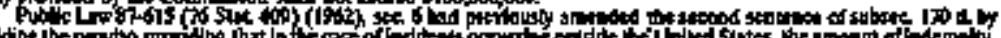

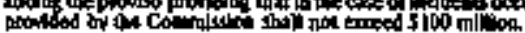


Effective date.

Claims.

Effective date.
"(B)(i)(I) Beginning 60 days after the date of enactment of the Price-Anderson Amendments Act of 1988, agreements of indernnification under subparagraph (A) shall be the exclusive means of indemnification for public liability arising from activities described in such subparagraph, including activities conducted under a contract that conteins an indentuification clause under Public Law 85-804 entered into between August 1, 1987, and the date of enactment of the Price-Anderson Amendments Act of 1988 .

"(II) The Secretary may incorporate it agreements of indemniEcation under subparagraph (A) the provisions relating to the waiver of any issue or defense as to charitable or governmental immunity authorized in subsection $n$. (1) to be incorporated in agreements of indemnification. Any such provisions incorporated under this subclause shall apply to any nuctear incident arising out of nuclear waste activities subject to an agreement of indenunification under subparagraph (A).

“(ii) Public liability arisung out of nuclear waste activities subject to an agreement of indennification under subparagraph (A) that are funded by the Nuclear Waste Fund established in section 302 of the Nuclear Waste Policy Act of 1982 (42 U.S.C. 10222) shall be compensated from the Nuclear Waste Fund in an aneaunt not to exceed the maximum amount of funancial protection required of licensees under subsection b.

(2) In agreements of indemaification entered into under paragraph (I), the Secretary may require the contractor to provide and maintain sinancial protection of such a type and in such amounts as the \$ecretary shall determine to be appropriate to cover public liability arising out of or in connection with the contractual activity, and shall indemnify the persons indemnified against such claims above the arrount of the financial protection recuised, to the full extent of the aggregate public liability of the persons indemuified for each nuclear incident, including such legal costs of the contraxtor as are approved by the Secretary.

(3) (A) Notwithstanding paragraph (2), if the maximum amount of financtai protection requited of licensees under subsection $b$. is increased by the Commission, the amount of judemanity, together with any financial protection required of the contractor, shall at all times remain equal to or greater than the masigum antotent of financial protection required of licensees under subsection $b$.

(B) The arnount of indemnity provided contractors under this subsection shall pot, at any tirae, be reduced in the event that the maximum amount of fimancial protection required of licensees is rechiced.

(C) All agreements of indemniliestion under which the De. partment of Energy (or its predecessor agencies) may be re. quired to indemnify any person, shall be deemed to be amended, on the date of the enactment of the Price-Anderson Arnendments Act of 1988, to reflect the amount of indermity for public liability and any applicabie financial protection required of the contsactor under this subsection on stech date. 
(4) Finamcial protection under paragraph (2) and indemnificaton under paragraph (1) sha't be the exclusive means of finsncial protection and indentification under this section for any Department of Enesgy demonstration reactor licensed by the Commission under section 202 of the Energy Reorganization Act of 1974 (42 U.S.C. 5842).

(5) In the case of nuclear incidents ocouring outside the United States, the amount of the indemrity provided by the Secretary unter this subsection shall not exceed $\$ 100,000,000$.

(6) The provisions of this subsection mat be appliceable to lump sum as well as cost type contracts and to contracts and projects financed in whole or in part by the Secretary.

(7) A contractor with whom an agreement of indemnification has been executed under paragraph (1)(A) and who is engaged in activities comected with the underground detonation of a nuclear explosive device shall be liable, to the, extent so indernnified under this zubsection, for injuries or,damage sustained as a result of such detonation jin the same manner and to the same extent as would a private person acting as princigal, and no tuntunity or deferase founded in the Feckeral, State, or municipal character of the contractor or of the work to be performed under the contract shall be effective to bar sucb liability. 154

e. Limitiation On A Egrgegate Public Ijability.-(1) ${ }^{155}$ The aggregate pablic liabjlity for a stingle nuclear incident of persons indennified, inclucing such $\mathrm{kgal}$ costs as are authorized to be paid under subsection o.(1)(D), shall not exceed"'

(A) in the case of facilities designed for producing substantial amounts of electricity and having a rated capactly of 100,000 electrical kilowatts or more, the maximum anount of financial protection required óf such facilities under subsection b. (plus any surcharge assessed uidder subsection o.(1)(E));

(B) In the case of contractors with whon the Secretary has entered into an agreement of indemnification under subsection $d_{\text {.; }}$ the maximum amount of financial protection and required under ' subsection b. or' the amount of indernity' and financial protection that may be required under'paragraph (3) of subsection $d$., whichever amount is more; and

(C) in the case of all other licensees of the Comunission required to maintain financial protection ufder this section-

(i) $\$ 500,000,000$, together with the amount of financial protection requited of the licensete; or

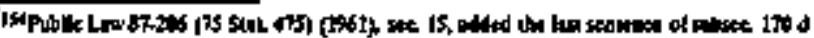

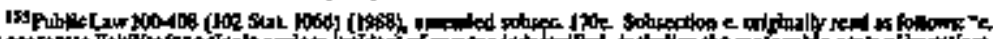

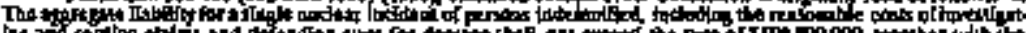

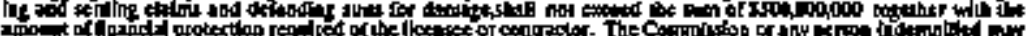

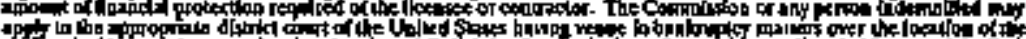

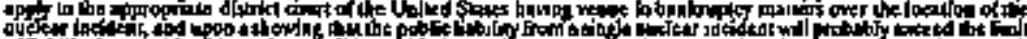
of pin is

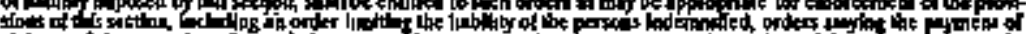

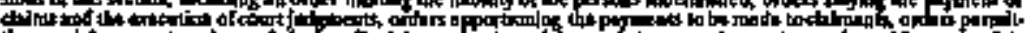

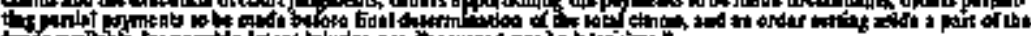

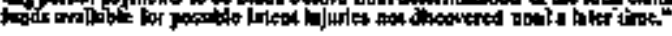


Claims.

(ii) if the amount of finsncial protection required of the licensee exceeds $\$ 60,000,000, \$ 560,000,000$ or the amount of 5 nancial protection required of the licensee, whichever amount is more.

(2) In the event of a nuclear incident involving damages in excess of the amount of aggregate public liability under paragraph (1), the Congress will thoroughly review the particular incident in accordance with the procedires set forth in section $170 \mathrm{i}$, and will in accordance with; such procedures, take whatever action is determined to be necessary (including approval of appropriate compensation plans and appropriation of funds) to provide full and prosispt compensation to the public for all public liability claims resulting from a disaster of such magnitude.

(3) No provision of paragraph (I) may be constsued to preclude the Congress from enacting a reveptue meastire, applicable to licensees of the Commission required to maintain financial protection purstuatt to subsection $b$., to fund any action undertaken pursuant to paragraph (2).

Contracts.

(4) With tespect to any nuclear incident occanting outside of the United States to which an agrecanent of indernnification entered into under the provisions of subsection d. is applicable, such aggregate public liability shalt not exceed the amount of $\$ 100,000,000$, together with the arount of finarcial protection required of the contractor.

[Cominods

Poble [2w

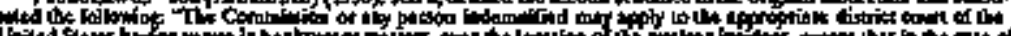

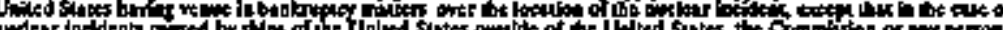

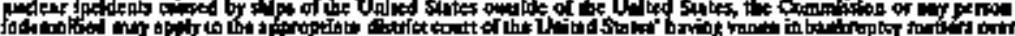

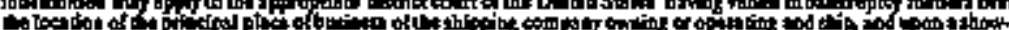

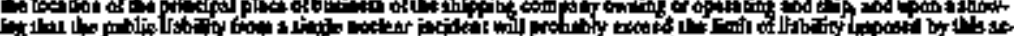

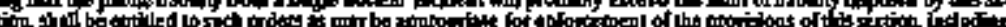

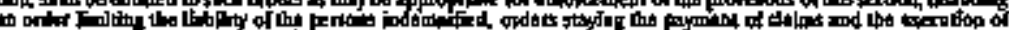

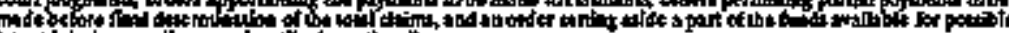

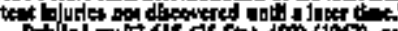

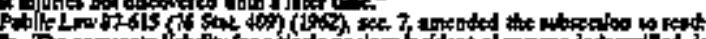

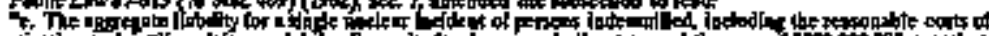

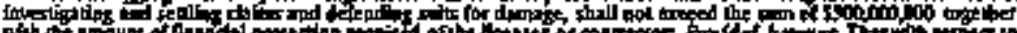

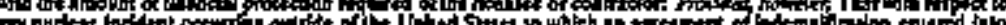
Din

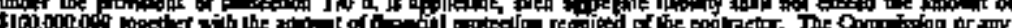

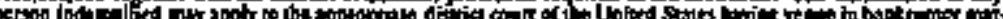

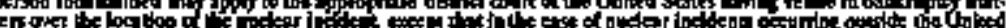
Stake Le Chith

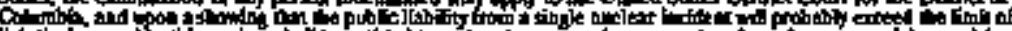

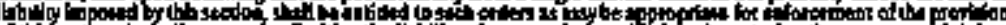

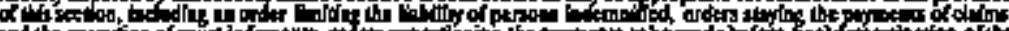
ad ferestiog of

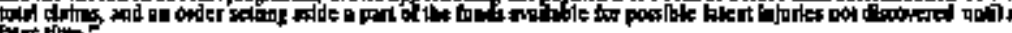

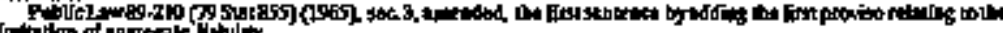
Pito of

P.

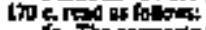

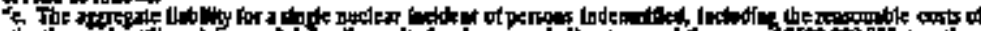

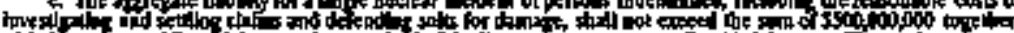
in the apor

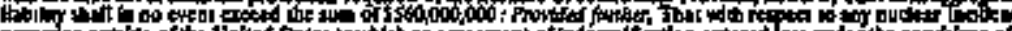

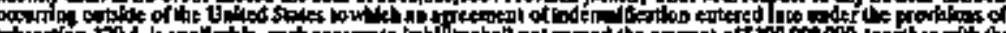

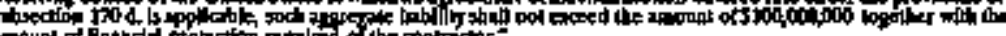

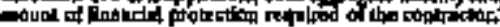

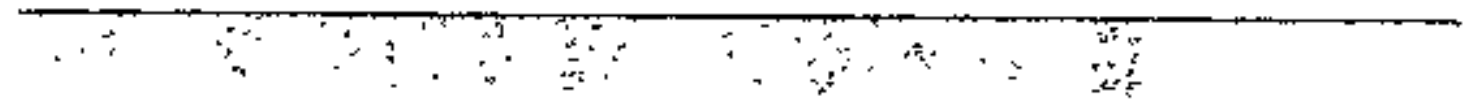


Private । insurance organítations. Use of services.

42 USC 252

(c) See 41) USC $26^{\circ}(\mathrm{b})$ ). Terms of settlement. t. The Commission or the Secretary, as appropriate, is authorized to coflect a fee from all persons with whon an indemnification agreenent is exectated tuxder this section. This fee shall be $\$ 30$ per year per thousand kjlowatts of thenpal energy capacity for facilities licensed under section 103: Provided, That the Commission or the Secretary, as appropriate, is authorized to reduce the fee for such facilities in reasonable telation to increases in financial protection required above a level of $\$ 60,000,000$. For facilities licensed under section 104, and for constrution permits under section 185, the Commission is authotized to reduce the fie set forth abowe. The Comnission shall establish critc-

- ria in writing for deteraination of the fee for facilities licensed under section 104, taking into consideration such factors as (1) the type, size, and location of facility involved, and other factors pertaining to the hazard, and (2) the nature and purpose of the facility. For other ljcenses, the Commission stall collect such nominal feer as it deems appropriate. No fee under this subsection shall be less than \$100 per year. 156

g. In administering the provisions of this section, the Commission or the Secretary, as apptopriate, shall use, to the maximum extent practicable, the facilities and services of private insurance organizations, and the Commission or the Secretary, as appropriate, may contract to pay a reasonable comptrisation for such services. Any coptract made under the provisions of this subsection may be made without regard to the provisions of section 3709 of the Revised Statutes (41 U.S.C. 5), as amended, upon a showing by the Commission or the Sectetary, as appropriate, that advertising is not reasonable practicable and advance payments may be made.

b. The agreement of jademnification may contain such terms as the Commission or the Sectetary, as appropriate, detems apptopriate to carry out the purposes of this section. Such agremaent shall provide that, when the Compunission or the Secretary, as appropriate, makes a determination that the United States will probably be required to make indemnity payments under this section, the Commission or the Secretary, as appropriate, shall , collaborate with any person indemnified and may approve the payment of any claim under the agreement of indemnification, appear through the Attorney General on behalf of the person inderinified, take charge of such action, and settle or defend ary sach action. The Commission or the Secretary, as appropriate, shall have final authority on behalf of the United States to settle or approve the settlerfent of any such claim on a fair and reasonable basis with due regard for the purpases of this Act. Such settlement shall not inclade expenses in connection with the clain incurred by the person indernified. 157

i. Compensation Plans.-(1) After any nuclear incident involviug damages that are likely to exceed the applicable amount of aggregate

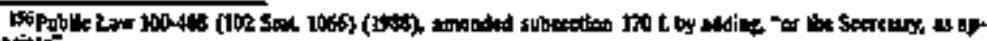

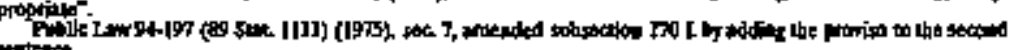
watrete.

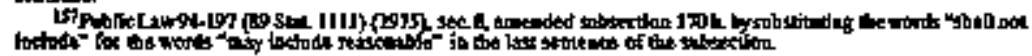


Reports, Defense and mational security.

President of U.S.

Claims.

Claims. public tiability under subparagraph (A), (B), or (C) of subsection e. (1), the Secretary or the Conumission, as appropriate, shall-

(A) make a sturvey of the causes and extent of damage; and

(B) expeditiously submit a report setting forth the results of such survey to the Congress, to the Representatives of the affected districts, to the Senators of the affected States, and (except for information that witl cause serious damage to the national defenst of the United States) to the public, to the parties jnvolved, and to the courts.

(2) Not later than 90 days after any determination by a court, pursuant to subsection $o_{\text {, }}$ that the public liability from a single nudear jncident may exceed the applicable amount of aggregate public liability under subparagraph (A), (B), or (C) of subsection e. (1) the President shall subinit to the Congress-..

(A) an estirate of the aggregate dollas vatue of persomal injuries and property damage that arises from the auclear incident and exceeds the amount of aggregate public liability under subsection e. (1);

(B) Jecommendations for additional sources of funds to pay claims exceecting the applicable amount of aggregate public liabijity under subparagraph (A), (B), or (C) of subsection e. (1), which recommendations shall consiđer a broad range of possibie sources of Eurds (induding possible revenue measures on the sector of the econoury, or on any other class, to which such revenue measures might be applied);

(C) 1 or more compensation plans, that either individually or collectively shall provide for full and prompt compensation for all valid claims and contain a recommendation or recommendations as to the relief to be provided, jacluding any recommendations that funds be allocated or set aside for the payment of claims that may arise as a result of latent injuries that jaky not be discovered until a later date; and

(D) any additional legislative astborities necessary to iniplement such compensation plan or plass.

(3)(A) Any compensation plan transmitted to the Congress pursuant to paragraph (2) shall bear an identification number and shall be transmitted to both Houses of Congress on the same day and to each House while it is in session.

(B) The provisions of paragraphs (4) through (6) shall apply with respect to consideration in the Senate of any compensation plan transmitted to the Senate pussuant to paragraph (2).

(4) No such coappensation plan may be considered approved for purposes of stubsection 170 e. (2) unless between the dare of transmittal and the end of the first period of sixty calendar days of continuous session of Congress after the date on which such action is transinitted to the Senate, the Senate passes a resolution described in paragraph 6 of this subsection.

(5) For the purpose of paragraph (4) of this subsection-

(A) continuity of session is broken only by an adjolarnment of Congress sine dit; and 
(B) the days on which either House is not in session because of an adjournoent of more than three days to a day certain are exctuded in the computation of the sixty-day calendar period.

(6)(A) This paragraph is enacted-

(i) as an exercise of the rulemaking power of the Senate and as such it is deemed a part of the roles of the Senate, but applicable only, with respect to the procedure to be followed in the Senate in the case of resolutions described by subparagraph (B) and it supersedes other nules only to the extent that it is inconsistent therewith; and

(ii) with full,recognition of the constitutional sight of the Senate to change the nules at any time, in the same manner and to the same extent as in the case of any other rule of the Senate.

(B) For purposes of this paragraph, the term 'resolution' means only a joint resolution of the Congress the matter after the resolving clatuse of which is as follows: "That the plan numbered approves the compensation submitted to the Congress on , $19 \therefore$, the first blank space therein being filled with the name of the resalving House and the other blank spaces being appropriately filled; but does not,incfude \& resalution which specifies more than one com* pensation plan.

(C) Aresolution once introduced with respect to a compensation plan shall immediately be reforred to a committet (and all resolutions with respect to the satre compensation plan shall be referred to the same committee) by the President of the Senate.

(D)(i) If the committee of the Senate to which a resolution with respect to a compensation plan laas been referred has not reported it at the end of twenty calendar days after its referral, it shall be in order to move either to discharge the contrittee.from further consideration of such resotution or to discharge the committee from further consideration with respeet to such compensation plan which has been referred to the conmittet.

(ii) A motion to disctarge may be made only by an jadividual favoring the resolution, shall be highly privileged (except that it may not be made after the committee has reported a resolution with respect to the same compensation plan), and debate thereon shall be limited to not more than one hour, to be divided equally between those favoring and those opposing the resolution. An amendment to the motion shall not be in order, and it shall not be , in order to move to reconsider the vote by which the motion was agreed to or disagreed to.

(iii) If the motion to discharge is agreed to or disagreed to the motion may not be renewed, nor may another motion to discharge the committee be made with respect to any other resolution with respect to the samie compensation ptan.

(E)(i) When the oommittee has teported, or has beerl discharged from further consiceration of, a resolution, it shall be at any time thereafter in order (even though a previous motion to the same effect has been disagreed to ) to move to proceed to the consideration of the resolution. The motion stall be bighly privileged and shall not be 
debatable. An amendinent to the motion shall not be in order, and it shail not be in order to mowe to reconsider the wote by which the motion was agreed to or disagreed to.

(ii) Debate on the resolution referred to in clause (i) of this subparagraph shall be linited to not more than ten hours, which shall be divided equally betueen those favoring and those opposing such resolution. A motion further to limit debate shall not be debatable. An amendment to, $\mathrm{cr}^{\mathrm{r}}$ mation to recommit, the resolution shall not be in order, and it shall not be in order to move to reconsider the vote by whici such resolution was agreed to or disagreed to.

(F)(i) Motions to postpone, made with respect to the discharge from committee, or the consideration of a resolution or motions to proceed to the consideration of other business, shall be decided without debate.

(ii) Appeals from the decision of the Chair relating to the apphication of the rules of the Senate to the procedures relating to a resolution shall be decided without debate. ${ }^{158}$

Contracts in ádvance of appropriations $31 \mathrm{USC} 665$.

Educational activities. j. In administering the provisions of this section, the Commission or the Secretary, as appropriate, may make contracts in advance of appropriations and neur obligations without regard to sections 1341, $1342,1349,1350$, and 1351, and subchapter II of chapter 15, of tite 31 , United Strates Code.

k. With respect to any license issued pursuant to section $53,63,81$, 104a., or 104c. for the conduct of educational activities to a person found by the Commission to be a nonprofit educational institution, the Commission shall exempt such lioensee from the financial protection requirement of subsection a. With respect to licenses issued between Algust 30, 1954, and August 1, 2002, for which the Commission grants such exemption:

(1) the Commission shall agree to indemnify and hold harmless the licensee and other persons indemnified, is their interests may appear, from public biability in excess of $\$ 250,000$ arising from nuclear incidents. The aggregate indernnity for all persons indem. nified in connection with each nuclear incident shall not erceed $\$ 500,000,000$, including such legal costs of the licensee as are approved by the Commission;

(2) such contracts of indernification shall cover public liability arising out of or in connection with the licensed activity; and shal! include damage to property of persons indennified, except property which is located at the site of and used in connection with the activity where the nuclear incident occurs; and

(3) such contracts of indeminification, when entered into with a licensee having immunity from public liability because it is a State agengy, strall provide also that the Commission shall make payments under the contract on account of activities of the licensee in

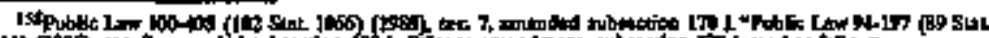

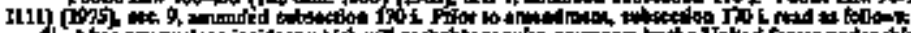

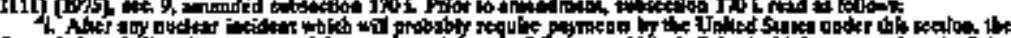

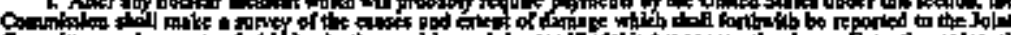

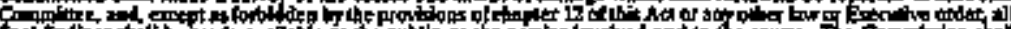

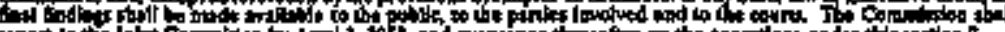

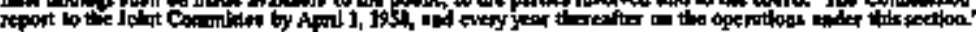

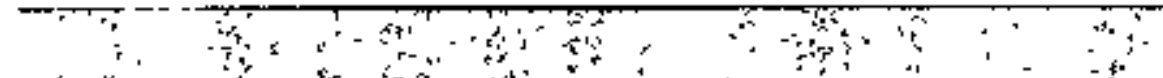


the same mapner and to the same extent as the Commission would be required to do if the licensee were not such a State agency.

Any licensee may waive an exemption to which it is entitled under this subsection. With respect to any production or utilization facility for .which a construction permit is issued between August 30,1954, and August 1, 2002, the requirements of this subsection shall apply to any license issued for such facitity subsequent to Alvgurt 1, 2002.139

(1) Presidential Commission On Catastrophic Nuclear Accidents(1) Not later than 90 days atter the date of the enactment of the PriceAnderson-Amendments Act of 1988, the President shall establish a conmusssion (in this subsection referred to as the 'stidy comulassion') in accordance with the Federal Advisory Cornmittee Act (5 U.S.C. APp.) to study means of fully compensating victirns of a catastrophic nuclear accident that exceeds the amount of agrgegate public liability nuder subsection e. (1).

(2)(A) The study commission sball consist of not less than 7 and not more than 11 menobers, who-

(i) shall be appointed by the President; and

(ii) shall be representative of a broad range of views and interests.

(B) The menbers of the study commission shalt be appointed in a maminer that ensures that not more than a mere majority of the members are of the same political party.

(C) Each member of the study conmission shall hodd office until the termination of the study comnisstion, but may be renowed by the President for inefficiency, neglect of duty, or malfeasance in office.

(D) Any vacancy in the study commission shall be filled in the manner in which the original appointment was made.

(E) The Prestident shall designate one of the members of the study commission as chairperson, to serve at the pleasure of the President ,

Reports.

(3) The study commission shalt conduct a comprehensive study of appropriate means of fully compensating victims of a catastrophic nuclear accident that exceeds the amount of aggregate public liability under subsection e. (1), and shall submit to the Congress a final report settiois forth-

(A) recornmendations for any changes in the laws and rules governing the liability or civil procedures that are necessary for the equitable, prompt, and efsicient resolution and payment of alt valid damage clajens, including the advisability of adjudicating public liability.claims through an administrative agency instead of the judicial system;

(B) recommendations for any standards of procectures that are necessaty to establish priorities for the hearing, resolution, and

ISf

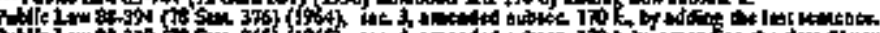

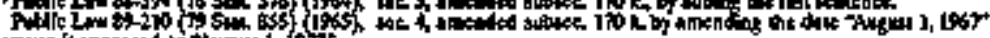
wherever 14 appened bo मे

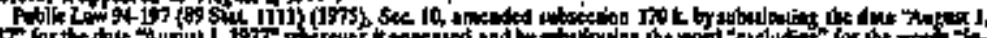
Fing or ture 
payment of clains when awards are likely to exceed the amount of Funds available within a specific time period; and

(C) recommendation for any spectal standards or procedures necessary to decide and pay claims for latent injuries caused by the nuclear facident.

(4)(A) The chairperson of the study comnission may appoint and fix the compensation of a staff of such persons as may be necessary to discharge the responsibilities of the study commission, subject to the applicable provisions of the Federal Advisory Committee Act (5 U.S.C. App.) and title 5, United States Code.

(B) To the extent permitted by law and requested by the chairperson of the study commission, the Administrator of General Services shall provide the study conumission with necessary administrative services, facilities, and suppott on a reimbursable basis.

(C) The Attorney General, the Secretary of Health and Human Services, and the Director of the Federal Energency Management A enency shall, to the extent permitted by law and subject to the availability of funds, provide the study commission with such facilities, support, funds and services, including staff, as may be necessary for the effective performance of the functions of the study commission.

(D) The study commission may request any Executive agenty to furnish such information, advice, or assistance as it determines to to itcessary to carry out its functions. Each such agency is direeted, to the extent permitted bylaw, to fumish such information, advice or assistance upon request by the chairperson of the study commission.

(E) Each menber of the study commission may receive compensation at the maximusn rate prescribed by the Federal Advisory Cornmitte Act (5 U.S.C. App.) for each day such mernber is engaged in the work of the study cormutssion. Each member magy also receive travel expenses, inchuding per diem in tieu of subsistence under sections 5702 and 5703 of tiflo 5, United States Code.

(F) The furctions of the President under the Federal Advisory Cormittee Act (5 U.S.C. App.) that are applicable to the study commission, except the function of reporting anmualy to the Congress, shall be performed by the Administrator of General Services.

Reports.

(5) The final report requited in paragraph (3) shall be submitted to the Congress not later than the expiration of the 2-year period beginning on the date of the ensctment of the Price-Anderson Amenoments Act of 1988 .

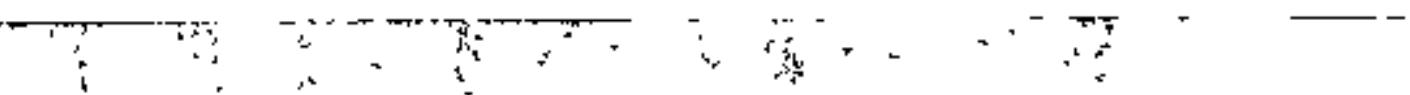


Termination

date.

Emergency

assistance

payments.

Waiver of defenses.

(6) The study conmission shall termintete upon the expixation of the 2-month period beginning on the date on which the final report required in paragraph ( 3 ) is stobmitted, 160

II. The Conjuission or the Secretary, as appropriate, is authoized to entor jato agreements with other Indemnitors to establish coordinated procedures for the prompt handling, investigation, and settlement of claims for public liability. The Commisston on the Secretary, as approptrate, and other indemnitors may make payments to, or for the aid of, claimants for the purpose of providing innediate assistance following a nuclear ineident. Ary funds appropriate to the Commission or the Secretary, as appropratate, shatl be avajable for such payments. Such payments may be made without stecuing Itleases, shall not constinte an admission of the liability of any person indenusitited or of any indemnitor, and shall operate as a satistaction to the extent thereof of any fingl settlement or judigment, 161

n. (1) With respect to any extraordinary nuclear occtarrence to which an insurance policy or contract, fursished as proof of fuancial protection ot an indemnity agreement applies and which-

(A) arises out of or results from or ocours in the course of the اـ Construction, possession, or operation of a protuction or utilization facility,

(B) arises out of or results from or octurs in the course of transportation of soturce material, by॰product material, or special nuclear material to or from a production of utilization facility,

(C) during the course of the contract activity arises out of or results from the possession, operaition, or use by a Department of Energy contractor or subcontractor of a device utilizing special nuclear material or by-pioduct material,

(D) arises out of, results from, or occurs in the course of, the construction, possesstion, or operation of any facility licensed under sections $\$ 3,63$, or 81 , for which the Commission has imposed as a contition of the license a requiteratent that the ficensed bave and maintain fanancial protection under subsection a.,

(E) arises out of, results from, or occurs in the course of, trans. portation of source material, byprochuet material, or special nuclear material to or from any facility licensed under section 53,63 , or 81, for which the Commission has imposed as a condition of the license a requirement that the licensec bave and maintain financial protection under subsection a., or

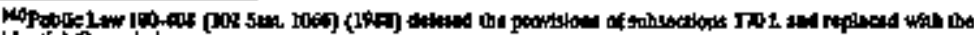

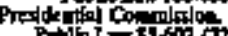

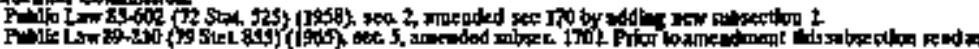
followis:

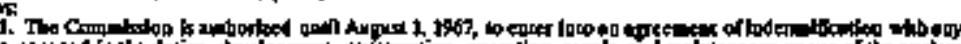

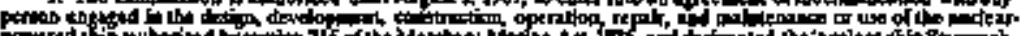

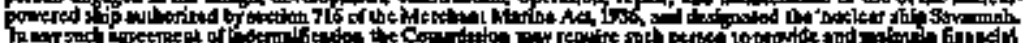

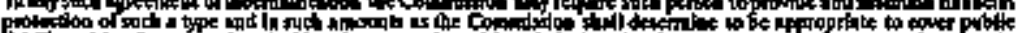

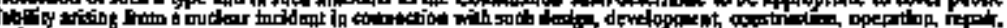

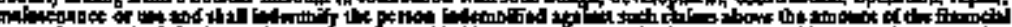

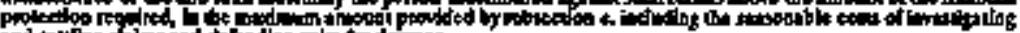

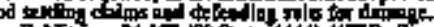

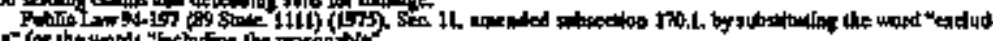

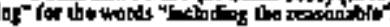

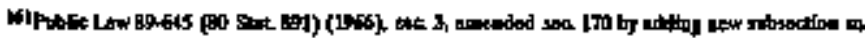


(F) arises out of, results from, ar ocaurs in the course of nuclear waste activities.

the Commission or the Secretary, as approprjate, may incorporate provisions in indemnity agreements with licensees and contractors under this section, and nagy require provisions to be incorporated in insurance policies or contracts furnished as proof of filancial protection, which waive (i) any issue or defense as to conduct of the claimant or fault of persons indemnified, (ii) any issue or defense as to charitable on governmental immunity, and (iii) any isste or defense based on any statute of limitations if suit is instituted within thee years from the date on which the claimant first knew, or reasonable could have know, of his injury or damage and the ceuse thercof. The waiver of any such issue or defense shall be effective regerdless of whether stich issue or defense may otherwise be deemed jurisdictional or relating to an element in the cause of action. When so mocorporated, such waivers shall be judicially enforceable in accordance with their terms by the claimant against the person indennified. Such worvers shall not preclude a defense based upon a failure to take reasonable steps to mitigate damagres, nor shall such waivers apply to injury or damage to a claimant or to claimants property which is intentionally sustained by the claimant or which results from a nuclear incident intentionally and wrongtully caused by the clainant. The waiver's authorized in this subsection shatl, as to indernnitors, be effective only with respect to those obligations set forth to the insurance policies or the contracts furnished as proof of financial protection and in the indemnity agreements. Such waivers shall not apply to, or prejudice the prosecution or defense of, any claim or portion of claim which is not within the protection afforded under (i) the terms of instrance policies or contracts furtrished as proof of funancial protection, or indennity agreentents, and (ii) the limit of liability provisions of subsection $\mathrm{e}$.

76 STAT 410

42 USC 2210

(2) With respect to any public liability action arising out of orresulting from a nuclear incident, the United States district court in the district where the muclear incident takes place, or in the case of a moclear incident taking place outside the United States, the United States District Court for the District of Columbia, shall have original jurisdiction without regard to the citizenship of any party or the amount in controversy. Upon motion of the defendant or of the Contunission or the Secretary, as appropriate, any such action pending in any State court (including any such action pending on the date of the enactment of the Price-Anderson Amendments Act of 1988) or United States district court shall be removed or traisferred to the United States district court having venue under this subsection. Process of such district court shalt be effective throughout the United States. In any action that is or becomes removable pursuant to his paragraph, a petition for removal shall be fled within the period provided in section 1446 of title 28 , United States Code, or within the 30-day period beginning on the date of the enactment of the Price Anderson Alnerdinests Act of $198 \%$, whichever occurs later.

Coutls, U.S. (3) (A) Following any nuclear incident, the chief judge of the United States district court having jurisdiction under paragraph (2) with 
respect to public liability actions (or the judicial council of the judtcial circuit in which tho nuclear incidtent oceturs) may appoint a special castoload managemont panel (in this paragraph referred to as the imanagenent panel') to coordinate and assign (but not necessarty hear thennselves) cuses arising out of the rucletur incident, if-

(i) a court, acting pussuant to stbsection o. deternjines that the aggregate amount of public liability is likely to exceed the amount of primary fulansial protection available under subsection b. (or an equivalant atrount in the case of a contractor indemnified under subsection d.); or

(ii) the chief judge of the United States district court (or the judicial cotncil of the judicial circuit) determines that cases arising out of the nuclear incident will have an unusual impact on the work of the coutt.

(B)(i) Each management panel shall consist only of members who are United States district judges or circuit judges.

(ii) Members of a management panel may include any United States district judge or circuít judge of asother district cout or court of appeajs, if the chief judge of such other district court or court of appents consents to sich assignment.

(C) It shatl be the function of each management panel-

(i) to consolidate related or similar claims for hearing or trial;

(ii) to establisth priorities for the bandling of different classes of cases;

(iji) to assign cases to a partictular judge or special master;

(iv) to appoint special masters to bear particular types of cases, or particutar elemerts or procectural steps of cases;

(v) to promulgate special rules of court, not inconsistent with the Federal Rilles of Civil Procedure, to expedite cases or allow more equitable consideration of claims;

(vi) to implement stıch other meastres, consistent with existing lay and the Federal Rules of Civil Procedure, as will ecoourage the

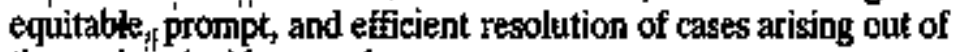
the nuclear incident; and

(vii) to assemble and subriit to the President such data, avaibable to the court, as nay be useful in estimating the agegregate damages from the nticlear incident. 162

Allocation of funds.

0. Plan For Distribution Of Funds.-(1) Whenever the United States district court it the district where a nuclear incident occurs, or the United States District Court for the District of Colunbia in case of a nuciear incident occusting outside the United States, determinges upon the petition of arry jodemnitor or other jnterested person that public liabilty from a single nuclear jncident may excetd the limit of liability under the applicable limit of liability under subparapraph (A), (B), or (C) of subsection e. (1):

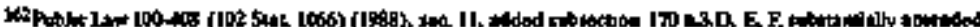

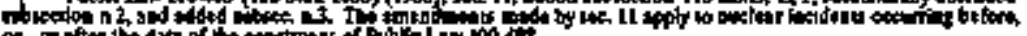

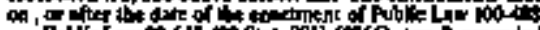

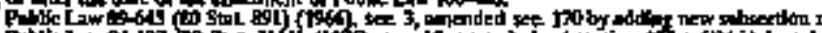

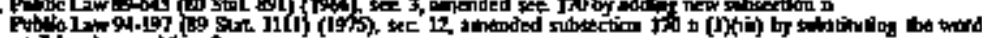

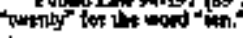
1 
(A) Total payments made by or for all indemuitors as a result of such nuclear incident shall not exoed is per centum of such limit of liability without the prior approval of such court;

(B) The court shall not authorize payments in excess of 15 percentum of such limit of liability unless the court determines that such payments are or will be in accordance with a plan of distribution which has been approved by the court of such payments are not likely to prejudice the strbsequent adoption and irmplementation by the court of a plan of distrtbution pursuant to subpara. graph (C); and

(C) The Commission or the Secretary, as appropgratac, shall, and any other indemnttor of other interested person may, submit to such district costrt a plan for the disposition of pending cfaims and for the distribution of remaining funds available. \$uch a plan shall include an allocation of appropriate amounts for personal injury claims, property damage claims, and possible latent injury claims which ray not be discovered until a later time and sball include establishment of priontites berween clatimants and classes of clainos, as necessary to insure the rnost equitable allocation of available funds. Such court shall have all power necessary to ap. prove, disapprove, or modify plans proposed, or to adopt another plan; and to determine the proportionate share of funds available for each claimant. The Commission or the Secretary, as appropriate, any other indennitor, and any person indennitied shall be entitled to such orders as may be appropriate to implement and enforce the provisions of this section, induding orders liniting the liability of the persons indemnified, onders approving or modifying the plan, orders staying the payment of claims and the execution of court judgraents, orders apportioning the paynents to be made to claimants, and orders permitting partial payments to be made before final determination of the total claims. The orders of such court shall be effective throughout the United States.

(D) A coutrt may authorize payment of only such legal costs as are permitted under paragraph (2) from the amount of Enancial protection required by subsection $b$.

(E) If the sum of pubtic liability claims and legal costs authotized under paragraph (2) arising from any nuclear incident exceeds the maximum amoust of financial protection required under subsectoon b., any licensee required to pay a standard deferred premium under subsection b.(1) shall, in addition to such deferred premium, be charged such an amount as is necessary to pay a pro rata share of such clains and costs, but in no case more than 5 percent of the maximum amount of such standard deferred premun described in such subsection.

(2) A court may authorize the payment of legal costs under paragraph (1) (D) only if the person requesting such payment has-

(A) subsuitted to the court the amount of such payment requested; and

(B) demonstrated to the court-

(i) that such costs are reasonable and equitable; and 
(ii) that such person has-

(I) litigated in good faitly;

(II) avoided unnecessary duplication of effort with that

of other parties simulariy situated;

(III) Dot urade finvolous clains or defensts; and

(IV) not attempted to unreasonably delay the prompt settlement or adjudication of such claims. ${ }^{163}$

p. Reports To Congress.-(1) The Commission and the Secretary sball submit to the Congress by August 1, 1998, detailed reports coneerning the need for continuation or modibication of the provisions of this section, taking into account the condition of the nuclear industry, availability of private, insurance, and the state of knowiedge concern. ing nuclear safety at that time, among other relevant factors, and shall include recommendations as to the repeal or modification of any of the provisions of this section.

(2) Not later than April 1 of each year, the Commission and the Secretary shall each submit an annual report to the Congress setting forth the activities under this section ching the preceeding calendar yeas.

a. Limitation Ö Avarding Of Precautionary Evacuation Costs.No court may apqard costs of a precautionary evacuation unless such costs constinite a public liability.

r. Linitation of Liability Of Lessors. - No person under a bona fide lease of any utilization or production facility (or part there of or andivided interest therein) shalt be liable by reason of an isterest as lessor of suct production or utilization factíty, for any legal liability arising out of or resulting from a nuclear incidents resulting from such facility, unless such facility is in the actual passession and control of such person at the time of the nuclear incident giving rise to such legal liability.,

5. Limitation On Punitive Damages.-No court may award punitive damages in any axtion with respect to a mucjear incident or ptecaution. ary evacuation against a person on behalf of whom the United \$tates is obligated to make payments under an agreement of indemnification cowering such incident or evacuation.

t Inflation Adjustment.-(1) The Commission shall adjust the amount of the maximum standard deferred premion under subsection b.(1) not less than once daring each 5-year period following the date of the enactment of the Price-Anderson Amendments Act of 1988 in accordance with the aggregate percentage change in the Consumer Price Index sines-

(A) such date of enactment, in the case of the first adjustment under this subsection; or

(B) the previous adjustment under this subsection.

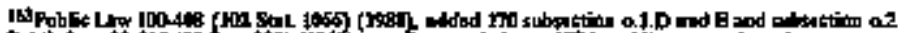

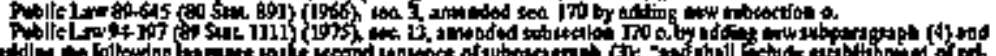

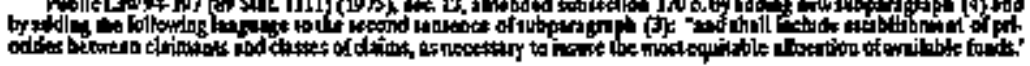


Conflict of

interest.

42 USC set. 2210\%,

Publication.

Report to

Congyess and

President.
(2) For purposes of this subsection, the term "Consumer Price Index" means the Consumer Price Index for all urban consumers published by the Secretary of Labor. 364

"See 170A. Conflicts Of Interest Relating To Contracts And Other Arrangements.-

"a. The Commission shalt, by ntle, require any person proposing to enter into a contract, agreement, or other arrangement, whether by competitive bid or negotiation, under this Act or any other law administered by it for the conduct of research, development, evaluation activities, or for tecturteal and manageroent support services, to provide the Commission, prior to entering into any such contract, agreement, or arrangement, with all relevant infor* nation, as determined by the Commission, bearing on whether that person bas a passible conflict of interest with respect to-

(1) being abte to render impartial, techrically sound, or objective assistance or advice in light of other activities or zelationships with otber persons, or

(2) being given an unfair competitive advantage. Such person shall insure, in accordance with regulations preseribed by the Commission, compliance with this section by any subcontractor (other than a supply subcontractor) or such person in the case of any subcontract for more than $\$ 10,000$.

"b. The Conmission shall not enter into any such contract agreement or arrangement unless it finds, after evaluating all information provided under subsection $a$. and any other information otherwise available to the Commission that-

(1) it is unlikely that a conflitet of interest would exist, or

(2) such conflict has beert avoided after appropriate conditions bave been included in such contract, agreement, or arrangement; except that if the Commission determines that stuch conflict of interest exiss and that such conffict of interest cannot be avoided by including appropriate conditions thereit, the Commission may enter into such contract, agreement, or arrangement, if the Commission determines that it is in the best interests of the United States to do so and inchudes appropriate conditions in such contract, agreement, on anrangtment to mitigate suct confliet.

"c. The Commission sball publish rules for the implementation of this section, is accordance with section 553 of Titte 5, United States Code (without regard to subsection (a)(2) thereof) as saon as practicable after the date of the enacturent of this section, but in no event later than 120 days after such date. 165

"Sec. 170B. Uraniom Supply-

"a. The Secretary of Energy shall monitor and for the years 1983 to 1992 report ammually to the Congress and to the President a

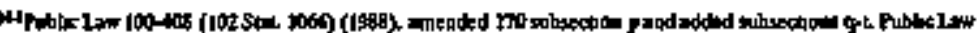

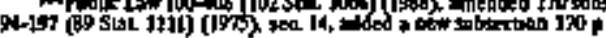

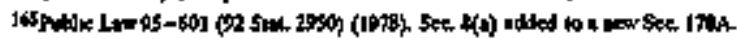


42 USC 22100.

42 USC 2231

Regulations.

Proprietary information, tisctosure.

Critería.

Imported material, impact on domestic industry and national security. determination of the viability of the domestic uranium mining and miling industry and shatl establiș by rule, after public notice and in accordance with the requirenents of section 181 of this Act, within 9 months of enactment of this section, specific criteria which shall be assessed in the annual reports on the domestic tranium industry's viability. The Secretary of Energy is authorized to issue regulations providing for the collection of such inforuation as the Secretary of Energy deems necessary to carry out the monitoring and reporting requirements of this section.

"b. Upon a satisfactory slicuting to the Secretary of Energy by any persont that any information, or portion thereof obtained under this section, would, if made public, divulge proprietary informaton of such person, the Secretary shall not disclose such information and disclosure there of shal be punishable under section 1905 of title 18, United States Coìe.

c. The criteria seferted to in subsection a. shall also include, but not be limited to-

"(1) an assessment of whether executed contracts or options for source rtaterial or special nocker material will Iesult in greater than $371 / 2$ percent of actual or projected domestic uranintm requirements for any two-conscentive-year ptriod bting supplied by source material or special nuclear material from foreign sources;

"(2) projechions of uranium requirements and inwentories of demestic utilities for a 10 year period;

"(3) present and probeble future use of the dotmestic market by foreign imports;

"(4) whether domestic economic reserves can supply all future needs for a future 10 year period;

(5) proșent and projected domestic tarintum exploration expenditures and plass:

(6) present and projected employment and capital investment in the uranium industry;

(7) the level of domestic uranium production capacity sufficient to meet projected domestic nuclear power needs for a 10 year period; and

"(8) a projection of donsestic uranium production and uranium price levels which will be in effect urater various assninjtions with respect to imports.

“d. The Secretary on Entrey, at any time, anay detentelne on the basis of the monitoring and anmul reports required under this section that source material or special nuclear material from foreign soutces is being imported in such increased quantities as to be a substantial cause of serious injury, or threat thereof, to the United States urajoum mising and milling industry. Based on that determination, the United Stetes Trade Representative shall request that the United States Interrational Trade Commission initite an investigation under section 201 of the Trade Act of 1974 (19 U.S.C. 2251). 
Investigations.

*e. (1) If, during the period 1982 to 1992 , the Secretary of Energy determines that executed contracts or options for source material or special muclear material from foreign sources for use in utilization facilities within or under the jurisdiction of the United States represent greater than $371 / 2$ percent of actual or projected domestic utanium requirements for any two-consecutive-year period, or if the Secretary of Energy determines the level of contracts or options involving soturce material and speciat nucleat material from foreign sources may threaten to impair the national security. the Secretary of Energy shall request the Secretary of Commerce to initiate under section 232 of the Trade Expansion Ast of 1962 (19 U.S.C. 1862) an investigation to determine the effects on the national security of imports of source material and special nuclear material. The Sectetary of Energy shall cooperate fully with the Secretary of Commerce in carrying out such an investigation and shall make available to the Secretary of Commerce the findings that lead to this request and such other information that will assist the Secretary of Commerce is the conduct of the investigation.

"(2) The Secretary of Comunerce sball, in the conduct of any investigation requested by the Secretary of Energy pursuant to this section, take into account any information made available by the Secretary of Energy, including information regarding the impact on national securtity of projected or executed contracts or options for source material or special nuclear material from foreign sources or whether domestic progiction capacity is sufficient to supply projected national security requitements.

“(3) No sooner than 3 years following completion of any investigation by the Secretary of Commiere under paragraph - (1), if no recommendation has been made pursuant to such study for trade adjustments to assist or protect domestic uranium production, the Secretary of Energy may initiate a request for another such inzestigation by the Secretary of Conmerce." 1650

\section{"CHAPTER 15-COMPENSATION FOR PRIVATE PROPERTY ACOUIRED}

Just

compensation. 42 USC sec 2221

"Sec, 171. Just Compensation.-The United States shall make just comperisation for any property or interests therein taken or requisitioned pursuant to sections $43,{ }^{166} 55,{ }^{167} 66$, and 108. Except in case of real property of any interest therein, the Commission shal determine and pay such just compensation. If the cominensation so determined is unsatisfactory to the person entitled thereto, such person shall be paid 75 per centum of the ampount so determined, and shall be

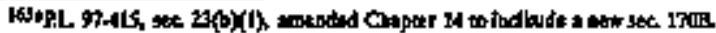

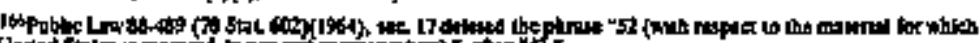

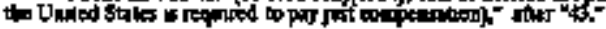

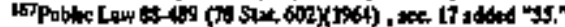


" entitled to sue the United \$tates Court of Federal Claims," or in any district court of the United States for the district in which such claimant is a resident in the manner provided by section 1346 of Title 28 of the

i. United States Code to recover such further sum as added to said 75 per centum will constitute just compensation.

Condemnation "Sec 172. Condemnation of Real Propierty-Proceedings for conof real property. dembation shall be instituted pursuant to the provisions of the Act 42 USC sec. 2222, , approved August 1, 1988, as amended and section 1403 of Title 28 of the 40 USC 257. United States Codol The Act approved February 26, 1931, as anended, 258a-259e. shall be applicable to any such procectings.

"Sec 173. Patent Application Dischionres.- In the event that the - Commission communicates to any nation any Restricted Data based on

Patent application disclosures. 42 USC. $\sec 2223$.

... any patent application not belonging to the United States, just comperssation shall be peid by the United States to the owner of the patent application. The Commission strall deternine such compensation. If the compensation so determinted is unsatisfactory to the person entitled thereto, such person shall be paid 75 per centum of the amount so determined, and shall be entitited to sue the United States Court of Federal Claims* or in any district court of the United States for the district in which such claimant is a resident in a manner provided by section 1346 of Title 28 of the United States Code to recover such furtber. sum asadked to such 75 per centum will constitute just compensation.

"Sec- 174. Attomey General Approwal of Title-All real property Attorney Geaeral approval of title. 42 USC sec. 2224.

40 USC 255. acciuired under this Act sball be subject to the provisions of section 355 of the Revised Statutes, as amended: Provided, however, That real propetty acquired by purchese or donation, or ather means of transfer may also be occupied, used, and inproved for the purposes of this Act prior to approval of title by the Attomey General in those cases where the Pressident-determines that such action is required in the futerest of the common defense and security. :

\section{"CHAPTER 16-JUDICIAL REVIEW AND ADMINISTRATVVE-PROCEDURE}

General.

"Sec 18t. General.-The provisions of the Administrative Procedare Act (Public Law 404, Seventy-rinth Conpress, approved Jtune 11, 1946) shall apply to' all agency action taken under this Act, and the terms 'agency' and 'agency action' shall have the useaning specified in the Administrative Procedure Act Provided, however, That in the case of agency

42 USC

sec. 2231. proceedings or actions which involve Restricted Data, defense information, safeguarcs information protected from disclosure under the authority of section $147^{168}$ or information protected from dissemi-

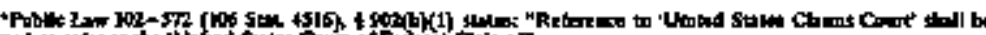

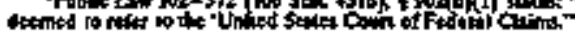

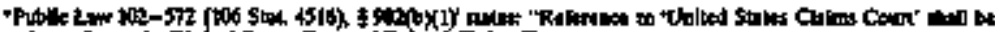

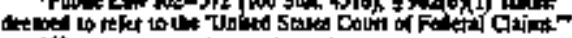

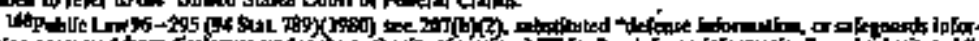

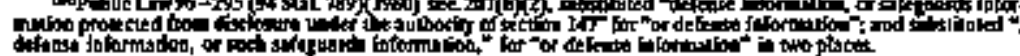


License eppliestions 42 USC sec. 2232.

ACRS Report. nation under authority of section $148^{169}$ the Commission shall prowide by regulation for such parallel procedures as will effectively safeguard and prevent disclosure of Restricted Data, defense foforenation, or such safeguards information, or information protected from dissemination under the authiority of Section 148 to unauthorized persons with minimum inpairment of the procedural rights which would be avajlable if Restricted Data, cefense inforntation, or such safeguards information, ${ }^{170}$ or infomation protected from dissemination under the au. thority of Section 148 were not involved.

"Sec. 182. Jicense Applications.

"a. Each application for a license beteunder shall be in writing and shall speciffeally state such information as the Comnission, by rule ar regulation, may determine to be necessary to decide such of the techujcal ard financial qualifications of the applicant, the character of the applicante, the citizenship of the applicant, or any other qualifications of the applicant as the Commission may deem appropnjate for the license. In connection with applications for licensts to operate production or utilization factities, the applicant shall state such technical specifications, including information of the amount, kind, and source of special nuclear matertal requited, the place of the use, the specific characteristies of the facitity, and such other information as the Commission may, by rule or regulation, deem necessary in order to enable it to find that the utilization or production of special nuclear material will be in accord with the common defense and security and will provide adequate protection to the health and safery of the publis. Such techitical spectifications shall be a part of any license issued. The Commission roy at any time after the filing of the original application, and before the expitation of the license, require further written statements in order to enable the Commission to determine whether the application should be grasted or denied or whether a license should be modjfied or revoked. All applications and statements shall be signed by the applicant or licensee. Applications for, and statements made in connection with, licenses under sections 103 and 104 shall bo made under oath or affinmation. The Contrission may require any other application or statements to be made usder oath or affirmation. Ito

"b. The Advisory Committee on Reactor Safeguards shall review each application under section 103 or section $104 \mathrm{~b}$. for a construction permit or an operating hicense for a facility, any application under section $104 \mathrm{c}$ for a construction permit or an operating license for a testing facility, any application under section $104 \mathrm{a}$. or c. specificalty referred to it by the Commission, and any apptica-

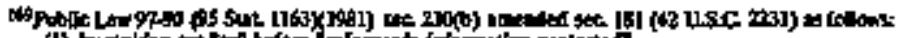

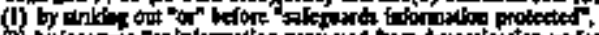

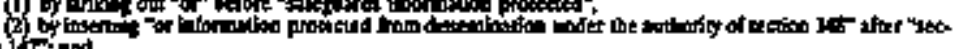
Wo litimed

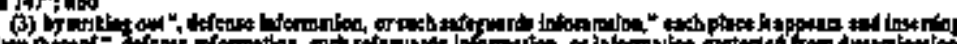

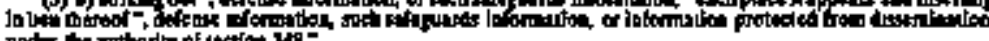

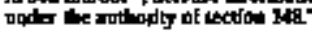

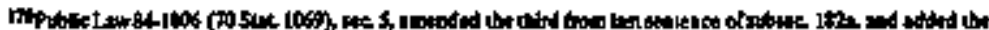

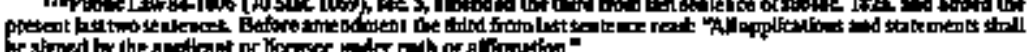


Commercial power.

tion for an amendment to a construction permit or an amendment to an operating license under section 103 or 104 a., b., or specifically referred to it by the Commlission, and shall submit a report

- thereon which shall be made part of the record of the application

, , and available to the public except to the extent that security classification prevents disclosure ${ }^{171}$

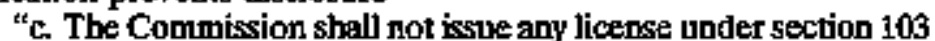
for a tatilization or production facility for the gentration of commereial power until it hes given notice in writing to stich regulatory agency as may have jurisdiction over the rates and services incident to the proposed activity; until it has published notice of the application in such trade or news publications as the Commission deems appropriate to give reasonable notice to mumicipalities, private utilities, ptoblic,bodies, ard cooperatives which might have a patential interest in such utilization or production facility; and until it bas published notice of such application once each week for four consecutirye weeks in the Federal Register, and until four weels after the last notice. 172

"d. The Commission, in issuing any.license for a utilization or production facility for the generation of contuercial power under section 103, siall give preferred constertation to applications for such facilities which will be located in bigh cost power areas in the United States if there are comflicting applications for a finited opportunity for suck licenste. Where such conflicting applications sesulting from limited opportunity for such license include those submitted by publice or cooperative bodies such applications sball be given prefered consideration.

Terms of licenses. 42 USC sec. 2233.

"Sect 183. Therins of Uicenses. Each jicense shall be in such form and comtain stıch terms and conditions as the Commission may, by rule or regulation, prescribe to effechate the provisions of this Act, inclucting the following provisions:

${ }^{4} \mathrm{~b},{ }^{17}$ No right to the special muclear material shall be conferred by the license except as defined by the license.

" $c$. Neither the license nor auy right under the license shall be as. sigied or otherwise transferred in violation of the provisions of this Act.

-d. Every license issued under this Act sball be subject to the right of recapture or control reserved by section 100 , and to all of the other provisions of this Act, now or bereafter in effect and to all valid rules and regutations of the Commission.

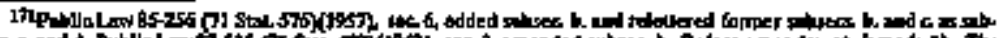

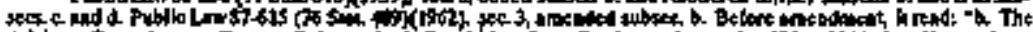

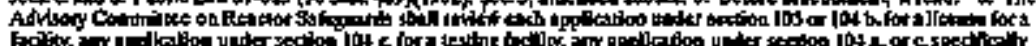

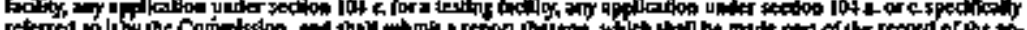

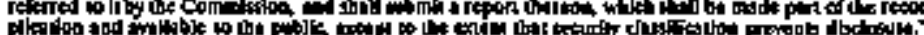

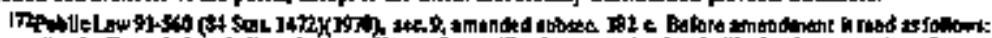

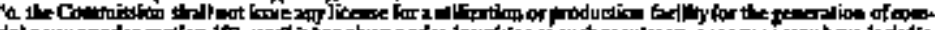

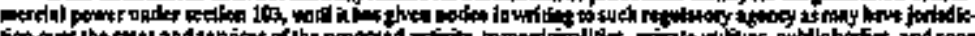

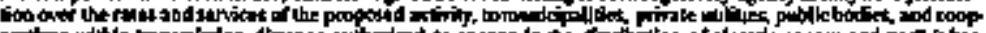

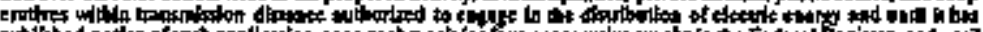

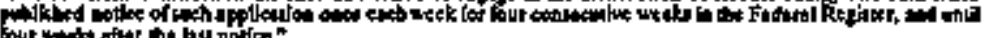

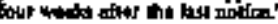

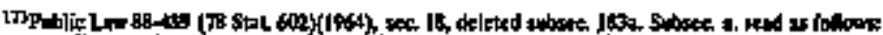

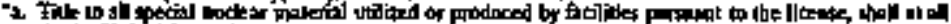

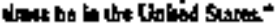


Inalienability of licentes. 42 USC sec. 2234 .

Construction permits 42 USC $\sec 2235$.
"Sec. I84. Inalienability of Licenses, - No license granted herelinder and no right to utitize or produse spectal nuclear material granted hereby shall be transferred, assigned or in any mamner disposed of, either voluntarily or involuntarily, directiy or indirectly, through transFer of control of any license to any person, tanless the Commission shall, after securing fall information, find that the transfer is in accordance with the provisions of this Act, and shall give its consent in writing. The Commission may give such consent to the creation of a mortgage, pledge, or other lien upon any facility or spectal nuclear material, 174 owned or thereafter acquired by a licensee, or tpon any leasehold or other interest in such facility, 135 and the rights of the creditors so secured may thereafter be enforced by any court subject to rules and regulations established by the Commission to protect public health and safety and promote the conmon defense and security.

"Sec. 185. Construction Permits and Operating Licenses.-

"a. All applicants for licernses to construct or modify production or utílization facilities shajl, if the application is otherwise acceptable to the Comnission, be initialy granted a constraction pentait. The construction permit shall state the earliest and latest dates for the completion of the constuuction or modification. Unless the construction or modification of the facility is completed by the conpletion date, the construction perait shall expire, and al] rights thereunder be forfeited, unless upon good cause shown, the Commission extends the completion date. Upon the completion of the construction or modification of the facility, upon the filing of any additjonal juformation needed to bring the original application up to date, and upon finding that the facility aathorized has been constructed and will operate in conformity with the application as amended and in conformity with the provisions of this Act and of the rules and regulations of the Commission, and in the absence of any good cause bejag shown to the Commission why the grantiog of a license would not be in accordance with the prowistons of this Act, the Commission shall thereupon issie a license to the applicant. For all other purposes of this Act, a construction permit is deemed to be a 'license'.

"b. After holding a public hearing under section $189 \mathrm{a}$. (1)(A), the Commisston shall issue to the applicant a combined construction and operating license if the application contatns sufficient information to support the issuance of a combined license and the Comanission determines that there is reasonable assurance that the facility will be constructed and will operate in contormity with the license, the provistons of this Act, and the Comnission's rules and regulations. The Commission shall identify within the connbined license the inspections, tests, and analyses, inctuding those applicable to emergency planning, that the licensee shall perform, and the acceptance criteria that, if met, are necessary and sufficient to provide reasonable assurance that the facility has beent constructed and wil] be operated in conformity with the license,

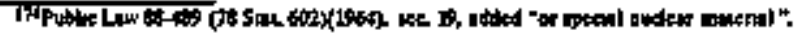

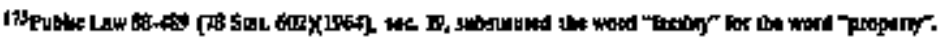


Revocation. 42 USC $\sec .2236$.

\$0 STAT 388, 5 USC 558(b).

5 USC 551.

Modification of license. 42 USC sec. 2237.

Continued operation of facilities. $42 \mathrm{USC} \sec 2238$ the provisions of this Act, and the Commisston's rules and rtgulations. Following issuance of the combined license, the Coramis. sion shall ensure that the prescribed inspections, tests, and analyses are performed and, prior to operation of the facility, sball find that the presmibed acceptan crteria are met. Any finding made under this subsection shall not require a hearing except as provided is section 189 a. (1)(B)."176 and NOTE.

"Sec. 186. Rewacation.-

"a. Any'license may be revoked for any material false statement in the application or any statement of fact required under section. 182, or because of conditions revealed by such application or statemerit of fact or any report, recorc, or inspection or other - means which would warrant the Comnission to refuse to grant a license on an originad application, or for fajlure to construct or operate a factitity in accordance with the terms of the construction permit or license or the technical specifications in the application, or for violation of, or failure to observe any of the terms and proristions of this Act or of ary regulation of the Comnission.

"b. The Commission shall follow the provisions of section 9(b) of the Adritoistrative Procedure Act in revoking any license.

ce. Upon revocation of the license, the Commission may imne. diately retake possession of all special nuclear material held by the licensee. In cases found by the Comnission to be of extreme inportance to the nationel defense and security or to the health and safety of the puiblic, the Commission may recapture any special

1 nuclear Inaterial beld by the licensee or may enter upon and operate the facility prior to ary of the procedures provided under the Administrative Procedurts Act Just compensation shall be paid for the use of the facility.

"Sec. 187. Modifieation of Leense-The terms and conditions of all licersses shall be subject to amendment, revision, or modification, by reason of amendinents of this Act, of by reason of rules and regulations issued in accordance with the terms of this Act.

* Sec 18. Continued Operation of Facilities.-Whenever the Commission finds that the public converience and necessity or the production frograta of the Commisston requires continued operation of a production facility or utilization facility the license for which has been rewoked pursuant to section 186, the Commission may, after consultation with the appropriate regulatory agency, State or Federal, having jurtsdiction, order that possession be taken of and such facility be operated for such period of time as the public convenience and necessity or the production program of the Commission Jaay, in the judgment of the Commission, require, or until a license for the operation of the facility shall become effective. Just compensation shall be paid for the use of the facility.

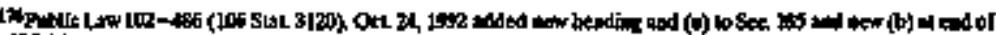
Sath I 185 (

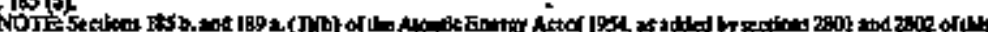

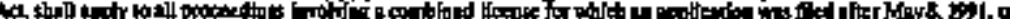
der boch whious. 
Heatiniss and

judicial review.

42 USC sec. 2239.

Federal

Register.

Publication
“Sec. 189. Heariogs and Jurlicial Review.-

"a. (1)(A) In any proceeding under this Act, for the granting, suspending, revoking, or amending of any license or construction permit, or application to tratsfer control, and it any proceediog for the issuance or modification of roles and regulations dealing with the activities of licensees, and in any proceeding for the payment of compensation, an award, or royalties under sections 153, $157,186 \mathrm{c}$, or 188 , the Commission shall grant a hearing upon the request of any person whose interest may be affected by the proceeding, and shall adtitit any such person as a party to such proceeding. The Commission sball hold a hearing after thircy days' notice and publication once in the Federai Register, on each application under section 103 or $104 \mathrm{~b}$. for a construction permit for a facility, and on any application under section $104 \mathrm{c}$ for a construction permit for a testing facility. In cases where such a construction permit has beefl issted following the holding of stch a hearing, the Commission may, in the absenoe of a request therefor by any person whose tisterest may be affected, issue an operatints license of an amendment to a construxction permit or an amendment to an operating license without a hearing, but upon thirty days notice and publication ono in the Federal Register of its intent to do so. The Commission may dispense with such thirty days' notice and publication with respect to any application for an aroendment to a construction permit or an amendment to an operatiog license upon a determination by the Cornmission that the aroenduent inwolves no significant hazards consideration. $177+177 \mathrm{a}$

"(B)(i) Not less than 180 days beforte the date schedutes for initial loading of fuel into a plant, by a licensee that has been isstued a combined construction permit and operating ticense ander section $185 \mathrm{~b}$., the Commisston shall publish in the Federal Register notice of intended operation. That notice shall provide that any person whose inrerest may be affected by operation of the plant, may within 60 days request the Com. mission to hold a hearing on whether the facility as conseructed complies, or on completion will comply, with the acceptance criteria of the license.

"(ii) A request for hearing under clause (i) shall show, prima facie, that one or more of the acceptance criteria in the combined license have not been, or will not be met, and the specific operational consequences of nonoonfor, mance that would be contrary to provicing reasonable

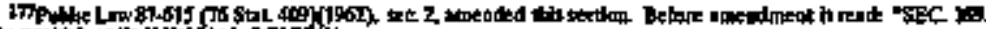

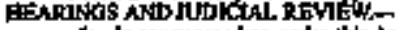

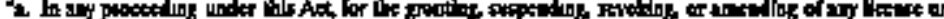

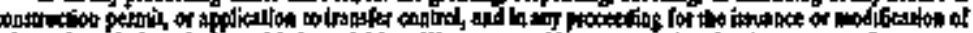

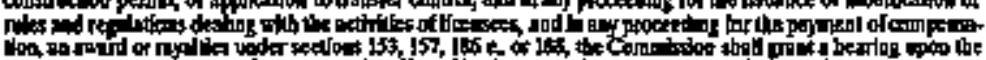

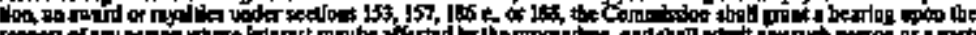

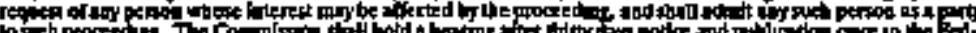

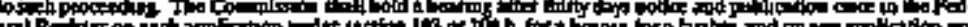

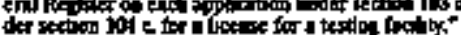

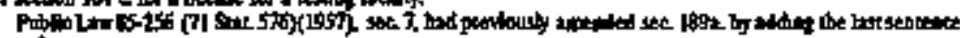
itipeot

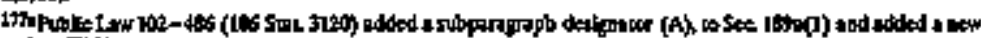
Difmertal (B) 
Notice

publication.

assurance of adequate protection of the public health and safety.

"(tii) After receiving a request for a bearing trinder clause (i), the Commission expeditiously shall either deny or graat the request. If the request is granted, the Comunission 'shall determine, after considering petitioners' prima facie showing and any answers thereto, whether during a poriod of interim operation, there will be reasonable assurance of adequate protection of the public bealth and safety. If the Commission determines that there is such teasonable assurance, it shalf allow operation during an interim period under the combined license.

"(iv) The Comtnission, in its discretion, shall determine appropriate hearing procedures, whether informal or formal adjudicatory, for any hearing uxder clause (i), and shall state jts reasons therefor.

"(v) The Commission shall, to the maximum possible extent, render a decision on issues raised by the hearing request within 180 days of the publication of the notice provided by clause (i) or the anticipated date for initial loading of fuel into the reactor, whichever is latex. Commencement of operation under a combjued license is not subject to stibparagraph.(A).".177b

4(2)(A) The Commission may issue and nake ingriediattly effective any aroendment to an operating license or any amendment to a combined construction and operating license, upon a determization by the Commission that such amendment involves no significant hazards consideration, notwith. standing the pendency before the Commission of a request for a hearing from any person. Such amendment may be issued and made immediately effective is advance of the holding and completion of any required hearing. In determining under this section whether such aruendment involves no signisicant haz"ards consideration, the Comurission shall consult with the State in which the facility itwolved is located. In all other respects such amendment shall meet the requirements of this Act.

"(B) The 'Combission shall periodically (but not less frequently than once every thirty days) publish notice of any amendments issued, or proposed to be issued, as provided in subparagraph (A). Each such notice shall include all amendments issued, or proposed to be issued, since the date of pubiication of the last such periodic notice. Such notice shall, with respect to each amendment or proposed amendment (1) jdentify the facility involved; and (ii) provide a brief description of

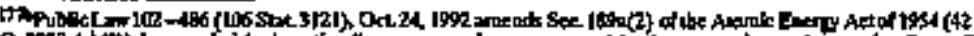

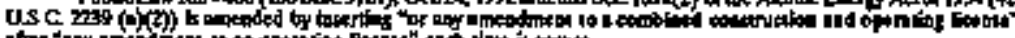

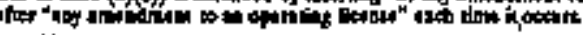

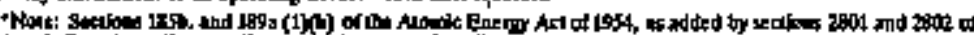

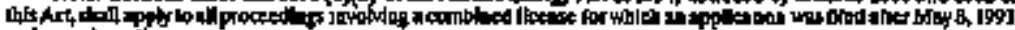
ader enct pections. 
Regulations essablishing standards, criteria, and procodares.

42 USC sec. $2239(6)$

Atomic Safety and Licensing Board 80 STAT. 386, 387,5 USC
42 USC sec. 2240. " $\mathrm{Sec} 190$. Yicensee Incident Reparts.-No report by any licensee of

such amendment. Nothing in this subsection shall be construed to delay the effective date of any amendiment.

"(C) The Cornmission shall, during the ninety-day period following the effective date of this paragraph, promulgate Iegulations establishing (j) standards for detemining whether any amendment to an operating license involves no significant hazards consideration; (ii) criteria for providing or, in emergency situations, dispensing with prior notice and reasonabje opportanity for public comment on any such determination, which criteria shall take jato account the exigency of the need for the amendment involved; and (jii) procedures for consultation on any such determination with the State in which the fa. cility involwed is located." 178

b. The following Commission actions shall be subject to judicial review in the manner prescribed in chapter 158 of title 28 , United States Code, and chapter 7 of titte 5, United States Code:

(1) Any final order entered in any proceeting of the kind specified in subsection (a).

(2) Any final order allowing or prohibiting a facility to begin operattog under a combtoed construction and operating license.

(3) Any fulal order establtshing by regulation standard's to govern the Depertment of Energy's gaseots diffusion uranium enticlement plants, inchuding any such facílities leased to a corporation established uncker the USEC Privatization Act.

(4) Any firal determination under section 1701(c) relating to whether the gaseous diffusion plants, including any such facilities leased to a corporation established under the USEC Privatization Act, are in conpliance with the Commission's standards governing the gasecus diffusion plants and al applicable lawr. 178 a any incident arising out of of in connection with a licensed activity made pursuant to any requirement of the Commission shall be admitted as evidence in any suit or action for damages growing out of any matter mentioned in such report. ${ }^{179}$

"Sec. 191. Atomic Safaty and Licensíg Boand,-

"a. Notwithstapting the provisions of sections $7(a)$ and $8(a)$ of the Adrniristrative Procedure Act, the Commission is authorized to establish one or more atomic safety and licensing boards, each comprised of three members, one of whom shall be gualified in the

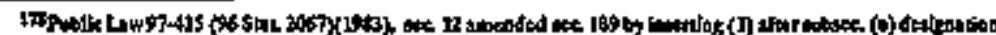

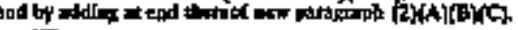

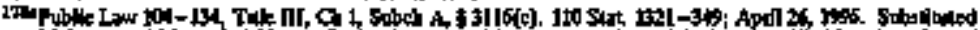

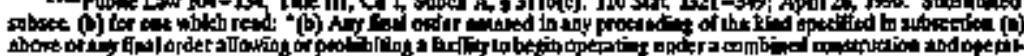

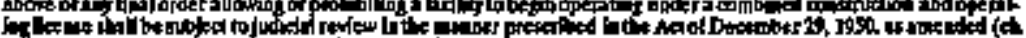

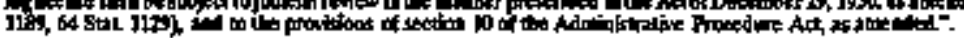

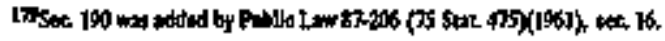

i


556,557 . 42 USC $\sec 2241$.

Temporary licensing authority. 42 USC sec. 2242.

42 USC 2133, 2134.

Port. p. 2073.

Initial petition. conduct of administrative proceedings and two of whom shall have such technical or other qualifications as the Comrission deems appropriate to the issues to be decided, to condluct such hearings ies the Commission may direct and make such internediate or final dexistons as the Commission may authorize with Jespect to the gratnting, suspendimg, revoling or amending of any license or atrthorization under the provisions of this Act, any other provision of law, of any Iegulation of the Commission issued thereunder. ${ }^{180}$ The Commission may delegate to a board such other reglalatory functions as the Commission deents appropriate. The Commission may appoint a panel of qualified persons from which board Inembers may be selected.

tb. Board members may be appointed by the Commission from private life, or designated from the staff of the Commission or other Federal agency. Board members appointed from private life shall receive a per diem compensation for each day' spent in meetings or conferemces, and alt members shall receive their necestary traveling or other expenses while engaged to the work of a board. The provisions of section 163 shall be applicable to board members appointed from private life. 181

"Sec. 192. Temporary Operating License.-

"a. In any proceeding upon an application for an operating license for a utilization facility required to be licensed under section 103 or $104 \mathrm{~b}$. of this Act, in whici a bearing is otherwise required pursuant to section 189 a, the applicant may petition the Commission for a temporary operationg license for such factity authorizing fuel loating, tosting, and operation at a specifict power level to be determired by the Commission, pending final action by the Commission on the application. The fnitial petition for a temporary operating license for each such facility, and any tempporary operating license issued for stak facility based upon the taitial petition, shall be limited to power levels not to exceed 5 percent of rated full thermal power. Following issuance by the Commission of the temporary operating license for each such facility, the licensee may file petitions with the Commission to amend the license to allow facility operation in staged increases at specific

1. power levels, to be determined by the Commission, exceeding 5 percent of rated full thermal power. The initial potition for a temporary operating license foreach such facility may be filed at any time after the filing of: (1) the report of the Arvisory Committe on-Reactor Safeguards required by section 182 b.; (2) the filing of the initial Safety Evaluation Report by the Nuclear Regulatory Commission staff and the Nuclear Regulatory Commission staff's

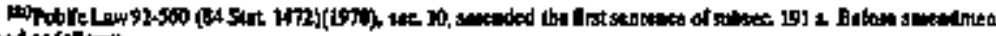
it rosd an follition

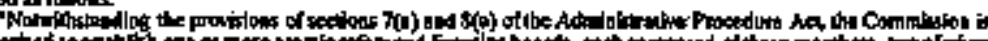

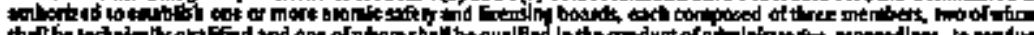

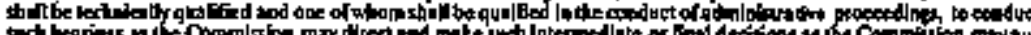

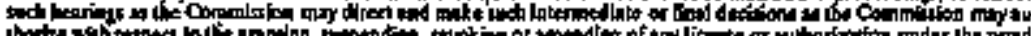

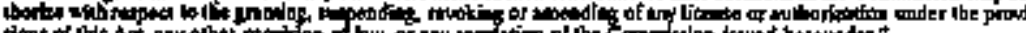

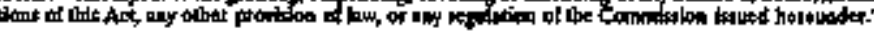

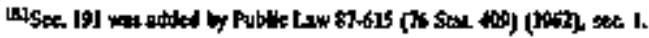


Affidavits,

Publdeation in

Federal

Register.

Final order, transmittal to congressional committees. fist supplement to the report prepared in response to the report of the Advisory Committee on Reactor Safeguards for the facility; (3) the Nuclear Regulatory Commission staff's inal detailed statement on the environmental impact of the facility prepared pussuant to section 102(2)(C) of the National Enpironmental Policy Act of 1969 (42U.S.C. 4332(2)(C)); and (4) a State, tocal, or utitity emergency preparedness plan for the facility. Petitions for the issuance of a temporaty operating license, or for an amendment to such a license allowing operation at a spectific power level greater than that anthorized in the initial temporary operating license, shall be accompanted by an affidevit or affidavits setting forth the specific fact upon which the petitioner relies to justify issuance of the temporary operating license or the amendment thereto. The Commission sball publish notice of each stcht petition in the Federal Register and in such trade or news publications as the Commission deems appropitate to give reasonable notfoe to persons who might have a potential interest in the grant of such temporary operating license or atnendment thereto. Any person may file affidavits or statements in support of, or in epposition to, the petition within thirty days after the publication of stich notice in the Fedieral Register.

"b. With respect to any petition Etled pursuant to sabsection a. of this section, the Commission may issue a temporary operating jicense, or amend the license to authorize temporary operation at each specific power level greater than that authorized in the initial temporary operating licenst, as determined by the Commission, upon finding that-

“(1) in all respects other than the conduct or completion of any required hearing, the requirements of law are met;

"(2) in acoordance with suct requirements, there is reasonable assurance that operation of the facility curing the period of the temporary operating license in accordance with ths terms and condittons will provide adequate protection to the public health and safety and the environment during the period of temporary operation; and

"(3) denial of such tomporary operating license will result in delay between the date on which construction of the facility is sufficiently completed, in the judgment of the Commission, to permit issuance of the temporary operating license, and the date when such facility wowld otherwise receive a final operat. ing license pussuant to this Act.

The temporary operating license shall become effective tupon issuance and siall contain such terms and confitions as the Commission may deem necessary, tucluding the duration of the license and eny provision for the extension thereof. Any fssal order authorizing the issuanee or amendment of any temporary operating license pursusit to this section shall recite with sperificity the facts and reasons justifying the findings under this subsection, and shail be transmitted upon such issuance to the Committes on Interior and 
Jutiofial teview.

28 USC 2341

ef steq.

Post, p. 2073.

Hearing.

Infre.

Expiration date.
Insular Affairs and Energy and Commerce of the House of Representatives and the Committee on Envinonment and Puttic Works of the Senate. The final order of the Commission with respect to the issuance or amendment-of a temporary operating jicense shall be subject to judicial revieg pursuant to chapter 158 of -, title 28, United States Code. The requirements of section $189 \mathrm{a}$ of this Act with respect to the issuance or amemiment of facility licenses shall not apply to the issuance or amendment of a temporary operating license under this section.

"c. Any hearing on the application for the final operating license for a facility requited.pursuant to section 189 a. shall be conduded as promptly as practicable. The Commission shall suspend the temporary operating license if it finds that the applicant is not prosecuting the applicatoion for the final operating license with due dijgence. Issuance of a temporay operating license under subsection $b$ of this section shall be without prejudice to the right of any party to raise any issue in a bearing required pursuant to section 189 a.; and failure to assert any ground for Genial or limitation of a temporary operatiag Jicerise shill not bar the assertion of such ground in connection with the issuance of a subsequent final operating license. Any party to a bearing required pursuant to section 189 a. on the final operating license for a facilfy for which a temporary operating license has been issued under subsection $b_{n}$ and any member of ths Atomie Safety and Licensing Board conducting such hearing, shall promptly notify the Commission of any information indicating that the terms and conditions of the temporary operating license are not being met, or that such tenns and conditions are not sufficient to comply with the provisions of paragraph (2) of subsection b.

"d. The Commission is anthorized and directed to adopt such administrative renedies as the Commission deems appropriate to minimize the need for issuance of temporary operating licenses pursuant to this section.

"e. The authority to issue new temporary operating licenses undir this stotion shall expire on Deceraber 31, 1983." Is2

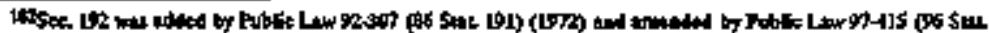

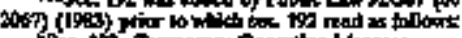

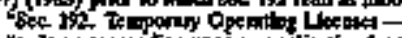

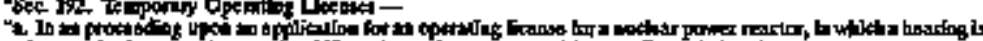

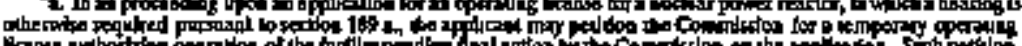

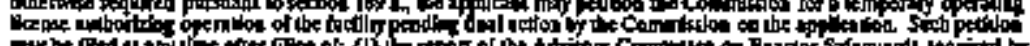

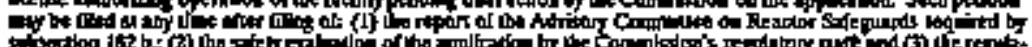

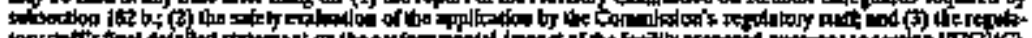

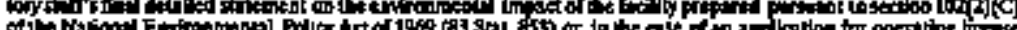

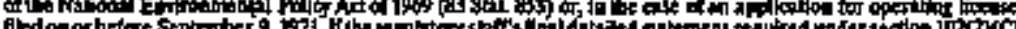

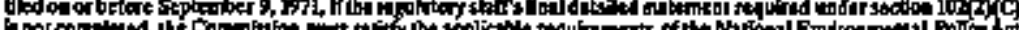

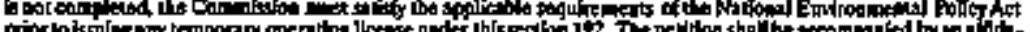

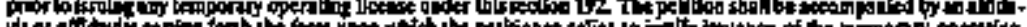

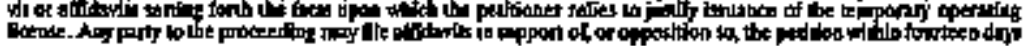

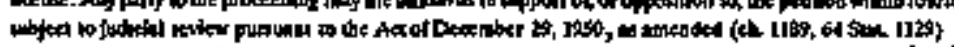


42 USC 2243.

Fepderal

Register, publication. Nuclear materials. Clains.
"Sec. 193. Licensing of Uranium Enrlchment Facilities.

"(a) Environuental Inpact Statement.-

"(1) Major Federal Action-The issuance of a license under sections 53 and 63 for the construction and operation of any urartum errichment factlity shalt be contsidered a major Federal action significantly affecting the quality of the buman environment for purposes of the National Environmental Policy Act of 1969 (42 U.S.C. 4321 et seq.).

"(2) Timing, An environirientaI inpect statement prepared under paragraph (1) shall be prepared before the bearing on the issuance of a license for the construction and operation of a urartum enrichonent facility is completed.

(b) Adjuticatory Hearing. -

"(1) In General.-The Commission shall conduct a singte adjudicatory hearing on the record with regard to the licensing of the construction and operation of a uraniem enrichment facility under sections 53 and 63 .

"(2) Truing - Such hearing shall be completed and a decision issued hefore the isstrance of a license for such construction and operation.

"(3) Single Proceeding.-No further Commission licensing action shalt be required to authorize operation.

"(c) Inspection and Operation-Prior to commencernent of operation of a urgnium enrichment facility licensed hereunder, the Conmission shall verify through inspection that the facility has been constracted in acoordance with the requirements of the license for construction and operation. The Conunission shall publish notice of the inspection results in the Federal Register.

"(d) Insurance and Decomanissioning-

"(1) The Commission shall require, as a condition of the issuance of a license under sections 53 and 63 for a uranium enrichment facility, that the licensee have and maintain liability insurajec of stich type and in such amounts as the Commission judges appropriate to cover liability clainss arising out of any occurrence within the United States, causing, within or outside the United States, bodily injury, sickness, disease, or death, or loss of or damage to property, or loss of use of property, arising out of or resulting from the radioactive, toxic, explosive, or other hazardous properties of chemical comporinds containing source or special nuclear materiat.

(2) The Comritssion shall require, as a condition for the issuance of a license under sections 53 and 63 for a uranium entichment facility, that the licensee prowide adequate assur-

(com:and)

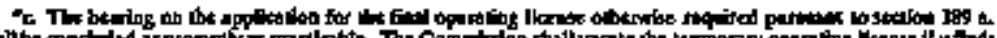

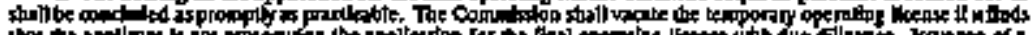

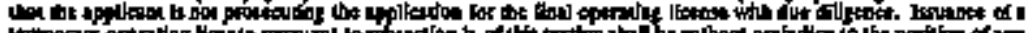

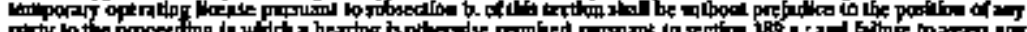

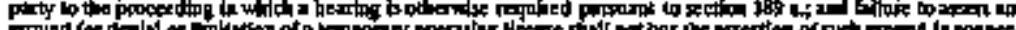

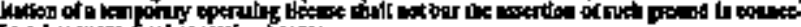

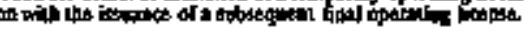

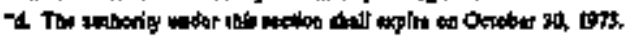


ance of the ayailability of funds for the decommissioning (including decontamination) of such facility using funding mechanisns that may include, but are not necessatily limited to, the following:

-(A) Prepayment (in the form of a trust, escrow accourt, govermment fund, certiffcate of deposit, or deposit of government securities).

(B) Surety (in the form of a surety or performance bond, letter of cretit, or line of credit), insurance, or other, guarantee (including parent company guarantee) method.

"(C) Exteral sinking fund in which deposits are made at least annuably.

"(c) No Price-Anderson Cowerage.--Section 170 of this Act shall not apply to any license under section $\$ 3$ ot 63 for a urapium enrichment facility constructed after the date of enactment of this section. 183 ,

"(f) LIMITATION-No license or certificate of compliance may be issued to the United States Errichment Corporation or its supcessor under this section of sections 33,63 , or 1701, if the Commission determines that-183a

(1) the Corporation is owned, controlled, or dominated by an alien, a foreign corporation, of a forejgn governnent; or

(2) the issuance of such a license or certificate of compliance would be inimical to-

(A) the common defense and security of the United States; or

(B) the maintenante of a reljable and economical domestic source of etrichument services."

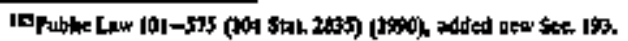

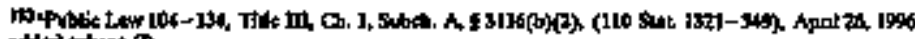
atdid subset (1). 


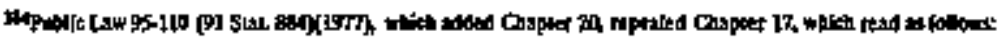

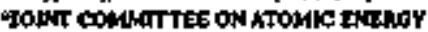

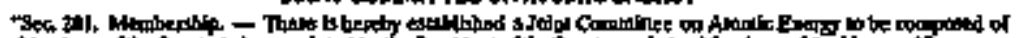

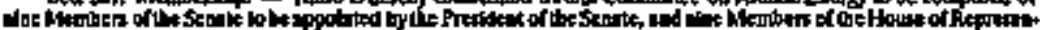

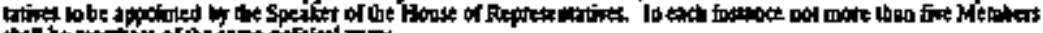

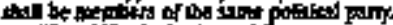

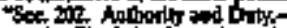

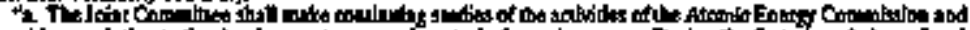

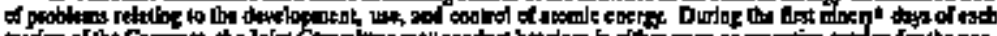

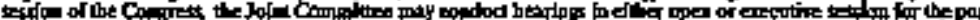

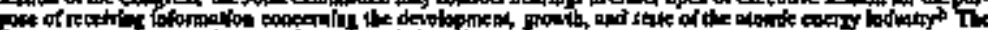

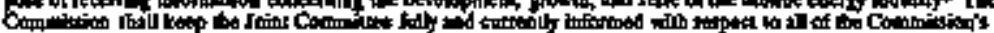

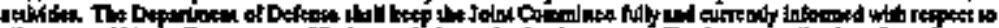

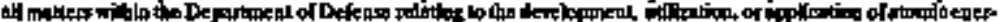

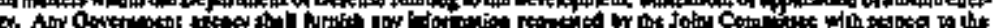
. A

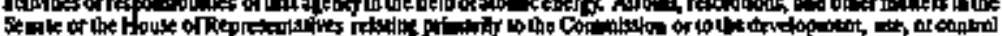
t

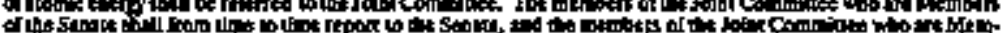

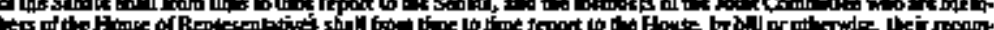

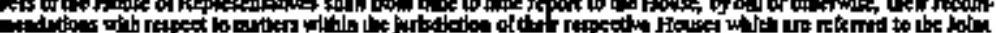

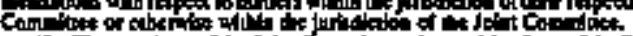

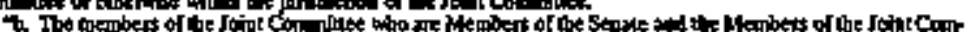

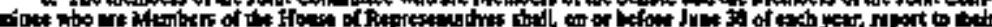
topection Tor pecto

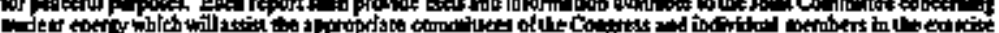

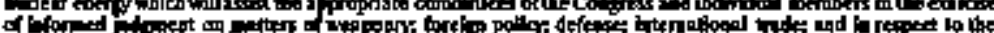

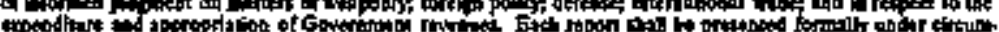

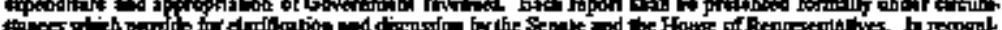

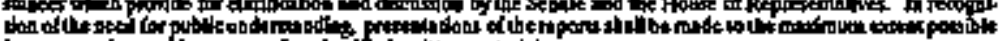

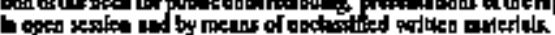

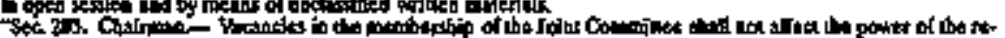

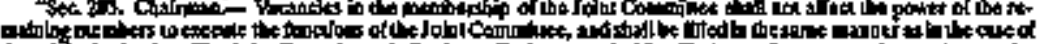

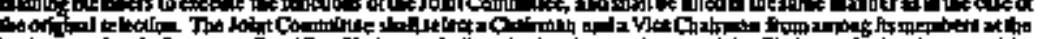

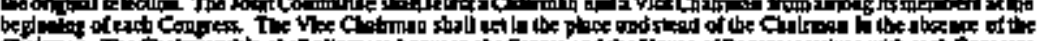

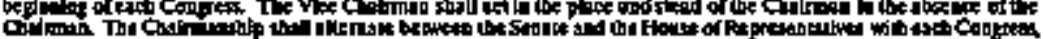

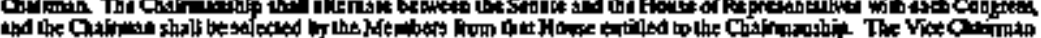

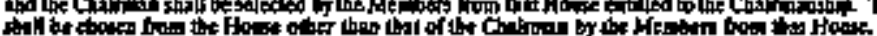

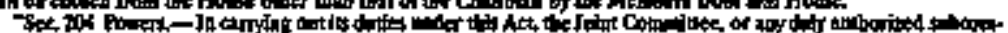

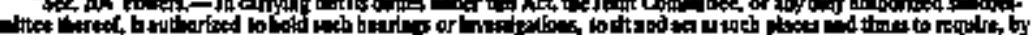

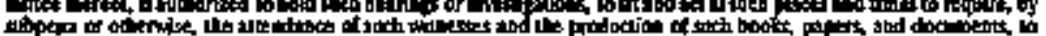

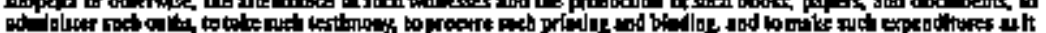

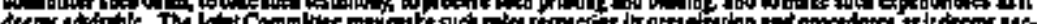

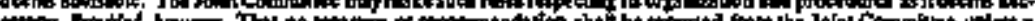
on

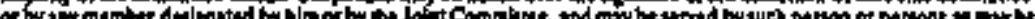
ar by a (1)

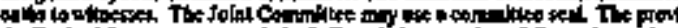

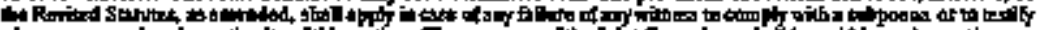

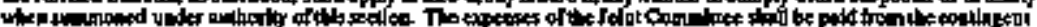

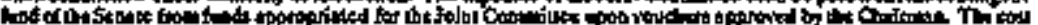
of teropa

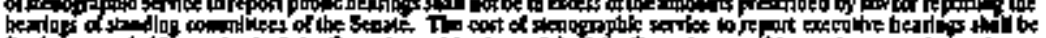

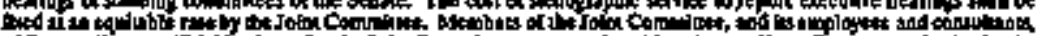
1.

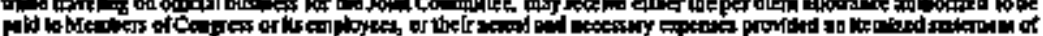

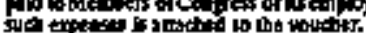

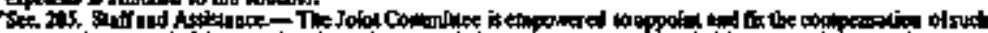

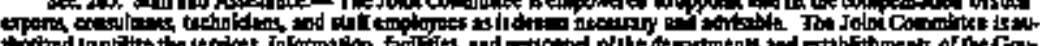

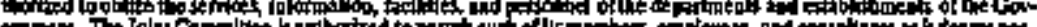

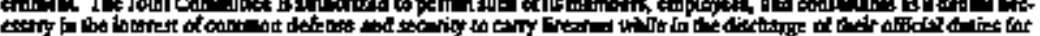
the nom liee.

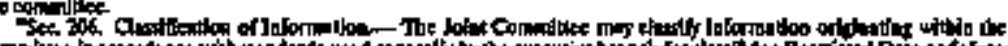

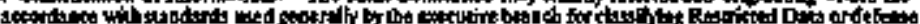
qLormation.

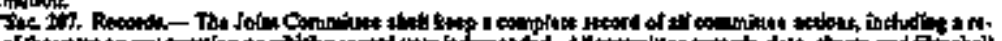

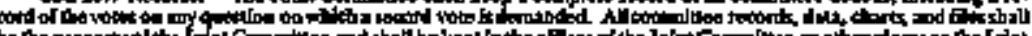

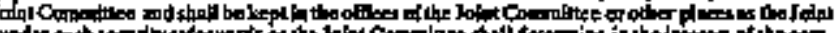

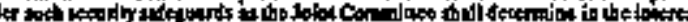

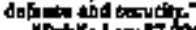

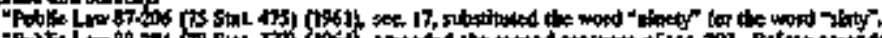

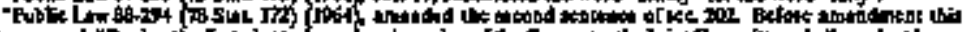

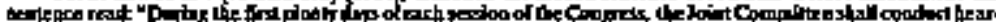

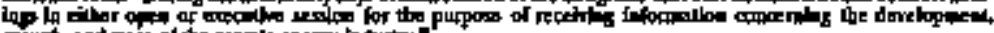

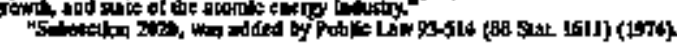

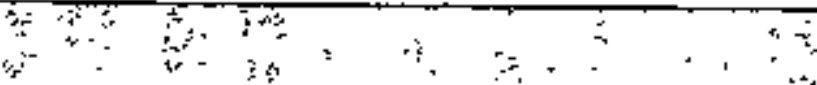


Gentral protisions. 42 USC $\sec .227 \mathrm{t}$

Vioktion of specific sections. 42 USC sec. 2272

Volation of sections generally. 42 USC stc. 2273.

\section{CCHAPTER 18-JNFORCEMENT}

“Sec. 221. General Provisions.-

*a. To protect against the unlawful dissenínation of Restricted Data and to safeguard facilities, equipment, materials, and other property of the Commission, the President shell have authority to utilize the services of any Government agency to the extent be may deen necessary or desirable.

"b. The Federal Bureau of Investigation of the Departsont of Justice shall investigate atl alleged or suspected criminal violations of this Act.

"c. No action sialt be brought against any individual or person for any wiolation under this Aetunless and until the Attorney General of the United States has advised the Cormmission with respect to such action and no such action shall be commenced except by the Attornty General of the Unived States: Provided, however, That nothing in this subsection shall be construed as applying to administrative action taken by the Commission ${ }^{185}$

"Sec. 222. Volations of Specific Sections. - Whoever willfully viotates, attempts to violate, or conspires to violate; any provisions of sections 57, 92, or 101, or whoever unlawsully interferes, attempts to interfere, or conspires to interfere with eny recaptute or entry under section 108, shall, upon conviction thereof, be purished by a fine of not more than $\$ 10,000$ or by imprisomment for not more than ten ${ }^{186}$ years, or both, except that whosver commits such an offense with jntent to injure the United States or with intent to secture an advantage to any foreign nation shall, upon conviction thereof, be pumished by impitsonment for life, or by imprisonment for any term of years or a fine of not more than $\$ 20,000$ or both. ${ }^{187}$

Sec. 223. Violation of Sections Generally,-a. Whoever ${ }^{188}$ witlfully violates, attempts to violate, or conspires to violate, any provision of this Act for which no criminal ${ }^{16}$ penalty is specifically provided or of any regulation or order prescribed or isstied under section 65 or subsections $16 \mathrm{I}$ b., i., or 0 , ${ }^{190}$ shall, upon corviction thertof, be punished by a fime of got more than $\$ 5,000$ or by imprisonment for not more than two years, or both, except that whoever commits such as offense with intent to injure the United States or with intent to secure an advantage to any foreign nation, shall, upon conviction thereof, be punished by a fine of not nore than $\$ 20,000$ or by imprisonment for not more than twenty years, or both.

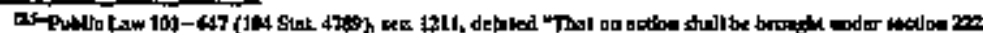

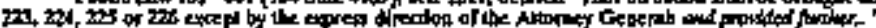

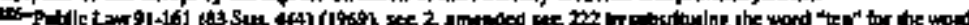

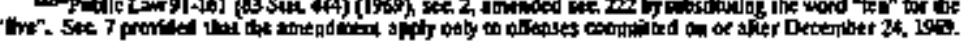

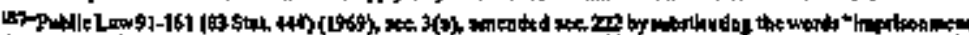

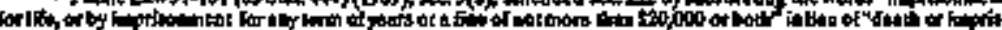

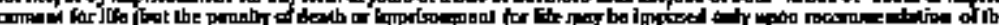

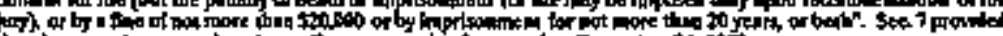

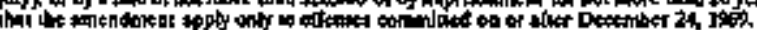

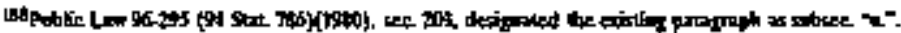

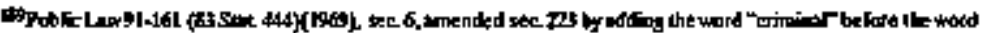
"pralty",

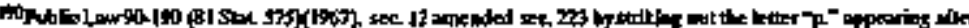

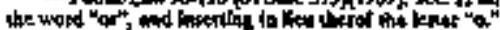


b. Afy individual director, ofticer, or employee of a firm constructing, or supplying the components ofany utilization facility required to be licensed under section 103 or $104 \mathrm{~b}$. of this Act who by act or omission, in connection with such constnuction or stpply, knowingby and willtully violates or causes to be violated, any section of this Act, any rule, regulation, or order issued thereunder, or any license condition, which violation results, or if undetected could have resulted, in a significant impairment of a basic component of such a facility shall, upon conviction, be subject to a fine of not more than $\$ 25,060$ for each day of violation, or to imprisonment not to exceed two years, or both. If the conviction is for a violation committed after a first conviction under this subsection, prnishment shall be a fine of not more than $\$ 50,000$ per day of volation, or imprisonment for not more than two years, or both.

HBasic component."

1.

42 Usc 2133. 2134.

Contracts. For the purposes of this stebsection, the term 'basic component' means a facility structure, system, component or part thereof necessary to assure-

(1) the integrity of the reactor coolant pressure boundary,

(2) the capability to stut-down the facility and maintain it in

a safe shut-down condition, or

(3) the capability to prevent or mitigate the consequences of accidents which could result in an utiptanned ofísite release of quantities of fission products in excess of the limits established by the Commission.

The provisions of this subsection shall be prominently posted at each site where a utilization facility reguired to be licensed under section 103 or $104 \mathrm{~b}$. of the Act is under construction and on the premises of each plant where components for such a facility are fabricated.

c. Any individual director, officer or employee of a person indemnified under as agreement of indemnification under section $170 \mathrm{~d}$. (or of a subcontractor or supplier thereto) who, by act or omission, boowingly and willfully violates or causes to be violated ary section of this Act or any applicable nuclear safety-related ruke, Iegulation or order issued thereunder by the Secretary of Energy (or expressiy incorporated by reference by to Secretary for purposes of nuclear safecy, exsept any jule, regulation, or order issued by the Secretary of Transportation), which violation results in or, if undetected, would bave resulted in a nuclear jactdent as defined in subsection 11 q. shall, upon conviction, notwithstanding section 3571 of title I8, United States Code, be subject to a fire of not more than $\$ 25,000$, or to imprisonment gat to exceed two years, or both. If the conviction is for a violation committed after the first conviction under this subsection, notwithstanding section 3571 of title 18 , United States Code, punishment shall be a fine of not more than $\$ 50,000$, or imprisoturnent for not more than five years, or both 191

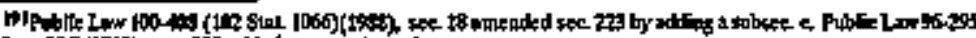

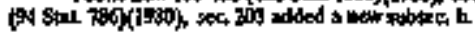


Comurnucation of restricted

data.

42 USC see, 2274

Receipt of restricted data. 42. ISC sec. 2275 .

Tamporing with restricted data. 42 USC sec. 2276.

Ditsclosure of restricted data. 42 USC sec. 2277

Sec. 224. Commumication of Restricted Data,-Whoever, lawfully or unlawfully, having possession of, access to, control over, or being entrusted with arry document, writang, sketch, photograph, plan, model, instrument, appliance, note, or information involving or jicorporating Restricted Data-

"a. communicates, transmits, or discloses the same to any indivicual or person, or attempts or conspires to co any of the foregoing, with intent to injure the United States or with jntent to secure an advantage to any forejgn nation, upon conviction thereof, shall be punished by imprisonment for life, or by imprisonment for any terun of years or a fine of not more than $\$ 20,000$ or both; 192

"b. communiegtes, transmits, or discloses the same to any iodividual or person, of attempts or conspires to do any of the foregoing, with reason to believe such data will be utilized to injure the United States or to secure an advantage to any foreign nation, shall, upon conviction, be punished by a fine of not more than $\$ 10,000$ or imprisonment for not uore than ten years, or both. . “Ser. 225. Receipt of Restrictedi, Data. Whoever, with intent to injure the United States or with intent to secure an advautage to any foreign nation, acquires, or attempts or conspires to acquire any docu. ment, writing, sketch, photograph, plan, model, instrument, appliance, rote, or jnformation involving or incorporating Restricted Dats shall, upon conviction thereof, be punished by imprisonment for life, or by imprisonment for any term of years or a fine of not more than $\$ 20,000$ or both 192

"Sec. 226. Tampering with Restricted Deta.-Whoever, with intent to injure the United States or with intent to secure an gdvantage to eny foreign nation, remowes, conceals, tampers with, alters, mutilates, of destroys amy document, writing, sketch, photograph, plan, Jnodel, instrument, appliance, or note inwolving of incosporating Restrictod Data and used by any individual or person in comnection with the production of special nuclear material, or reseatch or development relating to atomic energy, condncted by the United States, or financed in whole or in part by Feoteral fonds, or conducted with the aid of special nuclear material, shall be punished by imptisonment for life, or by inprisonment for ary term of years or a fine of not more than $\$ 20,000$ or both.

"Gec. 227. Disclesure of Restricted Dafa,-Whotver, being or having been an employee or ntember of the Comutission, a menber of the Aruled Forces, an employee of any agency of the United States, or being or having been a contractor of the Commission of of an agensy of the United States, or being-or having been an employte of a contiractor of the Commissiont of of an agency of the Untited States, or being or having been a licensee of the Commission, or betng or having been an employee of a licensee of the Commission, knowingly communicates, or whoever conspires to communicate or to receive, any Restricted

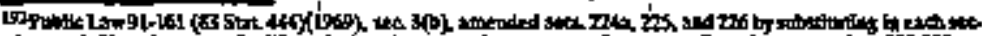

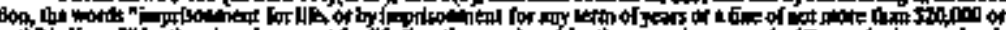

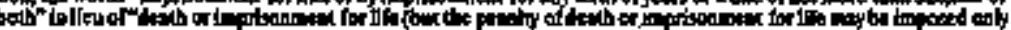

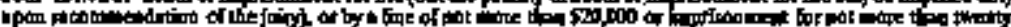

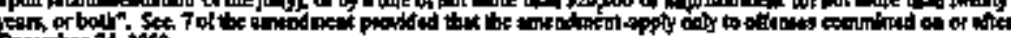

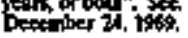


Data, knowing or baving reason to believe that such data is Restricted Data, to any person not authorized to receive Restricted Datz pursuant to the provisions of this Act or under rule or regulation of the Commission issued pursuant thereto, knowing or having reason to believe such person is not so authorized to receive Restricted Data shall, upon conviction thereof, be purishable by a fine of not more than $\$ 2,500$.

Statute of jimitations. 42,USC 2278 .

Trespass on Commíssion installations. 42 USC

sec. 22783 .

Photographing of Commission tnstallations. 42 USC sec. $2278 \mathrm{~b}$.
"Sec 228. Statote of Limitations.-Except for a capital offense, no individual or person shall be prosecuted, tried, or punished for any offense prescribed or defined in sections 224 to 226, inclusity, of this Act, unless the indictment is found or the information is instibuted within toll years next after such offense shall have been conmitted.

"Sec. 229. Trespass Upon Commission Installations." 193

"a. The Commission is authorized to issue regulations relating to the entry uppo or canying, trassporting, or otherwise introducing or causing to be introduced any dangerous weapon, explosive, or otber dangerons instrument or material likely to produce substan. tial injury or dasnage to persons or property, into or upon any faciity, installation, or real property subject to the jurisdiction, administration, or . in the custody of the Commission. Exery such regulation of the Commisston shall be posted conspiouously at the location imvolved.

"b. Whoever shall willfully violate any regulation of the Commission issued pursuant to subsection a. shall, upon conviction thereof, be punishable by a fine of not more than $\$ 1,000$.

${ }^{4} \mathrm{c}$. Whoever shall willfully violate any regulation of the Commission issued prusuant to subsection a. with respect to ary installation or other property whith ts enclosed by a fence, wall, floor, roof, of other structural barrier shall be guilty of a misdemeanor and upon corviction thereof shall be pusished by a fine of not to exceed $\$ 5,000$ or to imprisonment for not more than one year, or both. 193

"Sec. 230. Photographing, etc, of Commission Installations. 194-It shall be an offense, purishable by a fine of not more than $\$ 1,000$ or inprisoniment for not more than one year, or bots-

(1) to make any plotograph, sketeh, picture, dratwing, map or graphical representation, while present on property subject to the juristiction, administration or in the custody of the Comanission, of any instaltations or equipunent desigatated by the President as requiring protection against the general dissemination of information relative thereto, in the interest of the common defense and security, without first obtatning the permission of the Comminission, and promptly submitting the product obtained to the Commission for inspection or such other action as may be deerned necessary; or

(2) to tse or permit the use of an aireraft or any contrivance used, or designed for navigation or Dight in air, for the purpose of making a photograph, sketch, picture, drawing, map or graphical

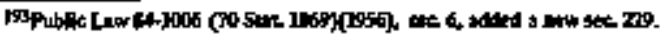

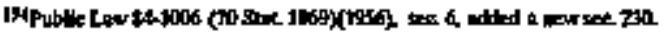


Olber laws.

representation of any installation or equipment designated by the President as provided in the preceding paragraph, unless authorized by the Commission. Injunction proceedings. 42 USC sec. 2280.

Sec. 231. Other Laws. 195 Sections 224 to 230 shall not exclude the applicable provisions of any other laws . . . . 1 it

Sec. 232.196-Injunction Proceedings-Whenewtr in the judgment of the Commission any person has engaged or is about to engage in any acts or practices which constitute or will constitute a violation of any grovision of this Act, or any regutation or order issued thereunder, the Attorney General on behalf of the United States may make application to the appropriate court for an order enjoining such axts or practices, or for an order enforcing /compliance with such provision, and upon a showing by the Commission that such person has engaged or is about to engage in any such acts or practices, a permanent or temporary injunction, Jestraining order, or other order may be granted.

Contempt procetdings.

Sec. 233. Contempt Proceedings-In case of failure or refusal to 42 USC sec. 2281 . obey a subponena served upon any person ptrsuant to stbsection $161 \mathrm{c}$, the district eourt for any district fo which such person is found or resides or transacts business, upon application by the Attorney General on behalf of the United States, shall bave jurisdiction to issue an order requiring such person to appear and give testimony or to appear and produce documents, or both, th accordance with the subpoena; and any failure to obey such oroter of the court may be punished by such court as a contempt thereof.

Civil penalties. 42 USC soc. 2282

68 STAT. 930 . 42 USC 2073, $2077,2092,2093$, $2111,2112,3131$, $2133,2134,2137$ 2139 . $42 \mathrm{USC} 2236$.

Sec. 234. ${ }^{197}$ Civil Monetary Penalties for Vholations of Ltcensing Requirements.-

a. Any person who (1) violates any licensing or certification provision of section $53,57,62,63,81,82,101,103,104,107,109$, or 1701 of any rule, regulation, or order issued thereunder, or any term, condition, or timitation of any license or certification issued thereunder, or (2) comonts any violation for which a licentse may be revoked under section 186, stall be subject to a civil pentalty, to be imposed by the Commission, af not to exceed $\$ 100,000$ for each such violation. 198 If any violation is a continuing one, each day of such violation shall constitute a sepasate violation for the purpose of conputing the applicable civil penalty. The Commission shall have the power to comproutise; mitigate, or remit such penalties.

83 STAT. 445.

b. Whenever the Commission has reason to believe that a person has become subject to the imposition of a civil penalty under the

Whitten notification provisions of this section, it shall notify such person in writing (1) setting forth the date, facts, and nature of each act or omission with whach the person is charged, (2) specificatly jdentifying the

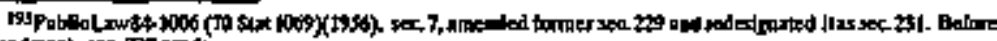

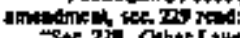

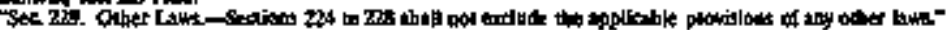

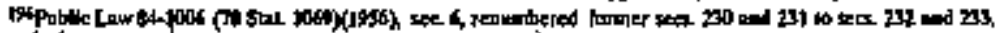
nospectuaty.

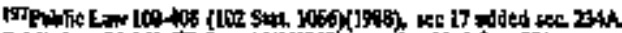

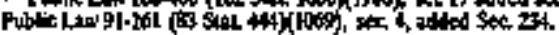

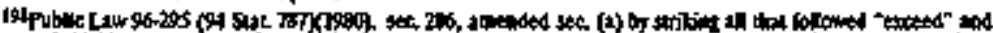

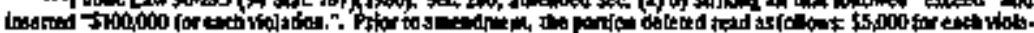

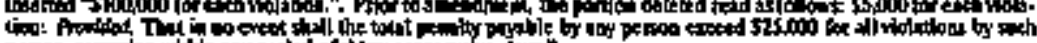

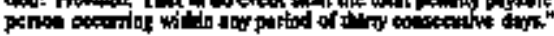


42 USC 2282s. Contracts. particular provision or provisions of the section, rtole, regulation, order, or license irwolved in the violation, and (3) advising of each penalty which the Commission proposes to impose and its amount. Such written notice slall be stent by registered or certified mail by the Commission to the last known addiress of such person. The person so notified shall be granted an opportunity to show in writing within such reasonable period as the Commission shall by regulation prescribe, why such penalty should not be imposed. The notice shall also advise such person that upon failure to pay the civil penalty subsequently determined by the Commission, if any, the penalty may be collected by civil action.

c. On the request of the Commission, the Attomey General is authorized to institute a civil action to collect a penalty imposed pursuant to this section. The Aftorney General shall have the exdussve power to compromise, mitigate, or remit such civil pedisties as are referred to him for collection

Sec. 234A. Civil Monetary Penalties For Volatlons Of Department Of Bnerky Regulations.-

a. Any person who has entered into an agrement of indernntitication under subsection $170 \mathrm{~d}$. (or any subcontractor of supplier thereto) who violates (or whose employete violates) any applicable rule, regulation or order related to puclear safety prescribed or issted by the Secretary of Energy pursuant to this Act (or expressty incorporated by reference by the Secretary for purposes of nuclear safety, except any rule, regulation, or order issaed by the Secretary of Transportation) shall be subject to a civil penalty of not to exceed $\$ 100,000$ for each such violation. If any violation under this subsection is a continuing one, each day of such violation shall constitute a separate violation for the purpose of computing the applikable civil penalty.

b. (1) The Secretary shall have the power to compromise, modify or renit, with or without conditions, such civil penalties and to prescribe regulations as he may deem necessary to implement this section.

(2) In determining the amount of ary civil penalty under this subsection, the Secretary shall take into account the nature, circumstances, extent, and gravity of the violation or violations and, with respect to the violator, ability to pray, effect on ability to continue to do business, any history of prior such violations, the degree of culpability, and such other natters as justice may require. In implementung this section, the Secretary shall determine by rule whether nonptofit educational institutions should receive automatic renission of any pentlalty under this section.

c. (1) Before issuing an order assessing a civil penalty against any person under this section, the Secretary shall prowide to such person notice of the proposed pentalty. Such notice shall informt such person of his opportunity to elect un writing within thitty days after the date of receipt of such notice to have the procedures of paragraph (3) (in lieu of those paragraph (2)) apply with respect to such assessment.

a


Courts, U.S.

Courts, U.S.

Courts, U.S.

( (2) (A) Unless an election is made within thirty calendar days after receipt of notice tinder paragraph (1) to have paragraph (3) apply with respect to such penalty, the Secretary shall assess the penalty, by order, after a determination of violation has been made on the recoxd after an opporhunity for an agency hearing pursuant to section 554 of title 5, United States Code, before an administrative law Judge appointed under section 3105 of such title 5. Such assessment order shall include the administrative lew judge's 5ndings and the basis for such assessutent.

(B) Any person against whom a penalty is assessed under this paragraph inay, within'sixty calenclar days after the date of the order of the Secretary assessing such penaity, institute an action in the United States court of appeals for the appropriate judicial circujt for judicial review of such order in accardarlce with chapter 7 of title 5, United States Code. The court shall have jurisdiction to enter a final judgment affirming, modifying of setting aside in whole or in part, the order of the Secretary, or the court may remand the proceeding to the Secrenary for such further action as the court may tirect.

(3) (A) In the case of any civil penalty with respect to which the

s procedures of this paragraph hare been elected, the Secretary shall promptly-assess such penalty, by order, after the date of the ejection under paragraph (1).

(B) If the civil penalty bas not been paid withto sixty calendar days after the' assessment order has been made under subparagraph (A), the Secretary shall institute an action in the appropriate district court of the United States for as order affirming the assessment of the civil penalty. The court shall have authority to teview'de nowo the law and facts involved, and shall have jurisdictón to enter a judgment enforcing, roódifying, and enforcing as so modified, or setting aside in whole or in part, such assessment.

(C) Ary election to bave this paragraph apply may not be revoked except with consent of the Sectetary.

(4) If any person fails to pay an assessment of a civil penalty after it has becone a final and unappealable order under paragraph (2), of after the appropniate district court has entered anal judgment in favor of the Secretary under paragraph (3), the Stcretary shall institute an action to recover the amount of such penalty in any appropriate district court of the Untied States. In such action, the validity and appropriateness of sucti final assessment order of judgment shatl not be subject to review.

Schooks gnd colleges. Corporations.

(1) The University of Chicago (and any subcontractors of suppliers thereto) for activities assoctated with Argonne $\mathrm{Na}$ tional Laboratory;

(2), The University of Califormia (and any subcontractors or suppliers thereto) for activities associated with Los Alamos National Laboratory, Lawrence Livermore National Laborrtory, and Lawemce Berkeley National Laboratory; 
(3) American Telephone and Telegraph Company and its subsidiaries (and any subcontractors or suppliers thereto) for activities assocjated with Sandia National Laboratories;

(4) Unviersities Research Assoctation, Inc. (and any subcontractors or suppliers thereto) for activities associated with FERMI National Laboratory;

(5) Princetori University (and any subcontractors or suppliers thereto) for activities associated with Princeton Plasma Physics Laboratory;

(6) The Associated Universities, Inc (and any subcontractors or suppliers thereto) for activities associated with the Brookhaven National Laboratory; and

(7) Battelle Memorial Instibute (and any subcontractors or suppliers thereto) for activitites associated with Pacitic Narthwest L-aboratory.

42 USC 2283.

Sec. 235. Protection OP Nuclear Inspeetors.-

a. Whoever kills any person who performs uny inspections which-

"(1) are related to any activity or facility licensed by the Commission, and

(2) are carried out to satisty requirements under this Act or 42 USC 2133, 2134. under any other Federal law goveming the safely of utilization facilities required to be licensed under section 103 or $104 \mathrm{~b}$, ot the safety of radioactive materials, shall be punished as provided under sections 11 ltl and 1112 of title 18, United States Code. The preceding sentence shall be applicable only if such person is killed while engaged in the perfortante of such inspection duties or on account of the performance of such duties.

b. Whoever forcibly assaults, resists, opposes, inpedes, intimidates, or interferes with any person who performs inspections a described under subsection a. of this section, while such person is engaged in such inspection duties or on account of the perfor. mance of such duties, shall be punished as provided under section 111 of title 18, United States Code. ${ }^{19}$

42 USC sec. 2284. "Bec- 236. Sabottupe Of Nucleater Facilities Or Futl.-

a. Any person who intentionally and willfully destroys or causes physical danaage to, or who intentionally and willfully attempts to destroy or cause plysical damage to-

(1) any production facility or utilization facility licensed under this Act:

"(2) any nuclear waste storage facility licensed under this Act;

(3) any nuclear fuel for such a utilization façility, or any spent pucleaer fuel from such a factitity or

(4) any uranium enrichment facility licensed by the Nuclear Regulatory Commission." 200

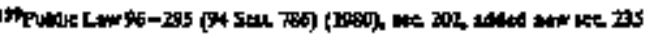

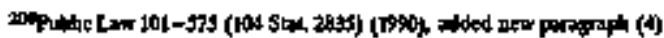

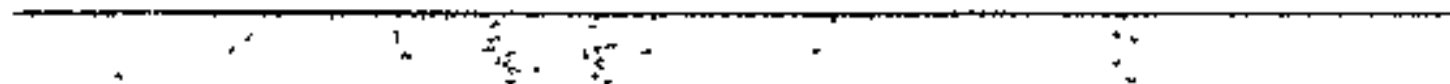



cause an interruption of norulal operation of any such facility thorugh the unauthorized use of or tampering with the machinery, components, or controls of any such facility, shall be Ened not more thas $\$ 10,000$ or imprisoned for not more than ten years, or both."201

\section{- “CHAPTER 19-MI\$CRLANEOUS}

Transfes of property.

"Sec. 241. Transier Or Property-Nothing in this Act shall be 42 țsc deemed to repeal, nodify, anend, or alter the provisions of section 9(a) 42 USC Conpress. of the Atomic Energy Act of 1946, as heretofore amended 202

" "Sec 251. Report To Congress.-The Commission shall subnit to the Congress, in January ${ }^{203}$ of each year, a report concerning the activities 42 U\$C sec. 2016. of the Commitssion. The Commission stall indude in such report, and shall at such other times as it deems desirable submit to the Congress, such recommendations for adotitional legislation as the Commission deems necessary of desirabłe.

42 USC sec. 2017. "\$ex. 26t. Appropriations.-204

"a. No appropration 205 shall be made to the Commission, nor ' shall the Commisston waive charges for the use of materials under the Cooperative Power Ratactor Denponstration Program, unless prewionsly authorized by legislation enacted by the Congress. ${ }^{205}$

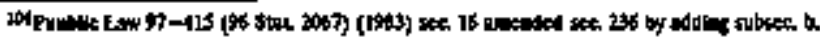

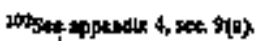

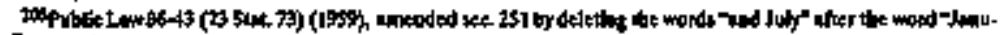
r.

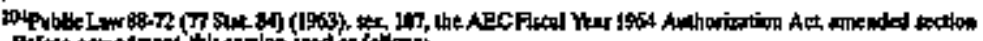

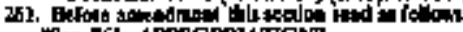

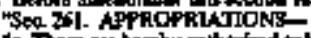

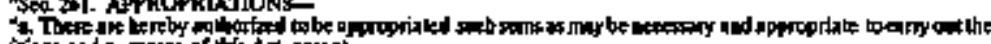

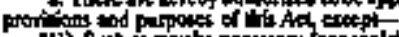

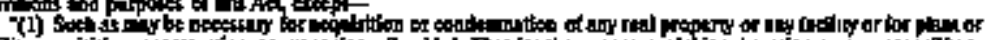

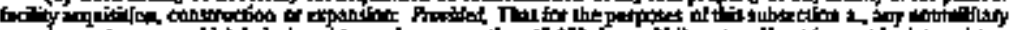

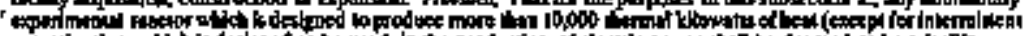

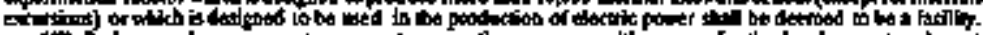

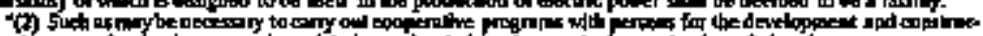

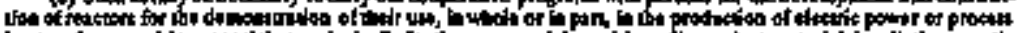

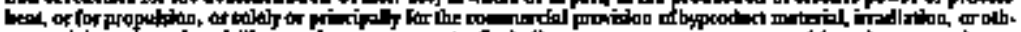

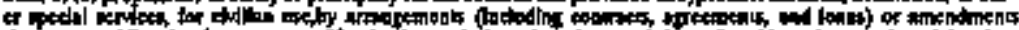

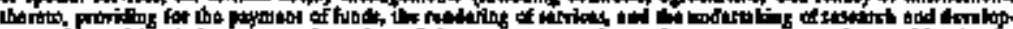

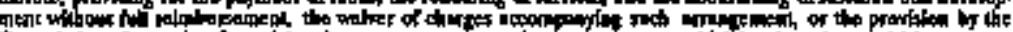

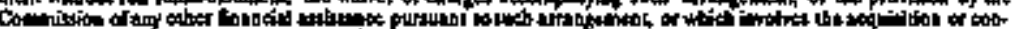

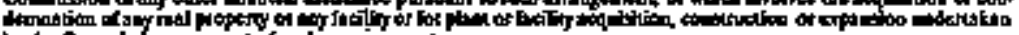

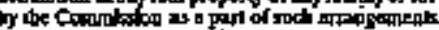

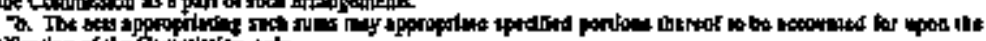

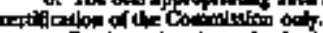

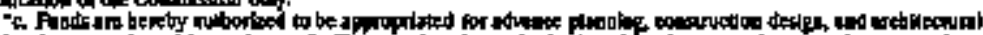

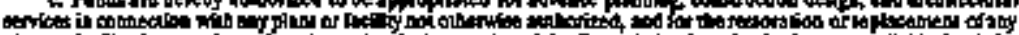

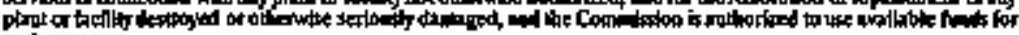
Deh propous

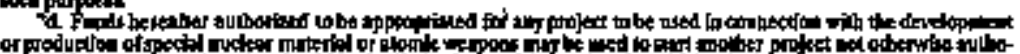

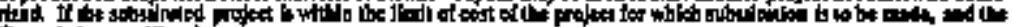
Continition atrifies lat-

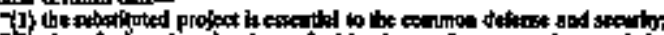

ate

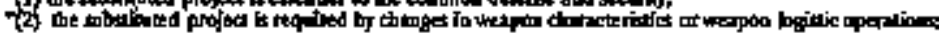

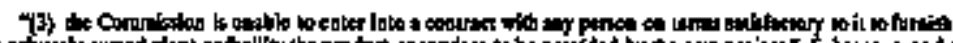

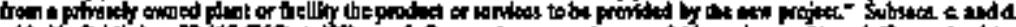

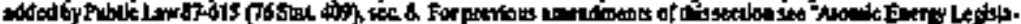

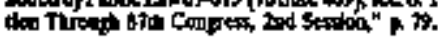

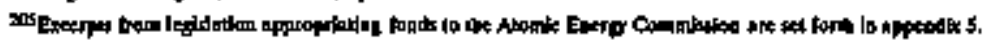

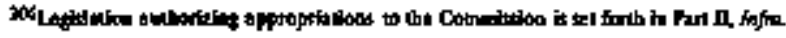


"b. Ary Act appropriating funds to the Corrmission may approptiate specified portions thereof to be accounted for upon the certification of the Commission only.

"c. Notwithstanding the provisions of subsection a, funds are bereby authorized to be appropriated for the restoration or replacenrent of any plant or facility destroyed or otherwise seriousty damaged, and the Commission is atthorized to use avaitable funds for such purposes.

"d. Funris authorized to be appropriated for any construction project to be used in connection with the cevelopment or produc. tion of special nuclear material or atomic weapons may be used to start another constrution project not atherwise anthorized if the substituted construction project is within the limit of cost of the construction project for which substitution is to be made, and the Commission eertiffes that-

"(1) the substtuted project is essential to the common defense and security;

"(2) the substituted project is required by changes in weapon characteristics or weapon logistics operations; and

"(3) the Commission is tunable to enter into a contract with any person on terms sattsfactory to it to furnish from a privateby owned plant or facility the product or services to be provided by the new project

Agency juristiction. 42 USC soc. 2018 .

Applicsbulity of Federal Power Act. 42 USC sec. 2019.

Licensing of Government agencies. 42 USC sec 2020.

Cooperation with States. 42 USC sec. 2021
"Sec. 271. Agency Jurkdicthon-Nothing in this Act shall be constnied to affect the authority or regulations of any Federal, State, or Local agency with respect to the generation, sale, or transmission of electric power produced through the use of nuclear facilities licensed by the Commission: Provided, That this section shall not be deemed to confer upon any Federal, State, or local agency any zuthority to regulate, control, or restrict any activities of the Commission. 207

"Sec. 272. Applicability Of Federal Power Act-Every licensee under this Act who holds a license from the Commission for a utilization of production facility for the generation of commercial electric energy under section 103 and who transmits such electric energy in interstate commerce or selts it as wholesale in interstate commerce shall be subject to the regulatory provisions of the Federal Power Act.

"Sec. 273. Llcensing Of Government Agencles,-Nothing in this Act shall preclude any Oovernment agency now or hereafter authorized by law to engage in the production, marketing, or distribution of electric energy from obtaining a license under section 103, if qualified under the provisions of section I03, for the construction and operation of production of utilization facilities for the primary purpose of prociticing electric energy for disposition for ultimate public consumption.

"Sec. 274. Cooperation With States. 2018

"a. It is the purpose of this section-

"(1) to recognize the interests of the States in the pesceful uses of atomic energy, and to clarify the respective responst-

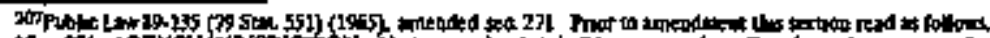

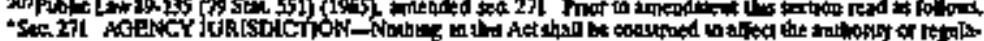

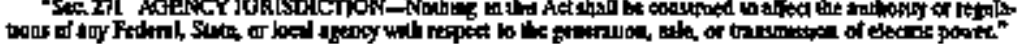

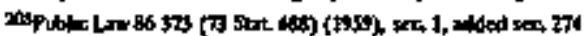


Agreements with States. bilities under this Act of the States and the Commission with respect to the regulation of byproduct, source, and spectal nuclear materials;

“(2) to recognize the reed, and estabtish programs for cooperation between the States and the Commission with respect to controi of radiation hazards associated with tse of such niaterials;

"(3) to promote an orderly regulatory pattem between the Commission and State governments with respect to nuclear developnent and use and regulation of typroduct, source, and special nuclear.matezials;

"(4) to establish procedures and criteria for discontinuance of certain of the Comunission's regulatory responsibilities with respect to byproduct, source, and special nuclear materials, and the assumption thereof by the States;

"(5) to provide for coordination of the development of radiation standards for the-guidance of Federal agencies and cooperation with the States; and

${ }^{4}(6)$ to recognize that, as the States improwe their capabilities to segulate effectively such materials, additional legislation may be desirable.

"b. Except as provided in subsection an the Commission is authorized to enter into agreements with the Governor of any State providing for discontinuance of the regulatory atthority of the Commission under chapters 6, 7, and 8, and section 161 of this Act, with respect to any one or more of the following materials within the State-

"(1) byproduct materials as defined in section $11 \mathrm{e}$. (1):209

"(2) byproduct materials as defined in section 11e. (2); 210

"(3) source materials;

"(4) special nuclear materials in quantities not sufficient to form a critical mass.

During the dyration of such ar agreement it is recognized that the State shall have authority to regulate the materials covered by the agreement for the protection of the public health and safety from radiation -hazards.

"c. No agreement entered into pursuant to subsection b. shall provide for discontinuance of any authority and the Commission shall retain authority and responsibility with respect to regulation of-

"(1) the construction and operation of any production or utilization facility or any uranium enrichment facility; 2103

"(2) the export from or import into the United States of byptoduct, source, or special nuclear material, or of any production or utilization fotity;

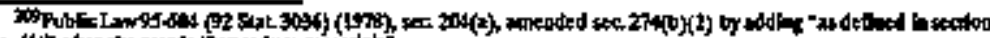

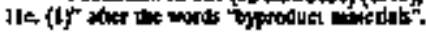

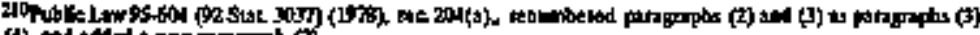

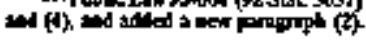

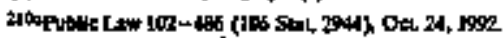




\section{USC 2014}

"(3) the disposal into the ocean or sea of byproduct, source, or special nuclear waste materials as defined in regulations or orters of the Commission;

"(4) the disposal of sutch other byproduct, source, or special muclear material as the Commission determines by regulation or orter should, because of the hazerds or potential hazards thereof, not be so disposed of without a license from the Commission. The Conmission shall also retain authority under any such agreement to make a detemination that all applicable standards and requirements hive been met prior to termination of a license for byproduct material, as defined in section 11e. (2) 211

Notwithstanding any agreement between the Commission and any State pursuant to subsection $b_{\text {, the }}$ Conntission is authorized

\section{Conditiong.} by rule, regulation, or order to require that the manufacturer, processor, or producer of any equipment, device, commodity, or other product containing source, byprociuct, or spextal nudear materital shall not trassfer possession or control of such product except pursuant to a license issued by the Comimission.

"d. The Commission shall enter into an agresment under subsection b. of this section with any State if--

“(1) The Governor of that State certifies that the State has a program fot the control of radiation hazards arlequate to protect the public bealth and safety with respect to the materials within the State covered by the proposed agreement, and that the State desires to assume regulatory responsibitity for such materials; and

"(2) the Commission finds that the State program is in accordance with the requirements of subsection 0 . and is all other respects 212 compatible with the Commission's program for regulation of such materials, and that the State progran is adequate to protect the public hellth and safety with respect to the materials covered by the proposed agreanent.

Publication in F.R.

" $e_{\text {. }}$ (I) Before any agreement trater subsection $b$. is signed by the Commission, the terms of the proposed agreement and of proposed excmptions pursuant to subsection $f$. shall be pubtisixed once each week for four consecultive weeks in the Federal Register; and such opportunity for comment by interested persons on the proposed apreement and exemptions shall be allowed as the Commission determines by regulation or order to be appropriate.

(2) Each proposed agreement shall include the proposed effective date of suct proposed agreement or exemptions. The agreement and exemptions shald be published in the Federal Register within thirty days after signature by the Commission and the Gowernor.

Licensing requïrements.

"f. The Conmmission is atuthorized and directed, by regulation or order, to grant such exemptoons from the licensing requirements

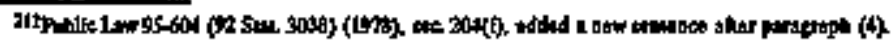

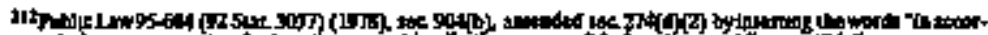

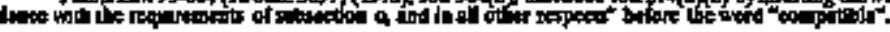

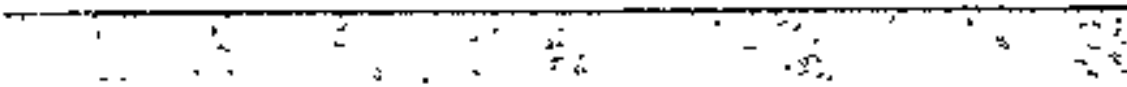


Exemptions.

Federal Rodiation Coumell.

Inspections.

Termination of agreemuent. . contained in chapters 6,7 , and 8 , and from its regulations applicable to licensees as the Commission linds necessary or appropriate to carry out any agreement 'entered into pursuant to subsection b. of this section.

sg. The Commisston is authorized and directed to cooperate with the States in the formulation of standards for protection against hazards of radiation to assure that \$tate and Commission programs for protection against hazards of radiation will be coorçinated and compatible.

"h. There is hereby established a Federal Radiation Council, consisting of the Secretary of Health, Education, and Welfare, the Chairman of the Atomic Energy, Commission, the Sectetary of Defense, the Secretary of Comunerce, the Secretary of Labor, or their designees, and such other members as shall be appointed by the President. The Council shail consult qualified scientists and experts in radiation matters, including the President of the $\mathrm{Na}$ tional Acaderny of Sciences, the Chairman of the National Contmittee on Rachation Protection and Measurement, and qualified expents in the field of bioloby and medicine and in the field of health physics. The Special Assistant to the President for Seience and Tecturology, or his designee, is authoized to attend metings, participate in the destberations of, and to advise the Council. The Chairman of the Council shall be destignated by the President, from time to time, from anong the members of the Countil. The Council sball advise the President with respect to radjation mat- ters, directly or indireetly' affecting heatth, including guidanoe for all Federal agencies in the formulation of radiation standards and in the establishment and execution of programs of cooperation with States. The Council shall also perform stect other funetions as the President may assign to it by Executive order.

"i. The Commission in carrying out its licensing and regulatory responsibilities under this Act is authorized to enter into agreements with any State, or grotlp of States, to perform insptctions or other functions on a cooperative basis as the Conmission deems appropriate. The Connission is also authorized to provide training, with or without aharge, to employees of, and such other assis. tance to, any such State or political subdivision there of or group of States as the Connaission deems appropriate. Any such provision or assistance by the Commission shall take into account the additional expenses that:may be incurred by a State as a consequence of the State's entering rinto an agreement with the Commission pursuant to subsection b.

"j. i(1) ${ }^{213}$ The Commission, upon its own initiative after reasonable notice and opportunity for bearing to the State with which an agreement usder subsection $b$. has become effective, or upon request of the Governor of such State, may terminate or stspend all os part of ${ }^{214}$ its agreement with the State and reassert the

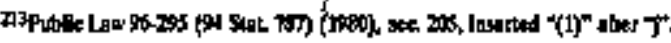

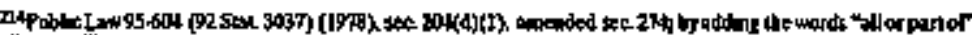

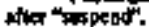


licensing and regulatory authority vested in it under this Act, if the Commission finds that (1) ${ }^{215}$ such termination or suspension is required to protect the public health and safety, or (2) the State has not comptied with one or imore of the requirements of this section. The Contmission shall pertodically review such agreements and actions taken by the States under the agreements to insure conpliance with the provisions of this section. 216

"(2) The Connmission, upon its owp motion or upon reguest of the Governor of any State, may, after notifying the Governor, temporarily suspend all or part of its agreement with the State without notice or hearing if, in the judgment of the Com. mission:

"(A) an emergency sitnation exists with respect to afy material covered by such an agreement creating danger which requires itmmediate action to protect the health or safety of persons either within or outside of the State, and

"(B) the State has failed to take steps necessary to contain or eliminate the cause of the danger within a reasonable time after the sftuation arose.

A temporary suspension under this paragraph shall remain in effect only for such time as the emergency situation exists and shal] authonize the Commission to exercise its asthority only to the extent necessary to contain or eliminate the danger."217

"k. Nothing in this section stiall beconstrued to affect the authority of any state or local agency to regulate activities for purposes other than protection against radiation hazards.

"T. With respect to each application for Commisston license authorizing an activity as to which the Commission's authority is continued pursuant to subsection $c$, the Commission shall give prorapt notice to the State or States in which the activity will be conducted of the filing of the license application; and shall afford reasonable opportunity for State representatives to offer evidence, interrogate witnesses, and advise the Conntission as to the application without requirting such representatives to take a posttion for or against the granting of the application.

"m. No agreernent entered into under subsection b., and no txemption granted pursuant to subsection $f$, shall affect the autbority of the Comunission under subsection $161 \mathrm{~b}$. or $\mathrm{i}$. it issue rules, regulations, or orders to protect the common defense and security, to protect restricted dats or to guard against the loss or diversion of special nucletar material. For purposes of subsection $161 \mathrm{t}$. activities covered by exemptions granted pursuant to subsection $\mathrm{f}$. shall be deerned to constitute activities authorized pursuant to this Act; and special nuclear material acquired by any person pursuant

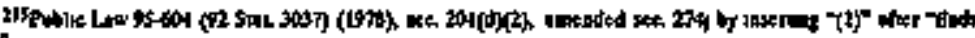

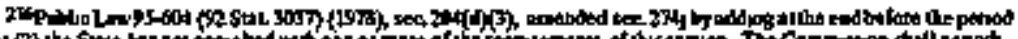

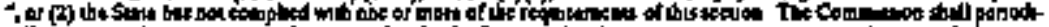

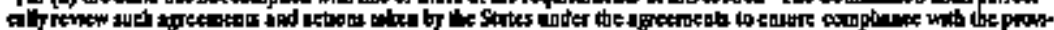

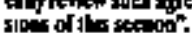

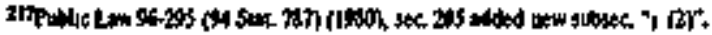

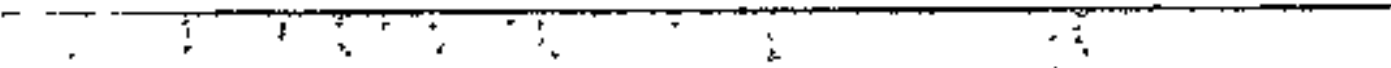


to such an exemption shall be deened to have been acguined pursuánt to section 53. . .

Detinition.

"Agresment"

Anes, p. 3033.

Post. p. 3039.

"í. As used in this section, the term 'State' means any State, Territory, or possession of the lUnited States, the Canal Zone, Puerto Rico, and the District of Columbia. As used in this section, the term fagreement' includes any amendment to any agree. mient. ${ }^{218}$

tio. In the licensing and regulation of byproduct material, as defined in section 11 e. (2) of this Act, or of any activity which results in the production of byprodtlet material as so defined un-

I dek an agreement entered.tinto pursuant to subsection b, a State shall reguire-

"(1) compliancer with the requirements of subsection b. of section 83 (respecting ornership of byproduct material and landi), and

"(2) conpliance with standards which shall be adopted by the State for the protection of the public bealth, safecty, and the environment from hazards assoctated with such material which are equivalent, to the extent practicable, or more stringent than, standards adopted and enforced by the Commission for the same purpose, including requitements and standards pro* mulgated by the. Cotmmission and the Administrator of the Environmental Protection Agency pursuant to sections 83, 84, and 275 , and .

"(3). procedures which-

"(A) in the case of licenses, provide procedures under State law which include-

$1_{i} \quad$ "(j) all opportunity, after public notice, for written comments and a public hearing, with a transcript,

"(ii) an opportunity for cross examination, and

"(iii) a written determination which is based upon

findings included in such determination and upon the is evidence presented during the public comment period n. and whict is subject to judicial review;

" (B) in the case of rulemaking, provide an opportunity

- for public participation through written comments or a putsichearing and provide for judicial review of the rute;

"(C) Iequite for each lisense which has a significant imr pact on the humast environment a written analysis (which - shall be available to the public before the commencement

$\therefore$ of any such proceecings) of the fuppact of such license, incluofing any activities conducted pursuant thereto, on the efvironment, which anatysis shal] include-

"(i) an assessment of the radiological and nonradiologicl inpacts to the public health of the activities to be conctucted pursuant to stich licenst;

"(ii) an assessment of any impact on any waterway and groundwater resulting from such activities;

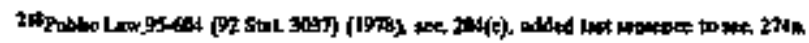


"(iii) consideration of alternatives, including alternative sites and enginetering methods, to the activities to be conducted pursuant to such license; and

"(iv) consideration of the long-term impacts, inckuding decommissioning decontamination, and reclamaton impacts, associated with activities to be conducted pursuant to such license, including the management of any byproduct material, as defined by section 11 e. (2); and

“(D) prohibit any major construction activity with respect to stech material prior to complying with the provisions of subparagraph (C).

If asy State under such agreement imposes upon any licensee any requirement for the payment of funds to such State for the reclamation or long-term maintenance and moritoring of such material, and if transfer to the United States of such material is requires in accordance with section 83 b. of this Act, such agreement shall be aruended by the Ante, p. 3033. Commission to provide that such State shall transfer to the United States upon termination of the license issued to such licensee the total amount collected by such State from such licensee for such purpose. If such paymitents are required, they must be suffictent to ensure compliance with the standards established by the Commission pursuant 42 USC 2201. to section $161 \mathrm{x}$ of this Act. No State shalI be required under paragraph (3) to conduct proceedings concentung any license or regulation which would duplicate proceedings conducted by the Commisston.219

"In adopting requizements pursuant to peragraph (2) of this subsection with respect to sites at which ores are processed primarily for their source material content or which are used for the disposal of byproctuct

42 USC 2014. material as defined in section $11 \mathrm{e}$. (2), the State may adopt alternatives (including where appropriate, site-specific altergatives) to the requirements adopted and enforced by the Commission for the same purpose if, after notice and opportunity for public hearing, the Commission determines that such alternatives will achieve a level of stabilization and containanent of the sites concerned, and a level of protection for publite health, safety, and the environment from ractiological and nomadiological hazards associated with such sites, which is equivalent to, to the extent practicable, or mote striogent than the level which would be achieved by standards and recpuirements adopted and enforced by the Commission for the same purpose and any final standards promulgated by the Administrator of the Environmental Protection Agency in accordance with section 275.

42 USC 2022. Such alterinative State Iequirements may take into account local or regional conditions, inctuding geology, topograpby, hydrology and metcorology." 220

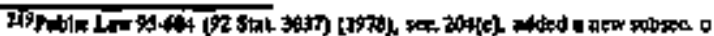

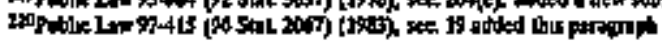


.- -sa. As soon as practicable, but not later than October 1, 1982, 221 the Administrator of the Environmental Protection Agency (hereinafter referred to in this section as the 'Administrator")

Rule. ' shall, by rule, promulgate standards of general application (ivcluding standards applicable to licenses under section 104(h) of the Uraniura Mill Tailings Radiation Control Act of 1978) for the protection of the public health, safety, and the evivironmsnt from radfological and nortradiological bazards associated with residual radioactive materiats (as defined in section 101 of the Uranius Mill Tailings Ratijation Control Act of 1978) located at inactive uranium mill tailings sites and depository sites for such materjals selected by the Secretary of Energy, pursuant to title I of the Uranum Mill Tailings Radiation Control Act of 1978. Standards promulgated pirsuant to this subsection shall, to the maximum extent practicable, be consistent with the Iequirements of the Soljd Waste Disposal Act, as anended. In establishing sncti standards, , the Administrator shall consides-the fisk to the public health, safe-

' ty, and the environment, the environmental and economic costs of applying such standards, and such other factors as the Administrator determines to be appropriate. ${ }^{222}$ The Administrator may periodically revise any standard promulgated pursuant to this subsection.

'1. After October 1, 1982, if the Adnúnistrator has not promuigated standards in firtal form under this subsection, any action of the Secretary

42 USC 7911. „, of Energy under title I of the Uranum Mil Tajlings Radiation Control Act of 1978 which is required to comply with, or be taken in accordance with, standards of the Adininistrator 'shall comply with, or be takeit in accordance with, the standards proposed ty the Administrator under this subsection until such time às the Administrator promulgates such statulards in final form. ${ }_{+} 223$

9

42 USC 6901 . note.

$42 \operatorname{Usc} 2014$.

Promulgation " authoríty. 'b. (1) As soor as practicable, but not later than October 31,

: 1982, the Adintoistrator stall; by rule, propose and within 11 months theretaftor phomulgate in final-fotm, 24 standards, general application' for the protection' of the public bealth, safety, and the enviromment from radiologicat and non-radiological bazards associated with processing and with the possession, transfer, and disposal of byproduct material, as defined in section 11 e. (2) of ' ' '. 'this Act, at sites at which ores ase processed primarily for their source material content or which are used for the disposal of such byproduct material.

"If the Administrator fails to prontulgate standards in final form under this subsection by October 1,1983 , the authority of the Administrator to promulgate such standards shall terminate, and the

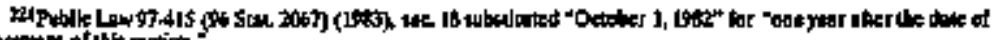

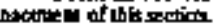

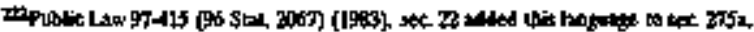

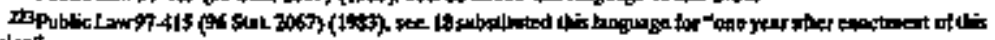
realoner,

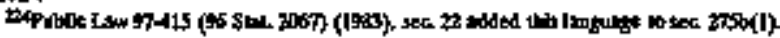


Commisston may take actions under this Act without regard to any psovision of this Act requiting stach actions to comply with, or be taken in accordance with, standerds promulgated by the Administrator. In any such case, the Commission shall promulgate, and fron time to time revise, any such standards of general application. Which the Commission deems necessary to carry out its responsibjLities in the conduct of jes licensing activities undist this Act. Re. quirements established by the Commission under this Act with respect to byproduct material as defined in section 11 e. (2) shall con-

42 USC 2014. firm to such standards. Any requirements adopted by the Commission respecting such byproduct material before promulgation by the Commission of such standards shall be anoended as the Commission deems necessary to conform to such standards in the same manner as provided in stubsection $f$ (3). Nothing in this subsection shall be construed to prohibit or suspend the implementation or enforcement by the Commission of any requirement of the Commission respecting byproduct material as deined in section 11 e. (2) pending promulgation by the Commission of any such standard of general application. ${ }^{225}$ In establishing such standards, the Administrator shall consider the risk to the public health, safety, and the environment, the environmental and economic costs of applying such standards, and such other factors as the Adiministrator determines to be appropriate. 226

"(2) Such generally appticable standards promulgated pursusant to this subsection for nonradiological hazards shall provide for the protection of buman health ayd the entironment consistent with the standards requirect under subtitle Cof the Solid Waste Disposal Act, as amepded, which are applicable to stch hazards: Provided, howewer, That no permit issuted by the Administrator is required uncter. this Aet or the Solid Waste Disposal Act, as arcended, for the processing, possession, transfer, or disposal of byprodect material, as defined in section 11 e. (2) of this Act. The Adninistration may periodically revise any standard promulgated purrsuant to this subsection. Within three years after such revision of any such stapdard, the Commission and any State permitted to exercise authorty under section 274 b. (2) shall apply such revised standard in the case of any license for byproduct material as defined in section 11 e (2) on any revision thereof.

"c. (1) Beforto the promulgation of any rule pursuank to this

Publication in Federal Register. Notice, hearing opportusity. section, the Administrator shal] publish the proposed rile in the Federal Register, together with a statement of the Jeseatch, analysis, and other avaifable information in support of such proposed Jule, and provide a period of public comment of at least thirty days for written comments thereon and an opporturity, after such comment period and after public notice, for any interested person to present oral data, wiews, and arguments at a public

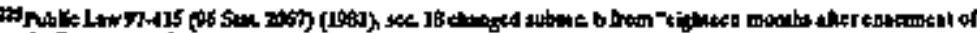

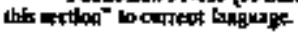

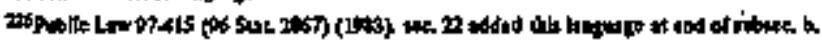


Consultation.

Judicial review.

5USC, ef seg.

$42 \mathrm{isc} 2021$.

42 USC 2014. $42 \mathrm{UsC} 7401$

note.

Uranimmon milt licensing requirtement Iegulations.

Implementation and enforcement

Review, public comment, and suspension. hearing. There siall be a transcript of any such hearing. The Administrator shall consult with the Commission and the Secretary iof Energy before promulgation of any such sule.

"(2) Judicial.review of any rule promulgated under this section may be obtained by atry suterested person only upon such person filing a petition for Ieview within sixty days after such promulgation in the Uatited States coort of appeals for the Federal judjitat

in circuit in which such person resides or bas his principal place of business. A copy of the petition shall be forttyvith transmitted by the clerk of the court to the Administrator. The Adudinistattor theseupon shallf file;in the court the written submission to, and 'transuxipt of, the writters or oral proceedings on which such rule was based as provided in section 2112 of title 28 , United States Code. The court shall bave jurisdiction to review the rule in accor. danoe with chapter 7 of title 3, United States Code, and to grant approptiate-relief as grotided in sact chapter. The judgment of the coutt affirming, modifying, or setting aside, it whole or in part, asty such rule shall be final, subject to judicial review by the Stpreme Court of the United States upon certiotari or certification as povided in section 1254 of title 28, United States Code.

"(3) Any rule promalgated under this section shall not take effect earlier than sixty calendar days after such promulgation.

"d. Implementation and enforcement of the standards promulgated pursuant to subsection $b$, of this section shall be the responsibility of the Commission in the conduct of its licensing activities under this Act. States exercistag authority pursuantio to section 274 b. (2) of this Act , siall implement and enforce such standards in accordance with subsection o* of sach section.

" $\theta$. Nothing to this Act applizable to byprotuct material, as defined in section $11 \mathrm{e}$. (2) of this Act, shall affect the authority of the AdminIstrator under tho Clean Air Actiof 1970, as annended, or the Federal Waten Pollution Control Act as amended 227

"f,(1) Prior to January 1, 1983, the Comunission shall not inplement or enforce the provisions of the Uraniam Mill Licensing Requirements published as I nnal rules at 45 Federal Register 65521 to 65538 on October 3, 1980 (hereinafter in this subsection referred to as the 'October 3 regulations'). After December 31, 1982, the Commission is atuthorized to impiement and enforce the provisions of stich October 3 regulations (and any subsequeat moritications or additions to such regulations which may be adopted by the Commission), except as otherwise provided in paragraphs (2) and (3) of this subsection.

(2) Foltowing the proposal by the Afiministrator of standands under subsection b., the Commission shall review the October $\mathbf{3}$

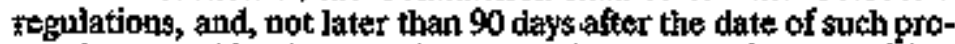
posal, suspend implementation and enforcentent of any provistors of such regulations which the Conmisstion determines after notice and opportumity tor public comment to require a major action or major commitment by licensees which woukt be unnecessary if-

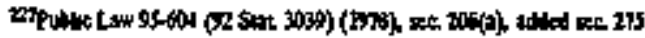


"(A) the standands proposed by the Admintstrator are promulgated in final form without modification, and

"(B) the Commission's requirements are modified to contform to such standards.

Such suspension shall terminate on the earlier of April 1, 1984 or the date on which the Commission amends the October 3 regulations to conform to find standards promulgated by the Administrator under subsection b. During the period of such suspension, the Commission shall continue to regulate byproduct material (as defined in section 11 e. (2)) under this Act on a ticensee-by-licensee basis as the Commission deems necessary to protect public bealth, safety, and the environment.

"(3) Not later than 6 montlks after the date on which the Administrator promingates final standards pursuant to subsection $b$. of this section, the Comumission shall, after notice and opportunity for public comment, amond the October 3 regulations, and adopt such modjficettons, as the Commission desms necessary to conform to stuch fanal standards of the Adriministrator.

42 USC 2114,

(4) Nothing in this subsection may be construed as affecting the authority or responsibility of the Commission under section 84 to promulgate regulations to proeect the public health and safety and the environgent."2283

"Sec. 276. Stafe Aathority to Regulate Radiation Below Level of Regulatory Concern of Nuclear Regulatory Commisston.

"(a) IN GENERAL. -No provision of this Act, or of the LowLevel Radioactive Waste Policy Act, may be construed to prohibit or otherwise sestrict the authoity of any State to regulate, on the basis of racijological nazard, the disposal or off-site incineration of low-]evel radioactive waste, if the Nixclear Regulatory Coranission, after the date of the enactment of the Energy Policy Act of 1992 exempts stich waste from regulation.

"(b) RELATION TO OTHER STATE AUTHORITY.-.This section may not be construted to imply preemption of existing State authority. Except as expressty provided in subsection (a), this section may not be construed to confer on any State any add:tional authority to regulate activities licensed by the Nuclear Regulatory Commission.

(c) DEFINITIONS.-For purposes of this section:

'(1) The term 'low-level radioactive waste' means radioactive material classigied by the Nuxlear Regulatory Comumission as low-level radioactive waste on the date of the enactment of the Energy Policy Act of 1992.

"(2) The term 'off-site incinetation' means any jucineration of radioactive materials at a factity tiat is located off the site where such materials were generated.

"(3) The term 'State' means each of the several States, the District of Columbia, and any commonrsealth, territory, or possession of the United States.".

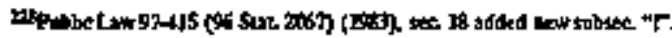


Separability.

(b) REVOCATION OF RELATED NRC POLICY STATEMENTS.-The policy statements of the Nuclear Regulatory Commission publisined in the Federal Register on July 3, 1990 (55 Fed. Reg. 27522) and Augúst 29,1986 (51 Fed. Reg. 30839), relating to radioactive waste below regulatory concern, shall have no effect after the dare of the enactment of this Act. 2280

"Sec, 281."Stparahility,-If any-provision of this Act or the 'application of such provision to any person or circumstances, is held invalid, the reutainder of this Act or the application of such proviston to persons or circumstances other than those as to thich it is held invalid, shali not be affected thereby.

Short titk. "Sec. 291. \$HORT TITLE-This Act may be cited as the fatomic Energy Act of 1954 ?

\section{"CHAPTER 20-JONT,COMMTTEE ON ATOMIC ENERGY ABOLISHED; FUNCTIONS AND RESPONSIBILITIES REASSIGNRD}

42 USC 2258.

"Sec 301.Joint Committex On-Atomíc Einergy Abolished,-

«a: The Joint Cómmittee on Atomic Energy is abolished.

"b. Any reference in ary rule, resolution, or order of the Senate or the House of Representatives or in any law, regulation, or Executive oxder to the Joint Comunittee on Atomic Energy shall, On and after the date of enactment of thits section, bo constidered as - referring to the committees of the Senate and the House of Representatives which, under the rules of the Senate and the House, have juristiction over the subject matter of such reference.

Records, trantier $\quad-\quad$. . ${ }^{k} \mathrm{c}$. All reoirds, data, charts, and files of the Joint Committee on Atomic Energy are transferred to the committees of the Senate ' and House of Representatives which, under the rules of the Senate and the House, have jurisciction over the subject matters to which such records, data, charts; and files relate. In the event that any record, data, 'chart, or file shall be within the jurisdiction of more than one comunittee, duplicate copies shall be provided upon request:

“Sec. 302. Transfer Of Certain Fuactions OrThe Joint Commlttee On Afonic Energy And Conforming Amendments To Certaln Other Lains,-

Repeal.

42 USC 2251

ef seg.

Repeat.

*a. Effective on the date of enactment of this section, chapter 17 of this Act is tepealed.

tb. Section 103 of the Atomic Energy Commenity Act of 1955, as amended, is repealed.

"c. Section 3 of the Congressional Budget and Impoundment - Control Act of 1974 is amended by-

Repeal.

"(1) striking the stubsection designation '(a)'; and

"(2) repealing subsection (b).

Repeal. ' . ir .4. Section 252(a)(3) of the Legislative Reorganization Act of 2USC 190j. $\quad 1970$ is repealed.

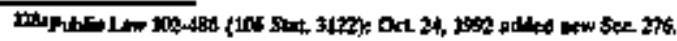


42 USC $225 \%$.

"Sec. 303. Information And Assistance To Congressional Committees, -

"a. The Secretary of Energy and the Nuclear Regulatory Conmission shall keep the committees of the Senate and the House of Representatives which, under the rules of the Senate and the House, have jurisdictions over the functions of the Secretary or the Commission, fulty and currently informed with respect to the activities of the Secretary and the Comrnission.

"b. The Department of Defence and Department of State shall keep the committees of the Senate and the House of Representatives which, under the roles of the Senate and the House, have jurisdiction over national security considerations of nuclear energy, fully and currently informed with respect to such matters within the Department of Defense and Department of State relating to national security considerations of nuclear technology which are within the jurisdiction of such committees.

"c. Ally Government agency shall furnish any information requested by the contmittees of the Senate and the House of Representatives which, under the rules of the Serate and the House, have jurisdiction over the developinent, utilization, or application of nuclear energy, with respect to the activities or responsibilities of such agency in the field of nuclear energy which are within the jurisdiction of such committees.

"d. The committees of the Senate and the House of kepresentatives which, under the rules of the Senate ard the House, have jurisdiction ower the development, utilization or application of muclear energy, are authorized to utilize the services, information, facitities, and personnel of any Government agency which has activities or responsibilities in the field of ntaclear energy whith are within the junisdietion of such committes: Provlded, however, That any utilization of personnel by such cormittees shall be on a reimbursable basis and shall requite, with respect to committees of the Senate, the prior written consent of the Committee on Rules and Administration, and with respect to commitfees of the House of Representatives, the prion written consent of the Committee on House Administration. 229

Approved Alugust 30, 1954, 9:44 a.m., E.D.T.

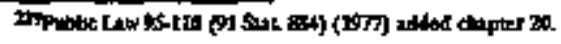


42 USC 2286. ， Sec 311. Establishment.

(a)' Establishment.-There is bereby established an independent 'establishrient in the executive branch, to be knowg as the 'Defense Nuclear Facilities Safety Board' (hereafter in this chopterr referred to as the 'Board').

President of U.S. + (b) Membership-(1) The Board shall be composed of five members appointed from evivilian life by the President, by and with the-advice and consent of the Senate, from among United States citizens who areirespected experts in the field of miclear safety with a demonstrated competerce and krowledge relevant to the independent investigative and cversight tunctons of the Board. Not more than three menters of the Board shall be of the same political party.

(2) Any vacancy in the niembership of the Board shall be filled in the same mamner in which's the original appointment was Joade.

(3) No mejober of the Board may be an employee of, or have any sigrificant financinl relationship with, the Department of Energy of any contractor of the Depaitment of Energy.

Pressdent of U.S.

(4) Not later than 180 days after the date of the enaciment of Reports. 42 USC 2286.

President of U.S. this chapter, the President shall submit to the Senate nominations for appointment to the Board. In the event that the Presi-

' dent is unable to submit the nominations within such 180-day -period, the Fresident shall submit to the Committees on Armed Services and on Appropriations of the Senate and to the Speaker of the House of Representatives a report describ' ing the treasons for such inability and a plan for submitting the nominations within the tiext 90 days. If the Prestdent is unable to submit the nominations within that 90-day period, the President shall aggia 'submit to śuch coinmittees and the Speaker such a report and plan. The President shall continue to submit to such committees and the Speaker such a repport and plan $t$ ery 90 days until the nominations are submitted.

(c) Chatrman and Vice Chairman-(1) The President shall desigrate a Chatrman and Vice Chairman of the board from anong snernbers of the Board.

(2) The Chaiman shall be the chief executive officer of the Board and, subject to such policies as the Board may establish, stall exercise the functions of the Board witt respect to-

(A) the appointment and supervision of employees of the Board,

(B) the organization of any administrative units established by the Board; and

(C) the use and expenditure of funds.

(3) The Chatrman may delegate any of the functions under this paragraph to any other menber or to any appropriate officer of the Board. 
(4) The Vice Chairman shall act as Chairman in the event of the absence or incapacity of the Chairman or in case of a vecancy in the office of Chairman.

(d) Terms.--(1) Except as provided under paragraph (2), the members of the Board shall serve for terms of five years. Members of the Board may be reappointed.

(2) Of the members first appointed-

(A) one shall be appointed for a term of one year;

(B) one shall be appointed for a term of two years;

(C) one shall be appointed for a tern of three years;

(D) one shall be appointed for a term of four years; and

(E) one shall be appointed for a term of five years, as

designated by the President at the fime of appointment.

(3) Arry member appointed to fll a vacancy accurring before the expiration of the term of office for which such nember's predecessor was appointed shalt be appointed only for the remainder of such term. A member may serve after the expiration of that member's term until a successor has taken office.

(e) Quorum.-Three members of the Board skall constitute a quorum, but a lésser nuonber may hold beartogs.

42 Usc 2286a. Sec. 312. Functions Of The Board.

The Board shall perform the following functions:

(1) Review And Evaluation Of Standards-The Board shall review and evaluate the content and implementation of the stan'darcs relating to the design, construction, operation, and decommissioning of defense nuclear facilities of the Department of Energy (inclucing all applicable Department of Energy orders, Ieguilations, and requirements) at each Department of Entergy defense nuclear facility. The Board shall recommend to the Secretary of Energy those spectfic measures that should be adopted to ensire that public health and safety are adequately protected. The Board shall include in its recommendations necessary changes in the content and implementation of such standards, as well as matters on which additional data or additional research is needed.

(2) Investigations.-(A) The Board shall invtstigate any ovent or practice at a Depariment of Energy defense auclear facility which the Boagd detennines has adversely affected, or may adversely affect, public heaith and safety.

(B) The puipose of any Board investigation under subpara* graph (A) shall be-

(i) to-determine whether the Secretary of Energy is adequately implenenting the standards described in paragraph (1) of the Department of Energy (inclucting all appljcable Department of Energy orders, regulations, and requirements) at the facility;

(ii) to ascertain information concerning the circumstances of such event or practice ard its implications for such standards; 
(iii) to deterimine whether such event or practice is related to otber events or practices at other Department of Energy defense nuclear facilities; and

I. 1 (iv) to provide to the Secretary of Energy such reconsmendations for changes in such standards or the implementation of such standards (inctuding Department of Energy orders, regulations, and requirements) and such jecommendations relating to data or research needs as may be prucient or necessary.

(3) Analysis Of Design And Operational Data.-The Board shall, have access to and may systematically analyze design and operational data, including safery analysis reports, from any Department of Entrigy deforist nuxiear ficility.

(4) Review Of Facility Design And Construction-The Board shall review the design of a new Department of Energy defense nuclear facility before construction of such facility begins and shall recammend to the Secretary, within a reasonable time, such modifications of the design as the Board considers necessary to ensure adequate protection of public health and safety. During the construction of any such facility, the Board shall periodically review and monitor the construction and shall submit to the Secre. tary, within a reasonable time, such recommendations relating to the construction of that facility as the Board considers necessary to ensure adequate protection of public health and safety. An action of the Board, on a fallure to act, under this paragraph may not delay or prevent the Secretary of Energy from carrying out the construction of such a facility.

(5) Recommendations.-The Board shall make such reconnmendations to the Secretary of Energy with respect to Department of Energy defense puclear facilities, including operations of such facilities, standards, and research needs, as the Board deter. mines are necessary to ensure adequate protection of public bealth and safety. In making its recommmendations the Board shalt consider the technical and economic feasibility of implementing the recortinended measures.

42 USC 22866.

Stc. 313. Powers Ot Bosird

' (a) Hearings-(1) The Eloard or a member authonzed by the Board may, for the purpose of carrying out this chapter, hold such hearings and sit and act at such times and places, and requite, by subpoena or otherwise, the attendance and testimeny of such whtmesses and the production of such evidence as the Board or an authorized member may find advisable.

(2) (A) Subpoenas may be issued only under the signature of the Chairman or any menber of the Board desugnated by him and shall be served by any person designated by the Chairman, any member, or any person as otberwise provided by law. The attendance of witresses and the production of evidence may be required from any place in the Untied States at any designated place of hearng in the United States. 
(B) Any menber of the Board may administer oaths or atfirmations to witresses appearing before the Board.

(C) If a person issued a subpoena under paragraph (1) refuses to obey such subpoena or is guilty of conturtacy, any coturt of the United States within the judichal district within which the hearing is conducted or within the judticial district rithin which such person is found or resides or transacts business may (upontapplication by the Board) order such person to appear before the Board to produce evidence or to give testimony relating to the matter under imvestigation. Any failure to obey such order of the court unay be panished by such court as a contempt of the count.

(D) The subpoenas of the Board shall be served in the manner provided for subpoentas issued by a United States cistrict court under the Federal Rules of Civil Procedure for the United Stetes distriet courts.

(E) All protess of any court to which application may be made under this section may be served in the judicial district in which the person required to be served resides or may be found.

(b) Staff.-The Board may, for the purpose of performing its responsibilities under this thapter-

(1) hire such staff as it considers necessary to perform the functions of the Board, but not more than the equivalent of 100 full-time employees; and

(2) procure the temporary and intermittent services of experis and consultants to the extent authorized by section 3109 (b) of title 5, United States Code, at rates the Bosrd determines to be reasopable.

(c) Regulations.-The Board may prescribe regulations to casty out the responsibilities of the Board under this chapter.

(d) Repotting Requirenents.-The Board may establish report-

Classified information.

42 USC 2286b. ing requirements for the Secretary of Energy which shall be binding upon the Secretary. The information which the Board may require the Secretary of Energy to report under this subsection may include any information designated as classified information, or any information designated as safeguards information and protected from disclosure under section 147 or 148 of this Act.

(e) Use Of Government Facilities, Exc--The Board may, for the purpose of carrying out its responsibilities under this chapter, use any facility, contractor, or employee of any other departraent or agency of the Federal Governument with the consent of and under appropriate support arrangernents with the head of such department or agency and, in the case of a contractor, with the consent of the contractor.

(f) Assistance From Certain Agencies Of The Federal Government.-With the consent of and under appropriate support arrangements with the Nuclear Regulatory Comunission, the Board may obtain the advice and recommendations of the staff of the Commission on matters relating to the Broard's responsibilities 
and may obtain the advice and recommendations of the Advisory Committe on Reactor Safeguards on such matters.

(g) Assistance From Organizations Outside The Federal Government-The Board may enter into an agreement with the $\mathrm{Na}$. tional Research Council of the National Arademy of Sciences or any other appropriate group or organization of experts cutside the Federal Government chosen by the Board to assist the Board in carrying out its responsibilities under this chapter.

(h) Resident Inspectors.-The Board may assign staff to be stationed at any Department of Energy' defenge nuclear facility to carry out the functions of the Board

(i) Special Studies-The Board may conduct special studies pertaining to adequate protection of public bealth and safety at any Department of Energy defense nuclear facility.

(j) Evaluation Of Information.-The Board may evaluate information received from the scientific and industrial communities, and from the itterested public, with respect to-

(1) events or practices at any Department of Energy defense nuclear facility; or

(2) suggestions for specific measures to improve the content of standards described in section 312(1), the implementation of such standards, or research relating to such standards at Department of Energy defense nuctear facilities.

42 UsC 2286c. Contracts.

42 UsC 2286d.

Federal Register, publication.

\section{Responsibullities of The Secretary Of Energy.}

(a) Cooperation.-The Sectetary of.Energy shail fully cooperate with the Board and provide the Board with ready access to such facilities, personnel, and information as the Board considers necessary to carry out its Iesponsibilities under this chapter. Each contractor operatiog a Departaent of Energy deferse nuclear facility under a contract awarded by the Secretary shall, to the extent provided in such contract or otherwise with the contractor's consent, fully-cooperate with the Board and provide the Board with ready access to such facilities, personntel, and information of the contractor as the Bosrd considers necessary to carry out ies responsibilities under this chapter.

(b) Access To Information.-The Secretary of Energy may deny access to infoctmation provided to the Board to any person who-

(1) has not been granted an appropriate security clearance or access authorization by the Secretary of Energy; or

(2) does not need such access in connection with the duties of stich person.

Sec 315. Board Recommendations.

(a) Public Availability And Comment.-Subject to subsections (g) and (b) and after receipt by the Secretary of Energy of any recommendations from the Board under section 312, the Board prompty shall make such recommendations ayailable to the pubjic in the Department of Energy's regional public reading rootns 7 and shall publish in the Federal Register such recommendations and a request for the submission to the Board of public comments on stich recommendations. Interested persons shall have $\mathbf{3 0}$ days 
Federal Register. poblication.

Federal Register, publication.

Reports. after the date of the publication of such notice in which to stbmit comments, data, views, $o$ arguzpents to the Board concerning the recommendations.

(b) Response By Secretary,-(1) The Secretary of Energy shall transsuit to the Bosrd, in vriting, a statement on whether the Secretary accepts or rejects, in whole or in part, the recommendators submitted to him by the Board under section 312, a descripbon of the actions to be taken in response to the reconmendations, and his views on such recommendations. The Secretary of Energy shatl transmit his response to the Board within 45 days after the date of the publication, under subsection (a), of the notice with respect to such recommendations or within such additional period, not to exceed $\mathbf{4 5}$ days, as the Board may grant.

(2) At the same time as the Secretary of Energy transmits his response to the Board under paragraph (1), the Secretary, subject to subsection (h), shall publish such response, together with a request for pablic comment on his response, in the Federal Register.

(3) Interested persons shall have 30 days after the date of the publication of the Secretary of Energy's response in which to submit cormments, data, views, or arguments to the Board conceming the Secretary's response.

(4) The Board may hold hearings for the purpose of obtain. ing public comments on its recommendations and the Secretary of Energy's responst.

(c) Provision Of Information Th Secretary.-The Board shall furnish the Secretary of Enerty with coptes of all comments, data, views, and arguments subnitted to it under subsection (a) or (b).

(d) Final Decision.-If the Secretary of Energy, in a response under stbsection (b)(1), rejects (in whole or part) any recommendation made by the Board under section 312, the Board shall either reaffirm its original recommendation or make a revised recommendation and shall notify the Secretary of its action. Whthin 30 days after receiving the notice of the Board's action under this subsection, the Secretary shall consider the Board's action and make a final decision on whether to implement all or part of the Board's recommendations. Subject to sibsection (h), the Secretary shall publish the final decistion and the reasoning for such decision in the Federal Register and shall transmit to the Committees on Anoed Services and on'Appropriations of the Senate, and to the Speater of the House of Representatives a written report containing that decision and reasoning.

(e) Implementation Plan.-The Secretary of Energy sball prepare a plan for the imaplementation of each Board recommendation, or part of a recommendation, tiat is acopted by the Secretary in his final decision. The Secretary shall transmit the implementation plan to the Board within 90 days after the date of the publication of the Secretary's final decision on such reconmendation in the Federal Register. The Secretary may have an additional $\mathbf{4 5}$ days to transmit the plan if the Secretary submits to 
Reports.

the Board and to the Conumittees on Armed Services and on Appropriations of the Senate and to the Speaker of the House of Representatives a notification setting, forth the reascoss for the delay and describing the actions the Sectetary is takizg to prepare an implementation plan under this subsection. The Secretary may implextent any such recommendation (or part of any suxh tecommendation) before, on, or after the date on which the Secretary transmits the implementation plan to the Board under this subsection. "

(f) Implementation.-(1) Subject to paragraph (2), not later then one year after the date on which the Secretary of Energy - transmits an implementation plan with respect to a recominendawtion (or part thereof) under subsection (e), the Secretary shall carcy but and completerthe implerinentation plan. If complete implementation of the plan takes more than 1 year, the Secretary of Energy s'ball submit a report to the Committees on Armed Services and on Appropriations of the Senate and to the Speaker of the House of Representatives setting forth the jeasons for the delay and when implementation will be completed.

Reports. (2) If the Secretary of Energy determines that the imple"I mentation of a Board recominendation (or pert thereof) is imoracticable because of budgetary considerations, or that the inplementation would affect the Secretary's ability to meet the antulal nuclear weapons stockpile requirements established pursuant to section 91 of this Act, the Secretary shall submit to the Prestident, to the Committees on Amred Services and on Appropriations of the Senate, and to the Speaker of the House of Representativies a report containing the recommendation and tbe Secretary's determination.

Public health and safety.

(g) Imminent Or Severe Threat.-.(1) In any case in which the Board determines that a recotmmendation submitted to the Secretary of Energy under section 3/2 relates to an imminent or severe threat to public health and safety, the Board and the Secretary of Energy shall proceed under this subsection in lieu of subsections (a) through (d).

(2) At the same time that tie Board:transmits a recommendation relating to an imminent or severe threat to the Secretary of Enorgy, the soard shall also transuit the recommendation to the President and for information purposes to the

Presidant of U.S Sectetary of Defense. The Secrstary of Energy shall submit his recomnendation to the President. The President shall review the Secretary of Energy's recommondation and shall make the decision conterning accoptance or rejection of the Board's recommendation.

Public information.

(3) After receipt by the President of the recorimendation

, fl from the Board under this subsection, the Board prompty shall make such recommendation available to the public and shall transmit such recommendation to the Committees on Armed Services and on Appropriations of the Senate and to the 
President of U.S.

42 USC 2286.

42 USC 2286e.

$42 \mathrm{USC} 22866$.

$42 \mathrm{USC} 2286 \mathrm{~g}$
Speaker of the House of Representatives. The President shall promptly notify such committees and the Speaker of his decision and the reasons for that decision.

(h) Limitation-Notwithstanding any other provision of this section, the requirements to make information arailable to the public under this section-

(1) shall not apply in the case of information that is classibed; and

(2) shall be subject to the oriers and regulations issued by the Secretary of Energy under sections 147 and 148 of this Act to prohibit dissemination of certain information.

Sec. 316. Reports

(a) Board Report.-(1) The Board shall stumit to the Committees on Armed Services and on Appropriations of the Senate and to the Speaker of the House of Representatives each year, at the same time that the President submits the budget to Congress pirstant to section 1105(a) of title 31, United States Code, a written report concerning its activities under this chapter, including all recommendations riade by the Board, during the year precedjug the year in which the report is submitted. The Board may also issue periodic unclassified reports on matters within the Board's responsibilitios.

(2) The angusl report under paragraph (1) shall include an assessment of-

(A) The improvements in the safery of Department of Energy defense mulear facilities during the period cov. ered by the report;

(B) the improvements in the safety of Department of Energy defense nuclear facilities resulting from actions taken by the Board or taken on the basis of the activities of the Board; and

(C) the outstanding safety probleros, if any, of Department of Energy defense nuclear facilities.

(b) DOE Report-DThe Secretary of Energy shall submit to the Committees on Armed Services and on Appropriations of the Senate and to the Speaker of the House of Representatives each year, at the same time that the President submits the budget to Congress pursuant to section 1105(a) of title 31, United State Code, a written report concerring the activities of the Department of Energy under this chapter during the year preceding the year in which the report is submitted.

Sec 317. Judicial Review.

Chapter 7 of title 5, United States Code, shall apply to the activities of the Board under this chapter.

Sec. 318. Definition.

As used in this chapter, the term Department of Energy defense suclear facility' means any of the following:

(1) A production facility of utilization facility (as defined in section 11 of this Act) that is under the control or jurisdiction of 
the Secretary of Energy and that ts operated for mational security purposes, but.the term does,not inclade-

(A), any facility or activity coweried by Executive Order No. 12344, dated February 1, 1982, pertaining to the Naval nutlear propulsion program;

(B) any facility or activity involved with the assenbly or testing of nuclear, explosives or with the transportation of nuclear explosives or nticlear material;

(C) any facility that does not conduct atomic energy defense activities; or

(D) any facility owned by the United States Enrichment Corporation.

(2) A nuclear waste storage facility under the control of jurisdiction of the Secrepary of Enetgy, but the tertm does not melude a 'facility developed pursuant to the Nuclear Waste Policy Act of 1982 (42 U.'S.C. 10101' latory Cómmissióti

42 USC 2286b. Sec. 319. Contract Avithority Subject To Appropriations.

The authority of the B́dard to enter intó contracts under this chapter is effective only to the extent that appropiriations (including transfers of appropriations) are provided in advance for such purpose.

42USC 2286h-1 Sec. 320. Transmittal Of Certain Informatión to Congress.

Whenever the Board submits br transmits to the President or the Director of the Office of Management and Budget any legislative reconsoendation, or any statement or information in preparation of a tepport to be submitted to the Congress pursuant to section 316(a), the Boardshail sabmit at the samé time a copy thereof to the Congress. $229 \mathrm{a}$

42 USC 2286i.

Set. 321. Annual Antborization OP Appropriations.

Authorizations of appropriations for the Board for fiscal years beginning afterifiscal year 1989 shall be provided anntally in authorizations Acts.

(2) The table of contents at the beginning of the Atomic Energy Act of 1954 is amended by adding at the end the following:

"CHÁPTER 21-DEFENSE NUCLEAR FACIIMTIES SAFETY HOARD

"Sec. 311. Establishment.

"Sec. 312. Functions of the Bóad.

"Sec 313. Powters of Board.

"Sec 314. Responsibilities of the Secretary of Energy.

1 sec 315. 'Board recoutunendations.

¿Sec. 316. 'Reports.

"Sec. 317. Judicial review. ${ }^{-r}$ ' '

"Sec. 318. Definition. 1

"Sec. 319. Contract authority subject to appropriations.

"Sec. 320.' Anmual authorization of appropriations."

(b) Salary For Board Members'At Executive Schedule Level III.Section 5314 of title 5, United States Code, is amended by inserting after "Members, Nuclear Regulatory Commission:" the following:

"Members, Defense Nuclear Facilities Safety Board.".

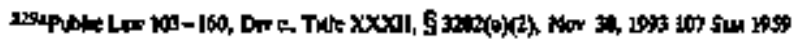


42 USC 2286e note. (c) Requirements For Finst Annual Report-D(I) Before suberission of the first annual report by the Defense Nuclear Facilities Safety Board under section 316(a) of the Atomic Energy Act of 1954 (as added by subsection (a)), the Board shall conduct a study on whether nuclear facilities of the Department of Energy that are excluded from the definition of "Department of Energy defense nuclear facility" in section 318(1)(C) of such Act (hereafter in this subsection referred to as "non-defense nuclear facilities") should be subject to independent external oversight. The Board shall include in such first annugl report the results of such study and the recommendation of the Board on whether non-defense rucleat facilities should be subject to independent external oversight.

(2) If the Board recommends in the report that non-defense nuclear facilities should be subject to such oversight, the report shall include a discussion of alternative mechanisms for implementing such oversight, including mechanisms such as a separate executive agency and oversight as a part of the Board's responsibilities. The discussion of altemstipe mectouxtisms of oversight also shall include considerations' of budgetary cossts, protection of the security of sensitive nuclear weapons information, and the similarities and differences in the design, construction, operation, and decommissioning of deferise and non-defense nuclear facilities of the Department of Energy.

(d) Requirements For Fifth Anmual Report.-The fifth anлual report - submitted by the Defense Nuclear Facilities Safety Board under section 316(a) of the Atomic Energy Act of 1954 (as added by subsection (a)) shail includs-

(1) an assessment of the degree to which the overall adiministration of the Bloard's activities are believed to meet the objectives of Congress in establishing the Board;

(2) recommendations for continuation, termination, or modification of the Board's functions and programs, including recommendations for transition to some other independent oversight arrangement if it is advisable; and

(3) recommendations for appropriate transition requirements in the event that moctifications art recommended.

SEC. 1442. TRANSFER

The Secretary of Energy, to the extent provided in appropriations Acts, shall transfer to the Defense Nuclear Facilities Safety Board es. tablished by section 311 of the Atorgie Energy Act of 1954 (as added by section 1441) from sums available for obligation for nationat security programs such sums as may be necessary, as determined by sticin Board, for the operation of the Board during fiscal year 1989, but in no case may more that $\$ 7,000,000$ transferred for such purpose. Sums transferred shall be available to such Board to carry out jts responsibilities under Chapter 21 of the Atomic Energy Act of 1954 (as added by secton 1441) and shall remain available until expended 230

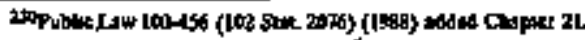


42 USC 2210

note.

Contracts.

Conltracts.
NEGOMATED' RULKMAKING 'ON' FINANCLAL PROTRCTION FOR RADIOPHARMACEUTICAL LICENSEES.

(A) Rulemaking Proceeding.-

(1) Purpose.-The Nuclear Regulatory Commission (hereafter in this section teferted to as the "Commission") shall initjate a proceeding, in accordance with the requirements of this section, to deternime whether to enter into indemnity agreenents under section 170 of the Atomic Energy Act' of 1954 (42 U.S.C. 2210) with persons licensed by the Commission under section 81, 104(a), or 104(c) of the Atouric Energy Act of 1954 (42 U.S.C. 211i, 2134(a), and 2134(c)) or by a State under section 274(b) of the Atomic Energy Act of 1954 (42 U.S.C. 2021(b)) for the manufacture, prodaction, possession, or use of radioisotopes or radiopharmaceutical for medical purposés (hereafter in this sectionl referred to as "radiopharmaceutical licensees")

(2) Final Determination.-A final determination with respect to whether radiopharmaceutical licensees, or any class of such licen. sees, shall be indemuified pursuant to section 170 of the Atomic Energy Act of 1054 (42 U.S.C.2210) and it so, the terms and conditons of such indernification, shall be, rendered by the Commission within 18 monthis of the date of the enactment of this Act.

(b) Negotiated Rulemaking.-

(1) Administrative Conference Gutdelines-m-For the purpose of making the deternpination required under subsection (a), the Commission shall, to the extent consistent with the provisions of this Act, conduct a negotiated nulenaking in accordance with the gutidance provided by the Administrative Conference of the United States in Recomomendation 82-4; "Frocedures for Negotiating Proposed Regulations" (42Fed. Reg. 30708, July 15, 1982).

(2) Designation Of Convener.-Within 30 days of the date of the enactment of this Act, the Commission shall designate an individual or individuals recommended by the Administrative Conference of the Untited States to serve as a convener for such negotiations:

( (3) Submission Recommendations of The Convener-The convener shall, not Jater than 7 months after the date of the enactsnent of this Act, submit to the Commission recommendations for a proposed rule regarding whether the Commission should enter into indentrity agreements under section 170 of the Atomic Ener. gy'Act of 1954 (42 U.S.C. 2210) with radiopharmaceutical licensees and, if so, the terms and conditions of sich indernnification. If the convener recommends that such inderinity be provided for radiopliarmaceutical licensees; the proposed rule subuitted by the converer shall set forth the procedures for the execution if indemrification agreements with radiopharmacentical licensees.

(4) Publication Of Recommendations And Proposed Rule.-If the convener recommends that such indemnity be provided for radiopharmaceutical licensees, the-Commission shall publish the recommendations of the convener submitted under paragraph (3) 
as a notice of proposed rulemaking within 30 days of the stbmisston of such recommentations under such paragraph.

(5) Administrative Procedures-To the extent consistent with the provisions of this Act, the Commission shall conduct the proceeding required under subsection (a) in accordance with section 553 of title 5, United States Code. 231 
"SEO. 1201، DEFTINITIONS:

"For purposes of this title:

"(1) The term 'alternative techpologies for uranium turichment' means technologies to entrich uranium by methods other than the gaseous diffusion process.

"(3) The term 'AVLIS' means atomic vapor laser isotope separation technology.

"(3) The term 'Board' means the Board of Directors of the Corporation established under section 1304.

"(4) The term "Corporation" means the United States Enjichment Corporation.

"(5) The term "corrective actions" has the meaning given wuch term by the Administrator of the Environmental Protection Agency under section 3004(u) of the Solid Waste Disposal Act (42 U.S.C. 6924(u)).

"(6) The tern "decontamination and deconunissioning" means those activities, other than response actions or corrective actions, undertaken to decontaminate and decommission inactive uranium enrichment facilities that have residual radioactive or mixed radioactive and hazardous chemical contanination, including depleted tailings.

"(7) The tema 'Department' mears the Department of Energy.

“(8) The term 'bughly erriched uranium' meens urarisum enriched to 20 percent or more of the urativom $\rightarrow 235$ isotope.

"(9) The term 'Jow-enriched uranium' means uranium enriched to less than 20 percent of the uramiutr-1 -235 isotope.

"(ID) The term 'releases' has the meaning given the term 'release' in section 101(22) of the Corpptohersive Envinonmental response, Compensation, and Liability Act of 1980 (42 U.S.C. $96012(22))$.

(1i) The term 'remedial action' has the meaning given such term in section 101(24) of the Comprefiensive Environmental Response, Comperssation, and Liability Act of 1980 (42 U.S.C. $9601(24))$.

'(12) the term 'response actions' has the meaning given the term 'response' in section 101(25) of the Comprebensive Environmental Response, Compersation, and Liability Act of 1980 (42 U.S.C. $9601(25))$.

"(I3) The term 'Secretary' means the Secretary of Energy.

“(14) The temm 'uranium enricistent' means the separation of uranium of a given isotopic content into 2 components, 1 having a 
higher percentage of a fissile isotope and $1 \mathrm{having}$ a lower percentage."

"SEC 1202. PURPOSES.

"The Corposation is created for the following purposes:

"(1) To operate as a business enterprise on a profitable and efficient basis.

(2) To maximize the long-term value of the Corporation to the Treasury of the United States.

"(3) To lease Department uranium enrichment facilities, as needed.

"(4) To acquire uranium for uranium enrichment, low-enriched urarum for resale, and highly enriched uravium for contrersion into lowsenricted uranium, as needed.

"(5) To market and sell its enriched uraniuml and uranium enrichment and related services to-

- $"$ (A) the Department for goveramental purposes; and

(B) dontestic and foreign persons, as provtded in section $1303(6)$.

4(6) To conduct research and development as required to meet business objectives for the purposes of identifying, evaluating, improving, and testing altemative technologies for aranium en* richment

"(7) To conouct the business as a self-financing corporation and eliminate the need for Federal Governiment appropriations or sources of Federal Enancing other than those provided in this title.

"(8) To help maintain a reliable and economical domestic sousce of uranium entithunent services.

"(9) To comply with laws, and regulations promulgated thereunder, to protect the pubtic health, stafey, and the enviromment.

"(10) To continue at all times to meet the objectives of ensuring the Nation's common defense and securtity, inchuding abiding by Uníted States laws and policies concertuing special nuclear materials and nonproliferation of atomic weapons and other nonpeacefull uses of atomic energy.

"(11) To take all other lawful_actions in furtherance of these purposes.

"CHAPTRR 23- ESTABLISHMENT, POWRRS, AND
ORGANIZATION OF CORPORATION

42 USC 2297b. "SEC. 1301. ESTABLISHMENT OF THE CORPORATION.

"(a) IN GENERAL - There is established a body corporate to be known as the United States Eurichment Corporation.

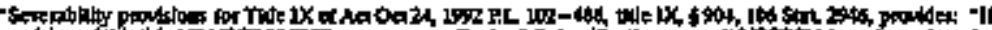

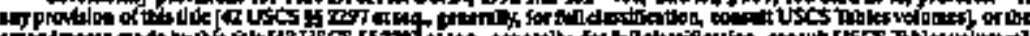

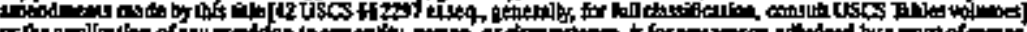

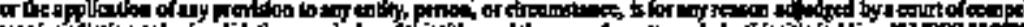

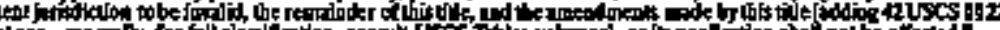

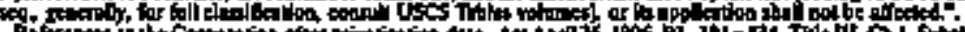

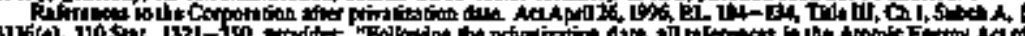

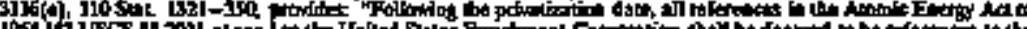
mitric eocporilion."
} 
42 USC 22976-I.

42 USO2297b-2. "(b) GOVERNMENT CORPORATION-The Corporation shad be established as a wholly owned Government corporation sobject to chapter $\$ 1$ of title 31, United \$tates Code (commonly referred to as the Government Corporation Control Act), except as otherwise provided in this title ,

"(c) FEDERAL AGENCY,-The Corporation shall be an agency and instrumentality of the United States. I

"SEC. 1302. CORPORATE OFFICES.

" "The Corporation shall maintain an office for the service of process and papers in the District of Columbia, and shall be deemed, for purposes of venute in civil actions, to be a resident thereot. The Corporation may establish offices in swch other place or places as it may deem necessary or appropriate in the condinct of its business.

"SEC, 1303. POWERS OF THE CORPORATION.

"In order to accomplish its purposes, the Corporation-

"(1) shall, except as provided in this title or applicable Federal law, have ail the powers of a-private corporation incorporated under the District of Columbia Business Corporation Act;

"(2) shall have the priority of the United States with respect to the payuient of debis out of barkrupt, insolvent, and decedents' estatest

"(3) may obtain from the Adrinistrator of General Services the services the Administrator is authorized to provide agencies of the United States, on the satne basis as those services are provided to other agericies of the United States;

"(4) shall encrich urantím, provide for uranium to be enriched by others, or acquire enriched urasuum (ínchuding low-enriched uranium derived from highty enriched uranitum provided under section 1408);

"(5) may conduct, or provide for coinducting, those research and developmerit activities related to uraniuí enrichment and related processes and activities the Cotporation considers decessary or advisable to maintain the Corporation a a conmercial enterprise operating on a próitiable and efficient basis;

"(6) may enter into transsactions regarding uranium, enriched uranium, or depleted urasium with

"(A) persons licensed under section 53, 63, 103, or 104 in accordance vith the licenses held by those persons;

"(B) persons in accordanie with, and within the period of, an agreemefit for copperation arranged under section 123; or

"(C) persons otherwise authorized by law to enter into such transactions;

"(7) may enter isto contracts with persons-licensed under section 53, 63; 103, or 104, for as long as the Corporation considers necessary or desirable, to provide uranium or uranium enrichment and related services;

"(8) may enter into contracts to provide uranitm or uranium enrichment and related services in accordance with, and within the period of, an agreement for cooperation arringed under section 123 or as otherwise authorized by law; and 
42 USC 22976-3.

"(9) shall sell to the Department as prowided in this title, without regard to section $57 \mathrm{e.}$, the amounts of uranium esuricinnent and related services that the Department determines from time to time are requited for it to-

"(A) carry out Presidential directions and authorizations under section 91; and

t(B) conduct other Depistment progirams.

"SEC. 1304. BOARD OF DIRECTORS.

"(a) IN GENERAL-The powers of the Corporation are vested in the Board of Directors.

"(b) APPOINTMENT.-The Board of Directors sialt consist of 5 individuas, to beappointed by the President by and with the advice and consent of the Senate. The President shall designate a Chairman of the Board from among merobers of the Board.

"(c) QUALIFICATIONS,-Members of the Board shall be citizens of the United States. Na member of the Boarc shall be an employee of the Corporation or bave any direct financial relationship with the Corporation other than that of being a member of the Board.

(d) TERMS.-

“(1) IN GENERAI_-Except as provided in paragraph (2), menbers of the Board shall serve 5-year terms or until the election of a new Board of Directois under section 1704, whichever comes first.

"(2) INITIAL MEMBERS. - Of the menabers first appointed to the Board-

"(A) 1 shall be appointed for a 1-year terbl;

"(B) 1 shall be appointed for a 2-year term;

"(C) 1 shall be appointed for a 3-year term; and

"(D) 1 shall be appointed for a 4-year term.

(i) REAPPOINTMENT.-Members of the Board may be reappototed by the Prestdent, by and with the advice and consent of the Senate.

"(e) VACANCIES,-.Upon the occurrence of a vacancy on the Board, the President by and with the advice and consent of the Serate shail appoint an individual to fill suct vacancy for the rentainder of the applicable term.

(f) MEETINGS AND QUORUM.-The Board shall meet at any time pursuast to the call of the Chairman and as provided by the bylaws of the Corporation, but not less than quarterly. Three voting menabers of the Board shall constitute a quorum. A majority of the Board shall adopt and from time to time may amend bylaws for the operation of the Board.

(g) POWERS, - The Board shall be responsibte for general maragement of the Corporation and shall have the same authority, privileges, and responstbilities as the board of directors of a private corporation incorporated under the District of Columbia Business Corporation Act.

"(h) COMPENSATION,-Members of the Board shall serve on a part-time basis and shall receive per diem, when engaged in the actual performance of Corporation duties, plus reimbursement for travel, 
subsistence, and other necessary expenses incurred in the performance af their duties.

"(i) MEMBERSHIP OF SECRETARY OF TREASURY.+.The President may appoint the Secretary of the Treasury or his designee to serve as a member of the Board or as a nonwoting, ex officio member of the Board.

"(j) CONFLICT OFINTEREST REQUIREMENTS,-No director, offices, or other management level employec of the Corporation may have a financial interest in any cuseomer, contractor, or competitor of the Corporation or in any business that may be adversely affected by the success of the Corporation.

\section{USC 2297b-4. "SSEC.130S. EMPLOYEES OF THE CORPORATION.}

"(a) APPOINTMENT.-The Board shall appoint such officers and employes as are necessary for the transaction of jes business.

"(b) COMPENSATION, DUTIES, AND REMOVAL - The Board shall, without regard to section 5301 of titk 6, United States Code, fix the compensation of all officersiand employees of the Corporation, define their duites, and provide a system of organization to fix responsibility and promote efficiency. Any officer or employee of the Corpora. tion may be removed in the discretion of the Board.

"(c) APPLICABLE CRITERIA-The Board shall ensure that the persongel function and ofganization is consistent with the principles of section 2301(0) of title 5, United States Code, relating to merit system principles, Officers and employees shall be appointed, promoted, and assigned on the basis of merit and fitmess, and otber personnel actions shall be consistent with the principles of fatmess and due process but without regard to those provisions of tite 5 of the United States Code gowerning appointments and other personnel actions in the competitive service.

"(d) TREATMENT OF PERSONS EMPLOYED PRIOR TO TRANSITIONDATE-Compensation, benefits, and other terms and conditions of employment in effect immediately prior to the transition date, whether provided by statute or by rtues of the Deparatant or the executive branch, shall continue to apply to officers and employees who transter to the Corporation from other Federal employment until changed by the Board.

“(e) PROTECTION OF EXISTING EMPLOYEES.-

(1) IN GENERAL. - It is the purpose of this subsection to ensure that the establishment of the-Corporation pursuant to this chapter shall not result in any adverse effects on the employment jights, wages, or benefits of employees at facilities that are operated, directly or under contract, in the perfordance of the functions vested in the Corporation.

(2) APPLICABLITY OF EXISTING COLAECTIVE BARGAININO AOREEMENT.-Any employer (including the Corporation) at a facility described in paragraph (1) shall abide by the terus of a collective bargaining agreenent in effect on April 30, 1991, at each individual facility until-

(A) the earlier of the date on which a new bargatining agreement is signed; or 
"(B) the end of the 2-year period beginning on the date of the eractinent of this title.

(3) APPLICABILITY OF NLRA.-Except as specifically provided in this subsection, the Corporation is subject to the provisions of the National Labor Relations Act (29 U.S.C. 151 etseg.).

(4) BENEFITS OF TRANSFEREES AND DETAIL.EES.-

At the request of the Board and subject to the approval of the Secretary, at employee of the Department may be transferred or detailed as provided for in section 1315, to the Corporation without any loss in accrued benefits or standing within the Civi] Service System. For those employees who accept transfer to the Corporation, it shall be their option as to whether to bave any accrued retirement benefits transferred to a retircment system established by the Corporation or to retain their coverage under either the Civil Service Retirement System or the Federal Employes' Rttirement System, as applicabie, in lieu of coverage by the Corpora. tion's retirement system. For those emptoyees electing to remain with one of the Federal retirement systems, the Corporation shall withhold pay and make such payments as are required under the Federal retirement system. For those Department employees detailed, the Department shail offer those entployees a position of like grade, compensation, and proximity to their official duty station after their services are no longer required by the Corporation.

42 USC 2297b-5. 4SEC. 1306. AUOTHS.

(a) INDEPENDENT AUDITS.-

(1) IN GENERAL-The financial statements of the Corporation shail be prepared in accordanoe with generally accepted ac counting principies and shall be audited anmually by an independent certified public accountant in accordance with autiting standards issued by the Comptronler General. Such auditing standard ds shall be consistent with the private sector's generally accepted auditing standards.

"(2) REVIEW BY GAO.-The Comptroller General may review any audit of the Corporation's financial statements con. dueted under paragraph (1). The Comptroller General shall report to the Congress and the Corporation the results of any stuch review and shall include in such report appropriate recommendations.

"(b) GAO AUJDITS.-

(1) IN GENERAL.-The Comptroller General may audit the financial statements of the Corporation for anyyear in the manner provided in subsection (a)(1).

"(2) REIMBURSEMENT BY CORPORATION-The Corporation shall reimburse the Comptroller General for the full cost of any aixdit conducted under this subsection, as detemined by the Comptroller General.

"(c) AVAILABILITY OF BOOKS AND RECORDS,-Al] books, accounts, finandal records, reports, files papers, and other property belonging to or in use by the Corporation and its auditor that the Comptroller Generat considers necessary to the performance of any 
audit or review under thissection shail be made available to the Comptrolier General, strbject to section 1314.

(d) TREATMENT OF GAO AUDITS.-Activitites the Comptroller General conducts under this section shall be in lieu of aty other audit of the financial transactions of the Corporation the Comptroller General is required to make under chapter 91 of title 31, United States Code, or other law.

42 USC 22\%76-6. "SEC 1307. ANNUAL REPORTS.

"(a) IN GENERAL. - The Corporation shall prepare and submit an annual report of jts activities to the President and the Congress. This report shall contain-

"(1) a general description of the Corporation's operations:

"(2) a summary of the Corporation's operating and funancial performance, including an explanation of the decision to pay or not pay dividends;

"(3) copies of audit reports prepared under section 1305;

- "(4) the information reguired under regulations issued under section 13 of the Securities Exclange Act of 1934 (15 U.S.C. $78 \mathrm{~m}$ ); and

“'(5) an identitication and assessment" of any impairment of capital or'ability of the Corporation to comply with this title.

(b) DEADLINE-The report shall be completed not later than 150 'days following the close of tach of the Corporation's fiscal years and shall accurately reflect the financial position of the Corporation at fiscal year end.

42 USC 2297b-7. "SkC. 1308. ACCOUNTS.

"(a) ESTABLISHMENT OF UNITEDD STATES ENRICHMENT CORPORATION FUND.-There is estabitished in the Treasury of the United States a revolving fund, to be known as the "United States Enrictiment Corporation Fund, which shall be available to the Corporation, without need for further approptiation and without is scal year linitation, for carrying out its purposes, functions, and powers, and which shall not be subject to apportion ment under subchapter II of chapter 15 of title 31, United States Code.

"(b) TRANSFER OF UNEXPENDED BALANCES-On the transfer date, the Secretary shall, wichout need of further appropriation, transfer to the Corporation the unexpended balance of appropriations and other monies avaslable to the Department (inclusive of funds set aside for accounts payable), and accounts receivable which are related to functions and actjvities acquired by the Corporation from the Department pursuant to this title, includirg all advance payments.

42 USC 2297b-8. t "SEC 1309, OBLIGATIONS.

"(a) ISSUANCE-

"(I) IN GENERAL-The Corporation may issue and sell bonds, notes, and other evidences of indebtedress (collectively referred to in this title as "bonds'), except that the Corporation may not issue, or sell bonds for the purpose of constructing new uranium entrichment facilities or condueting directly related preconstruction activities. Borrowing under this paragraph during 
any fiscal year ending before October 1, 1996, shall be subject to approval in appropriation Acts.

(2) USEOF REVENUES.-The Corporation may pledge and use its reventues for payment of the principal of and interest on its bonds, for their purchase or redemption, and for other purposes incidental to these functions, including creation of reserve fundis and other funds that may be similarly pledged and used.

(3) AGREEMENTS WITH HOLDERS AND TRUSTEES.The Corporation may enter into binding covenants with the hotders and trustees of its bonds with respect to

(A) the establishnent of reserve and other funds;

"(B) stipulations concerning the subsequent issuance of bonds; and

"(C) other matters not inconsistent with this title; that the Corporation determines necessary or desirable to enhance the marketability of the bonds.

“(b) NOT OBLIGATIONS OF UNTTED STATES.-Bonds issued by the Corporation under this section shall not be obligations of, or guaranteed as to mincipal or interest by, the United States, and the bords shall so plainty state.

"(c) TERMS AND CONDITIONS.-

"(1) NEGOTIABLE; MATURITY.-Bonds issued by the Corporation under this section shall be aegotiable instruments unless otherwise specitied in the bond and shall mature not more than 50 years after thejr date of issuance.

"(2) ROLE OF SECRETARY OF THE TREASURY.-

(A) RIGHT OF DISAPPROVAL,-The Corporation Joay set the terms and conditions of bends issued under this section, subject to disapproval of such terms and conditions by the Secretary of the Treasury within 5 days after the Secretary of the Treasury is notified of the following terms and conditions of the bonds:

"(i) Their forms and denominations.

"(ii) The titnes, amounts, and prices at which they are sold.

"(iii) Their rates of interest.

"(iv) The termis at which they may be redeened by the Corporation before maturity.

"(v) The priority of their claims on the Corporation's net revenues with respect to principal and interest paythents.

"(vi) Any other terms and conditions.

“(B) INAPPLICABILITY OF RIGHT TO PRESCRIBE TERMS. Section 9108(a) of title 31, United States Code, shall not apply to the Comporation.

(d) INAPPLICABILITY OF SECURITIES REQUIREMENISThe Corporation shall be considered an executive department of the United States for purposes of section 3(c) of the Securities Exchange Aet of 1934 (15 U.S.C. 78 (c)) ).

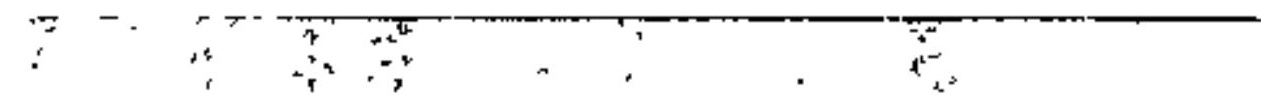


"(e) INAPPLICABiLITY OF FEE-The Corporation shall not issuc or stll any bonds to the Federal Financing Bank.

"SEC. 1310. KXEMPTION FROM TAXATION AND PAYMENTS IN LIEU OF TAXES.

"(a) EXFMPTION FROM TAXATION-I -I order to render financial assistance to those States and localities in which the facilities of the Corporation are located, the Corporation shall, beginning in fiscal year 1998 , make payments to State and local governments as provided in this section. These payments shall be in lieu of any and all State and local taxes on the real and personal propesty of the Corporation. Ali property of the Corporation is expressly exempted from taxation in any manner or form by any State, county, or other local government entity inclading State, coumty, or other loeal government sales tax.

"(b) PAYMENTS IN LIEU OF TAXES.-Beginging in fiscal yeat 1998, the Corporation shall make annual payments, in anounts determined by the Corporation to, be fair and reasonable, to the State and local governmental agencies having tax jurisdiction in any area where facitities of the Cotporation are located. In making these determinations, the Corporation shall be guided by the following criteriat

"(1) The Corporation shall take into account the customs and practices prevailing in the area with respect to appraisal, assessment, and classification of ínoustrial property and any special considerations extended to large-scale industrial operations.

"(2) The payment made to any taxing authority for any period shall not be less than the payments that would bave been rade to the taxing authority for the same period by the Department and its cost-type contractors on behalf of the Department with respect to property that has'been transferred to the Corporation under section 1404 and that would have been attributable to the ownership, management, operation, and maintenance of the Department's uranium enrichment facilities, applying the laws and policies preyailing immediately prior to the transition date.

"(c) TIME OF PAYMENTS.-Payments shall be made by the Corporation at the time when paysuents of taxes by taxpayers to etach taxing aathority are due and payable.

(d) DETERMINATION OF AMOUNT DUE-The determination by the Corporation of the amounts due under this section shall be final and conclusive.

42 USC 2297b-10. "SEC. 1311. COOPRRATION WTTH OTHER AGENCIES

"The Corporation may request to use on a reimbursable besis the available services, eqtipment, persontiel, and facilities of agencies of the United States, and on a stmilar basis may cooperate with such agencies in the establishment and ust of strvices, equipment, and facilities of the Corporation. Furfher, the Corporation may confer with and avail itself of the cooperation, services, records, and facilities of State, territorial, municipal, or other local agencies.

42 USC 2297\%-11. "SEC. 1312. APPLCABILITY OF CERTAIN FEDERAL LAWS.

"(a) ANIITRUST LAWS.-The, Corporation shall conduct its activities in a manter consistent with the policies expressed in the following antittrust laws: 
"(1) The Sherman Act (1S U.S.C. 1-7).

"(2) The Clayton Act (15 U.S.C. 12-27).

9).

(3) Sextions 73 and 74 of the Wilson Tariff Aet (15 U.S.C. 8 and

"(b) ENVIRONMENTAL LAWS.-The Corporation shall be subject to, and comply with, all Federal and State, interstate, and local environmental laws and requirements, both substantive and procedural, in the same manner, and to the same extent, as any person who is subject to such laws and requirements. For purposes of enforcing any such law or substantive or procedural requirements (including any in. junctive relief, administrative order, or civil or administrative penalty or fine) against the Corporation, the United States expressly waives any immunity otherwise applicable to the Corporation. For the purposes of this subsection, the term 'person' means an individual, trust, firm, joint stock company, corporation, partmership, assocjation, State, municjpality, or politicas subduvision of a State.

"(c) OSHA REQUIREMENTS.-Notwithstanding sections 3(5), 4(b)(1), and 19 of the Occupational safety and Health Act of 1970 (29 U.S.C. 652(5), 653(b) (1), and 668)), the Corporation shall be subject to, and comply with, such Act and all regulations and standards promulgated thereunder in the same manner, and to the same extent, as an employer is subject to such Act. For the purposes of enforcing such Act (including any injunctive relief, administrative order, or civil, administrative, or criminal penalty or fine) agaist the Corporation, the United States expressty waives any immunity otherwise applicable to the Corporation.

"(d) LABOR STANDARDS.-The Act of March 3, 1931 (known as the Davis-Bacon Act) (40U.S.C. 276a et seq.) and the Service Contract Act of 1965 (41 U.S.C. 351 et seq.) siall apply to the Corporation. All laborers and mechanics employed on the construction, alteration, or repair of projects funded, in whole or in part, by the Corporation shall be paid wages at rates not less than those prevailing on projects of a similar character in the locality as determined by the Secretary of Labor in accordance with such Act of March 3, 1931. The Secretary of Labor shall tave, with respect to the labot standards specined in this stbsection, the althority and functions set forth in Reprganization Plan Numbeted 14 of 1950 (15 F.R. 3176, 64 Stat. 1267) and the Act of June 13, 1934 (40 U'S.C. 276c).

"(๕) ENERGY REORGANIZATION ACT REQUIREMENTSThe Corporation is subject to the provisions of section 210 of the Energy Reorganization Act of 1974 (42 U.S.C. 5850) to the same extent as an employer subject to such section, asd, with respect to the operation of the facilities leased by the Corporation, section 206 of the Energy Reorganization Act of 1974 (42 U.S.C. 5846) shall apply to the directors and officers of the Corporation.

"(ी) EXEMPTION FROM FEDERAL PROPERTY REQUIREMENTS.-The Corporation shall not be subject to the Federal Property and Adrninistrative Services Act of 1949 (41 U.S.C. 471 et seq.). 
42 USC 22976-12. " "SEC. 1313. SECURITY.

"Any references to the term 'Commission' or to the Department in sections 161k: 221a., and 230 shall be considered to include the Corporation.

42 USC 2297b-13. «SEC 1314. CONTHOL OF INFORMATION.

"(a) IN GENERAL-Except as provided in subsection (b), the Corporation may protect trade secrets and commercial or financial information to the same extept as a privately owned corporation.

(b) OTHER APPUCABLE LAWS-Section 552(d) of title 5, United, States Code, shali apply to the Corporation, and such infortuation shall be subject to the applicabie provisions of law protectiog the confidentiality of trade secrets and business and financial information, including section 1905 of title 18, United States Code.

42 USC 2297b-14. "SEC. 13IS. TRANASITION.

President

"(a) TRANSITIONMANAGER,-Wtthin 30 days after the date of the enlactmient of this title, the President shal appoint a Transition Manager, who shall serve at the pleasize of the President until a quorum of the Boird has been appointed and confirmed in accordance with section 1304.

"(b) POWRRS.-

(1) IN GENERAL. Until a quorum of the Board has qualified; the Transition Manager shall exercise the powers and duties of the Board and shall be responsible for tajking all actions needed to effect the transfer of the uraniurn enrichaient enterprise from the Secretary to the Corporation on the transition date.

- (2) CONTINUATION UNTIL BOARD HAS QUORUM.In the event that a quorum of the Board has not qualified by the trapsition date, the Transition Manager sball contfinue to exerctse the powers and duties of the Board until a quorum has qualified.

(c) RATIFICATION OF TRANSITION MANAGER'S ACTIONS-All actions taken by the Transition, Marager before the qualisication of a quorum of the Board shall be subject to ratification by the Board. I

(d) RESPONSIBILITIES OF SECRETARY.-Before the transifion date, the Secretary shals--

(1) contimue to be responsitble, for the management and operation of the uranium enricturent plants;

"(2) provide funds, to the extent provided in appropriations Acts, to the Transition Manager to pay salaries and expenses;

"(3) delegate Department employees to assist the Transition

Manager in meeting his responsibjlities under this section; and

(4) assist and cooperate with the Transition Manager in preparing for the transfer of the uranium enrichment enterprise to the Corporation on the transition date.

"(s) TRANSITION DATE:-The-transition date shall be July 1, 1993.

“(f) DETAIL OF PERSONNEL-For the purpose of continuity of operations, maintenance, and authority, the Department shall detail, for up to 18 months after the date of thie enactment of this title, appropriate Departonent personuel as may be required in an acting capac. 
iny, until such time as a Board is confirmed and top officers of the Corporation are hired. The Corporation shall reimburse the Department and its contractors for the detail of such personnel.

"SEC. 1316. WORKING CAPITAL ACCOUNE

"There shall be established within the Cotporation a Working Capital Account in which the Corporation may retain all revenue necessary for legitimate business expenseg, or investments, related to carrying out its purposes.

$42 \mathrm{UsC} 2297 \mathrm{c}$

\section{"CHAPTER 24—RIGHTS, PRIVILEGES, AND ASSETS OF THE CORPORATION}

"SEC. 140t. MARKETING AND CONTRACTING AUTHORITY.

"(a) EXCLUSIVE MARKETING AGENT.-The Corporation shill act as the exclusive marketmg agent on behalf of the United States Government for entering into contracts for proviling enriched uraritum (including low-enriched uranibm derived from highty onsiched uranium) and uranium errichment and related services. The Department may not market enriched uranium (including low-enriched uranium derived from highly enricbed uraniura), or uranium enrichmest and ralated services, after the transition date.

(b) TRANSFER OF CONTRACTS.-

“(i) IN GENERAL-Except as provided in paragraph (2), all contracts, agreements, and leases with the Department, including all uranium enrichenent contracts and power purchese contracts, that have been execuled by the Department before the transition date and that relate to uranium enrichment and related services shall transfer to the Corporation.

${ }^{*}$ (2) EXCEPTIONS.-

"(A) TVA SETTLEMENT.-The rights and responsibilities of the Department under the sertlement agreement with the Tennessee Yalley Authority, filed on December 18, 1987, with the United States Court of Federal Claims," shalt not transfer to the Corporation.

"(B) NONTRANSFERABLE POWER CONTRACTS-If the Secretary determines that a power purchase contract executed by the Department prior to the tansition date cannot be trarsferred under its terms, the Secretary may continge to receive power under the contract and resell such power to the Corporation at cost.

"(C) NONPOWER APPLICATIONS.-Contracts for enriched uranium and uranium services in existence as of the date of the enactment of this titie for research and development or other nonpower applications shall remain with the Department. At the request of the Department, the Corpora-

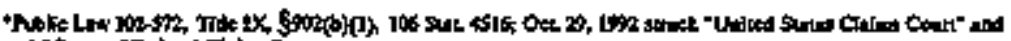
incented "Cour of Fudend Clation.-

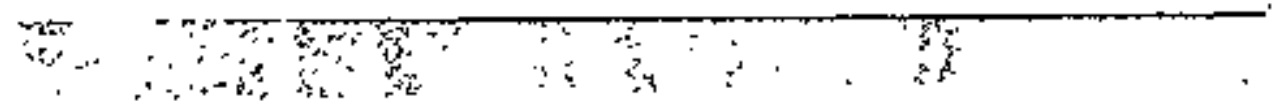


42 USC $2297 \mathrm{c}-1$.

tion, in consultation with the Department, may enter into stich conteacts it determines to be appropriate."

“SEC.1402, PRJCING.

(a) SERVICES PROVIDED TO COMMERCIAL CUSTOMERS.

-The Corporation stall establish prices for its products, materials, and services provided to customers other than the Department on a basis that will allow it to attain the normal business objectives of a profitmak. ing corporation.

(b) SERVICES PROVIDED TO DOE.-The Corporation shal] charge prices to the Department for uranium enrichment services pro. vided under section 1303(9) on a basis that will allow it to recover its costs, on a yearly basis, fot providing prochucts, materials, and services, and provide for a reasonable profit.

42 USC 229\%-2 "SEC 1403, LEASING OF,GASEOUS DIFEUSION FACILITIES OF DEPARTMENT.

(a) IN GENERAL-The Corporation shall lease the Paducah Gaseous Diffusion Plant in Paducah, Kentiucky, the Partsmouth Gaseous Diffusion Plant in Piketon, Ohio, and related propesty of the Department, for a period of 6 years from the transitjon date. Thereafter, the Corporation shall have the exclusive option to lease such facilities and related property for additional periods.

(b) TERMS OF LEASE-The Corporation and the Department shall set mutually agreeable terms for a lease under subsection (a), including specifying annual payrients to the Department by the Corporation to be made. The amount of antrual payments shall be equal to the cost incurred by the Department is administering the lease and providing services related to the lease to the Corporation (excluding depreciation and inpited jiterest on original pant izvestanents in the Department's gaseous obffision plants and costs under subsection (d)).

"(c) EXCLUSION OF FACILITBES FOR PRODUCTION OF HIGHLY ENRICHED URANIUM,-Subsection (a) shall not apply to Department facilities necessary for the production of highly enrictied urantum. The Secretary may grant to the Corporation access to such facilities for purposes other than the prodnction of highly entiched usanturis.

"(d) DOE "RESPONSIBILITY FOR PREEXISTING CONDITIONS.-The payment of any costs of decontamination and decommissioning, response actions, or corrective actions with respect to contditions existing before the transition date, in connection with property of the Depertment leased under subsection (a), shall remain the sole responsibility of the Department.

(e) ENVIRONMENTAL AUDIT.-The Secretary, in consultation with the Administrator of the Emwtronmental Protection Agency, shall conduct a comprebensive enviromental audit identifying emviron-

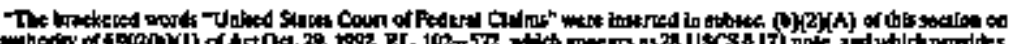

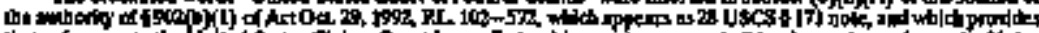

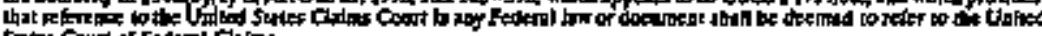
sates Count of Ftown Chin

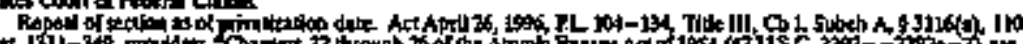

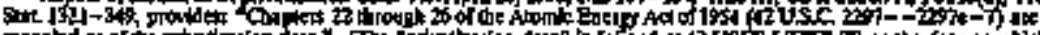

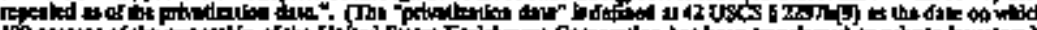

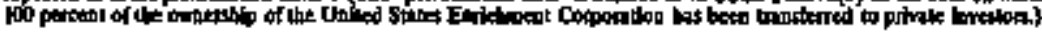


mental conditions that will remain the responsibility of the Department parsuant to subsection (d) after the transition date. Such audit sball be completed no later than the transition date.

"(i) TREATMENT UNDER PRICE-ANDERSON PROVISIONS. -Any lease executed between the Secretary and the Corporation under this section shall be deemed to be a contract for purposes of section $170 \mathrm{~d}$.

"(g) WAIVER OF EIS REQUIREMENT.-The execution of the lease by the Corporation and the Department shall not be considered a major Fecteral action significantly affectiog the quality of the buman environjent for purposes of section 102 of the National Environmestat Poljey Act of 1969 (42 U.S.C. 4332).

42 USC 22979-3. "SEC. 1404. CAPITAL STRUCTURE OF CORPORATION.

\section{"(a) CAPITAL STOCK,}

"(1) ISSUANCE TO SECRETARY OF THE TREASURY.The Corporation shall issue capital stock representing an equity investmeat equal to the greater of-

(A) $\$ 3,000,000,000$; or

(B) the book value of assets transferred to the Corporation, as reported in the Uranium Enrichment Anmual Report for fiscal year 1991, modified to reflect continued depreciation and other usual changes that occue up to the transfer date.

The Secretary of the creasury shall hold such stock for the United States, except that all rights and duties pertaining to management of the Corporation shall remain vested in the Board.

(2) RESTRICTION ON TRANSFERS OF STOCK BY UNITED STATES.-The capital stock of the Corporation shall not be sold, transferred, or conveyed by the United States, except to carry out the privatization of the Corporation under section 1502.

"(3) ANNUAL,ASSESSMENT.-The Secretary of the Treasury shall annuality assess the value of the stock beld by the Secretary under paragraph (1) and submit to the Congress a report setting forth such value. The annual assessment of the Sectetary shall be subject to review by an independent auditor.

(b) PAYMENT OFDIVIDENDS,-The Corporation shall pay into miscellaneous receipts of the Treasury of the United States or such other fund as is provided by law, dividends on the capital stock, out of earnings of the Corporation, as a return on the investment represented by such stock. Until privatization occurs under section 1502, the Corporation shall pay as dividepds to the Treasury of the United States all net revenues remaining at the end of each tiscal year not required for operating expenses or for deposit into the Working Capital Account established in section 1316.

"(c) PROHIBITION ON ADDITIONAL FEDERAL ASSISTANCE. - Except as otherwise specifically provided in this title, the Corporation shall receive no appropriations, loars, or other financial assistance from the Federal Gowemment.

“(c) SOLE RECOVERY OF UNRECOVERED COSTS.-Receipt by the United States of the proceeds from the sale of stock issued by the 
$42 \mathrm{USC} 2297 \mathrm{c}-4$.

42 USC 22970.5.

42 USC $2297 \mathrm{c}-6$.

$42 \mathrm{USC} 2297 \mathrm{c}-7$.
Corporation under subsection (a)(I), and the dividends paid under subsection (b), shall constitute the sole recovery by the United States of previously unrecowered costs (including depreciation and inguted interest on originlal plant investurents in the Department's gaseous diffu. sion plants) that have been iacurred by the United States for uranium enrichment activities prior to the transition date.

uSEC. 140S. PATENTS AND INVENTIONS.

"The Corporation may at any time apply to the Department for a patent license'for the use of an invention or discovery useful in the production or utilization of special nuclear material or atomic entergy covered by a pattot when the patent has not been declared to be affected with the public interest under section 153 a and when use of the patent is within the Corporation's authority. An apptication stal! constitute an application under section $153 \mathrm{c}$ subject to section $153 \mathrm{c}$, d., e., f., g., and $h$.

"SEC. 1406. LABILITES.

"(a) LIABILITIES BASED ON OPERATIONS BEFORE TRANSITION. - Except as otherwise provided in this title, all liabilities attributable to operation of the uraniut entichument enterprise before the transition date shall remain direct liabilities of the Department.

“(b) JUDGMENTS BASED ON OPERATIONS BEFORE TRANSITION.- Ary judgunent entered against the Corporation imposing liability arising out of the operation of the uranium enrichment enterprisse before the transition date shall be considered a judgment against and shall be payable solely by the Department.

"(c) REPRESENTATION, - With regasd to any claim seeking to inpose liability under subsection (a) or (b), the United States shall be represented by the Department of Justice.

(d) JUDGMENTS BASED ON OPERATIONS AFTER TRANSITION, - Any judgment entered against the Corporation arising from operations of the Corporation on or after the transition date shall be paysble solely by the Corporation from its own funds. The Corporation shall not be considered a Federal agency for purposes of chapter 171 of title 28, United States Code.

"SEC 1407. TRANSFER OF URANIUM INVENTORIES.

"The Secretary shall transfer to the Corporation without charge al] risw and low-enriched uranium inventories of the Department necessary for the fulfilment of contracts transferred under section 1401(b).

"SEC 1408. PURCHASE OF HIGHLX ENRICHED URANIUM FROM FORMER SOVIET UNION

"(a) IN" GENERAL_-The Corporatton is authorized to negotiate the purchase of all highly enciched uranius made avaitlable by any State of the former Soviet Union under a government-to-govermment agreement or,shall assume the obligations of the Department under any contractual agzeement that has been reached with any such State or any private entity before the transition date. The Corporation may only purchase this materiai so long as the guality of tine material can be made suitable for use in commercial reactors. 
“(o) ASSESSMENT OF POTENTIAL USE-The Corporation shall prepare an assessment of the potential use of highty exricheo uranium in the business operations of the Corporation.

"(c) PLAN FOR BLENDING AND CONVERSION_-In the event that the agreement under subsection (a) prowides for the Corporation to provide for the bleading and conversion the assessment stall include a plan for such blending and conversion. The plan shall determine the least-cost approach to providing blending and conversion services, compatible with environmental, safety, security, and nomproliferation requirements. The plan shall inclute a competitive process that the Corporation shall use for selecting aprovider of such services, including the public solictation of proposals from the private sector to allow a determination of the least-cost appoach.

"(d) MINIMIZATION OF IMPACT ON DOMESTIC INDUSTRIES.-The Corporation shall seek to minimize the impact on doInestic industries (including uranium raining) of the sale of low-tnriched uranium derived from highly enriched uranium.

42 USC $2297 \mathrm{~d}$.

\section{"CHAPTER 25-PRIYATIZATION OF THE CORPORATION} "SRC. 1501. STRATEGIC PLAN FOR PRIVATIZATION.

"(a) IN GENERAL.W Within 2 years after the transition date, the Corporation shall prepare a strategic plan for transferring owrlerstip of the Corporation to private investors. The Corporation shall revise the plan as needed.

"(b) CONSIDERATION OF ALTERNATIVE MEANS OF TRANSFERRING OWNERSHIP.-The plan shall include consideration of alternative means for transferring ownership of the Corpora. tion to private investors, including public stock offering, private place. ment, or merger or acquisition. The plan may call for the phased transfer of cownership or for complete transfer at a single point of time. If the plan calls for phased transfer of ownership, then-

"(1) privatization shall be deemed to occur when 100 percent of ownership bas been tratsferred to private investors;"

"(2) prior to privatization, stich stock stall be nonvoting stock; and

"(3) at the tinge of privatization, such stock shall convert to roting stock.

(c) EVALUATION AND RECOMMENDATION.-The plan shall evaluate the relative merits of the alternatives considered and the estimated return on the Government's investment in the Corporation achievable through each alternative. The plan shall include the Corpo. ration's recomamendation on its preferred means of privatization.

"(d) TRANSMITTAL_T.he Corporation shall transmit copies of the strategic plan for privatization to the Prestdent and Congress upon corppletion.

42 USC 2297d-1. "SEC. 1502. PRIVATIZATION.

*(a) IMPLEMENTATION-Subsequent to transmitting a plan for privatization pursuant to section 1501, and subject to subsections (b) 
and (c), the Corporation may implement the privatization plan if the Corporation determines, in consultation with appropriate agencies of the-United States, that privatization will-

"(1) result in a return to the United States at least equal to the net present value of the Corporation;

"(2) nof restlt in the Corporation being owned, controlled, or dominated by an alien, a foreiga corporation, or a foreign government; $1 ;$

"(3) not be inimieal to the health and safety of the public or the common defense and security and

"(4) provide reasonable assurance that adequate enrichynent capacity will remain available to meet the domestic electric utility indusery.

(b) REQUIREMENT OF PRESIDENTIAL APPROVAL-The Corporation may not implement the privatization plan without the approval of the President.

"(c) NOTIFICATION OF CONGRESS AND GAO EVALUAMION.-The Corporation shall notify the Congress of its intent to implement the privatization plan. Within 30 days of notification, the Comptrollet General shall submit a report to Congress evaluatiog the extent to which-

"(1) the privatization ptan would result in any ongoing obligation or undue cost to the Federal Government; and

(2) the revemues gamed by, the Federal Government under the privatization plan would represent at least the net present value of the Corporation.

"(d) PERIOD FOR CONORESSIONAL REVIEW.-The Corporation may not implempent the privatization plan less than 60 days after notification of the Congress.

"(e) DEPOSIT OF PROCEEDS.'-Proceeds fron the sale of captta] stock of the Corporation under this section shall be deposited in the general foud of the Treasury.

\section{"CHAPTER 26-AVLIS AND ALTERNATVE TECHNOLOGIES} FOR URANIUM ENRICFMENT

\section{"\$EC. 1601. ASBESSBENT BY UNTTED STATES ENRICHMENT CORPORATTON.}

"(a) IN GENERAL.The Corporation shall prepare an assessment of the economic viability of propeding with the commercialization of AVLIS and alternative technologies for uranium enrictment fo accordance with this chapter. The assessinent sbat include-

"(1) an evaluation of market conditions together with a marketing strategy,

(2) an analysis of the economic viability of competing enrichment technologies;

"(3) an identífication of predeployment and capital require. ments for the commercfalization of AVLIS and alternative .techrologies for uranium enrichment; 
"(4) an estimate of potential earnings from the licensing of AVLIS and alternative technologies for uranium enrichment to a private government sponsored corporation;

"(5) ant anabysis of outstanding and potential patent and related claims with respect to AVLIS and alternative technologies for uranium enrichment, and a plan for resolving such claims; and

"(6) a contingency plan for providing enriched uranium and related services in the event that deploytrient of AVLIS and alteroative technologies for uranium enrichment is determined not to be economically viab]e.

"(b) DETERMINATION BY CORPORATION TO PROCEED WTTH COMMERCIALIZATION OF AVLIS OR ALTERNATIVE TECHNOLOGIES FOR URANIUM ENRICHMENT-The succeeding sections of this chapter shall apply only to the extent the Corporation detentinies in its business judgment, on the basis of the assessment prepared undier subsection (a), to proceed with the commercialization of AVLIS or alternative technologies for unanum enrichument.

$\triangle S E C$. 1602. TRANSFER OF RIGHTS AND PROPERTY TO UNITED STATES ENRICHMENT CORPORATION

"(a) EXCLUSTVE RIGHT TO COMMERCIALIZE.-The Corpo* ration shall have the exclusive contmercial right to deploy and use any AVLIS patents, processes, and technical infommation owned or controlled by the Government, tpon completion of a royalty agreement with the Department.

(b) TRANSFER OF RELATED PROPERTY TO CORPORATION--

"(1) IN GENERAL-TO the extent reguested by the Corporation, the President shall transfer without charge to the Corporation all of the Department's right, title, or interest in and to property owned by the Department, or by the United \$tates but under control or custody of the Department, that is directly related to and materially useful in the performance of the Corporation's purposes tegarding AVIIS and aIternative technsologies for urarium earichinent, jncludtag-

(A) facilities, equipment, and materials for research, development, and demonstration activities; and

"(B) all other facilties, equipment, matertals, processes, patents, technical information of any kind, contracts, agreements, and leases.

“(2) EXCEPTION.-Facilities, real estate, inpropernents, and equipment related to the gaseous ojffustion, and gas centrifuge, uraníum enrichment programs of the Department shall tot transfer under paragraph (1)(B).

(3) EXPIRATION OF TRANSFER AUTHORITY.TTh President's authority to transfier property under this subsection shall expirc upon privatization under section 1502.

"(c) LIABIIITY FOR PATENT AND RELATED CLAIMS,-With respect to any right, titte, or interest provided to the Corporation under subsection (a) or (b), the Corporation shall bave sole liability for any

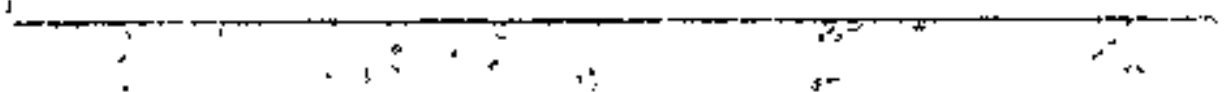


42 USC 2297e-2. "SEC. 1603. PREDEPLOYMENT ACTIVTIES BY UNITED STATES

\section{ENRICHMENT CORPORATION-}

"The Corporation may begin activities necessary to prepare AVLIS or alternative technologies for uranium exrichment for commercialization including-

"(1) completion of preapplication activities with the Nuclear Regulatory Commission;

"(2) preparation of a transition plan to move AVLIS or alteradtive techrologies for ufanium enrictsment from the laboratory to the marketplase;

"(3) confirmation of techyical performande;

"(4) validation of ecomomic projections;

"(5) completion of feesibility and risk studies;

"(6) initiation of preliminary plant design and engineering; and

"(ग) site selection, site characterization, and environmental doeumentation activities on the basis of site evaluations and recommendations prepared for the Department by the Argonne National Laboratory.

42 USC 2297e-3." "SEC. 1604. UNITED STATES ENRICHMENT CORPORATION SPONSORSHIP OF PRIVATE FOR-PROFIT CORPORATION TO CONSTRUCT AVLIS AND ALTERNATIVE TECHNOLOGIES FOR URANIUM ENRICHMENT.

(a) ESTABLISHMENT:-

“(1) IN GENERAL. - If the Corporation determines to proceed with the commercialization of AVLIS or alternative technologies for uraniumenrichment under this chapter, the Corporation may provide for the establishment of a private for-profit corporation, which shall have as its initial purpase the construction of a urantum entichtement facility using AVLIS technology or alteroative technologies for tratuitu emrichment.

"(2) PROCESS OF ORGANIZATION,-For purposes of the establishment of the private corporation under paragraph (1), the Corporation shall appoint not less' than 3 persons to be incorporators. The incorporators so appointed shall each sign the articles of incorporation and shall serve as the initial board of directors until the members of the Ist regular board of directors shall have been appointed and elected Such incorporators shall take whatever actions are mecessary or appropriate to establish the private corporation, tncluding the filing of articles of incorporation in such juristiction as the incorporators determine to be appropriate. The incorporators shall also develop a plan for the issuance by the private corporation of woting combron stock to the public, which plan shall be subject to the approval of the Secretary of the Treasury.

(b) LEGAL STATUS OF PRIVATE CORPORATION- 
“(1) NOT FEDERAL AGENCY.-The private corporation established under subsection (a) shall not be an agency, instrumentality, or establishment of the United States Government and shall not be a Govemment corporation of Gowernment controlled corporation.

(2) NO RECOURSE AGAINST UNITED STATES,-OObligg tions of the private corporation established under subsection (a) shall not be chligations of, or guaranteed as to principal or interest by, the Corporation or the United States, and the obligations shall so plaityly state.

“(3) NO CLAIMS COURT JURISDICTION_-NO action Under section 1491 of titse 28, United States Code, shall be allowable against the United States based on the actions of the private cotporation established under subsection (a).

"(c) TRANSACTIONS BETWEEN UNITED STATES ENRICHMENT CORPORATION AND PRIVATE CORPORATION;-

(1) GRANTS FROM USEC.-The Corporation may make gramts to the private corporation established under sibsection (a) from antounts avalable in the AVLIS Cornmercialization Fynd. Such grants shall be used by the private corporation to carry out any remaining predeployment activity assigned to the private corporation by the Corporation. Such grants may not be used for the costs of constructing an AVLIS, or alternative technologies for uranium emrichment, production facility or engaging in disectly related preconstruction activities (other than such assigned predeployment activities). The aggregate amount of such grants silal] not exsced $\$ 364,000,000$.

"(2) LICENSING AGREEMENT-The Corporation shall license to the private oorporation estabtished upder subsection (a) the rights, titles, and interests provided to the Corporation under section 1602. The licensing agreement shall require the private corporation to make periedic payments to the Corporation in an amount that is not less than the aggregate amounts paid by the Comporation during the period involved under subsections (a) and (c) of section 1602 .

(3) PURCHASE AGREEMENT.-The Corporation may enter into a commitment to purchase all enriched uranium produced at an AVLSS, or alternative technologies for uraniam enrichment, facility of the private corporation established under subsection (a) at a price aegotiated by the 2 corporations that- -

"(A) provides the private corporation with a reasonable re-

turn on its irvestment; and

(B) is less costly than enricked uranium available from other sourtes.

“(4) ADDITIONAL ASSISTANCE.-The Comporation may provide to the private corporation estabtished under subsection (a), on a reimburstable basis, such additional personnel, services, and equipment as the 2 corporations may determine to be appropriate. 
"SEC. 1605. AVLIS COMMERCIALIZATION FUND WTHIN UNITED STATES ENRICHMENT CORPORATION.

“(a) ESTABLISHMENT. - The Corporation may establish within the Corporation an AVLis Commericialization Fund, which shail consist of nat mote than $\$ 364,000$,000 paid into the Fund by the Corporation from amounts provided in appropriation Acts for such purposes and from the retained earnings of the Corporation.

“(b) EXPENDITURES FROM FUND.-Amoonts in the AVLIS Commercialization Fund shalt be available for-

"(1) expenses of the Corporation in preparing the assessment under section 1601; , '

(2) expenses of predeployinent activities under section 1603; and

“(3) grants to the private corporation under section 1604 ,

“(c) LIMITATIONS.-

“(1) EXCLUSIVE SOURCE OF FUNDS.-The Corporation may not incur any obligation, or expend any amount, with respect to AVLIS or alternative technologies for uranium enrictment, except from amounts available in the AVLIS Commercialization Fund.

“(2) UNAVAIL ABLE FOR CONSTRUCTION COSTS.-No amount may be used from the AVLIS Commerctalization Fund for the costs of conistructing an AVLIS, or alternative tectunologies for uranium enrichment, production facility or engaging in directly related preconstruction activities (other than activities specified in subsection (b) .

“(d) AUTHORIZATION OF APPROPRIATIONS,-There is authorized to be appropriated $\$ 364,000,000$ from the Uranium Errichment Special Fund for purposes of this section.

"(e) COST REPORT-On the basis of the assessment under section 1601 (a) (3), the Corporation shal] submit to the Congress a report on the capital requirenents for commercialization of AVLIS.

$\$ 2$ USC 2297e-5. "SEC. 1606. DEPARTMENT RESEARCH AND DEVELOPMENT ASSISTANCE.

"If requested by the Corporation, the Secretary shatl provide, on a reimbursab]e basis, research and development of AVLis and alternative technologies for uranjum enrichment.

42 USC 2297e-6. "SBC. 1607. SIFE SELECTION.

"This chapfer shall not prejudice consideration of the site of an existing uranium enrichment facilty as a candidate site for future expansion or replacement of uranium emrichument capacity through AVLIS or alterative techuologits for uranium enrichiment Selection of a site for the AVLIS, or alternative technologies for uranium enrichnentt, facility shall be made on a competitive basis, taking into consideration econoraic performance, environmental compatibility, and use of any existing uranium enrichment facilities.

42 USC 2297e-7. “SEC. 1608. EXCLUSION FROM PRICE-ANDERSON CONERAGE. "Section 170 shall not apply to any license under section 53, 63, or 103 for a uranium enrichment facility constructed after the date of the enactment of this title". 


\section{"CHAPTER 27-LICENSING AND REGULATION OF URANIUM ENRJCHMENT EACILITYES}

\section{"SEC 170t. GASEOUS DIFFUSION FACILITIES}

"(a) ISSUANCE OF STANDARDS. - Within 2 years after the date of the enactment of this titte, the Nuclear Regulatory Commission shall establish by regulation such standards as are necessary to govern the gaseous diffusion uranium enrichment facilities of the Department in order to protect the public health and safety from radiological hazard and provide for the conyon defense and security. Regulations promulgated pursuant to ehis stubsection shall, among other things, require that adeguate safteguards (within the meaning of section 147) are in place.

"(b) ANNUAL REPORT-

*(1) IN GENERAL.-The Nuclear Regulatory Commission in consultation with the Department and the Environmental Protecton Agency, shall report at least annually to the Congress on the status of health, safery, and environmental conditions at the gascous Giffusion uranium entichement facilities of the Depardatent.

"(2) REQUIRED DETERMINATION. - Such report shall include a derenmination regarding whether the gaseous diffusion uranium entichment facilities of the Department are in compjiance with the stardards established under subsection (a) and all applicable laws.

"(c) CERTIFICATION PROCESS.-

"(I) ESTABLISHMENT.-The Nuclear Regulatory Commission shall establish a certification process to ensure that the Corporation complies with standards established under subsection (a).

"(2) PERIODIC APPLICATION FOR CERTIFICATE OF COMPLIANCE.The Corporation shall apply to the Nuclear Regulatory Conmission for a certificate of compliance under paragraph (I) perioctically, as determined by the Comuissiont, but not less than every 5 years. The Coramission shall review any such application and any determination made under subsection (b)(2) shall be based on the results of any such review.*

"(3) TREATMENT OF CERTIFICATE OF COMPLIANCE.-The requirement for a certificate of compliance under paragraph (1) shall be in lieu of any requirement for a license for any gaseous diffusion facility of the Department leased by the Corporation.

\section{"(4) NRC REVIEW-}

(A) IN GENERAL-The Nuclear Regulatory Commission, in consultation with the Enviranmental Pratection Agency, shall review the operations of the Corporation with respect to asy gaceous diffusion uranium enrichment facilities of the Department leased by the Corporation to enstre that public bealth and safery are adequately protected.

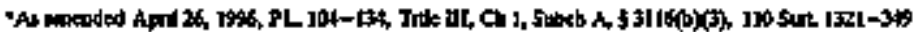


(B) ACCESS TO FACILITIES AND INFORMATION.The Corporation and the Department shall cooperate fully with the Nuclear Regulatory Commission and the Environmental Protection Agency and shall provjde the Nuclear Regulatory Commission and the Environmental Protection Agency with the ready access to the facilities, persongel, and informaiton the Nuclear Regulatory Commission and the Environmental Protection Agency consider necessary to carry out their responsibilities under this subsection. A contractor operating a Corporation facility for the Corporation shall provide the Nuclear Regulatory Conamission and the Environmental Protection Agency with ready access to the facilities, personnel, and information of the contractor as the Nuclear Regulatory Commission and the Environmental Protection Agency consider necessary to carry out their responsibilities under this subsection.

"(C) LIMITATION.-The Nuclear Regulatory Commission ' shall limit its finding under subsection (b)(2) to a determination of whefher the facilities are in compliance with the stardards established under'súbsection (a).

"(d)REQUIREMENT FOR OPERATION.-The gaseous diffusion uranium eratchment facilities of the Department may not be operated by the Corporation unless the Nuclear Regulatory Commission, in cor sultation with the Ervironmental Protection Agency, makes a determination of conspliance under subsection (b) or approves a plan prepared by the Department for achieving compliance required under subsection (b).

42 USC 22976-1. "SEC 1702, LICENSING OF OTHER TECHNOLOGIES.

(a) IN GENERAL, - Corporation faxilities using alternative technologies for uranium enrichment, including AVLIS, shall be licensed under sections 53,63 , and 193:*

(b) 'COSTS FOR DECONTAMINATION AND DECOMMISSIONING,-The Corporation shall provide for the costs of decontamination and decommissioning of any Corporation facilities described in subsection (a) in actordance with the requirements of the imendurents made by section 5 of the Solar, Wind, Waste, and Geothermal Power Production Act of 1990.

42 USC 22976-2, "SBC. 1703. REGULATION OF RESTRICTED DATA.

"The Corporation shali be subject to this Act with respect to the use of, or access to, Restricted Data to the same extent as any private corporation.

42 USC2297g.

"CHAPTER 28-DECONTAMINATION AND DECOMMISSIONING "SEC. 1801. URANIUM ENRICHMENT DECONTAMINATION AND DECOMMISSIONING FUND

"(a) ESTABLISHMENT.-There is establisited in the Treasury of the United States an account to be known as the Uranium Enrichment

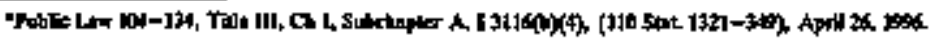


Decontamization and Deconnmissioning Fund (referred to in this chapter as the 'Fund'). The Fund, and any amounts deposited in it, including any interest earned thereon, shall be avaitable to the Secretary subject to appropitations for thit exclustive purpose of carrying out this cilapter.

"(b) ADMINISTRATION,-

"(1) IN GENERAL,-The Secretary of the Treasury shall hold the Fund and, after consultation with the Secretary, annually report to the Congress on the financial sondition and operations of the Fund during the preceding fiscal year.

"(2) INVESTMENTS.-The Secretary of the Treasury stall invest amounts contained within the Fund in objigations of the United State-

"(A) having maturities deteruined by the Secretary of the Treasury to be approprate for what the Department determines to be the needs of the Fund; and

"(B) bearing interest at rates determined to be appropriate by the Secretary of the Treasury, taking into consideration the current average market yield on outstanding marketabte ob. ligations of the United States witt remaining periods to mattrity comparable to these obligations.

42 USC 2297g-1.

"SEC. 1802. DEPOSITS.

(a) AMOUNT.-The Fund shall consist of deposits in the anount of $\$ 480,000,000$ per fiscal year (to be annually adjusted for inflation using the Consumer Price Index for all-urban consumers published by the Department of Labor) as provided in this section.

- (b) SOURCE-Deposits described in subsection (a) shall be from the following sources:

(1) Sutns collected putsuant to subsection (c).

"(2) Appropriations made pursuant to stbsection (d).

"(c) SPECIAL ASSESSMENT.-The Secretary shall collect a special assessinent from domestic utijties. The total amount collected for a fiscal year shall not exceed $\$ 160,000,000$ (to be annually adjusted for inflation using the Consumer Price Index for all-urban consumers published by the Departuent of Labor). The amount collected from each utility pursuant to this subsection on for a fisceal year shall be in the same ratio to the amount required under subsection (a) to be deposited for such fiscal year as the total amount of separative work urits such utility has purchased from the Department of Energy for the purpose of commercial electrictity generation, before the date of the enactsont of this title, bears to the total amount of separative work units purchased from the Department of Energy for all purposes (including units purchased or produced for defense purposes) before the date of the enactment of this title. For purposes of this subsection-

"(1) a utlity shall be considered to have purchlased a separative work unit from the Department if such separative wotk unit was produced by the Departrment, but purchased by the utility from another source; and

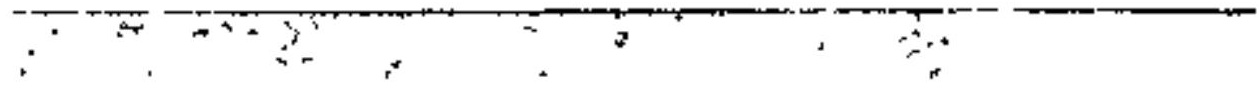


"(2) a utility shall not be considered to have peurchased a stparative work unit from the Departaent if such separative work unit was purchased by the utility, but sold to another source.

"(d) AUTHORIZATION OF APPROPRIATIONS.-There are authorized to be approptiated to the Fund, for the period encompassing 15 years after the date of the enactment of this title, such sums as are necessary to ensure that the amount required under subsection (a) is deposited for each fiscal year.

"(e) TERMINATION OF ASSESSSMENT'S.-The eollection of amoun's under subsection $(c)$ shal cetase after the earlier of -

"(1) I6 years after the date of the enactiont of this title; or

(2) the collection of $\$ 2,260,000,000$ (to be annually adjusted for inflation twing the Consumer Price Index for all-urban consumers publisted by the Departronent of Labor) wnder such subsection.

"(f) CONTINUATION OF DEPOSITS.--Except as provided in subsection ( $c$ ) deposits shalr'continue to be made into the Fund under subsection (d) for the period specifed in such subsection.

"(g) TREATMENT OF ASSESSMENT-Any special assessment levied under this section on domestic utilities for the decontamination and decommissioning of the Department's gaseous diffusion enrichment facilities shall be decried á necessary ánd reasonable current cost of fuel and shall be fully recoverable in rates in all jurisdictions in the same manner as the utility's ofther futel cost.

SEC. 1903. DEPARTMIENT FACILITIES

"(a) STUDY BY NATIONAL ACADEMY OF-SCIENCES-TTe National Acaderny of Sciences shall conduct a study and provide recommendations for reducing cests associated with decontamination and decommissioning, and shall report its fincings to the Congress within 3 years after the date of the enactment of this title. Such report shall intlude a determination of the decontamination and decomunissioning reguired for each facility spall identify alternative methods, using different technologies, shall indude sit-specific, surveys of the actual contamination, and shall provide estimated costs of those activities.

"(b) PAYMENT OF DECONTAMINATION AND DECOMMISSIONING COSTS.-The costs of all decontamination and decommissioning activities of the Department shall be patd from the Fund until such timie as the Secretary certifies and the Congress concurs, by law, that stich activities are corpplete,

"(c) PAYMENT OF REMEDIAL ACTÍON COSTS,-The annual cost of remedial 'action at the Departinent's gaseduis diffusion facilities shall be paid from the Fund to the éxtent the amount available in the Fund is sufficient. To the extent the amount in the Fund is insufficient, the Department strall be responsible for the cost of remedial action. No provision of this title may be construed to relieve in any way the resporssibility or liability of the Department for remedial action under applicable Federal and State laws and regulations.

42 USC 22978-3. “SEC. 1804. EMPLOYEE PROVISIONS.

"All laborers and mechanics employed by contractors or subcontractors in the performance of decontamination or decommissioning of uranium enrichment facilities of the Department shall be paid wages at 
rates not less than those prevailing on projects of a similar character in the locality as determined by the Secretary of Labor in accordance with the Act of March 3, 1931 (known as the Davis-Bacon Act) (40 U.S.C. 276a et seg. +. The Secretary of Labor shall bave, with respect to the labor standards specified in thits section, the authority and functions set forth in Reorganization Plan Numbered 14 of 1950 (15 F.R. 3176, 64 Stat. 1267) and the Act of June 13, 1934 (40 U.S.C. 276c). This section may not be construed to require the contracting out of activities associated with the decontamination or decommissioning of uranium enrichment facilities.

42 USC 2297\%.4. "SEC. 1805. REPORTS TO CONGRESS.

"Within 3 years after the date of the enactment of this title, and at least once every 3 years thereafter, the Secretary shall report to the Congress on progress under this chapter. The Sth report submitted under this section shall contain recommendations of the Secretary for the reauthorization of the program and Fund under this title. 
TITLE III-RESCISSIONS AND OFTSETS**

CHAPTER 1-FWNERGY AND WATER DEVRLOPMENT URANIUM ENRICHMENT CAPACITY

SUBCHAPTER A-TMTTED STATES KNAICHMENT CORPORATION

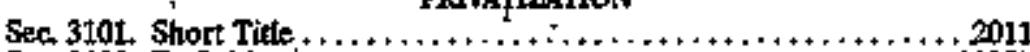

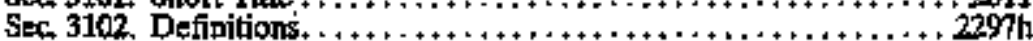

Sec. 3103. Sale of the corporation. ..................., 2297h-1

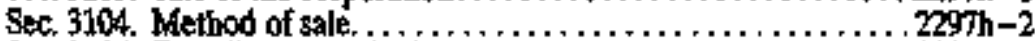

\$ec \$105. Estabtishment of private corporation $+\ldots \ldots+\ldots \ldots \ldots+.2297 \mathrm{~h}-3$

Sec 3106 . Transfers to the private corporation............2297h-4

Sec 3107 . Leasing of gaseous diffision facilities $\ldots+\ldots+\ldots+\ldots \ldots+2297 \mathrm{~h}-5$

Sec. 3108. Transfer of contracts. . . . . . . . . . $\ldots \ldots \ldots+\ldots+\ldots 2297 \mathrm{~h}-6$

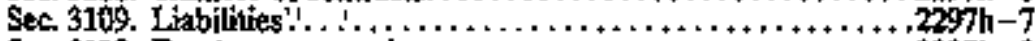

Sec 3110 . Employee protections. . . . . . .

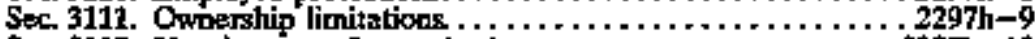

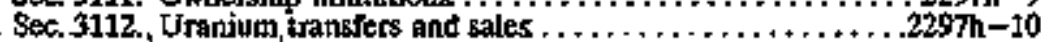

Sec. 3113. Low-level waste. . . . . . . . . . . . . . . . . . . 2297h-11

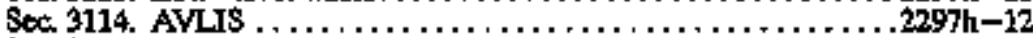

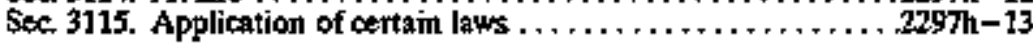

USEC

Privatization Act.

42 USC 2011

note

42 USC 2297h
TTTLE III-RESCISSIONS AND OFFSETS*

\section{CHAPTER 1-ENERGY AND WATER DEVELOPMENT}

URANIUM ENRICEMIENT CAPACITY

SURCFAPTER A-UNITED STATES ENRTCHMENT CORPORATION PRTYATIZATION

\section{SEC. 3101. \$HORT 'TTLE.}

This subchapter may be cited as the "USEC Privatization Act".

SEC. 3102. DEFINITIONS.

For purposes of this subchapter:

(1) The term "AVLIS" means atornic vapor laser isotope separation technology.

(2) The term "Corporation" means the United States Enrichment Corporation and, unless the tontext otherwise r $\leftarrow$ quir $\$ s_{4}$ includes the private corporation and any strecessor thereto following privatization.

(3) The term "gaseous diffusion plants" means the Paducah Gaseous Diffusion Plant at Paducah, Kentucky and the Portsmouth Gasenus Diffusion Plant at Piketon, Ohio.

(4) The term "highly enriched uranium" means uranium enriched to 20 percent or more of the urarium-235 isotope.

(5) The term "low-enriched urantum" means uranium enriched to less than 20 percent of the uranium-235 isotope, including that which is derived from highly enriched uranium.

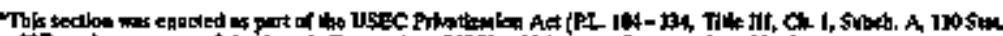

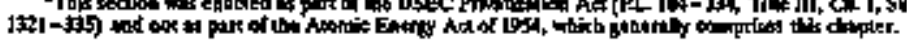


(6) The term "low-level radioactive waste" has the meaning given such term in section 2(9) of the Low-Level Radjoactive Waste Policy Aet (42 U.S.C. 2(121b(9)).

(7) The term "pritate corporation" Intears the corporation established under section $\$ 105$.

(8) The term "prtvatization" means the transfer of ownership of the Corporation to private investors.

(9) The term "privatization date" means the date on which 100 percent of the ownership of the Corporation has been transfersed to private infestors.

(10) The terra "public offerites" means an underwritten offering to the publis of the cormmon stock of the private corporation pursuasit to section 3104.

(11) The "Russian HEU Agreement" means the Agreement Between the Gowesurnent of the United States of America and the Goverament of the Russian Federation Concerining the Disposition of Highly Enriched Uranium Extracted from Nuclear Weap. ons, dated February 18, 1993.

(12) The term "Secretary" means the Secretary of Energy.

(13) The "Suspension Agreentent" means the Agreement to Susperd the Antichuping Investigation on Urarium from the Russtan Federātion, as amended.

(14) The term "vranium enrichment" means the separation of uranium of a given isotopic content into 2 components, 1 haviug a higher percentage of a fissile isotope and 1 having a lower percentage.

42 USC 2297t-1. SRC. 3103. SALE OF THE CORPORATION.

(a) Authorization,-The Board of Ditectors of the Corporation, with the approwal of the Secretary of the Treasury, shall transfer the interest of the United States in the United States Envichrient Corporation to the private sector in a manner that provides for the Iong-term viability of the Corporation, provides for the centinuation by the Corporation of the operation of the Department of Energy's gaseous diffusion plants, provjides for the protection of the public jpterest in maintaining a reliable and economical domestic source of uranium mining, enrichment and conversion services, and, to the extent not inconsistent with such purposes, secures the naximum proceeds to the United States.

(b) Proceeds.-Proceeds from the sale of the United States' interest in the Corporation shall be deposited in the general fund of the Treasury.

42 USC 2297h-2. SEC. 3104. METHOD OF SALE.

(a) Authorization.-The Board of Ditectors of the Corporation, with the approval of the Secretary of the Treasury, shall transfer ownership of the assets and obligations of the Corporation to the private corporation established under section 3105 (which may be constrmmated through a teerger or consolidation effected in acoordance with, and having the effects provided under, the law of the State of incorporation of the private corporation, as if the Corporation were incorporated thereunder).
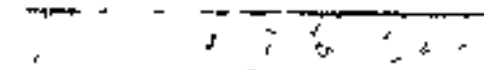

$$
\therefore
$$


(b) Boerd Determination-The Board, with the approval of the Secretary of the Treasury, shall select the-method of transter and establish terms and conditions for the transfer that will provide the maximum proceds to the Tteasury of the United States and will provide for the long-term viability of the private corporation, the continued operation of the gaseous diffusion plants, and the public interest in maintaining seliable and economical domestic uranium mining and enrichment industries.

(c) Adequate Proceeds.-The Secretary of the Treasury shall not allow the privatization of the Corporation unless before the sale date the Secretary of the Treasury determines that the method of transfer Will provide the maximaga proceteds to the Treasury consistent with the principles set forth in section 3103(a).

(d) Application of Securitios Laws,-Any offering or salc of securtities by the private corporation shall be subject to the Secturities Act of 1933 (15 U.S.C. 77a et seq), the Securities Exchange Act of 1934 (15 U.S.C. 78 a et seq.), and the provisions of the Constitution and laws of any State, terpitory, or possession of the United States rejating to transactions in securities.

(e) Expenses, - Exponses of putratization shall be pajd from Conporation revenue accounts in the United States Treasury.

42 USC 2297h-3. SEC. 3105. ESTABLISHMENT OF PRIVATE CORPORATION.

(a) Incorporation.-(1) The directors of the Corporation shall establish a private for-profit corporation under the laws of a State for the purpose of receiving the assets and obligations of the Corporation at privatization and continuing the business operations of the Cotporation following privatization.

(2) The ditectors of the Corporation may serve as tincorporators of the private corporation and shall take all steps necessary to establish the private corporation, including the filing of artieles of incorporation consistent with the provistons of this subchapter.

(3) Employees and officers of the Corporation (including menbers of the Board of Directors) acting in accordance with this section on befalf of the private conporation shall be deemed to be acting in their official capacities as employees or officers of the Corporation for purposes of section 205 of title 18, United States Code.

(b) Status of the Private Corporation.-(1) The private corporation shali not be an agency, instrumentality, or establishment of the United States, a Goverament corporation, or a Government-controlled corporation.

(2) Exceept as otherwise provided by this subchapter, financial obligations of the private comporation shall not be obligations of, or guaranteed as to principal or interest by, the Corporation or the United States, and the obligations shall so plainly state.

(3) No action under section 1491 of title 28, United States Code, shat be allowabie against the United States based on actions of the private corporation. 
(c) Application of Post-Governnent Employment Restrictions.-Beginning on the privatization date, the restrictions stated in section 207 (a), (b), (c), and (d) of title 18, United States Code, shall not apply to the acts of an individual done in carying out official duties as a director, afficet, or enployee of the mivate corporation, if the individual was an afficer or enployes of the corporation (including a director) continuously during tine $\mathbf{4 5}$ days prior to the privatization date.

(d) Dissolution.-In the event that the privatization does not occur, the Corporation will provide for the dissolution of the private corporation within 1 year of the private corporation's incorporation unless the Secretary of tie Treasury or his delegate, upon the Corporation's request, agrees to delay any such dissolution for an additional year.

42 USC 2297h-4. SEC. 3106. TRANSFERS TO THE PRIVATE CORPORATION.

Concurrent with privatization, the Corporation shall transfer to the private corporation-

(1) the lease of the gaseous diffusion plants in accordance with section 3107,

(2) all personal property and inventories of the Corporation,

(3) all contracts, agreements, and leases under section 3108(a),

(4) the Corporation's right to purchase power from the Secretary under section 3108 (b),

(5) suct funds in accounts of the Corporation held by the Trea. stiry or on deposit with any bank or other financial institution as approved by the Secretary of the Treasury, and

Records.

(6) all of the Corporation's records, including all of the paptrs and of her documentary naterials, regardless of physical form or characteristics, made or teceived by the Corporation.

42 USC 2297h-5, \$EC. 3107. LEASING OF GASEOUS DIFHUSION FACILITIES.

(a) Transfer of Lease.-Concurrent with privatization, the Corporation shall transfer to the private comporation the lease of the gaseous diffusion plants and related property for the remainder of the term of such lease in accordance with the terms of such tease.

(b) Renewal.-The private corporation shall bave the exclusive option to lease the gaseous diffusion plants and related property for additional periods following the expiration of the initial term of the lease.

(c) Exclusion of Facilities for Production of Highly Earicied Uranium.-The Secretary shall not lease to the private corporation any' facilities nexessary for the production of highly enriched uranjum but may, stabject to the reguirements of the Atomic Energy Act of 1954 (42 U.S.C. 2011 et seq.), grant the Corporation access to such facilities for purposes other than the production of highly enriched uranturn.

(d) DOE Responsibility for Preexisting Condjtions. -The payment of any costs of decontamintation and decommissioning, response actions, or corrective actions with respect to conditions existing before July 1, 1993, at the gaseous diffision plants shall remain the sole responsibility of the Secretary.

(e) Environmental Audit-For purposes of subsection (d), the conditions existing before July 1, 1993, at the gaseous diffusion plants shall be 
determined from the environmental audit conducted pursuant to section 1403(e) of the Atomic Energy Act of 1954 (42 U.S.C. 2297c-2(e)).

(f) Treatment Under Price-Anderson Provisions-Any lease exencuted between the Secretary and the Corporation or the private corporation, and any extension or renewal thereof, utider this section shall be deemed to be a contract for purposes of section 170d. of the Atornic Energy Act of 1954 (42 U.S.C. 2210(d)).

(g) Waiver of EIS Requirement--The execution or transfer of the lease between the Secretary and the Corporation or the private corporation, and any extension or renewal thereof; shal\} not be coasidered to be a major Federal action significantly affecting the quality of the human environment for purposes of section 102 of the National Environmental Policy Act of 1969 (42 U.S.C. 4332).

42 USC 2297h-6. SEC. 3108. TRANSFER OF CONTRACTS.

(a) Transfer of Contracts.-Concurrent with privatization, the Corporation shall transfer to the private corporation all contracts, agreements, and leases, inchuding all uranium efrichment contracts, that were-

(1) transferred by the Secretary to the Corporation pursuant to section 1401(b) of the Atomic Energy Act of 1954 (42 U.S.C. $2297 \mathrm{c}(\mathrm{b})$ ), or

(2) entered into by the Corporation before the privatization date.

(b) Nontransferable Power Contracts. - The Corporation sha!l transfer to the pirivate corporation the right to purchase power from the Secretary under the power pirchase contracts for the paseous diffision plants executed by the Secretary before July 1, 1993. The Secretary shall continue to receive power for the gaseous diffuston plants under stuch contracts and shall continue to resell such power to the private corporation at cost during the term of such contracts.

(c) Effect of Iransfer--(1) Notwithstanding subsection (a), the United States shall remain obligated to the parties to the contracts, agreements, and leases transferred under subsection (a) for the performance of its obligations under such contracts, agreements, or leases during their terms. Performance of such obligations by the private corporation shalt be considered perfarmance by the Untted States.

(2) if a contract, agreement, or lease transfersed under subsection (a) is terminated, exteaded, of materially amended after the paivatization date-

(A) the private corporation shall be responsible for any obligation aising under such contract, atgreement, or lease after any extension or material amendment, and

(B) the United Stater shall be responsible for any obligation arising under the contract, ageement, or lease before the termination, extenston, or material amendment.

(3) The private corporation shall rejmburse the United States for any amount paid by the United States under a settlement agreement entered into with the consent of the private corporatoon or under a judgment, if the settlement or judgment- 
(A) arises out of an obligation under a contract, agreement, or lease transferred under subsection (a), and

(B) arises out of actions of the private corporation between the privatization date and the date of a termination, extension, or material amendment of such contract, agreement, or lease. (d) Pricing.-The Corporation may establisí prices for its products, materials, and services provided to customers on a basis that will allow - it to attain the normal business abjectives of a probit making corporation.

42 USC 2297h-7. SEC. 3109. LIABILITIES.

(a) Liability of the United States -

(1) Except as otherwise provided in this subchapter, all liabilities arising out of the operation of the uranium enrichment enterprise before July 1, 1993, shall remain the direct liabilities of the Secretary.

(2) Except as provided in subsection (a)(3) or otherwise provided in a memorandum of agreement entered into by the Corporation and the Office of Management and Budget prior to the privatization date, all liabilities arising out of the operation of the Corporation between July 1, 1993, and the privatization date shall remain the direct liabilities of the United States.

(3) All liabilities aristing out of the disposal of depleted uranium teperated by the Corporation between Jaty 1, 1993, and the privatization date shall become the direct liabitities of the Secretary.

(4) Any stated or implied consent fot the United States, or any agent or officer of the United States, to be sued by any person for any legal, equitable, or other relief with respect to any chajor arising from any action taken by any agent or officer of the United States is connection with the privatization of the Corporation is bereby witboirawn.

(5) To the extent that any claim agatnst the United States under this section is of the type otherwise required by Federal statute or regulation to bepresented to a Federal agency or official for adju- dication or review, such claim shall be presented to the Department of Energy in sccordance with procedures to be established by the Secretary. Nothing in this paragraph shall be construed to impose on the Department of Energy liability to pay any claisn presented purstant to this paragraph.

(6) The Attorney General shall represent the United States in any action seektog to impose liability under this subsection.

(b) Liability of the Comporation-Notwithstanding any provistion of any agrement to whith the Cotporation is a party, the Corporation shall not be considered in breach, default, or violation of any agreement because of the transfer of such agreement to the private corporation under section 3108 or any other action the Corporation is required to take under this subchapter.

(c) Liabilty of the Private Corporation,-Except as provided in this subchapter, the privale corporation shall be liable for any ltabilitites arising out of its operations after the privatization date.

(d) Liability of Officers and Directors.- 
(1) No officer, director, employee, or agent of the Corporation shall be liable in any civil proceeding to any party in conmection with any action taken in connection with the privatization if, with respect to the subject matter of the action, suit, or proceeding, such person was acting within the scope of his employarent.

(2) This subsection sball not apply to claims arising under the Securities Act of 1933 (15 U.S.C 77a. et seg.), the Securities Exchange Act of 1934 (15 U.S.C.78a. etseq-), or under the Constitution or laws of any State, territory, or possession of the United States relating to transactions in securities.

42 USC 2297h-8, SEC. 3110. EMPLOYER PROTECTIONS.

(a) Contractor Employees.-

(1) Privatization shall not diminish the accrued, vested pension benefits of employees of the Corporation's operating contractor at the two gaseous diffirsion plants.

(2) In the event that the private corporation terminates or changes the contractor at either or both of the gaseous diffusion plants, the plan sponsor or other appropriate fiduciary of the pension plan covering employees of the prior operating contractor shall artange for the transfer of all plan assets and liabilities relating to accried pension benefits of such plan's participants and beneficiaries from such plant to a pension plan sponsored by the new coutractor or the private corporation or a joint labor-manage. ment plan, as the sase by

(3) In addition to any obligations arising under the National Labor Relations Act (29U.S.C. 151 et seq), any employer (includIng tite private corporation if it operates a gaseous diffusion plant without a contractor or any contractor of the private corporation) at a gasecous diffiustion plant shall-

(A) abide by the terms of any unexpired collective bargaining ageement covering employees in bargaining units at the piant and in effect on the privatization date until the stated expira. ton or termination date of the agreement; or

(B) in the event a collective bargaining agreement is not in effect upon the privatization date, have the same bargaining obligations uncter section 8(d) of the National Labor Relations Act (29 U.S.C. 158(d)) as it had inmediately before the privatization date.

(4) If the private corporation replaces its operating contractor at a gaseous diffusion plant, the new employer (including the new contractor or the private corporaton it it operatos a gascous diffusion plant without a contractor) shall-

(A) offes employment to non-management enployees of the predecessor contractor to the extent that their jobs still exist or they are qualified for new jobs, and

(B) abide by the terws of the predecsssor contractor's collective bargaining agreement until the agreement expires or a new agreement is signec. 
(5) In the event of a plant closing or mass layoff (as such terms are defined in section 2101(a) (2) and (3) of title 29, United States Code) at either of the gaseous diffusion plants, the Secretary of Energy shall treat any adversely affected employee of an operating contractor at either plant who was an employee at such plant on July 1, 1993, as a Department of Energy employee for purposes of sections 3161 and 3162 of the National Defense Authorization Act for Fiscal Year 1993 (42 U.S.C. 7274h-7274t).

(6)(A) The Secretary and the private corporation shall cause the post--Tetirement health benefits plan provider (or its suc. cessor) to continue to provide-benefits for eligible persons, as described under subparagraph (B), employed by an operating contractor at either of the gaseous diffusion plants in an economically efficient manner and at substantially the same level of coverage as eligible tetirees are entitled to receive on the privatization date.

(B) Persons eligible for cowerage under subparagraph (A) shall be limited to:

(j) persons who retired from active employment at one of the gaseous diffusion plants on or before the privatization date as vested participants in a pension plan maintatued either by the Corporation's operating contractor or by a contractor enployed prior to July 1, 1993, by the Department of Enersy to operate a gaseous diffusion plant; and

(ii) persons who are employed by the Corporation's operating contractor on or before the privatization date and are vested participants in a pension plan maintained either by the Corporation's operating contractor or by a contractor employed prior to July 1, 1993, by the Department of Enery to operate a gaseous diffusion plant.

(C) The Secretary shall fund the entire cost of post-retirement health benefits for persons who retired from employment with an operating contractor prior to Jutly 1, 1993.

(D) The Secretary and the Corporation shall fund the cost of post-retirement health beneîts for persons who retite from employment with an operating contractor on or after July 1 , 1993 , in proportion to the retired person's years and months of service at a gaseous diffusion plant under their respective management.

(7)(A) Any suit under this subsection alleging a violation of an agreement between an employer and a labor organization shall be brought in accordance with section 301 of the Labor Management Relations Act (29 U.S.C. 185).

(B) Any charge under this subsection alleging an unfair labor practice violative of section 8 of the National Labor Relations Act (29 U.S.C. 158) shall be pursued in accordsnce with section 10 of the National Labor Relations Act (29 U.S.C. 160).

(C) Any suit alleging a violation of asty provision of this subsection, to the extent it does not allege a viotation of the National Labor Relations Act, may be brought in any district 
court of the United States having jurisdiction over the parties, without regard to the amount in controversy or the citizenship of the parties.

(b) Former Federal Employets-(I)(A) An employee of the Corporation, that was subject to either the Civil Service Retirement System (referred to in this section as "CSRS") or the Federal Employees' Retirement System (referred to in this section as "FERS") on the day immediately preceding the privatization date shall elect-

(i) to retain the employee's coverage under either CSRS or FERS, as applicable, in lietu of coverage by the Corporation's retirement-system, or

(ii) to receive a deferred annuity or iump-sum benefit payable to a terminated employee upder CSRS or FERS, as applicable.

(B) An enployee that makes the election under subparagraph (A)(ii) shall bave the option to transfer the balance in the employee's Thrift Savings Plan account to a defined contribution plan, under the Corporation's retirement system, consistent with applicable law and the terms of the Corporation's defined contribution plan.

(2) The Corporation shall pay to the Civil Service Retirement - and Disability Fund-

(A) such employee deductions and agency contributions as are required by sections 8334,8422 , and 8423 of title 5 , United States Code, for those employees who elect to retain their coverage under either CSRS or FERS parsuant to paragraph (1);

(B) such additional agency contributions as are deteruined necessary by the Office of Persornel Management to pay, in combination with the sums under subparagraph (A), the "normal cost" (determined using dynamic asstrmptions) of tetirement benefits for thase employes who elect to retain their coverage under CSRS pursilant to paragreph (1), with the concept of "tormal cost" bejng used consistent with generally ascepted actuantal standards and principles; and

(C) such additional amounts, not to exceed two percent of the amounts under subparagraphs (A) and (B), as are determined necessary by the Office 'of Personnel Management to pay the cost of administering retirement besefits for etrployecs who retire from the Corporation after the privatization date under either CSRS or FERS, for thuir survivors, and for survivors of employees of the Corporation who die after the privatization date (which amounts shali be available to the Office of Personnel Management as provided in section 8348(a)(1)(B) of title 5, United States Code).

(3) The Corporation shall pay to the Thrift Savings Fund such employee and agency contributions as are required by section 8432 of title 5, United States Code, for those employees who elect to retain thoir coverage under FERS pursuant to paragraph (1).

\lrcorner (4) Any employe of the Corporation who was subject to the Federal Enoployee Health Benefits Program (referred to in this 
section as "FEHBP") on the day inmediately preceding the privatization date and who elects to retain coverage under either CSRS or FERS purstant to paragraph (1) shall hawe the option to receive heatth benefits from a health beneilt plan established by the Corporation or to continue without interruption coverage under the FEHBP, in lien of coverage by the Cotporation's health benefit system.

(5) The Corporation shall pay to the Employees Health Bepefits Fund-

(A) such enployee deductions and agency contributions as are recuired by section 8906 (a) -(f) of title 5, United States Code, for those enployees who elect to retain their coverage under FEHBP pursuant to paragraph (4); and

(B) such amounts as are determined necessary by the Office of Persominel Management under paragraph (6) to reimburse the Office of Personnel Management for contributions under section $8906(\mathrm{~g})$ (1) of title 5, United States Code, for those employees who elect to retain their coverage under FEHBP pursuant to paragaaph (4).

(6) The amounts required under paragraph (5)(B) shall pay the Government contributions for retired employees who retire from the Corporation after the privatization date under either CSRS or FERS, for survivors of such retired emaployees, and for survivors of employees of the Corporation who die after the privatization date, with said amounts prorated to reflect only that portion of the total service of such enoployees and retired persons that was performed for the Cotporation after the privatization date.

42 USC 2297h-9. SEC. 3111. OWNERSHIP LIMITATIONS.

(a) Securities Limitations.-No Airector, officer, or employee of the Corporation may acquire any securities, or any rigbts to acquire any securities of the private corporation on terms more favorable than those offered to the general public-

(1) in a public offering designed to transfer ownershtp of the Corporation to private investors,

(2) pursuant to any agreenent, arrangement, or understanding entered into before the privatization date, or tion.

(3) before the election of the directors of the private corpora-

(b) Ownership Limitation-Immediately following the cortsummaton of the transaction or series of transactions pursuant to which 100 percent of the ownership of the Corporation is transferred to private investors, and for a period of three years thereafter, no person may acquire, directly or indirectly, beneficial ounnership of securities representing more than 10 percent of the total votes of all cutstanding voting secunities of the Corporation. The foregoing limitation shall not apply to-

(I) any employee stock ownesshp plas of the Corptration,

(2) members of the anderwriting syndicate purchasing sbares in stabilization transactions in connection with the privatization, or 
42 USC 2297h10.
(3) in the case of shares beneficially held in the ordinary course of business for others, any commercial bank, broker-dealer, of dearing agency.

SEC. 3112. URANIUM TRANSFERS AND SALES.

(a) Transfers and Sales by the Secretary.-The Secretary shall not provide enrichment services or transfer or sell any uranium (including naniral uranium concentrates, natural uranium hexafluoride, or enriched uranium in any form) to any person except as consistent with this section.

(b) Russian HEU,-(1) On or before December 31, 1996, the United States Executive Agent under the Russian HEU Agreement shal] tratsfer to the Secretary without charge title to an amount of uranium bexafluoride equivalent to the natural uranium component of Jowp-enriched uranium deriwed from at least 18 metric tons of highly entriched , uraniam purchased from the Russian Executive Agent under the Russian HEU Agrecment. The quantity of such uranium hexafuotide delivered to the Secretary shal be based on a trils assay of $0.30 \mathrm{U}^{235}$. Uranium hexafluoride transferred to the Secretary purstant to this paragraph shall be deemed under United States law for all purposes to be of Russiat ofipin.

(2) Within 7 years of the date of enactment of this Act, the Secretary shall sell, and receive payment for, the uranium bexafluoride transferred to the Secretary pursuant to paragraph (1). Such uranium hexafluoride shall be sold-

(A) at any time for use in the United States for the purpose of overfeeding;

(B) at any time for end use outside the United States;

(C) in 1995 and 1996 to the Russtan Executive Agent at the purchase price for use in matched sales pursuant to the Suspension Agreement; or,

(D) in calendar year 2001 for consumption by end users in the United Stafes not prior to January 1, 2002, jil volumes not to exceed $3,000,000$ pounds $\mathrm{U}_{3} \mathrm{O}_{8}$ equivalent per year.

(3) With respect to all emriched tranium delivered to the United States Executive Agent under the Russiat HEU Agremaent on or after Jamuary 1, 1997, the United States Executive Agent shall, upon request of the Russian Executive Agent, enter into an agreemont to deljver concurrently to the Russian Executtive Agent an amount of uranium hexafteoride equivalent to the natural uranfum component of such uranitum. An agreement executed pursuant to a request of the Russian Executive Agent, as contemplated in this paragraph, may pertain to any deliveries dut during any period remaizing under the Russian HEU Agreement. The quantity of such uranium hexafluoride delivered to the Russian Executive Agent shall be based on a tails assay of $0.30 \mathrm{U}^{235}$. Titie to uranium hexafluoride delivered to the Russian Executive Agent pursuant to this paragraph shal] transfer to the Russian Executive Agent upon delsvery of such material to the Russian Executipe Agent, with such delivery to take place at a North American facility designated by the Russian Executive Agent. Uranium hexaffuo- 
ride delivered to the Russian Executive Agent purstant to this paragraph shall be deened under U.S. law for all purposes to be of Russtan orjgin. Such uranium hexafluoride may be sold to any person or entity for delivery and use in the United States only as permitted in subsections (b)(5), (b)(6) and (b)(7) of this section.

(4) In the event that the Russian Exegitive Agent does not exercise its right to enter into an agreenent to take delivery of the natural urastum component of any low-erriched uranium, as contemplated in paragraph (3), within 90 days of the date such low-enriched uranium is defivered to the United States Executive Agent, or upon request of the Russian Executive Agent, then the United States Executive Agent shall ergage an independent entity through a competitive selection process to auction an amourt of uranium hexafluoride or $\mathrm{U}_{3} \mathrm{O}_{8}$ (in the event that the conversion component of such hexafluoride has previously been sold) equivalent to the natural uranium component of such low-enriched uranium. An agreement executed pursuant to a request of the Russian Executive Agent, as contitemplated in this paragraphi, may pertain to any deliveries due during any period remajning under the Russian HEU Agreement. Such independent entity shall sell such urawium hexafluoride in one or brore lots to any person or entity to maximize the proceeds from such sales, for disposition consistent with the limitations set forth in this subsection. The independent entity shall pay to the Russian Executive Agent the proceeds of any such auction less all reasonable transaction and other administrative costs. The quantity of such uranium hexafluoride auctioned shall be based on a tails assay of $0.30 U^{235}$. Title to uraningm bexafluoride auctionted pursuant to this paragraph shall transfer to the buyer of such material upon delivery of such material to the buyer. Uranium bexaftuoride auctioned pursuant to this paragraph stial] be deemed under United States taw for ail purposes to be of Russian origin.

(5) Except as provided in paragraphs (6) and (7), uranium bexafluoride delivered to the Russian Executive Agent under paragraph (3) or auctioned purstant to paragraph (4), may not be delwered for consumption by end users in the United States eitber directly or indirectity prior to Jamsary 1, 1998, and thereafter only in accordanoe with the following schedile: 


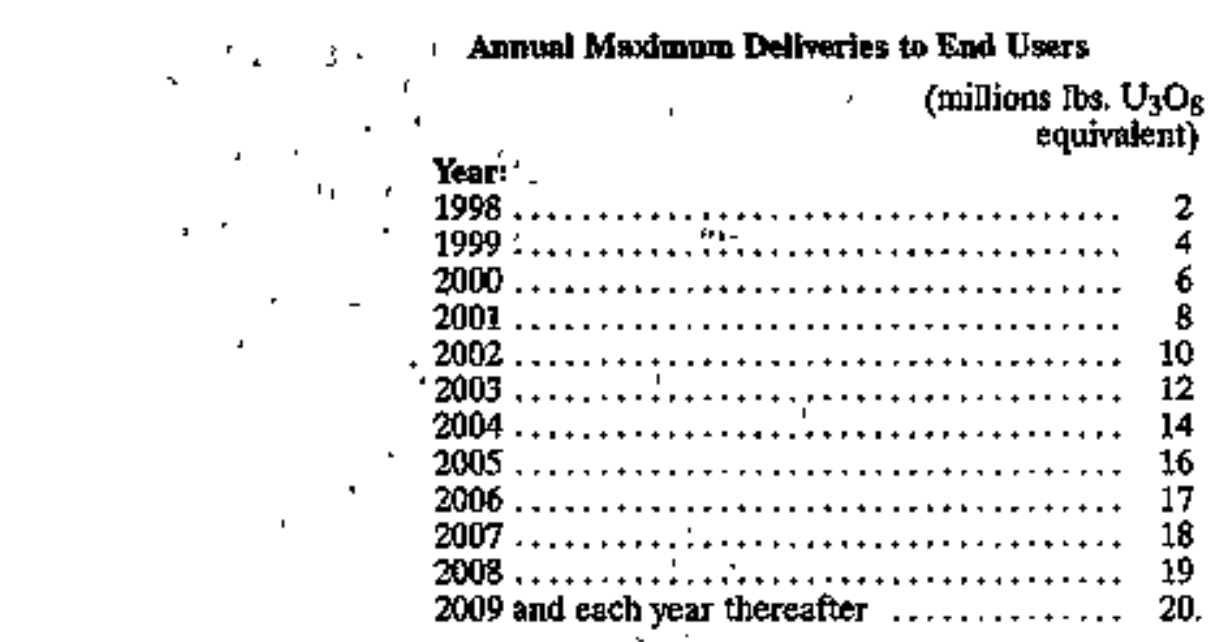

President

Reports.

(6) Uraniam hexafluoride delivered to the Russian Executive Agent under paragraph (3) or auctioned pursuant to paragraph (4) may be sold at any time as Russian-origin natural uranium in a Inatched sgle purtisunt to the Suspension Agreement, and in such case shall not be counted against the annual maximum deliveries set forth in paragraph (5).

(7) Uranium bexafluoride delivered to the Russian Executive Agett under paragraph (3) or auctioned pursuant to paragraph (4) may be sold at any time for use in the United Statos for the purposs of overfeeding in the operation's of enrichment facilities.

(8) Nothing in this subsection (b) spall restrict the sale of the conversion conponnent of such uranitun hexafourside.

(9) The Stcretary of Commerce shall have resporsibility for the administration and enforement of the limitations set forth in this subsection. The' Secretary of Commerce may require any person to provide any certifications, information, or take any action that may be necessary to enforce these limitations. The United States Custoins Service shall maintaip and provide any information required by the Secretary of Commerce and shatil take any action requested by the Secretary of Commerce which is necessary for the addinistration and enforcement of the uratium delivery limitations set forth in this section.

(10) The President shall monitor the actions of the United States Executive Agent undert the Russian HEU Agreement and shatl report to the Cangress not later that December 31 of each year on the effect the low-enriched uranitm delivered uader the Russias HEU Asreement is having on the domestic uranium mining, conversion, and enrichment industries, and the operation of the gaseous diffusion plants. Such report shall include a description of actions taken or proposed to be taken by the President to prevent of mitigate any material adverse impact on such intustries or any loss of employment at the gaseous diffision plants as a result of the Riassian HEV Agreement. 
(c) Transfers to the Corporation.-(1) The Secretary shall transfer to the Corporation without charge up to 50 metric tons of enriched uranium and up to 7,000 metric tons of natural uranium from the Departwent of Eniergy's stockpile, subject to the restrictions in subsection (c)(2).

(2) The Corporation shall not deliver for commercjal end use in the United States-

(A) any of the uranium transferred under this subsection before January 1, 1998;

(B) more than 10 percent of the usanium (by uranium hexafluonide equivalent content) transfersed under this subsection or more than $4,000,000$ pounds, whichever is less, in any calendar year after 1997; or

(C) more than 800,000 separative work units coptained in low-entiched uranjum transferred under this subsection in any calendar year.

(d) Irventory Sales.-(1) In addition to the transfers authortized under subsections (c) and (e), the Secretary may, from time to time, sell natural and Jow-enriched uratiun (including low-entrithed urastum derived from highly enriched uranium) from the Department of Energy's stockpile.

(2) Except as provided in subsections (b), (c), and (e), no sale or transter of natural or low-enrictied uranium shall be ngade unless-

President.

42 USC 2297t-

11.
(A) the President determines that the material is not pecessary for national security meteds,

(B) the Secretary determines that the sale of the material will not bave an adverse mational inpact on the donestic urajtutu mining, conversion, or enrictument industry, taking into account the sales of uraniatu under the Russian HEU Agreentent and the Sispension Agreement, and

(C) the price paid to the Secretary witl not be less than the fair market value of the material.

(e) Governanent Transfers,-Notwithstanding subsection (d)(2), the Secretary may transfer or sell enriched urajtiun-

(1) to a Federal agency if the material is transferred for the use of the recesving abency without any resale or trassfer to another entity and the material does not meet commercial specitiscations;

(2) to any person for national security purposes, as determined by the Secretary; or

(3) to any State or local agency or nonprofit, charitable, or educational institution for use other than the generation of electricity for commercial ust.

(I) Savings Provision-Nothing in this subchapter shall be read to modify the terms of the Russian HEU Agreement.

SEC. 3113. LOW-LEVEL WASTE.

(a) Responsibility of DOE-(i) The Secretary, at the request of the generator, shall accept for disposal low-level radjoactive waste, includ- 
ing depleted uranium if it were ultimately detemnined to be low-level radioactive waste, generated by-

(A) the Corporation as a result of the operations of the gaseous diffiusion plants or as a result of the treatunent of such wastes at a location other than the gaseous diffusion plants, or

(B) any person licensed by the Nucleat Regulatory Commission to operate a uranjum enrichment facility under sections 53, 63, and 193 of the Atomic Entergy Aat of 1954 (42 U.S.C. 2073,2093 , and 2243).

(2) Except as provided in paragraph (3), the generator shal] reinburse the Secretary for the disposal of low-level radioactive waste pursuant to paragraph (1) in an amount equal to the Secretary's costs, including a pro rata share of any capital costs, but in no event more thas an amount equal to that which woukd be charged by commercial, State, regional, or interstate compact entities for disposal of such waste.

(3) In the event depleted uranium were ultimately determined to be low-level radioactive waste, the generator shall reimburse the Secretary for the disposal of depleted uranium pursuant to paragraph (1) in an amount equal to the.Secretary's costs, inctuding a pro rata share of ary capital costs.

(b) Agreements With Other Persons.-The generator may also enter into agreements for the disposel of low-level radioactive waste subject to subsection (a) with any person other than the Secretary that is authorized by applicable laws and regulations to dispose of such wastes.

(c) State or Interstate Compacts.-Notwithstanding any other provision of law, no State or interstate compact shall be liable for the treatment storage, or disposal of any low-level radioactive waste (iacluding mixed waste) attributable to the eperation, decontamination, and decomnissioning of any urasium enrichment facility.

42 USC 2297h-

12.

President.

\section{SEC. 3114. AVLIS.}

(a) Exclusive Right to Commercialize-The Corporation shall bave the exclusive commercial right to deploy and use any AVLIS patents, processes, and techrical information owned or controlled by the Govermment, upon completion of a royalty agreement with the Secretary.

(b) Transfer of Related Propenty to Comporation.

(1) In general.-To the extent requested by the Corporation and subject to the requirements of the Atomic Energy Act of 1954 (42 U.S.C. 2011, et seq.), the President shall transfer without charge to the Corposation all of the right, title, ot interest in and to property owned by the United States under control or custody of the Secretary that is directly related to and materially usefiul in the performance of the Corporation's purposes regarding AVLIS and alternative technologies for uranium enrichment, including-

(A) facilities, equipsent, and materials for research, deve]opunent, and demonstration activities; and 
(B) all other facilities, equipment, materials, processes, patents, technical intornation of any kind, contracts, agreements, and leases.

(2) Exception-Facilities, real estate, improvements, and equipment related to the gaseous fiffusion, and gas centrifuge, urantum enrichment programs of the Secretary shall not transfer under paragraph (1)(B).

(3) Expiration of transfer authority.-The President's authority to transier property under this subsection shail expire upon the privatization date.

(c) Liability for Patent and Related Clairss.-With respect to any right, title, or interest prowided to the Corporation under subsection (a) or (b), the Corporation sball have sole liability for any paymants ntade or awards under section 1576.(3) of the Atomic Energy Act of 1954 (42 U.S.C. 2187(b)(3)), or any sentements or judgments involving claims for alleged patent infringement. Any royaly agreement under subsection (a) of this section shall provide for a reduction of royalty payments to the Secretary to ofiset any payments, awards, settlements, or judgments upder this strbsection.

\section{SEC. 3115. APPLICATION OF CERTAIN LAWS.}

(a) OSHA - (1) As of the privatization date, the private corporation shail be subject to and comply with the Oxcospational Safety and Health Act of 1970 (29 U.S.C. $651 \mathrm{et} \mathrm{seg}$.).

Contracts.

(2) The Nuckear Regulatory Commission and the Occupational Safety and Health Administration shall, vithin 90 days after the date of enactment of this Act, snter into a memorandum of agreeunent to goverin the exercise of their authority over occupational safety and bealth hazards at the gaseous diffusion plants, including inspection, investigation, enforcement, and rulemaking relating to stich hazards.

(b) Antitust Laws-For purposes of the antitrust laws, the performance by the private corporation of a "matched iniport" contract under the Suspension Agreenent shal] be considered to have occurred prior to the privatization date, if at the time of privatization, such contract had been agreed to by the parties in all material terms and confirmed by the Secretary of Commerce under the Suspension Agree+ ment.

(c) Energy Reorganization Act Reguirements-(1) The private corporation and its contractors and subcontractors shall be subject to the provisions of section 211 of the Energy Reorganization Act of 1974 (42 U.S.C. 5851) to the same extent as an employer subject to such section.

(2) With respect to the operation of the facilities leased by the private corporation, section 206 of the Energy Reorganization Act of 1974 (42U.S.C. 5846) shall apply to the directors and officers of the private corporation. 


\section{ENÉRGY REORGANZZATION ACT OF 1974}

Pablic Law 93-488

(88 Stat. 1233)

PAGE DSC

$42 \mathrm{USC}$

Sec.

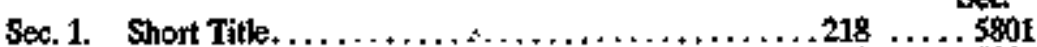

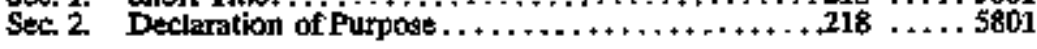

․ . TILE I - ENERGY RESEARCH AND DEVELOPMENT

ADMINISTRATION

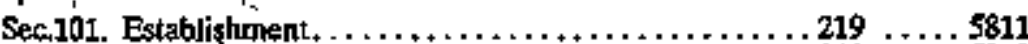

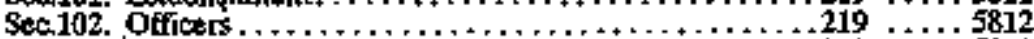

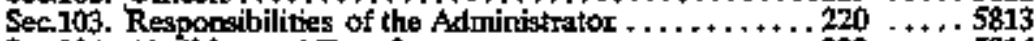

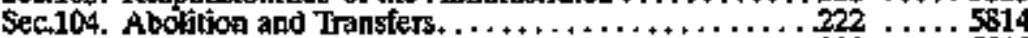

Sec.105. Administrative Prowisions. $\ldots \ldots \ldots \ldots \ldots \ldots \ldots \ldots .223, \ldots \ldots 5815$

Seci106. Personnel and Services $\ldots \ldots \ldots+\ldots \ldots \ldots \ldots \ldots .224 \ldots \ldots \$ 816$

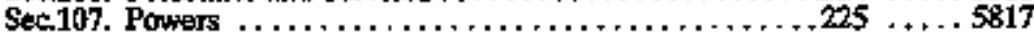

Sec108. Repeated

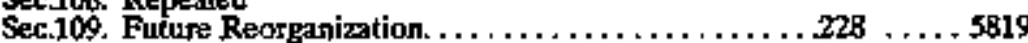

Sec.110. Coordination with Emvíonmental Efforts...... $228 \ldots \ldots, 5820$

sec.111. Prowisionis Applicable to Anuual

Authorizatton Acts $+\ldots \ldots+\ldots++\ldots+\ldots+\ldots \ldots 229 \ldots \ldots 5821$

\section{TITLE II - NUCLEAR REGULATORY COMMISSION:} NUCLEAR WHISTLEBLOWER PROTECTION

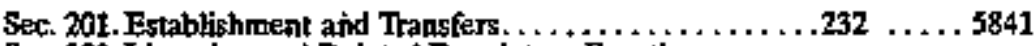

Sec. 202. I.jcensing and Related Regulatory Functions

- Respecting Selected Administration Facilities . . . . 234 . . . . 5842

Sec. 203. Offrce of Nuckar Reactor Regulation. . . . . . . . $235 \ldots \ldots \$ 84$

Sec. 204. Office of Nuclear Material Sefety and

Safeguards $\ldots \ldots+\ldots+\ldots \ldots \ldots+\ldots+\ldots \ldots \ldots \ldots 235 \ldots \ldots 585$

Sec. 205. Office of Nuclear Regulatury Researth. ....... $236 \ldots \ldots 5845$

Sec 206 . Noncompliance $\ldots+\ldots \ldots+\ldots+\ldots+\ldots \ldots \ldots+\ldots 237 \ldots \ldots 846$

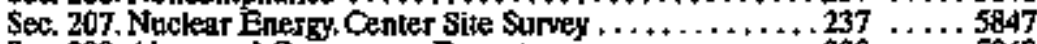

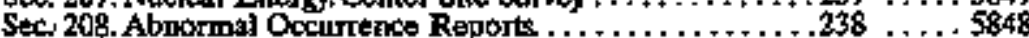

\$ec. 209. Other Officers $\ldots \ldots+\ldots \ldots+\ldots \ldots+\ldots+\ldots \ldots+239 \ldots \ldots 5849$

Sec. 210 . Uaresolved Safety lssues Plan .............. $240 \ldots \ldots 850$

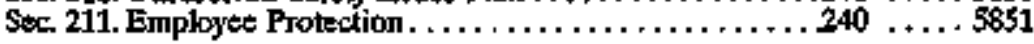

\section{TITLE III - MDSCELLANEOUS AND TRANSITIONAL PROVISIONS}

${ }_{4}$ Sec. 301. Transitional Provisions $\ldots \ldots \ldots \ldots \ldots \ldots \ldots \ldots \ldots .243 \ldots \ldots \$ 871$

Sec 302 . Transfer of Personnel and Other Matters . . . . . . $345 \ldots \ldots 5872$

Sec 303. Ix

Sec. 304. Definttions .......................... $246 \ldots \ldots .5674$

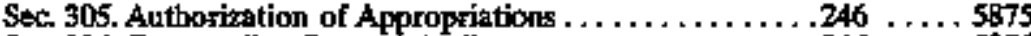

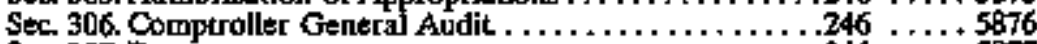

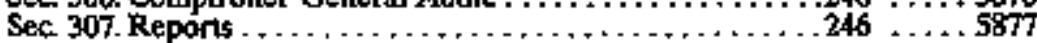

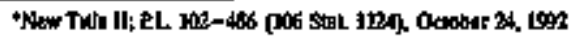


PAGE USC

42 USC

Sec.

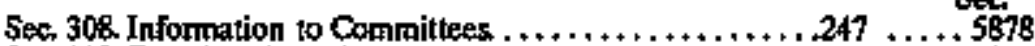

Sec. 309. Transfer of Funds....................... 247 ..... 5879

Sec 310. Conforming Amendments to Certain Other Laws. + 247 ...+ SBO1

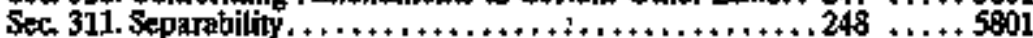

Sec. 312. Effective Date and Iaterim Appointments ........ 248 ....+5801

\section{TITLE IY - SEX DISCRIMINATION}

Sec. 401. Sex Dtsctimination Prohibited...............249 ..... sk91

Reorganization Plan No. 3-1970. . . . . . . . . . . . . . 250

Reorganizatlon Plas No, 1-1980. ..................254

Executive Order No, 1183 - Activation of the BRDA

and the NRC $\ldots \ldots, \ldots \ldots \ldots \ldots, \ldots, \ldots \ldots \ldots, \ldots, \ldots, 258$ 


\section{ENERGY REORGANIZATION ACT OF 1974}

Public Law 93-438

88 STAT. 1233

Energy Reorganization Aet of 1974 .

42 USC 5801

note.

42 USC 5801

Energy Research and Development Administration, establishment.

88 Stat. 1239 88 Stat. 1234.

Separation of AEC licensing and regulatory functions.

Small bussiness participation
An Act

To reorganize and consolidate certain functions of the Federal Government in a new Energy Research and Development Administration and in a new Nuclear Regulatory Commission in order to promote more efficient management of such functions.

Be it enacted by the Senate and House of Representatives of the United States of America in Congress assembled,

That the Energy Rearganization Act of 1974, as amended, is amended to read as follows:

\section{"SHORT TTILE}

" $\mathrm{gec}$ 1. The Act may be cited as the 'Energy Reorganization Act of 1974.'

\section{"DECLARATION OF PURPOSE}

rSec. 2. (a) The Congress hereby declares that the general welfars and the common defense and secarity require effective action to develog, and increase the effictency and reliability of use of, all energy sources to theet the needs of present and future generations, to inerease the pro. ductivity of the national economy and strengthen its position in regard to interational trade, to make the Nation self-sufficiept in energy, to advance the goals of restonjg protecting, and enhancing environmental quality, and to assure public health and safety.

"(o) The Congress finds that, to best achiove these objectives, improve Government operations, and assure the coordinated and effective development of alt energy sources, it is decessary to establish an Esetry Research and Development Admitsistration to bring together and direct Federal activities rejating to research and development on the various sources of energy, to increase the efficiency and relizbility in the use of energy, and to carry out the performance of other functions, including but not limited to the Atomic Energy Commission's military and production activities and its general basic research activities. In establishing an Enersy Research and Developinent Adnuinistration to achieve these objectives, the Congress intends that all possible sources of energy be developed consistent with warranted priorities.

(c) The Congress finds that it is in the public interest that the licensing and related regulatory functions of the Atomic Energy Commission be separated from the performance of the other functions of the Commission, and that this sepration be effected in an orderly manner, pursuant to this Act, assuing adequacy of technial and other resources necessary for the performance of each.

"(d) The Congress declares that it is in the public interest and the poltcy of Congress that small business concerns be given a reasonable opporturnity to participate, insofar as is possible, fairly and 
Priouttites.

\section{USC 5811. \\ Administrator, 42 USC 5812 .}

Depuly

Admínistrator.

88 Stal. 1234.

88 Stal. 1235.

Assistant Administrators. equitably in grants, contracts, purchases, and other Federal activities relating to research, development, and demonstration of sources of energy efficiency, and utilization and conservation of energy. In carrying out this policy, to the extent practicable, the Administrator shall consult with the Administrator of the Small Business Administration.

"(e) Determination of priorities which are warranted should te based on such considerations as power-related values of an etaergy source, preservation of material resources, reduction of pollutants, export market potential (including reduction of inports), amoong others. On suctia basis, energy sources warranting priority might include, but not be limited to, the various methods of utiliz: ing solar energy.

\section{WITILE I-ENERGY RESTEARCH AND DEVELOPMENT} ADMTNISTRATION

\section{UESTABLISHMENT}

"Sec. 101. There is hereby established an independent executive agency to be known as the Energy Research and Development Administration (hereinafter in this Act referred to as the 'Administration').

\section{MOFFCERS}

"Sec. 102. (a) There shall be at the head of the Administration an Administrator of Energy Research and Development (hereinafter in this Act referred to as the "Administrator'), who shall be appointed from civilian life by the President by and with the advice and consent of the Senate. A person may not be appointed as Administrator within two years after release from active duty as a commissioned officer of a regular component of an Armed Force. The Administration shall be administered under the supervision and direction of the Administrator, who shalt be responsible for the efficient and coordinated management of the Administration.

"(b) There shall be is the Administration a Deputy Administrator, who shall be appointed by the President, by and with the advice and consent of the Senate.

"(c) The President shall appoint the Administrator and Deputy Administrator from among individuals who, by reason of their general backgrotind and experience are specially qualified to manage a fulI range of energy research and development progranns.

"(d) There shall be in the Administration six Assistant Administrators, one of whom shalt be tesponsible for fosst energy, another for muclear energy, asother for environment and safety, another for conservation, another for salar, geotbermal, and advanced energy systems, and another for national security. The Assistant Adruinistrators shall be appointed by the President, by and with the advice and consent of the Senate. The President shall appoint each Assistant Administrator from among individuals who, by reason of general background and experience, are specially qualified to manage the energy technology area assigned to such Assistant Administrator. 
Geogral Counsel.

Additional officers.

Direclor af Military Application.

42 USC 2011

note.

Internationat cooperation

Onder of successtion.

42 USC 5813.

8 Stal. 1235.

88 Stgl. 1236. "(e) There shall be in the Administration a Generai Counsel who shall be appointed by the Administrator and who shall serve at the please of and be removable by the Administrator.

"(f) There shall we in the Administration not more than eight additional officers appointed by the Administrator. The positions of stchl oficers shall be considered career positions and be subject to subsection 161 d. of the Atomic Erergy Axt.

"(g) The Division of Mititary Application teansferred to and establisbed in the Administration by section 104 (d) of this Act sball be under the direction of a Director of Military Application, who stall be appointed by the Adiministrator and who shall serve at the pleasure of and be removable by the Admínistrator and shall be an active commissioned ofjeer of the Armed Forces berving in general or flag officer rank or grade. The functions, qualíications, and compensation of the Director of Military Application shall be the same as those provided under the Atomic Exergy Axt of 1954, as amended, for the Assistant General Manager for Military Application.

(b) Officers appointed pursuant to this section shall perform such functions as the Administrator shall delegate to one such officer the special responsibility for intemational copperation in all energy aidd related erviromnental research and development.

"(i) The Deputy Administrator (or in the absence or distability of the Deputy Administrator, or in the event of a vacancy in the office of the Deputy Administrator, an Assistant, Administrator, the General Counsel or streh other official, deterimined according to such ordir as the Administrator shall'prescribe) shall act for and pertorm the furzctions of the Admizistrator during any absence or distability of the Aoministrator or in the event of a vacancy in the office of the Administrator.

\section{'RESPONSIBILIIES OF THE ADMINISTRATOR}

"Sec. 103. The responsibilities of the Administrator shall inchude, but not be limited to-

"(l) exercising central responsibility for policy planning, coord - natoon, support, and management of research and development programs respecting ail energy sources; including assessing the requirements for research and development in regard to various energy sources in relation to near-term and long-range needs, policy planning in regard to meeting those requixements, undertaking programs for the optimal development of the various forms of enorgy sources, managing such programs, and disseminating information resulting thereftom;

(2) encouraging and conducting research and development, including demonstration of commercial feasibility and practical applications of the extraction, conversion , storage, transmission, and utilization phases related to the development and use of energy from fossil, nuclear, solar, geothermal, and other energy sources; 
(3) engaging in and supporting environtmeatal, biomedical, plysical, and safety research related to the developonent of energy sources and utilization technologies;

4(4) taking into account the existence, progress, and results of other public and private research and development activities, including those activities of the Federal Energy Admitistration reJating to the development of energy resources waing currently available technology in pronoting increased utilization of energy resources, relevant to the Administration's misstion in formulating its own research and development programs;

"(5) participating in and supporting cooperative research and development projects which may involve contributions by public or private persons or agencies, of financial or other resources to the performance of the work;

"(6) dereloping, collecting, distributing, and making avaflable for distribution, scientific and techrical information concerming the manufacture of developtrent of energy and its efifient extraction, conversion, transmission, and utilization;

"(7) establisbing, in accordance with the National Energy Extension Servilee Act, an Energy Extension Service to provide technical assistance, instruction, and practical demonstration on enerry conservation measures and alternative energy systems to individuals, businesses, and State and lacal govemrent officials; 1

"(8) creating and encouraging the development of gentral information to the public on all energy conservation techmologits and energy sources as they become available for general use, and the Administrator, in conjunction with the Administrator of the Federal Energy Administration shall, to the extent practicable, disseminate such information through the use of mass communications;

"(9) encouraging and conducting research and development in energy conservation, which shall be directed toward the goals of reducing total energy consumption to the maximum extent practicable, and toward maximum possib]e inprovertent in the efficiency of energy use. Development of new and improved conservation measures shall be conducted with the goal of the most expeditions possible application of these measures;

"(10) encouraging and participating in intermational cooperafion in energy and related environmental research and development;

88 Stat. 1236. 83 Stal. 1237.

"(1i) belping to assure an adecuate supply of manpower for the accomplishment of energy research and developrient programs, by sponsoring and assisting in extucation and training activities in institutions of higher education, vocational schools, and other institutions, and by assuring the collection, anabysis, and dissemination of necessary manpower supply and demand data;

"(12) encouraging and conducting research and development in chean and renewable energy sources.

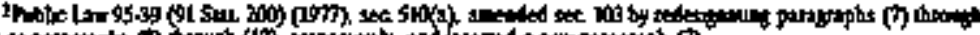

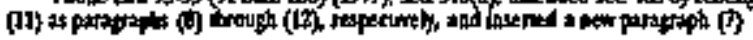


Atomic Enery Commistion. 42 USC 5814.

Interitor Department funclions.

88 Slat. 1238.

Helium applications study. 88 Strt. 1239. Report to President and Congress.

\section{WABLLION AND TRANSFERS}

«Sec 104. (a) The Atorric Energy Coinmission is hereby abolished. Sections $2 t$ and 22 of the Atomic Energy, Act of 1954, as aniended (42 U.S.C. 2031 and 2032) are repaled.

"(b) All other functions of the Commission, the Crairman and members of the Commission, and the afticers and components of the Commission are hereby transferred or allowed to lapse pursuant to the provisions of this Act.

"(c) There, are hentoby tsansferred to and vested in the Adininistrator all funictions of the Atontic Energy Commission, the Clatutan and members of the Commission, and the officers and components of the Contuission, except as otherwise provided in this Act.

(d) The General Advisory Committee established pursuant to section 26 of the Atomic Energy Act of 1954, as amended (42 U.S.C. 2036), the Patent Comperisation Boand established pursuant to section 157 of the AtomicEnergy Act of 1954, as amended (42 U.S.C. 2187) and the Divisions of Military Application and Naval Research established pussuant- to section 25 of the Atomic Evergy Act of 1954, as amended (42 U.S.C. 2035), are transferted to the Energy Research and Development Administration and the functions of the Commission with respect thereto, and with respect to relations with the Military Liaison Committee extablished by section 27 of the Atomic Energy Act of 1954, as amended (42 Ù.S.C. 2037), are transferred to tive Administrator.

"(e) There, are bereby transferred to and vested in the Administrator such functions of the Secretary of the Interior, the Department of the Interior, and officers and components of such depart. ment-

"(I) as relate to or are ittilized by the $O$ fitio of Coal Research established pursuant to the Act of July 1, 1960 (74 Stat. 336; 30 U.S.C. $661-668$ );

"(2) as It]ate to or are utilized in connection with fossil fuel energy research and developinont programs and related activities condacted by the Burtant of Mines 'energy' centers' and synthane plant to provide greater efficiency in the extraction, processiag and utitization of eriergy resources for the purpose of coinserving those resources, developing altemative energy Jesourees stikh as oil and gas seconxdary and tertiary recovery, oil shale and synthetic fuels, jumproving methods of managing energy-related wastes and pollutants, and providing technical guidance necded to establish and administer nationtal energy policies; and

"(3) as relate to or are utilized for underground electric power transmisston research..

The Adrninistrator stall conduct a studyr of the potential energy applications of helfum and, within stix months from the date of the enactment of this Act, report to the President and Congress his recommendations concerming the managernent of the Federal helium programs, as they relate tō energy.

“(f) There are hereby transferred to and vested in the Adminis- 
National Science

Foundation

funclions.

Environumental Protection Agency functions.

Ust of other agentives' capabilíties.

Regulations. 42 USC S81S.

Policy planning

and ovalustion.

Delegation of functions.

Organizstion. trator such functions of the National Science Foundation as relate to of are utilized in connection with--

"(I) solar heating and cooling development; and

"(2) geothermal power development.

(g) There are hereby transferred to and vested in the Administrator such functions of the Environmental Protection Agency and the officers and componeats thereof as relate to or are utilized in connection with research, development, and demonstration, but not assessment or monitoring for regulatory purposes, of alternative automotive power systems.

(h) To the extent necessary or appropriate to perform functions and carry out programs transferred by this Act, the Adritinistrator and Commissions may exercise, in relation to the funcrions so transferred, any authority or part thereof available by law, includ. ing appropriation Acts, to the official or agency from which swch furmetions were transierred.

"(i) In the exercise of his responsibitities under section 103, the Adninistrator shall utilize, with their consent, to the fullest extent he determines advisable the technical and managenent capabilties of other executive agencies having facilities, personnel, or other resources which can assist or advantageously be expanded to assist in carrying out such responsibilities. The Admínistrator shall consult with the bead of each agency with respect to such factities, personmel, ot other resources, and may assign, with their consent, spectific fuograms or projects in energy research and development as approptitate. In making such assignments under this subsection, the head of each such agency shall insure that-

4(1) such assignments shall be in addition to and not detract from the basic nission responsibilities of the agency, and

"(2) such assigmments shall be carried out under such guidance as the Administrator deeuls appropriate.

\section{"ADMINISTRATTE PROVISIONS}

"Sec. 105. (a) The Administrator is authorized to prescribe such policies, standards, criteria, procectures, rules, and regulations as be may deem to be necessary or appropriate to perform functions now or hereafter vested in him. and

“(b) The Administrator silall engage in such policy playuting, perform, such progrant evaluation analyses and other stadies, as maty be necessary to promote the efficient and coosdinated administration of the Administration and properly assess progress toward the achievement of its missions.

* (c) Except as otherwise expressly provided by law, the Aoninistrator may delegate any of his finctions to such offioers and anployees of the Administration as he may desigrate, and may authorize such successive sedelegations of such functions as be ntay deem to be necessary or appropriate.

"(d) Except as provided in section 102 and in section 104(d), the Administrator may organize the Administration as he may deem to be necessary or approppiate. 
Fiteld offices.

88 stel. 1239.

Seat

Working captal fund.

Information from other agencies.

Appointment and pay.

42 USC $\$ 816$

Experts and consultants.

Military personpel. "(e) The Administrator is authorized to establish, majntain, alter, or discontinue such State, regional, district, local, or other field offices as he may deem to be necessary or appropriate to perform functions now or hereafter vested in him.

"(f) The Administrator shall cause a seal of office to be made for the Administration of strch device as he shall approve, and judicial notice shall be taken of such seal.

"(g) The Adsotnistrator is authorized to establish a working capital fund, to be available without fiscal year limitation, for expenses necessary for the mainterance and operation of such common administrative services as he shall find to be desirable in the interests of economy and efficiency. There shall be transferred to the fund the stocks of supplies, equipuent, assets other than Ieal property, liabilities, and umpatd obligations relating to the servicts which he determines will be periormed through the fund. Appropiriations to the fund, in such ariounts as may be necessary to provide additional working capital, are authorized. The working capttal fitod shall recover from the appropitations and funds for which services are performed, either in advance or by way of reimburserient, amounts which will approximate the costs incurred, including the accrual of ansulal leave and the depreciation of equipment. The fund shall also be credited with receipts from the sale or excharge of its property, and receipts in payment for loss or dartage to property owned by the fund.

(b) Each department, agency, and instrumentaily of the executive branch of the Government is authorized to furnish to the Administrator, upon his request, any infoumation or other data which the Administrator deems necessary to carry out his duties under this titlo.

\section{"PERSONNEL AND S'ERVICES}

"Sec. 106. (a) The Administrator is authorized to select, appoint, employ, and ix the compensation of such officers and employees, inclusing attorneys, pussuant to section $161 \mathrm{~d}$. of the Atomic Energy Act of 1954, as amended (42 U.S.C. 2201 (c) ) as are necessary to perform the functions now or hereafter vested in him and to prescribe their finctions.

“(b) The Adninistrator is authorized to obtain services as provided by section 3109 of title 5 of the United States Code.

(c) The Administrator is authorized to provide for participation of Jitititary personuel in the performance of his functions. Merabers of the Army, the Nayy, the Air Force, or the Marime Corps Inay be detailed for service in the Administration by the appropriate military Secretary, pursuant to cooperative agreements with the Secretary, for service in the Administration in positions other than a postition the occupant of which mest be approved by and with the'advice and consent of the Sersite.

"(d) Appointunent, detail, or assignment to, acceptance of, and service in, arry appointive or other position in the Adininistration under this section shall in no way affect the status, office, rank, or grade which such officers or enlisted men may occupy or hold, of 
Transportation and per diem.

B8 S1at. 1240.

Personnel of other agencies.

Advisocy boards.

5 USC app. I.

Noncitizens.

Research and development.

42 USC 5817.

Contracts, etc.

42 USC 2011 note. any emołument, prerequisite, night, privilege, or benefit jncident to of arjing out of any such status, office, rank, or grade. A methber so appointed, detailed, or assigned shalt not be subfect to direction or control by his Armed Force, or any officer thereof, directly or indirectly, with respect to the responsibilities exercised in the position to which appointed, detailed, or assigned

"(e) The Administrator is authorized to pay transportaton expenses, and per dient in lieu of subsistence expenses, in accordance with chapter 57 of title 5 of the United States Code for travel between places of recruiturent and duty, and while at places of duty, of persons appointed for emergensy, temporary, or seasonal services in the field service of the Administration.

"(f) The Adininistrator is authorized to utilize, on a reimbursable basis, the services of any personnel trade available by any depertment, agency, or instrumentalty, iacluding any independent agency of the Government.

(g) The Administrator is authorized to establish advisory boards, ith accordance with the provisions of the Federal Advisory Committee Act (Public Law 92-463), to advise with and make recoummendations to the Administrator on legislation, policies, administration, research, and other matters.

"(h) The Administrator is authotized to employ persons who are not citizens of the United States in expert, scientatic, tecturical, or professional capacities whenever he deeps it in the public interest.

\section{IPOWERS}

"Sec. I07. (a) The Administrator is authorized to exercise his powers in such manner as to insure the continued conduct of research and development and related activities in areas or fields deemed by the Administrator to be pertinent to the acquisition of an expanded sund of scientific, techtical, and practical knowwiedge in energy matters. To this end, the Administrator is authortzed to make arrangements (including contracts, agreements, and loass) for the conduct of research and development activities with private or public institutions or persons, including participation in joint or cooperative projects of a research, development, or experimental nature; to make payments (in lump sum or instatlments, and in advance or by way of rejmbursement, with necessary adjustunents on account of overpayments or underpayments); and generally to take such steps as be may deem necessary or appropriate to perform functions now or hefeafter vested in ham. Sench functions of the Administrator under this Act as are applicable to the nuclear activities transferced purseant to this title shall be subject to the provisions of the Atomic Energy Act of 1954, as ampended, and to other authority applicable to such muclear activities. The nor-nuclear responsibilities and functions of the Adpizistrator referred to in sections 103 and 104 of this Act shall be carried out pursuant to the provisions of this Act, applicable authority extiting immediately before the effective date of this Act, or in accordance with the provisions of Chapter 4 of the Atomic Energy Act of 1954, as amended (42 U.S.C. 2051-2053). 
Facilities and real property. 40 USC 601

note.

sțc

app. II.

Services for employees at Jemote locations.

89. Stot. 1241.

Acquisition of copyrights, patents, etc. “(b) Except for public bujldings as defined in the Public Butdings Act of 1959, as amended, and with respect to leased space subject to the provisions of Reorganization Plan Numbered 18 of 1950, the Adroinistrator is authorized to acquire (by purchase, lease, condemnation, or otherwise), construct, inprove, repair, operate, and maintain facilities and real property as the Administrator deems to be necessary in and outside of the District of Columbia. Such authority shall apply oniy to facilities required for the maintenance and operation of laboratories, research and testing sites and facilities, quarters, and related acoonnmodations for employees and dependents of employees of the Aniministration, and such other special-purpose real property as the Administrator deems to be necessary in and outside the District of Columbia. Title to any propesty or interest therejin, real, personal, or mixed, acguired purstant to this section, shall be in the United States.

"(c)(1) The Administrator is authorized to provide, constswt, or maintain, as necessary and when not otherwise avallable, the following for employees and their dependents stationed at remote locations:

"(A) Emergency medical services and supplies.

"(B) Food and other subsistence supplies.

"(C) Messing facilities.

"(D) Audiovisual equipment, accessories, and supplies for recreation and training.

"(E) Reimbursement for food, clothitug medicine, and other supplies furrished by stch employees in emergencies for the temporary relief of cistressed persons.

"(F) Living and working quarters and facilities.

"(G) Transportation for school-age dependents of employees to the nearest appropriate education facilities.

"(2) The fumishing of medical treatment under sub-peragraph (A) of paragraph (1) and the furnishing of services and supplies under paraGraphs (B) and (C) of paragraph (1) shall be at prices reflecting ressonable value as determined by the Administrator.

"(3) Proceeds from reimbursements under this section shall be deposited in the Treastry and may be withdrawn by the Administrator to pay difetctly the cost of such work or services, to repay or make advances to appropriations or funds which do or will bear all or a part of such cost, or to refund excess sums when necessary; except that such payments may be crexlited to a service or worlong capital fund otherwise established by law, and used under the law governing such funds, if the fund is available for use by the Administrator for performing the work or gervices for which payment is received.

"(d) The Admimistrator is authorized to acquire any of the following described rithts if the property acquired thereby is for use in, or is usefil to, the performance of functions vested in him;

(1) Copyights, patents, and applications for patents, designs, processes, specifications, Tand data.

"(2) Licenses under copyrights, patents, and applicants for patents.

“(3) Releases, befort su't is brought, for past infringenent of patents or coppritights. 
Dissemination of information.

Gifs and bequests. "(e) Subject to the provisions of chapter 12 of the Ataujic Energy Act of 1954, as amerdied (42 USC 2161-2166), and other applicable law, the Administrator shall disseminate seientific, technical, and practical information acquired pursuant to this title through information prograus and other approptiate means, and shall encourage the dissemination of scientítc, techuical, and practical information relating to energy so as to enlarge the fund of such information and to provide that free izterchange of ideas and criticism which is essential to scientific and industrial progress and public understanding.

(f) The Administrator is authorized to accept, hold, administer, and utilize gifts, and bequests of property, both real and personal, for the purpose of aiding or facilitating the work of the Administration. Gifts and bequests of money and proceeds from sales of other property recejved as gifts or bequests shall be deposited in the Treasury and shall be disbursed upon the order of the Administrator. For the purposes of Federal inconte, estate, and gift taxes, property accepted under this section shall be considered as a gift or bequest to the United States.

"Sex. 108.2

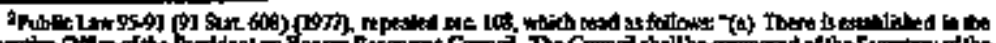

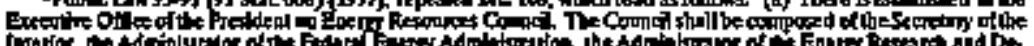

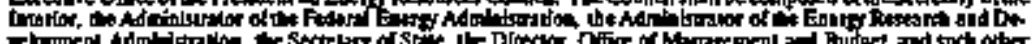

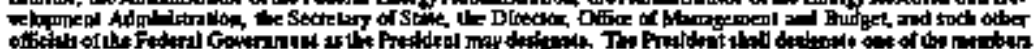

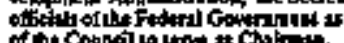

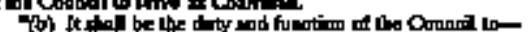

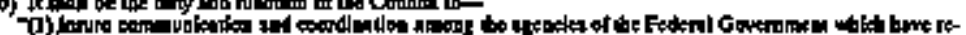

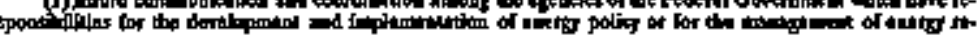
xusexs

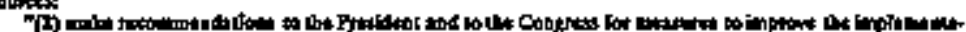

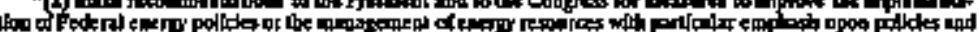

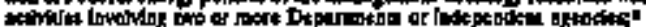

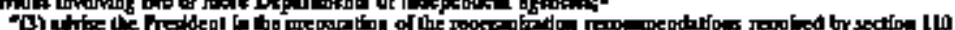
(3) (1)

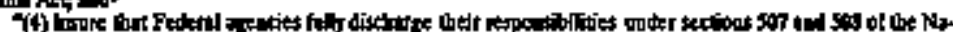

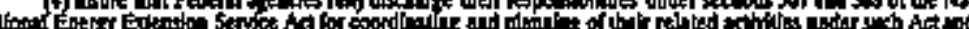

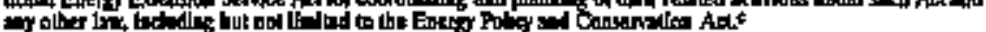

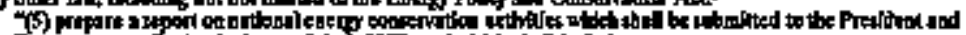

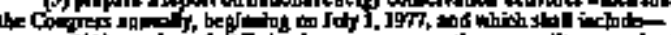

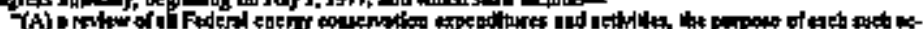

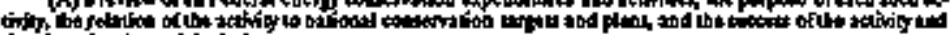

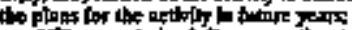

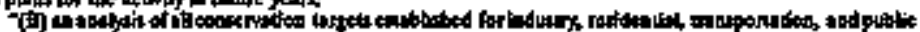

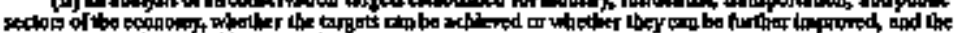

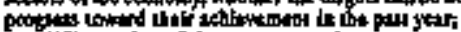

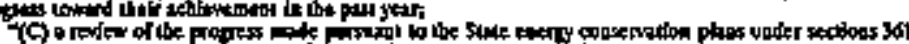

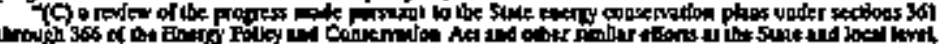

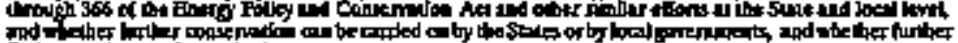

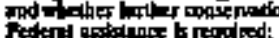

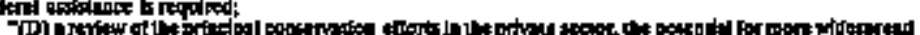

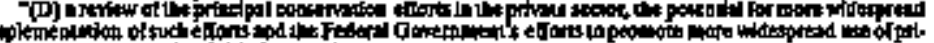

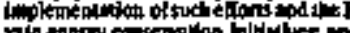

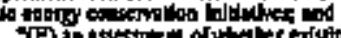

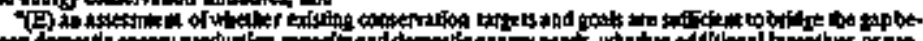

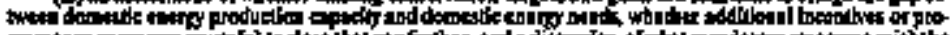

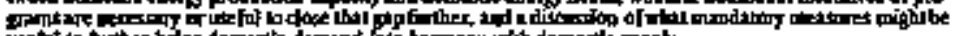

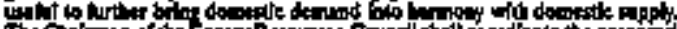

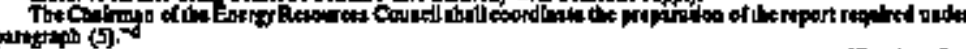

(Cooldonat) 
Report to

Congress.

42 USC $5 \$ 19$.

Ante, p. 109.

42 USC 5820.

\section{"FUTURE REORGANIZATION}

«Sec. 109. (a) The President shall transmit to the Congress as - promptly as possible, but not later than Júne 30, 1975, such additional recontumendàtions as he deems advisable for organization of energy and related functions in the Federal Govetumtent, including, but not limited to, whether or not there shall be established (1) a Department of Energy and Nanral Resources, (2) an Enery Policy Council, and (3) a con'solidation in whole or fn part of Jegulatory functions concerning enerey.

"(b) This report shall replace and serve the purposes of the report required by section 15(a)(4) of the Federal Ebiergy Administration Act.

\section{"COORDINATION WITH ENVRONMENTAL EFFORTS}

"Sec 110. The Administrator is atthorized to establish programs to utilize research and development performed by other Federal agencies to minituize the adverse environmental effects of energy projects. The Administrator of the Einvironmental Protection Agency, as well as otheraffected agencies and departments, shall cooperate fully with the Administrator in establishifig and maintaining such programs, and in establishing appropriate interagency agreeménts to develop cooperative programs and to avoid unnecessary duplicatłon.

\footnotetext{
(Cowent])

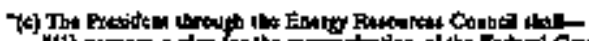

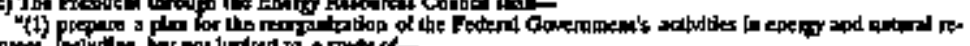

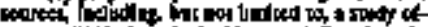

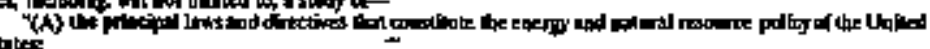
tates:

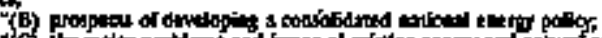

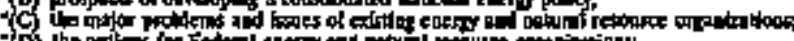

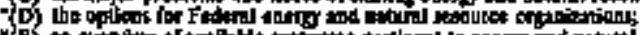

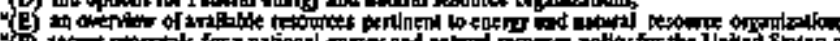

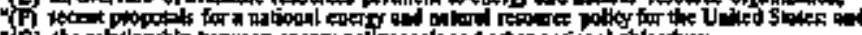

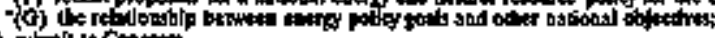

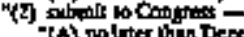

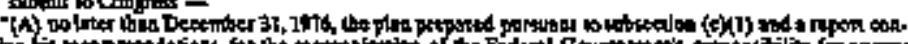

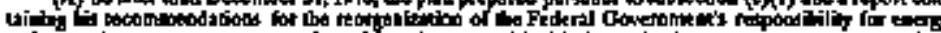

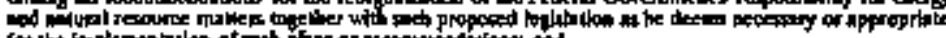

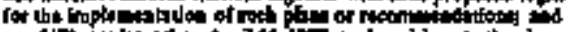

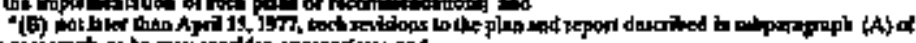

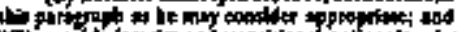

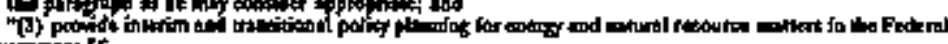
conernineph"

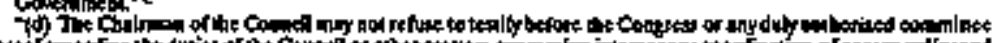
Wottor twith ativiner

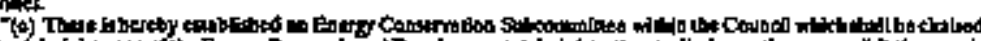

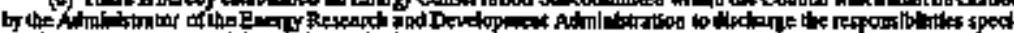

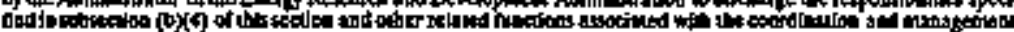

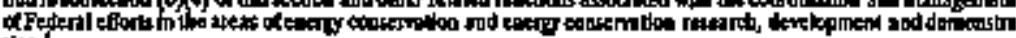
lion

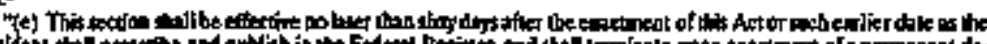

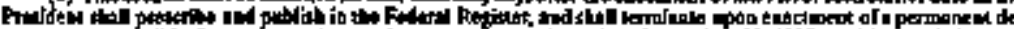

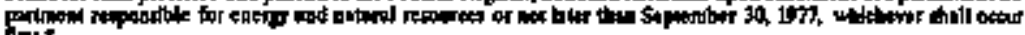
bar

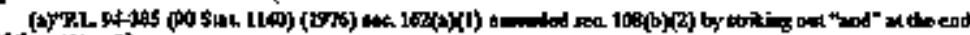

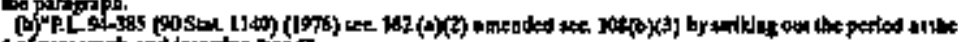

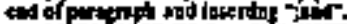

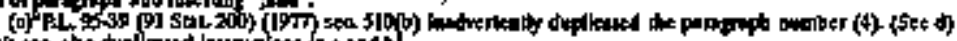

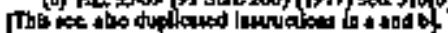

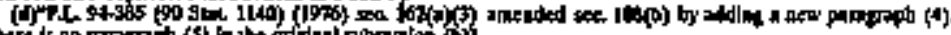

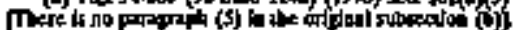

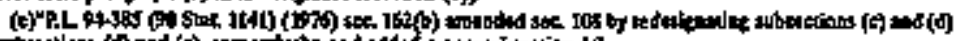

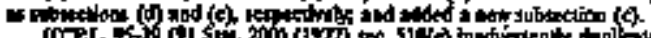

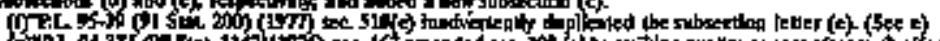

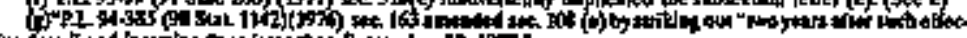

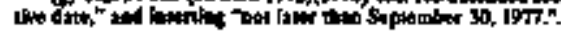


42 USC 5821.

42 USC 2017.

42 USC 5915.

Post, p.\$1.

"Operating expenses", appropriations.

Report to congressional comintitect.

Expenditure linitations.

\section{Report to}

i congressional comitittees.
«Sec. 111 (a) All approprations made to the Energy research and Development Administration or the Administrator shall, except as otherwise provided by law, be subject to annual authorization in accordance with section 261 of the Atomic Energy Act of 1954, section 16 of the Federal Nonnuclear Energy Research and Development Act of 1974, and section 305 of this Act. The provisions of this section shatt apply with respect to appropriations made pursuant to the Act providing such authorization (hereinafter in this section referted to as 'anrual authorzation Acts').

(b)(1) Funds appropriated pursuant to an annual authorization Act for 'Operating expenses' may bo used for-

"(A) the cotsstntetion or acquitition of any facilities, or major items of equipment, which may be required at locations other than installations of the Administration, for the performance of Iesearch, development, and demonstration activities, and

"(B) grants to any organization for purchase or construction of research facilities.

No such funds shall be used under this subsection for the accuisition of land. Fee title to all such facilities and items of equipment shail be vested in the United States, unless the Administrator or his designee determines in writing that the research, development, and demonstration authorized by such Act would best be implemented by permitting fee title or any other property interest to be vested in an entity other than the United States; but before approving the vesting of such title or interest in such entity, the Administrator shall (i) transmit such determination, together with all pertinente dats, to the Cominitree on Science and Tectnology of the House of Representatives and the Committee on Energy and Nanural Resources of the Senate and (ii) wait a period of thirty ealendar days (not including any day in which either House of Congress is not in session tectause of adjournment of more than three calendar days to a day certain), unless prior to the expiration of such period each such committee has transmitted to the Administrator written notice to the effect that such committee bas no objection to the proposed action.

"(2) No funds shall be used under paragraph (1) for any facility or major item of equipment, including collateral equipment, if the estimated cost to the Federal Government exceeds $\$ 5,000,000$ in the case of such a facilty or $\$ 2,000,000$ in the case of such an item of equipment, unless sudi facility or item has been previousty authorized Oy the appropriate committees of the House of representatives and the Senate, or the Administrator-

"(A) transmit to the appropiate committees of the House of Repressentatives and the Senate a report on stech facility or item showing its nature, purpose, and estímated cost, and

"(B) waits a period of thinty calendar days (not including any day in which either House of Congress is not in session because of adjotmment of more than three calendar days to a day certain), unless prior to the expiration of such period each such committee 
Limitation.

Report, transmittal to congressional comritles. Notice.

Report, transmittal to congressionaI committes. Notice. has transmitted to the Administrator written notice to the effect that sucfi committee has no objection to the proposed action.

(c)(1) Not to exceed I per centum of all finds appropriated pursuant to any annual authorization Act for 'Operating expenses' may be used by the Administrator to construct, expand, or modify laboratories and other facilities, ischuding the acquisition of land, at any location under the control of the Administrator, if the Administrator deteruines that (A) sucth action would be necessary because of changes in the nationel programs atthorized to be funded by such Act or because the netw scientific or engineering developments, and (B) deferral of such action until the enactinent of the next authorization Actwould be inconsistent with the policies established by Congress for the Adnoinistration.

“(2) No funds may be obligated for expenditure or expended undir paragraph (1) for activities described jan such paragraph unless-

"(A) a period of thirty calendar days (not jocluding any day in which either House of Congress is not in session because of adjournment of more than three calendar days to a day certain) has passed after the Administrator has transmitted to the appropriate committees of the House of Representatives and the Senate a written report containing a full and complete statement concersing (i) the nature of the construction, expansion, or modification involved, (ii) the cost thereof, including the cost of any real estate action pertaining thereto, and (iii) the reason why such construction, expansion, or modification is necessary and in the national interest, of

"(B) each such committee before the expiration of such period has transmitted to the Administrator a written notice to the effect that such committee has no objection to the proposed action; except that this paragraph shall not apply to any project the estimated total cost of which does not exceed $\$ 50,000$.

"(d)(1) Except as otherwise provided in the authorization Act involved-.

"(A) no amourt appropriated pursuant to any aneual authorization Act miay be used for any program in excess of the amount actually autborized for that particular program by such Act, and

"(B) no amount appropriated pursuant to any annual authorization Act may be used for any prograng which bas not been presented to, or requested of the Congress,

unless (i) a period of thirty calendar days (not including any day in which either House of Congress is not in session because of adjournment of more than three calendar days to a day certain) has passed after the recespt by the appropitiate cortinittees of the House of Representatives and the Senate of notice given by the Administrator containing a full and complete statement of the action.proposed to be taken and the facts and circumstances relied upon in support of such proposed action, or (ii) each such committee before the expiration of strch period has transmitted to the Administrator written notice to the effect that such committer has no objection to the proposed action.

"(2) Notwithstancing any other provision of this section or the authorization Act towolved, the aggregate amount avaitable for use within the 
categories of coal, petroleum and natural gas, oil shale, solar, geothermal nuclear energy (non-weapons), environment and safety, and con. servation from sums appropriated pursuant to an aniual authorization Act may not, as a result of reprogramming, be decreased by more than 10 per centum of the total of the sums appropriated pursuant to such Act for those categories.

Fuods merger, Itimitations.

Construction desigen services.

Funds transter.
"(E) Subject to the applicable requirements and limitations of this section and the authorization Act ìwolved, when so specified in an appropriation Act, amounts appropriated pursuant to any annual authorization Act for 'Operating expenses' or for 'Plant and capital equ'pment' may be merged with any other amounts appropriated for fike purposes pursuant to any other Act authorizing approptiations for the Administration: Frovided, That no such amounts appropriated for 'Plant and capital equipment' may be rierged with amounts appropitated for 'Operatiog expenses'.

"(f) When so specified is an appropriation Act, amounts appropriated pirssant to any arusual authorization Act for 'Operating expenses' or for 'Plant and capital equipment' may remain available until expendec.

"(g) The Administrator is authorized to perform construction design services for any administration construction project whenever (1) such construction project has been included in a proposed authorization bill transmitted to the Congress by the Adininistration, and (2) the Administration deternimes that the project is of such urgency in order to meet the needs of national defense or protection of life and property or bealth and safety that construce tion of the project should be initiated promptly upon enactment of legissation appropriating funds for its construction.

"(h) When so specified in appropriation Acts, any moneys received by the Administration may be retained and used for operating expenses, and nay remain available until expended,notwith. standing the provisions of section 3617 of the Revised Statutes (31 U.S.C. 484); except that-

"(1) this subsection shall not apply with respect to surns received from disposal of property under the Atomic Energy Community Act of 1955 or the Strategic and Critical Materials Stockpiling Act, as amended, or with respect to fees received for tests or investigations under the Act of May 16, 1910, as amended (42 U.S.C. 2301; 50 U.S.C. 98h; 30 U.S.C. 7); and

"(2) revenues received by the Administration from the enrichuent of uranium shal (when so specified) be retained and used for the specific putpose of offsetting costs incurred by the Administration in providing uraniun enjichment service activities.

"(i) When so specified in an appropriation Act, transfers of sums from the 'Operating expenses' appropriation made persuant to an annual authorization Aet may be made to other agencies of the Government for the performance of the work for which the ap- 
propriation is made, and in such cases the sums so transferred may be merged with the appropriations to which they are transferred.

Members and Chaisman. 42 USC 5941.

8s Stot.. 1243.

Seal.

Commission Chaiman, functions.

42 USC 5801 note.

\section{"TIILE Il - NUCLEAR REGULATORY COMMISSION: NUCLEAR WHISTLEBLOWER PROTECTION}

"ESTAEI ISHMENT AND TRANSFERS

"Sec. 201. (a) (1) There is establisbed an independent regulatory commission to be known as the Nisclear Regulatory Commisston which shalt be composed of five axmbers, each of whom shall be a citizen of the United States. The Ptesident shall designate one member of the Commission as Chairman thereof to serve as stch curing the pleasure of the President. The Chairman may from time to tirie designate any othes member of the Commission as Acting Chairman to act is tfie place and stead of the Chairman during his absence. The Chairman (or the Acting Chairman in the absence of the Chairman) shall preside at all moetings of the Commission and a quosum for the transaction of business shatl consist of at keast three members present. Each member of the Commission, including the Chairmsn, shall bave equal responsibility and authority in all decisions and actions of the Commission, shall have full access to all information relating to the performance of his duties or responsibilities, and shall bave one vote. Action of the Commission shall be determined by a majority vote of the members present. The Chairman (or Acting Chairman in the absence of the Chainnan) shail bo the official spokesman of the Coinmission in its relations with the Congress, Goverantont agencies, persons, or the public, and on behalf of the Commission, shall see to the fatthful exemution of the paticies and decisions of the Commissian, and shall report therent to the Commission som time to time or as the Commission may direct. The Commission shall have an official stal which shall be judicialy noticed.

(2) The Chairman of the Commission shall be the principal executive oficer of the Commission, and he shall exercise all of the executive and administrative functions of the Commission, inctuding functions of the conmission with respect to (a) the appointment and supejvision of personnel employed under the Commission (other than personne] employed regularly and foll time in the immediate offices of Commissioners other than the Chaiman, and except as otherwise provided in the Energy Reorganization Act of 1974), (b) the distribution of business amoing such personnel and among administrative units of the Commission, and (c) the use and expenditure of funds.

(3) In carrying out any of his functions under the provisions of this section the Chairman shall be gowemed by general policies of the Commission and by such regulatory decisions, Endings, and determinations as the Commission may by law be authorized to make.

(4) The appointment by the Chairman of the heads of major adminis. trative untts under the Commission shall be subject to the approwal of the Commutsion.

(5) There are hereby reserved to the Commission its functions with respect to revising budget estimates and with respect to determining

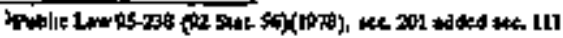

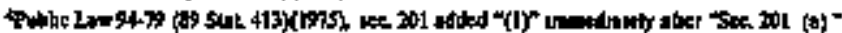


Phutoaium shipmenls, restrictions. 42 USC 5841 note.

Term of Office. 42 USC 5841.

Submisston of appointments to Sente. upon the distribution of appropriated funds according to major programs and purposes.

The Nuclear Regulatory Commission shall not license any shipments by air transport of plutoniuma in any form, whether exports, imports of domestic shipments: Provided, however, That any plutonium in any form contained in a medical device designed for individual human application is not subject to this restriction. This restriction shall be in force until the Nuclear Regulatory Commission has certified to the Joint Committee on Atomic Energy of the Congress that a safe container has been developed and tested which will not nipture under crash and blast-testing equivalent to the crash and explosion of a high-flying airctaft. 5

(b) (1) Members of the Commission shall be appointed by the President, by and with the advice and consent of the Senate.

(2) Appointments of members pursuant to this subsection shall be made in such a manner that not more than three members of the Commission shall be members of the same political party.

(c) Each member shall serve for a term of five years, each such term to commence on July 1, except that of the five members first appointed to the Commission, one shall serve for one year, one for two years, one for three years, one for four years, and one for five years, to be designated by the President at the time of appointment; and excepk that any member appointed to fill a vacancy occurring prior to the expiration of the term for which his predecessor was appointed, shall be appointed for the remainder of such term. For the purpase of determining the expiration date of the terms of office of the five members first appointed to the Nuclear Regulatory Commission, each such term "shall" be deemed to have begin July 1,1975 . $^{\text {t }}$

(d) Such initial appointonents shall be subroitted to the Senate within sixty days of the signing of this Act. Any individual who is serving as a member of the Atomic Energy commission at the time of the entactment of this Act, and who may be appointed by the President to the Commission, shalt be appointed for a term designated by the President, but which term shall terminate not later than the end of his present term as a member of the Atomic Energy Commission, without regard to the requirements of subsection (b)(2) of this section. Any subsequent appointment of suct individuals shall be subject to the provisions of this section.

(c) Any member of the Commission may be removed by the President for inefficiency, neglect of duty, or malfeasance in office. No member of the Commission shail engage in any business, vocation, or employment other than that of serving as member of the Commission.

(3)

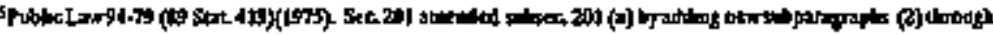

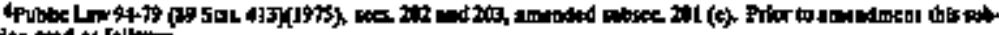

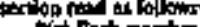

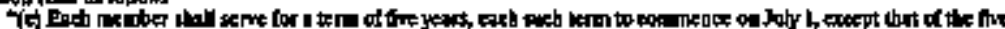

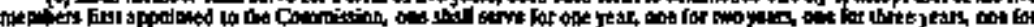

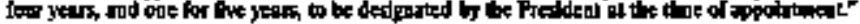


Transfer of AEC functions end petsonnet

Addfitiona] trantfers.

Sg S1at. 1244.

42 USC 5842

42 USC

2071-2112, $2131-2140$. (f) There are hereby transferred to the Comunission all the licensing and related regulatory functions of the Atomic Energy Commission, the Chairratan and member of the Commission, the General Counsel, and other officers and components of the Comuission-which functions, officers, components, and personntel are excepted from the transfer to the Administrator by section 104(c) of this Act.

(g) In addition to other functions and personnel transferred to the Cornmission, there are also transferred to the Commission-

(1) the functions of the Atomic Safety and Licensing Board Panel and the Atomic Safety and Licensing Appeal Board;

(2) such personnel as the Director of the Office of Maragement and Budget determines are necessary for exercising responsibilities under section 205, relating to, research, for the purpose of confirmatory assessment refating to licensing and other regulation under the provistions of the Atomic Energy Act of 1954, as amended, and of this Act.?

\section{"LICENSING AND RELATED REGULATORY FUNCTIONS RESPECTING SELECTED ADMINISTRATION FACILITIES}

Sec. 202. Notwithstanding the exclustorts provided for in section 110 a. or any other provisions of the Atomic Energy Act of 1954, as amended (42 U.S.C. 2140(a)), the Nuclear Regulatory Commission shall, except as otherwise specifically provided by section $110 \mathrm{~b}$. of the Aromic Energy Act of 1954, as amended (42 U.S.C. 2140,(b)), or other law, have licensing and related regulatory authority pursuant to chapters 6,7,8, and 10 of the Atomic energy Act of 1954, as amended, as to the folkowing facilities of the Adrininistration:

(1) Demonstration Liquid Metal Fast Breeder reactors when operated as part of the power generation factitities of an electric utility system, or when operated in any other mannes for the purpose of demonstrating the stritability for commercial application of such a reactor.

(2) Other demonstration nuclear reactors-except those in exjstence on the effective date of this Act-when operated as part of the power generation facilities of an electric utility systert, or when operated in any other manner for the purpose of demonstrating the suitability for commercial apptication of such a reactor.

(3) Facilities used primarily for the rexeipt and storage of highlevel radioactive wastes resulting from activities licensed under such Act.

"(4) Retrievable Surface Storage Facilities and other factlities authorized for the express purpose of subsequent long-term storage of high-level radioactive waste generated by the Adrinistration, which are not used for, or are part of, research and develop. uent activities.

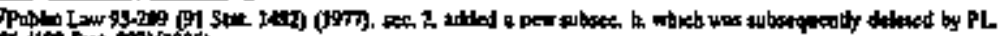

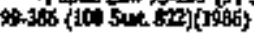


Estabtianment. 42 USC 5843 .

Director.

Functions.

42 USC 2011. note.

88 Stat. W45.

Establishroent. 42 USC 5845. Director.

Functions,

42 USC 2011. note.

\section{"OFFCE OF NUCLEAR REACTOR REGULATION}

"Sec. 203. (a) There is hereby established in the Commission an Office of Nuclear Reactor Regulation under the direction of a Director of Nuclear Reactor Regulation, who shall be appointed by the Commisston, who may report directly to the Commission, as provided in section 209 , and who shall serve at the pleasure of and be removable by the Conomission.

(b) Subject to the provisions of this Act, the Director of Nuclear Reactor Regulation shall perform such functions as the Commission shall delegate including

“(1) Principal licensing and regulationt involving all facilities, and materials licensed under the Atomic Energy Act of 1954, as andended, assoctated with the construction and operation of nuclear reactors licensed under the Atomic Energy Act of 1954, as anended;

${ }^{*}$ (2) Review the safety and safeguards of all such facilities, materials, and activities, and such review functions shall include, but not be limited to-

"(A) monitoring, testing and recommending upgrading of 5y5tems designed to prevent substantial health ar safety hazards; and

(B) evaluating methods of transporting special nucleas and other nuclear materials and of transporting and storfog highlevel radioactive wastes to prevent radiation hazards to employees and the gentral pubtic.

(I) Recommend research necessary for the discharge of the functions of the Commission.

(c) Nothing in this section shall be construed to limit in any way the functions of the Administration relating to the safe operation of alI facilities restlleing from all activities within the jurisdiction of the Administration pursuant to this Act.

\section{"OFFICE OF NUCLEAR MATERIAL SAFETY AND SAFEGUARDS}

"Sec. 204. (a) There is hereby estabtished in the Commission an Office of Nudear Material Safety and Safeguards under the direction of a Director of Nuctear Material Safecy and Safeguards, who shall be appointed by the Commission, who may report directiy to the Cammission as provided in section 209, and who shall serve at the pleasure of and be removable by the Commission.

"(b) Stubject to the movisions of this Act, the Director of Nuclear Material Safety and Safeguards shall perform such functions as the Commission shail delegate including:

"(1) Principal licensing and regulation involving all facilities and materials, licensed under the Atomic Energy Act of 1954, as amended, associated with the processing, transport, and handling of nuclear materials, including the provision and maintenance of safeguards against threats, thefits, and sabotage of such licensed facilities, and materials.

"(2) Review safecy and safeguards of all such facilities and materials licensed under the Atomic Energy Act of 1954, as amended, and such review shall jnclude, but not be limited to-

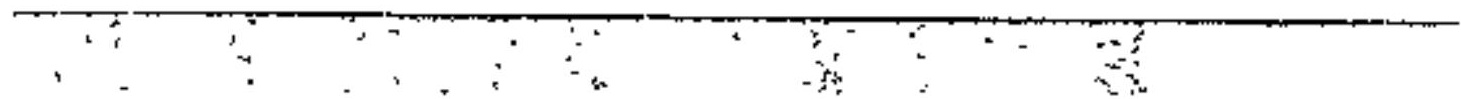


Report to Congress.

89 Stot. 1246.

Establishment. 42 USC 5845. Director.

Functions.

Cooperation of Federal agencies.
"(A) mokitoring testing, and recommending upgrading of - interal accounting systems for special nuclear and other nuclear materials licensed under the Atonaic Energy Act of 1954, as amended:

"(B) developing, in consultation and coordination with the Administration, contingency plans for dealing with threats, thefts, and sabotage relating to special nuclear materials, high-kevel radioactive wastes and nuclear facilities resulting from all activities licensed under the Atomic Enengy Act of 1954, as amended;

"(C) assessing the need for, and the feasibility of, establisting a security agency within the office for the performance of the safeguards functions, and a report with recormmendations on this matter shall be prepared within one year of the effective date of this Act and promptly transmitted to the Congress by the Commission.

"(3) Reconmending research to enable the Commission to more effectively perfotm its functions.

(c) Nothing in this section shall be construed to limit in any way the functions of the Administration relating to the safeguarding of special nuclear materials, high-level radioactive wastes and nuclear facilities resulting from all activities within the jurisdiction of the Adrutistration pursuant to this Act.

\section{"OFFICE OF NUCLEAR REGULATORY RESEARCH}

"Sec. 205. (a) There is hereby established in the Commission an Office of Nuclear Regulatory Research under the ditection of a Director of Nuclear Regulatory research, who shall be appointed by the Commission, who may report directly to the Commission as provided in section 209, and who shall serve at the pleasture of and be removatle by the Commission.

"(b) Subject to the prowisions of this Act, the Director of Nuclear Regulatory Research shall perform such functions as the Commission shall delegate inchading:

"(1) Developing recommendations for research deemed necessary for performatict by the Commission of its licensing and related regulatory functions.

"(2) Engaging in or contracting for research which the Commission deems necessary for the performance of its licensing and Ielated regulatory functions.

"(c) The Administrator of the Administration and the head of every other Federal agency shatl-

"(1) cooperste with respect to the establishment of priorities for the furnishitg of stch restearch services as requested by the Commission for the conduct of its functions;

"(2) furnish to the Commission, on a reimbursable basis, through their own facilities os by contract or other arrangement, stch research strvices as the Commission deerns necessaty and requests for the performance of jts functions; and

"(3) consult and cooperate with the Commission on research and development matters of mutual interest and provide such information and physical access to its facilities as will assist the 
Information and restarch services.

I

Improved Safety Sysiems Research Lang-term platt development, 42 USC 5845.

42 USC 5846.

42 USC 2011 note.

88 Sigl. 1247.

Penalty.

42 USC 2282.

Posting of requirements. 42 USC 2011 note.

Enforesmont.

42 USC 5847.

Federal-Slatelocal cooperation
Commission in acquiring the expertise necessary to perform its licensiong and related regulatory functions.

"(d) Nothing in subsections (a) and (b) of this section or section 201 of this Act shall be construed to limit in any way the functions of the Administration relating to the safety of activities within the jurisdiction of the Administration.

"(e) Each Fecteral agency, subject to the provisions of existing law, shall cooperate with the Commission and provide such information and research services, on a reimbursable basis, as it may have or be reasonably able to acquire.

"(f) The Commission shall develop a long-term plan for projects for the development of new or improved safety systems for nuclear powerplants. ${ }^{B}$

\section{"NONCOMPLIANCE}

"Sec. 206, (a) Ary individual director, or responsible officer of a titrl constructing, owning, operating, or supplying the components of any facility or activity which is licensed or otherwise regulated pursuant to the Atomic Energy Act of 1954 as amended, or pursuant to this Act, who obtains information reasonably indicating that such facility or activity or basic components supplied to stech facility or activity-

"(1) fails to comply with the Atomic Energy Act of 1954, as amended, or any applicable nule, regutation, order, or license of the Commission relating to substantial safety hazards, or

"(2) contains a defect whith could ceeate a substantial safety bazard, as defined by regulations whith the Commission shat promulgate,

shall immediately notify the Commission of such failure to contply, or of such defect, unless such person has achal knowledge that the Comnission has been adequately informed of such defect of failure to comply.

“(b) Any person who knowingly and consciously fails to provide the notice required by subsection (a) of this section shall be subject to a civil penalty in an amount equal to the amount provided by section 234 of the Atoric energy Act of 1954, as amendtod.

“(c) The requirements of this section shall be prominently posted on the premises of any facility licensed or otherwise regulated pursiant to the Atomic Energy Act of 1954, as amended.

“(d) The Commission is authorized to conduct such reasonable inspections and other enforcement activities as needed to iasure compliance with the provisions of this section.

\section{"NUCLEAR ENERGY CENTER SETE SURYEY}

"Sec. 207. (a)(1) The Commission is autharized and directed to make or caluse to be jade under its ditection, a national struey, which shall include consideration of each of the existing or future electric reliability regions, or other appropiate regional areas, to locate and identify possible nuclear energy center sites. This survey shall be conducted in cooperation with other jaterested Federal, State, and lacal agencies,

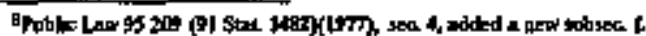


Solictitation of views.

Deftinition.

Report to

Congress and

Council on

Environmetital

Quality; pubtic. availability.

88 Stat. 1248

Reports 6

Conjress.

42 USC 5848.

42 USC 2011

note. and the views of interested persons, including electric utilities, citizens' groups, and others, shall be soljeited and considered.

"(2) For pujposes of this section, the term 'nuclear energy center site' means any site, including a site not restricted to land, large enough to support utility operations ct ofler eleroents of the total nuckear fiel cycle, or both including, if appropriate, nuclear fuel reprocessing facili. tees, nuclear fucl fabrication plants, retrievable uuclear waste storage facilities, and uratum errichurent factitites.

"(3) The survey shall include-

"(a) a regional evaluation of natural'resources, includine land, ajr, and water rosources, avaflable for use jo connection with nuclear energy center sites; estimates of future electric power tequirenents that can be served by each nuclear energy center site; an assessment of the ecoromic impact of each auclear energy site; and consideration of any other relevant factors, including but not limited to population distribution, ptoximity to electric load centers and to other elements of the fuel oycle, transmission tine rights-of-way, and the availability of other fuel rescources;

"(b) an evaluation of the epvironinental impact likely to result frou constniction atod operation of such nuclear enory centers, including an evaluation whether such ruclear energy centers will result in greater or lesser envitonmeital inpact than separate siting of the feactors and/or fuel cyole facilities; and

"(c) consideration of the use of federally owned property and other property desigrated for public use, but excluding national parks, nafional forests, aational wilderiess areas, and national bistoric monüutents.

"(4) A report of the resilts of the survey shall be published and rransmitted to the Congress and the Courcil on Environmental Quality not later than one year from the date of the enactment of this Act and shall be made available to the pnblic and shall be updated from time to tome thereafter as the Commission, in its discretion, deems advisable. The report shal! jnclude the Commission's evaluation of the results of the survey and any conclusions and recoimmendations, including recommendations for legislation, which the Cominission may have concerning the feasibility and practicality of locating nuclear power resctors and/or oflier elements of the pucléar fuel cycle or nucleas energy center sites. The Commission is authorized to atopt policies with will encourage the location of molear power reactors and related fuel cycle facilities on nuclear energy center sites insatar as practicable.

\section{MANORMAL OCCURRONCE REPORTS}

"Sec. 208. The Combrission shall submit to the Coryress an anrual report listing for the previous fisial year ang abnormal occurrences at or associated with any facility which is licensed or otherwise regulated pur. suant to the 'Atorvic' Energy Act of 1954 as amende'd, or pursuant to this Act. For the puposes of this section an abnormal occurrence is an unscheduled incident or event which the Commission determines is significant from the standpoint of ptblic bealth or safety. Nothing in the preceding sentence shall linit the authority of a court to review the determination of the Commission Each such report shall contain- 
Public dis. semination of jnformation.
Executive

Dizector. 42 USC 5849. Functions.

Equal employment opportunity, report,

Annual status report.

Report to

Congress.

42 USSC 5877. Olber officers.
“(1) the date and place of each occurrence;

(2) the nature and probable conseguence of each ocourrence;

"(3) the cause or causes of eaci; and

"(4) any action taken to prevent reoccurrence;

the Commission shall also provide as wide dissemination to the public of the information specified in clauses (1) and (2) of this section as rtasonably possible within fifteen days of its receiving information of eacil abnormal occurrence and shall provide as wide dissemination to the publicas reasonably possible of the information specibed in clauses (3) and (4) as soon as such information becomes available to it*

\section{"OTHER OFFICERS}

«Sec. 209. (a). The Commission shall appoint an Executive Director for Operations, who shall serve at the pleasure of and be removatle by the Commission.

"(b) The Execurive Director shall perform such functions as the Commission may direct, excepe that the Executive Director shall not limit the authority of the director of any component onganization provided in this Act to communicate with or report directly to the Commission when such director of a component organization deems it necessary to carry out his responsibilities. Not withstanding the preceding senterce, each such director shall keep the Executive Director fully and currenty informed concensing the content of all such direct communtications with the Cornmission,?

"(c) The Executive Director shall report to the Contunission at semtarmulal public meetings on the problems, progress, and status of the Commission's equal employment opportunity efforts. ${ }^{10}$

"(d) The Executive Director shall prepare and forward to the Commission an annual report (for the fiscal year 1978 and each succeeding fiscal year) on the status of the Commission's programs concerning domestic safeguards matters induding an assessment of the effectiveness and adequacy of safeguards at faclitites and activities licensed by the Commission. The Comutission shall forward to the Corgress a report under this section prior to February 1,1979, as a separate document, and prior to February 1 af each succeeciing year as a separate chapter of the Commission's annual report (required under section 307(c) of the Energy Reorgantzation Axt of 1974) following the fiscal year to which such report applies. 11

"(e) 10 There shall be in the Commission not more than five additional officers appointed y the Commission. The positions of such oficers shall be considered career positions and be subject to subsection $161 \mathrm{~d}$. of the Atomic energy Act.

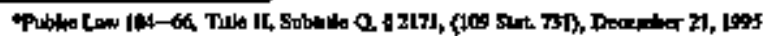

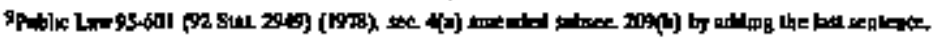

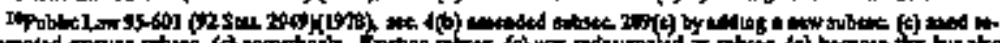

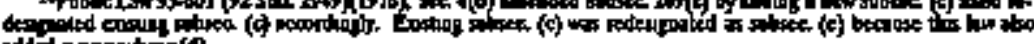
added on war subsec(0)

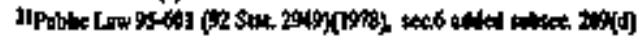


42 USC 5850.

Submitlal to

Congress.

Progeress

reports.

42 USC 5851

42 U\$SC2011

note.

\section{"UNRESOLVED SAFETY ISSUES PLAN}

"Sec. 210. The Commission skall develop a plan providing for the specification and analysis of unsesolved safety issues selating to nuclear reactors and shali take such action as may be gecessary to implement corrective measures with respect to steh issues. Such plars shall be submitted to the Congress on or before January 1, 1978, and progress reports shall be included in the annual report of the Commission thereafter. ${ }^{12}$

\section{"EMPLOYEE PROTECTION*}

“Sec. 211. (a)(1) No employer may discharge any employee or other. wise discriminate against any enployee with respect to his compensation, terms, conditions, or privileges of employment because the enploye (or any person acting pursuant to a request of the employee)"(A) notified his employer of an alleged violation of this Act or the Atomic Energy Act of 1954 (42 U.S.C. 2011 et seg.);

“(B) refused to engage in any practice made unlawful by this act of the Atomic Energy Act of 1954, if the employee has identitied the alleged illegality to the employer;

"(C) testified before Congress or at any Federal or State procesting regarding any provision (or proposed provistion) of this Act of the Atomic Erergy Act of 1954;";

- "(D) tommenced, caused to be commented, or is about to commence or cause to be commenced a proceeding under this Act or the Atomic Energy Act of 1954, as amended, or a proceeding for the adrutnistration or enforcentent of any reguirement imposed uider this Act or the Atomic Energy Act of 1954, as amended;

"(E) testified or is about to testify in any such proceeding or;

"(F) assisted or participated or is about to assist or partictpate in any manner in such a proceeding or in any other manner in such a proceeding or in any other action to carry out the purposes of this Act or the Atomic Entrgy Act of 1954, as amended.

"(2) For purposes of this section, the term 'employer" ineludes-

"(A) a licensee of the Commission or of an Agreement State under section 274 of the Atomic Energy Act of $19 \$ 4$ (42 U.S.C. 2021);

"(B) an applicant for a license from the Coumission or such an Agreement \$tate;

"(C) a contractor or subicontractor of such a licensee or applicant; and

"(D) a contractor or subcontractor of the Department of Energy that is indemnitied by the Department ander section 170 d of the Atomíc Energy Act of 1954 (42 U.S.C. 2210(d)), but such tèrus sistall not include any contractor or subcontractor cowered by Exectitive Order No. 12344".

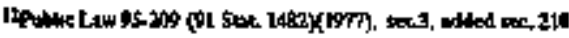

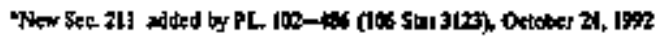


Complaint, filing and notificalion.

Iovestigstion .

and

notítication.

Order.

Notice askt

hearing.

Settlement.

Relief. "(b)(1) Any employee who believes that he has been discharged or otherwise discriminated against by any person in violation of subsection (a) may, within 180 days after such violation oceurs, file (or bave any person file on his behalt) a complaint with the Secretary ofLabot (in this section referred to as the 'Secretary') alteging such discharge or discrimination. Upon receipt of such a vomplaint, the Secretary sboll notify the person named in the complaint of the filing of the complaint, the Commission and the Department of Energy.

(2)(A) Upon receipt of a complaint filed under paragraph (1) the Secretary shall conduct an isvestigation of the violation aleged in the complaint. Within thirty days of the receipt of such complaint, the Secretary shall complete such investigation and shail notify in writing the complaimant (and any person acting in his bebalt) and the person alloged to have committed such violation of the results of the investigation condacted pursuant to this subparagrapit. Within nimety days of the receipt of sucil comptaint the Secretary shall, unless tlee proceeding on the complatant is terminated by the Secretary on the basis of a settlement entered into by the Secretary and the person alleged to bave committed such violation, issue an order ejther providiug the relief prescribed by subparagraph (B) or denging the complaint. An order of the Secretary shail be made on the itcord after notice and opportunity for public hearing. Upon the conclusion of such hearing and the issuance of a recommended decision that the complaint has merit, the Secretary shall issue a preliminary order providing the relief prescribed in subparagraph (B), but may not order compensatory damages pending a final order. The Secretary may not enter into a settlement terminating a proceeding on a complaint without the participation and consent of the complainant.

"(B) If, in response to a complaint filed under paragraph (1) the Secretary determines that a violation of subsection (a) has accourred, the Sectetary shall order the person who committed such violation to (i) take affirmative action to abate the violation, and (it) reinstate the complainaant to his former position together with the compensition (including back pay), terms, conditions, and privileges of his employment, and the Sectetary may arder such person to prowide compersatory damages to the complainant. If an order is issued under this paragraph, the Secretary, at the request of the complainant shatl assess against the person against whorn the order is issured a sum equal to the aggregate amount of all costs and expenses (including attomeys' and expert witness fees) reasonably itcurred, as determined by the Secretary, by the complajnant for, or in connection with, the bringing of the complaint upon which the order was issued.

“(3)(A) The Secretary sholl dismiss a complaint filed under paragraph (1), and sbali not conduct the investigation required under paragraph (2), unless the complainant has made a prima facie showing that any behavior described in subparagraphs

T. .


Review.

5 USC 701

elseg.

Jurisdiction.

Litigative

costs.
(A) through (F) of subsection (a)(1) was a contributing factor in the unfavorable personnel action alleged in the complaint. “(B) Notwithstanding a fonding by tie Secretary that the complatiant has made the showisg required by subparagraph (A), no investigation required under paragraph (2) shall be conducted if the employer dononstrates, by clotar and convincing evidence, that it woukd have taken the same unfavorable persomel action tin the absence of such bebavior.

i(C) The Secretary may deternine that a violation of subsection (a) bas occurred only if the conplainant has demonstrated that any behavior described in subparagraphs (A) through (F) of subsection (a)(1) was a contributing factor in the unfavorable personnel action alleged in the comptaint.

r “(D) Relief maty not be ordered under paragrapt (2) if the employer demonstrates by clear and convincing evidence that

- it would have taken the same tufavorable personnel action in the absence of such behavior.".

(c)(1) Any person adversely affected or aggieved by an order issued under subsection (b) may obtain review of the order in the United States court of appeals for the circuit in which the violation, with re' spect to which the order was issued, allegedly occurted. The petition for review must be filed within sixty days fon the issuance of the Secretary's order. Review shall confors to chapter 7 of title 5 of the United States Code. The commencement of proceedings turder this subparagraph sball not, unless ordered by the cotut, operate as a stay of the Sectetary's order.

"(2) An order of the Secretary with respect to which reviow colld bave been obtained under paragraph (1) shatl not be subject t to judicial review in any criminal or other civil proceeding.

"(d) Whenever a person has failed to comply with an order issued under subsection (b) (2), the Secretary may file a civil action in the United States district caut for the distriet in which the violation was found to accur to enforce such order. In actions brought under this subsection, the district cours shall have jurisdiction to grant all appropriate relief inclikding, but not limited to, injunctive relief, compensatory, and exemplary damages.

"(c)(I) Any ptison on whost behalf art order was issued under paragraph (2) of subsection '(b) may commence a civil action against the person to whom such order was issued to require compliance with such oider. The appropriate United States district court shall bave jurisdiction, without regard to the amount in controversy or the citizenship of the parties, to eaforce such order.

"(2) The court, in issuing any final order under this subsection, may award costs of litigation (jncluding reasonable attorney and expert witness fees) to any party whenever the court determines such award is appropriate.

"(f) Any nondiscretionary chty imposed by this section shat be enforcetable in a mandamus proceeding brought uader section 1361 of title 28 of the United States Code. 
42 USC 2011.

"(g) Subsection (a) shall not apply with respect to any employee who, acting without direction from his or her employer (or the employer's agent), deliberately causes a violation of any requirement of this Act or of the Atomic Energy Act of 1954, as amended. ${ }^{13}$

"(b) This section may not be construed to expand, diminish, of otherwise affect any right otherwise available to an employee under Federal or State law to rectress the employee's discharge or other discriminatory action taken by the employer against the employee.".

"(i) The provisions of this section shall be prominently posted in any place of employment to which this section applies. ${ }^{n}$.

"(j)(1) The Cominission or the Department of Energy shall not delay taking appropriate action with respect to an allegation of a substantial safety hazard on the basis of-

1 "(A) the filing of a comptaint under subsection (b)(1) arising from such allegation; or

- "(B) any ínestigation by the Secretary, or other action, un-der this section in response to such complaint.

"(2) A determination by the Secretary under this section that a violation of subsection (a) has not cocumred shall not be considered by the Cominission or the Department of Energy in its determination of whether a substantial safety hazard exists.".

Lapses of agencies and posítions. 42 USC 5871 .

88 Stat. 1249. Saving clauses,

\section{TMTLE III-MISCELLANEOUS AND TRANSITIONAL PROVISIONS}

\section{MRANSTrONAL PROMTSONS}

HSec, 301. (a) Except as otherwise provtded in this Act, whenever all of the functions or programs of an agency, or other body, or any component thereof, affectsol by this Act, have been transfenced from that agency, of other body, or any component thereof by this Act, the agency, ox other boty, or component thereof shal! lapse. If an agency, or other body, or any compontent thereof, lapses pursuant to the preceding stutence, each position and office theretin which was expressly authorized by law, or the incumbent of which was authorized to recejve compensation at the rate prescribed for an officer or position at level II, III, IV, of V of the Executive Schedule (5 U.S.C. 5313-S316), shatl lapse.

"(b) All orders, determinations, niles, regitlations, permits, contracls, certificates, licenses, and privileges-

"(1) which have been issued, made, granted, or allowed to be come effective by the President, any Federal department or agency or official thereof, or by a court of competent jurisctiction, in the performance of functions which are transferced under this Act, and

(2) which are in effect at the time this Act takes effect, shall continue in effect according to their terms until modified, terminated, superseded, set aside, or revoked by the President, the Admirnistrator, the Commission, or other autionized officials, a court of competent jurisdiction, or by operation of law.

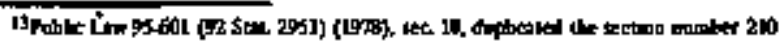


"(c) The provisions of this Act shall, not-affect any proceeding pending, at the time this section takes effect, before the Atomic Energy Commission or any department or agency (or component thereof) functions of which are transferred by this Act; but sact prockedings, to the extert that they relate to functions so transferred, shall be continued. Orders shall be issued in such proceedings, appeals shall be taken therefrom, and payments shall be made pursuant to such orders, as if this Act had not been enacted; and orders issued in any such proceed. ings shall contintue in effect until ;modified, terminated, superseded, or revoked by a duly authorized official, by a court of competent jtrisdiction, or by operation of law. Nothing in this subsection sball be deemed to prohibit the discontinuance or modification of any such proceeding under the same terns and conditions and to the same extent that such proceecting could have been disconnected if this Act had not been enacted.

(d) Except as provided in subsection (f)-

"(1) the provisions of this Act sball not affect suits commenced prior to the date this Act takes effect, and

"(2) in all stich stits proceetings shali be had, appeals taken, and judgements rendered, in the stane magner and effect as if this Act had not been enacted.

"(e) No sujt, action, or other proceeding commenced by or against any officer in his official capacity as an officer of any department or agency, functions of which are trassferred by this Act, shall abate by reason of the enactment of this Act. Nocause of action by ot against any departuient or agency, finctions of which are transterted by this Act, or by or against any officer thereof is his official capacity shall abate by reason of the enactroent of this Act. Causes of actions, suits, actions, or other procetedings may be asserted by or against the United States or such official as may be appropriate and, in any litigation pending when this section takes effect, the court may at any time, on its own motion or that of amy party, enter any order which will give effect to the provisions of this section. :

"(f) If, before the date on which this Act takes effect, any department or agency, or officer thenef in his official capacity, is a party to a suit, "and under this Ast any function of such department, agency, or officer is transferred to the Administrator or Conamission, or any other official, - 'then such suit shall be continued as if this Act had not been enacted, with the Administrator of Commission, or' other official, as the case may be, substituted.

"(g) Final ordets and actions of any otitizal or component in the performance of functions transferred by this Act shall be subject to judjcial review to the same extent and in the same manner as if stuch orders or actions had been make or taken by the officer, department, agency, or instrumentality in the performance of such functions immediately preceding the effective date of the Act. Any statutory requirements relating to notices, hearings, action upon the record, or administrative review that apply to any function transferred by this Act shall apply to the performance of those functions by the Administrator or Connuission, or any officer or component. 
"(h) With respect to any function transferred by this Act and performed after the effective date of this Act, reference in any other law to any departinent or agency, or any officer or office, the functions of which are so transferred, shall be deemed to refer to the Administration, the Administrator or Commission, or other office or official in which this Act vests such functions.

"(t) Nothing contained in this Act shall be construed to limit, curtail, abolish, or terminate any function of the President which he had junntdiately before the effective date of this Act or to limit, curtail, abolish, or terminate his authority to perform such function; or to limit, curtail, abolish, or terminate his authority to delegate, redelegate, or terminate any delegation of functions.

"(i) Asy reference in this Act to any provision if law shall be deemed to include, as appropriate, references thereto as now or hereafter ariendeo or supplemented,

"(k) Except as may be otherwise expressly provided in this Act, all functions exppressly conferred by this Act shall be in addition to and not in substítution for tunctions existing fouraediately before the effective date of thits Act and transferred by thts Act.

"TRANSFRR OF PERSONNIS AND OTHER MATTSRS

"Bec, 302 (a) Except as provided in the next sentence, the personnel employed in connection with, and the personnel positions, assets, liabilities, contracts, property, records, and unexpended balances of appropriations, authorizations, allocations, and other funds employed, held, used, arising from, available to or to be made availabte in connection with the functions and programs transferred by this Act, are, subject to section 202 of the Budget and Accounting Procedtures Act of 1950 (31 U.S.C. 581c), correspondingly transferred for appropriate allocation Personnel positions expressly created by law, personinel $\alpha c c 1-$ pying those positions on the effective date of this Act, and personnel authorized to receive compensation at the rate prescribed for offices and positions at levels IJ, II, IV, or V of the Executive Schedule (5 U.S.C. 5313-5316) on the effective date of this Act shall be subject to the provisions of subsection (c) of this section and section 301 of this Act.

"(b) Except as provided in subsection (c), transfer of nontemporary personnel pursuant to this Act siali not cause any such employee to be separated or rectuced in grade or compensation for one year after such transfer.

"(c) Any person who, on the effective date of this Act, held a position compensated in accordantes with the Executive Schedule prescribed in chapter 52 of title 5 of the United States Code, and who, without a break in service, is appointed in the Administration to a position having duties comparable to those performed fimmediately preceding his appointuent, shall continue to be compensated in his new position at not jess than the rate prowided for his previous position.

"INCTDENTAL DIEPOSTHONS

42 USC 5873 "Sec. 303. The Director of the Office of Management and Budget is authorized to make such adbitional incidental dispositions of personnel, persomal positions, assets, liabilities, contracts, property, records, 
88 \$tat.. 1251.

42 USC 5874.

42 Usc 3875.

42 USC 5876.

42 USC 22016

Ante, pg. 1234, 1242 .

Report to Congress.

Reports to the President and Congress. $42 \mathrm{USC} 5877$. and unexpended balances of appropriations, authorizations, allocations, and other finds held, used, arising from, available to or to be made available in connection with functions transferred by this Act, as be may deem necessary or approptiate to accomplish the intent and purpose of this Act.

"Sec. 304. As used in this Act-

\section{"DEFINITIONS}

"(1) any reference to "function" or "functions" shall be deented to jaclucle references to duty, obligation, power, authority, ren sponsibility, right, privilege, and activity, or the plural thereof, as the case may be; and

"(2) any reference to "pefform" or "performance", when used in selation to sanctions, shall be deemed to include the exercise of power, authority, rights, and privileges.

\section{AUTHORIZATIONS OF APPROPRIATIONS}

aSec, 305. (a) Except as othtrwist provided by law, appropriations made under this Act shatl be subject to an anulual authorization.

"(b) Authorization of appropriations to the Commission shall reflect the need for effective licensing and other regulation of the molear power industry in relation to the groweth of such industry.

\section{"COMPTROLLER GENERAL AUDIT}

"Sec 306. (a) Section 166. "Comptrolle General Aatdit" of the Alomte Energy Act of 1954, as antended, shall be deensed to be applicable, respectively, to the pucleas and nomnuclear activities under title I and to the activities under title II.

"(b) The Comaptroller General of the Untited States sbal audit, Itview, and evaluate the implementation of the provisions of aitte II of this Act by the Nuclear Safety and Licensing Commission not later than sixty months after the effectipe diate of this Act, the Comptroller General shall prepare and submit to the Congress a report on his audit, which shall contain, but not be limited to-

"(1) an evaluation of the effectiveness of the licensing and related regulatory activities of the Commission and the operations of the Ofise of Nuclear Safety Research and the Bureau of Nuciear Materials Security,

"(2) an évaluation of the effect of such Commission activities on the efficiency, effectiveness, and safety with which the activities licensed under the Aromic Energy Act of 1954, as amended, are carried out;

"(3) recommendations concerning any legisiation he deems necessary, and the reasons therefor, for improving the implementation of title II.

\section{MREPORTS}

"Bec.307. (a) The Administrator shall, as soon as practicable after the end of each fiscal year, make a report to the President for submission to the Congress on the activities of the Administration during the preceding fiscal yeas. Such report sball include a statentent of the short-range 
Adrmintstration attivities and progress.

Feastibility of transferring military application functions. 98 Stat 1252 .

Carmmission activities and ftedings.

\section{'.}

42 Usc 5878

42 USC 5879 and long-range goals, priorities, and plans of the Administration together with an assessment of the progress made toward the attaimment of objectives and toward the more effective and efficient management of the Administration and the coordination of tits functions.

“(b) During the first year of operation of the Administration, the Administrator, in collaboration with the Secretary of Defense, shall conduct a thorough review of the desirability and feasibility of transferring to the Department of Defense or other Federal agencies the func. bions of the Administrator reppecting militacy application and restricted data, and within one year after the Administrator first takes office, the Administrator shall make a report to the President, for submission to the Congress, setting forth his comprehensive aralysis, the principal alternatives, and the specific recommendations of the Administrator and the Secretary of Deferse.

"(c) The Commission shall, s00n as practicable after the end of each fiscal year, make a report to the President for submission to the Congress on the activities of the Commission during the preceding fis. cal year. Such report shall include a clear statement of the short-range and long-range goals, priorities, and plans of the Commission as they rejate to the benefits, costs, and risks of commercial nuclear power. Such report shall also include a clear description of the Commission's activities and findings in the following areas-

"(1) insuring the safe design of nuclear power plants and other licensed facilities;

"(2) imvestigating abnormal cocurrences and defects in nuclear powerplants and other liconsed facilities;

"(3) safeguarding special nuclear materials at all stages of the nuclear fuel cycle;

"(4) irvestigating suspected, attempted, or actual thefts of spe. cial nuclear materials in the licensed sector and developing contingency plans for dealing with such incidents;

(5) insuring the safe, permanent disposal of high-level radioactive wastes through the licensing of nuclear activities and facilitics;

"(6) protecting the public against the hazands of low-level radioactive emissions from licensed nuclear activities and facilities.

\section{mRTOBMATTON TO COMMITTEES}

"Sec. 308. The Administrator shall keep the appropriate congressional committees fully and currently informed with respect to all of the Administration's activities.

\section{TIRANSFER OF FILNDS}

"Sec 319. The Admintstrator, when authorized in an appropriation Act, may, in any fiscal year, transfer funds from one appropriation to another within the Administration; except, that no appropriation shall be either increased of cerreased pursuant to this section by more than 5 per centum of the appropriation for such fiscal year.

"CONFORM1NG AMIENDMIENTS TO CERTAIN OTETER LAWS

"Sec. 310. Subchapter II (relating to Executive Schedple pay rates) of chapter 53 of title 5, United States Code, is amended as follows:

"(1) Section 5313 is angended by striking out '(8) Chairman, Atomic Energy Conmission, ${ }^{*}$ and inserting in lieu there of '(8) 
88 Stat. 1253. .

42 USC 5\$01

note.

42 USC 5801

note.

Publication , in Federal Registe:.
Chairman; Nuclear Regulatory Commission,; and by adding at the end thereof the following:

'(22) Administrator of Energy Research and Developintent Administration.'.

"(2) Section 5314 is amended by strikjng out "(42) Members, Atomic Energy Commission.' and inserting in lieu thereof '(42) Members, Nuclear Regulatory Commission.', and by adding at the end thereof the following:

'(60) Deputy Administrator, Energy Research and Development Admimistration.'

"(3) Section 5315 is amended by striking out paragraph (50), and by adding at the end thereof the following:

'(100) Assistant Administrator, Energy Researcti and Development Admiristration (6).

'(101) Director of Nuclear Reactor Regulation, Nuclear Regulatory Conanission.

(102) Director of Nuclear Material Safety and Safeguarck, Nuclear Regulatory Commisston.

(103) Director of 'Nuclear Regulatory Research, Nuslear Regulatory Commission.

(104) Executive Director for Operations, Nucterar Regulato-

ry Commission.'

(4) Section 5316 is amended by strikting out paragraphs (29), $(62),(69)$, and (102), by striking out '(81), General Counsel of the Atomic Energy Commission,' and inserting in lien thereof '(81) Getheral Counsel of the Nuclear Regulatory Commission.', and by adding at the end thereof the following:

(134) General Counsel, Euergy Research and Developanent Administration.

'(135) Additional officers, Energy Research and Development Administration (8).

'(136) Additional officers, Nuclear Regulatory Commission (5) ${ }^{*}$.

\section{"SEPARABITTY}

asec. 311. If any provistion of this Act, or the application thereof to any person or circumstance, is held invalid, the remainder of this Act, and the application of such provision to other persons or circunastances, shall not be affected thereby.

\section{"EFFECTIVE DATE AND INTERIN APPOINTMTENTS}

"Sec. 312. (a) This Act shall take effect one hundred and twenty days after the date of its entactment, or on such earliter date the President mayt prescribe and petblish in the Federal Register; except that any of the officers provided for in title I of this Act may be nominated and appointed, as ptovided by this Act, at any time after the date of enactment of this Act. Funds available to any department or agency (or any official or component thereof), any functions of which are transferred to the Adiministrator and the Commission by thils Act, may, with the approval of the President, be used to pay the compensation and expenses of any offices appointed pursuant to this subsection until such time as funds for that purpose are otherwise available. 
8B Stat. 1254 .

42 USC 5891.

42 USC 2000d. “(b) In the event that any officer required by this Act to be appointed by and with the advice and consent of the Senate shab not have entered upon office on the effective date of this Act, the President may designate any officer, whose appointment was required to be made by and with the advice and consent of the Senate and who was such an ofticer inmediately prior to the effective date of this Act, to act in such office antil the office isfilled as provided in this Act. While soacting, sucti persons shall receive compensation at the rates provided by this Act for the respective offices in which they act.

\section{"TTTLE IV - SEX DISCRIMINATION}

\section{"SEX PISCRIMINATION PROHIBITYT}

"Sec. 401. No person shall on the ground of sex be exctuded from participation in, be denied a license under, be denjed the benefits of or $^{\text {be }}$ subjected to discrisingation under any program or activity curried on or receiving Federal assistance under any tide of this Act. This provision vill be enforced through agency provisions and rules similas to those already established, with respect to racias and other discrimination, under titie VI of the Civil Rights Act of 1964. However, this remedy is rot exclusive and will not prejudice or cut aff any other legal remedies avaflable to a discriminatee. 


\section{PRESIDENTIAL DOCUMENTS}

\section{TITLE 1 - THE PRESIDENT \\ REORGANIZATION PLAN NO. 3 OF 1970*}

5 USC, App. I

"Prepared by the President and tratsinitted to the Senate and the House of Representatives in Congress assembled July 9, 1970, pursuant to the provisions of chapter 9 of title 5 of the United States Code. 1

Tavironmental Protection Agergy

Section 1. Estabilshment of Agency. "(a) There is hereby established the Envirouroental Protection Agency, hereiratter referred to as the "Agency."

(b) There shall be at the hegd of the Agency the Administrator of the Environmental Protection Agency, hereinafter referred to as the "Administrator." The Administrator shall be appointed by the President, by and with the advice and consent of the Senate, and shall be compensated at the rate now or bereafter provided for Level II of the Execultive Schedule Pay rates (5 U.S.C. 5313).

(c) There shall be in the Agency a Deputy Adninistrator of the Emvironmental Pratection Agency who shall be appojinted by the President, by and with the advice and consent of the Senate, and shall be compensated at the rate now or hereafter provided for Level III of the Execu. twe Schedule Pay Rates (3 U.S.C. 5314). The Deputy Administrator shall perform such functions as the Administrator shall from time to time assign or delegate, and shall act as Administrator during the ab. sence or disability of the Administrator of in the event of a vacancy in the office of Administrator.

(d) There shall be in the Agency not to exceed five Assistant Administhators of the Enwironmental Potection Agency who shats be appointed by the President, by and with the advice and consent of the Senate, and shal] be compensated at the rate now or hereafter provided for Level IV of the Executive Schedule Pay Rates (5 U.S.C. 5315). Each Assistant Administrator shall perform such functions as the Administrator shall from time to time assipn or delegate.

Section 2. Transfers to Environmental Protection Agency. (a) There are hereby ransferred to the Administrator:

(1) All finctions vested by law in the Secretary of the lnterior and the Department of the lnterior which are administered through the Federal Water Quality Admimistration, all functions which were transterred to the Secretary of the Interior by Reorganization Plan No. 2 of 1966 ( 80 Stat 1608), and all functions vested in the Sceretary of the Interior or the Department of the Interior by the Federal Water Pollution Control Act or by provisions of law amendatory or supplementary thereof.

(2)(j) The functions vested in the Secretary of the Interior by the Act of August 1, 1958, 72 Stat. 479, 16 U.S.C. $742 \mathrm{~d}-1$ (being an Act

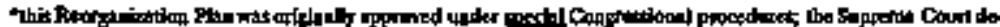

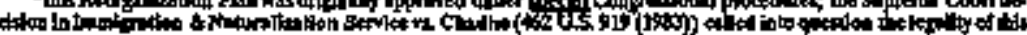

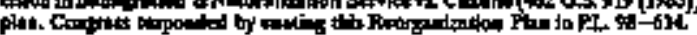

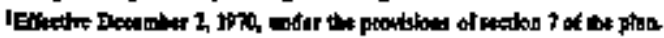


relating to studies on the effects of insecticides, herticides, fungicides, and pesticides upon the fish and wildlife resources of the United States), and (ii) the functions vested by law in the Secretary of the Interior and the Departusent of the Interior which are administered by the Gulf Breeze Biological Laboratory of the Bureau of Commercial Fisheries at Gulf Breeze, Florida.

(3) The functions vested by law to the Sectetary of Health, Education, and Welfare or in the Departuett of Health, Ectucetion, and Welfare which are administered through the Environmental Health Service, including the functions exercised by the following components thereof:

(i) The Nationat Air Pollution Control Adusinistration,

(ii) The Environmental Control Administration

(A) Bureau of Solid Waste Management,

(B) Bureau of Water Hygiene,

(C) Bureau of Radiotogical Health,

except that functions carried out by the following components of the Environmental Control Administration of the Environmental Health Service are not transferred: (i) Bureau of Community Environmental Mapagement, (ii) Bureau of Occupational Safety and Health, and (iii) Bureau of Radiological Health, insofar as the functions carried out by the latter Bureau pertain to (A) regrolation of ractiation from consumer products, inchuding electronic proctuct radjation, (B) radiation as used in the healing arts, (C) occupational exposures to radiation, and (D) reseatch, technical assistance, and training related to clatuses (A), (B), and (C).

(4) The functions vested in the \$ecretary of Health, Education, and Welfare of establishing tolerantes for pesticide chemicals under the Federal Food, Drug, and Cosmetic Act as amended, 21 U.S.C. 346, 346a, and 348, together with authority, in connection with the functions trassferred, (i) to monitor compliance with the tolerances and the effectiveness of sarveillance and enforcenent, and (ii) to provide technical assistance to the States and conduct research under the Federal Food, Drug, and Cosmetic Act, as annended, and the Public Health Servtce Act, as amended.

(5) So much of the functions of the Council on Envirosimental Quality under section 204(5) of the National Envirommental Policy Act of 1969 (Public Law 91-190, approved Jaruary 1, 1970, 83 Stat, 855), as pertains to ecological systems.

(6) The functions of the Atomic Energy Commission under the Atomic Energy Act of 1954, as amended, administered through its Division of Radtation Protection Standards, to the extent that such functions of the Commission consist of establishing generally applicable environmental standards for the protection of the general epvironment from radiogctive material. As used herein, standards mean limits on radjation exposures or levels, or cortcentrations or quantities of radioactive material, in the general environment outside the boundaries of locations under the controt of persons possessing or using radioactive material. 
(7) All functions of the Federal Radiation Counkil (42 U.S.C. 2021(b)).

(8)(i) The functions of the Secretary of Agriculture aud the Department of Agriculture under the Federal Insecticide, Fungicide, and the Rodenticide Act, as amended (7 U.S.C. 135-135k), (ii) the functions of the Secretary of Agriculture and the Department of Agriculture under section 408 (1) of the Federal Food, Dng, and Cosmetic Act, as amended (21 U.S.C. 346a (1)), and (iii) the functions vested by law in the Secretary of Agticulture and the Department of Agriculture which are adrainistered through the Envirosmental Quality Branch of the Plant Protection Divjsion of the Agricultural Research Service.

(9) So much of the functions of the transieror officers and agen. cies referred to in or affected by the foregoing provisions of this section as is incidental to or necessary for the performance by or under the Admitaistrator of the functions transferred by those provisions or relates primarily to those functions. The transfers to the Administrator made by this section shall be deemed to include the,transfer of (1) authority, provided by law, to prescribe regalations relating primarily to the transferred functions, and (2) the Functions vested in the Secretary of the Interior and the Secretary of Health, Edutcation, and Welfare by section 169(d)(1)(b) and (3) of the Internal Revenue Code of 1954 (as enacted by section 704 of the Tax Reform Act of 1969,83 Stat. 668); but,shall be deemed to exclude the transfer of the functions of the Bureau of Reclamation under section 3(b)(1) of the Water Pollution Control Aat (33 U.S.C. $466 a(b)(1))$.

(b) There are hereby, transfered to the Agency:

(1) From the Departuent of the Interior, (i) the Water Pollution Control Adyisory Board (33 U.S.C. 466t), together with jts functions, and (ii) the hearing boards provided for in sections 10(c)(4) and 10(f) of the Federal Water Follution Control Act, as antended (33 U.S.C. $466 \mathrm{~g}$ (c) (4): $466 \mathrm{~g}(\mathrm{f})$ ). The functions of the Secretary of the Interior with respect to bejig or designating the Cbairman of the Water Pollution Control Advisory Board are hereby transferred to the Administrator.

"(2) From the Department of Health, Education, and Welfare, the Air Quality Advisory Board (42 U.S.C. 185\%), together with its functions. The functions of the Secretary of Health, Education, ' and Welfare with respect to being a member and the Chatrman of that Board are bereby transferred to the Administrator.

Section 3. Performance of transferned functions, The Administrator naty from time to time make such provisions as he shall detm appropriate authorizing the performance of any of the functions transferred to him by the provisions of this reorganization ptan by any other officer or by any organizational entity or exaployes, of the Agency.

Section 4. Incidental transfers. (a) So unch of the personnel, property, records, and unexpended balances of appropriations, allocations, and other funds employed, used, heli, available, or to be made available in conrection with the functions transferred to the Administrator or the 
Agency by this reorganization plan as the Director of the Office of Management and Budget shall determine shatl be transferred to the Agency at such time or times as the Director sisall direct.

(b) Such further measures and dispositions as the Director of Office of Maragement and Budget shall deem to be necessary in order to effectuate the transfers referred to in subsection (a) of this section shall be carried out in such manner as he shall direct and by stuch agencies as he shall designate.

Section 5. Interim officers. (a) The President may authorize any person who inmediately prior to the effective date of this reorganization plan held a position in the exectutive branch of the Govemment to act as Administrator until the office of Aomimistrator is for the first time filled pursuant to the provisions of this reorganization plan or by recess appointment, as the case may be.

(b) The President may similarly authorize any such person to act as Deputy Administrator, authorize any stch person to act as Assistant Administrator, and authorize any such person to act as the head of any principal constituent organizational entity of the Administration.

"(c) The President may authotize any person who serves in an acting capacity under the foregoing provisions of this section to rective the compensation attached to the office in respect of which he so serves. Such compensation, if authorized, shal] be in lieu of, but not in addition to, other contpensation from the United States to which such person may be entitled.

Section 6. Abolitions. (a) Subject to the provisions of this rearganization plas, the following, exclusive of any functions, are hereby abolished:

(1) The Federal Water Quality Administration in the Department of the finterior (33 U.S.C. 466-1).

(2) The Fedesal Radiation Council (73 Stat 690; 42 U.S.C. 2021(h)).

(b) Such provisjons as may be necessary with respect to tetminating any outstanding affains shall be made by the Stecretary of the Interior in the case of the Federal Water Quality Administration and by the Administrator of General Services in the case of the Federal Radiation Council.

Section 7. Effective date. The provisions of this reorganization plan shall take effect sixty days after the date they wotld take effect under 5 U.S.C. 906 (a) in the absence of this section.

(F.R. Doc. 70-13374; Filed, Oct. 5, 1970; 8:45 a.m.) 


\section{REORGANIZATION PLAN NO. 1 OF 1980*}

5 USC, App. I

Prepared by the President and submitted to the Senate and the House of Representatives in Congress assembled March 27, 1980, ${ }^{1}$ pursuant to the provisicons of Chapter 9 of Title 5 of the United States Code.

\section{Nuclear Regulatory Commission}

Sec 1. (a) Those functions of the Nuclear Regulatory Commission, bereinafter refepred to as the "Commission", concerned with:

(1) policy formulation;

(2) rulemaking, as defined in section 553 of Title 5 of the United States Code, except that those matters set forth in 553(a)(2) and (b) which'do not pertàin to póticy formulation orders or adjudications shall be reserved to the Chairman of the Commission;

(3) ordérs and adjudications, as defined in section $5 \$ 1$ (6) and (7) of Title 5 of the United States Code;

shall remain vested in the Commission. The Commission may determirié by majority wote, in'an area of 'doubt, whether any matter, action, question or area of inquiry pertain's to one of these functions. The pexforinance of any portion of these functions may be delegated by the Coimmission to a member of the Commisston, incluting the Chatrman of the' Nuclear Regulatory Commission, hereinafter referred to as the "Chairman", and to the staff thitoigh'the Chairman.

(b) (1) Wth respect to the following of ticers or puccessor officers dity 'established th statie or by the Commission, the Chairman shall initiate the appointment, sabject to the approval of the Commission; and the Chairman or a member of the Commission may initiate an action for removal; subject to the approval of the Commission:

(i) Executive Director for Operations,

(ii) General Counsel,"

(iib) Secretary of the Commission;

(iv) Director of the Office of Policy Evaluation,

(v) Director of the Office of Inspector and Auditor,

(vi) Chairmati, Vice Chairman, Executive Secretary, and Members of the Atomic Safety and Licensing Board Panel,

(vii) Chairmsn, Vice Chairman and Members of the Atomic Safely and Licensing Appeal Panel.

(2) With respect to the following officers or successot offtcers duly established by statute or by,the Comonission, the Chairman, after consultation with the Executive Director for Operations, shall initiate the appointment, subject to the approval of the Conrmission, and the Chairman, or a member of the Commission may initiate an action for removal, stibject to the approval of the Commission:

(i) Director of Nuclear Reactor Regulation,

(ii) Director of Nuclear Material Safety and Safeguards,

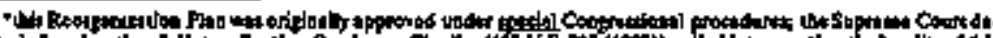

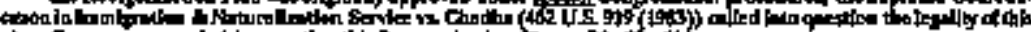

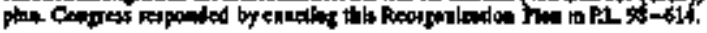

IAs aneded Miny 5. tivel 
(iii) Director of Nuclear Regulatory Research,

(iv) Director of Inspection and Enforcement.

(v) Director of Standards Development.

(3) The Chairman or a member of the Commission shall initiate the appointment of the Members of the Advisory Committee on Reactor Safeguards, subject to the approval of the Commission. The provisions for appointment of the Chairman of the Advisory Committee on Reactor Safeguards and the term of the members shall not be affected by the provisions of this Reorgantization Plan.

(4) The Commission shall delegate the function of appointing, remoxing and supervising the staff of the following offices or successor offices to the respective heads of such offices: Geseral Counsel, Secretary of the Commisston, Ofíce of Public Evaluation, Office of Inspector and Auditor. The Commission shall delegate the functions of appointing, removing and supervising the staff of the following pantels and committee to the respective Chairmas thereof: Atomic Safety and Licensing Boand Panel, Atomic Safety and Licensing Appeal Panel and Advisory Committee on Reactor Safeguards.

(c) Each member of the Commission shall continue to appoint, remove and supervise the personnel employed in his or her immediate office.

(d) The Commission shall act as provided by subsection 201(a)(1) of the Energy Recrganization Act of 1974, as amended (42 U.S.C. 5841 (a)(1), as amended) in the performance of its functions as described in subsections (a) and (b) of this section.

Sec. 2. (a) Al! other functions of the Commission, not specified by Section 1 of this Reorganization Plan, are hereby transferted to the Chairman. The Chairman shall be the official spokesman for the Commission, and shall appoint, suptrvise, and remove, without further action by the Commission, the Ditectors and staff of the Office of Public Aftairs and the Office of Congressional Relations. The Chairnan may consult with the Commission as he deems appropriate in exercising this appointment rusction.

(b) The Charman shall also be the principal executive officer of the Commission, and shall be responsible to the Commixsion for developing policy planning and guidance for consideration by the Conmission: shall be responsible for the Cormission for assuring that the Executive Director for Operations and the staff of the Commission (other than the officers and staff referred to in sections (1)(b)(4), (1)(c) and (2)(a) of this Reorganization $P$ lan) are responsive to the requirements of the Commission in the performance of its functions; shall determine the use and expenditure of funds of the Commission, in accordance with the distribution of appropriated funds according to major programs and purposes approved by the Commission; shall present to the Contmisston for its consideration the proposals and estimates set forth in subsection (3) of this paragrapb; and shall be responsible for the follow. ing functions, which he shall delegate, subject to his direction and supervision, to the Executive Director for Operations unless otherwise provided by thís Reorgarization Plan:

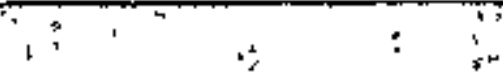


(1) aduinistrative functions of the Conmission:

(2) distribution of business among such personnel and annong

administrative units and offices of the Commission;

(3) preparation of

(i) proposals for the reorganization of the major offices with-

in the Commission;

(ii) the budget estimate for the Commission; and

(iii) the proposed distribution of appropriated funds accord-

ing to major programs and purposes.

(4) appointing and removing without any further action by the Commission, all officers and employees under the Combission other than those whose appointment and removel are specifically "provided for by subsections 1,(b), (c) and 2(a) of this Reorgantization Plan.

(c) The Chairman as principal exceutive officer and the Executive Director for OTeration shall be governed by the general policies of the Commission and by such regtlatory decisions, findings, and determinations, including those for reorganization proposals, budget revistons and distribution of appropriated funds, as the Commission may by law, including this Plan, be authorized to make. The Chairman and the Executive Director for Operations, through the Chairman, shall be responsible for insuring that the Commission is fully and currently informed about matrers within its functions.

Sec 3. (a) Notwithstanding sections 1 and 2 of this Reorganization Plan, there are hereby transferred to the Chairman all the functions vested in the Commission pertaining to an emergency concerning a particular facility or materials licensed or regulated by the Commission, including the functions of declaring, responding, issuing orders, deter* mituing specific policies, adjising the civil autborities, and the public, directing, and coordinating actions selative to such emergency incident.

(b) The Chairnan may delegate the authority to perform such entergency functions, in whole or in part, to any of the other members of the Commission. Such authortty may also be delegated or redelegated, in whole or in part to the staff of the Commission.

(c) In acting under thits section, the Chairman, or other member of the Commission delegated authority under subsection (b), shall conform to the policy guidelines of the Commisston. To the maximus extent possible under the emergency conditions, the Chairman or other member of the Commission delegated authority under subsection (b), shall inform the Commission of actions taken telative to the emergency.

(d) Following the conclusion of the emergency, the Chairman, or the mentber of the Commission delegated the emergency functions under subsection (b), shall render a complete and timaly report to the Commission on the actions taken during the emergency.

Sec. 4. (a) The Chairman maymake such delegations and provide for such reporting as the Chairman deens necessary, subject to provisions of law azd this Reorganization Plan. Any officer or employee under the Commission may communicate ditectly to the Commission, or to any menber of the Commission, whentever in the view of such officer or 
employee a critical problem or public bealth and safety or common defense and security is not being properly addressed.

(b) The Executive Director for Operations shall report for all matters to the Chairman.

(c) The function of the Director of Nuclear Reactor Regulations, Nuclear Material Safety and Safeguards, and Nucleat Regulatory Research of reporting ditectly to the Commission is hereby transferred so that such officers report to the Executive Dinector for Operations. The function of receiving such reports is hereby transferred from the Cornmission to the Executive Director for Operations.

(d) The heads of the Commission level offices or successor offices, of General Counsel, Secretary to the Commission, Office of Policy Bvalu. ation, Office of inspector and Auditor, the Atomic Safety and Licensing Board Panel and Appeal Panel, and Advisory Committee on Reactor Safeguards shall continue to seport directly to the Conmuission antd the Commission shall continue to receive such reports.

Sex. 5. The provisions of this Reorganization Plan shall take effect October 1,1980, or at such earliter time or tiutes as the President shall specify, but no sooner than the earliest time allowable under Stction 906 of Titte 5 of the United States Code. ${ }^{2}$

2457.40561

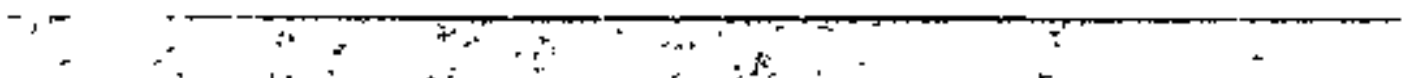




\section{THE WHITE HOUSE}

\section{EXECUTTVE ORDER 11834}

\section{ACTIYATION OE THE ENERGY RESEARCH ANT DEVELOPMENT ADMINISTRATION AND THE NUCLEAR REGULATORY COMMISSION}

By virbue of the authotity vested in my by the Energy Reorganization Act of 1974 (Public Law 93-438; 88 Stat. 1233), section 301 of title 3 of the United States Code, and as President of the United States of Amerjca, it is herety ordered:

Sec. 1. Pursuant to section 312(a) of the Energy Reorganization Act of 1974, I hereby prescribe Jantuary 19, 1975, as the effective date of that Act. This action shall not juppair in any way the activation of the Entrgy Resources Council by Executive Order No. 11814 of October 11, 1974.

Sec 2. The Director of the Office of Management and Budget shall take all stops necessary or appropriate to ensure or effectuste the transfers provided for in the Energy Reorganization Act of 1974, the Solar Heating and Cooling Demonstration Act of 1974 (Public Law 93-409; 88 Stat. 1069), the Geotherual Energy Research, Development, and Demonstration Act of 1974 (Public Law 93-410; 88 Stat. 1079), the Solar Energy Research, Development, and Demonstration Act of 1974 (Public Law 93-473; 8BStat. 1431), to the extent requirect or permitted by law, including transfers of bunds, personnel and positions, assets biabilities, contracts, property, records, and other items related to the transfer of functions, programs, or authorities.

Sec. 3. As required by the Energy Reorganization Act of 1974, this Order shall be published in the Federal Register.

THE WHITE HOUSE, January 15, 1975.

GERALD R. FORD 


\title{
LOW-LEVEL RADIOACTIVE WASTE POLCY AMENDMENTS ACT OF 1985*
}

Public Law $99-240$

(99 Stat. 1842)

\section{TITL I - LOW-LEYEL RADIOACTIVE WASTE POLICY AMENDMENTS ACT OF 1985}

\author{
PAGE USC \\ $12 \mathrm{USC}$ \\ $260 \ldots .20216$ \\ Sec. I02, Amenderent to tie Low-Level \\ Radioactive Waste Policy Aet $\ldots \ldots \ldots \ldots \ldots \ldots \ldots 260 \ldots \ldots+2021 \mathrm{~b}-\mathrm{d}$ \\ Note \\ Sec. 1. Short title ...........................260 ...20210 \\ Sec. 2. Defintitions ..........................260 $\ldots .20216$ \\ SeG. 3. Responsibilities for Disposal of Low-Level \\ Radioactive Waste $\ldots \ldots \ldots \ldots \ldots \ldots \ldots \ldots \ldots .261 \ldots . .2021 \mathrm{c}$ \\ Sec. 4. Regional Compacts for Disposal of \\ Low-Levet Radioactive Waste $\ldots \ldots \ldots \ldots \ldots \ldots \ldots .263 \ldots \ldots$ 2021d \\ Sec. 5. Limited Availabeity of Certain Reysonal \\ Disposal Facilities During Transition and \\ Licensing Periods........................... 264 $\ldots .2021 \mathrm{k}$

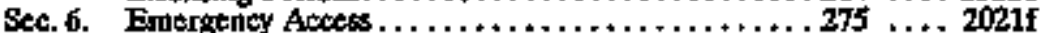 \\ Sec.7. Responsibitities of the Department

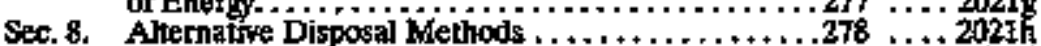 \\ Sec.9. Licensing Review and Approvai................278 .....202it \\ Sec. 10. Radioactive Waste Below Regalatory \\ Concem $+\ldots+\ldots \ldots++\ldots+\ldots+\ldots, \ldots+\ldots+\ldots \ldots+278$ \\ "NOTE: \\ P.L. 96-573, "Low-Level Radioactive Waste Policy Act," \\ (94 Stat. 3347); Dec 22, 1980 was antended by PL. 99-240. \\ The text of PL. $96-573$ is printed at the end of P.L $99-240$.
}




\section{LOW-LEVRL RADIOACITVE WASTE POLICY AMENDMENTS ACT OF 1985}

Public Law 99-240

99 Stat. 1842

\section{An Act}

$\operatorname{Lan} 15,1986$

[H.R. 1083]

State and local governuthents.

Low-Level Radioactive Waste Policy Amerdments Act of 1985. 42 USC 2021b note.

42 USC 20216-2021d, $2021 b$ note. 42 USC 2021b notẹ.

$42 \mathrm{USC} 2021 b$
To amend the Low-Level Radjoactive Waste Policy Act to improve procedures-for the implementation of compacts providing for the tstablishment and opteration of Ispional disposal facilities for lowlevel radioactive waste; to grant the consent of the Congress to certain interstate compacts on low-level radioactive waste; and for other purposes.

Be it enocled by the Senate and Howse of Repressentatives of the United States of America in Congress assembled

\section{TITLE I-LOW-LEVEL RADIOACTFVE WASTE POLICY AMIENDMENTS ACT OF 1985}

Sec. 101. Short Title.

This Title may be cited as the "Low-L'evel Radioactive Waste Policy Antendimenits Act of 1985".

Sec 102. Amendment To The Low-level Radioactive Waste Policy Act.

The Low-Level Radioactive Waste Poliey Act (42 U.S.C. 2021b et sen.) is amended by striking out sections $1,2,3$, and 4 and inserting in lieu thereof the following:

rextion 1 Short Title.

"Thjs Act nray be cited as the 'Low-Level Racioactive Waste Policy Act.

"Sec. 2. Definitions.

"For purposes of this Act:

'(1) Agreement State,-The term 'agrement State' mears a State that-

"(A) has entered into an agreement with the Nuclear Regulatory Commission under section 274 of the Atonic Energy Act of 1954 ( 42 U.S.C. 2021); and

"(B) has authority to regulate the disposal of low-level radioactive waste under such agreement.

"(2) Alocation.-The term 'allocation' means the assignunent of a specific amount of low-lewel radioactive waste disposal capacity to a commetcial nuclear power reactor for which acoess is required to be provided by sited States strbject to the conditions specified under this Act.

"(3) Conunercial Nuclear Power Reactor.-The term 'commercial nuclear power reactor' means any unit of a civilian light-water moderated utilization facility required to be licensed under section 103 or 104b. of the Atomic Energy Act of 1954 (42 U.S.C. 2133 or 2134(b)). 
"(4) Couppact.-The term 'compact' taeans a compact entered into by two or more States pursuant to this Act.

'(S) Compact Commission-The term 'compact commission' means the regional commission, committee, or board established in a compact to administer such compact.

"(6) Compact Region-The term "compact region" means the area consisting of all states that are membexs of a compact.

"(7) Disposal.-The term 'disposal' means the permanent isodation of low-level radioactive waste pursuant to the reguirements established ty the Nuclear Regulatory Cormission under applicable laws, or by an agreement State if such isolation occturs in such agreement State.

"(8) Generate.-The term 'generate', when used in relation to low-level radioactive waste, means to produce low-level radioactive waste.

"(9) Low-levei Radioactive Waste.-The term 'low-lewel radioactive waste' meass radioactive material that-

"(A) is not higl--Jevel tadioactive waste, spent nuclear fuel, or byproduct matesial (as defned in section 11e.(2) of the Atonic Energy Act of 1954 (42 U.S.C. 2014(e)(2))); and

"(B) the Nuclear Regulatory Commission, consistent with existing law and in acourdance with paragraph (A), classifies as low-level radioactive waste.

“(10) Non-sited Compact Region- - The term 'non-sited cornpact region' ateans any compact region that is not a sited compact region.

(11) Regional Disposal Facility.-The term 'regtonal disposal facility means a non-Federad low-level radjoactive waste disposal facility in operation on January 1, 1985, or subsequently estabIished and operated under a compact.

“(12) Secretary.-The term 'Secretary' means the Secretary of

South Carolina. Washington. Nevada.

42 USC 2021t Energy.

“(13) Sited Compact Region-The term 'sited compact region' means a compact region in which there is located one of the regional disposal facilities at Barnwell, in the State of South Carolina; Richland, in the State of Washington; or Beatty, in the State of Nevada.

“(14) State-The tern 'State' means any State of the United States, the District of Columbia, and the Commonwealth of Puerto Rtco.

Sec. 3. Responsibjlities For Disposal of Low-level Radioactive Waste. "Section 3(a)(1) State Responsibilities.-Each State shall be respon. sible for providing, either by jiself or in cooperation with other States, for the disposal of -..

"(A) loti-level radioactive waste generated within the State (other thas by the Federal Government) that consists of or contains dass A, B, or Cradjoactive waste as defined by section 61.55 of title 10, Code of Federal Regulations, as in effect on January 26, 1983; 
Vessels.

Research and dewelopmeat.

Post, pp. 1846, 1855 .

Vessets.

Research and development

Health.

Safety.

42 USC 2011 note.

Report.
"(B) low-level radioactive waste described in subparagraph (A) that is genterated by the Federal Government except such waste that is-

“(j) owned or generated by the Departinent of Entergy;

"(ii) owned or generated by the United States Navy as a result of the decommisstoning of vessels of the United States Navy; or

(iii) owned or generated as a result of any research, developunent, testing, or production of any atomic weapon; and

"(C) low-level radioactive whste described in subparagraphs (A) and (B) that is generated outside of the State and accepted for disposal in accordance with sections 5 or 6 .

"(2) No regional disposal facility may be requiced to accept for disposal any matarial-

"(A) that is not low-level radioactive waste as defined by section 6155 of title 10, Code of Federal Regtations, as in effect on January 26, 1983, or

“(B) identified under the Formerly Utilized Sites Remedial Action Program.

Nothing in this paragraph shall be deemed to prohibit a State, subject to the provisions of its compact, or a compact region from accepting for disposal any material identified in subparagraph (A) or (B).

"(b)(1) The Fedisral Government shall be responsible for the dispasal of-

"(A) low-level radioactive waste owned or generated by the Department of Energy;

"(B) low-level tadioactive waste owned or generated by the United States Navy as a result of the decommissioning of vessels of the United States Navy;

(C) low-level radicactive waste owned or generated by the Federal Govermment as a result of any research, development, testing, or production of any atonic weapon; and

"(D) any other low-level radtoactive waste with concentra. tions of radionuctides that exced the limits established by the Conuoission for class $C$ radiogctive waste, as defined by section 61.55 of title 10, Code of Federal Regulations, as in effect on Jantuary 26,1983 .

"(2) All radioactive waste designated a Federal responsibility pursuaut to subpargigraph (b)(1)(D) that results from actuvities bicensed by the Nuclear Regulatory Commission under the Atomic Euergy Act, of 1954, as amended, shall be disposed of in a facitity licensed by the Nuclear Regulatory Commission that the Commission determines is adequate to protect the public health and safety.

“(3) Not later than 12 months' after the date of enactment of this Axt, the Secuetary shall subuit to the Congress a comprehensive , report setting forth the recoumenchations of the Sectetary for ensuring the safe disposal of all radioactive waste designated a Fed- 
Probibition.

Report.

$42 \mathrm{USC} 2021 \mathrm{~d}$

Arte, p. 1843.

Prohibition.

eral responsibility pursuant to subparagraph (b)(1)(D). Such report shall include-

"(A) an identitication of the radioactive waste involved, including the source of such waste, and the volume, concenteration, and other relevant characteristics of such waste;

(B) an identification of the Federal and non-Federal options for disposal of such radioactive waste;

"(C) a description of the actions proposed to ensure the safe disposal of such radioactive waste;

«(D) a description of the projected costs of undertaking such actions;

"(E) an identification of the options for ensuring that the beneficiaries of the activities resultion in the generation of such radioactive wastes bear all reasonable costs of disposing of such wastes; and

"(F) an jdentification of any statutory authority required for disposal of such waste.

"(4) The Secretary may not dispose of any radioactive waste designated a Federal responsibility pursuant to paragraph (b)(I)(D) that beconnes a Federal responsibility for the first time pursuant to stach paragraph until nindty days after the report prepared pursuant to paragraph (3) bas been submitted to the Congress. Taste.

Sec. 4. Reglonal Compacts For Disposal of Low-level Radloactive

"(a) In General-

(1) Federal Policy.-It is the policy of the Federal Government that the responsibilities of the States uncer section 3 for the disposal of low-level radioactive waste can be most safely and effectively managed on a regional basis.

(2) Interstate Compacts.-To carry out the policy set forth in paragraph (1), the States may enter into such compacts as may be necessary to provide for the establishment and operation of re. gional disposal facilities for low-jevel radionctive waste.

"(b) Applicability To Federal Activities-

"(1) In General.-

"(A) Activities of The Secretary,-Except is provided in subparagraph (B), no cornpact or act taken under a compact shall be applicsble to the transportation, management, or disposal of any low-level radioactive waste designated in section $3(\mathrm{a})(\mathbf{1})$ (B) (i)-(iji).

"(B) Federal Low-level Radioactive Waste Disposed Of At Non-federal Facilities.-L ow-level radionctive waste owned or generated by the Federal Government that so disposed of at a regional disposal facility or non-Federal disposal facility within a State that is not a member of a compact shall be subject to the same conditions, regulations, reguirements, fees, taxes, and surcharges imposed by the compact commission, and by the State in which such facility is located, in the same master and to the same extent as any low-level radioactive waste not generated by the Federal Gowemment. 
Probibition.

Prohitoition.

Trasnportation.

Regalations.

Health.

Safety.

Pollution.

Government organization ankd enmployees.

$28 \mathrm{USC} 2671$ ef seq.

Probjaition.

Prohibition.

Prohjbition.

42 USC 2021e.
"(2) Federal Low-leve] Radioactive Waste Disposal FacilitiesAvy Jow-level radioactive waste disposal facility established or operated exclusively for the disposal of low-level radioactive waste owned or generated by the Federal Government shall not be subfect to any compact or any action taken under a compact.

(3) Effect Of Compacts On Federal Law,-Nothing contained in this Act or any compact may be construed to confer any new authority on any compact commission or Stat:-

“(A) to regilate the packaging, generation, treatment, storage, disposal, or transportation of low-level tadioactive waste in a manner incompatible with the regulations of the Nuclear Regulatory Commission or inconsistent with the regulations of the Department of Transportation;

"(B) to regulate health, safety, or envisonmentel hazards from source material, byprochet material, or special nuclear Joatortat;

(C) to inspect the facilities of lipenses of the Nuclear ReguJatory Connistion;

(D) to inspect security areas or operations at the site of the generation of any low-level racjoactive waste by the Federal Goverument, or to inspect classified information related to such areas or operations; or

“(E) to require indemmification pursuant to the provisions of chapter 171 of title 28, United States Code (comronly referted to as the Federal Tort Clajms Act), or section 170 of the Atomic Energy Act of 1954 (42 U.S.C. 2210) (commonly referned to as the Price-Arderson Act), whichever is applicable.

"(4) Federal Authortty, Except as expressly provided in this Act, nothing contained in this Act or any compact may be construed to limit the applicability of any Federal law or to dintinish or otherwise impair the jurisdiction of any Federal agency, or to alter, amend, or otherwise affect any Federal law goversing the judicial review of any action taken pursuant to any compact.

"(5) State Authority Preserved.-Except as expressly provided in this Act, nothing contained in this Act expands, diminishes, or otherwise affects state law.

“(c) Restricted Use Of Regional Disposal Facilities.-Any authority in a compact to restrict the use of the regional disposal facilities under the compact to the disposal of low-[ere] radioactive waste generated within the compact region shall not take effect before each of the tollowing oceurs:

"(1) Jantuasy 1, 1986; and

(2) the Congress by law consents to the compact.

“(d) Congressional Review.-Each compact shall prowide that evtry 5 years after the compact has taken effect th. Congress aray by law withdraw tts consent.

uSec. 5. Linited Avallahillty Or Certain Regional Disposal Facillties During Transition And Licensing Periods.

"(a) Availability Of Disposal Capacity.- 
“(1) Pressurized Water And Eoiling Water Reactors.-During the seven-year period beginning January 1,1986, and ending December 31,1992 , subject to the provisions of stbsections (b) through (g), each State in which there is located a regional disposal facility referred to in paragraphs (1) through (3) of subsection (b) shall make disposal capacity available for low-level radioactive waste generated by pressurized water and boiling water commercial nuclear power reactors in accordance with the allocetions established in subsection (c).

(2) Other Sources of Low-level Radjaactive Waste.-Durjug the seven-year period beginuing January 1, 1986 and ending December 31, 1992, subject to the provisions of subsections (b) through (g), each State in which there is located a regional disposal factity referred to in partigraphs (1) through (3) of subsection (b) shall make disposal capacity available for lows-level radioactive waste generated by any source not referred to in paragraph (1).

“(3) Allocation Of Disposal Capacity.-

"(A) Duting the seven-yea period beginning Jantary 1, 1986 and ending December 31, 1992, low-level racioactive waste generated within a stited compact region shall be accorded priority under this section in the allocation of availabłe disposal capacity at a regional disposal facility referred to in para. graphs (1) through (3) of subsection (b) and located in the sited compact region in which such waste is gemerated.

"(B) Any State to which a regional disposal facility referred to it paragraphs (1) through (3) of subsection (b) is located may, subject to the provisions of its compact, prohfbit the disposal at sucis facility of low-level radioactive waste generated outside of the compact region if the disposal of such waste in any given calendar year, together with all other low-level radioactive waste would result in that facility disposing of a total annisal volume of low-level radioactive waste in excess of 100 per centum of the average anmual volume for such facility designated in subsection (b): Provided, howverer, That in the event that all three Stares in which regional disposal facilities referred to in paragraphs (I) through (3) of subsection (b) act to prohibit the disposaj of low-łovel radioactive waste pursuant to this subparagraph, each such State shall, in accordance with any applicable procechures of its compact, permit, as necessary, the disposal of additional quantities of such waste in increments of 10 per centum of the average annual voluox for each such facility designated in subsection (b).

Prohibition.

“(C) Nothing in this paragraph shall require any disposal facility or State referted to in paragraphs (1) through (3) of subsection (o) to acospt for disposal Jow-level radioactivt waste it excess of the total amounts designated in subsection (b).

Prohibítion.

4(4) Cessation Of Operation Of Low-level Radioactive Waste Disposal Facility.-No provision of this section shall be construed to obligate any State referred to in paragraphs (1) through (3) of subsection (b) to accept low-hevel sadioactive waste from any

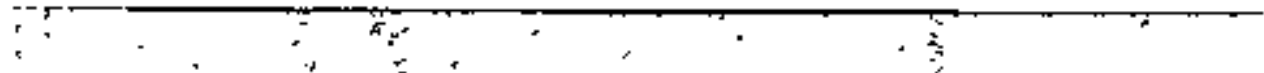


source in the event that the regional cisposal facility located in such State ceases operations.

"(b) Limitations.-The availability of disposal capacity for low-level radioactive waste from any soture shall be subject to the following limitations:

"(1) Barrwwell, South Carolina.-The State of South Carolina, in

$\therefore$ acsordance with the provisions of its compact, may limit the volume of low-level radioactive waste accepted for disposal at the regional dispasal facility located in Barmwell, South Carolina to a total of $8,400,000$ cubic feet of lor -jevel radioactive waste during the 7-year period beginning January 1, 1986 and ending December 31,1992 (as based on an average ammual volume of $1,200,000$ cubic fert of low-level radioactive waste).

"(2) Richland, Washington-The State of Washington, in accordance with the provisions of its compact, may limit the volume of low-level radioactive waste accepted for disposal at the regional disposal facility located at Richland, Washington to a total $\mathrm{c}^{\prime}$ $9,800,000$ cubtc feet of low-level radioactive waste during the 7-year period beginming January 1, 1986, and ending December 31,1992 (as based on an average annual volume of $1,400,000$ cubic feet of low-level radioactive waste).

(3) Beatty, Nevada. -The State of Nevada, in accordance with the provisions of its comapact, may limit the volume of low-leved radioactive waste accepted for disposal a the regional disposal facility located at Beatty, Nevada to a total of $1,400,000$ cubic feet of low-level radioactive waste during the 7-year period boginning Janiany 1, 1986, and ending December 31, 1992 (as based on an average ammual volutite of 200,000 cubte fet of low-level radioactive waste).

"(c) Comunercial Nuclear Power Reactor Allocations-

"(1) Amount. - Subject to the provisions of stribections (a) through (g) each cormercial nuclear porter reactor shall upon request receive an allocation of low-level radjoactive waste disposal capacity (in cubic feet) at the factilites referred to in subsection (b) during the 4-year transition period beginning Jantary 1, 1986 and ending December 31, 1989, and during the 3-year licensjing period beginning January 1, 1990, and ending December 31, 1992 in an annount calculated by multiplying the appropriate number from the following table by the number of months temaining in the applicable period as determined under paragraph (2).

\begin{tabular}{|c|c|c|c|c|}
\hline \multirow{2}{*}{ "Reactor Type } & \multicolumn{2}{|c|}{ 4-vear Transition Period } & \multicolumn{2}{|c|}{ 3-yea Licensing Pefiod } \\
\hline & $\begin{array}{l}\text { In Sited } \\
\text { Region }\end{array}$ & $\begin{array}{l}\text { All Other } \\
\text { Locations }\end{array}$ & $\begin{array}{l}\text { In Sited } \\
\text { Regionl }\end{array}$ & $\begin{array}{l}\text { Al Other } \\
\text { Locations }\end{array}$ \\
\hline $\begin{array}{l}\text { PWR } \\
\text { BWR }\end{array}$ & $\begin{array}{l}1027 \\
2300\end{array}$ & $\begin{array}{r}871 \\
1951\end{array}$ & $\begin{array}{r}934 \\
2091\end{array}$ & $\begin{array}{r}685 \\
1533\end{array}$ \\
\hline
\end{tabular}

"(2) Method Of Calculation-For purposes of calcalating the aggregate amount of disposal capacity availabte to a commercial 
nuclear power reactor under this subsection, the number of months shall be computed begirning with the first month of the applicable petiod, ot the sixtenth month after receipt of a full power operating license, whbichever occurs later.

"(3) Unused Allocations. - Any unused allocation under para. graph (1) received by a reactor durjug the transition period or the licensing period may be used at any time after such reactor receives its full power license or after the beginting of the pertinent period, whichever is later, but not in any event after December 31, 1992, or after commencement of operation of a regional disposal facility in the compact region or State in which such reactor is located, whichever occurs first.

"(4) Transferability-Any comroercial nuclear power reactor in a State or compact region that is in conpliance with the requirements of subsection (e) may assign any oisposal capacity allocated to it under this subsection to any other person in each State or compact region. Such assignment may be for valuable consideratton and shall be th writing, capies of which shall be filed at the affected compact commissions and States, along with the assignor's unconditional written waiver of the disposal capacity being assigned.

(5) Unusual Volumes.-

"(A) The Secretary may, upon petition by the owner or operator of any commercial nuclear power reactor, allocate to such reactor disposal capacity in excess of the amount calculated under paragraph (1) if the Secretary finds and states in writing his reasons for so finding that making additional capacity avajable for such reactor through this paragraph is sequired to permit unusual or unexpected operating, maintenance, repsir or safety activities.

Prohtbition.

"(B) The Secretary may not make allocations pursuant to subparagraph (A) that would result in the acseptance for disposal of more than 800,000 cubic feet of low-level radjoactive waste or would result in the total of the allocations made purstant to this subsection exceeding 11,900,000 cubic feet over the entire seven-year interim access period.

Prohibition.

(6) Limitation.-During the seven-year interin access period referred to is subsection (a), the disposal facilities referred to in subsection (b) shall not be required to accept more than $11,900,000$ cubic feet of low-level radioactive waste generated by commerctal nuclear power reactors.

"(d)(1) Surchtarges. - The disposal of any low-level radioactive waste under this section (other than low-level radioactive waste generated in a sited cormpact region) may be charged a surcharge by the State in which the applicable regional disposal facility is located, addition to to the foes and surchatges generally applicable for disposal of low-level radioactive waste in the regional disposal facility involved. Except as

Probitition. provided in subsection (e)(2), such surcharges shalt not exceect-

"(A) in 1986 and $1987, \$ 10$ per cubic foot of low-level radioactive waste; 
"(B) in 1988 and 1989, \$20 per cubric foot of Jow-level radioactive waste; and

"(C) in 1990, 1991, and 1992, \$40 per cubic foot of low-level radioactive waste.

"(2) Milestone Incentives. -

"(A) Escrow Account-m Twenty-five per centum of all surcharge fees received by a State pursuant to paragraph (1) during the seven-year period referred to in subsection (a) shall be transferred on a monthly basis to an escrow account held by the Secretary. The Secretary stall deposit all funds received in a special escrow accolnt. The funds so deposited shall not be the property of the United States. The Secretary shall act as trustee for such funds and-shall invest them in interest-bearing United States Government Securities with the highest availabjo yield. Such funds shal] be held by the Secretary until-m

"(t) paid or repaid in accordance with subparagraph (B) or (C); or

"(ii) paid to the State wllecting such fees in accordance with subparagraph (F).

(B) Faypreats, -

"(i) July 1, 1986. -The twenty-five per centum of any amount collected by a State under paragraph (1) for low. level radioactive waste disposed of under this section dur. ing the period bsginning on the date of enactment of the Low-Level Radicactive Waste Policy Amendments Act of 1985 and ending June 30,1986 , and transfersed to the Secretary under subparagraph (A), shall be paid by the Secretary in accordance with subparagraph (D) if the mikestone described in subsection (e)(1)(A) is met by the State in which such waste originated

"(ii) January 1,-1988.-The twrenty-five per centum of any amount collected by a.State under paragraph (1) for low-level ractioactive waste fisposed of under this section during the period beginsting Jily 1, 1986 and ending December 31,1987 , and transiferred to the Secretary under subparagraph (A), shall be paid by the Secretary in accordance with subparagraph (D) if the milestone described in subsection (e)(1)(B) is met by the state in which such waste originated (or its corspact region, where applicable).

“(iii) Jenuary 1, 1990_-The twenty-five per centum of any amount collected by a State under paragraph (I) for low-level radioactive waste disposed of under this section ftring the period beginning January 1, 1988 and ending December 31, 1989, and transferred to the Secretary under subparagraph (A), shall be paid by the Secretary in accordance with subparagraph (D) if the milestone described in subsection $(e)(1)(C)$ is met by the State in which such waste originated (or its compact region, where applicable). 
"(iv) The twenty-five per centum of any amount collected by a State under paragraph (1) for low-level radioactive waste disposed of under this section during the period beginning Jamuary 1,1990 and ending December 31,1992 , and transterred to the Secretary under subpara. graph (A), shall be paid by the Secretary in accordance with subyaragraph (D) if, by January 1, 1993, the State in which such waste originated (or its compact region, where applicable) is able to prowide for the disposal of all lowlevel radioactive waste generated within such State or compact region.

"(C) Failure To Meet January 1,1993 Deadline.- -If, by January 1, 1993, a State (or, where applicable, a comapact region) in which low-level radioactive waste is genterated is unable to provide for the disposal of all such waste generated within such State or compact region-

"(i) each State in which such waste is gentrated, upon the request of the generator or owner of the waste, shall take title to the waste, shall be obligated to take possession of the waste, and shall be liable for all damages directly or incirectly menred by such gererator oc owner as a consequence of the fature of the State to take possession of the waste as soon after Jartuary 1, 1993 as the generator or owner notifies the Stare that the waste is avaitabte for shipment or*

"(ii) if such State elects not to take title to, take possession of, and assume liability for such waste, pursuant to clause (j), twenty-five per centum of any amount collected by a Stafs under paragraph (1) for low-level radionctive waste disposed of under this section during the period beginning January 1, 1990 and ending December 31, 1992 shatl be repaid, with interest, to each generator from whom such surcherge was collected. Repayments made pursuant to this clause shall be made on a monthly basis, with the first such repayment beginning on February 1, 1993 , in an amount equal to one thirty+sixth of the total amount required to be repaid purstant to this clatse, and shall continue until the State (or, where applicab]e, compact region) in which such low-level radioactive waste in generated is able to provide for the disposal of all such waste generated within such State or compact Iefion or until January 1, 1996, whichever is earlier.

If a State in which low-level radioactive waste is generated elects to take title to, take possession of, and asstene liability for such waste pursuant to clause (i), such State shall be paid such anounts as are designated in subparagraph (B)(iv). If a State (or, where applicable, a compact region) in which jow-level radjoactive waste is genterated provides for the disposal of such waste at ary time after January 1,1993 and prior to Jan-

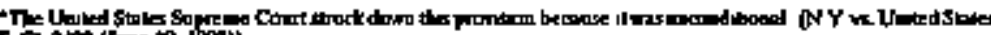

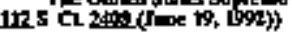


uary 1, 1996, such Stare (or, where applicable, compact region) shall be paid in accordanoe with subparagraph (D) a lump sum amount equal to owenty-five per cennum of any amount collected by a State under paragraph (1): Provided, however, That such payment shall be adjusted to reflect the remaiming number of months between January 1,1993 and January 1, 1996 for which such State (or, where applicable, contpact region) provides for the disposal of such waste. If a State (or, where applicable, a compact region) in which low-level radioactive waste is generatted is unable to provide for the disposal of all such waste genterated within stch State or compact region by January 1, 1996, each State in which such waste is genertated, upon the request of the generator or owner of the waste shall take title to the waste, be obligated to take pos. session of the waste, and shall be liable for all damages directly or indirectly inctirred by such generator or owner as a consequence of the fail. wre of the State to take possesssion of the waste as soor after January 1 , 1996, as the genterator or owner notifies the State that the waste is available for shipment.

(D) Recipients Of Payments.-The payments described in subparagraphs (B) and (C) shall be paid within thirty days after the applicable date--

"(i) if thie Stafe in which such waste originated is not a member of a compact region, to such State;

"(ii) if the State in which such waste originated is a member of the compact region, to the compact commission serving "such State,

“(E) Uses Of Payments-

"(i) Limitations.-Any amount paid under subparagraphs (B) or (C) may only be used to-

"(I) establish low-level radioactive waste disposal facilities;

"(II) mitigate the impact of low-level radioactive waste disposal facilities on the host State;

"(III) regulate low-level radioactive waste disposal facilities; or

"(IV) ensure the decommissioning, closure, and care during the period of institutional contsol of lowlevel radioactive waste disposal facilities.

"(ii) Reyorts-

"(I) Recipient--Any State or compect commission receiving a payment under subparagraphs (B) or (C) shall, on December 31 of each year in which any such

Reports. funds are expended, submit a report to the Department of Energy itemizing any such expenditures.

"(II) Department Of Energy.-Not later than six months after receiving the reports under subclause (I), the Secretary shall'submit to the Congress a summary of all such reports that shall include an assessment of the comptiance of each such State or compact comanission with the requirements of clause (i). 
Prohibition.

(F) Payment To States-Any amount coltected by a State under paragraph (1) that is placed in escrow under subparagraph (A) and not paid to a State or compact commission under subparagraphs (B) and (C) or not repaid to a generator under subparagraph (C) shall be paid from such escrow account to such State collecting such payment under paragraph (1). Such payment shall bo made not later than 30 days after a determination of ineligibility for a refund is made.

"(G) Penalty Surcharges. - No rebate shall be made under this subsection of any surcharge or penalty surcharge paid during a period of noncompliance with subsection (e)(1).

"(e) Requirements For Access To Regional Disposal Facilities.-

"(1) Requirements For Non-sited Compact Regions And Nonmember States,-Each non-sited compact region, or State that is not a Jaember of a compact region that does not have an operating disposal factitity, shall comply with the following requirements:

"(A) By July 1,1986, eachsuch non-member State shall ratify compact legistation or, by the enactment of legislation or the certification of the Governor, indicate its intent to develop a site for the location of a low-level radjoactive waste disposal facility within such State.

"(B) By January 1, 1988. -

"(i) each non-sited compact region shall identify the State in which its low-level radiogctive waste disposal facility is to be located or shall bave selected the developer for such facility and the site to be developed, and each compact region or the State in which its low-level radioactive waste disposal facility is to be located shall develop a situng plan for sucb faclity providtog detalled procedures and a schedule for establishing a facility location and preparing a facility license application and shall delegate authority to implement such plar;

"(ii) each non-member \$tate shall develop a siting plan providing detailed procectures and a schectule for establishing a facility location and joparing a facility license application for a low-level radioactive weste disposal facility and shall delegate authonty to implement suctiplan; and

(iii) The siting plan required pursuant to this para* graph shall include a description of the optimum way to attain optration of the Jow-level radjoactive waste disposal facility involved, within the turbe period specified to this Ace Such plan shall include a desctiption of the objectives and a sequence of dearlintes for all entities required to take action to impiement such palan, inciuding, to the extent practicable, an identification of the activities in which a delay in the start, or completion, of such activities will cause a delay in beginning facility operation. Such plan shall also identify, to the extent practicable, the process for (1) screening for browd siting areas; 
Foderal Register, publication.

Contracts.
(2) identifying and evaluating specific candidate sites; and (3) characterizing the preferted site(s), completing all nocessary envitonmental assessments, and preparing a license application for submission to the Nuclear Regulatory Commission or an Agreentent State.

(C) By January 1, 1990...

(i) a complete application (as determined by the Na- dear Regulatory Commission or the appropriate agency of an agreement State) shall be filed for a ticense to operate a low-level radioactive waste disposal facility within -each non-sited compact region or within each non-member State; or

(ii) the Governor (or, for any State without a Governor, the chisf executive officer) of any State that is not a member of a compact region in compliance with clause (9), or has riot complied vith such clause by its opn actions, shall provide a written certification to the Nticlear Regulatony Coumission, that suct State will be capable of providing for, and will provide for, the storage, disposal, or management of any low-level radioactive waste gererated within such State and requiring disposal after December 31,1992 , and include a description of the actions - that will be taken to ensure that such capacity exists.

(D) By January 1, 1992, a complete application (as determined by the Nuclear Regulatory Commission or the appropriate agency of an agresmont State) shall be filed for a lictnse to operate a low-level radioactive waste disposal facility within each non-sited compact region or wiţuin each non-member State.

"(E) The Nuclèar Regulatory Commission shall transmit any certification received under subparagraph (C) to the Congress and publtsh any.such certification in the Federal Register.

(F) Any State Inay, subject to ail applicable provisions, if any, of any applicable compact, enter into an agreement with the compact commission of a region in which a regional disposal facility is located to provide for the disposal of all low-jevel radioactive wasté generated within such State, and, by virtue of suct agreement, may, with the approval of the State in which the regional disposal facility is located, be deemed to be in compliance with subparagraphs (A), (B), (C), and (D).

"(2) Peralties For Failure To Comply.-

"(A) By July 1, 1986,-If any' State fails to comply with subparagrapb (1)(A)-

"(j) any gentsator of low-level radionactive waste within such region or votn-member State shall, for the period beginining July 1, 1986, and ending December 31, 1986, be charged 2 times the surcharge otherwise applicable under subsection (d)i and

"(ii) on or after January 1, 1987, any tow-kevel radioactive waste generated within such region or non-member 
State may be denied access to the regional disposal facilities referred to in paragraphs (1) through (3) of subsection (b).

(B) By January 1, 1988.-If any non-sited compact region or non-member State fails to comply with paragraph (1)(B) -

"(i) any generator of low-level radioactive waste within such region or non-member State shall-

"(I) for the period beginning January 1, 1988, and ending June 30,1988 , be charged 2 times the surcharge otherwise applicable under subsection (d); and

"(Ii) for the period beginning July 1, 1988, and ending Decentber 31, 1988, be chasged 4 times the surcharge otherwise applicable under subsection (d); and "(ii) on or after January 1, 1989, any low-level radionactive waste generated within such region or non-member State may be denied access to the regional disposal factities referred to to paragraphis (1) through (3) of subsection (b).

(C) By January 1, 1990.-If any non-sited compact region or non-member State fails to comply with paragraph (1)(C), any low-level ractiogctive waste generated within such region or non-member State may be denied axcess to the regional disposal facilities referred to in paragraphs (1) through (3) of subsection (b).

"(D) By Jafuary 1, 1992.-lf any non-sited compact reglon or non-member State fails to comply with paragraph (I)(D), any generator of tow-level radioactive waste with in such region or non-member State shall, for the period begining January 1, 1992 and ending upon the filing of the application described in paragraph (1)(D), be charged 3 times the surcharge otherwise applicable under subsection (d).

Prohttition.

“(3) Denial of Access.-No denial or suspension of access to a regional disposal facility under paragraph (2) maty be based on the source, class, or type of low-level radioactive waste.

"(4) Restoration OF Suspended Access; Penalties For Fatlure To Comply.-Any access to a regional disposal facility that is suspended under paragraph (2) shall be restored after the nowsited compact region or non-member State involved complies with such

Tẹrnúnatiọn. requirement. Any payment of surcharge penalties pursuast to paragraph (2) for failure to comply with the requirements of subsection (e) shalt be terminated after the non-sited compact region or non-meraber State involved complies with sucil requirements. "(f)(1) Adrisisistration.-Each State and compact commission in which a regional disposal facility referred to in paragraphs (1) through (3) of subsection (b) is located shall have authortity-

(A) to monitor compliance with the limitations, allocations, and requirements establisted in this section; and

(B) to deny access to any non-Federal low-level radicactive waste disposal facilities within its borders to any low-level radioactive waste that- 
South Carolina. Washingtor.

Nevade.

South Carolina. Washingtoen. Noveda.

\section{Prohibition.}

Govermment organization and errployees. Commerce and trade. "(f) is in excess of the livitutions or allocations established in this section; or

"(ii) is not required to be accepted due to the failure of a compact region or State to comply with the requirements of subsection (e)(1).

"(2) Availability Of Infomation During Interim Acoess Period."(A) The States of South Carolina, Washington, and Nevada may require information from disposal facility operators, gererrators, intermediate bandlers, and the Department of Energy that is reassonebly necessary to monitor the avaikability of disposal capacity, the use and assigmment of atlocations and the applicability of surcharges.

"(B) The States of South Carolina, Washington, and Nevada may, after written notice followed by a period of at least 30 days, deny access to disposal copacity to any generator or intermediate handler who fails to provide information under subparagraph (A).

(C) Proprietary Information-

"(i) Trade secrets, proprietary and other confidential information shall be made available to a State under this subsection upon recuest only if such Stat:-

"(I) consents in writing to restrict the dissemination of the information to those who are cirectly involved in monitoring under subparagraph (A) and who have a need to know;

"(II) accepts liability for wrongful disclosure; and

"(III) demonstrates that such information is essential to such monitoring.

(ii) The United \$tates shall not be liable for the wrongfil disclosure by any individual or State of any information provided to stech individual or State under this subsection.

"(iii) Whenever any individual or State bas obtained possession of information under this subsection, the indjvidual shall be subject to the same provisions of law with respect to the disclosure of such foformation as would apply to an officer or employee of the United States or of any department or agency thereof and the State shall be subject to the same provisions of taw with respect to the disclosure of such information as would apply to the United States or any department or agency thereof. No State or State officer or employee who receives trade secrets, proprietary information, or other confictential information under this Act may be required to disclose such informarion unders State law.

"(g) Nondiscrimination.-Except as provided in subsections (b) through (e), low-lewel radioactive waste disposed of under this section shal] be subject withont discrimination to al applicable legal requirements of the compact region and State in which the disposal fasility is 
42 USC $2021 \%$.

Hoalth.

Safety.

Defense and

national

security.

Health.

Safety.

Defense and

national

stecurity.

Ante, p, 1846.

Prohibätion. located as if stch low-level radioactive waste were generated within such compect region.

"Sec, 6. Eonergenty Access.

(a) In Genera1.-.-The Nuclear Regulatory Commission may grant emergency access to any regional disposal facility or non-Federal disposal facility within a State that is not a member of a compact for specific low-level radioactive waste, if necessary to elininate an immentete and serious threat to the public health and safety or the common defense and security. The procedure for granting emergency access shall be as provided in this section.

"(b) Reguest For Emergency Access.-Any generator of low-level radioactive waste, or any Governor (or, for any \$tate without a Gover. nor, the chief execultive officer of the State) on behalf of any generator or generatoss loeated in his or her State, may request that the Nuclear Regulatory Commission grant emergency access to a regionel disposal facility or a non-Federal disposal facility within a State that is not a member of a compact for specifir low-level radioaetive waste. Any such request shall contajn any juformation and certifications the Nuclear Regulatory Commission may requite.

"(c) Determination Of Nuclear Regulatory Commisston.-

"(1) Required Determination.-Not later thian 45 dass after receiving a request under subsection (b), the Nuclear Regulatory Commission shall determine whether-

"(A) emergency access is necessary because of an immediate and serious threat to the public health and safety or the common defense and security; and

"(B) The threat cannot be mitigated by any alternative consistent with the public health and safety, jocluding storage of low-level radicactive waste at the site of generation or in a storage facility obtaining access to a disposal facility by voluntary agreement, purchasing disposal capacity avalable for assignment pursuant to section S(c) or ceasing activities that general Jou-[evel radioactive waste.

(2) Required Notification- - If the Nuclear Regulatory Commission makes the determinations required in paragraph (1) in the affirmative, it shall designate an appropriate non-Federal disposal facility or facilities, and notify the Governor (or chief executive officer) of the State in which such facility is located and the appropriate compact commission that emergency access is required. Such notification shall specifically describe the low-teve] radioactive waste as to source, phissical and radiological characteristics, and the minimum volume and duration, not exceeding 180 days, necessary to alleviate the immediate threat to publichealth and safety or the comaron defense and security. The Nuclear Regulatory Commission shall also notify the Governor (or chief executive officer) of the State in which the low-level radioactive waste requiring emergency access was generated that emergency access has been granted and that, pursuant to subsection (e), no extersion of emergency access may be granted absent diligent \$tate action during the period of the imitua grant. 
Health.

Safety.

Deferse and

national ,

security.

Healti.

Safety.

Defense and national security. 4(d) Temporary Emergency Access-Upon deterníging that emergency access is necessary because of an immediate and serious threat to the piblic bealth and safety or the common defense and security, the Nuclear Regulatory Commission may at its discretion grant temporary energency access, pending its determination whether the threat could be mitigated by any alternative consistent with the public health ' and safefy. In granting access under this subsection, the Nuclear ReguJatory Commission shall provide the same notification and information required under subsection (c). Absent a determination that no alternative consistent with the public health and safety would mitigate the threat, access granted under this subsectioi shall expire 45 days after the granting of temporary omergency access under this subsection.

“(e) Extension Of Emergency Access,-The- Nuclear Regulatony Commission may grant one extension of emergency access beyond the period provided in subsection (c), if it deternints that tmergenty acoess continues to be necessury because of an inmectiate and serious threat to the public health and safety or the common defense and security that cannot be aitigated by any alternative consistent with the public health and safecy, and that the. generator of low-level radioactive waste granted emergency access and the State in which such lowsevel radioactive waste was generated heve diligently though unsuccessfully acted during the period of the initial grant to elimirate the need for emergency access. Any extension grantediunder this subsection shail be for the minimum volume and duration the Nuclear Regulatory Commission finds necessary i to eliminate the immediate threat to public health and safery or the common defense and security, and shall not in any event troecd 180 days.

"(f) Reciprocal Arxess.-Any compact rejion or State not a member of a compact that provides emergency access to non-Federal disposal facilities within its borders shall be entitled to Jectiprocal access to any subseguently operating non-Federal disposal facility that serwes the State or compact region in which low-level radioactive waste granted entergency access was generated. The compact commission or State having authortity to approve importation of low-level radioactive waste to the.disposal facility to which emergency access was granted sball designate for reciprocal access an equal volume of low-level radioactive waste baving similar characteristics to that provided emergencr access.

“(g) Approwal By Compact Commission.-Any grant of access under , this section shall be sibmitted to the conpact commission for the region in, which the designated disposal facility is located for such approwal as nay be required under the terms of its compact. Any such compact combission shall act to approwe emergency access not later than 15 days after receiving notification from the Nuclear Regulatory Commission, or teciprocal access not later than 15 days after receiving notification from the appropriate atthority under subsection (f).

Prohibitions. $\quad$ "(h) Linitations.-No State shall be requited to provide emergency or rectprocal access to any regional disposal facility within its borders for low-level radioactive waste not meeting criteria established by the license or license agreement of such facility, or in excess of the approved capacity of such factity, or to delay the closing of any sucti facili- 
ty pursuant to plans establisbed before recejing a request for emergency or reciprocal access. No State shall, curing any 12-month period, be required to provide emergency or reciprocal acsess to any regional disposal facility within its borders for more than 20percent of the total volume of low-level radioactive waste accepted for disposal at sucti facility churing the previous calendar year.

(i) Volume Reduction And Surcharges.-Any low-level ractioactive waste delivered for disposal under this section shall be reduced in volume to the maximum extent practicable and shafl be subject to surcharges established in this Act.

"(j) Dediction From Alocation-Any volume of low-level radioactive waste granted emergency or reciprocal access under thìs section, if

Ante, p. 1846. generated by any commercial nuclear power reactor, shall be deducted Prohibition. $5(\mathrm{c})$.

(k) Agreement States.-Any agreement under section 274 of the Atomic Energy Act of 1954 (42 U.S.C. 2021) shalI not be applicable to the deteruinations of the Nuclear Regtulatory Connoission under this section.

\section{USC 2021. "Sec. T. Responsibilities Of The Department Of Energy.}

"(a) Fintancial And Technical Assistance. - The Secretary shall, to the extent provided in appropriations Act, provide to those compact regiors, host States, and normember States determined by the Secretary to recuire assistance for purposes of carrying out this Act-

Science and technologyTransportation. Health.

Safoty.

Science and technology. Transportation. "(1) continuing techrixal assistance to assist them in fulfiliting their responsibilities under this Act. Such technical assistance shall include, but not be limited to, technical guidelines for site selection, alternative technologies for low-level radioactive waste disposal, volume reduction options, management techniques to reduce low-level waste generation, transportation practices for shipment of low-level wastes, health and safety considerations in the storage, shipment and disposal of tow-level radioactive wastes, and establishment of a computertzed database to monitor the management of low-level sadioactive wastes; and

"(2) through the end of fiscal year 1993, financial assistance to assist them in folfilling their responsibilities under this Act.

"(b) Reports.-The Secretary shail prepare and submit to the Congress on an annual basis a Ieport whith (1) summarizes the progress of low-level waste disposal siting and licensing activities within tach compact region, (2) reviews the avalable volume reduction technologies, their applications, effectiveness, and costs on a per unit volume basis, (3) reviews interim storage facility requirements, costs, and usage, (4) summarzes transportation requirements for such wastes on an inter- and intra-regional basis, (5) summarizes the data on the total amount of low-lewel waste shipped for disposal on a yearly basis, the proportion of suth wastes subjected to volume reduction, the average volume reduction attained, and the proportion of wastes stored on an interim basis, and (6) projects the interim storage and final disposal vot- 
42 UsC 2021b.

Ante p. 1842.

42 USC 2021i.

Ante, p. 1842 ume requirements anticipated for the following year, on a regional basis.

tsec. 8. Alternatlve Disposal Methods.

"(a) Not Iater than 12 months after the date of enactment of the Low-Level Radiogctive Waste Policy Amendments Act of 1985, the Nuclear Regulatory Commission shall, in consultation vith the States and other interested persons, identify methods for the disposal of low-level radioactive waste other than shallow land burial, and establish and publish technical guidance regarding lioensing of facilities that use sucti methads.

(b) Not later than 24 months after the date of enactment of the Low-Level Radioactive Waste Policy Amendments Act of 1985, the Comunission shall, in consultation with the States and other interested persons, identify and publish all relevant techuical information regarding the methods identified pursuant to subsection (a) that a State or compace must provide to the Commission in order to pursue such methods, together with the technical requiretments that such facilities must meet, in the judgment of the Cormuission, if pursued as an alternative to shallow land burial. Such technical information and requirements shall include, but need not be limited to site suitability, site design, facility operation, disposal site closure, and environsental monitoring, as necessary to meet the performance objectives established by the Commisston for a licensed low-level radicactive waste disposal facilityThe Commission shall specify and ptublish such rexuirements in a manner and form deemed appropriate by the Commission.

“Sec. 9. Lisensing Review And Approval.

"In order to ensure the timely derelopment of new low-level radioactive waste disposal facilities, the Nuclear Regulatory Commission or, as appropriate, agreement States, shall consider an application for a disposal facility license in accordance with the laws applicable to such application, except that the Commission and the agreement state shall-

(1) notilater than 12 months after the date of enactonent of the Low-Level Radioactive Waste Policy Amendments Act of 1985, establish procedures and develop the technical capability for processing applications for such licenses; :

"(2) to the extent practicable, complete all activities associated with the review and processing of any application for such a license (except for petblic hearings) no later than 15 months after the date of xeceipt of such application; and

"(3) to the extent practicable, consoljdate all required technical and environmental seviews and public hearings.

"Sec. 10. Radlogetlve Waste Below Regulatory Concern.

"(a) Not Jater than 6 months after the date of enactment of the Low-Level Radioactive Waste Policy Amendments Act of 1985, the Comumission shall establish standarcis and procedures, pursuant to existing authority, and develop the technical capability for considering and acting upon petitions to exempt specific radioactive waste streams from regulation by the Commission due to the presence of radionu- 
Health.

Sajety.

Regulation.

clides in such waste streams in sufficiently low concentrations or quantities as to be below regulatory concern.

${ }^{*}$ (b) The standards and procedures estabtished by the Commission pursuant to subsection (a) shall set forth all information required to be submitted to the Commission by licensees in stpport of such petitions, inchuding, but got limited to-

"(1) a detailed description of the waste materials, including their origin, chemical composition, physical state, volume, and mass; and

"(2) The concentration or contamination levels, half-lives, and identities of the radionuclides present.

Such standards and procedures shall prowide that, upon receipt of a petition to exempt a specific radioactive waste stream from regulation by the Commission, the Commission shall determine in an expeditious manner whother the concentration or quantity of radionuclides present in such waste streaml requires regulation by the Commission in order to protect the public health and safety. Where the Commission determines that regulation of a radioactive waste stream is not necessary to protect the public health and safety, the Commission shall take such steps as may be necessary, in an expeditious manner, to exempt the disposal of such radioactive waste from regulation by the Commission.".

NOTE: TILLE II OF THIS LAW WHICH CONSISTS OF THE TEXT OF SIX COMPACTS IS FOUND EN YOLUME II OF THIS NUREG. 


\author{
An Act \\ Dece 22,1980 \\ [S. 2189] \\ To set forth a Federal policy for the disposal of low-level tediosctive \\ - wastes, and for other purposes. \\ Lon-Lewel \\ Be it enacted by the Senate' and House of Representotives of the Unired \\ Radioactive \\ Waste Policy Act \\ 42 USC $2021 \mathrm{~b}$ \\ nole. \\ 42 USC 2021b \\ States of America in Congress assembled,

\section{"Section 1 Short Title} \\ Act'. \\ "This Act may be cited as the Low-Level Radiaactive Waste Policy \\ "Sec. 2. Defintions. \\ "As used in this Act:
}

(1) The term 'disposal' means the isolation of low-level radioactive-rwaste pursugnt to requiremeats established by the Nuclear Regulatory Commisston under applicable laws.

«(2) The term 'low-level radioactive waste' means radioactive waste not classified as high-Ievel radioactotue waste, transnanic waste, spent nuclear fuel, or byproduct materitl as defined in section I1e.(2) of the Atomic Energy Act of 1954.

'(3) The teru' 'State' means any State of the United States, the District of Columbia, and, subject to the provisions of Public Law 96-205, the Commonwealth of Puerto Rico, the Visgin Islands, Guam, the Northern Mariana Islands, the Tust Territory of the Pacific Islands, and any other territory or possession of the United States.

"(4) For purposes of this Act the term 'atomic energy defense activities of the Secretary includes those activities and facilities of the Department of Energy carrying out the furstion of-

(i) Naval reactors development and propulsios,

(ii) weapons activities, werification and control technology,

(iii) defense materials production,

(iv) incrtial continement fiscion,

(v) defense waste management, and

(vi) defense nuclear matertals semurity and safeguards (all as inclided in the Department of Energy appropriations apcount in any fiscal year for atomic enery defense activities).

42 Usc 2001c

«sec, 3. General Provisions. (a) Compacts established under this Act or actions taken under such compacts sball not be applicable to the transportation, manageruent, or disposal of low-level radicactive waste From atomic energy defense activities of the Secretary or Federal research and development activities.

"(b) Any facility establisted or operated exclusively for the disposal of low-level radioactive waste prodiced by atomic energy deferse activities of the Secretary or Federal research and development activities shall not be subject to compacts established under this Act ot actions taken under such compacts. 
State compacts

regarding

regional

facilities.

42 USC 2021d.

Congressionat consent.

Report to Conteress and States
"Sec. 4. Low-Leved Redioactive Waste Disposal. (a)(1) It is the policy of the Federal Governinent that-

(A) each State is responsible for providing for the avastability of capacity either within or outside the State for the disposal of low-jevel radjoactive waste generated within its borders except for waste generated as a result of defense activities of the Secretary or Federal research and developuent activities; and

(B) low-tevel radioactive waste can be most safely and effi. ciently managed on a regional basis.

(2)(A) To carry out the poliey set forth in paragraph (1), the States may enter into such compacts as may be necessary to provide for the establishiment and operation of regional disposal facilities for low-level radioactive waste.

(B) A compact entered into tnder sulbparagraph (A) shall not take effect until the Congress has by law consented to the compact. Each such compact shall provide that every 5 years after the compact has taken effeet the Congress may by law withdraw its corsent. After January 1, 1986, any such compact may restrict the use of the regional disposal facilities under the compact to the disposal of low-level radioacive waste generated withto the region.

(b)(1) In order to assist the States in carrying out the policy set forth in subsection (a)(1), the Secretary shali prepare and submut to Congress and to each of the States within 120 days after the date of the enactment of this Act a report which-

(A) defines the disposal capacity needed for present and fuhtre low-level radioactive waste on a regional basis;

(B) defines the status of all commercial low-level radjoactive waste disposal sites and includes an evaluation of the license status of each such site, the state of operation of each site, including operating history, an analysis of the adequacy of disposal technology employed at each site to contain low-level radioactive wastes for their hazardous lifetimes, and suxh recommendations as the Secretary considers appropriate to assure protection of the public health and safety from wastes transported to such sites;

(C) evaluates the transportation reguirements on a regional basis and in comparison with performance of present transportation practices for the shipgant of low-level radioactive wastes, jncluding an inventory of types and quantities of lowlevel wastes, and evaluation of shipurent requirements for each type of waste and an evaluation of the ability of generators, shippers, and carriers to meet such requirements; and

(D) evaluates the capability of the low-level radtoactive waste dispostal facilities owoted and operated by the Department of Energy to provide interin storage for comemercially generated low-level waste and estimates the costs assockater with such interim storage.

(2) In carrying out this subsection, the Sexretary shall consult with the Governors of the States, the Nuclear Regulatory Com- 
mission, the Environmental Protection Agency, the United States Geological Survey, and the Secretary of Transportation, and such other agencies and departanents as he finds appropriate. 


\section{NUCLEAR WASTE POLICY ACT OF 1982}

Public Law 97-425 (96 Stat. 2201)

\section{OMNIBUS BUDGET RBCONCILATION ACT OF 1987}

TITR V, SUBTTTLE A

NUCLEAR WASTE AMENDMINTS

Publle Law 100-203

(101 Stat. 1330)

OFHCE OF NUCLEAR WASTE NEGOTIATOR,

MRS COMMISSION

Publc Law 100-s07 (102 Stat. 2541)

\section{SHORT TTLLE AND TABLE OF CONTENTS}

Section 1. This Act may be cited as the "Nucloar Whaste Policy Act of 1982".

TABLE OF CONTENTS

\begin{tabular}{|c|c|c|}
\hline & PAGE & USC \\
\hline & & 42 USC \\
\hline $\begin{array}{l}\text { Sec } 1 . \\
\text { Sec } 2 . \\
\text { Sec. } 3 . \\
\text { Sec } 4 . \\
\text { Sec. } 5 . \\
\text { Sec. } 6 . \\
\text { Sec. } 7 .\end{array}$ & 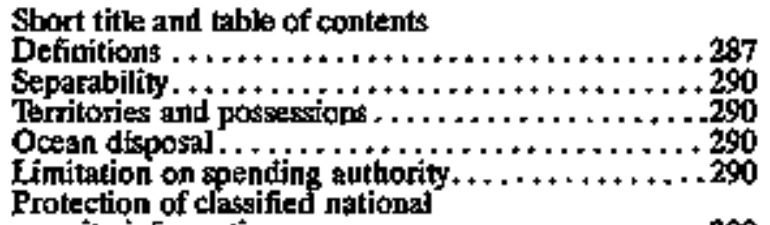 & $\begin{array}{l}10101 \\
\cdots 1002 \\
\cdots 1003 \\
\cdots 10105\end{array}$ \\
\hline $\begin{array}{l}\text { Sec, } 8 . \\
\text { Sec. } 9 .\end{array}$ & 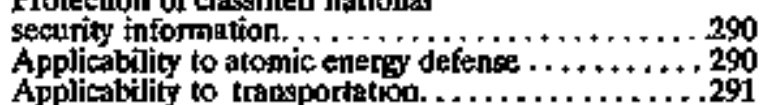 & $\begin{array}{r}10106 \\
\cdots 100109\end{array}$ \\
\hline
\end{tabular}

TITLR I-DISPOSAL AND STORAGE OF HIGH-LEVEL

RADIOACTIVE WASTE, SPENT NUCLEAR KUEL, AND LOW-LEVEL RADIOACTTVE WASTE

Sec. 101. State and affected Indian tribe participation is development of proposed repositoties for defense waste. 


\section{SLBBTITLE A-REPOSITORIES FOR DISPOSAL OF HIGH-LEVEL RADIOACTIVE WASTE AND SPENT NUCLRAR FUEL}

PAGE

UsC

$42 \mathrm{Usc}$

Set.

Sec. 111. Findings and purposes. 10131

\$ec. 112. Recommendation of candidate sites for site characterization. ................. $293 \ldots 10132$

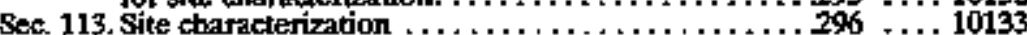

Sec. 114. \$ito approval and construction authorization

$298, \ldots 10134$

Sec. 115. Review of jepository site selection. . . . . . . . . . $301 \ldots \ldots 10135$

Sec. 116. Participation of States. . . . . . . . . . . . . $305 \ldots \ldots 10136$

Sec. 117. Consultation with States and Affected Indian

Tríbes $\ldots \ldots \ldots \ldots \ldots \ldots+\ldots+\ldots \ldots \ldots \ldots \ldots+30 . \ldots \ldots 137$

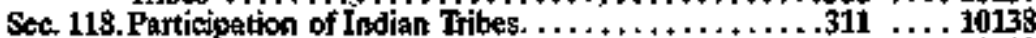

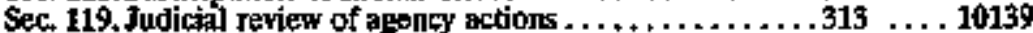

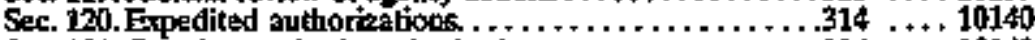

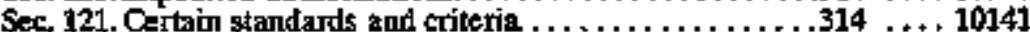

\$ec 122. Disposel of spent nuclear fuel $\ldots \ldots \ldots \ldots \ldots \ldots \ldots .315 \ldots \ldots 10142$

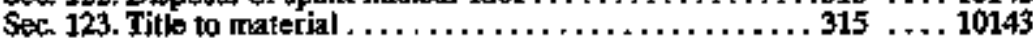

Sec. 124. Consideration of effect of aquisition

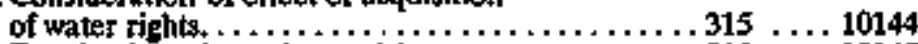

Sec. 125. Termination of certain provisions. . . . . . . . . $316 \ldots 10145$

\section{SUBTTTLE B-INTERIM STORAGE PROGRAM}

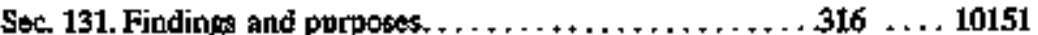

Sec. 132. Available capacity for interim storage

316 .... 10151

of spent nuclear fuel $\ldots \ldots \ldots \ldots \ldots \ldots \ldots \ldots \ldots, 316, \ldots, 10152$

Sec. 133. Interim at-reactor storage. $+\ldots \ldots \ldots+\ldots+\ldots+\ldots .317 \ldots \ldots 10153$

Sec. 134. Licensing of facility expansions and

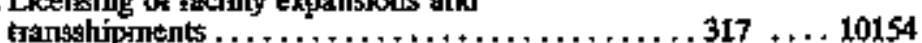

Sec. 135. Storage of spent nuckar furel $\ldots \ldots \ldots \ldots \ldots \ldots \ldots \ldots .318 \ldots \ldots$. $\ldots 155$

Sec 136. Interim Storage Fund $\ldots+\ldots+\ldots \ldots+\ldots \ldots \ldots+\ldots+325 \ldots$ tol $\ldots 6$

Sec. 137. Transporlation $\ldots \ldots \ldots+\ldots+\ldots, \ldots \ldots \ldots, \ldots+\ldots+329 \ldots+10157$

\section{SUBTITLE C-MONTORED RETRIEVABLE STORAGE}

Sec 141. Monitored retrievable storage $\ldots \ldots \ldots \ldots \ldots \ldots \ldots 32 \ldots 10161$

Set 142. Authorization of monitored

$332 \ldots 10162$

Sec. 143. Moritored Retrievable Storage

Commisston $\ldots \ldots \ldots, \ldots, \ldots, \ldots \ldots \ldots, 392 \ldots 10163$

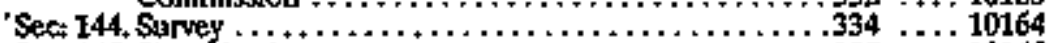

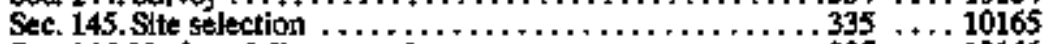

Sec 146. Notice of disapproval. $\ldots+\ldots \ldots \ldots \ldots \ldots \ldots \ldots \ldots+\ldots 33 \ldots \ldots 106$

Sec. 147. Benefits agreennent $\ldots \ldots \ldots \ldots \ldots+\ldots++\ldots+\ldots .336 \ldots 10167$

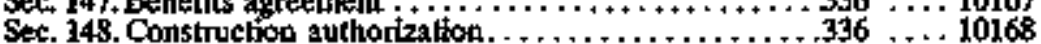

Sec. 149. Ftnancial assistance $\ldots \ldots \ldots \ldots+\ldots \ldots \ldots \ldots \ldots+337 \ldots 10169$

\section{SUBTITLE D-LOW-LEVEL RADIOACTTV WASTE}

Sec. 151. Finarxiłal arrangements for șite closure

$337 \ldots 10171$ 
PAGE USC

42 usc

Sec.

Sec, 160. Selection of Yucca Mountain site . . . . . . . . $338 \ldots \ldots 1017$

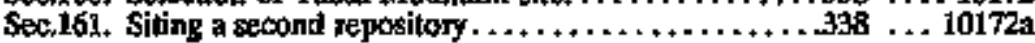

SUBTTTLE F-BENEFTTS

PAGE USC

42 USC

Ste.

Sect 170 . Benefits atreements $+\ldots \ldots+\ldots+\ldots++\ldots \ldots+\ldots+339 \ldots 10173$

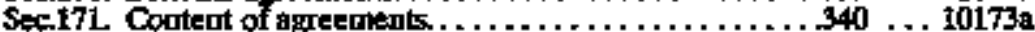

Seci17. Review Panel. ...., $\ldots+\ldots+\ldots \ldots+\ldots \ldots++\ldots+341 \ldots 10133 b$

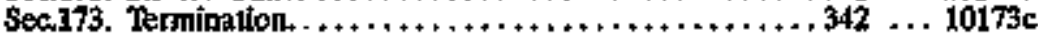

\section{SUBTITLE G- OTHER BENEFITS}

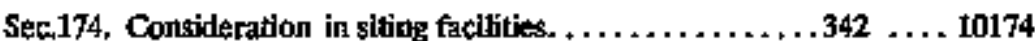

Sec.175. Report. ..............................342 +.. 10174a

SUETTLE H-TRANGPORTAMON

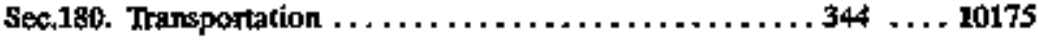

TITLE II-RESRARCH, DEVELOPMENT, AND

DEMONSTRATION REGARDING DISPOSAL OF HIGH-LEYEL RADIOACTIV WASTE AND SPENT NUCLEAR FUEL

PAGE USC

42 USC

Sec.

Sec 211. Purpose. $\ldots \ldots \ldots \ldots \ldots \ldots \ldots \ldots \ldots \ldots \ldots \ldots \ldots 34 \ldots \ldots 19 \ldots \ldots$

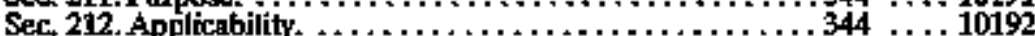

Sec. 213. Identification of sites . . . . . . . . . . . . . . . 345 . . 10193

Sec 214. Siting research and retated activities...........

Sec. 215. Test and evaluation facility sting

review and reports. . . . . . . . . . . . . . . . $347 \ldots 10195$

Sec. 216. Feteral agency actions. ...................

Sec. 257. Research and development on disposal

of high-level radioactive waste. ..... $\ldots \ldots \ldots \ldots+348 \ldots+\ldots 197$

Sec, 218. Research and development on spent

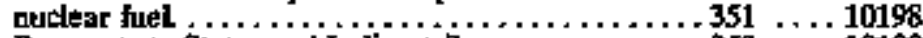

Sec. 219. Payments to States and Indiant tibes .......... $353 \ldots 10199$

Sec. 220. Stuxdy of research and developement needs for monitored retrievable

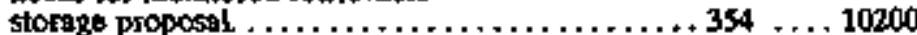

Sec. 221.Judicial review $\ldots \ldots \ldots \ldots \ldots \ldots+\ldots+\ldots \ldots \ldots+\ldots .354 \ldots 10201$

Sec. 222, Research on altematives for the permantent disposal of high-kvel radionctive waste.. $\ldots . \ldots+\ldots+\ldots .$.

$354+\ldots 10202$

Sec. 223. Technical assistance to non-numeat
weapon states in the field of spent

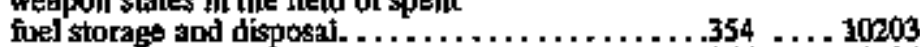

Sec. 224. Subseabed disposal............... $\ldots \ldots .355 \ldots+10204$ 


\section{TITLE II -OTHER PROVISIONS REILATING}

TO RADIOACTIVE WASTE

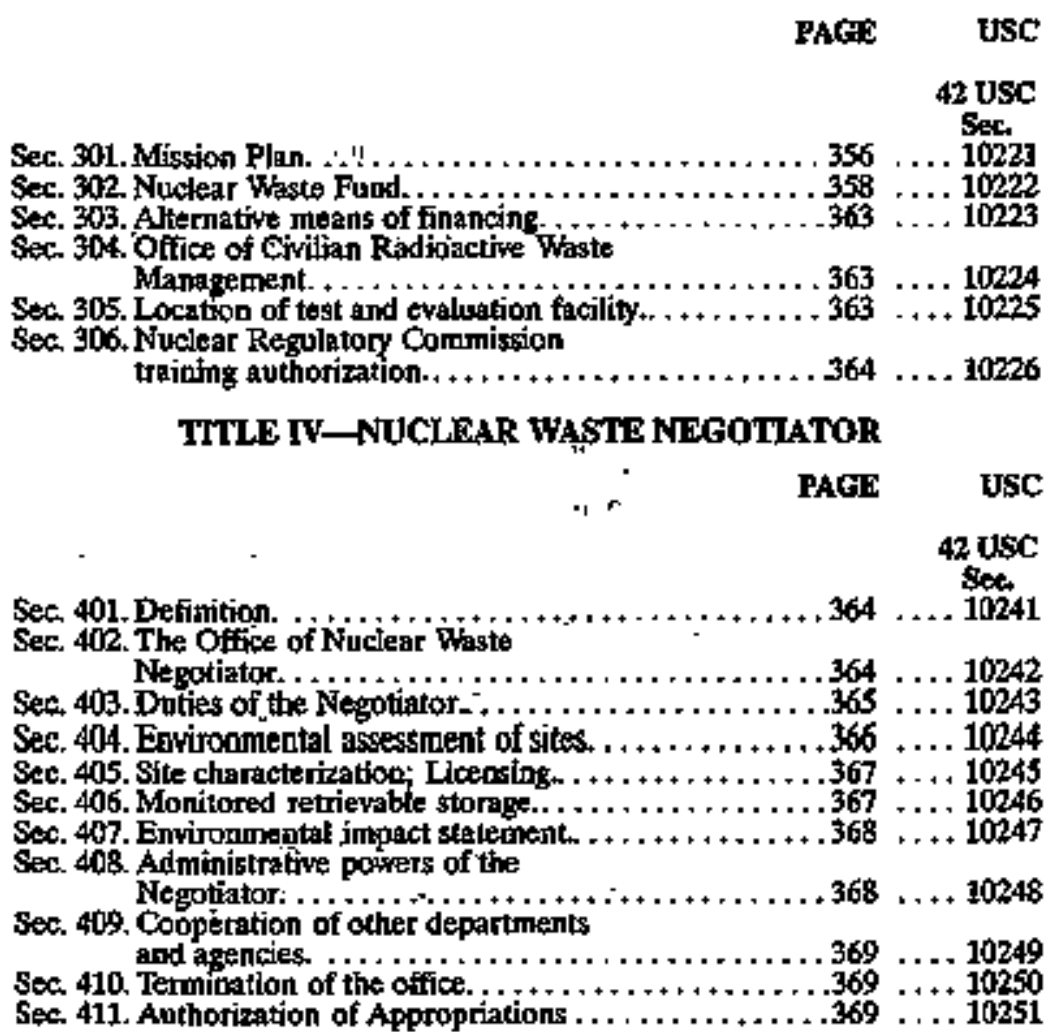

\section{TITLE V_-NUCLEAR WASTE TECHNICAL REVLEW BOARD}

PAGE USC

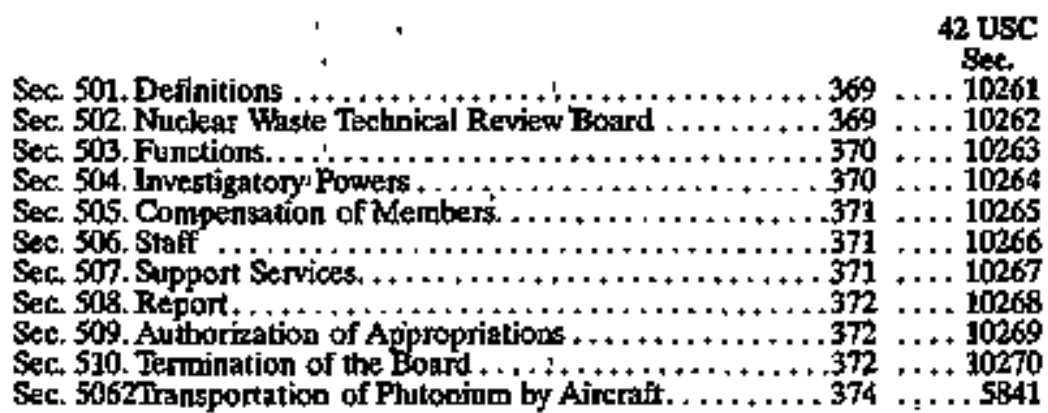


NUCLEAR WASTE POLICY ACT OF 1982, AS AMENDED

Public Law 97-425

96 Stat. 2201

42 USC 10101.

Sec. 2. For purposes of this Act:

DAFHIIIONS

(1) The term "Administrator" means the Administrator of the Envinononental Protection Agency.

(2) The term "affected Indian tribe" means any Indian tribe(A) within whose reservation boundaries a moritored re. trievable storage farility, test and evaluation facitity, or a tepository for high-level radioactive waste or spent fuel is proposed to be located;

(B) whose federally defined possessony or usage rights to other lands outside of the reservation's boundaries arising out of congressionally rati5ed treaties may be substantially and adversely affected by the locating of sucti a facility: Provided, That the Secretary of the Interior finds, upon the petition of the appropriate governmental officials of the tribe, that such effects are both substantial and adverse to the tribe;

(3) the torm "atomic epergy defense activity" means any activity of the Secretary performed in whole or in part in carrying out any of the following functions:

(A) naval reactors development;

(B) weapons activities including defense inertial confinement fusion;

(C) verification and control technology;

(D) defense nuclear materials production;

(E) defentse nuclear waste and materials by-products management;

(F) definse muclear materials security and safeguards and security investigations; and

(G) defense research and developinent.

(4) The term "candidate site" means an area, within a geologic and hydrologif system, that is recomanended by the Secretary under section 112 for stite chactacterization, approved by the President under section 112 for site charseterization, or undergoing site characterization under section 113.

(5) The term "civilian nuctear activity" means any atomic energy activity other than an atomic energy defense activity.

(6) The term "civilian nuclear power reactor" means a civilian muclear powerplant required to be licensed under section 103 or 104 b. of the Alomic Erergy Act of 1954 (42 U.S.C. 2133, 2134(b)).

(7) The term "Commission" mears the Nuclear Regulatory Commission.

(8) The term "Department" means the Department of Energy.

(9) The term "disposal" means the enplacement in a repository of high-level radioactive waste, spent nuclear fuel, or other highly radioactive material with no foreseeable intent of recovery, whether or not such emplacement permits the recovery of such waste- 
- (10) The terms "disposal prokage" and "package"mean the primary container that holds, and is in contact with, solidified highlevel radioactive waste, spent muclear fuel, or other radioactive materials, and any overpacks that are emplaced at a repository.

(11) The term "engineered barTiess" means manmade conponents of a disposal system designed to prevent the telease of rationuclides into the geologic mediun involved. Such term includes the high-level radioactive waste form, high-level radioactive waste canisters, and other materials placed over and around such chnis. ters.

(12) The term "high-Jevel sadioactive waste" means-

(A) the highty radioactive material resulting from the reprocessing of spent nucleas fuel, inchuding tiquid waste productod directy in reprocessing and any solid material derived from such liquid waste that contains fission products in sufficient concentrations; and

(B) other highly radioactive material that the Comrnission, consistent with existing law, determines by rule requires permarent isolation.

(13) The term "Federal agency" means any Executive agency, as defined in section 105 of title 5 , United States Code.

(14) The term "Gowernor" means the chief executive officer of a State.

(15) The term "Indian tribe ${ }^{n}$ rleans any Indian tribe, band, nation, or other organized group or community of Indians recognized as eligible for the services provided to Indiars by the Secretary of the Interior because of their statis as Indians, including any Alaska Native village, as defined in section 3(c) of the Alaska Native Claims Settlenent Act (43 U.S.C. 1602(c)).

(16) The term "low.level radioactive waste" means radioactive material that-

(A) is not high-level radioactive waste, spent nuclear fuel, trassuranic waste, or by-product material as defined in section 11 (2) of the Atomic Energy Act of 1954 (42 U.SC. 2014(e)(2)); and

(B) the Commission, consistent with existing law, classifies as low level radioactive waste.

(17) The term "Office" means the Office of Civilian Radioactive Waste Management established in section 305.

(18) The term "repository" means any system licensed by the Commission that is intended to be used for, or may be used for, the permanent deep geologic disposal of high-level radioactive waste and spent nuclear fuel, whether or not, such system is designed to permit the recovery, for a limited period during initial operation, of any materials piaced in such system. Such term includes both surface and subsurface areas at which high-level radioactive waste and spent nuclear fuel handling activities are conducted.

(19) The term "reservation" means- 
(A) any Indian reservation or dependent Indian conmunity referred to in clause 9a) or (b) of section 1151 of title 18 , United States Code; or

(B) any land selected by an Alaska Native village or regional corporation under the provtsions of the Alaska Native Claims Settlement Act (43 U.S.C. 1601 et seq.).

(20) The term "Secretary" means the Secretary of Energy-

(21) The term "site characterization" means-

(A) siting research activities with respect to a test and evaluation facility at a candidate site; and

(B) activities, whether in the laboratory or in the field, undertaken to establish the geologic condition and the ranges of the paranaterers of a candidate site relevant to the lacation of a repository, including borings, sturface excavations, excavations of exploratory shafts, limited subsurface lateral excavations and borings, and in situ testing needed to evaluate the suitability of a candidate site for the location of a repository, but not including prelininary borings and geophysical testing needed to assess whether site characterization should be undertaken.

(22) The term "siting research" moans activities, including borings, surface excavations, shaft excavations, sobsurface lateral excavations and borings, and in ston testing, to determine the suitability of a site for a test and evaluation facility.

(23) The term "spent nuclear fuel" means fuel that has been withdrawn froma a nucleas reactor following irradiation, the constituent elements of which have not been separated by reprocessing.

(24) The tern "State" means each of the several States, the District of Columbia, the Commonwealth of Puerto Rico, the Virgin Islands, Guam, American Samoa, the Northern Mariana Islands, the Trust Territory of the Pacific Islands, and any other territory or possession of the United States.

(25) The term "storage" means retention of high-level radioactive waste, spent mrclear fuel, or transuranic waste with the intent to recover sutcl waste or fael for subsequent use, processing, or disposal.

(26) The term "Storage Fund" means the Interim Storage Fund established in section 137 (c).

(27) The term "test and evaluation facility" means an at-depth, prototypic, underground cavity with subsurface lateral excavations extending from a central shat that is used for research and development porposes, including the development of data and ex. perienoe for the safe bandling and disposal of solidified high-Jevel radioactive waste, transuranic waste, or spent nuclear fuel.

(2B) The term "umit of general local government" means any borough, city, county, parish, town, township, village, or other general purpose political stubdivision of a State.

(29) The term "Waste Fund" means the Nuclear Waste Fund established in section 302(c). 
42 USC 10102

42 USC 10103

42 USC 10104

42 USC 10105

42 USC 10106

42 USC 10107

Post, p. 2207
(30) The term 'Yucea Morntain site' means the candidate site in the State of Nezada recommended by the Secretary to the President under section 112(b)(1)(B) on May 27, 1986.

(31) The term 'affected unit of local government' means the unit of local government with jurisdiction over the site of a repository or a monitored retrievable storage facility. Such term may, at the dismetion of the Secretary, include units of local government that are contiguous with such wit.

(32) The term 'Negotiator' means the Nuclear Waste Negotiator.

(33) As used in title IV, the term 'Office' means the Office of the Nuclear Waste Negotiator established under title IV of this Act.

(34) The term'monitored retrievable storage facility' means the storage factity described in section 141(b)(1). ${ }^{n 1}$

SEPARABITITY

Sec. 3. If an provision of this Act, or the application of such provision to any person or chcumstance, is held invalid, the remainder of this Act, or the application of such provisions to persons or circumstances other thart those as to which it is held intalid, shall not be affected thereby.

TERRITORIES AND POSSESSIONS

Sec. 4. Nothing in this Act shall be deemed to repeal, modify, or amend the provistons of section 605 of the Act of March 12, 1980 (48 U.S.C. 149i).

\section{OCIXAN DISPOSAL}

Sec. 5. Nothing in this Act shall be deemed to affect the Marine Protection, Research, and Sanctuaries Act of 1972 (33 U.S.C. 1401 et seg.).

\section{LDMTATION ON SPENOTNG ALIFORTYY}

Sec 6. The authority under this Act to focur indebtedmess, or enter into contracts, obligatiog amoumts to be expended by the Federal Government shall be effective for any fiscal year only to such extent or in such anounts as are provided in advance by appropriation Acts.

PROTECTION OF CLASSIFED NATIONAL SECUIRITY INFORMATON

Sec. 7. Nothing in this Act shall require the release or disciosure to any person or to the Commission of any classified national security information.

\section{APPICARTITY}

Sec. 8. (a) Atomic Energy Defense Activities.-Subject to the provisions of subsection (c), the provisions of this Act shall not apply with respect to any atomic energy defense activity or to any facility used in conjunction with any such activity.

(b) Evaluation By President.- (1) Notlater than 2 years after the date of the enactment of this Act, the President shall evaluate the use of disposal capacity at one or more repositories to be developed under subtitle A of title I for the disposal of high-level radioactive waste resulting from atomic energy defense activities. Such evaluation shall take into consideration factors relating to cost efriciency, health and safety, regulation, transportation, public acceptability, and national security.

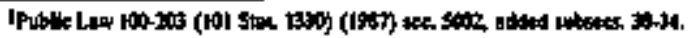


Post, p. 2256

Post, p. 2257

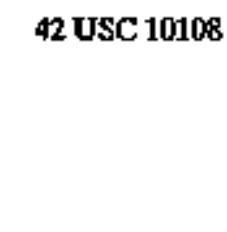

42 USC 10121
(2) Unless the President finds, after conducting the evaluation requited in paragraph (1), that the development of a repository for the dispossal of high-level radioactive waste resulting from atomic energy defense activities only is required, taking into ac count all of the factors deseribed in such subsection, the Secretary shall proceed promptly with arrangement for the use of one or more of the repositories to be developed under subtitle A of titie I for the disposal of such waste. Such arrangements shall include the allocation of costs of developing, constructing, and operating this repository or repositories. The costs resulting from permanent disposal of high-level radioactive waste from atomic energy defense activities stall be paid by the Fedieral Government, into the special account established under section 302.

(3) Any repository for the disposal of high-level radioactive waste resulting from atomic energy defense activities only shal] (A) be subject to licensing under section 202 of the Energy Reorgarization Act of 1973 (42 U.S.C. 5842); and (B) comply with al] requirements of the Commission for the siting, development, construction, and operation of a repository.

(c) Applicability To Certain Repositories,-The provisions of this Act shall apply with respect to any repository not ased exclusively for the disposal of high-level sadioactive waste or spent nuclear fuel resulting from atomic energy defense activities, research and development activities of the Secretary, or both.

\section{APPUCABIIITY}

Sec. 9. Transportation-Nothing in this Act shall be construed to affect Fecteral, State, or local laws pertaining to the transportation of spent muclear fuel or high-level ractioactive waste.

\section{TITLE I-DISPOSAL AND STORAGE OF HIGH-LEVEL RADIOACTIYE WASTE, SPENT NUCLEAR FUEL, AND LOW-LEVEL RADIOACTTVE WASTE}

\section{STATE AND AFFECTED INDIAN TRIBE PARMCIPATION IN DEVELOPMIENT OF PROPOSED REPOSITORIXS FOR DEFENSE WASTE}

Sec 101. (a) Notification To States And Affected Indian Tribes.Notwithstanding the provisions of section 8 , upon any decision by the Secretary or the President to develop a repository for the disposal of ligh-level radioactive waste or spent nuclear fuel resulting exclusively from atomic entergy defonse activities, restearch and development activities of the Secretary, or both, and before proceeding with any site-speciffe investigations with respect to such repository, the Secretary shall notify the Govemor and legislature of the State in which such repository is proposed to be located, or the governing body of the affected Indian tribe on whose reservation such repository is proposed to be located, as the case may be, of such decision.

(b) Participation Of States And Affected Indian Tribes,-Following the receipt of any notification under subsection (a), the State or Indian tribe inwolved shall be entitled, with respect to the proposed repository 
involved, to rights of participation and consultation identical to those provided in section 115 through 118, except that any funancial assistance authoized to be provided to such State or affected Indian tribe under section 116(c) or 118(b) shall be made from ansounts appropriated to the Secretary for purposes of carrying out this section.

\section{SUBTTILE A-REPOSITORIES FOR DISPOSAL OF HIGH-LEVEL RADIOACTIYE WASTE AND SPENT NUCLEAR FUEL}

42 USC 10 dis3.

\section{FINDINGS AND PURPOSES}

Sec. 111. (a)' Findings-The Congress finds that-

(1) radioactive waste cтeates potential risks and requires safe and enyironmentally acceptable methods of disposal;

(2) a national problem bas been created by the accumaulation of (A) spent puclear fuel from nuclear reactors; and (B) radioactive waste from (j) reprocessing of spent nuclear fuel; (ii) activities tetated to medical research, diagnosis, and treatraent; and (iti) other solarces;

(3) Federal efforts during the past 30 years to devise a pernanent solution to the problems of civlian radjoactive waste disposal have aot been adectuate;

(4) while the Federal Gowemenent has the responsibility to provide for the permanent disposal of high-level radioactive waste and such spent nuclear fuel as may be disposed of in order to protect the public health and safety and the environumedt, the costs of such disposal should be the responsibility of the geverators and owners of such waste and spent fuel;

(5) the generators and owners of high-level radioactive waste and spent nuctear fuel bave the primaiy resporsibility to provids for, and the responsibility to pay the costs of, the interim storage of such waste and spent fuel until such waste and spent fuel is accepted by the Secretary of Energy in accordance with the provisions of this Act:

(6) State and public participation in the planning and development of repositories is essential in order to promote pablic confdence in the safety of disposal of such waste and spent fuel; and

(7) high-level radioactive waste and spent nuclear fuel have become major subjects of public concern, and appropriate precautions may be taken to enstre that such waste and spent fuel do not adversely affect the public health and safety and the environment for this or future generations.

(b) Purposes. - The purpases of this subtite are-

(1) to establish a schedule for the siting, construction, and operation of repositorites that wil] provide a reasonable assurance that the public and the environment will be adecguately protected from the hazards posed by hifgt-towe] radtoactive waste and such spent nuclear fuel as raay be disposed of in a rêpository;

(2) to estabtish the Federal tesponsibility, and a definite Federal poticy, for the disposel of such waste and spent fuel; 
(3) to define the relationship between the Federal Government and the State government with respect to the disposal of such waste and spent fuel; and

(4) to estabiish a Nuclear Waste Fund, composed of payments made by the generators and owners of such waste and spent fiel, that will ensure that the costs of carrying out activities relating to the disposal of such waste and spent fuel will be borne by the persons responsible for generating such waste and spent fuel.

42 USC 10132.

RECOHMENDATION OF CANDIDATE STIES FOR STIE CHARACTERIZATION

Sec. 112. (a) Guidelines,-Not Jater than 180 days after the date of the enactment of this Act, the Secretary, following consultation with the Council on Environmental Quality, the Administrator of the Environmental Proeection Agency, the Director of the Geological Survey, and interested Governors, and the concurrence of the Commission shall issue general gujdelines for the recommendation of sites for repositories. Such guidelines shali specify detailed geologic considerations that shall be primary criteria for the selection of sites in various geologic media. Such guidelines shall specify factors that qualify or disqualify any site from developtrent as a repository, including factors pertaining to the location of valuable natural resources, hydrology, geophysics, seismic activity, and atomic erergy defense activities, proximity to water supplies, proximity to populations, the effect upon the rights of users of water, and proximity to components of the National Park System, the National Wildjife Refuge System, the National Wikd and Scenic Rivers System, the National Waderness Preservation System, or National Forest Lands. Such guidelines shall take jnto consideration the proximity to sites where high-kevel radioactive waste and spent nuclear fuel is generated or temporarily stored and the transportation and safery factors involved in moving such waste to a Itpository. Such guidelines shal] sipecify population factors that will disqualify any site from development as a repository if ary surface facility of sucti repository would be located (1) in a highly populated area; or (2) adjacent to an area 1 mile by 1 mile having a population of not less than 1,000 individuals. Such guidelines also shall require the Secretary to consider the cost and impact of transporting to the repository site the solidified high-level radioactive waste and spent fuel to be disposed of in the reposttory and the actrantages of regional distribution in the siting of repositories. Such guidelines shatl require the Secretary to consider the various geo. logic media in which sites for repositories may be located and, to the extent practicable, to recommend sites in different geologic media. The Secretary shall use guidelines established under this subsection in considering candidate sites for recomrnendation under subsection (b). The Secretary may revise such guidejines from time to time, consistent with the provisions of this subsection.

(b) Recommendation By Secretary To The President-(1)(A) Following the issuance of gaidelines under subsection (a) and consultation with the Governors of affected States, the Secretary shall nominate at least 5 sites that he determines suitable for site characterization for selection of the first repository site.

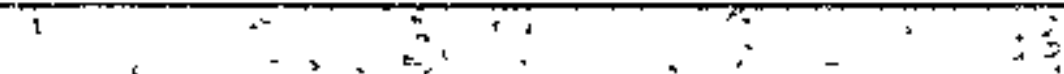


Recommentation date.

Environmental assessment.
(B) Subsequent to such nomination, the Secretary shall recommend to the President 3 of the nominated sites not later than January 1,1985 for characterization as candidate sites.

(C) Such recommendations under subparagraph (B) sball be consistent with the provisions of section 305 .

(D) Each nomiration of a site under this subsection shalt be accompanied by an environmental assessment, which shall include a detail statement of the basis for such recommendation and of the probable impacts of the site characterization activithes planned for such site, and a discussion of alternative activtties relating to site characterization that may be undertaken to avojd such inppacts. Sucil esririronmental assessment shall include-

(i) an evaluation by the Secretary as to whether such site is suitable for site charactepization under the guidelines establisted under subsection (a);

(ii) an'evalustion by the Sectetary as to whether such site is stitable for development as a repository under each suct guidelise that does not tequíre site characterization as a prerequisite for application of such guidelines;

(iii) an evaluation by the Secretary of the effects of the site characterization activities at such site on the public health and safety and the environtment;

(iv) a reasonable comparative evaluation by the Secretary of such site with other sites and locations that have been considèred:

(v) a description of the decision process by which such site was recommended; and

(vi) an assessment of the regional and local impacts of locating the proposed repository at such site.

(E)(i) The issuance of any environmental assessment under this paragraph shall be considered to be a final agency action subject to judicial revitw in accordance with the provisions of chapter 7 of title 5, United States Code, and section 119. Such judicial review shall be limited to the sufficiency of such environmental assessinent with respect to the items described in clauses (i) through (vi) of subparagraph (D).

(F) Each environmental assessment prepared under this paragraph shall be made available, to the public.

(G) Before nominatiog a site, the Secretary shall notify the . Governot, and legislature of the State in which such site is located, of the governing body of the affected Indian tribe where sucti site is located, as the case glay be, of sucin nomination and the basis for such nomination.

(2) Before nominating any site the Secretary shall hold public hearings in the vicinity of such site to inform the residents of the area in which such site is located of the proposed nomination of such site and to receive their comments. At such hearings, the Secretary shall also solicit and receive any recommendations of such residents with respect to issues that should be addressed in the en- 
vtronmental assessment described in paragraph (1) and the site characterization plan described in section $113($ (b) (1).

(3) In eraluating the sites nominated under this section prior to anf decision to recommend a site as a candidate site, the Secretary shall use available geophysical, geologic, geochemical and tydrologic, and other information ard shall not conduct any preliminary borixgs or excavations at a site unless (i) such preliminary boring or excavation activities were In progress upon the date of enactment of this Act or (ii) the Secretary certifies that such available information from other sources, in the absence of preliminary borings of excavations, will not be adequate to satisfy applicable requirements of this Act or any other law: Prowided, That preliminary borings or excavations under this section shall not exceed a diameter of 6 inches.

(c) Presidential Review Of Recommended Candidate Sites-(1) The

Decision transmittal or notification.

President shall review each candidate site recommendation made by the Secretary under subsection (b). Not later than 60 days after the subnission by the Secretary of a recommendation of a candidate site, the President, in his discretion, may either approve or disapprove such candidate site, and shall transmit any such tecision to the Secretary and to ejther the Governor and legislature of the State in which such candidate site is located, or the governing body of the affected Indian tribe where such candidate site is located, as the case may be. If, during such 60-day period, the President fails to approve or disapprove such candidate site, or fails to invoke his authority under paragraph (2) to delay his deciston, such candidate site shall be considered to be approved, and the Secretary shatl notify such Governor and legislature, or governing bodt' of the affected Indian tribe, of the approral of such candidate site by reason of the inaction of the President.

(2) The President may delay for not more than 6 months his decision under paragraph (1) to approve or disapprope a candidate site, upon determining that the information provided with the rec. ommendation of the Secretary is insufficient to permit a decision within the 60-day period refented to in paragraph (1). The Prestdent may inwoke his authority under this paragraph by submitting written notice to the Congress, within sukh 60 -day period of his intent to invoke such authority. If the President invokes such au. thority, but fails to approve or disapprove the candidate site in. volved by the end of such 6-month period, stech candirate site sitall be considered to be approved, and the Secretary shall notify such Governor and legislature, or governing body of the affected Indian tribe of the approval of such candidate site by reason of the inaction of the President.

(d) Preliminary Activities.-Except as otherwise provided in this section, each actrity of the President or the Secretary under this section shall be considered to be a preliminary deciston making activity. No stxch artivity shall require the preparation of an environmental impact statement under section 102(2)(C) of the National Environmental Policy Act of 1969 (42 U.S.C. 4332(2)(C)), or to require ary environm- 
42 USC 10133 Jeview and comment. ental revitw under subparagraph (E) or (F) of section 102(2) of such Act. ${ }^{2}$

\section{r STIE CHARACTERZATION}

Sec. 113. (A) In General.-The Secretary shall carry out, in accordance with the provisjoins of this section, appropriate site characterization activities at the Yucca Mountain site. The Secretary shall consider fully the comments received under subsection (b)(2) and section $112(b)$ (2) and shall, to the maximum extent practicable and in consultation with the Gowernor of the State of Nevada conduct site characterization activities in a rianner that minimizes any significant adverse enviroumental impacts identiffed in such comments or in the environmental assessment submitted under subsection (b)(1).

(b) Commission And States-(1) Before proceeding to stink shafts at the Yucca Mountain site, the Secretary shalt subrait for such candidate site to the Comptission and to the Governor or legislanire of the State of Nevada for their review and comment-

(A) a general plan for site characterization activities to be conductéd at such candidate site, which plan shall includo(i) a description of such candidate site;

(ii) a description of such site characterization activities, including the following: the extent of plasened excavatons, plans for any onsite testing with radioactive or norradioactive material, plan for any irwestigation activities that may affect the capabilities of such centidate site to isoláte high-level radioactive waste and spent nuclear fuel, and plans to cóntrol any adverse, safety-related impacts from such site characterization activities;

(iii) plan for the deoontamination and decommissioning of such candidate site, and for the mitigation of any significant adverse environmental impacts caused by the site characterization activities if it is determined unsuitable for application for a construction authorization for a repository;

(iv) criteria to be lased to determine the suitability of sucticandidate ste for the location of a repository, developed pursuant to section 112(a); and

(v) any other information required by the Commission;

(B) a description of the possible form or packaging for the high-level sadioactive waste and spent nuclear fuel to te $\mathrm{em}$ placed in such repository, a description, to the extent practicable, of the relationship between such waste form or packaging and the geologic medilum of stlch site, and a description of the activities being conducted by the Secretary with respect to such possible waste form or packaging or such relationship, and

(C) a conceptual repository design that takes into account likely site-specific requirements.

Public availability; hearings.
(2) Before proceeding to sink shafts at the Yucca Mountain site, the Secretary shatl (A) make available to the public the site characterization pian described in paragraph (1); and (B) hold public hearings in the vicinity of such candidate site to inform the

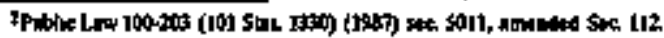


Report.

Repot1s. residents of the area in which such candidate site is located of such plan, and to receive theit commerts.

(3) During the conduct of site characterization activities at the Yueca Mountain site, the Secretary shall report not less than once every 6 menths to the Commission and to the Governor and legislature of the State of Nevada on the nature and extent of such activities and the information developed from such activities.

(c) Restrictions-(1) The Secretary may conduct at the Yucea Mountafn site only such site characterization activities as the Secretary considers necessary to provide the data requited for evaluation of the suitability of such site for an application to be subenitted to the Commission for a construction authorization for a repository at such site, and for compliance with the National Environmental Policy Act of 1969 (42 U.S.C. 4321 et seq.).

(2) In copducting site characterization activities-

(A) the Secretary may not use any ratioactive material at a site unless the Commission concurs that such use is necessary to prowide data for the preparation of the required environmental reports and an application for a construction authorization for a repository at such site; and

(B) if any radioactive material is used at a site-

(i) the Secretary shall use the minimum quantity necessary to determine the suitability of such sites for a repository, but in no event more than the curie equivalent of 10 metric tons of spent nuclear fuel; and

(ii) such radioactive material shal] be fully retrievable. (3) If the Secretary at any time determirtes the Yuoca Mountain site to be ansuitable for development as a repository, the \$ecre. tary shal]-

(A) terminate all site characterization activities at such site; (B) notify the Congress, the Governot and legislature of Nevada of such termination and the reasons for such tercination;

(C) remove any high-level radioactive waste, spent nuclear fuel, or other radioactive materials at or in such site as promptly as practicable;

(D) take reasonable and necessary steps to reclaim the site and to miligate any significant adverse environmental impacts caused by site characterization activities at such site;

(E) suspend all future benefits payments under subtitle F with respect to such site; and

(F) report to Congress not Jater than 6 months after such determination the Secretary's recommendations for further action to assure the safe, permanent disposal of spent nuclear fuel and high-level radioactive waste, including the need for new kegisjative authority.

(d) Prefisminary Activities.-Each activity of the Secretary under this section that is in compliance witt the provisions of subsection (c) shall be considered a preliminary decisiont making activity. No such activity shall require the preparation of an envinonmental impact statement un-

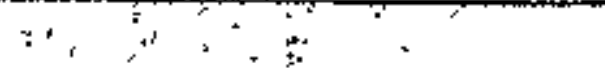


42 USC 10134.

Notification of decision.

Public availability. der section 102(2)(C) of the National Environmental Policy Act of 1969 (42 U.S.C. $4332(2)$ (C)), or to require ang environitiental review under subparagraph (E) or (F) of section 102(2) of stuch Act $^{3}$

STIE AFTROWL AND CONSTROCTION AUTHORZATION

Sec 114. (a) Hearings And Presidential Recommendation.-The Secretary shall hold public hearings in the vicinity of the Yucea Mountain site for the puposes of informing the tesidents of the area of such consideration and receiving their coumuents regarding the possible recomIotendation of such site. If, upon completion of such hearings and completion of site characterization activitis' at, the Yucca Mountain site under section 113, the Secretary decides to rectimmend approval of such site to the President, the Secretary shall notify the Gowernor and legislature of the State of Nevada of such deciston. No sooner than the expiration of the 30-day period following such notification, the Secretary shall submit to the President a recommiendation that the Presidert ap prove such site for the development of a repository. Any such recoumendation by the Secretary shail be based on the record of information developed by tive Secretary under section 113 and this section, inchuting the information described in subparagraph (A) through subparagraph (G). Together with any recommendation of a site under this paragraph, the Secretary shall make available to the public, and submit to the President, a comprehencive statement of the basis of such recommendation, including the following:

(A) a description of the proposed repository, including preliminary engineering specitications for the facilizy;

(B) a description of the waste form or packaging proposed for use at such repository, and an explanstion of the relationship between such waste form or packaging and the geologic medium of such site;

(C) a discussion of data, obtained in site characterization activities, relating to the safety of such site;

(D) a final environmental impact statement prepared for the Yucca Mountain site pursuant to subsection (f) and the $\mathrm{Na}$ tional Euvironmental Policy Act of 1969 (42 U.S.C. 4321 et seq.), together with comments made coucerning such torvitonmental impact statement by the Sectetary of the Interior, the Council on Envtrommenta] Qualit, the Administrator, and the Commission, except that the Secretary shall not be required in any such envirosinental impact statement to consider the need for a repository, the alternatives to geological disposal, or alternative sites to the Yuoca Monntain site;

(E) preliminary comments of the Comujssion conceming the extent to which the at-depth site characterzation analysis and the raste form proposal for such site semm to be sufficient for incluston in any application to be submitted by the Secretary for licensing of such site as a repository;

(F) the views and comments of the Governot and legislature of any State, or the governing body of any affected Indian tibe,

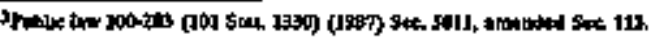


as determined by the Secretary, together with the response of the Secsetary to such views;

(G) suct other information as the Secretary considers ap. propriate; and

(H) any inapact report subnitted under section 116(c)(2)(B) by the State of Nevada.

(2)(A) If, after recommendation by the Sexretary, the Ptesident considers the Yucca Mountain site qualified for application for a construc. tion authonization for a repository, the Prestdent shall submit a recommendation of such site to Congress.

(B) The President shall submit with such recommendation a copy of the statement for such site prepared by the Secretary under paragraph (1).

(3)(A) The President may not recommend the approval of Yucca Mountain sice unjess the Secretary bas recommended to the President under paragraph (1) approval of such site and has sobritted to the President a statement for such site as required under such paragraph.

(B) No recommendation of a site by the President under this subsection shall requirs the preparation of an environruental impact statenent under section 102(2)(C) of the National Environmentad Policy Act of 1969 (42 U.S.C. 4332(2)(C), or to require any environmental review under subparagraph (E) or (F) of section 102(2) of such Act.

(b) Submission Of Application.-If the President reoommends to the Congress the Yuesa Mountain site under subsection (a) and the site desienation is permitted to take effect under section 115, the Secretary shall submit to the Commission an application for a constnuction authorization for a reppository at such site not later than 90 days after the date on which the recommendation of the site designation is effective under such section and shall provide to the Governor and legislature of the State of Nevada a copy of such application.

(c) Stanus Report On Application-Not later than 1 year after the date on whish an application for a construction authorization is submitted under subsection (b), and annually thereafter until the date ont which suct authorization is granted, the Commission shall submit a report to the Congress describing the proceeding undertaken through the date of such report with regard to such application, including a descrip. ton of-

(I) any major unresolved safety issues, and the explanation of the Secretary with respect to design and operation plats for resolving sucis issues;

(2) any matters of contention regarding stach application; and

(3) any Commission actions regarding the granting of denial of such authorization.

Construation authorization applications.

(d) Commission Action-Tue Commission shall consider an application for a construction authorization for all or part of a repository in accordance with the laws applicable to such applications, except that the Conmission shall issue a final decision approving or disapproving the issuance of a construction autborization not later that the expiration of 3 years after the date of the subrission of such application, except that 
Report submittal to Secretery and Congress.

Report resporese, filing with Congress. the Commission may extend such deadlines by not more than 12 months if, not less than 30 days before such deadlines, the Comnaission cornplies with the reporting requirements establisbed in subsection (e)(2). The Comnission decision approving the first such application shall prohibit the emplacement in the first jepository of a quantity of spent fuel containizg in excess of 70,000 metric tons of heavy metal or a quantity of solidified high-level ractioactive waste resulting from the reprocessing of such a quantity of spent fuel until such time as a second repository is in operation. In the event that a monttoreti retrievable storage facility, approved pursuant to subtitle $C$ of this Act, shall be located, or is planhed to be located, within 50 miles of the first repository. then the Commission decision approving the first stch application shall prohibit the emplacement of a quality of spent fuel contajning in excess of 70,000 metric tons of heavy metal or a quantity of solidified high-level radioactive waste resulting from the reprocessing of spent fuel in boththe repository and monitored retrievable storage facility until such time as a second reposttory is in operation.

(c) Protect Decision Schedule-(1) The Secretary shall prepare and update, as appropriate, in cooperation with all affected Federal agencies, a project decision schedule that portrays the optimum way to attajn the operation of the repository within the time periods specified in this subtitle. Stach schedule shail include a description of objectives and a sequence of deadlines for afl Federal agencies required to take action, inchading an identification of the activities is which a delay in the start, or completion, of such activities will cause a delay in beginning repository operation.

(2) Any Federal agency that determines that it cannot comply with ary deadline in the project decision schedutle, or fajls to so comply, shall subuit to the Secretary and to the Congress a written report explaining the reason for its failure or expected failure to meet such dęadlines, the reason why such agency could not reach an agreement with the Secretary, the estimated time for coxpletion of the activity or activities involved, the associsted effect on its other deadlines jut the project decision schedule, and any reconmendations it may have or actions it intends to take regarding any improvements in its operation or organization, or changes to its statutory directives or authority, so that it will be able to mítigate the delay jivolved. The Serretary, within 30 days after receiving any such report, shall file with the Congress his response to such report, including the reasons why the Secretary could not amend the project decision schedule to accommodate the Federal agency involved.

(1) Environmental Impact Statement.-(1) Avy recommendation made by the Secretary under this section shall be considered a major Federal action significantly affecting the quality of the fuman environment for purposes of the National Environmental Policy Act of 1969 (42 U.S.C. 4321 et seq.) A final envitonmental impact statement prepared by the Secretary under such Act shall accompany any recommendation to the President to approve a site for a repository. 
(2) With respect to the requirements imposed by the National Exvironnental Policy Act of 1969 ( 42 U.S.S.C. 4321 et sey.), compliance with the procechures and requirements of this Act shalt be deemed adequate consideration of the need for a repository, the time of the initiai availability of a repository, and all alternatives to the isolation of high-level radioactive waste and spent muclear fuel in a repository.

(3) For purposes of complying with the requirements of the $\mathrm{Na}$ tional Envitonmental Policy Act of 1969 (42 U.S.C. 4321 et seq.) and this section, the Sectetary neted not consider alternative sites to the Yucca Mountain site for the repository to be developed under this subtitle.

(4) Ary ervironmental impsct statement prepared in connection with a repository proposed to be constructed by the Secretary under this subtitle shall, to the ex tent practicable, be adopted by the Commission in connection with the issuance by the Commission of a construction anthorzation and license for such repository. To the extent such statement is adopted by the Comrnission, such adoption shall be desmed to also satisfy the responsibilities of the Commìssion under the National Environmental Policy Act of 1969 ( 42 U.S.C. 4321 et seo.) and no further consideration shall be required, except that nothing in this subsection shall affect any independent responsibilities of the Commission to protect the public health under the Atomic Energy Act of 1954 (42 U.S.C. 2011 et seq-).

(5) Nothing in this Act shall be construed to anend or otherwise detract from the licensing requirements of the Nuclear Regulatory Commission established in title II of the Energy Reorganization Act of 1974 (42 U.S.C. 5841 et seq.).

(6) In any such statement prepared with respect to the repository to be constructed under this subtitle, the Nucdear Regulatory Commission reed not consider the need for a repository, the time of initial availability of a repository, alternate sites to the Yuoca Mountain site, of nongeologic alternatives to such site.

\section{REVIEW OP REPOSTTORY STEE SETECTION}

42 USC 10135. Sec. 115. (a) Definition-F or purposes of this section, the term "resolution of repasitory siting approval" means a joint resolution of the Congress, the unatter after the resolving clause of which is as follows: "That there bereby is approwed the site at ... for a repository, with respect to which a notice of disapproval was submitted by ... on ...". The first blank space in such resolution shall be filled with the name of the geographic location of the proposed site of the repository to which such resolution pertains; the second blank space in such resolution shall be filled with the desienation of the State Governor and legislature or Indian tribe govenning body submitting the notice of disapproval to which such resolution pertains; and the last blank space in such resolution shall be flled with the date of such submission.

(b) State Or Indian Tribe Petitions.-The designation of a site as suitable for application for a consinuction authorization for a repository

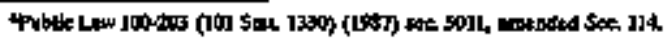


Notice of disapprowal, submittal to Congress.

Introduction of resolution.

Comrnittee recormmendations.

Dtecharge of commitutee. shall be effective at the end of the 60 -day period beginning on the date that the President recommend such siteto the Conyress under section 114, untess the Government and legislature of the State in which such site is located, or the governing body of an Indtan tribe on whose reservation such site is located, as tho cast may be, has submitted to the Conpress a notice of disapproval under section 116 or 118. If any such notice of disapproval has been submitted, the designation of stch site sball not be' effective except as provided under subsection (c).

(c) Congressional Review $O$ f Petitions.-If any notoe of disapproval af a repository site designation bas been submitted to the Congress under section 116 or 118 after a recommendation for approwal of stact site is made by the President under section 114, such site thall be distaproved unless, during the first period of 90 calendar days of continutous session of the Congress after the date of the receipt by the Congress of such notice of disapproval, the Congress passes a resolution of repository siting approwal in accordance with this subsection approving such site, and such resolution thereatter becomes law.

(d) Procedores Applicable To The Seniate-(1) The provisions of this subsection are enacted by the Congress-

$\therefore$ (A) as an exercise of the rulemaking power of the Senate, and as such they are deemed a part of the rules of the Senate, but applicable only with respect to the procedure to be followed in

- the Senate in the case of resolutions of repository sibing approwal, and such provisions supersede other rules of the Senate onfy to the extent that they are inconsistent with such other rules; and

(B) 'with full recognition of the constitutional right of the Senate to change the rules (so far as Jelating to the procecture of the Senate) at any time; in the saito, marner and to the sarate extent as in 'the case of any other rule of the Senate.

(2)(A) Not later than the first day of session following the day on which any rotice' of disapproval of a 'repository site selection is sub. mitted to the Congress under section 116 or 118, a resolution of repository siting approval shalt be introxtuced (by request) it the Sente by the chainnart of the commtttee to which such notice of disapproval is referred, or by a Member of Members of the Senate designated by such chairman.

(B) Upon introduction, a resolution of repositary siting approval shall be referred to the appropriate committee or comJittees of the Senate by the President of the Senate, and all such resolutions with respect to the same repository site shadt be referred to the same committee or committees. Upon the expiration of 60 calendar days of contionsous session after the introduction of the first resolution of repository siting approval with respect to any site, each committee to which such resoJution was refertred shall make its recommendations to the Senate.

(3) If any committes to which is referred a resolution of stiting approval tutroduced under paragraph (2)(A), or, in the absence of such a resolution, apy other resolntion of siting approval 
Debate,

Appeals. introduced with respect to the site involved, has not reported such resolution at the end of 60 days of continuous session of Congress after introduction of such tesolution, such committee shall be deemed to be discharged from further consideration of such reso. hution, and such resolution shall be placed on the appropriate calendar of the Senate.

(4) (A) When each committee to which a resolution of siting approval has been referred has reported, or has been detmed to be discharged from further consideration of, a resolution described in paragraph (3), it shall at any time thereafter be in order (even though a previous motion to the same effect bas been disagreed to) for any Member of the Senete to move to proceed to the consideration of such resolution. Such motion shall be highly privilege and shall not be debatable. Such motion shall nat be subject to amendinent, to a motion to postpone, or to a motion to proceed to the consideration of other business. Amotion to reconsider the vote by whitch such motion is agreed to or disagreed to shall not be in order. If a motion to proceed to the consideration of such resolution is agreed to, strch resolution shall remain the tinfurtished bustness of the Senate tuntil disposed of.

(B) Debate on a resolution of siting approval, and on all debatable mottons and appeals in connection with such resolution, shall be limited to not more than 10 hours, which shall be divided equally between Members favoring and Members opposing such resolution. A motion further to limit debate shall be in order and shall not be debatable. Such motion shall not be subject to amendment, to a motion to postpone, or to a motion to proceed to the consideration of other business, and a motion to reconmit such resolution shall not be in order. A motion to reconsider the vote by which such resolution is agreed to or disagreed to siall not be in order.

(C) Immediately following the conclusion of the debate on a resolution of siting approval, and a single quorum calt at the conclusion of such debate if tequested in accordance withrutes of the Senate, the vote on final approval of such resohution shall occur.

(D) Appeals from the decisions of the Chair relating to the application of the rules of the Senate to the procedure relating to a resolution of siting approval shall be decided without debate.

(5) If the Senate receives from the House a resolution of repository siting approval with respect to any site, then the following procedure shall apply:

(A) The resolution of the House with respect to such site shall not be referred to a committee.

(B) With respect to the resolution of the Senate with respect to such sits-

(i) the procedure with respect to that or other resolutions of the Senate with respect to such site shall be the same as if no resolution from the House with respect to such site had been received; but

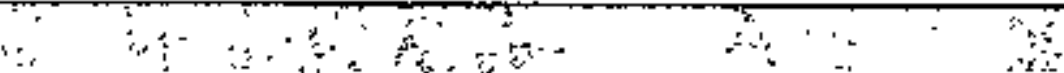


(ii) on any vote on final passage of a resolution of the Senate with respect to such site, a resolution from the House with respect to such site where the text is identical shall be atutomaticaly substituted for the resolution of the Senate.

(c) Procectures Applicable To TherHouse Of Representatives-

(1) The provisions of this section are enlacted by the Congress-

(A) as an exercise of the rolemaking power of the House of Representatives, and as such they are deemed a part of the rutes of the House, but applicable only with respect to the procecture to be followed in the House in the case of resolutions of repository siting spprowal, and such provisions supersede other rules of the House only to the extent that they are inconsistent with such other nules; and

(B) with full recongnition of the constitutional right of the House to change the rules (so far as relating to the procedure of the House) at atiy time, in the same manner and to the same extent as in the case of any other rule of the House.

(2) Resolutions of repository siting approval shall upon introduction be immediately seferred by the Speaker of the House to the appropriate committee or committees of the House. Any such resolution recteived from the Sintate shall be held at the Speaker's table.

Discharge of comminittee.

Resolution, consideration and debate.
(3) Upon the expiration of 60 days of continuous session after the introduction of the first resolution of repository siting approval with respect to any site, each combittee to which such resolution was referred shail be discharged from further consideration of such resolution, and such resolution shall be referred to the appropriate calendar, unless zuch resolution or an identical resolution was previously teported by each committee to which it was referted.

(4) If shall be to order for the Speaker to recogrize a Member favoning a resolution to call up a resolution of repository sitiog approval after it has been on the appropriate calendar for 5 legislative days. When any such resolution is called up, the House shall proceed to its immediate consideration and the Speaker shall rec. ogatize the Member catling up such resolution and a Member opposed to such resolution for 2 hours of debate in the House, to be equally divided and controlled by such Members. When such time has expired, the previous question shall be considered as ordered on the resolution to adoption without intervering motion. No amendment to any such resolution shall be in order, nor shall it be in order to move to reconsider the vote by which such resolution is agreted to or disagret to.

(5) If the House receives from the Senate a resolution of repository siting approval with respect to any site, then the following procechure shall apply:

(A) The resolution of the Senate with respect to such site shall not be referted to a corminittec. 
(B) With respect to the resolution of the House with respect ' to sulch sito-

(i) the procecture with respect to that or other resolutions of the House with respect to such site shall be the same as if no resolution from the Sepate with respect to such site bad been rectived; but

(ii) on any vote on final passage of a resolution of the House with respect to such site, a resolution from the Sen. ate with respect to such site where the text is identical shall be automatically substituted for the ressolution of the House.

(f) Computation Of Days-For purposes of this section-

(1) continuity of session of Congress is broken only by an adjournment sine die; and

(2) the days on which either flouse is not in session because of an adjournment of more than 3 days to a day certain ase excluded in the computation of the 90-day period referred to in subsection (c) and the 60-day period referred to in subsections (d) and (e).

(g) Information Provided To Congress.-In considering any notice of disapproval submitted to the Congress under section 116 or 118, the Congress may abtain any comments of the Commission with respect to such notice of disapproval. The provision of such comments by the Commission shall not be construed as binding the Commission with respect to any licensing or authorization action concerning the repository involved.

42 USC 10136. Sec. 116. (a) Notification OfStates And Affected Tnibes-The Secretary shall identify the States with one or morte potentially acceptable sites for a repository withto 90 days after the date of enactment of this Act. Within 90 days of such iclentification, the Secrotary shall sotify the Governor, the State legislature, and the tribal connct of any affected

Potentially acceptable stte. Indian tribe in any State of the potentially acceptable sites within such State. For the purposes of this title, the term "potentially acceptable siter means aby sits at which, after geologic stuóies and fiold mapping but before detailed geologic data gathefing the Department uxdertakes preliminary drilling and geoplyysical testing for the definition of site location.

(b) State Participation In Repository Siting Decisions.-(1) Unless otherwise provided by State law, the Govenor or Iegislature of each State shall have authority to submit a notice of disapproval to the Congress under paragraph (2). In any case in which State law provides for submission of any such notice of disapproval by any other person or entity, any reference in this subtitle to the Governor or legislature of such State shall be considered to refer instead to such other person or entity.

Notice of disappowal, subsiittal to Congress.
(2) Upon the submission by the President to the Congress of a recominendation of a site for a repository, the Governor or legislature of the State in which such site is located nuy disapprove the site designation and submit to the Congress a notice of disapproval. Such Goveruor or legislature may submit such a votice of disapproval to the Congress not later than the 60 days after the 
date that the President recoumands such site to the Corgress un. der section 114. A notice of disapproval shall be considered to be submitted to the Congress on the date of the transmittal of such notice of tisapproval to the Speaker of the House and the President pro tempore of the Senate. Such notice of disapproval shall be accompanied by a statement of reasons explaining why such Governor or legislature disapproved the recommended reposito1 ry site involved.

(3) The authority of the Govertor or legislature of each State under this subsection shall not be applitabie with respect to any site located on a reservation.

(c) Financial Assistance.-(1)(A) The Secretary shall make grants to the State of Nevada and any affected usit of local government for the purpose of participating in activities required by this section and section 117 or authorized by written agreentent entered mto pursuant to section 117(c). Any salary or travel expense that would ordinarily be incurred by such State or affected unit of local government, may not be constiered eligible for finding utider this paragraph.

(B) The Secretary shall make grants to the State of Nevada and any affected unit of local governiment for purposes of erabling such State or affected unt of local governatent-

(i) to seview activities taiken under this subtitle with re. spect to the Yucca Mountain site for purposes of determining any potential economic, social, public health and safety, and environmental impacts of a repository on such State, or affected unit of local goverument and its restdents;

(ii) to develop a request for impact assistance under paragraph (2);

(iii) to engage in any monitotitis, test, of evaluation activities with respect to site characterization prograns with regard to such site;

(iv) to provide information to Nevada residents regarding any activities of such State, the Secretary, or the Commission with respect to such site; and

(v) to request information from, and make comments and recommetidations to, the Sectetary regarding any activities taken under this subtitle with respect to such site.

(C) Any salary or travel expense that would ordinarily be incurred by the State of Nevada or any affected unit of local govermment may not be constdered eligible for funding under this paragraph.

(2)(A)(t) The Secretary shall provide financial and technical assistance to the State of Nevada, and any affected unit of local govermment requesting such assistance.

(ii) Such assistarce shall be designed to mitigate the intpact on such State or affected unit of local government of the development of such repository and the characterization of such site. 
(iii) Such assistance to such State of affected unit of lo. cal government of such State shall commence upon the initiation of site characterization activities.

(B) The State of Nevada and any affected unit of local government may request assistance under this subsection by preparing and submitting to the Secsetary a report on the economic, social, public health and safety, and environmental impacts that are likely to result from site characterization activities at the Yuces Mountain site. Such report shall be submitted to the Secretary after the Secretary has submitted to the Skate a gencral plan for site characterization activities under section 113(b).

(C) As soon as practicable after the Secretary has subnitted stch site characterization plan, the Secretary sinall seek to enter into a bjading agreenent with the State of Nevada setting forth-

(i) the amount of assistance to be provided under this subsection to such State or affected unit of local govermment; and

(ii) the procedures to be followed in providing such as. sistance.

(3)(A) In adilition to financial assistance provided under paragraphs (1) and (2), the Secretary shall grant to the State of Nevada and any affected umit of local governionent an amount each fiscal year equal to the amount such State or affected unit of local govcrument, respectively, would recefve if authorized to tax site characterization activities at such site, and the development and operation of such repository, as such State or affected unit of local government taxes the non-Federal reaj property and industrial activities oceurring within such State or affected unit of boel govern. ment

(B) Such grants shall continue until such time as ail such 'activities, development, and operation are terminated at wach stich site.

(4) (A) The State of Nevada or any affected unit of local government may not receive any grant onder paragraph (1) after the expiration of the 1 year period following-

(i) the date on which the Secretary notifits the Governor and legislative of the State of Nerada of the termination of site characterization activities at the site in such State;

(ii) the date on which the Yusca Mountain site is disapproved under section 115; or

(ii) the date on which the Commissjon disapprowes an application for a construction authorization for a repository at such site; whichever occurs first.

(B) The State of Nevada or any affected unit of local government may not recejve any further assistance under paragraph (2) with respect to a site if repository construction activities or site characterization activities at such site are terminated by 
the Secretary or if such activities are permanently enjoined by any court.

(C) At the end of the 2-year period beginning on the effective date of any license to receive and possess for a repository in a State, no Federal funds, shall be made available to such State or affected unit of local government under paragraph (1) or (2), except for-

(i) such funds as may be necessary to support activities related to any other repository located in, or proposed to be located in, such State, and for which a license to receive and possess has not been in effect for thore than 1 year;

(ii) such funds as may be necessary to support State acrivities pitrstant to agretments or contracts for impact assistance entered into, under paragraph (2), by such State with the Secretary durtin such 2-year period; and

(ii) such fonds as may be provided under an agreement entered into under title IV.

(5) Financial assistance autborized in this subsection shall be made out of amounts held in the Waste Fund.

(6) No State, otker than the State of Nevada, may receive finarcial assistance under this subsection after the date of the enactment of the Nuclear Waste Policy Amendments Act 1987.5

(d) Additional Notíication And Consultation-Whenever the Secretary is required under any provision of this Act to notify or consult with the goveraing body of an affected Indian tribe where a site is located, the Secretary shall also notify or consult with, as the case may be, the Governor of the State in which such reservation is located.

, CONSUILTATION WITH STARES AND AFTECTTED INDIAN TRIBES

42 USC 10t37. Sec.117. (a) Provision OfInformation.-(1) The Secretary, the Commission, and other agencies involved in the construction, operation, or regutation of any aspect of a repository in a State shall provide to the Governor and legislanure of such State, and to the governing body of any affected Indian tribe, timely and complete information regarding determinations or plans made with respect to the site characterization stiting, development, design, licensing, construction, operation, regulation, or decommissioning of such repository.

Information

request,

responsto.

(2) Upon written request for such information by the Governor or legislatuse of such State, or by the governing body of any affected Indian tribe, as the case may be, the Secretary shall provide a written response to such request withis 30 days of the re+ ceipt of such request. Such response shall provide the information requested or, in the alternative, the reasons wity the information cannot be so provided. If the Secretary fails to so respond within such 30 days, the Governor or Legislature of such State, or the governing body of any, affected Indian tribe, as the case may be, may transmit a formal written objection to such failure to respond to the President. If the President or Secretary fails to respond to such written request within 30 days of the receipt by the President of such formai written objection, the Secretary shall immediately sus-

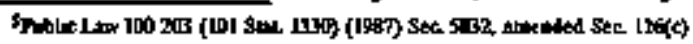


pend ail activities in such State authorized by this subtitie, and shall not renew such activities until the Govemor or legislature of such State, or the governing body of any affected Indian tribe, as the case may be, has received the written response to such written request required by this subsection.

(b) Consultation And Cooperation-In perfonting any study of an area within a State for the pirpose of determining the sujtability of such area for a repository pursuant to section 112(c), and in subsequently developing and loading any repository within such State, the Secretary shall consult and cooperate with the Governor and legislature of such State and the governing body of any affected Indian tribe in an effort to resolve the concerns of such State and any affected Indian tribe regarding the public bealth and safety, environmental, and economic impacts of any such repository. In carrying out his duties under this subtitle, the Secretary shall take such concoms into acsount to the maximusn extent feasible and as specified in written agreements entered jnto under stbsection (c).

(c) Written Agreement.-Not later than 60 days after (1) the approval of a site for site characterization for such a repository under section 112 (c), or (2) the written request of the State or Indian tribe in any iffected State notified under section 116(a) to the Secretary, whichever, first oscurs, the Secretary shall seek to enter into a binding written agreement, and shall begin negotiations, with such State and, where appropriate, to enter into a separate binding agreement with the goteming body of any affected Indian tribe, setting forth (but not limited to) the procedures under with the requirements of subsections (a) and (b), and the provisions of such written agreement, shall be carried out. Any such written agreengent shall not affect the authority of tie Conmission under existing Jaw. Each such written agreement shall, to the maximum extent feasible, to completed no later than 6 months after such notifitation. If such written agretsnent is not completed within

Report to Congress.

Report, review and comments. such period, the Secretary shal] report to the Congress in writing withir 30 days on the status of aegatiation to develop such agreentent and the reasons why such agreenent has not been completed. Prior to submission of such report to the Congress, the Secretary shall transmit such Ieport to the Governor of such State or the governine body of such affected Indian tribe, as the case may be, for their review and comments. Such comments shall be inclucted in stucti report prior to submission to the Congress. Such written agreement shall speeify procedures-

(1) by which such State or governing body of an affected lndian tribe, as the case may be, may study, detemnine, comment on, and make recommendations with regard to the possible public health and safety, environmental, social, and economic impacts of any such repository;

(2) by which the Secretary shall consider and respond to comments and recommendations made by stuch State or governing body of an affected Indian tribe, including the period in which the Secretary shall so respond; 
Transportation of radioactive waste and spent nuclear fuel, State notification. Monitoring and testions.
(3) by which the Secretary and stuch State or governing body of an affected Indian tribe naay review or modify the agreentent periodically,

(4) by which such State or governing body of an affected Indian tribe is to subsit an inapact xeport and request for impact assistance under section 116(c) or section 118(b), as the case may be; (j) by which the Secretary shall assist such State, and the units of general local government in the vicinity of the repository site, in resolving the offsite concerns of such State and units of generai local government, jucluding, but not limited fo, questions of State liability arising from accidents, necessary road upgrading and access to the sitt, ongoing emergency preparedness and emergency response, monitoning of transportation of high-level radioactive waste and spent nuclear fuel through such State, conduct of base. line health studies of inhabitants in neightboring communities near the repository site and reasonable periodic shonitoring thereafter, and monitoring of the repository site uppon any decomunissioning and decontamination;

(6) by which the Secretary shall consult and cooperate with such State on a regutar, ongoing basis and provide for an orderly process and timely schedule for State review and evaluation, including identification in the agreement of key events, milestones, and decision points in the actrvities of the Secretary at the potential repository site;

(7) by which the Secretary stiall notify such State prior to the transportation of any high-level radioactive waste and spent nuclear finel into such State for disposal at the repository site;

(8) by which such State may conduct reasonable independent monitoring and testing of activities on the repository site, except that such monttoring and testing shall not unreasonably interfere with or delay onsite activities;

(9) for sharing, in accordance with applicable law, of all technical and licensing information, the utilization of avalable expertise, the facilitating of permit procectures, joint project review, and the formation of joint surveillance and monitoring arrangements to carry out applicable Federal and State laws;

(10) for peblic notification of the procedures specified under the preceding paragraphs; and

(11) for resolving objections of a State and affected Indian tribes at ary stage of the planning, siting, development, construction, operation, or closure of such a facility within spch State through negotiation, arbitration, or other appropiate mechanisms.

(d) On-site Representative.-The Stcretary stall offer to any State, Indian tribe or unit of local goverument within whose jurisdiction a site for a repository or monitored retrievable storage facility is located urlder this title an opportunity to designate a Iepresentative to conduct on-site oversight activities at such site. Reasonable expenses of such representatives shall be paid out of the Waste Fund. ${ }^{6}$

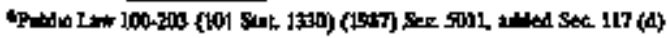




\section{PAENICEATTON OF INDUAN TEIBES}

Notice of disapprovat, submittal to Congress. 42 USC 10138

Grants.
Sec. 118. (a) Participation Of Indjan Tribes In Repository Siting Dectsions.- Upont the submission by the President to the Congress of a recornonendation of a site for a repository located on the reservation of an affected Indian tribe, the governing body of such Indian tribe may disapprove the site designation and submit to the Congress a notice of disap. proval. The governing body of such Indian tribe ntay subuit such a notice of disapprowal to the Congress not later than the 60 days after the date that the President recommends such site to the Congress under section 114. A notice of disapproval shall be considered to be submitted to the Congress on the date of the transrnittal of such notice of disapproval to the Speaker of the House and the Prestdent pro tempore of the Sertate. Such notice of disapprowal shall be accompanied by astatement of reasons explatining why the goveruting body of such Indian tribe disapproved the recomunended repository site involved.

(b) Financial Assistance-(1) The Secretary shall make grants to each affected tribe natified under section 116(a) for the purpose of participating in activities reguired by section 117 or authorized by written agreement entered into pursiant to section 117 (c). Any salary or traves expense that would ordinarily be incurred by such tribe, may not be considered eligible for funding under this paragraph.

(2) (A) The Secretary shall make grants to each affected Indian tribe where a candidate site for a repository is approwed under section 112(c). Such grants may be made to each such Indian tribe orly for purposes of enabling such Indian tribe-

(i) to review activities taken under this stbtitle with respect to such site for purposes of determining any potential economic, sociat, public health and safety, and environmental inipacts of such repository on the reservation and its residents;

(ii) to develop a request for impact assistance under paragraph (2);

(iii) to engage in any monitoring, testing, or evaluation activities with respect to site characterzation prograns with regard to such site;

(iv) to provide information to the residents of its reservation regarding any activities of such Indian tribe, the Secretary, or the Commission with respect to such sile; and

(v) to request information from, and make comments and recommendations to, the Secretary regarding any ace. tivities taken under this subtitle with respect to such site. (B) The amount of funds provided to any affected Indian tribe under this paragraph in any fiscal year may not exceed 100 percent of the costs incurred by such Indian tribe with respect to the activities described in clauses (i) through ( $v$ ) of ssibparagraph (A). Any salary or travel expense that would ordinarily be incurred by such Indlan tribe may not be considered eligible for furding under this paragraph.

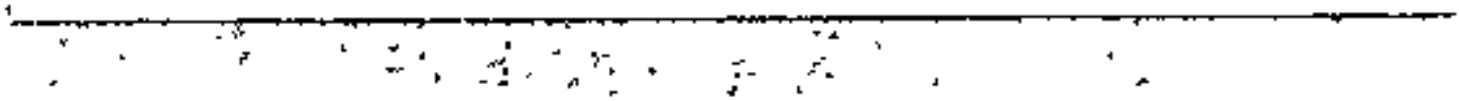


Report submittal.
(3) (A) The Secretary shall provide financiat and technical assistance to arty affected Indian tribe requesting such assistance and Where there is a site with respect to which the Commission bas au. thorized construction of a repo'sitory. Such assistance shall be designed to mitigate the impact on such Indian tribe of the development of such repesitory. Such assistance to such Fndian tribe shall comrnence within 6 months following the granting by the Comumission of a construction authorization for such repository and following thie intiation of construction activities at such site.

(B) Any affected Inxtian tribe destring assistance tonder this paragraph shall prepare and subouit' to the Secretary a report on any economic social, public bealts and safety, and envitonmental impacts that are likely as a result of the development of a repository at a site on the reservation of stch Incian tribe. Such report shall be submitted to the Secretary following the ompletion of site characterization activities at such site and before the recommendation of such site to the President by the Secretary for application for a construction authorization for a repository. As soon as practicable following the granting of a construction authorization for such repository, the Secretary shell seck to enter into a bitwing agreement with the Indian tribe involved setting forth the antount of assistance to be provided to such Indian tribe under this paragraph and the procecures to be followed in providing such assistance.

(4) The Secretary shall grant to tach affected Indian tribe where a site for a repository is approved under section 112(c) an amount each fiscal year equal to the ampunt such Inctian tribe would recerve were it authorized to tax site characterization activitits at ${ }_{2}$ stuch site, and the development and operation of sucis repository, as such Indian tribe taxes the atter comnercial activities occurring on such reservation. Such grants shall continue until such time as all such activities, developuent, and operation are terminated at such site.

(5) An affected Indian tribe may not receive any grant under paragraph (1) after the expiration of the 1-year period following-

(i) the date on which the Seretary notifies such Indian tribe of the termination of site characterization activities at the condidate site involved on the reservation of such Intian tribe;

(ii) the date on which such site is disapproved under section 115;

(iii) the date on which the Commisston distapproves an 'apphication for a construction authorization for a repositony at such site;

(iv) the date of the eractrment of the Nuclear Waste

- Policy Amendments Acts of $19877^{7}$

whichever occurs first, unless there is another candidate site on the reservation of such Indian trtbe that is approved under section 112(c)

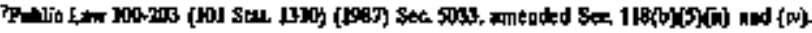


and with respect to which the actions described in clauses (i), (ii), and (iii) have not been taken.

(B) An affected Indian tribe may not receive any further assistance under patagraph (2) with respect to a site if repository construction activities at stich site are terminated by the Secretary or if such activities are penmanently enjoined by any court.

Funding

Fosf p. $225 \%$.

42 USC $10 \pm 39$

(C) At the end of the 2-year period beghning on the effective date of any license to receive and possess for a repository at a site on the reservation of an affected Indian tribe, no Federal funds shall be made azailable under paragraph (1) or (2) to such Indian tribe, except for-

(i) such funds as may be necessary to support activitues of such Indian tribe related to any other repository where a licentse to recaive and possess has not been in effect for more than I year; and

(ii) such funds as may be necessary to support activities of sixch intian tribe pursuant to agresments or contracts for impact assistarce entered isto, tunder paragraph (2), by such Indian tribe with the Secretary during such 2-year period.

(6) Financial assistance authorized in this subsection skall be made out of amounts held in the Nuclear Waste Fund established in section 302 .

\section{JDICTAL REVIEW OF AGINCY ACTIONS}

Sec. 119. (a) Jurisdiction of Untted States Courts Of Appeals-(1) Except for review in the Supreme Court of the United States courts of appeals shall bave original and exchusiwe jurisdiction over any civil action-

(A) for review of any final decision on action of the Secretary, the President, or the Commission under this subtitle;

(B) alleging the failure of the Secretary, the President, or the Commission to make ary decision, or take any action, rexuired under this subtitle;

(C) challenging the constitutionality of any deciston made, or acton taken, under any provision of this subtitle;

(D) for revier of any epvisonanental inpact statement prepared pursuant to the National Envrtonmental Policy Act of 1969 ( 42 U.S.C. 4321 et seq.) with respect to any action under this subtitle, or as required under section 135(c) (1), or alleging a failure to prepare such statement with respect to any such action;

(E) for review of any environmental assessment prepared under section 112(b) (1) or 135(c) (2); or

(F) for review of any research and development activity under title II.

(2) The venue of any proceseding under this section shall be in the 
Post, p. 2245.

$42 \mathrm{USC} 10140$

42 USC 10141 . juticial circuit in which the petitioner fovolved resided or has its principle office, or in the United States Court of Appeals for the District of Columbia.

(c) Deadline For Conmencing Action- A civil action for judicial review described under subsection (a)(1) may be brought not later than the $180 \mathrm{kth}$ day after the date of the decision or action or failure to act involved, as tine case may be, except that if a party shows that he oid not know of the decision or action complained of (or of the failuse to act), and that a reasonable person acting under the circunstances would not have known, stach party may bring a civil action not later than the 180th day after the date such party acquired actual or constructive knowledge of such dectision, action, of fajlure to act.

\section{EXPEDITED ALTHORTZATON'S}

Sec. 120. (a) Issuance Of Authorization.-(1) To the extent that the taking of any action related to the site characterization of a site or the construction or initial operation of a repository under this subtitle requires a certificate, right-of-way, permit, lease, or other authorization from a Federal agency or officer, such agency ot officer shall issue or grant any such authorization at the earliest practicable date, to the extent perritted by the applicable prowisions of law administered by such agency or officer. Al] actions of a Federal agency or officer with respect to consideration of applications or rogtests tor the issuance or prant of any such authorization shall be txpedited, and any such application or request shall take precedence over any sirilar appltcations on requests not related to such repositories.

(2) The protisions of paragraph (1) shall not apply to any certificate, right-of-way, permit, lease, or other aythorization issued or granted by, or requested from, the Commission.

(b) Teniss Of Authorizations.-Any authorization issued or granted pursuant to subsection (a) shall include such terms and conditions as may be recuired by law, and may include terms and conditions permitted by law.

\section{CRRTAIN STANDARDS AND CRTTKRA}

Sec. 121. (a) Environmental Protection Agency Standards.-Not later tian 1 year after the date of the enactinest of this Act, the Adninistrator, pursuant to authority under other provisions of law, shall, by role, promulgate generally applicable standards for protection of the general environment from offsite releases from radioactive material in repositories.

(b) Conmission Requirements And Criteria-(1) (A) Not later thar January 1, 1984, the Conmission, pursuant to authority under other provisions of law, shall, by rule promulgate tectinical requirements and criteria that it will apply, under the Atomic Energy Act of 1954 (42 U.S.C. 2011 et seq.) and the Energy Reorganization Act of 1974 (42 U.S.C. 5801 et seq.), in approving or disapproving.--

(i) applications for authorization to construct repositories;

(ii) applications for licenses to receive and possess spent nuclear fuel and high-tevel radioactive waste in such repositories; and 
(iti) applications for authorization for closure and decounmissioning of such repositories.

(B) Such criteria shall prowide for the use of a system of multiple barriers in the design of the repository and shall include such restrictions on the retrievability of the solidified high-jevel radioactive waste and spent fuel emplaced in the repository as the Commission deems appropriate.

(C) Such requirements and criteria shall not be inconsistent with any comparable standards promulgated by the Administrator under subsection (a)*

(2) For purposes of this Act, nothing in this section shall be constructed to prohibit the Commission from promulgating requirements and criteria under paragraph (1) before the Axtministrator promulgates standards under subsection (a). If the Administrator promulgates standards under subsection (a) after Iequitements and criteria are promilgated by the Commission under paragraph (1), such requirements and eriteria shall be revised by the Commission if necessary to compty with paragraph (1) (C).

(c) Environmental Inpact Statements.-The promulgation of standards or criteria in aceordance with the prowisions of this section shal not require the preparation of as environmental impact statement under section 102(2)(C) of the National Environmental Policy Act of 1969 (42 U.S.C. 4332(2)(C)), or to require any envitonmental review under subparagraph (E) or (F) of section 102(2) of such Act.

\section{DISPOSAL OF SPENT NOCLEAR FUEL}

Sec. 122. Notwithstanding any other provision of this subtitle, any repository constructed on a site approved under this subtitle shall be designed and constructed to permit the retrieval of any spent nuclear fuel placed in such repository, during an appropriate period of operation of the facility, for any reason pertaining to the public bealth and safety, or the environment, or for the purpose of permitting the recovery of the economically valuabte contents of such spent fuel. The Secretary shat specify the appropriate period of retrievability with respect to any repository at the time of design of such repository, and such aspect of such repository shall be subject to approval or disapproval by the Commission as part of the construction authorization process under subsections(b) through (d) of section 114.

42 USC 10143. Sec. 123. Delivery, and acceptance by the Secretary, of any high-lewel radioactive waste or spent mielear fuel for a repository constructed under this subtitle shall constitute a transfer to the Secretary of titie to such waste or spent fuel.

CONSIDERATION OF EFTECT OF ACQUISTION OF WATER RIGHTS

42 UȘC 10144. Sec. 124. The Secretary shall give full consideration to whether the development, constriction, and operation of a repository may require any purchase or other acquisition of water rights that will have a significant

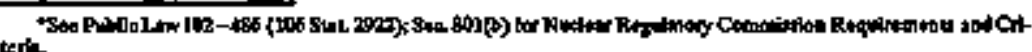


adverse effect on the present or future development of the area in which such repository is located. The Secretary shall mitigate any such adverse effects to the maximum extent practicable.

TERMINATION OF CERTAIN PROWISLONS

Sec.125. Sections 119 and 120 shall cease to have effect at such time os a repository developed under this subtitte is licensed to receive and possess high-level radioactive waste and spent nuclear fuel.

42 USC 10151.

\section{Sec. 131 (a) Findings.-The congress finds that--}

(1) the persons owning and operating civilian nuclear power reactors have the primary responsibility for providing interim storage of spent quclear fiel froms sucti reactors by maximizing, to the extent practical, the effective use of existing storage facilities at the site of each civilian' nuclear power reactor, and by adding Dew onsite storage capacity in a tinely manuer where practical;

(2) the Federal Government has the responsibility to encourage and expedite the effective use of existing storage facilities and the addition of ueeded new storage capacity at the site of each civilian nuclear power reactor; and

(3) the Federal Government has the responsibility to provide, in accordance with the provisions of this subtitle, not joote than 1,900 metric tons of capacity for interim storage of spent muclear fuel for civilian nuclear power reactors that cannot reasonably provicie adequate storage capacity at the sites of such reactors when reeded to assure the contimued, orderly operation of such reactors.

(b) Purposes.-The purposes of this subtitle ate-

(1) to provide for the utilization of available spent nuclear fuel poods at the site of each civilian suckear power reactor to the extent practical and the addition of new spent nuclear fuel storage capacity where practical at the site of such reactors, and

(2) to provide, in accordance with the provisions of this subtitle, for the establishment of a federally owned apd operated system for the interim storage of spent tuclear fuel at one or more facilities owned by the Federal Government with not more than 1,900 metric tons of eapacity to prevent disruptions in the onderty aperation of any civilian niclear power reactor that cannot reasonably provide adeqtuate spent muciear fuel storage capacity at the site of such reactor when needed.

42 USC 10152.

AVAILABLS CAPACTTY FOR INTERIM STORAGE OF SPENT NUCLEAR KUEL

Sec. 132. The Secretary, the Commission, and other anthorized Federal officials shall each take such actions as such official considers necessary to enconrage and expedite the effective use of available storage and necessary additional storage, at the site of each civilian nucleas power reactor consistent wittr-

(1) the protection of the public health and saftry, and the environment;

(2) econonic considerations; 
(3) continued operation of stels xeactor;

(4) any applicable provisions of law; and

(5) the views of the poptlation surroundine such reactor.

\section{IMTERM AT RSACTDR STORAGE}

Licensing procedures. 42 USC 10153.

42 USC 10154

Summary submittal of facts, data and arguments.

Sec. 133. The Commission shall, by rule, establish procedures for the lisensing of any techinology approved by the Commission under section 219 (a) for use at the site of any civilian nuclear power reactor. The estabishment of such procedures shall not preclude the licensing, under any applicable procedures or rules of the Commission in effect prior to such establishonents, of any technology for the storage of civilian spent nuclear fuel at the site of any civilian nuclear potwer reactor.

\section{LICERSING OF FACILITY EXPANSIONS AND TRANSSHIPMENTS}

Sec. 134. (a) Oral Asgunent.-In any Commission hearing under section 189 of the Atomic Energy Act of 1954 (42 U.S.C 2239) on an application for a license, or for an amendment to an existing license, filed after the date of the enactunent of this Act, to expand the spent nuclear fuel storage capacity at the site of a civilian nuclear power teactor, through the use of high-density fuel storage racks, fuel rod compaction, the transshipment of spent nuclear fuel to another civilian nuclear pow. et reactor within the same utility system, the construction of additional spent nuclear fuel pool capacity or dry storage capacity, or by other means, the Commission shall, at the request of any party, provide an opportunity for oral argument with respect to any matter which the Commission determines to be in controversy among the parties. The oral arguments shall preceded by such discovery procedures as the rules of the Commission shall provide. The Commission shall requite each party, including the Conmission staff, to subrnit in written form, at the time of the oral arguntent, a summary of the facts, data, and arguments upon which such party proposes to rely that are known at such time to such party. Orly facts and data in the form of sworn testinony or written submiscion may be relied upon by the parties during oral arguments. Of the material that may be submitted by the parties during oral arguments, the Commission shall only consider those facts and data that are submitted in the form of sworn testimony or written submission.

(b) Adjudicatory Hearing-(I) At the conclusion of ary oral argument under subsection (a), the Commission shall designate any disputed questions of fact, rogether with any remaining questrons of law, for resolution in an adjudicatory hearing only if it determines that-

(A) there is a genuine and stibstantial dispute of fact which can only be resolved with sufficient accuracy by the introduction of evidence in an adjudjcatory hearing; and

(B) the decision of the Commission is likely to depend in whole or in part on the resolution of stech dispute.

(2) In making a determination under this subsection, the Commission-

(A) shall designate in writing the specific facts that are in genuine and substantial dispute, the reason why the decision of the agency is likely to depend on the resolution of such facts,

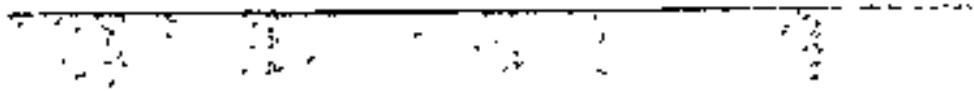


and the reason why an adjudicatory hearing is likely to resolve the' dispute; and

(B) shall not consider--

(i) any issue relating to the design, construction, or operation of any civilian nuclear power reactor already licensed to operate at such site; or any civilian muclear power reactor for which a constnuction permis has been 'gitanted at such site, uniless the Commission determines that any such issus substantially affects the design, construction, or operation of the facility or activity for which such license application, authorization, or amendment is being considered; or

(ii) any siting or design issue fully considered and decided by the Commission in connection with the isstrance of a construction permit or operating license for a civilian nuclès porker reactor at such site, ayless (I) such issite results from any revision of sting or design csiteria by the Corsuission following such decision; and (II) the Com. mission determines that such issue substantially affects the design, construction, or operation of the facility or activity for which such license application, authorization, or antendment is being considered.

(3) The provisions of paragraph (2)(B) shall apply only with respect to licenses, atthorizations, or amendments to licenses or allthorizations, applied for under the Atorric Energy Act of 1954 (42 U.S.C. 2011 et seq.) betore December 31, 2005.

(4) The provisions of this section shall not apply to the fitst apptication for a license or license amentment received by the Com. mission to expand onsite spent futl storage capacity by the use of a new technology not previouisly approved for use at any nuctear power plant by the Commission.

(c) Judicial Reviow.--No court shall hold unlawtul or set aside a decision of the Commission in any proceeding described in subsection (a) because of a failure by the Commission to use a particular procedure pursuant to this section unless-

(1) an objection to the procedure used was presented to the Commission in a timely fashion or there are extsaordinary circumstances that excuse the faihure to present a timely objection; and

(2) the court finds that such fatlure has precluded a fair consideration andinformed resolution of a significant issue of the proceeding taken as a whole.

\section{STORAGE OS SHENT NUCUEAR FUSL}

42 USC 10255. Sec. 135 (a) Storage Capacity.--11) Subject to section 8, the Secretary Ante, p. 2205. shall provide; in accordance with paragraph (5), not more than 1,900 metric tons of capacity for the storage of spent nuclear fuel from civilian nuclear power reactors. Such storage capacity shall be provided through any one or more of the following methods, used in any combination determined by the Secretary to be appropriate:

(A) use of available capacity at one or more facilities owned - by the Federal Government on the date of the enactment of 
this Act, including the modification and expansion of any such facilities, if the Commission determines that such use will adequately protect the public health and safety, except that such use shall not-

(i) render such facilities subject to licensing under the Atomic Energy Act of 1954 (42 U.S.C. 2011 et seg.) or the Energy Reorganization Act of 1974 (42 U.S.C. 5801 et. seq.); or

(ii) except as prowided in subsection (c) require the preparation of as environmental impact statement under section 102(2)(C) of the National Euvironmental Policy Act of 1969 (42U.S.C. 4332(2)(C)), such facility is already being used, or has previously been used, for such storage or for any similar purpose.

(B) acquisition of any trodular or mobile spent muclear fued storage equipment, including spent nuclear fuel storage casks, and provision of such equipment, to any person generating or holdfong title to spent nuclear fuel, at the site of any civilfan nuclear power reactor operated by such person or at ary site owned by the Federal Government on the date of enactment of this Act;

(C) construction of storage capacisy at any site of a civillan nuclear power reactor.

(2) Storage capacity authorzed by paragraph (I) shall not be provided at any Federal or non-Federal site within which there is a candidate site for a repository. The restriction in the preceding sentence shall only apply until stich time as the Secretary decides that such candidate site ts no longer a candidate site under consid. eration for development as a repository.

(3) In selecting methods of providing storage capacity under partagraph (I), the Sectetary shall consider the timeliness of the availability of each stch method and shall seek to minimize the transportation of spent nuclear fuel, the public health and safety impacts, and the costs of proviting such storage capacity.

(4) In providing storage capacity through any method described in paragraph (1), the Secretary sha!l comply with any applicable requitements for licensing or authorization of such method, except as provided in paragraph (1) (A) (i).

(5) The Sectetary shall ensure that storage capacity is made avalable under paragraph (1) when needed, as determitned on the basis of the storage needs specified in coptracts entered jnto under section 136(a), and shall accept upon request any spent muclear fuel as covered under such coniracts.

(6) For purposes of paragraph (I) (A), the term "facility" means any building of structure.

(b) Contracts.-(1) Subject to the capacity limitation established in subsections (a) (1) and (d), the Secretary shall offer to enter into, and may enter into contracts under section 136(a) with any person generating or owidig spent medear fuel for pujposes of providing storage ca- 
Public availabitity. pacity for such spent fuel under this section only if the Commnission determines that-

k (A) adequate storage capacity to ensure the continued orderly operation of the vivilian muclear power reactor at which sarch spent nutear fuel is generated carnot reasonably be provided by the person owning and operating streb reactor at stxch site, or at the site, of any other civilian nadear power reactor operated by such person, and such capacity cannot be made available in a timely manner through any method described in subparagraph (B); and

(B) such person is diligently pursting licensed alternatives to the use of Federal storage capacity for the storage of spent nutclear fuel expected to be iefserated by such person in the future, including-

, (i) expansion of storage factities at the site of ariy civil- ian nuclear power reactor operated by such person;

(ii) construction of new or additionat storage facilities at the site of any civilian nuclear power reactor operated by such person;

(iii) acquisition of modular of mobile spent nuclear fuel storage equipment, including spent muclear fuel storage casks, for use at the site of any civilian nuclear power reactor operated by such person; and

(iv) transshipment to another covilian nuclear power reactor owned by such person.

(2) In making the determination described in paragraph (1) (A), the Commission shall ensure maintenance of a full corte reserve storage apability at the site of the civilian nuckear power reactor sovolved unless the Commuision determines that maintenance of such capability is not necessary for the continued ordery operation of such reactor.

(3) The Commission shall complete the determinations required in paragraph' (1) with respect to any request for storage capacity not later thar 6 months after receipt of such requtest by the Commission.

(c) Envifonmental Review.-(1) The provision of 300 or more metric tons of storage capacity at ang one Federal site under subsection (a)(1)(A) shall be considered to be a major Federal action requiring preparation of an environmental impact statement under section 102(2)(C) of the National Envirommental Policy Act of 1969 (42 U.S.C. $4332(2)(C))$.

(2) (A) The Secretary shall prepare, and make available to the public, an envizonmental assessment of the probable impacts of any provision of less than 300 metric tons of storage capacity at any one Federal site under subsection (a)(1)(A) that requires the modification or expansion of any facility at the site, and a disctussion of alcernative activities that may be undertaken to awojd such impacts. Such environmental assessment shall include-

(i) an estinate of the amount of storage capacity to be made available at such site; 
Judicial review.

5 USC $70 \mathrm{t}$ et, seg.

Investigation, (ii) an evaluation as to whether the facilities to be used at such sits are suitable for the provision of such storage capacity;

(iii) a description of activities planned by the Secretary with respect to the modification or expansion of the faciltties to be used at stich site;

(iv) an evaluation of the effects of the provision of such storage capacity at such site on the public health and safety, and the environment;

(v) a reasonable comparative evaluation of current infortation with respect to such site and facilities and other sites and facilities avallable for the provision of such stor* age capacity;

(vi) a description of any other sites and factlities that have been considered by the Secretary for the provision of such storage capacity; and

(vii) an assessment of the regional and local impacts of providing such storage capacity at such site, including the impaces on transportation.

(B) The isssuance of any environmental assessment under thìs paragraph shall be considered to be final agency action subject to juxticial review in accordanxe with the provisions of chapter 7 of title 5, United Stat ited to the sufficiency of such assessment with respect to the items described in clauses (i) through (vii) of subparagraph (A).

(3) Judicial revitur of any engironmental inpact statement or environmental assessment prepared pursuant to this subsection shall be conducted in accordance with the provisions of section 119.

(d) Review Of Sites And State Participation.-(1) In carrying out the provisions of this subtitle with regard to any interim storage of spent fuel from civilian muclear power reactors which the Secretary is authorized by section 135 to provide, the Secretary shall, as soon as practicable, notify, in writing, flut Governor and the \$tate legislathere of any State and the Tribal Council of any affected Indian tribe in such State in which is located a potentially acceptable site or facility for such interin storage of spent fuel of his intention to investigate that site or factlity.

(2) During the coturse of imvestigation of such site or facility, the Secretary shall keep the Gowomor, State legislature, and affected Tribal Council currently informed of tho progress of the work, and results of the investigation. At the time of selection by the Secretary of any site or existing facility, but prior to undertaking any site-specific work or alterations, the Secretary sball promptly notify the Governor, the legislature, and any affected Tribal Council in writing of such selection and subject to the provisions of paragraph (6) of this subsection, sball prompty enter jito negotiations with such State and affected Tribai Council to establish a cooperative agreement under which such State and Councal shatl bave the right to participate in a process of consultation and cooperation, based on public health and safety and environmental concenn, in 
Guideliues.

Cooperative agreement.

"Process of consulation and cooperation."

Report to Congress. all stages of the plauring, developrent, modification, expansion, operation, and closure of storage capacity at a site or facility within such State for the intertin storage of spent fuel from civijan nuclear power reactors. Public participation in the negotiation of stich an agreement shall be provided for and encouraged by the Secretary, the State, and the affected Tribal Council. The Secretary, in cooperation with the State and Indian tribes, shall dewejop and publish minimum guidelines for public participation in suct negotiations, but the adequacy of such gaidelints or any faiture to comply with such guidelines shat not be a basts for judicial review,

(3) The cooperative agreement shall include, but need not be limited to, the sharing in accordance with applicable law of all technical and licensing fnfortmation, the utilization of available $\mathrm{ex}$ pertise, the facilitading of permitting procedures, joint project review, and the formulation of jost surveillance and montoring ar. rangements to carry out applicable Federal and State laws. The copperative agreement also shall jnclude a detailsd plan or schedule of milestones, decision points and opportunities for State or eligible Tribal Conancil review and objection. Such cooperative agreement shall provide procecitires for megotiatimg and resolving objections of the State and affected Tribal Councti in any stage of planning, developnent, modification, expansion, operation, or closure of storage capacity at a site or facility within such State. The terms of any cooperative agrement shall not affect the authority of the Nuclear Regulatory Conmtisston under existing law.

(4) For the purpose of this subsection, "process of consultation and cooperation" means a methodology by which the Secretary (A) keeps the Statte and eligible Fribal Counct fully and cunentiy fuformed about the asperts of the project related to any potential jupact on the public health and stety and emvironingnt; (B) solicits, Ieceives, and evaluates concerms and objections of such State and Council with rogard to such aspects of the project on an ongoing basts; and (C) works diligently and cooperatively to resolve, through arbitration or other-appropriate mechanisms, such concerns and objections. The process of consultation and cooperation shall not includt the grant of a right to any State or Tribal Council to exercise an absolute veto of any aspect of the planning, development, modification, expansion, or operation of the project.

(5) The Secretary and the State and affected Tribal Councl shali seek to conclude the agreement required by paragraph (2) as soon as practicable, but not later than 180 days following the date of notification of the selection under paragraph (2). The Secretary shall periodically report to the Congress thereafter on the status of the agreements approved under paragraph (3). Ary report to the Congress on the status of negotiations of such agreement by the Secretary shall be accompanied by comments solicited by the Secretary from the State and eligible Tribal Council.

(6) (A) Upon'deciding to provide an aggregate of 300 or more metric tons of storage capacity under subsection (a)(1) at any one site, the Secretary shall potify the Gowernor and legislature of the 
State where such site is located, ox the governing body of the Indian tribe in whose reservation such site is located, as the case may be, of such decision. During the 60-dky period following reseipt of notification by the Secretary of his decision to provide an aggregate of 300 or more metric tons of storage capacity at any one site, the Governor or legislature of the State in which stuch site is located, or the governing body of the affected Indian tribe where such site is located, as the case may be, may disapprowe the provision

1 Notice of disapproval, subroittal to Congress.

Alis, p. 2217, "Resolution." of 300 or more metric tons of storage capacity at the site involved and submit to the Congress a notice of sucti disapproval. A notice of disapproval shall be considered to be submitted to the Congress on the date of the transmittal of such notice of disapproval to the Speaker of the House and

(B) Unless otherwise provided by State law, the Govenor or legistature of each State shall have authortly to submit a notice of disapproval to the Congress under stbparagraph (A). In any case tn which State law provides for subenission of any such notice of disapproval by any otier person or entity, any reference in this subtitle to the Governor or legislature of such State shall be considered to refer instead to such other person or entity.

(C) The authority of the Gowemor and legislature of each State under this paragraph shall not be applicable with respect to any site located on a reservation.

(D) If any notice of disapproval is submitted to the Congress under subparagraph (A), the proposed provision of 300 or more metric tons of storage capacity at the site intolved shal] be disapproved unless, during the first period of 90 calendar days of continuous session of the Congress following the date of the receipt by the Congress of such notice of distapprotal, the Congress passes a resolution approving such proposed provision of storage capacity in accordance with the procedures established in this paragraph and subsections (d) through (f) of section 115 and such resolution thereafter becomes law. For purposes of this paragraph, the term "resolution" means a joint resolution of either House of the Congress, the matter after the resolving ctause of which is as follows:." That there hereby is approved the provision of $\mathbf{3 0 0}$ or more metric tons of spent nuclear fuel storage capacity at the site located at with respect to which a notice of disapproval was submitted by on. The first blank space in such resolution shall be filled with the geographic location of the site involved; the second blank space in such resolution shall be filled with the designation of the State Governor and legislature or affected Indlian tribe governing body submitting the notice of disapproval involved; and the last blank space in such resolution shall be filled with the date of submission of such natice of disapproval. 
"Affected Tribal Coumdl."

5 USC 533
(E) For purposes of the constideration of apy resolution described in stubparagraph (D), each reference in subsections (d) and (e) of section 115 to a resolution of repository siting approval stali be considered to refer to the resolution described in such subparagrapth.

(7) As used in this section, the term "affected Ttibal Council" means the governing body of any Indian tribe within whose reservation boundaries there is located a potentially acceptable site for interim storage capacity of spent nuclear fuel fron civilian nuclear power reactors, or within whose boundaries a site for such capacity is selected by the Secretary, or whose federally defined possessory or usage rights to other lands outside of the reservation's boundaries arising out of congressionally ratified treaties, as determined by the Secretary of the Interior pursuant to a petition filed with him by the appropriate governmental officials of such tribe, may be substantially and adversely affected by the establishment of any such storage capacity.

(e) Limitations.-Any spent nuclear fuet stored under this section shalt be remowed from the storage site or facility involved as soon as practicable, butin any event not later than 3 years following the date on which a repository or monitored retrievable storage facility developed under this Act is arailabile for disposal of such spent nuclear fuel.

(f) Report-The Secretary shall annualiy prepare and submit to the Congress a report on any plans of the \$ecretary for providing storage capacity under this section. Such report shall include a description of the specific manner of providing such storage selected by the Secretary, if any. The Secretary shall prepare and submit the first such report not later than' 1 year after the date of the enactment of this Act.

(g) Criteria For Determining Adequacy Of Available Storsge Capacity.- Not later than 90 days after the date of the enactment of this Act, the Commisston purstant to section $\mathbf{5 5 3}$ of the Administrative Procedures Act, shall proprase, by rule, procedures and criteria for making the determination required by subsection (b) that a person owning and oporating a civilian guclear power reactor cannot reasonably provide adequate spent nucleas fiel storage capacity at the civiljan nuclear power reactor site when needed to ensure the continued orderly operation of such reactor. Such criteria shall ensure the maintenance of a full core reserve storage capability at the site of such reactor unless the Commission determines that maintenance of such capability is not necessary for the continued orderly operation of such reactor. Such criteria shall jdentify the feasibjiity of reasonably providing such adequate spent nuclear fucl storage capacity, taking into actount economic, technical, regulatory, and public bealth and safety factors, through the use of high-density fuel storage racks, fuel rod compaction, transshípment of spent auciear fiel to another civilian nuclear powser reactor within the same utility system, construction of additional spent nuclear fuel pool capacity, or such other technologies as may be approved by the Commisstion.

(h) Application-Notwithstanding any other proviston of law, nothing in this Act shall beconstrited to encourage, autborize, or require the 
private or Federal use, purchase, lease, or other acquisition of any storage facility located away from the site of any civilian nuclear power reactor and not owned by the Federal Government on the date of the - entactment of this Act.

(i) Coordination with Research and Development Program,-To the extent available, and consistent with the provisions of this section, the Secretary shal] provide spent nuclear fuel for the research and development program authorized in section 217 from spent nuclear fuel received by the Secretary for storage under this section. Such spent nuclear fuel shall not be subject to the provisions of subsection (e).

A2USC 10156.

\section{INTERIM STORAGE FUNE}

Sec. 136. (a) Contracts.-(1) During the period following the date of the ensctment of this Act, but not later than January 1, 1990, the Secre. tary is authorized to enter into contracts with persons who generate or own spent nuclear fuel resuleing from civilian nuclear activitites for the storage of such spent juclear fuel in any storage capacity provided under this subtitle: Provided, however, That the Secretary shall not enter into contracts for spent nuclear fuel in amounts in excess of the avaj]able storage capacity specinied in section 133(a)- Those contracts shall provide that the Federal Government will (1) take title at the civitian naclear power reactor site, to such amounts of spent nuclear fuel from the civitian nuclear power reactor as the Commission determines cannot be stored onsite, (2) transport the spent muclear fuel to a federally owned and operated interim away-from-reactor storage facility, and (3) store such fuel in the facility pending further processing, storage, or cisposal. Each such contract shall (A) provide for payment to the Secretary of fees determined in accordance with the provisions of this section; and (B) specify the amount of storage capacity to be provided for the person involved.

Shuty, seport to Congress.

Publication in Federal Register.
(2) The Secretary shail untertake a study and, not later than 180 days after the date of the enactment of this Act, submit to the Congress a report, establishing payment charges that shall be calculated on an annual basis, commencing on or before January 1 , 1984. Such payment charges and the calculation thereof stall be published in the Federal Register, and shalt become effective not less than 30 days after publication. Each payment charge published in the Federal Register under this paragraph shell remain effective for a period of 12 months from the effective date as the charge for the cost of the interim storage of any spent nuclear fuel. The report of the Secretary stall specify the method and manner of collection (including the rates and manner of payment) and any legislative recommendations determined by the Secretary to be appropriate.

(3) Fees for storage under this subtitle shall be estabilshed on a nondiscriminatory basis. The fees to be paid by each person entering into a contract with the Secretary under this subsection shall be besed upon an estimate of the pro rata costs of storage and related activities under this subtitle with respect to such person, induding the acquisition, construction, operation, and majntenance of any' facilities under this subtitle. 
(4) The Secretary shall establish in writing criteria sett苗 forth the terms and conditions under which such storage services shall be made available.

(5) Except as provided in section 137, nothing in this of any other Act requiles the Secretary, in carrying out the responsibilities of this section, to obtain a license or permit to possess or own spent nuclear fuel.

(b) Limitation--No spent nuclear fuel generated or onned by any department of the United States referted to in section 101 or 102 of title 5 , United States Code, may be stored by the Secretary in any storage capacity provided under this subtitle unless such department transfers to the Secretary, for deposit in the Interim Storage Fund, amounts equivalent to the feees that would be paid to the Secretary under the contracts referred to in this section if such spent nuclear fuel were generated by any other person.

(c) Establishment of Interim Storage Fund,-There hereby is established, in the Treasury of the United States a separate fund, to be know as the Interim Storage Fund. The Storage Fund shall consist of-

(1) all receipts, proceeds, and, recoveries realized by the Secretarry under subsections (a), (b), and (e), which shall be deposited in the Storage Fund immediately upon their realization;

(2) any appropriations made by the Congress to the Storage Fiund; and

(3) any unexpented balances available on the date of the enactment of this Act for functions or activitites necessary or incident to the intering storage of civilian spent nuclear fuet, which shall automatically be transferred to the Storage Fund on such date.

(d) Use of Storage Fund.-The Secretary may riake expenditures from the Storage Fund, subject to subsection (e), for any purpose necessary or appropriate to the conduct of the functions and activities of the Secretary, or the provision or anticipated provision of services, under this subtitle, including -

(1) the identification, development, licensing, construction, operation, decommissioning, and post-decommissioning maintenance and monitoring of any interim storage facility provided under this stibtitle;

(2) the administrative cost of the titeritu storage program;

(3) the costs associated with acquisition, design, modification, reptacement, operation, and construction of facilities at an interin storage site, consistent with the restrictions in section 135;

(4) the cost of transportation of spent nuclear fuel; and

(5), ingact assistance as described tin.subsection (e).

Payments. (c) Impact Assistance.-(1) Begiauing the first fiscal year which commences after the date of the enactment of this Act, the Secretary shall make annual,impact assistance payments to a State or appropriate unit oflocal government, or both, jn order to suitigate social or economic inpacts occasioned by the establishruent and subsecpuent operation of any interim storage capacity within the jurisdictional boundaries of such goverument or govermments and authorized under this subtitle: Provided, however, That such impact assistance payments shall not exceed 
(A) ten percentum of the costs incoured in paragraples (1) and (2), of (B) $\$ 15$ per kilogram of spent fuel, whichever is less:

(2) Payments made available to States and units of local government pursuant to this section stall be-

(A) allocated in a fair and equitable manter with a priority to thase States or unts of local government suffering the most severe impacts; and

(B) utilized by States or units of local governments only for (i) planning, (ii) construction and maintenance of publicservices, (jii) provision of publicservices related to the providing of stach interim storage authorized under this bitle, and (iv) compensation for loss of taxable properizy equivalept to that if the storage had been provided under private ofnership.

Regulations.

"Untt of local goverturnent."

Roport to Congress.

Budget submittal.

Ante, p. 907.

(3) Such payments shail be subject to such terms and conditions as the Secretary determines necessary to ensure that the purposes of this subsection shall be achieved. The Secretary shall issue such regulations as may be necessary to carry out the provisions of this subsection.

(4) Payments under this subsection shall bo made avatlable solely from the fees determined under subsection (a).

(5) The Secretary is authorized to consult with States and appropriate units of local government in advance of commencement of establishment of storage capacity authortzed under this subtìtle in an effort to determine the level of the payment such government would be eligible to receive pursuant to this subsection.

(6) As used in this subsection, the term "unit of Jocal government" means a county, parish, township, municipaity, and shall jolude a borongh existing in the State of Alaska on the date of the enactment of this subsection, and any other unit of government below the State lowel which is a unit of general govemment as de. temined by the Secretary.

(f) Administration of Storage Fund-(1) The Secretary of the Treasury shall hold the Storage Fund and, after consultation with the Secretary, arnually report to the Congess on the financial condition and operations of the Storage Fund during the precoding fiscal year.

(2) The Secretary shalt subuit the butget of the Storage Fund to the Office of Management and Budget triennially along with the budget of the Department of Energy submitted at such time in accordance with chapter 11 of title 31. United States Code. The budget of the Storage Fund shall consist of testimates made by the Secretary of expenditures from the Storage Fund and other relevant financial matters for the sikceeding 3 fiscal years, and shall be included in the Budget of the United States Govemureit. The Secretary may make expenditures from the Stotage Find, subject to appropriations which shall remain available until expended Appropriations sball be subject to trienoial authorization.

(3) If the Secretary determines that the Storage Fund contains at any time anounts in excess of current needs, the Secretary may reguest the Secretary of the Treasury to invest such amounts, or any

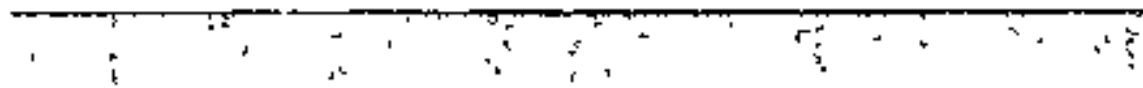


portion of such amounts as the Secretary detemines to be appropriate, in obligations of the United States-

(A) having maturities determined by the Secretary of the Treasury to be appropriate to the neecis of the Storage Fund; and

(B) bearing interest at rates determined to be appropriate by the Secretary of the Treasury, taking into consideration the current average market yjekd on outstanding marketable obligations of the United States with remaining periods to miturity comparable to the maturities of such javestments, except that the interest rate on such investments shall not exceed the ayerage toterest rate applicable to existing boirowings.

Ante, p. 927.

(4) Receipts, proceeds, and recoveries realized by the Secretary under this section, and expenditures of anounts from the Storage Fund, shall be exempt from anpual apportionment under the provisions of subchapter 11 of chapter 15 of title 31, United States Code.

(5) If at any time the moneys ayailable in the Storage Fund are insuffictent to enable the Sectetary to discharge his responsibilities, under this subtitle, the Secretary shall issue to the Secretary of the Treasury obligations in such forms and denominations, bearing such maturities, and subject to such terms and conditions as may be agreed to by the Secretary and the Secretary of the Treasury. The tokal of such obligations shall not exceed anounts provided in appropriation Acts. Redemption of such obligations shall be inade oy the Secretary from moneys available in the Storage Fund. Such obligations shali bear interest at a rate determined by the Secretary of the Treasirry, which shall be not less than a rate determined by taking into consideration the average market yield on outstanding marketable obligations of the United States of comparable maturities during the month preceding the issuance of the obligations under this paragraph. The Secretary of the Trea-sury shall purchase any issued obligations, and for such purpose the Secretary of the Treasury is authorized to use as a public debt transaction the proceeds from the sale of any securtities issued under

Anite, p. 927.

1. chapter 31 of title 31, United States Codte, and the purposes for which securities may be issued under such Act are extended to include any purchase of stict obligations. The Secretary of the Treasury rray at any tane sen any of the obligations acquired by hím under this paragraph. All redemptions, purchases, and sales by the Secretary of the Treasury of obligations under this paragraph shall be treated as public debt trassactions of the United States.

Interest payments.

(6) Any appropriations made available to the Storage Fund for any purpose described in subsection (d) shall be repaid into the general fund of the Treasury, together with interest from the date of availability of the appropriations until the date of repayment. Such interest shall be paid on the cumulative amount of appropriations available to the Storage Fund, less the average undisbursed cash balance in the Storage Fund account ouring the fiscal year involved. The rate of such interest shall be detergined by the Secre- 
Deferral.

42 USC 10157

42 USC 10161 tary of the Treasury taking into consideration the average market yield during the month preceding each fiscal year on outstanding marketable obligations of the United States of comparable mantrity. Interest payments may be deferred with the approval of the Secretary of the Treasury, but any interest payuents so deferred shall themselves bear interest.

Sec. 137. (a) Transportatioth-(1) Transportation of spent puclear fuel under section 136 (a) shall be subject to licensing and regulation by the Commission and by the Secretary of Ttansportation as provided for transportation of commercial spent nuclear fuel under existing law.

(2) The Secretary, in providing for the transportation of spent nuclear fuel under this Act, shall utilize by contract private industry to the fullest extent possible in each aspect of such transportation. The Secretary shall use direct Fecieral services for such transportation only upon a determination of the Secretary of Transportation, in consultation with the Secretary, that private industry is anable or uruilling to provide such transportation sertvices at reasonable cost.

\section{SUBTITLE C-MONTTORED RETRIEVABLE STORAGE}

\section{MONITOAED RETFUEVABLE STORAGE}

Sec. 141. (a) Findings-The Congress finds that-

(1) long-term storage of high-level radioactive waste or spent nuclear fuel in monitored retrievable storage facilities is an option for providing safe and reliable management of such waste or spent futej;

(2) the executive branch and the Congress should proceed as expeditjously as possib]e to consider fully a proposal for construction of one or more monitored retrievable storage facilities to provide such long-terite storage;

(3) the Federal Gowernment has the responsibility to ensure that site-specific designs for such facilities are available as prowided in this section;

(4) the generators and owners of the high-level radioactive waste and spent nuclear fuel to be stored in such facilities have the responsibility to pay the costs of the long-term storage of such waste and spent fuel; and

(5) disposal of high-level radioactive waste and spent nuclear fuel in a repository developed under this Act should proceed regardless of any construction of a monitored retrievable storage facility pursuant to this section.

(b) Subnuission of Proposal by Secretary. - (1) On or before June 1, 1985, the Secretary shal] complete a detailed study of the need for and feasibility of, and shall submit to the Congress a proposal for, the constniction of one or more monitored retrievable storage facilities for high-level radioactive waste axd spent nuclear fucl. Each such facility shall be designed-

(A) to accommodate spent muclear fuel and high-level radioactive waste restulting from civilian nuclear activities; 
Euvironmental assessment.
(B) to permit continuous monitoring, masagement, and maintenance of such spent fuel and waste for the foresecable future;

(C) to provide for the ready retrieval of such spent fuel and waste for further processing or disposal; and

(D) to safely store stch spent fuel and waste as long as may be necessary by mäintatning suct facility through appropjiate means, including any required replacenent of such facilty.

(2) Such proposal shall include-

(A) the establishment of a Federal program for the siting, developugent, construction, and operation of facilities capable of safely storing hitgh-level radioactive waste and spent nuclear fuel, which facilities are to be licensed by the Commission;

(B) a plan for the funding of the construction and operation of such facilities, which plan shall protide that the costs of such activities shall be borne by the generators and owners of the high-level radioactive waste and spent nuclear fuel to be stored in such facilities;

(C) site-specific designs, specifications, and cost estimates sufficient to (t) solicit bids for the construction of the first suct facility, (ii) support congressional authorization of the construction of such facility; and (iii) enable completion and operation of such lacility as soon as practicable following con. eressionat authorization of such facilty; and

(D) a plan for integrating facilities constructed pursuant to this section with other storase and disposal facilities authorized in this Act.

(3) In formulating such propossl, the Secretary shall consult with the Commission and the Administrator, and shall submit their comments on such proposal to the Congress at tie time such proposal is submitted.

(4) The propostal shall include, for the first such facility, at least 3 altertiative sites and at least 5 alternative combinations of stuch proposed sites and facility designs consistent with the criteria of paragraph (b) (1). The Secretary shall recommend the combina* tion anong the aiternatives that the Secretary deems preferable. The environmental assessinent under subsection (c) strall include a fill] analysis of the relative advantages and disadvantages of all 5 such alternative combinations of proposed sites and proposed fa. cility designs.

(c) Environmental Impact Statements.- (1) Preparation and subotission to the Congress of the proposal required in this section shall not require the preparation of an environmental impact staterient under section 102 (2) (C) of the National Exviromenental Policy Act of 1969 (42 U.S.C 4332(2)(C)). The Secretary shall prepare, in accordance with regulations issted by the Secretary implementing such Act, an environmental assessment with respect to such proposal. Such ervironmental assessinent shall be based upon available information regarding 
Subenittal to Congress.

\section{Pryments.}

Regulations.

Consultations. alternative technologies for the storage of spent nuclear fuel and highjevel radicactive waste. The Secretary shall submit such envirommentak assessment to the Congress at the time such proposal is submitted.

(2) If the Congress by law, after review of the proposal submitted by the Secretary under sabsection (b), specifically' authorizes construction of a momitored retrievable storage facility, the requirements of the National Environsuental Policy Act of 1969 (42 U.S.C. 4321 et seq.) shall apply with respect to construction of such facility, except that any environmental impact statement prepared with respect to such facility shal] not be required to consider the need for such facility or any alternative to the design criteria for such facility set forth in subsection (b) (1).

(d) Licensing.-Any facility authorized pursuant to this section shall be subject to licensing under section 202(3)) of the Energy Reorganization Act of 1974 (42, U.S.C. 5842(3). In reviewing the application filed by the Secretary for licensing of the irrst such facility, the Commission may nat consider the need for such facility or any atternative to the design criteria for such facility set forth in subsection (b) (1).

(e) Clarification. Nothing in this section limits the comsideration of alternative facility designs consistent with the criteria of paragraph (b) (1) in any environmental jmpact statement, or in any licensing procedure of the Commission, with respect to any monitored, retrituable facility authorized pursuant to this section.

(f) Impact Assistance-- (1) Upon receipt by the Secretary of congressional authorization to construct a facility described in subsection (b), the Secretary shall commence making annual impact aid payments to appropriate units of general local goversment in order to migrate any social or economic impacts resulting from the construction and subsequent operation of any such facility within the jurisdictional boundaries of any such unit.

(2) payments made avijlable to units of general lacal government under this subsection shail be-

(A) allocated in a fair and equitabie manser, with prionty given to units of general local government determined by the Secretary to be most severely affected; and

(B) utilized by units of general local government only for planning, construction, malntenance, and provision of public services related to the siting of such facility.

(3) Such paymonts shall be subject to stch terms and conditions as the Secretary determines are necessary to ensure achievernent of the purposes of this subsection. The Secretary shall issue such regulations as may be necessary to camy out the provisions of this subsection.

(4) Such payments shall be mads available entirely from funds held in the Nuclear Waste Fund established in section 302 (c) and shall be available only to the extent provided in advanoe in appropriation Acts.

(5) The Secretary may consult with appropriate units of general local government in advance of commencement of construction of 
Antes, p. 2208.

Usc 10162.

USC 10163.

Reports. any stuch facitity in an effort to determine the level of payments eaci such unit is eligible to receive under this subsection.

(g) Limitation.-No monitored retrievable storage facility development pursuant to this section may be construeted in any State is which there is located any site approved for site characterization under section 112. The iestriction in the preceding sentence stall only apply until such time as the Secretary dectides that such candidate site is no longer a can. didate site under consideration for develeprnent as a repository. Such restriction shall continue to apply to any site selected for construction as a repositoty.

(a) Participation of States and Indian Tribes-Any facility authorized pursuant to this section shall be subject to the provisions of sections 115, 116 (a), 116 (b), 116 (o), 117, and 118. For purposes of earrying out the provisions of this sibsection, any reference to sections 115 through 118 to a repository shall be considered to refer to a monitored retrievable storage facility.

\section{AUTHORIZATTON OF MONTTORED RETRIEVABLE STORAGE}

Sec. 142. (a) Nulinication of Oak Ridge Sitting Proposal.-The proposal the Secretary (EC-1022, 100th Congress) to locate a monitored retrievable storage facility at a site on the Clinch River in the Roane County portion of Oak Ridge, Terressee, with alternative sites on the Oak Ridge Resetvation of the Department of Enercy and on the former site of a proposed nuclear powserplant in Hartsville, Tennessee, is annulled and revoked. In carrying out the provissions of sections 144 and 145, the Secretary shall make no prestimption or preference to such sites by reason of their provious selection.

(b) Allthorization,-The Sectetary is authorized to site, construct, and operate one monitored retrievable storabe facility subject to the condítions described in sections 149 through 149.

$$
\text { MONTTOKED KETEIEVABLE STORAGE COMMASSION }
$$

Sec. 143. (a) Establishment.-(1) (A) There is established a Monttored Retrievable Storage Review Conumission (hereinafter in this section referred to as the 'MRS Comuission', bers who shall be appointed by and serve at the pleasure of the President pro tempore of the Senare and the Speaker of the House of Representatives.

(B) 75 Members of the MRS Commission shall be appointed mot later than 30 days after the date of the enactment of the Nuckear Waste Policy Amendmeats Act of 1987 from among persons who as a result of training, experience and attainments ere exceptionally well qualified to craluate the need for antonitored retrievable storage facility as a part of the Nation's nuclear waste management systeri.

(C) The MRS Commission shall prepare a report on the need for a monitored retrievable storage facility as a patt of a national pucleas waste management system that achjeves the purposes of this Act. In preparing the report under this subparagraph, the MRS Commission shall-

(i) review the status and adequacy of the Secretary's evaluation of the systems advantages and disadvantages 
of bringing such a facility into the national nuclear waste disposal system;

(ii) obtain comment and available data on monitored retrievable storage from affected parties, including States cortaining potentially acceptable sites;

(iii) evaluate the utility of a monitored retrievable storage facility from a technical perspective; and

(iv) nyake a recommendation to Congress as to whether such a facility should be included in the national nuclear waste management system in order to achyieve the purposes of this Act, including meeting needs for packaging and bandling of spent nudear furel, improving the flexibility of the repository development schedute, and providing tomporary storage of spent nuclear fuel acoepted for disposal.

(2) In preparing the report and making its recoramegdation urder paragraph (1) the MRS Commission shall compare stich a facility to the alternative of at-reactor storage of spent nuclear suel prior to disposal of such fuet in a repository under this Act. Such comparison shal take into consideration the impact on-

(A) repository design and construction;

(B) waste packege design, fabrication and standardization;

(C) waste preparation;

(D) waste transportation systems;

(E) the reliability of the national system for the disposal of radioactive waste;

(F) the ability of the Secretary to fulfill contractual commitments of the Department under this Act to accept spent nu* clear fuel for disposal; and

(G) economic factors, including the impact on the costs likely to be imposed on ratepayers of the Nation's electric utilities for temporary at-reactor storage of spent nuclear fuel prior to final disposal in a repository, as well as the costs likely to be imposed on ratepayers of the Nation's electric utilities in build. ing and operating such a facility.

Reports.

(3) The report under this subsection, together with the recommendation of the MRS Commission, shall be trarsmitted to Congress on Novermber $1,19899^{B}$

(4) (A) (i) Each mennber of the MRS Compission shalt te paid at the rate provided for level IIl of the Executive Schedule for each day (including travel time) such member is engaged in the work of tote MRS Commission, and shall receive travel expenses, including per diem in lieu of subsistence in the same manner as is permitted under sections 5702 and 5703 of title 5, United States code.

(ii) The MRS Commission may appoint and fix compensation, not to exceed the rate of basic pay payable for GS-18 of the General Schedule, for such staff as may be pecessary to carry out its functions.

(B) (i) The MRS Commission may hold hearings, stt and act at such times and places, take such testimony and recejve such

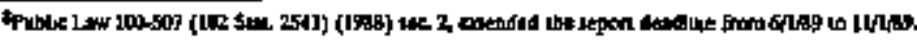


evidence as the MRS Comrnisston considers appropriate. Any member of the MRS Commission may adruinister oaths or affimmations to witnesses appearing before the MRS Commission.

(ii) The MRS Commission may request any Executive agenty, includiag the Department, to furnish such assistance or information, including records, daka, files, or documents, as the Contnission considers necessary to cany out its functions. Unless pohibited by law, such agency shall promptly furmish such assistance or information.

(iii) To the extent permitted by law, the Adjoinistrator of the General Servioes Adeninistration shall, upon re. quest of the MRS Commission, provide the MRS Commission with necessary adininistrative services, facilities, and support on a rejmbarsable basis.

(iv) The MRS Commission may procure temporasy and intermittent services from experts and consilatants to the same extent as is authorized by section 3109 (b) of title 5 , United States Code, at rates and under such rules as the MRS Commission considers reasonable.

(C) The MRS Commision shall cease to exist 60 days after the submission to Congress of the report required under this subsection.

\section{SURVEY}

42 USC 10164. See. 144. After the MRS Conmission stbmits its repart to the Congeess under section 143, the Sectetary may conduct a survey and evaluztion of potentially suitable sites for a monitored retrievable storage facility. In conducting such survey and evaluation, the Secretary shall consider the extent to which siting a nanitored retrievable storage facility at each site surveyed would-

(1) enhance the reliability and flexibility of the system for the disposal of spent nuclear fuel and high-level radioactive wasts established under this Act;

(2) minimize the impacts of transportation and handling of stch fuel and waste;

(3) provide for pablic confidence in the ability of such system to safely dispose of the fuel and waste;

(4) tupose minimal adverse effects on the local community and the local environinent;

(5) prowide a high probability that the facility will meet applicable environmental, health, and safety requirements in a timely fashion;

(6) provide such other benefits to the system for the disposal of spent nuciear fuel and high-level radioactive waste as the Secretary deems appropriate; and

(7) unduly burden a State in whish significant volumes of highleve] radioactive waste resulting from atomic energy defense activ* ities are stored. 
42 USC.10165. Sec. 145. (a) General.-The Secretary may select the site evaluated under section 144 that the Secretary determines on the basis of avaitable information to be the most suitabłe for a monitored retrievable storage facility that is an integral part of the system for the disposal of spent meclear fuel and high-level ractioactive waste established under this Act.

(b) Limttation.-The Secretary may not select a site under subsection (a) until the Secretary recommends to the President the approval of a site for development as a repository under section 114 (a).

(c) Site Specific Activities. -T the Secretary may conduct such site specific activities at each site strveyed under section 144 as he determines may be nesessary to support an apptication to the Commission for a license to construct a monjtored retrievable storage facility at such site.

(d) Envirommental Assessment.-Site spextific activities and sulection of a stre under this section shall not require the preparation of at entironmental impact statement under section 102(2)(C) of the National Environmenta] Policy Act of 1969 (42 U.S. C 4332(2)(C)). The Semetary shall prepare an environmental assessuent with respect to such selection in accordance with regulations issued by the Secretary imple. menting such Axt. Such environumental assessment shall be based upon avatlable information regarding alternative technologies for the storage of spent nuclear futs and high-level radioactive waste. The Secretary shall submit such environmental assessment to the Congress at the time such site is selected.

(c) Notification Before Selection.-(I) At least 6 months before se. lecting a site under subsection (a), the Secretary shall notify the Governor and legislature of the State in which such site is located, or the gov. erning body of the affected Indian tribe where such site is located, as the case may be, of such potential selection and the basis for anch selection.

(2) Before selecting any site under subsection (a), the Secretary shall hald at least one public bearing in the vicinity of such site to solicit any recommendations of interested parties with respect to issues raised by the selection of such site.

(f) Notification of Stection.-The Secrotary shall prompty notify Congress and the appropriate State or Indian tribe of the selection turder subsection (a).

(g) Limitation,-No monitored retrievable storage factity authorized puisuant to section 142 (b) may be constructed in the State of Nevada.

\section{MOTRCE OF DISAPPROVAL}

42 USC 10166. Sec. 146. (a) In General. -The selection of a site under section 145 shall be effective at the end of the period of 60 calendar days beginning on the date of notification under such subsection, unless the governing bodty of the Indian tribe on whose reservation such site is located, or, if the site is not on a reservation, the Governor and the legislature of the State in which the site is located, has subritted to Congress a notice of disapproval with respect to such site. If any such motice of disapproval has been submitted under this subsection, the selection of the site un- 
der section 145 shall not be effective except as provided under section 115(c).

(b) Referénces.-For-purposes of carrying out the provisions of this subsection, references jin section 115 (c) to a repository shall be considered to refer.to a monitored retrievable storage facility and references to a notice of disapproval of a repository site desigation under section 116 (b) or 118 (a) shall be considered to refer to a notice of disapproval under this section.

42 USC 10167.

BENEFTS AGRKEWENT

Sec. 147. Onice selection of a site for a montitored retrievable storage facility is jaade by the Secretary under section 145, the Indian tribe on whose reservation the site is located, or, in the case that the site is not located on a reservation, the State in which the site is located, shall be eligible to enter into a benefits agreement, with the Secretary under section 170.

\section{CONSTRUCIION AUTHOREATION}

42 USC 10168. Sec. 148 (a) Environmental Impact Statement.-(1) Once the selection of a site is effective under section 146, the requirements of the $\mathrm{Na}$ tional Environmental Policy Act of 1969 (42 U. S. C. 4321 et seq.) shall apply with respect to construction of a monitored retrievable storage facility, excèpt that any estrironmental impact statement prepared with respect to such facility shall not be required to consider the need for such facility or any alternative to the design criteria for such facility set forth in section 141 (b) (1).

- (2) Nothing in this section shall be construed to linit the constideration of alternative factlity desigets, consistent with the criteria described in section 141 (b) (1) in any environtnental impact statement, or in any licensing procedure of the Commission, with respect to any monitortd retrietable storage facility authorized uvder section 142 (b).

(b) Application For Construction License.-Onee the selection of a site for a monitored retrievable storage facility is effective under section 146, the Secretary may submit an application to the Commission for a lisense to construct such a facility as part of an integrated nuclear waste managenient system and in accordance with the provisions of this section and applicabie agreements under this Act affecting such facility.

(c) Licensing.- Any monitored retrievable storage facility authorized pursuant to section 142 (b) shall be subject to licensing under section 202(3) of the Energy Reorganization Act of 1974 (42 U. S. C. 5842 (3)). In reviewing the application fled by the Secretary for licensing of such facility, the Commission may not consider the need for such facility or any altemative to the design criteria for such facility set forth in section 141 (b) (1).

(d) Licensing Conditions.-Any license jssued by the Commission for amonitored retrievable storage facility under this section shall provide that-

(1) construction of such faclity may not begin until the Commission has issued a license for the construction of a repasitory under section 115 (d); 
42 USC 10169.

42 USC 1017.
(2) construction of such facility or acceptance of spent nuclear fuel or high-level radioactive waste shal] be prohibited during such time as the repository license is revoked by the Commission or construction of the repository ceases;

(3) the guantity of spent nuclear fuel or high-level radiosctive waste at the site of such facility at any one time may not exceed 10,000 metric tons of hetry metal until a repository under this Act first accepts spent nuclear fuel or solicified high-tevel radioactive waste; and

(4) the quantity of spent nuclear fuel or high-level radioactive waste at the site of the factily at amy one time may not exceed 15,000 metric tons of heavy metaj,

\section{MINANCIAL ASSESTANCE}

Sec. 149. The provisions of section 116 (c) or 118 (b) with respect to grants, technical assistance, and other financial assistance shall apply to the State, to affected Indian tribes and to affected urits of local government in the case of a monitored retrievable storage facility in the same manner as for a repository."

\section{SUBTITLE D-LOW-LEVKL RADIOACTTVE WASTE}

\section{FINANCLAL, ARRANGGMENTS FOR LOW-IEYRL, RADIOACTIVI WASTE SITH} CLOSURE

Sec. 151. (a) Financial Arrangements.-(1) The Commisstion shall establish by rule, regulation, or order, after public notice, and in accordarce with section 181 of the Atomic Energy Axt of 1954 (42 U. S. C. 2231), such standards and instructions as the Commission may deem necessary or desirgitle to ensure in the case of each license for the disposal of low-level radioactive waste that an adequate bond, surety, or other financial arrangement (as determined by the Commission) will be provided by a licensee to pernit completion of all requirements established by the Commission for the decontamination, decommissioning, site closure, and reclamation of sites, strucnures, and equipment used in conjunction with such low-level radioactive waste. Such financial arrangements shall be provided and approwed by the Commission, or, in the case of sites within the boundaries of any agreement State under section 274 of the Atomic Energy Act of 1954 ( 42 U. S. C. 2021), by the appropriate State or State entity, prior to issuance of licenses for lowlevel radioactive waste disposal or, in the case of licenses in effect on the date of the enactment of this Act, prior to termination of such licenses.

(2) If the Commission determines that any long-term maintenance or monitoring, or both, will be necessaty at a site described in paragrapis (1), the Commission shall ensure before termination of the license involved that the licentsee bas made arajlable such bonding, surety, or other financial antargendents as may be necessary to ensure that any nectessary long-term maintenance or monitoring needed for such site wilu be carried out by the person having titie and custody for such site following license termination.

(b)Title And Custady-(1) The Secretary sball heve authority to assume title and custody of kow-level sadioactive waste and the land on

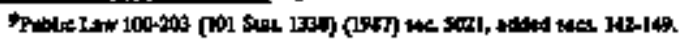


which such waste is disposed of, upon request of the ownter of such waste and land and following termumation of the license issued by the Commisstion for such disposal, if the Commisston determines that-

(A) the requirements of tile Conmisstion for site clostre, decommissioning, and decontamination have been unet by the licensee invoived and that such licensee is in compliance with the provisions of subsection (a);

(B) such title and custody will be transferred to the Secretary without cost to the Federal Government; and

(C) Federal ownership and management of such site is necessary or desirable in ordes, to protect the public health and safek, and the evrironment.

(2) If the Sectetary assumes title and custody of any such waste and laxd under this subsection, the Secretary shall mamtain such waste and land in a manner that will protect the public bealth and safety, and the environment.

(c) Special Sttes:-If the low-level radioactive waste inwolved is the result of a licensed activity to recover zirconium, hafniun, and rane earths from source tnaterial, the Secretary, upon request of the owter of the site involved, shall assume title and custody of such waste and the land on which it is disposed when such site has been decontaminated and stabilized in accondance with the requirements established by the Cour mission and when such owner has made adequate financial arradgements approved by the Commission for the long-term maintenance and monitoring of such site.,

\section{SUBTITLE R-REDIRECTION OF THE NUCLEAR WASTE PROGRAM}

$\$ 2 \mathrm{USC} 10172$

\section{SELECTION OF XUCCA MOLNTAIN STTE}

Sec. 160. (a) In General.-(1) The Secretary shall provide for an orderly phase-out of site specific activities at all candidate sites other than the Yucca Mountain site.

(2) The Secretary shall terminate all site specific activities (other than reclamation activities) at all candidate sites, other than the Yucca Mountain site, within 90 days after the date of enactroent of the Nuclear Waste Policy Amendments Act of 1987.

(b) Effective on the date of the enactment of the Nuclear Waste Policy Amendments Act of 1987, the State of Nevada shall be eligible to enter into a penefits agreement with the Stcretary under section $170^{10}$

STIING A SECOND REPOSTIORY

42 USC 10172a Sec.161. (a) Congressional Action Requited-The Secretary may not conduct site-specific activities with respect to a second repository unless Congress has specifically authorized and appropriated funds for such activities.

(b) Report-The Secretary shall report to the President and to Con. gress on or after January 1, 2007, but not later than January 1, 2010, on the aeed for a second repository.

(c) Termination of Granite Research--Not later than 6 months after the date of the enactment of the Nuctear Waste Policy Amendments Act

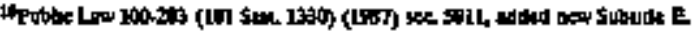


of 1987, the Secretary shall phase out in an orderty manner funding for all research programs jo existence on such date of enactment designed to evaluate the suitabilty of erystalline rock as a potential sepository bost medium.

(d) Additional Siting Criteria.--In the event that the Secretary at any time after such date of enactirent considers any sites in crystalline rocik for characterization or selection as a repository, the Secretary shall consider (as a supplement to the siting guidelines under section 112) such potentially disqualifying factors as-

(1) seasonal increases in population;

(2) proximity to public drinking water supplies, including those of metropotitan areas; and

(3) the impact that characterization or siting decisions would have on lands owned or placed in trust by the United \$tates for Indian tribes, 11

\section{SUBTILE F- BENEWTS}

42 USC 10173.

\section{BEATEIS AGREEMENTS}

Sec 170. (a) In General.-(1) The Secretary may enter into a benefits agreement with the State of Nevada concerning a repository or with a State or an Indian tribe concerning a monitored retrievable storage facilty for the acceptance of high-level radioactive waste or spent nuclear fixel in that State or on the reservation of that tribe, appropriate.

(2) The State or Indian tribe may enter into such an agreement only if the State Attorney General or the appropriate governing atthority of the Indian tribe or the Secretary of the Interior, in the absence of an apptopriate governitis althority, as appropriate, certifites to the satisfaction of the Sectetary that the laws of the State or Indian tribe provide adequate authority for that entity to enter into the benefis agreement.

(3) Any benefits ageetment with a State under this section shall be negotiated in consultation with affected units of local government in such State.

(4) Benenits and payments undes this subtitk may be made availabte only in accordanoe with a benefits agreement under this seo. tion.

(b) Amendment, $A$ benefits agreement entered into under subsection (a) may be amended only by the mutual consent of the parties to the agreenent and terminated only in arcordance with section 173.

(c) Agreement With Nevada-The Secretary shall offer to enter into abenefits agreenent with the Governor of Nevada. Any benefits agreement with a State under this subection shall be negotiated in consultation with any affected units of local government in such State.

(d) Monitored Retrievable Storage.-The Secretary shall offer to enter into a benefits agreement relating to a monitored retrievable storage facility with the governing body of the Indian tribe on those reservation the site for such facility is located, or, if the site is not located on a Ieservation, with the Governor of the Srate in which the site is located

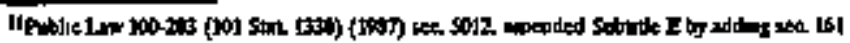


and in consultation with affected units of local government in such State.

(e) Limitation:-Only one benefits agreement for a repository and only one benefits agreement tor a monitored retrievable storage facility may be in effect at any one tirte.

(f) Judicial Review.-Decisions of the Secretary under this section are not subject to judjajal jeview.

\section{CONTENT OF AGREEMENTS}

42 USC 10173. Sec. 17L (a) In Geperal.-(1) In addition to the benefits to which a State, an affected unit of local government or Indian tribe is entitled un. der title I, the Secretary shall make payments to a State or Indian tribe that is a party to a benefits agreement under section 170 in accordance with the following schedulo:

BEREETSS SCHBDULL (andounts in 5 miarons)

\section{Event}

MRS

Repository

(A) Annual payments prior to first spent fute] recejpt $. \ldots \ldots \ldots \ldots \ldots, \ldots \ldots, 5$

(B) Upoir Iirst spent fuel receipt ........... to

(C) Amnual payments after the first spent fuel receipt until closure of the facility

(2) For,purposes of this section, the term-

(A) 'MRS' means a monitored retrievable storage facility,

(B) 'spent fuel' means high-level radioactive waste or spent ruclear fuel, and

(C) 'tirst spent fivel receipt' does not include receipt of spent fuel or kigh-level radioacive waste for purposes of testing of operational demonstration.

(3) Arrual payments prior to first spent fuel receipt under paragraph (1)(A) shall be made on the date of execution of the bentefits agrement and thereafter on the angiversary date of such execution. Alental payments after the first spent fuel receipt until closure of the facility under paragraph (I)(C) shall be made on the aniviversary date of such first spent fuel receipt.

. (4) If the first spent fuel.payment under paragraph (1)(B) is made within six months after the last asnual payment prior to the receipt of spent fize] under paragraph (1)(A), such first spent fuel payment under paragraph (1)(B) shall be reditod by an amount equal to one-twelfth of such andual payment under paragraph (1)(A) for each full month less than six that has not elapsed since the last anmual payment under paragraph (1)(A).

(5) Notwithstanding paragraph (1), (2), or (3), no pasment under this section may be made before January 1,1989 , and any payment cue under this tikle before January 1, 1989, shall be made on or after such date.

(6) Except as provided in paragraph (7), the Secretary may not restrict the purposes for which the payments under this section may be used. 
(7) (A) Any State receiving a payment uncter this section shall transfer an amount equal to not less than one-third of the amount of such payment to affected units of local government of such State.

(B) A ptan for this transfer and appropriate allocation of suct portion among such governments shall be included in the benetits agreement under section 170 covering stch payments.

(C) In the event of a dispute conceming such plan, the Secretary shall resolve such dispute, consistent with this Act and applicable State law.

(b) Contents.-A benefits agreement under section I70 sball prowide that-

(1) a Review Panel be established in accordance with section 172;

(2) the State or Indian tribe that is party to such agreement waive its rights under title I to disapprove the recommendation of a site for a repository;

(3) the parties to tine agreement shall share with one another information relevant to the licensing process for the repository of monitoned retrievable storage tacility, as it becomes available;

(4) the State or Indian tribe that is party to such agretment participate in the design of the repositosy or monitored retrievable storage facility and in the preperation of docunients required under law or regulation governing the effects of the factity on the public health and safety; and

(5) the State or Indian tribe waje its rights, if any, to ingact assistance under sections 116(c)(1)(B)(ii), 116(c)(2), $118(\mathrm{~b})(2)(\mathrm{A})(\mathrm{ii)}$, and 118(b)(3),

(c) The Secretary shall make payments to the States or affected Indian tribes under a benefits agreenent under this section from the Waste Fund. The signature of the Secretary on a valid benefits agreement under section 170 shall constitute a commitment by the United States to make payments in accordance witti such agreement.

42 USC 10173b.

\section{BEVIEW PANTE}

Sec. 172. (a) In General.-The Review Panel required to be estab. lished by section 171(b)(1) of this Act shall consist of a Chairman selected by the Secretary in consultation with the Governor of the State or gowerning body of the Indian tribe, as appropriate, that is party to such agreement and 6 other members as follows:

(1) 2 members selected by the Governor of such State or governing body of such Indian tribe;

(2) 2 members selected by units of local government affected by the repositony or monitoted retritwable storage facility,

(3) 1 momber to represent persons ruaking payments into the Waste Fund, to be selected by the Sexretary; and

(4) 1 member to represent other public interests, to be selected by the Secretary.

(b) Terms.- (1) The members of the Review Pant] shall serve for ternins of 4 years each.

(2) Members of the Review Panel who are not full-time employees of the Federal Gowernment, shatl receive a per diem com- 
42 USC 10173c.

pensation for each day spent contucting work of the Review Panel, including their necessary travel or other expenses while engaged in the work of the Review Panel.

(3) Expenses of the Panel shall be paid by the Secretary from the Waste Fund

(c) Duties.-The Review Panel sball-

(1) sdvise the Secretary on matters relating to the proposed repository or monitored retrievable storage facility, including issties relating to design, constsuction, operation, and deconmatissioning of the fatility,

(2) evaluate performance of the repository or monitored retrievable storage tacility, as it considers appropriate;

(3) recontmend comective actions to the Secretary;

(4) assist in the presentation of State or affected Indian tribe and local perspectives to the Secretary, and

(5) participate in the planming for and tht review of preopera. tional data on errvirormutental, demographic, and sacioeconomic conditions of the site and the local community.

(d) Information.-The Sectetary stiall promptly rnake available promptly any itformation in the Secretary's possession requested by the Panel of its Chairman.

(e) Federal Advisory Committee Act.-The requirements of the Federal Advisory Committee Act shal! not apply to a Review Panet established under this title.

\section{TERMINATION}

Sec. 173. (a) In General.-The Secretary may terminate a benefits agreement under this title it-

(1) the sitc under consideration is discualified for its failure to comply with gujdelines and technical requirements established by the Sectetary in accordance with this Act; or

(2) the Secretary determines that the Commission cannot jicense the facility withjo a reasonable time.

(b) Termination By State Or Indtan Tribe- -A State or Indian tribe may terminate a benefits agreement upder this title only if the Secretary disqualifies the site under consideration for tts failure to comply with technical requirements established by the Serretary in axcordance with this Act or the Sectetary determines that the Commission connot license the facility within a reasonable time.

(c) Decisions Of The Secretary-Decisions of the Secretary under thus section shall be in writing, shall bo avalable to Congress and the public, and are not subject to judiciat review.

\section{SUBTITLE G-OTHER BENEFITS}

\section{CONSITERATION IN SMTNG FACTITIES}

42 USC 10174. Sec. 174. The Secretary, in siting Federal research projects, shall give special consideration to proposals from States where a repository is located.

\section{RFPORT}

42 USC 10174a. Sec. 175. (a) In General.-Within one year of the date of the enactment of the Nudear Waste Policy Amendments Act of 1987, the Secre- 
tary shall report to Congress on the potential impacts of locating a repository at the Yuoca Mountata site, meluding the recommendations of the Secretary for mitigation of such impacts and a statement of which impacts should be dealt with by the Federal Government, which should be dealt with by the State with State resources, includtog the bonefits payments under section 171, and which should be a joint Federal-State responsibjility. The report under this subsection sball include the analysis of the Secretary of the authorities available to mitigate these impacts and the appropriate sources of funds for such mitigation.

(b) Impacts to Be Considered:-Potential impacts to be addressed in the report under this subsection (a) shalt include jmpacts on-

(1) education, including facilities and personnel for elementary and secondary schoots, community colleges, vocational and tech. nical schools and universities;

(2) public health, including the facilities and personnel for treatment and distribution of water, the treatment of sedrage, the controt of pests and the disposal of solid waste;

(3) law enforcement, including facilities and personnel for the courts, police and sheriff's departments, district attorneys and public defenders and prisons;

(4) fire protection, inchuding personnel, the construction of fire stations, and the acquisition of equipment;

(5) medical care, including emergency services and hospitals;

(6) cultural and recreational needs, including facilities and personnel for libraries and museums and the acquisition and expansion of parks;

(7) distribution of public lands to allow for the timely expansion of existing, or creation of new, communities and the construction of necessary residential and commercial facilities;

(8) vocational trajning and employment services;

(9) social services, including public assistance programs, vocational and physical rehabilitation prostams, mental health services, and programs relating to the abuse of alcobol and coutrolled substances;

(10) transportation, including any roads, terminals, airports, bridges, or yailways associated with the facility and the repair and mbaintenance of roarls, terminals, airports, bridges, or railways dasoaged as a result of the construction, operation, and closure of the facility;

(11) equipment and training for State and local personmel in the management of accidents jutolving high-letel radioactive waste;

(12) availability of energy;

(13) tourism and exonomic development, including the potential loss of revenue and fiture economic growth; and

(14) other needs of the State and local governments that would not bave arisen but for the characteritation of the site and the construction, operation, and eventual clostre of the repository facility ${ }^{12}$

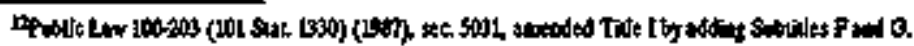




\section{SUETTILE H-TRANSPORTATION}

42 USC 10175.

\section{- TRANSPOATLITON}

, Sec. 180 (a) No spent nucfeanfuel or high-level radioactive waste may be transported by or for the Secretary under subtitle A or under subtitle $C$ except in packages that have been certified for such purpose by the Commisstion.

(b) The Secretary shall abide by regulations of the Commission regarding advance notification of State and local governments prigr to transportation of spent nuclear fuet or high-level radioactive waste urder subtitte A on under. subtitle C.

(c) The.Sectetary shali provide technical assistance and funds to Ștates for trainting for pụblic safety officials of appropriate units of local government and Indian tribes through whose jurisdiction the Semetary plans to transport spent nuclear fuel or high-level radioactive waste under subtitle A ox under subtitle, C. Training shall oover procedures recuired for safe routine transportation of these materials, as well as procedures for dealing with emergency response situations. The Waste Fund shall be the sounce of fands for work carried out under this subsection. ${ }^{3}$

TITLR II-RESEARCH, DEVKLOPMENT, AND DEMONSTRATION REGARDING DISPOSAL OF HIGH-LEVEL RADIOACTIVE WASTE » AND SPENT NUCLEAR FUEL

42 USC 10191

42 UsC 10192 PURPOSE

Sec. 211. It is the purpose of this title-

(1) to provide direction to the Secretary with respect to the disposal of high-level radioactive waste and spent puclear fuel;

(2) to althorize the Secretary, pursuant to this title(A) to provide for the construction, operation, and majnte- nance of a deep geologic test and evaluation facility; and

(B) to provide for a-focused and integrated high-level radioactive waste and spent nuclear fuel tesearch and development program, including the development of a test and evaluations facility to carry out research and prowtes an integrated demonstration of the technology for deep geologic disposal of highlevel radioactive waste, and the development of the facilities to demonstrate dry storage of spent nuclear fucl; and

(3) to provide for an improved cooperative rols between the Federal Government and States, affected Indian tribes, and units of general local government in the siting of a test and evaluation facility.

\section{APPLICABILITY}

Sec. 212. The provisions of this title are subject to section $B$ and shall not apply to facilities that are used for the disposal of high-level radioactive waste, low-tevel radioactive waste, transuranic waste, or spent nuclear fuel resulting from atomic energy defense activities.

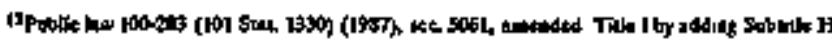




\section{IOENIIETCATION OR SITES}

Sec. 213. (a) Guidelines.-Not Iater than 6 months after the date of the enactment of this Act and notwithstanding the failure of other agencies to promulgete standards purstant to appicable law, the Secretary', in consultation with the Commission, the Director of the Geological Survey, the Administrator, the Council on Envisonmental Quality, and stch other Feckral agencies as the Secretary considers appropriate, is authorized to issue, pursuant to section 553 of title 5, United States Code, general gridelines for the selection of a site for a test and evalua. tion faxility. Under such gutidelines the Secretary sball specify factors that qualify or disquatify a site for development as a test and evaluation facility, inclisting factors pertitining to the location of valuable natural resources, bydrogeophysicx, seismic activity, and atowic energy defense activities, proximity to water supplies, proximity to populations, the effect upon the rights of users of water, and proximity to components of the National Park System, the National Wijdlife Refuge System, the National Wild and Scenic Rivers System, the National Wilderness Preservation System, or National Forest Lands. Such guidelines shall require the Secretary to consider the various geologic media in which the site for a test and evaluation facility miay be located and, to the extent practicable, to identify sites in different geologit media. The Secretary shall use guidelines established under this subsection in considering and selecting sites under this title.

(b) Site Identification By The Sectetary.-(1) Not later than 1 year after the date of the enactment of this Act, and following promulgation of guidelines under subsection (a), the Secretary is authorized to identiFy 3 or more sites, at least 2 of which shall be in different geologic media in the continental United States, and at least 1 of which shall be in medin other than salt. Subject to Commission requirements, the Secretary shall give preference to sites for the test and evaluation facility inmedia possessing geochemical charactetistics that retard aqueous transport of radionucleides in outler to provide a greater possible protection of public health and safery as operating experience is gained at the test and operation facility, and with the exception of the primary areas under teview by the Secretary on the date of the enactment of this Act for the location of a test and evaluation facility or repositosy, all sites identified under this subsection shall be more than 15 statute mifes from towns having a poputation of greater than 1000 persons as determined by the most recent census tuless such sites contain high-level radioactive waste prior to identification under this title. Each identification of a site

Environmentat assessment. shall be stupported by an environinentat assessment, which shall include a detailed statement of the basis for such identification and of the probable impacts of the siting research activities planned for such site, and a discussible impacts of the siting rebearch activities planned for such site, and a discussion of alternative activities relating to siting research that may be undertaken to avoid such impacts. Such environmental assessment shatl include-

(A) an evaluation by the Stcretary as to whtuther such site is suitable for siting research under the guidelines established under subsection (a);

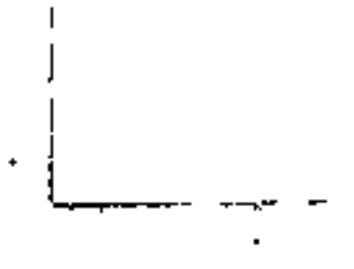


42 USC 10194.

(B) an evaluation by the Secretary of the effects of the siting research activties at such site on the public bealth and safecy and the environment,

(C) a teasonable comparative evaluation by the Secretary of such site with other sites and locations that have been considered;

(D) a description of the decision process by which such site was reconmended; and

(E) an assessment of the regional and local impacts of locating the proposed test and evaluation facility at such site.

(2) When the Secretary identifies a site, the Secretary shall as soon as possible notify the Governor of the State in which suchsite is located, or the governing bocty of the affected Indian tribe where such site is located, of such identification and the basis of such identification. Additional sites for the location of the test and evaluation facility authorized in section 302(d) may be identified after such 1 year period, following the same procedure as if such sites had been identified within such period.

\section{GITING RESRARCH AND RELATEO ACTIVITES}

Sec. 214. (a) In General.-Not later than 30 months after the date on which the Secretary completes the identification of sites under section 213 , the Secretary is authorized to complete sufficient evaluation of 3 sites to select a site for expanded siting researcit activities and for other activities under section 218 . The Secretary is authorized to canduct such preconstruction activities relative to such site selection for the test and evaluation facility as he deems appropriate. Additional sites for the Jocation of the test and evaluation facility authorized in section 302(d) Inay be evaluated after such 30-menth period, following the same procedures as if such sites were to be evaluated within such period.

(b) Public Meetings And Environmental Assessment.-Not later than 6 months after the date on which the Secretary completes the identification of sites under section 213 , and before begining siting research activities, the Secretary shall hold at least 1 pubfic meeting in the vicinity of each site to inform the residents of the aree of the activities to be conducted at such site and to receive their views.

(c) Restrietions,-Except as provided in section 218 with respect to a test and evaluation facility, in conducting siting research activities purstant to subsection (a)-

(1) the Secretary shall use the minimum quantity of bigh-level radioactive waste or other radioactive materials, if any, necessary to achieve the test or research objectives;

(2) the Secretary shall ensure that any radioactive material used or placed on a site shall be fully retrievable; and

(3) upon termination of siting researth activities at a site for any reason, the Secretary shall remove any radjoactive material at or in the site as promptly as practicable.

(d) Title To Materiaj.-The Secretary may take title, in the name of the Federal Government, to the high-level radioactive waste spent nutclear fuel, or other radioactive material emplaced in a test and evaluation facility. If the Secretary takes title to any such material, the Secre- 


\section{USC 10195.}

tary shall enter irto the appropriate financial arrangements described in subsection (a) or (b) of section 302 for the disposal of such material.

\section{TEST AND EVALUATION BACTLTYY STIING REVIEW AND REPOR'S}

Sec. 215. (a) Consultation And Cooperation.-The Governor of a State, or the governing body of ar affecked Indian tribe, notifed of a site identification under section 213 shall have the right to participate in a process of consultation and cooperation as soon as the site jnolved bas been identified pursuant to such section and throughout the life of the test and evaluation facility. For purposes of this section, the terin "process of conststation and cooperation" means a methodology-

"Prichess of consoltation and coperation."

(1) by which the Secretary-

(A) keeps the Governor or governing body involved fully and currently informed about any potential economic or public health and safety impacts in all stages of the siting development, construction, and operation of a test and epaluation facility;

(B) solicits, receives, and evaluates concerns and objections of such Governor or governing body with regard to such test and evaluation facility on an ongoing basis; and

(C) works ditigently and cooperatively to resolve such con. cerns and objections; and

(2) by which the Seate or affected Indian tribe jovolved can exercise reasonable fndependent monitoring and testing of onsite activities related to all stages of the siting, development, construction and opera. tion of the test and evaluation facility, except that any strch monitoring and testing shall not umeasonably interfere with onsite activities.

(b) Written Agreements.--The Secretary shall enter into written agreements with the Governor of the State in which an identified site is located or with the governing body of any affected Indian tribe where an identified site is located in order to expedite the consultation and cooperation process. Any such written agreement shall specify-

(1) procechures by which such Governor or governing body may stuxdy, determine, comntent on, and make recommendations vith regard to the possible theatth, safety, and econonic impacts of the test and evaluaton facility;

(2) procedires by which the Secretary shall constider and respond to comments and recommendations made by stuch Governor or governing body, including the period in which the Secretary shall so respond;

(3) the documents the Department is to submit to such Governor or governing body, the timing for such submissions, the timing for such Governor or governing body to identify public health and safety concerus and the process to be followed to fry to eliminate those concerns;

(4) procedures by which the Secretary and either such Gowernor or governing body may review or modify the ageement periodically; and

(5) procedures for public notification of the procedures specified under subparagraphs (A) through (D).

(c) Limitation.--Except as specifically prowided in this section, nothing in this title is intended to grant any State or affected Indian tribe any authority with respect to the siting, development, or loading of the test and evaluation facility.

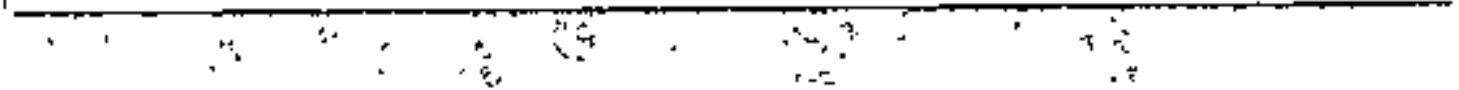


.

42 USC 10197.

Envionmental assessment.
Sec. 216. (a) Cooperation And Coordination.-Federal agencits shall assist the Secretary by cooperating and coordinating with the Secretary in the preparation of any necessary reports under this title and the mission plan under section $30 t$.

(b) Environmerital Review.- (1) No action of the Secretary or any other Federal agethoy requited by this title or section 301 with respect to a tess and evaluation facility to be taken prior to the initiation of onsite construction of a test and evaluation facility shall require the preparation of an environmental impact statement under section $102(2)(C)$ of the Esvironmental Policy Act of 1969 (42 U.S.C.: 4332(2)(C)), or to require the preparation of emvironmental reports, except as otherwise specifically provided for in this title.

(2) The Secretary and the heads of all other Federal agencies shall, to the maximum extent possible, avoid duplication of efforts in the preparation of reports under the National Environmental Policy Act of 1969 ( 42 U. S. C. 4321 et seq.).

\section{RESIXARCH AND DEVELOPMENT ON DISPOSAL OF HIGH-LEVEL RADLOACTTVE} WASTE

Sec. 217. (a) Purpose.-Not later than 64 months after the date of the enactonent of this Act, the Secretary is authorized to, to the extent practcable, begin at a site evaluated under section 214 , as part of and as an extension of siting research activities of such site under such section, the mining and construction of a test and evaluation facility. Prior to the mining and contstruction of sikch facility, the Secretary shall prepare an environmental assessment. the purpose of such facility shall be-

(1) to supplement and focis the repository site characterization process;

(2) to provide the conditions under which known technological components can be integrated to demonstrate a functioning repository-tike system;

(3) to provide a means of identifying, evaluating, and resolving potential sepository licensing issues that could not be resolved during the siting researci program conducted under section 212;

(4) to validate, under actual conditions, the scientific models used in the design of a repository;

(5) to refine the design and engineering of repository conponents and systems and to confirm the predicted behavior of sucti components and systems;

(6) to supplemest the siting data, the generic and specific geological characteristics developed under section 214 relating to isolating disposal materials in the physical environment of a repositoгу;

(7) to evaluate the design concepts for packaging, handling and emplacement of high-level radioactive waste and spent nticlear fuel at the design rate; and

(8) to establish operating capability without exposing workers to excessive radiation.

(b) Design.-The Stcretary strall design each test and evaluation facility- 
(1) to be capable of recejing not trore than 100 full-sized caristers of solinitied high-level radiogctive waste (which canisters shall not exceed an aggregate weight of 100 metric tons), except that spent nuclear tuel may be used instead of such waste if such waste cornot be obtained under reasonable conditions;

(2) to pormit ful] retrieval of solidified high-level radioactive waste, or other radioactive material used by the Secretary for testing upon completion of the tectuology demonstration activities; and

(3) based upon the principle that the hingh-level radioactive waste, spent nuclear fuel, or other radioactive material involved shail be isolated from the biosphere in such a way that the initial isolation is provided by engineered baniers functioning as a system with the geologic emvironment.

Testing.

(c) Operation.-(1) Not Jater than 88 months after the date of the enactment of this Act, the Secretary shall begin an in sttu testing program at the test and evaluation facility in accordance with the mission plan developed under stection 301, for purposes of -

(A) conducting in situ tests of bore hole sealing geologic media fracture sealing, and room closure to establish the techniques and performanee for isolation of high-level radioactive waste, spent nuclear fuel, of otjuer ractioactive materials from the biosphere;

(B) conducting in situ tests with radioactive sources and materials to evaluate and improve reliable models for radionuclide mitigation, absorption, and containment within the enginetered barriers and geologic medja juvolved, if the Secretary inds there is reasonable assurano that such radfoactive sources and materials will not threaten the use of such site as a repository;

(C) conducting in situ tests to evaluate and improve models for ground water or brine flow through fractured geologic media;

(D) conducting in situ tests under conditions representiting the real time and the accelerated tinae behavior of the engineered barriers within the geologic emvironment involved;

(E) conducting in situ tests to evaluate the effects of heat and presstre on the geologic media involved on the hyctology of the surrounding area and on the integrity of the disposal packages;

(F) conducting in situ tests under both normal and abnormal repository conditions to establish safe design limits for disposal packages and to determine the effects of the gross release of radiontaclides into sunnoundings, and the effects of vartious credible failure modes, including -

(i) seismic events leading to the coupling of aquifers through the test and evaluation facility;

(ii) therraal pulses significantly greater than the maximusn cakculated; axd 
(iii) human intrusion creating a direct pathway to the biosphere; and

(G) conducting such other research and development activities as the Secretary considers appropriate, including such activities necessary, to obtain the use of high-level radioactive waste, spent nuclear fuel, or other radioactive materials (such as any highly radiosctive material from the Three Mile Island nuclear powerplant or from the West Valley Demonstration Project) for test and evaluation purposes, if stich other activities are reasonably necessary to support the repository program and if there is reasonable assurance that the radioactive sources involved will not threaten the use of such site as a repossitory.

(2) The in situ testing authorized in this subsection shall be designed to ensure that the suitability of the site inwolved for licensing, by the Commission as a repository will not be adversely affected.

(d) Use Of Existing Departinent Facilities.-Duting the conducting of siting research activities under section 214 and for such period thereafter as the Secretary considers approppriate, the Secretary shall use Department facilities owned by the Federal Government on the date of the enacturent of this Act for the conducting of generically applicable test regarding packaging handjing, and emplacement technology for solidified high-fevel radioactive waste and spent nuclear fisel from civiljan muckear activities.

(e) Engtuetred Baniers. -The systen' of engineered barriers and selected geology used in a test and evalutation facility shall have a design life at least as long as that which the Commission requires by regula. tions issued under this Act, or under the Atomic Energy Act of 1954 (42 U. S. C. 2011 et seq.), for repositories.

(f) Role Of Commission. (1) (A) Not later then 1 year after the date of the enactment of this Act, the Secretary and the Commission shall reach a written uhderstanting establishing the procedures for review, consultation, and coordination in the planning, construction, and operation of the test and evaluation facility under this section. Such understanding shall establish a schedule, consistent with the deadijines set forth in this subtitle, for submission by the Secretary of, and review by the Conmission of and necessary action on-

(i) the mission plan prepared under section 301 ; and

(ii) such reports and other information as the Commission may reasonably require to tvaluate any health and safety impacts of the test and evaluation facility.

(B) Such understanding shall also establish the conditions under which the Commission may have access to the test and evaluation facility for the parpose of assessing any public health and safety concerns that it may have. No shafts may be excavated for the test and evaluation until the Secretary and the Comanission enter into such understanding.

(2) Subject to section 305, the test and evaluation facility, and the facilities authorized in section 217 , shall be constructed and 
operated as research, development, and demonstration facilities, and shall not be subject to licensing under section 202 of the Energy Reorganization Act of 1974 (42 U. S. C. 5842 ).

(3)(A) The Commission shall carry out a continuing analysis of the activities undertaken under this section to evaluate the adequacy of the consideration of public health and safety issues.

(B) The Commission shall report to the President, the Secretary, and the Congress as the Commission Considers appropriate with respect to the conduct of activities under this section.

(g) Environmental Review.-The Secretary shall prepare an environ. mental impact statement under section 102(2)(C) of the National Environmental Policy Act of 1969 (42 U.S. C. 4332)(2)(C) prior to conducting tests with radioactive materials at the test and evaluation factity. Such environmental impert statement shall incorporate, to the extent practicable, the environmental assessment prepared under section 217(a). Nothing in this subsection may be construed to limit siting research activities conducted under section 214. This subsection shall apply only to activities performed exclusively for a test and craluation facilty.

(h) Limitations - (1) If the test and evaluation facility is not located at the site of a repository, the Secretary shall obtain the concurrence of the Commission with respect to the decontamination and decommissioning of such facility.

(2) If the test and evaluation facility is not located at a candidate site or repository site, the Secretary shall conduct only the portion of the in situt testing program required in subsection (c) determined by the Secretary to be useful in carrying out the purposes of this act.

Termninations,

(3) The operation of the test and evaluation facility shall terminate not later than-

(A) 5 years after the date on which the initial repository begins operation; or

(B) at stuch time as the Secretary determines that the continued operation of a test and evaluation factity is not necessary for research, developuent, and demonstration pitiposes; whichever occurs sooner.

(4) Notwithstanding any other provisions of this subsection, as soon as practicable following any determination by the Secretary, with the concumence of the Commission, that the test and evaluation facility is unsuitable for continued operation, the Secretary shall take such actions as are necessary to remove from such site any radioactive material placed on such site as a result of testing and evaluation activities conducted under this section. Such requirement may be waived if the Secretary, with the concurrenee of the Commission, finds that short-term testing and evaluation actovities using radioactive material will not endanger the public heatth and safety.

RESEARCH AND DEVELOPMEAT ON SPENT NUCLEAR FUEL

42 USC 10198. Sec 218. (a) Demonstration And Cooperative Programs-The Secretary sball establish ademonstration program, in cooperation with the

, נ;


private sector, for the dry storage of spent muclear fuel at civilian nuclear power reactor sites, with the objective of establishing one or more technologies that the Commission may, by rule, approve for lase at the sites of civilian nuclear power reactors without, to the maximura extent practicable, the need for additional site-specific approvals by the Commission. Not later than l year after the date of the enactment of this Act, the Sexretary shall select at least 1, but not more than 3, sites evaluated under section 214 at such power reactors. In selecting steh site or sites, the Secretary shall give preference to civilian nuclear power resc. tors that will soon have a shortage of interim storage capacity for spent pucleas fiel. Subject to reaching agremement as provided in subsection (b), the Secretary sha!l undertake activities to assist such power reactors with demonstration projects at such sites, which may use one of the following types of alternate storage 'technologies; spent muclear fuel storage casks, caissons, or silos. The Secretary shall also undertake a cooperative program with civilian nuclear powver íactors to encourage the development of the technology for spent nuclear fuel rod consolidation ti existing power reactor water storage basins.

(b) Cooperative Agreements.-To carry out the programs described in subsection (a), the Secretary shal] enter into a cooperative agreement: with tach utility involved that specifies, at a minimum, that-

(1) such utility shall select the altertate storage fechnique to be used, make the land and spent nuclear fuel avaitable for the dry storage denjonstration, submit and provide site-spectitic documentation for a license application to the Commission, obtain a license refating to the facility involved, construct suct facility, operate such facility after licensing, pay the costs required to construct such facility, and pay all costs associated with the operation and maintetanice of such facility;

(2) the Secretary shall provide, on a cost-sharing basis, consultative and technical assistance, including design support and generic licensing documentation, to assist such utility in obtaining the constriction authorization and appropriate licesse from the Commission; and

(3) the Secretary shall provide generic research and development of altenative spent guctear fuel storage techniques to enhance utility-provided, at-reactor storage capacilitites, if authorized in any other provision of this act or in any other provision of law.

(c) Dry Storage Research And Development--(1) The consultative and technical assistance referred, to in subsection (b) \{2) rnay juclade, but shall not be limfted to, the establishenent of a researcfi and development program for the dry storage of pot more than 300 Jietric tons of spent nuclear fuel at facilities omed by the Federal Government on the date of the entactinent of this Act. The purpose of such program shall be to collect necessary data to assist the utidities involved in the licensing process.

(2) To the extent available, and consistent with the provisions of section 135, the Secretary shall provide spent nuclear fuel for the research andidevelopinent program autionized in this subsection 
Report to congressional committees.

42 USC 10199.

from spent nuclear fuel received by the Secretary for storage under section 135. Such spent muclear fuel shall not be subject to the provisions of rection $135(\mathrm{e})$.

(d) Funding.-The total contribution from the Secretary from Federal funds and the use of Federal facilities or services shall not exceed 25 percent of the total costs of the demonstration program authorized in subsection (a), as estimated by the Sexretary. All rejuaining costs of such program shall be paid by the utifities involved or shall be provided by the Secretary from the Interim Storage Fund established in section 136 .

(e) Relation To Spent Nuclear Fuel Storage Program.-The spent nuclear fuel storage program authorized in section 135 shall not be construed to authonze the use of research developinent or denonstration facilities owned by the Department unless-

(I) a period of 30 eslendar days (not including any day in which ejther House of Congress is not in session because of adjournment of more than 3 calendar days to a day certain) has passed after the Secretary has transmitted to the Cominittec on science and Technology of the House of Representatives and the Committee on Energy and Natural Resources of the Senate a written report containing a full and complete statement concerning (A) the factity inrolved; (B) any necessary modifications; (C) the cost thereof; and (D) the impact on the authorized research and development program; or

(2) each such committee, before the expiration of such period, has transmitted to the Secretary a written notice to the efiect that stuch committee has no objection to the proposed use of such facility.

PAMENIS TOSTATES AND INDLAN TRIBES

Sec 219. (a) Payments-Subject to subsection (b), the Secretary shall make payments to each State or affected Indian tribe that has entered into in agreement pursuant to section 215. The Secretary shall pay an amount equal to 100 percent of the expenses incurred by such State or Indian tribe in engaging in any monitoring, testing, evaluation, or other consultation and cooperation activity under section 215 with respect to any site. The amount paid by the Secretary under this paragraph shall not exceed $\$ 3,000,000$ per year from the date on which the site involved was identified to the date on which the decontamination and decommission of the facility is complete purstatant to section 217(h). Any such payment may only be made to a State in which a potential site for a test and evaluation facility has been identified under section 213 , or to an affected Indian tribe where the potential site has been identified under such section.

(b) Limitation.-The Secretary shall make any payment to a State under subsection (a) only if such State agrees to provide, to each unit of general local government within the jurisdictional boundaries of whici the potential site of effectively selected site involved is located, at least one-tenth of the payments made by the Secretary to such State under such subsection. A State or affected Indian tribe receiving any payment under subsection (a) shall otberwise have discretion to use such payment for whatewer purpose it deenns necessary, including the State or 
Report to

Congress.

42 USC 10200

42 USC 10201. Ante p. 2227. $42 \mathrm{JSC} 10202$.

42 USC 10203

Joint notice, publication in Federal Register.

Joint notice, teissuance. tribal activities pursuant to agreements entered into in accordance with section 215. Ariual payments shall be prorated on a 365-day basis to the specified dates.

\section{STUDOY OF RESEARCH AND DEVELOPKENT NEEDS POR MTONITORED} RETRETEAIE STORAGE PROPOSAI

Sec 220. Not later than 6 months after the date of the enactment of this Act, the Secretary shall submit to the Congress a report describing the researcin and development activities the Secretary considers necessary to develop the proposal required in section 141(b) with respect to a monitored retrievable storage facility.

\section{JUDKCLAL REUIEW}

Sec. 221. Judicial review of research and development activities under this shall be in accordance with the proviskons of section 119.

Sec. 222. Research on Altermatives for the Permanent Disposal of High-Level Radioactive Waste.-The Secretery shall continue and accelerate a program of research, development, and investigation of altemative means and technologies for the permanent disposal of tigghlevel radioactive waste from civilian nuclear activities and Federal research and cevelopment activities except that funding shall be made from amounts appropriated to the Secretary for purposes of carrying out this section. Such program shall include examinations of various waste disposal options.

\section{TRCHNICAL ASSESTAMCT TO NON-NUCT EAR WTAPON STATES IN THE FIELD OF} SPENT FUEL STORAGE AND DISPOSAI

Sec 223. (a) It shall be the policy of the United States to cooperate with and provide technical assistance to non-nuclear weapon states in the field of spent fuel storage and disposal.

(b)(1) Within 90 days of enactment of this Act, the Secretary and the Comouisston shall publish a joint notice in the Federal Register stating that the United States is prepared to cooperate with and provide technical assistance to non-muclear weapon states in the fields of at-reactor spent fiel storage; away-trom-reactor spent fuel storage; monitored, retrievable spent fuel storage; geologic disposal of spent fuel; and the health, safety, and envirommental regulation of such activities. The no. tice shall summarize the resources that can be made available for interuational cooperation and assistance in these fields through existing prograus of the Department and the Commission, including the availabilixy of: (i) data from past or ongoing research and development profects; (ii) consultations with expert Department or Commission personnel or contractors; and (jii) liaison with private business entities and croanizations working in these fields.

(2) The joint inotice described in the preceding subparagraph shall be updated and reissued annualły for 5 succeeding years.

(c) Following publication of the annual joint notice referred to in paragraph (2), the Secretary of State shall inform the governments of non-nuclear weapon states and, as feasible, the organizations operating nuclear powerplants in such states, that the United States is prepared to cooperate with and provide technical assistance to,non-nuclear weapon states in the fields of spent fuel storage and dispossal, as set forth in the 
Expressions of interest.

Non-nuxclear weapon state"

\section{Reports.} 42 USC 10204.

Establishment.

1 joint notice. The Secretary of State stall also solicit expressions of interest from non-nuclear weapon state governments and non-nuclear weapon state nuclear power reactor operators concerning their particjpation in expanded United States cooperation and technical assistance programs in these fields. The Secretary of State shall transmit any such expressions of interest to the Department and the Commission.

(d) With his budget presentation materials for the Department and the Commission for fiscal years 1984 through 1989, the President shal] include funding requests for an expanded program of cooperation and technical assistance with non-nucleat weapon states in the fields of spent fuel storage and disposal as appropriate in light of expressions of interest in such cooperation and assistance on the part of non-nuclear weapon state governments and non-nuclear weapon state nuclear power reactor operators.

(e) For the purposes of this subsection, the term "non-muclear weapon state" shall bave the same meening as that set forth in article $\mathrm{IX}$ of the Treaty on the Non-Proliferation of Nuclear Weapons (21 U.S.C. 438).

(f) Nothing in this suibsection shall atthorize the Department of Cominission to take any action aot authorized under existing law.

\section{BEDSEABED DSPOSAL}

Sec. 224. (a) Study.-Within 270 days after the date of the enactraent of the Nuclear Waste Policy Amendments Act of 1987, the Secretary shall report to Congress on stbseabed disposal of spent nuclear fuel and high-level radioaetive waste. The report under this subsection shall inclute-

(I) an assessment of the current state of knowiledge of subseabed disposal as an alternative technology for disposal of spent tuclear fuel and high-level radioactive waste;

(2) an esstimate of the cosits of subseabed disposal;

(3) an analysis of institutional factors associated with subseabed disposal, inclizdily intemational aspects of a decision of the United States to proceed with subseabed disposal as an option for nuclear waste management;

(4) a full discussion of the environmental and public health and safety aspects of subseabed disposal;

(5) recommendations on alternative ways to struchure an effort in restarch, development, and demonstration with respect to subseabed disposal; and

(6) the recommendations of the Secretary with respect to research, development and demonstration in subseabed disposal of spent nuclear fuel and high-level radioactive waste.

(b) Office Of Subseabed Disposal Research. - (1) There is hereby testablished an Office of Subseabed Disposal Research within the Office of Energy Research of the Department of Energy. The Office shall be headed by the Director, who shall be a member of the Senion Executive Service appointed by the Director of the Office of Energy Research, and compensated at a rate determined by applicable law.

(2) The Director of the Office of Subseabed Disposal Research shali be responsible for carrying out research, development, and demonstration activities on all aspects of subseabed dòsposal of 
Grants.

Contracis.

Reports.

Reports.

42 USC 10221, high-level radioactive waste and spent nuclear fuel, subject to the general superision of the Secretain. The Director of the Office skesl be directly responsible to the Director of the Office of Eniergy Research, and the first such Director shall be appointed within 30 days of the date of enactment of the Nuclear Waste Policy Amendments Act of 1987.

(3) In carrying out his responsitbilities under this Act, the Secretary may make prants to, or enter into contracts with, the Stabseabed Consortiam described in subsection (d) of this section, and ather persons.

(4) (A) Within 60 days of the date of enactment of the Nuclear Waste Policy Amendments Act of 1987, the Secretary shal] establish a university-based Subseabed Consortium involving leacing oceancgraphic universities and institutions, national laboratories, and other organizations to irvestigate the technical and institutional feasibility of subseabed disposal.

(B) The Subseabed Consorvium shali develop a research ptan and budget to achieve the following objectives by 1995:

(i) demonstrate the capacity to identify and characterize potential subseabed disposal sites;

(ii) develóp conceptual desigas for a subseabed disposal system, including estimated costs and institutional requirements; and

(iii) identify and assess the potential impacts of subseabed disposal of the human and marine environirnent.

(C) In 1990, and again in 1995, the Stubeabed Consortitin shall report to Congress on the progress being wade in achiewing the objectives of paragraph (2).

(5) The Director of the Office of Subseabed Disposal Research shall annually, prepare and submit a report to the Congress on the activities and expenditures of the Office. 14

\section{TITEE III-OTHER PROVISYONS REIATING TO RADIOACTTVE WASTE}

\section{MISSTOW PLAN}

Sec. 301. (a) CONTENTS OF MISSION PLAN,-The Secretary shall prepare a comprehensive report, to be known as the raisston plan, which shall provide an informational basis sufficient to permit infotmed decisions to be made in carrying out the repository program and the research, development, and demonstration programs required urder this Act. The mission plar shall include-

(l) an identification of the primary scientific, engineering, and technical information, including any necessary demonstration of enginesring or systems integration, with respect to the siting and construction of a test and evaluation facility and repositories;

(2) an identification of any information described in paragraph (1) that is not arailable because of ariy unresolved scientific, engiflecting, or technical questions, "or undemonstrated engineering or systems integration, a schedule including specitic major mile.

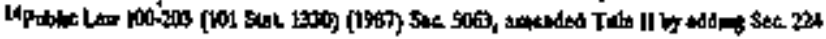


stones for the research, development, and technology demonstration program required under this Act and any additional activitits to be undertaken to perovide such information, a schedule for the activities necessary to achieve important programmatic milestones, and an estimate of the costs required to carry out such research, development and demonstration programs;

(3) an evaluation of financial, political, kegal, or institutional problems that riay impede the implementation of this Act, the plans of the Secretary to resolve such problems, and reconmendations for any tecessary legislation to resolve such probtems;

(4) any comments of the Secretary with respect to the purpose and program of the test and evaluation facility;

(5) a discussion of the significant results of research and development programs conducted and the implications for each of the different geologic medja under consideration for the siting of repositories, and, on the basis of such information, a comparison of the advantages and disadvantages associated with the use of such media for repository sites;

(6) the gujdelines issued under section 112(a);

(7) a description of known sites at which site characterization activities should be undertaken, a description of such siting characterization activities, including the extent of planned excrvations, plans for onsite testing with radioactive or nonradioactive material, plans for any investigations activities which may affect the capability of any such site to isolate high-level radjoactive waste or spent nuclear fuel, plans to control any adverse, safety-related intpacts from such site characterization activities, and plans for the decontamination arid decommissioning of such site if it is determined unsuitable for licensing as a repository;

(8) an ideritification of the process for solidifying high-levtl radioactive waste or packaging spent nuclear fuef, includiug a summary and analysis of the data to support the selection of the solidification process and packaging techniques, an anslysis of the requirengents for the number of solidification packoging facilities needed, a description of the state of the art for the materials proposed to be used in packaging such waste or spent fuel and the availability of such materials including impacts on strategic suppltes and any requirements for ntw or reactivated facilities to produte any such materials needed, ard a description of a plan, and the schedule for implementing such plan, for an aggressive research and development program to provide when needed a highintegrity disposal package at a reasonabłe price;

(9) an estimate of (A) the total repository capacity required to safely accommodate the disposal of all high-level radioactive waste and spent nuclear fuel expected to be generated through December 31, 2020, in the event that no commercial reprocessing of spent nuclear fuel occurs, as wetl as the repository capacity that will be required if such reprocessing does occur; (B) the number and type of repositories required to be constructed to provide such disposad capacity; (C) a schedule for the construction of such to- 
Publication in Federal Register. Public inspection and agency comments.

Plan submittal to congresstonal comtmittees.

42 USc 10222

Fees. positories; and (D) an estimate of the period during which each repository listed in such schectule will be accepting high-level radioactive waste or spent nuclear frel for disposal;

(10) an estimate, on an annual basis, of the costs required (A) to construct and operate the repositories anticipated to be needed under paragraph (9) based on each of the assumptions referred to in such paragraph; (B) to constuct and operate a test and evaluaton facility, or any other facílities, other than ropositories d*siribed to subparagraph (A), determined to be necessary; and (C) to carry out any other activities under this Act; and

(11) an idsntification of the posstble adverse economic and oth,er impacts to the State or Indian tribe irvolved that may arise from the developurent of a test and evaluation facility or repository at a site.

(b) Submission Of Mission Plan.-(1) Not later than 15 months after the date of the enactment of this Act, the Secretary shall submit a draft mission plan to the States, the affected Indian tribes, the Comnission, and other Government agencies as the Secretary deems appropriate for their comments.

(2) In preparing any conments on the mission plan, such agencies shali specify with precision any objections that they may have. Upon submission of the mission plan to such agencies, the Secretary shall publish a notice in the Federal Register of the suimisssion of the mission plan and of its avalability for public Inspection, and, upon receipt of any consnents of such agencies respecting the misston plan, the Secretary sball publish a notice in the Federal Register of the recetpt of comnents and of the availability of the comments for public insplection. If the Secretary does not revise the mission plan to meet objections specified in such comments, the Secretary shall pub]ish in the Federal Register a detailed statement for not so revising the mission plan.

(3) The Secretary, after reviewing ayy other comments made by such agencies and revising the mission plan to the extent that the Secretary may consider to be appropriate, shall submit the mission plan to the appropriate commitrees of the Congress not later than 17 montbs after the date of the enactment of this Act. The mission plan shall be used by the Secretary, at the end of the first period of 30 calendar days (not including any day on which either House of Congress is not in session becauss of adjournment of more than 3 calendar days to a day certaini) following receipt of the mission plan by the Congress.

\section{NUCLEAR WASTE FUND}

Sec. 302. (a) Contracts,-(1) In the performance of his functions under this Act, the Sectetary is authorized to enter into contracts with any person who generates or holds title to higb-kevel radionctive waste, or spent muclear fuel, of domestic origin for the acoeptance of title, subsequent transportation, ardi dispostal of such waste or spent fuel. Such contracts shall provide for payment to the \$tcretary of fees pursuant to partigraphs (2) and (3) sufficient to offset expenditures in subsection (d). 
Feess.

Ante, p. 2229.

Collection and payment procedures. Roview.

Transmittal to Congress.

42 USC 6421
(2) For electricity generated by a civilian nuclear power reactor and sold on or after the date 90 days after the date of enactonent of this Act, the fee under paragraph (1) shall be equal to $1.0 \mathrm{mil}$ per kilowatt-hous.

(3) For spent nuclear fucl, or solidified high-level radioactive waste derived from spent nuclear fuel, which fuel was used to generate electricity in a civilian nuclear power reactor prior to the application of the fee under paragraph (2) to such reactor, the Secretary shall, not later than 90 days after the date of enactment of this Act, establish a 1 time fee per kilogram of heavy metal in spent muclear fuel, or is solidified bigh-level radioactive waste. Such fee shall be in amount equivalent to an average charge of 1.0 mil per kilowatt-hour for electricity generated by such spent auclear fuel, or such solidified high-level waste derived thereErom, to be collected from any person delivering such spent nuclear fuel or hight-level waste, pursuant to section 123, to the Federal Gov* eriment. Such fee shall be paid to the Treasury of the Uaited States and shall be deposited in the separate fund established by stbsection (c) 126(b). In paying such a fec, the person delivering spent fuel, or solidised high-level radioactive wastes derived therefrom, to the Federal Government shall have no further financial obligation to the Federal Government for the long-term storage and permanent disposal of sach spent fuel, or the solidified high-level radioactive waste detived therefrom.

(4) Not later than 180 days after the date of enactment of this Act, the Secretary shall establish procedures for the collection and pryment of the fees established by paragraph (2) and paragraph (3). The Secretary shall annually review the amount of the fees established by paragraphs (2) and (3) above to ovaluate whether collection of the fee will provide sufficient revenues to offset the costs as defined in subsection (d) herein. In the event the Secretary determines that either insufficient or excess revennes are being collected, in order to recover the costs incurred by the Federal Government that are specified in sulbection (d), the Secretary shall propose an adjustment to the fee to insure full cost recovery. The Secretary shail immediately transmit this proposal for such an adjustment to Congress. The adjusted fee proposed by the Secretary shall be effective after a perion of 90 days of continuous session have elapsed following the receipt of such transmittal unless during such 90-day period either House of Congress adopts a resolution disapproving the Secretary's proposed adjustment in accordance with the procedures set forth for congressional teview of an energy action under section 551 of the Energy Policy and Conservation Act.

(5) Contracts entered into under this section shall provide that-

(A) following commencement of operation of a repasitory, the Secretary shall take title to the high-level radioactive waste or spent muclear fuel involved as expectitiously as practicable 
Disposal services, terms and conditions. License Jennewal or issuạice.
Disposal of radioactive waste or spent ruclear fucl. upon the request of the gexerator or onner af such waste ar spent fuel; and

(B) in return for the payment of fees established by this section, the Secretary, beginning not later than Jasuary 31, 1998, will dispose of the high-level radioactive waste or spent naclear fuel involved as provided in this subtitle.

(6) The Secretary sball establish in writing criterita setting forth the terms and conditions under which such disposal services shall be made available.

(b) Aovance Contracting Requirement-(1) (A) The Commission shall not issue or renew a license to any person to use a utilization or production facility under the authority of section 103 or 104 of the Atomic Energy Act of 1954.(42 USC 2133, 2134) unless-

1. (i) such person has entered jnto a contract with the Secretary under this section; or

(ii) the Secretary affirms in writing that such person is actively and in good faith negotiating with the Secretary for a contract under this section.

(B) The Cornmisstón, as it deems necessary or appropriate, may require as a precondition to the issuance or tenewal of a license under section 103 or 104 of the Atomic Energy Act of 1954 (42 U. S. C. 2133, 2134) that the applieant for such license shall have entered into an agreement with the Secretary for the disposal of high-level radioactive waste and spent nuclear fuel that may result from the use of such license.

(2) Except as provided in paragraph (1), no spent nuclear fuel or bigh-level radioactive waste generated or owned by any person (other than a department of the United States referred to in section 101 or 102 of titte 5, United States Code) may be disposed of by the Secretary in any repository constructed under this Act unless the generatort or owner of such spent fuel or waste has entered into a contract with the Secretary under this section by not later than--

(A) June 30, 1983; or

(B) the date on which such generator or owner complences generation of, or takes title to, such spent fuel or waste; whichever occurs later.

(3) The rights and duties of a party to a contract entered into under this section may be assignable with transfer of title to the spent nuclear fuel or high-leve],radioactive waste involved.

(4) No high-levet radioactive waste ot spent nuclear fuel generated or owned by any departatent of the United States referted to in section 101 or 102 of title 5, United States Code, may be disposed of by the Secretary in any repository constructed under this Act unless such deparment transfers to the Secretary, for deposit in the Naclear Waste Fund, amounts equivalent to the fees

, that would be paid to the Secretary under the contracts referred to in this section if stich waste or spent fiel were generated by any' other person. 
Ante, pp. 2205, 2245.

Ante, pp. 2220, $2225,2253$.

Report to

Budget submitral. (c) Establishment Of Nudear Waste Fund.-There hereby is established in the Treasury of the United States a separate fund, to be known as the Nuclear Waste Fund. The Waste Fund shall consist of-

(1) all recejpts, moceeds, and recoverites realized by the Secretary under subsections (a), (b), and (e), whtch shall be deposited in the Waste Fund immediately upon their realization;

(2) any appropriations ubade by the Congress to the Waste Fund; and

(3) any unexpended balances available on the date of the enactment of this Act for functions or activities necessary or incident to the disposal of civilian high-level radioactive waste or civilian spent nuclear fuel, which shall automatically be transferred to the Waste Fund on such date.

(d) Use Of Waste Fund.-The Secretary may make expenditures trom the Waste Fund, subject to subsection (c), only for purposts of radioactive waste disposel actrivities tpoder titles I and II, inchuding-

(1) the jdentification, development, licensing, construction, op eration, decommissioning, and past-decommissioning maintenance and monitoring of any repository, monitored retrievable storage facility or test evaluation facility constructed under this Act;

(2) the conducting of nongeneric research, development, and demonstration activities under this Act;

(3) the administrative cost of the radioactive waste disposal program;

(4) any costs that may be uxaurred by the Secretary in connection with the transportation, treating, or packaging of spent nuclear fuel ar high-Jevel radioactive waste to be disposed of fn a reposito$r y$, to be stored in a montored, retritwable storage site or to be used in a test and evaluation facility;

(5) the costs associated with acquisition, design, modification, replacement, operation and construction of facilities at a repository site, a monitored, retrievabie storage site or a test and evaluation facility site and necessary or incident to such repository, monitored, remievable storage facjlity or test and evaluation facility; and

(6) the provision of assistance to States, thits of general local gowernment, and Indian tribes nnder sections 116, 118 and 219.

No amount may be expended by the Secretary under this subtitk for the construction or expansion of any tacility unless such construction or expansion is expressly authorized by this or subsequent lepislation. The Secretary hereby is authorized to construct one repository and one test and evaluation facility.

(e) Adninistration of Whete Fund-(1) The Sectetaty of the Treasury shall bold the Waste Fund and, after consultation with the Secretary, annually report to the Congress on the financtal condition and operations of the Waste Fund during the preceding fiscal year.

(2) The Secretary shall submit the budget of the Whaste Fund to the Office of Management and Butget triennially along with the budget of the Department of Energy submitted at such toine in 
Ants, p. 907.

Anle, p.927.

Ante, p.937. accordance with chapter II of titte 31, United States Code. The budget of the Waste Fund shall consist of the estimates made by the Secretary of expenditures from the Waste Fund and other relevant financial matters for the succeeding 3 fiscal years, and shall be included in the Budget of the United States Government. The Secretary may make expenditures from the Waste Fund, subject to appropriations which sball remain available until expended. APpropriations shall be subject to trienuial authorization.

(3) If the Secretary determines that the Waste Fund contains at any time amounts frexcess of current needs, the Secretary may request the Secretary of the Treasury to inpest suct amounts, or any portion of such amounts as the Secretary determites to be appropriate, in obtigations of the United States-

(A) having Inaturities cetermined for the Sectetary of the Treasury to be appropriate to the neects of the Waste Fund; and

(B) bearing interest at rates detemined to be appropriate by the Secretary of the Treasury, taking into consideration the current average market yield on otrtstanding marketable obligations of the Untted States with remaining periods to matufity comprarable to the maturities of such investments, except that the juterest mate on such investments shell not exceed the average interest rate applicable to existing borrowings.

(4) Receipts, proceeds, and recoveries realized by the Secretary under this section, and expenditures of amounts from the Waste Fund, shall be exempt from annual apportionment under the provisions of sub. chapter II of chapter 15 of tite 31, United States Code.

(5) If at any time the moneys avaibable in the Waste Furd are insuffcient to enable the Secretary to discharge his respansibilitites under this subtitle, the Secretary sball issue to the Secretary of the Tretesury obligations in such forms and denominations, bearing such maturities, and subject to such terms and conditions as may be agreed to by the Secretary:and the Secretary of the Treasury. A total of stach obligations shall not exceed anounts prowided in appropitation Acts. Redemption of such obligations shall be made by the Secretary from moneys available jn the Waste Fund:Such obligations shall bear interest at a rate determined by the Secretary of the Treastry, which shall be not less than a rate determined by takjig into consigeration the average market yield on cutstanding marketable obligations of the United States of comparable maturities during the month preceding the issuance of the obligations under this paragraph. The Secretary of the-Treasury shall purchase any issued ob]igations, and for such purpose the Secretary of the Treasury is authorized to use as a public debt transactions the proceeds from the sale of any securities issued under chapter 31 of title 31. United Statss Codt, and the ptrposes for whteh securities may be issued under such Act are extended to include any purchase of such obligations. The Secretary of the Treasury may at any time sell any of the obligations acquiced by him under this paragraph. All Jedentptions, purchases, and salies by the Secretary of the Treasury of obligations under this parabraph shall be treated as pubiic debt transactions of the United States. 
Interest payments.

Deferral,

Sturty. 42 USC 10223 .

Report to Congress.

42 USC 10224.

Report to Congress.

42 USC 10225.
(6) Any appropriations made available to the Waste Fund for any pur* pose descrtbed in subsection (d) shafl be repaid into the general find of the Treasury, together with interest from the date of avallability of the appropiations until the date of repayment. Such interest shall be paid on the cumulative amount of appropitations available to the Waste Fund, less the average undisbursed cash balance in the Waste Fund account during the fiscal year inwolved. The rate of such interest shall be determined by the Secretary of Treasury talcing into consideration the grerage market yield during the month preceding each fiscal year on outstanding marketable obligations of the United States of comparable maturity. Interest payments may be deferred with the approval of the Secretary of the Treasury, but any interest paytnents so deferred shall themselves bear interest

\section{AlTFRN'THE MTANS OF FINANCTNC}

Sec. 303. The Secretary shall undertake a study with respext to alternative approaches to manging the construction and operation of all civilian radioactive waste management facilities, inckuding the feasibility of establishing a private corporation for such purposes. In conducting such study, the Secretary shall corrult with the Director of the Office of Management and Budget, the Chairman of the Commission, and surch other Federal agency representatives as may be appropriate. Such study shall be completed, and a report contajning the results of such study shall be submitted to the Congress, within 1 year after the date of the enactiment of this $A C$.

\section{OFFICE OF CIVILIAN RADUOACIIVE WASTE MANAGEMENI}

Sec. 304. (a) Establishment.-There hereby is established within the Department of Energy an Office of Civilan Radioactive Waste Management. The Office shall be headed by a Director, who shall be appoirted by the President, by and with the atvice and consent of the Senate, and who shall be compensated at the rate payable for level IV of the Exectitive Schedułe under section 5315 of tirle 5, Ǔnited \$tates Code. "

(b) Functions of Director.-The Director of the Office shall be responsible for carrying out the finctions of the Secretary under this Act, subject to the general supervision of the Secretary. The Director of the Office shall be directly responsible to the Secretary.

(c) Annual Report To Congress.-The Director of the Office shall annually prepare and submit to the Congress a comprehensive report on the activities and expenditures of the Office.

(d) Arnial Audit By Comptroller General.-The Comptroller General of the United States shall ansually make an audit of the Office, in accordance with such regulations as the Comptroller General may prescribe. The Comptroller Genoral shall have access to such books, Itcords, accounts, and other materjals of the Office as the Comptrol]er General determines to be necessary for the preparation of such audit. The Comptroller General shall submit to the Congress a report on the results of each audit conducted under this section.

\section{LOCATION ÓFTEST AND EVALUATION FACTLIYY}

Sec. 305. (a) Report To Congress.-Not later than 1 year after the date of the enactment of this Act, the Secretary sball transmit to the 
Ante, p. 2066.

Congress a report setting forth whether the Secretary plans to locate the test and evaluation facility at the site of a repository.

(b) Procedures - (I) If the test and evaluation facility is to be located at any candidate site or repository site (A) site selection and devekopmont of such facility shall be conducted in accordance with the procedures and requirements established in title I with respect to the site selection and development of repositories; and (B) the Secretary may not commence constsuction of any surface facility for such tests and craluation facility frior to issuance by the Commission of a construction authorization for a repository at the site involved.

(2) No test and evaluation facility may be converted into a repository unless site selection and development of such facility was conducted in accordance with the procedures and requirements established in title I with respect to the site selection and development of repositories.

(3) The Secretary may not commence construction of a test and evaluation facility at acandidate site or sste recommended as the location for a repository prior to the date on which the designation of such site is Anie, p. 2217, effective upder section 115.

NUCLEAR KEGULATORY COMMISEION TRAINING AUTHORIZTION

Regutations or giidance.

42 USC 10226.

Report to

Congress.

sec. 306. Nuclear Regulatory Commission Training Authorization. -Tbe Nuclear Regulatory Commission is authorized and directed to promulgate regulations, or other appropriate Commission regulatory guidance, for the training and qualincations of civilian nuclear powerplant operators, supervisors, texhnicians and other appropriate operating personitel. Such regulations or gujdance shall establisti stomulator training requftements for applicants for civiliar muclear powerplant operator licenses and for operator Iequalification prograns; requirements governists NRC acininistration of requalification examinations; requirements for operatiog tests at civilian nuclear powerplant simulators, and instructional requirentents for civilian nuclear porerplant licersec personnel training programs. Such regtlations or other regtulatory guidance shall be promulagated by the Comsoission within the 12-month period following enactment of this Act, and the Commission within the 12-month period following enactment of this Act shall stomit a report to Congress setting forth the actions the Comulission has taken with respect to fulfilling its obligations under this section. Approved Jamuary $7,1983$.

\section{* TITLE TH-NUCLEAR WASTE NEGOTMATOR}

42 USC 10241. Sec'401. For purposes of this title, the term 'State' means each of the several States and the District of Columbia 16

THE OFICE OR THE NUCLRAR WASTE NEGOMATOR

42 USC 10242. Sec. 402 (a) Establishment.-There is established the Office of the Nuclear Waste Negotiator that sball be an independent establishonent in the executive branch. 15

President of U.S. (b) The Nuclear Waste Negotiator-(1) The Office shall be beaded by a Ntulear Waste Negotiator who siall be appointed by the President,

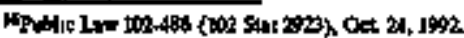

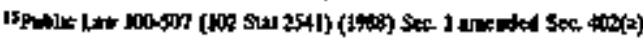


by and with the atvice and consent of the Senate. The Negotiator shall hold office at the pleasure of the President, and shall be compensated at the rate provided for level III of the Executive Schedule in section 5314 of title 5, United States Code.

(2) The Negotiator shall attempt to find a state or Indian tribe willing to host a repository or monitored retrievable storage facility at a teckinically qualified site on reasonable terms aild shall ne. gotiate with any State or Indian tribe which expresses an interest in hosting a repository or monitored retrievable storage facility.

\section{DUIIES OF THE NEGOTHTOR}

42 USC 10243.

Sec, 403. (a) Negotiations With Potential Hosts.-(1) The Negotiator shall-

(A) seek to enter finto negotiations on bebalf of the Lnited States, with-

(i) the Governor of any State in which a potential site is located; and

(ii) the gowerning body of any Indian tribe on whose reservation a potential site is located; and

(B) atrempt to reach a proposed agreement between the United States and ang such State or Indian tribe specifying the terms and conditions under which such State or tribe would agree to host a repostory of monitored retrievable storage facility within such State or teservation.

(2) In any case in which State law anthorizes any person or entity other than the Governor to negotiate a proposed agreement under this section on behalf of the State, any reference in this title to the Governor shal! be considered to refer instead to such other person or entity.

(b) Consultation Wth Affected States, Subdivistons Of States, And Tribes.-In addition to entering into negotiations under subsection (a), the Negotiation shall consult with any State, affected unit of local government, or any Indian tribe that the Negotiator determines may be affected by the siting of a tepository or motitored tetrievable storage facility and may include in any jroposed agzeement such terms and conditions relating to the interest of such States, affected units of local goverminent, or lindian tribes as the Negostator deterinines to be reasonable and appropriate.

(c) Consultation With Other Federal Agencies.-The Negotiator may solicit and consider the comments of the Secretary, the Nuclear Regulatory Commission, or any other Federal agensy on the suitability of any potential site for site characterization. Nothing in this subsection shall be construed to requitre the Secretary, the Nuclear Regulatory Commission, or any other Federal agency to make a finding that any such site is suitable for site characterization.

(d) Proposed Agreement_-(I) The Negotiator shall subuit to the Congress any proposed agreement between the United States and a State or Indian tribe negotiated under subsection (a) and an environmental assessment prepared under section 404(a) for the site concerned. 
(2) Any stuch propased agreement shall contain such terms and conditions (including such fnancial and institutional arrangements) as the Negotiator and the host State or Indian tribe determine to be reasonable and appropriate and shall contain such provisions as are necessary to preserve any right to participation or compensation of such State, affected umit of locel government, or Indian tribe under sections 116(c), 117, and 118(b).

(3) (A) No proposed agreentent entered into under this section shat have degal effect unless enacted into Federad law.

(B) A State or Indian tribe shall enter into an agreement under this Section in accordance with the laprs of such State or tribe. Nothing in this section utay be construed to probibit the disapproval of a proposed agreement between a State and the United States under this section by a referendunt or an act of the legislature of such Stàte.

(4) Notwithstanding any proposed agrement under this section, the Secretary may construct a repository or monitored retrituable storage facility at a site agreed to under this titte only if authorized by the Nuclear Regulatory Commistion in acoondance with the Atomic Energy Act of 1954 (42 U.S.C. 2012 et seg,), title II of the Energy Reorganization 'Act of 1982 ( 42 U.S.C. 5841 et seq.) and any other law applicable to authorization of such construction.

42 USC 10244.

\section{ENYIRONMIINTAL ASSESSMENT OF STTES}

Sec. 404. (a) In General.-Upon the request of the Negotiator, the Secretary shall prepare an environnental assessngent of any site that is the subject of negotiations under section 403 (a).

(b) Contents.-(1) Eacil ervitonmental assessment prepared for a repository site shall inchude a detailed statement of the probable inopacts of characterizing such site and the construction and operation of a repository at such site. 1. 1

(2) Each emvirommental assessment prepared for a monitored retrievable storage facility site shall include a detailed statement of the probable impacts of construction and operation of such a facility ar such site,

(c) Judicial Review,-The issuance of as environmental assessment under subsection (a) shall be considered to be a fonal agentcy action subject to judicial review in accordance with the provisions of chapter 7 of tite 5, United States Code, section 119.

(d) Public Hearings.- (1) In preparing an envinonmental assessment for any repository or monitored retrievable storage facility site, the Secretary shall hold public hearings in the vicinity of such site to inform the residerts of the area in which,such site is located that such site is being considered and to receive their comments.

(2) At such hearings, the Secretary shall solicit and receive any recommendations of such residents with respect to issues that should be addressed in the environmental assessment required under subsection (a) and the site characterization plan described in section 113 (b) (I). 
(c) Public Avadability.-Each environtaental assessment prepared under subsection (a) shall be made available to the public.

(f) Evaluation Of Sites.-(1) In preparing an environmental assess. ment under subsection (a), the Secretary shall use available geophysi$\mathrm{cal}$, geologic, geochemical and bydrologic, and other informationt and shall not conduct any preliminary borings or excawations at aby site that is the subject of such assessment unless-

(A) such preliminary boring or excavation activities were in progress on or before the date of the enactment of the Nuckeas Waste Policy Amendments Act of 1987; or

(B) the Secretary certifies that, in the absence of preliminary borings or excavations, actequate information will not be available to satisfy the requirements of this Act or any ather law.

(2) No prelimigary boing or excavation conducted under this section shall exceed a diameter of 40 inches.

42 USC 10245. Sec. 405. (a) Stte Ciaracterization,-Upon enactment of legislation to toplement an agreenent to site a repository nesotiated under sectoon 403(a), the Secretary shall conduct appropriate site characterization activities for the site that is the subject of such agreement subject to the conditions and terms of such agreement. Any such site characteriza. tion activities shall be conducted in acoordance with section 113, except that references in such section to the Yucoa Mountain site and the State of Nevada shall be deemed to refer to the site that is the subject of the agreement and the State of Indian tribe entering into the agreement.

(b) Leensing.-(1) Upon completion of site characterization activities carrited out under subsection (a), the Secretary shall submit to the Nuctear Regulatory Commission an application for construction anthorization for a repository at such site.

(2) The Nuclear Regulatory Commission shall consider an application for a construction authorization for a repository ormonitored retriewable storage facility in accordance with the laws applicable to such applications, except that the Nuclear Regulatory Commission shall issue a final decision approving of disapproving the issuance of a construction authorization not later than 3 years after the date of the submission of such application.

\section{MONITORED RETRISVAHIP STORAGE}

42 USC 10246. Sec. 406. (a) Construction And Operation-Upon enactment of legislation to implement an agreement negotiated under section 403(a) to site a monitored retrievable storage facility, the Secretary shall construct and opesate such facility as part of an integrated nuclear waste management system in accordance with the terms and conditions of such agreement.

Granks . (b) Finaxial Assistance--The Secretary may make grants to any State, Indian tribe, or affected unit of local government to assess the feasibility of siting a monitored retrievable storage facility under this section at a site under the jurisdiction of such State, tribe, or affected unit of local government. 


\section{ENYIRONMEFTAL IMPACT STATRMENT}

42 USC 10247. . Sec. 407. (a) In General.-Issuance of a construction authorization for a repository or monitored retrievable storage facility under section 405 (b) shall be considered a major Federat action significantly affecting the quality of the human envicomment for perposes of the National Exvironmeptal Policy Act of 1969 (42 U.S.C. 4321 et seq.)

(b) Pieparation.-A final envitommental impact statement shall be prepared by the Secretary under such Act and shall accompany any application to the Nuctear Regulatory Commission for a coistriction authorization.

(c) Adoption-(1) Any such envinonmental inapect stateruent shall, to the extent practicable, be adopted by the Nuclear Regulatory ComEnission, in accordance with section 1506.3 of title 40 , Code of Federal Regulations, in connection with the issuance by the Nucleas Regulatory Conmission of a construction authorization and license for such reposjtory or monitored retrievable storage factity.

(2) (A) In any such statemogt prepared with respect to a repository to be constructed under this tite at the Yucce Mountain site, the Nuclatar Regulatory Commission need not consider the need for a repository, the time of initial availability of a repository, altersiate sites to the Yucea Mountain site, or nongeologic alternatives to such site.

(B) In any such statement prepared with respect to a repository to be constructed under this tikle at a site other than the Yucta Mountain site, the Nuclear Regulatory Commission need not consider the need for a repository, the time of initial availability of a repository, or nongeologic alternatives to such site but shall consider the Yucoa Mountain site as alternative to such site in the preparation of such statement.

42 USC 10248.

\section{ADMTNISTRATTE POWIRS OFTHE NEECOCATOR}

Sec. 408. In carrying out his functions under this title, the Negotiator may-

(1) appoint such officers and employtees as he determines to be necessary and prescribe their duties;

(2) obtain services as atuthorized by section 3109 of title 5 , United States Code, at rates not to exceed the rate prescribed for grade GS-18 of the General Schedile by section 5332 of title 5 , United States Code;

(3) promulgate such rules and Jegulations as may be necessary to carry out such functions;

(4) utilize the services, personnel, and factlities of other Federal agencies (stbject to the consent of the bead of any such agency);

Contracts.

(5) for purposes of performing administrative functions urider this title, and to the extent funds are appropriated, enter into and perform such contracts, leases, cooperative agreements, or other tuanstactions as may be necessary and an such terms as the Negotator deternilues to be appropitate, with any agency or institumentality of the United States, or with any pubtic or private person or entity; 
(6) accept voluntary and uscomperstated services, notwithstanding the provisions of section 1342 of title 31 , United States Code;

(7) adopt as offictal seal, which stall be judicially noticed;

(8) use the United States mails in the same mamner and under the same conditions as other departments and agencies of the United States;

(9) hold such hearings as are necessary to determine the views of interested parties and the general public; and

(10) appoint atvisory committees under the Federal Aitvisory Compittee Aat (5 U.S.C. App.)

COOPERATION OF OTHER DEPARTMINMTS AND AGMNCIES

42 USC 10249. Sec- 409. Each department, agency, and instnmmentality of the United States, inctuding anty independent agency, may furnish the Negotiator such information as he determines to be necessary to cany out his funcetions under this titit.

TERMITATHON OF THE OFFICE

42 USC 10250. ' Sec. 410. The Ofifice shall cease to exist not later than 30 days after the date 7 years after the date of the enactment of the Nuclear Waste Policy Amendiments Act of 1987.17

\section{AUTHORIZATION OF APPROPRLTIONS}

42 USC 10251. Sec. 411. Notwithstanding subsection (d) of section 302, and subject to subsection (e) of such section, there are abthorized to be appropriated for expenditures from amounts in the Waste Fund established in subseetion (c) of such section, such surals as maty be necessary to carry out the provisions of this title. ${ }^{18}$

\section{TITLE V-NUCLEAR WASTE TECHNICAL REVIEW BOARD}

2 Usc 10261,

Sec, 501. As used in this title:

DEFINITIONS

(1) The term 'Chairman' means the Chairman of the Nuctear Waste Technical Review Board.

(2) The temB 'Board' means the Nuclear Waste Tectintiol Review Board established under section 502 .

NUCLEAR WASTE TECHNICAL REVIEW BOARD

2 USC 10262. Sec. 502. (a) Establishment.-There is estabijshed a Nuclear Waste 'Techyical Review Bowrd that shatl be an independent establishment within the execultive branch.

President of US. (b) Menbers - (1) The Board shall consist of 11 members who shall be appointed by the President not later than 90 days after the date of the enactment of the Nuclear Waste Policy Amendments Act of 1987 from among persons nominated by the National Academy of Sciences in accordance with paragraph (3).

President of U.S. (2) The President shal designate a member of the Board to serve as chairman.

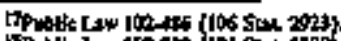

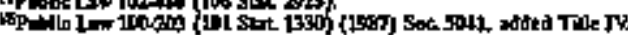


(3) (A) The National Acadeny of Sciences shall, not latter than $90 \mathrm{days}$ after the date of the enactment of the Nuclear Waste Policy Amendments Act of 1987, nominate not less than 22 persons for appointment to the Board from aniong persons who met the qualifications described in subparagraph (C).

(B) The National Acadenty of Sriences shall nominate not less than 2 persons to fill any vacancy on the Board from among persons who meet the qualifications described in subpara, praph (C).

(C) (i) Each person nominated for appointment to the Board shall be-

(I) eminent in a tield of science or engineering, inchuding environmental sciences; and

(II) selected solely on the basis of established records of distinguished service.

(ii) The membership of the Board shall te representa-

1 'bive of the broad range of scientifice and engineering disciplines related to activities under this title.

(iii) No person shall be norrinated for appointment to the Board who is an employee of-

(I) the Department of Energy;

(II) a national laboratory under contract with the Department of Energy; or

(III) an entity performing high-level radioactive 1 waste or spent nuclear fuel activitios under contract with the Department of Energy.

(4) Any vacancy on the Hoard shall be filled by the nomination and appointment process described in paragraphs (1) and (3).

(5) Members of the Board shall be appointed for terms of 4 years, each such term to commence 120 days after the date of enactment of the Nuclear Waste Policy Aunendments Act of 1987 , exoept that of the 11 members first appointed to the Board, 5 shall serve for 2 years and 6 shall serve for 4 years, to be designated by the President at the time of appointrnent.

42 USC 10263.

BUNCTIONS

Sec 503. The Board shall evaluate the technical and scientific valjdity of activities uidertaken by the Secretary after the date of the enactment of the Ntrclear Waste Policy Amendments Act of 1987, tochuding-

(1) site characterization axtivities; and

(2) activities relating to the packaging 'or transportation of high-

level radióactive waste or spent muclear fuel.

\section{INVESTIGATORY POWERS}

42 USC 10264. Sec.504. (a) Hearings,-Upon tequest of the Chairman or a majority of the members of the Board, the Board may hold such hearings, sit and act at such times and places, take stch testimony, and receive such evidence, as the Board considers appropriate. Any meinber of the Board may administer oaths or affimations to witnesses appearing before the Board. 
(b) Production Of Documents.-(1) Upon the reguest of the Chairman or a majority of the members of the Boand, and subject to existing law, the Secretary (or any contractor of the Secretary) shall provide the Board with such records, files, papers, data, or information as may be necessary to respond to any finquiry of the Baard under this title.

(2) Subject to enisting law, information obtainable uoder peragraph (1) shall not be linited to final work products of the Secretary, but shall inctude drafts of such producis and documentation of work in progress.

42 USC 10265.

\section{COMPENSATION OF MEMIBERS}

Sec. 505. (a) In General. Each mernber of the Board shell be paid at the rate of pay payable for Jevel III of the Executive Schedule for each day (including travel time) such member is engaged in the work of the Board.

(b) Travel Expenses,-Each member of the Board may recejve trave] expenses, including per diem to lieu of stubsistence, in the sarne manner as is pertuitted under sections 5702 and 5703 of title 5, United States Code.

42 USC 10266.

\section{STAFF}

Sec. 506. (a) Clerical Staff.-(1) Subject to paragraph (2), the Chair* man may appoint and fix the compensation of such clerical staff as may be necessary to discbarge the responsibilities of the Board.

(2) Clerical staff shall be appointed subject to the provisions of title 5, United States Code, governing appointments in the competítive service, and shall be paid in accordance with the provisions of chapter 51 and subchapter III of chapter 53 of such title relating to classification and Gemerat Schedute pay rates.

(b) Ptofessional Staff.-(1) Subject to paragraphs (2) and (3), the Chajtian may appoint and tix the compensation of such professional staff as may be nectessary to discbarge the responsibilities of the Board.

(2) Not more than 10 professional staff members may be appointed under this subsection.

(3) Professional staff members may be appointed without regard to the provisions of title 5, United States Code, governing appoint. ments in the competitive service, and may be paid without regard to the provisions of chapter 51 and subchapter III of chapter 53 of such title rejating to classification and General Schedule pay rates, except that no individual so appointed may recejve pay in excess of the anyual rate of basic pay paytable of GS-18 of the General Schedule.

42 USC 10267. Sec. 507. (a) General Services,-To the extent permitted by law and requested by the Chairman, the Administrator of General Services shall provide the Board with necessary administrative services facilities, and support on a reimbursable basis.

(b) Accounting, Research, And Technology Assessment Services.The Comptroller General, the Librarian of Congress, and the Ditector of the Office of Technalogy Assessment shall, to the extent permitted by law and subject to the availability of funds, provide the Board with such 
facilitites, support, funds and servicus, including staff, as may be necessary for the effective performance of the functions of the Board.

( (c) Additional Support.-Upon the request of the Chairman, the Board may sectre directly from the head of any department or agency ${ }$ - of the United States information necessary to enable it to carry out this title.

(d) Mails.-The Board may use the United States mails in the same manuer and under the same conditions as other departuoents and agencies of the United States.

(e) Experts And Consultants.-Subject to such rules as may be prescribed by the Board, the Chairman may procure temporary and inter; mittent services under section 3109 (b) of title 5 of the United States Code, but at rates for individuals not to exceed the daily equivalent of the maximum annual rate of basic pay payable for GS.18 of the General Sctiodule.

42 USC 10268. I

REPORT

Sec. 508. The Board shall report not less than 2 tiraes per year to Congress and the Secretary tis findings, conchusions, and recommendations. The first such report shall be submitted not later than 12 months after the date of the enactment of the Nuclear Waste Policy Amendments Act of 1987 .

\section{AUTAOATATION OP APPROPRIATIONS}

42 USC 10269. Sec. 509. Notwithstanding subsection (d) of section 302, and subject to subsection (e) of such stection, there are authorized to be appropriated for expenditures from amounts in the Waste Fund established in subsection (c) of such section such sums as may be necessary to carry out the provisions of this title.

\section{TERMINATION OF THE BOARD}

42 USC 10270. Sec. 510. The Board shall cease to exist not later than 1 year after the date on which the Secretary begins disposal of high-level radioactive waste or spent nuclear fuel in a repository. ${ }^{17}$

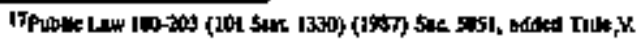




\section{OMNIBUS BUDGET RECONCIHATION ACT OF 1987}

Public Law 100-203

(101 Stat. 1330-251)

\section{TABLE OF CONTENTS}

PAGE USC

Sec-5062 Transportation of plutoxium by aireraft 42 USC

SEC

hưugh United States air space $+++\ldots \ldots \ldots+\ldots+\ldots+374$

5841 Nole

Sec.5064 Dry cask storage. . . . . . . . . . . . . . . . . . 375 
42 USC 5841

note.
Sec. 3062. Transportation Of Plutonium By Aircraft Through United States Air Space.-

(a) In General--Notwithstanding any other provision of law, no form of putonium may be transported by aircraft through the air space of the United States from a forejgn nation to a fareign nation unless the Nuclear Regulatory Commission has certified to Congress that the container in which such plutonium is transported is safe, as determined in accordance with subsection (b), the second undesignated paragraph under section 201 of Public Law 94-79 (89 Stat. 413; 42 U.S.C. 5841 atote), and all other applicable laws.

(b) Responsibilities of The Nuclear Regulatory Commission-

(1) Determination Of Safety.-The Nucfear Regulatory Commission stall determine whether the container refered to in subsection (a) is safe for use in the transportation of plutonium by aircraft and transmit to Congress a certification for the purposes of such subsection is the case of each container determined to be sale.

(2) Testing-In order to make a determination with respect to a container under paragraph (1), the Nuclear Regulatory Commissions shall.

(A) require an actual drop test from maximum cruising altitude of a full-scale sample of such container loaded with test materiaks; and

(B) require an actual crash test uf a cargo airctaft fully loaded with fuil-scale samples of such container loaded with test material unless the Commission determines, after consultation with an independent scientific review panel, that the stresses on the container produced by other tests used in developing the container exceed the stresses which would occur duritg a worst case plutonium air shipment accident.

(3) Limitation.-The Nuclear Reguiatory Commisston may not certify under this section that a container is safe for use in the transportation of plutonium by aircraft if the containat ruptured or released its contents during testing oondueted in accordance with paragraph (2).

(4) Evaluation,-The Nuctear Regulatory Commisston shall evaluate the container certification required by title II of the Energy Reorganization Act of 1974 (42 U.S.C. 5841 et seq.) and subsection (a) in accordance with the National Euvisonmental Policy Act of 1969 (83 Stat. 852; 42 U.S.C. 4321 et. seg.) and all other applicable law.

(c) Content Of Certification-A certification referred to in subsection (a) with respect to a container shall include-

(1) the detectrination of the Nuclear Regulatory Commission as to the safety of such containes,

(2) a statement that the requirements of subsection (b)(2) were satisfied in the testing of such container; and 
(3) a statement that the container did not rupture or release its contents into the ervironment during testing.

(d) Design Of Testing Procedures.-The tests required by subsection (b) shall be designed by the Naclear Regulatory Commission to replicate actual worst case transportation conditions to the maximum extent practicable. In designing such tests, the Commission shall provide for public notice of the proposed test procedures, provide a reasonable opporturity for public compent on suct procedures, and consider such comments, if any.

(e) Testitg Results: Reports And Public Disclosure.-The Nuclear Regulatory Commission shall transmit to congress a report on the results of each test conducted unier this section and shall make such results available to the public.

(f) Alternative Routes And Meang Of Transportation. W W th respect to any shipments of plutonium front a foreign nation to a forejgn pation which are subject to Untted States consent rights contained to an Agreement for PeacefuI Nuclear Cooperation, the President is authoirzed to make every effort to pursue and conclude arrangements for alternative routes and means of transpottation, including sea shipment. All such arrangements shall be subject to strintent physical stcurity conditions, and other conditions designed to protect the peblic bealth and safety, and provisions of this section, and all other applicable laws.

(g) Inapplicability To Medical Devices, - Subsections (a) through (e) shall not apply with respect to plutonium in any form contained in a medical device designed for incividual humas application.

(h) Inapplicability To Mtitary Uses.-Subsections (a) through (e) shall not apply to plutonium in the form of nuclear weapons nor to other shipments of plutonium determined by the Department of Energy to be directly connected with the United States national security or defense prograns.

(i) Inapplicability To Previously Certified Containers.-This section shail not apply to any containers for the shipment of plutonium previously certified as safe by the Nuclear Regulatory Commission under Public Law 94-79 (89 Stat. 413; 42 U.S.C. 5841 note).

(j) Payment Of Costs. All costs incirred by the Nuclear Regulatory Commission associated with the testing progism required by this section, and administrative costs related thereto, shall be reimbursed to the Nuclear Regulatory Commission by any foreign country receiving plutomium shipped through United States airspace in containers specified by the Commission. P $^{\circ}$

Sec 5064. Dry Cask Storage-

(a) Study.-During the period between the date of the exactment of the Nuclear Waste Policy Amendment Act of 1987 and October 1, 1988, the Secretary of Energy (hereinafter in this section referred to as the "Secretary") sball condiuct a stuhty and evaluation of the use of dry cask storage technology at the sites of civilian nuclear power reactors for the temporary storage of spent nuclear fise until such time as a permanent geologic repository has been constructed and licensed by the Nuclear

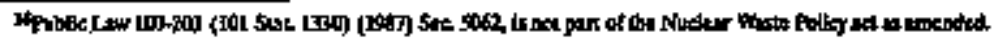


Reports.

Regulatory Commission (hereinafter in this section referred to as the "Commission" and is capable of receiving spent nuclear fuel. The Sectetary shall report to Congress of the study under this paragraph by October 1, 1988.

(b) Contents Of Study.-In conducting the study under paragraph (1) the Secretary shatl-

(1) consider the costs of dry cask storage technology, the extent to which aly cask storage on the site of civilian nuclear power reactors will affect buman bealth and the environment, the extent to which the storage on the sites of civilian nuclear power reactors affects the costs and risk of transporting spent nuclear fuel to a central facility such as a monitored retrievable storage facility, and any other factors the Secretary considers appropriate;

(2) consider the extent to which amounts in the Nuclear Waste Fund established in section 302(c) of the Nuclear Waste Policy Act of 1982 (42 USC 10222(c)) can be used, and should be used, to pro- vide funds to constuct, operate, maintain, and safeguard spent nuclear fuel in dry cask storage at the sites for civilian nuclear power reactors;

(3) consult with the Commission and inatude the views of the Conmission in the report under paragraph (1); and

(4) solicit the views of State and focal govermments and the public. 1

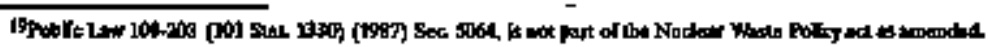


URANIUM MILL TAILNGS RADLATION CONTROL ACT OF 1978, AS AMENDED

Public Lati 95-604 [H.R. L3650]

(92 Stat. 3021)

An Act

SEOKT TITLE AND TABLE OB CONTENTS

TABLE OF CONTENTS

\begin{tabular}{|c|c|c|}
\hline & & \\
\hline & Short title and table of contents............. & $\begin{array}{c}42 \text { Usc } \\
\text { Sec. } \\
\ldots .7901\end{array}$ \\
\hline 2 & Findings and purposes................................ 378 & \\
\hline & TITLE I — REMEDIAL ACTION PROGRAM & \\
\hline $\begin{array}{l}\text { Sec. } 101 \\
\text { Sec. } 102 . \\
\text { Sec. } 103 \\
\text { Sec. } 104\end{array}$ & 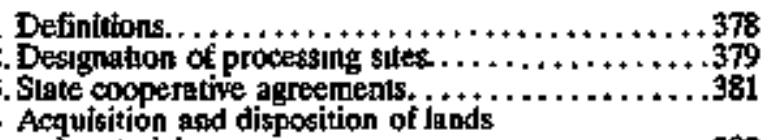 & $\begin{array}{r}\ldots 7911 \\
\cdots 7912 \\
\cdots 7913 \\
\cdots\end{array}$ \\
\hline $\begin{array}{l}\text { Sec } 105 . \\
\text { Sec.106. } \\
\text { Sec.107. } \\
\text { Sec.108. } \\
\text { Sect } 109 . \\
\text { Sec.110. } \\
\text { Sec.11. } \\
\text { Sec.112. } \\
\text { Sec.113. } \\
\text { Sec.114. } \\
\text { Sec.115. }\end{array}$ & 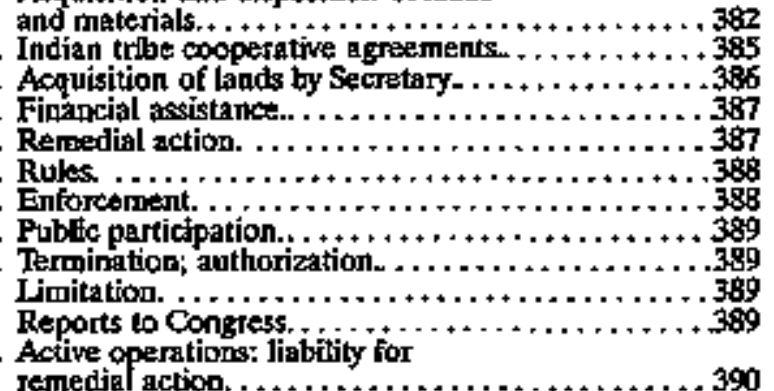 & $\begin{array}{r}7914 \\
7915 \\
7916 \\
77917 \\
7918 \\
7919 \\
7990 \\
7921 \\
7922 \\
7924 \\
7924 \\
7\end{array}$ \\
\hline
\end{tabular}

\section{TITE 1 — URANIUM MLL TAILINGS LICENSING AND} REGULATIONS

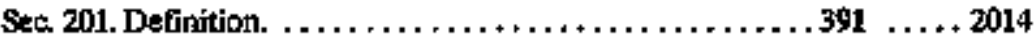

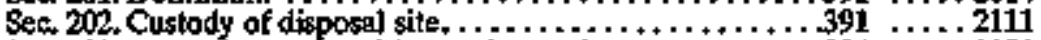

Sec. 203 . Authority to establisi certain requiremnents........ $394 \ldots \ldots 2201$

Sec. 204. Cooperation with States...................394 .....3021

Sec. 205. Authorities of Commission respecting

certain byproduct material..................398 ....2111

Sec. 206. Authority of Envitonmental Prolection Agepcy respecting certain byproduct

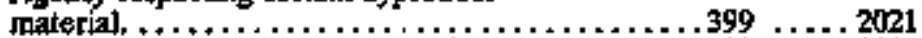

Sec. 207. Anthorization of appropriations for grants....... $400 \ldots+2021$

Sec. 208. Effective date, ........................ A01 ..... 2014

Sec. 209. Consolidation of licenses and

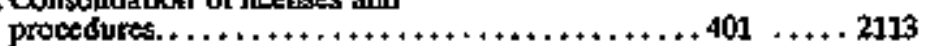

TITLE III - STUDY AND DESIGNATION OF TWO MILL TAILING SITES IN NEW MEXICO

Sec, 301, Sudy, $\ldots \ldots \ldots \ldots \ldots \ldots \ldots \ldots \ldots \ldots \ldots \ldots, 401 \ldots \ldots, 7941$ Sec, 302 . Designation by Secretary........................401 $\ldots \ldots .7942$ 
URANIUM MILL TAILINGS RADIATION CONTROL ACT OF 1978, AS AMENDED

Public Law 95-604

92 Stat. 3021

42 USC 7901.

\section{FINIDINGS AND PURPOSES}

Sec. 2. (a) The Congress finds that uranium mill tailings located at active and juactive mill operations may pose a potential and significant radiation health hazard to the publis, and that the protection of the public health, safety, and welfare and the regulation of interstate commerce require that every reasonable ffiont be made to provide for the stabjlization, tisposal, and control in a safe and envirounentally sound manner of such tailings is order to prevent or minimize radon diffusion into the environiment and to provent or minimize other envisonmental hazards from such tailings.

(b) The purposes of this Act are to provide-

(1) in cocperation with the jinterested States, Indjon tribes, and the persons who own or control iractive mill tailings sites, a progran of assessument and remedial action at such sites, jucluding, where appropriate, the reprocessing of taitings to extract residual urarium and other mineral values where practicable, in order to stabilize and control such tailings in a safe and environuentally sound manter and to minimize or eliminate radiation health hazards to the public, and

(2) a program to regulate mill tailings during uranium or thorium ore processing at active mill operations and after termination of such operations in order to stabilize and control such tailings in a safe and environmentally sound manner and to mínimize or elininate radiation bealth bazards to the public.

\section{TITLE I-RFMETLLL ACTION PROGRAM}

42 USC 791.

Sec. 101. For purposes of this title--

(1) The term "Secretary" means the Secretary of Energy"

(2) The term "Commission" meass the Nuciear Regulatory Commission.

(3) The term "Administrator" means the Administrator of the Environtuental Protection Agency.

(4) The term "Indian tribe" means any tribe, band, clan, group, pueblo, or community of Indians recognized as eligible for services provided by the Secretary of the Interior to Indians.

(5) The ters "person" means any individual association, partnership, corporation, firm, joint veature, trust, government entity, and anj other entity, except that such term does not include any Indian or Indian tribe.

(6) The term "proctsing site" theans-

(A) any site, inchuding the will, containing residual radioactive materials at which all or substantially all of the uranitum was produced for sale to any Federal agency prior to January 1 , 1971 under a contract with any Federal agency, except in the case of a site at or near Slick Rock, Colorado, unless- 
42 USC 2011

note.

42 USC2021.

42 USC 7912.

active materials denived from sich site.
Any ownership or control of an area by a Federal agency which is acquired pursuant to a cooperative agreement under this tille shall not be treated as ownership of control by such agency for purposes of subparagraph (A)(i). A license for the production of any uranium ptoduct from Iesidual radioactive materials shall not be treated as a license for production from ores within the meaning of subparagraph (A)(ii) if such production is in accordance with section $108(b)$.

(7) The terw "Iesidual radioactive material" means-

(A) waste (which the Sectetary deterimines to be radioactive) in the form of tailings resulting from the processing of ores for the extraction of urantum and other valuable constituents of the ores; and

(B) other waste (which the Secretary determines to be radioactive) at a processing site which relate to such processing, inclucing any residual stock of unprocessed ores or low-grade materials.

(8) The term "tailings" means the remaining portion of a metalbearing ore after some or all of such metal, such as uranium, has been extracted.

(9) The term "Federal agency" includes any executive agency as defined in section 105 of title 5 of the United States Code.

(10) The term "United States" mears the 48 contiguous States and Alaska, Hawaï, Puerto Rico, the District of Columbia, and the territories and possessions of the United States.

\section{DESIGNATON OF PkOCESTING STIR:}

Sec 102 (a)(1) As soon as practicable, but no later than one year after enactulent of this Act, the Secretary shall designate processing sites at or near the following locations:

Salt Lake City, Utah

Green River, Utah

Mexican Hat, Utah

Durango, Colorado

Grand Junction, Colorado

Rifle, Colorado (two sites)

Gunrison, Colorado

Naturita, Colorado 
Remedial action.

96. Stat. 222.

Heaith hazard assessment

Nobtfication.

\author{
Maybell, Colorado \\ Slick Rock, Colorado (tow sites) \\ Shiprock, New Mexico \\ Ambrosia Lake, New Mexico \\ Riverton, Wyoming \\ Converse County, Wyatring \\ Lakeview, Oregon \\ Falls City, Texas \\ Tutoa City, Arizona \\ Monument Valley, Arizona \\ Lowman, Idako \\ Canonsburg, Pennsyluaria
}

Subject to the provisions of titis title, the Secretary shall complete remedial action at the above listed sites before his authority terminates urder this title. The Secretary shal] within one year of the date of enactment-of this Act also designate all other processing sites within the United States which he determines requires remedial action to canry out the purposes of this title. In making such designation, the Secretary shall consult with the Administrator,' the Commission, and the affected States, and in the case of Indjan lands, the appropriate Indian tribe and the Secxetary of the Interior.

(2) As part of his designation 'under this subsection, the Secretary, in consultation with the Commission, shall detenmine 中e boundartes of each such site.

(3) No site or structure with respect to which remectial action is authorized under Public Law 92-314 in Grand Junction, Colorado, may be designated by the Secretary as a processing site under this section.

(b) Within one year from the date of the enactment of this Act, the Secretary shall assess the potential health hazard to the public from the rosidual tradionactive materials at destgnated processing sites. Based upon such assessment, the 'secretary shall, within such one year period, establissh priorities for carrying out remedial action at each such stite. In establishing such priorities, the Secretary shall rely primarily on the advice of the Administrator.

(c) Within thirty days after making designations of processing sites and establishing the priorities for such sites under this section, the Secretary shail notify the Governor of each affected State, and where appropriate, the Indtan tribes and the Secretary of the Interior.

(d) The designations made, and priorities established, by the Secretary under this section shall be final and not be subject to jucticial review.

(c)(1) The designation of processing sites within one year after enactment under this section shal include, to the maximum extent practicable, the azeas referred to in section 101(6)(B).

(2) Notwithstanding the one year timitation contained in this section, the Secretary may, after such one yeat period, include any areas described in section 101(6)(B) as part of a processing site designated under this section if be deternines such inclusion to be approptiate to carry out the purposes of this title. 
42 USC 791t.

42 Usc 7917.

42 USC 7913.

Terms and

Conditions.

Written

consent.

Waiver.
(3) The Secretary shall designate as a processing site within the meaning of section 101(6) any real property, or improvements thereon, in Edgemont, South Dakota, that-

"(A) is in the vicinity of the Tennessee Valley Authority uraanum suill site at Edgemont (but not including such site), and

${ }^{x}(B)$ is determined by the Secretary to be contaminated with residual radionctive materials.

In making the designation under this paragraph, the Secretary shall consult with the Administrator, the Commission and the State of South Dakota. The provisions of this titte shal] apply to the site so designated in the same manner and to the same extent as to the sites designated under subsection (a) except that, in applying such provisions to such site, any reference in this title to the date of enactment of this Act shall be treated as a reference to the date of the enactment of this paragraph and in deterninting the Stats share under section 107 of the costs of rentedial action, there shall be credited to the State, expenditures made by the State prior to the date of the enactment of titis paragraph which the Secretary defermines would have been made by the State or the United States in carrying out the requirements of this title.". ${ }^{1}$

\section{STATE COOPERATTE AGREEMENTS}

See 103. (a) After notifying a State of the designation referred to in section 102 of this title, the Sectetary subject to section 113, is authorized to enter finto cooperative apresment with such State to perform remedial actions at eech designated processing site in such State (other than a site location on Indian lands referred to in section 105). The Secretary shall, to the greatesk extent practicable, enter into such agree. ments and catry out such remedial actions in accordanee with the priorities established by him under section 102. The Secretary shall commeace preparations for cooperative agrements with respect to each designated processing site as promptly as practicable following the designation of each site.

(o) Each cooperative agreenent under this section shall contain such terms and conditions as the Secretary deems appropriate and consistent with the purposes of this Act, jacluding, but not timited to, a jinitation on the use of Federal assistance to those costs which are directly required to complete the remedial action selected pursuant to section 108 .

(c)(1) Except where the State is required to acquire the processing site as provided in subsection (a) of section 104, each cocperative agreement with a State under zection 103 shall prowide that the State shall obtain, in a form prescribed by the Secretary, written consent from any person holding any record interest in the designated processing site for the Sccretary or any person designated by him to perform remedial action at stech site.

(2) Such written consent shall include a waiver by each such person on behalf of himself, herself, his betits, successors, and assigns-

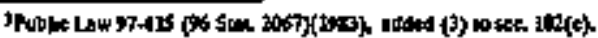


Past, p. 3059.

42 USC 7914.

(A) releasing the United States of any liability or claims thereof by such person, his heirs, successors, and assignts concerning such remedjal action, and

(B) holding the United States harmless against any claim by such person on bethalf of himself, his heirs, successors, or essigus arising out of the performance of any remedial action.

(d) Each cooperative agresment tinder this section shall require the State to assure that the Secretary, the Comntission, and the Admintistrator and their authorized representatives have a permantent right of entry at any time to inspect the processing site and the site provided pursuant to section 104(b))(1) in furtherance of the provisions of this title and to canry out sucla agreement and enforce this Act and any rules prescribed under this Act. Suct right of entry under this section or section 106 into an area described in section 101(6)(B) shall terminate on completion of the remedial action, as determined by the Secretary.

- (e) Each agreement under this section shall take effect only upon the concurrence of the Commission with the terms and conditions thereof.

(f) The Secretary may, in any cooperative agreement enter into this section or section 105, provide' for reimbursement of the actual costs, as determined by the Secretary, of any remedjal action performed with respect to so much of a designated processing site as is described in-sectoon 101(6)(B). Such reimbursement shall be made only to a property owner of reoord at the time such remedial action was undartaken and only with respect to costs incurred by such property owner. No such reinibursement may be made unless-

(I) such remedial action was completed prior to enactment of this Act, aind urless the application for such reimburse was filed by such owner within one yeat after a agreement under this section or section 105 is approved by the Secretary and the Commission, and

(2) the Secretary is satisfied that such action adequately achieves the purposes of this Act with respect to the site concerned and is corsistent with the standards established by the Administrator pursuant to section 275(a) of the Atomic Energy Act of 1954 .

\section{ACQUHSTRON AND DKSPSITON OF TANDS AND MATXRIALS}

Sec, 104. (a) Each cooperative agreement under section 103 shall require the State where determined appropriate by the Secretary with the concurrence of the Comsnission, to accuire any designated processing site, inchuding where appropriate any jiterest therein. In determining whether to require the State to acgutire a designated processing site or interest thertim, consideration shall be given to the prevention of windfall profits.

Residuat radfoactive material, (b) (1) If the Secretary with the cancurrence of the Commission determines that removal of residual tadioactive material from a processing site is approptiate, the cooperative agreement shall provide that the State shall asquire land (including, where appropriate, any interest therejin) to be used as a site for the permanent disposition and stabilization of such residual radioactive materials in a safe and environmentalby sound manner.

(2) Acquisition by the State shall not be required under this subsection if a sitte loctated on land coptrolled by the Secretary or 
made available by the Secretary of the Interior pursuant to section 106 (a)(2) is designated by the Sectetary, with the concurrence of the Comuassion, of such disposition and stabilization.

(c) No State shall be required under subsection (a) or (b) to acquire any real property or improvement outside the boundaries of-

(1) that portion of the processing site which is described in section 101(6)(A), and

(2) the site used for disposition of the residual radjoactive materials.

(d) In the case of tach processing site designated under this title other than a site designated on Indian land, the State shall take such action as may be necessary, and pursuant to regulations of the Secretary under this subsection, to assure that any person who purchases such a processing site after the removal of radioactive materials from such site shall be notified in any appropriate manner prior to such purchase, of the rature and extent of residual radioactive materials removed from site, including notice of the date when such action took place, and the condition of such site after such action. If the State is the owner if such site, the

Notification. State shall so notify any prospective purchaser before entering into a

Rutes and tegulations. contract, option or other arrangement to sell of otherwise cispose of such site. The Steretary shall issue appropriate rutes and tegalations to sequire notice in the tocal land records of the resichul radioactive materials which were located at any processing site and notice of the nature and extent of residual radioactive materials remtoved from the site, including notice of the date when such action took place.

(c)(1) The terms and conditions of any cooperative agreement with a State under section 103 shall provide that in the case of any lands or in. terests therein acquired by the State pursuant to subsection (a), the State, with the concurrence of the Secretary and the Commission, may-

(A) sell such lands and interests,

(B) permanently retain such land and interests in lands (or donate such lands and interests therein to another govenumental entity within such State) for permanent use by such State or entity solely for park, recreational, or other public purposes, or

(C) transfer such lands and interest to the United Sates as provided in subsection (f).

No lands may be sold under subparagraph (A) without the consent of the Secretary and the Commission. No site may be sold under subparagraph (A) ot retained under sulvparagraph (B) if stuch site is used for the disposition of residual radioactive materials.

(2) Before offering for sale any lands and interests therein which comprise a processing site, the State shall offer to sell such lands and interests at their fair market value to the person from whion the State acquited them.

(f)(I) Each agreernent under section 103 shall provide that title to-

(A) the residual radioactive materials subject to the agreement, and

(B) any lands and interests therein which have been acquired by the State, under subsection (a) or (b), for the disposition of 
Post, p.3059.

Fais market value.

such materials, shall be transferred by the State to the Secretary when the Secretary (with the concurrence of the Conmission) determines that remedial action is completed in accordance with the requirements impased pursuant to this title. No payment shall be made in connection with the transfer of such property from fund appropriated for parposes of this Act other than payments for any administrative and legal eosts incurred in carsying out stich transfet.

(2) Custody of any property transferred to the United States under this subsection shall be assumed by the Secretary or such Federal agency as the President may designate. Notwithstanding any other provision of law, upon completion of the remedial action program authorized by this title, sucti property and mínerals shall be maintained pursuant to a license issued by the Cornuission in such mannet as will protect the public health, safety, and the environment. The Conurission may, pursuant to such license or by rale or order, require the Sectetary or other Federal agency baving custody of such property and minerals to undertake such monitorjig. maintenance, and emergency measures necessary to protect public healtit and safety and other actions as the Cornmission deems necessary to comply with the standards of section 275 (a) of the Atomic Energy Act of 1954. The Secretary or such other Federal agency is authorized to carry out maintenance, monitoring and emergency measures under this subsection, but shal] take no other action pursuant to such license, rule or order witls respect to such property and minerals unless expressly authorized by Congress after the date of enectment of this Act. The United States shall not transfer title to property or interest therein acquired under this subsection to any person or State, except as prowided in subsection (b).

(g) Each agreement urder section 103 which permits any sale described in subsection (e)(1)(A) shalt provide for the proust retmbursement to the Sexretary forn the proceeds of such sale. Such retubursement shall be in an annount equal to the lesser of-

(1) that portion of the fair market value of the lands or interests therein which bears the same ratio to such fair market value as the Federal share of the costs of acquisition by the State to such lands or interest therein bears to the total cost of such acquisition, or

(2) the total amount paid by the Secretary with respect to such acquisition.

The fair market value of such lands or interest shall be determined by the Secretary as of the date of the sale by the State. Any amounts received by the Sectetary under this title shall be deposited in the Treastry of the United States as miscellaneous receipts.

(h) No provision of any agreement under section 103 shall prohtbit the Secretary of the Interior, with the concurrence of the Secretary of Energy and the Coramission, from disposing of any subsurface mineral rights by sale or lease (in accordance with laws of the United States applicable to the sale, lease, or other disposal of such rights) which are associated with land on which residual radioactive materials are disposed 
42 USC 7915 .

and which are transferred to the United States as tequired under this section if the Secretary of the Interior takes such action as the Commission deems necessary pursuant to a license issued by the Coumbission to assure that the residual radioactive materials will not be disturbed by Ieason of any activity carried on following such disposition. If any such materials are disturbed by any such activity, the Secretary of the Interior shall insure, prior to the disposition of the minerais, that such matenals will be restored to a safe and environmentally sound condition as determined by the Consnission, and that the costs of such restoration will be borne by the person acquiring such rights from the Sectetary of the Interior or from his successor or assign.

\section{INDLAN TRIBE COOPERATTVE AGREEMENTS}

Sec. 105. (a) After notifying the Indian tribe of the desigration pursuant to section 102 of this title, the Sectetary, in consultation with the Secretary of the Interior, is authorized to enter into a cooperative agreenent, stibject to section 113, with any Indian tribe to perform remedial action at a designated processing site located on land of such Indian tribe. The Secretary shall, to the greatest extent practicalble, enter into such agreements and carry out such remedial actions in accordance with the priorities estabFished by him under section 102 . In performing any remedial action under this section and fn carrytng out any continued montoring or maintenance respecting residual raơjoactive materials associated with any site stbject to a cooperative agreement under this section, the Secretary shall make fill use of any quatified nembers of Indian tribes resident in the vicinity of any such site. Each such agreement shall contain such terms and conditions as the Secretary deems

Terms and conditions. approptiate and consistent with the purpose of this Act. Such terms and conditions shall requite the following:

(1) The Indian tribe and any person holding any interest in such land shall execute a waiver $(A)$ releasing the United States of any liability or claim thereof by such tribe or petson concerning such remedial action and (B) bolding the United States harmless against any claim arising out of the performance of any such remedial action.

(2) The remedial action shall be selected and performed in accordance with section 108 by the Secretary or such person as he may desipnate.

(3) The Secretary, the Commission, and the Administrator and their authorized representatives shall have a permanent right of entry at any time to inspect such processing site in furtherance of the provisions of this title, to cany out sucis agreement, and to enforce any rules prescribed under this Act.

Each agreement under this section shall take effect only upon concurrence of the Commission with the terms and conditions thereof.

(b) When the Secretary with the concurrence of the Commission determines removal of residual radioactive materials from a processing site on land described on subsection (a) to be appropriate, he shial] provide, consistent with other applicable provisions of law, a site or sites for the permantent disposition and stabilization in a safe and envitonmen. taily sound manner of such ressidual radioactive materials. Such gatert- 
42 JSCT16.

Uraniuen Milt Tarlíng

Rermedial Action:

Ameniments Act of 1988.

42 USC 7901

note.

Public lands.

Stake listing. als shall be transferred to the Secretary (without payment therefor by the Secretary) and permanently retained and maintained by the Secretary under the conditions established in a license issued by the cominission, subject to section $104(\mathrm{f})(2)$ and $(\mathrm{h})$.

\section{ACQTISIMON OF LANTS BY SECRETARY}

Sec. 106. Where necessary or appropriate to order to consolidare in a safe and environmentally sound manner the location of residual radioactive materiais which are removed from processing sties under $\infty$ operative agreements under this title or where otherwise necessary for the permanent disposition and stabilization of such materials in such manner-.

(1) the Secretary miny acquire land and interest in land for such purposes by purchase, donation, of under any other authority of law or

(2) the Secretary of the Interior may transfer permanenty to the Sectetary to canry out the purposes of this Act, public lands under the juristiction of the Bureau of Land Management in the vicinity of processing sites in the following counties:

(A) Apache County fo the State of Arizona;

(B) Mesa,Gumison, Moffat, Montrose, Garfield, and San Miguel Counties in the State of Colorado;

(C) Boise County in the State of Idaho;

(D) Bilings and Bowman Counties in the State of North Dakota;

(E) Grand and San Juan Counties in the State of Utah;

(F) Converse and Frement Counties in the State of Wyoning; and

(G) Any other county in the vicinity of a processing site, if no site in the county in which a processing site is located is suitable.

Any permanent transfer of lands under the jurisdiction of the Bureau of Land Management by the Secretary of the Interior to the Secretary sball not take place until the Secretary complies with the requirements of the National Environmental Policy Act (42 U.S.C. 4321 et seq.) with respect to the selection of a site for the permanent disposition and stabilization of residual radioactive materjals. Section 204 of the Federal Land Policy and Managemest Act (43 U.\$.C. 1714) shall sot apphy to this transfer of jurisdiction. Prior to acquisition of land under paragraph (1) or (2) of this subsection in any State, the Sectetary shall consult with the Governor of such State. No lands may be acxuired ander such paragraph (1) or (2) in any State jin which there is no (1) processing sits designated under this title or (2) active uranium mifl operation, unless the Sectetary has obtained the consent of the Governor of such State. No tands controlled by any Federal agency may be transferred to the Secretary to cary out the purposes of this Act without the Concur. rence of the chief admiristrative officer of such agency.]

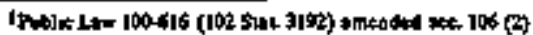


42 USC 7917.

FNNANCIAL ASSISTANCE

Sec. 107. (a) In the case of any designated processing site for which an agreement is execated with any State for remedial action at such site, the Secretary shall pay 90 per centurn of the actual cost of such remedial action, including the actual costs of acquiring such site (and any interest thercin) or any disposition, site (and any interest therein purstant to section 103 of this title, and the State shall pay the remainder of such costs from non-Federal funds. The Secretary shall not pay the administrative costs incurred by ary State to develop, prepare, and carry out any cooperative agreenient executed with sich State under this titie, except the proportionate shire of the administrative costs associated with the acquisition of lands and interests therein acquired by the State pursuant to this title.

(b) In the case of any designated processing site located on Indian lands, the Secretary shall pay the entine cost of such remedial action.

\section{BTAEDLALL ACTION}

42 USC 7918.

Sec. 108. (a)(1) The Secretary or such person as he may designate shall select and perform remedtal actions at designated processing sites and disposal sites in accordance with the general standazds prescribed by the Administrator pursuant to section 275 a. of the Atornic Energy Act

Past, p. 3039.

Ante, p. 20077

past, p. 2080. of 1954. The State shall participate fully in the selection and performance of a remedial action for which it pays part of the cost. Such remedial action shall be selected and performed with the concturnence of the Commission and in consultation, as approptiate, with the Indian tribe and the Seiretary of the Interior.

(2) The Secretary shail use technology in porforming such remedial action as will insure compliance with the general standards promulgated by the Administrator under section $275 \mathrm{a}$. of the Atomic Energy Act of 1954 and will assure the safe and environmentally sound stabilization of residual radioactive materials, consistent with existing law, ${ }^{2}$

(3) Notwtthstanding paragraph (1) and (2) of this subsection, after October 31, 1982, if the Administrator has not promulgated standards under section 275 a. of the Atomic Energy Act of 1954 in final form by such date, remedial action taken by the Secretary under this titk shall comply with standards proposed by the Administrator under such section 275 a. until such time as the Administrator promulgates the standards in final form. ${ }^{n} .^{3}$

Evaluation. (b) Prior to undertaking any renedial action at a designated site pursuant to this title, the Secretary shall request expressions of interest from private parties regarding the remilling of the residual radioactive materials at the site and, upon receipt of any expression of interest, the Secretary shall evaltate annong other things the sniseral concentration of the resitual radioactive materials at each designated processing site to determine whether, as a part if any remedial action program, recowery of such minerals is practicable. The Secretary, with the concurrence

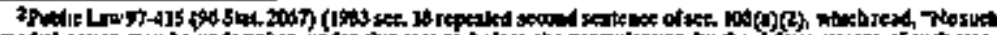

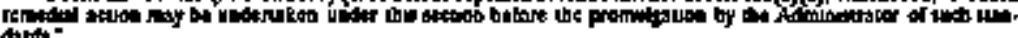

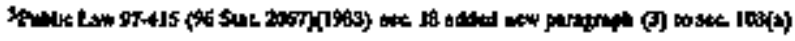


42 USC 202I.

$42 \mathrm{USC} 7919$.

42 USC 7920.

Notice, hearung opportunity.

5 USC 500

ef sect.

Jutisdiction.

42 USC 7172. of the Commission, may permit the recovery of such minerals, under such torms and conditions as he may prescribe to carty out the purposes of this title. No such recowery shalt be permitted usless sucti recovery is consistent with remedial action. Any person permitted by the Secretary to recover such mineral shall pay to the secretary a share of the net profits derived frop such recovery, as determined by the Secretary. Such share shall not exceed the total amount paid by the Secretary for carrying out remedial action at such designated site. After payment of suxh share to the United States under this subsection, such person shall pay to the State in which the residual radjoactive moterials are located a share of the net profits derived from such recovery, as determined by the Secretary. The person recovering such minerals shall bear all cost of such recovery. Any person carrying out mineral recovery activities un+ der this paragraph shall be required to obtain'any necessary license under the Atomic Energy Act of 1954 or under State law as permitted under section 274 of such Act.

RUR

Sec. 109. The Secretary may prescribe such rules consistent with the purposes of this Act as he deems appecopriate pursoant to title $V$ of the Department of Energy Orgarization Act.

\section{ENFORCEMENT}

Sec. 110. (a) (1) Any person who violates any prowision of this titk or any cooperative agreement entered into pursuant to this title or any nule prescribed under this Act concerning any designated processing site, disposition site, or remedal action shall be subject to an assessment by the Secretary of a civil penalty of not more than $\$ 1,000$ per day per violation. Such assessment shall be made by order after notice and an opportunity for a pubtic hearing, pursuant to section 554 of title 5 , United States Code.

(2) Any person against whom a penalty is assessed under this section may, within suxty calendar days after the date of the order of the Secretary assessing such penalty, instinte an action in the United States court of appeals for the appropriate jucicial circuit for judicial review of such order in accordance with chapter 7 of titie 5, United States Code. The court shal] have jurisdiction to enter a judgment affirming, modifying, or setting aside in whole or in part, the order of the Secretary, or the court may temand the proceeding to the Secretary for such further action as the court may direct.

(3) If any person fails to pay an essessinent of a civil penalty after it has become a final and urappealable order, the Secretary siall institute an action to recover the amount of such perfalty in any appropriate district court of the United States. In such action, the vaitdity and appropiateness of such final assessuent order or judgment shall not be subject to review. Section 402(d) of the Department of Energy Organization Act shafl not apply with respect to the functions of the Secretary under this section.

(4) No civil penalty may be assessed against the United States or any State or political subdivision of a State or any offictal or enployee of the foregoing. 
42 USC 2011 note.

$42 \mathrm{USC} 7921$

Water.

42 USC 7922

42 USC 7923

42. USC 7924
(5) Nothing in this section shall prevent the Secretary from enforcing any provision of this title of any cooperative agreentent or any such rule by tujunction or other equitable remedy.

(b) Subsection (a) shall not apply to any license requirement under the Atomic Energy Act of 1954, Such licensing tequirements shall be forced by the Commission as provided in such Act.

\section{PUELLC PAFTICIPATION}

Sec. 11t. In carrying out the provisions of this title, including the designation of processing sites, establishing priorities for stuch sites, the selection of remedial actions, and the execation of cooperative agreements, the Secretary, the Administrator, and the Comurission shall encourage public participation and, where appropriate, the Secretary shall bold public bearings rolative to such matters in the State where processing sites and disposal sites are located.

\section{THRMINATIONAAUTHORUZATION}

Sex-112(a) The authority of the \$ecretary to perform remedial action under this tits shall terminate on Septengber 30, 1994, except that the authority of the Secretary to perform groundwater restoration activities under this title is without limitation. ${ }^{3}$

(b) The aniounts authorized to be appropriated to carry out the purposes of this duty by the Secretary, the Administrator, the Commission, and the Secretary of the Interior shall not exceed such amounts as are established in annual authorization Acts for fiscal year 1979 and each Esscal year thereafter applicable to the Department of Energy. Any sums appropriated for the purposes of this title shall be available until expended.

\section{LMITATHON}

Sec. 113. The authority under this titls to siter into contacts or other obligations requiring the United States to make outlays may be exercised only to the extent provided in advance in annual autborization and appropriation Acts.

\section{REPORTS TO CONGRESS}

Sec. 114. (a) Beginning on Janurcy 1, 1980, and each year thereafter untit Japuary 1, 1986, the Secretary shall subanit a report to the Congress with respect to the status of the actions required to be taken by the Secretary, the Commisston, the Secretary of the Intertior, the Administrator, and the States and Indian tribes under this Act and any amendments to other laws made by this Aet. Each report shall-

(1) include data on the actual and estimated costs of the program authorized by this title;

(2) described the extent of participation by the States and Indian tribe in this program;

(3) evaluate the effectiveness of remedial actions, and describe any problens associated with the performance of such actions; and

(4) contain such other information as may be appropriate.

Such report shall be prepared in consultation with the Commission, the Secretary of the Interior, and the Admiristrator and shall contain their

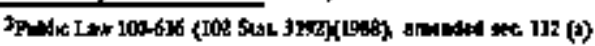


Cooperation.

separate views, comments, and recommendations, if any. The Commission shall submit to the Secretary and Congress such portion of the report under this subsection as relates to the authorities of the Cormmission tunter title II of this Act.

(b) Not later than July 1, 1979, the Secretary shall provide a report to the Congress which identifies all sites located on public or acquited lands of the United States containing residual radioactive materials and otber radioactive materials and other radioactive waste (other than waste resulting from the production of electric energy) and specifies which Federal agency has jurisdiction over such sites. The report shall molude the identity of proptrty and other stuctures in the vicinity of such site that are contasninated or inay be contaminated by such materials and actions planned or taken to remove such materials. The report shall describe in what manner such sites are adequately stabitized and otherwise controlled to prevent radon diffusion from such sites into the environment and other environmental harm. If any site is not so stabilized or controlled, the report shall describe the remedial actions planned for such site and the time frame for performing such actions. In preparing the reports under this section, the Sectetary shall avoid duplication of previous or ongoing studies and stall utilize all information available frotn other departments and anencies of the United Stares respecting the subject matter of such report. Such agencies shall cooperate with the Secretary in the preparation of sucki report and furnish such information as available to them and necessary for such reports.

(c) Not later than Jasuary 1, 1980, the Administrator, in consultation with the Commission, shall provide a report to the Congress which identifies the location and potential bealth, safezy, and envirommental hazards of uranium mine wastes together with reconmenciations, if any, for a program to eljminate these bazards.

(d) Copies of the reports required by this section to be submitted to the Congress shall be separately submitted to the Coulmittees on Interior and Instlar Affairs and on Interstate and Forteign Commerce of the House of Representatives and the Committee on Energy and Natural Ruscuurces of the Senate.

(o) The Commission, if cooperation with the Secretary, shall ensure that any relevant information, other than trade secrets and other proprietary information otherwise exempted from mandatory disclosuse under any other provision of law, obtained from the confluct of each of

, the remedial actions authorized by this tite and the subsequent perpetual care of those residual radioactive materials is documented systematically, and made publichy avaitable convenitntly for use.

ACTIVE OPERATIONS: LIABIITY FOR REMEDLAL ACTION

42 USC 7925.

Sec. 115. (a) No amount may be expended under this title with respect to any site licensed by the Commission under the Atomic Bnergy Act of

42 USC 2011 nate. 1954 or by a State as permitted under section 274 of such Act at which production of any uramium product from ores (other than from residuat radioactive materials) takes place.

42 USC 2021 (b) In the case of each processing site designated under this titte, the Study. Autorney General shatl conduct a study to determine the identity and legal responsibility which any person (other than the United \$tates, a 
State, or Indian tribe) who owned or operated or controlled (as deter* mined by the Attormey General) such site before the date of the entactment of this Act may have under any law or rule of law for rectamation or other remedial action with respect to sucis site. The Attorney General sball publish the results of such study, and provide copies thereof to the Congress, as promptly as practicable following the date of the enactment of this Act. The Attorney General, based on such study, shall, to the extent he deems it appropriate and in the public interest, take such action under any provision of law in effect when tranium was produced at such site to require payment by such person of all or any part of the costs incurred by the United States for such remedial action for which he determines such person is liable.

\section{TITE I-URANIUM MTILL TAILINGS LICENSING AND REGULATION DEFINITION}

42 USC20I4.

"Byproduct material"

42 USC2111

et sequ.

42 USC2113.

42 USC 2002,

2111.

42 USC 2014

42 USC 2014.

Rule, regulation or order.
Sec. 201. Section 11e. of the Atomic Energy Act of 1954, is amended to read as follows:

"e. The term 'byproduct material' means (1) any radioactive material (except special nuclear material) yielded in or made radioactive by ex. posure to the radiation incident to the process of producing or utilizing special nuclear material, and (2) the tailings or wastes produced by the extraction or concentration of uranium or thorjum from any ore processed primarily for its source material content"

\section{CUSTODY OF DISPOSAL SIIE}

Sec. 202. (a) Chapter 8 Of the Atomic Energy Act of 1954, is amended by adding the following new section at the end thereof

"Sec. 83. Ownership And Custody Of Certain By-product Material And Disposal Sites. -

"a. Any license issued or renewed after the effective date of this section under section 62 or section 81 for any activity which results in the production of any byproduct materials, as defined in section 11e. (2), shall contain such terms and conditions as the comnission determines to be necessary to assure that, prior to termination of stch license-

"(1) the licensee witl comply with decontamination, decommissioning, and reclamation stapdards prescribed by the Commisston for sites (A) at which ores were processed primarily for their source material content and (B) at which such byproduct materai is deposited, and

"(2) ownership of any byproduct material, as defined in section 11e. (2), which resulted from such licensed activity shall be transferred to (A) the United States or (B) in the State in which such activity occurred if such State exercises the option under subsection b. (1) to acquire land used for the disposal of byproduct material. Any license in effect on the date of the enacturent of this section shall either contain such terms and conditions on renewal thereof after the effective date of this section, or comply with paragraphs (1) and (2) upon the termination of such license, whichever first occurs.

"(b)(1)(A) The Commission shall require by rule, regulation, or order that prior to the termination of any license which is issued after the effective date of this section, title to the land, including any interests 
therein (other than land owned by the United States or by a State) which is used for the disposal of any byproduct material, as defined by section 1le. (2), parsuant to such license shal be transferred to-

(A) the United States, or

(B) the State in which such land is located, at the option of such State.

“(2) Unless the Commission deternimes prior to such termination that transfer of title to such land and such byproduct material is not necessary or desirable to protect the public bealth, safety, or welfare or to minimize or eliminate danger to life or property. Such determination shall be made in accordance with section 181 of this Act Notwithstanding any other provision of law or any such determination, such property and materiajs shall be maintained pursuant to a license' issued by the Coimmission pursuant to section $84(\mathrm{~b})$ in such manner as will protect the public health, safety, and the environment.

"(B) If the Comunission determines by order that use of the surface or subsurface estates, or both, of the land transferred to the United States or to a State under subperagraph (A) would not endanger the public health, safety, welfare, or envi' ronment, the Commission, pursuant to suah regtlations as it "may prescribe, shall permit the use of the sufface or subsurface estates, or both, of such land in a manner consistent with the provisions of this section. If the Commission permits such use of such land, it shall provide the person who transferred such land with the right of first refusal with respect to such use of such tand.

"(2) If the transfer to the United States of title to such by-produet material and such land is required under this section, the Secretary of Energy or any Federal agengy designated by the President shiall, follow the Commission's determination of compliance under subsection c., assume title and custody of such byprodisct material and land transferred as provided in this subsection. Such Secretary or Federal agency shall tantotain such material and land in such manner as will protect the public hesalth and safety and the environment. Such custody may be transfeited to another officer or instrumentality of the United States only upon approval of the President.

"(3) If transfer to a State of title to such byproduct material is required in accordance with this subsection, stech State shall, following the Commission's determitation of compliante under subsection d., assume title and custody of such byprochut material and land transferred as providect in this subsection. Such \$tate shall matntain such material and land in such manner as will protect the pubtic bealth, safely, and the tivironment.

"(4) In the case of any such license under section 62 , which was in elfect on the effective date of this section, the Commission may reguire, before the termination of such licesse, such trassfer of land and interests therein (as described in paragraph (1) of this subsection) to the United States or a State in which such land is 
Post, p. 3039.

42 USC2014.

Eiffective date. 42 USC 2113 note. located, at the option of such State, as may be necessary to protect the public health, wealtin, and the environment from any effects associated with such byprotutet material, In exersising the authority of this paragraph, the Commission shall take into consideration the status of the ownership of such land and interests thereit and the ability of the licensee to transfer title and custody thereof to the Uníted States or a State.

"(5) The Commission may, pursteant to a license, or by rule or order, require the Secretary or other Federal agency or State having custocy of stch property and materials to tmidertake such monitoring, mantenance, and emergency measures as are necessery to protect the public health and safety and such other actions as the Commission deems necessary to comply with the standards proroulgated pursuant to section 84 of this Act. The Secretary of such other Federal agency is authorized to carry out meintenance, monitoring, and energency meastures, but shall take no other action pursuant to sach license, rule or order, with respect to stuch property and materials unless expressly authortzed by Congress after the date of enactment of this Act.

"(6) The transfer of title to land or byproduct materials, as deined in section 11 e. (2), to a Stato or the Unjted States pursuant to this subsection shall not selieve any licensee of liability for any fraudulent or negligent acts done prior to such transter.

“(7) Material and land transferred to the United States or a State in acoordante with this subsection shail be transferred witlout cost to the United States or a State (other than administrative and legal costs incurred in carrying out such transfer). Stibject to the provisions of paragraph (1)(B) of this subsection, the United States or a State shall not transfer title to material or property acquired under this subsection to any person, uniess such transfer is in the same manner as provided under section 104(h) of the Uramiun Mill Tailines Radiation Control Act of 1978.

"(B) The provisions of this subsection respecting transfer of title and custody to land shall not apply in the case of lands held in trust by the United States for any Indian tribe or lands owned by such Indian tibe subject to a restriction against alienation inposed by the United States. In the case of stuch laiuds which are used for the disposal of byproduct material, as defined in section $11 \mathrm{e}$. (2), the license shall be reguired to enter into such arrangements with the Commission as may'be appropriate to assure the long-term maintenance and monitoring of such lands by the United States.

"c. Upon termination on any license to which this section applies, the Commission shall determine whether or not the licensee has complied with all applicable standards and requirements under such license.".

(b) this section shall be effective three years after the enactment of this Act.

(c) The table of contents for chapter 8 of the Atomic Estergy Act of 1954, is antended by inserting the following new item after the jtem relating to section 82: 
"Sec. 83. Ownership and custody of certain byproduct material and disposal sites".

\section{AUTHORITK TO ESTABLISA CERTANN REQUIREMIXNTS}

42 USC 2201.

42 USC 2231.

42 USC 2014.
Sec 203. Section 161 of the Atomic Energy Act of 1954, is amended, by adding the following new subsection at the end thereof:

" $x$. Establish by rule, regulation, or order, after public notice, and in accordance, with the requirements of section 181 of this Act, such standards and instructions as the Commission may deem necessary or desirable to enslire-

"(1) that an adeguate bond, surety, of other financial arrangement (as determined try the Coranission) will be provided before termination of any license for byproduct material as defined in section $11 \mathrm{e}$. (2), by a licensee to permit the completion of all requiremerits established by the Commission for the decontamination, decommissioning, and reclamation of sites, struchures, and equipment used in conjutpction with bypreduct thaterial as so defined, and

(2) that-.

"(A) in the case of any such license issued or renewed after the date of the enactment of this subsection, the need for long term maintenance and montitoring of such sites, structures and equipment after termination of such license will be minimized and to the maximum extent practicable, eliminiated; and

"(B) in the rase of each license for such material (whether in effect on the date of the enactment of this section or issued or renewed thereafter), if the Commission determines that any such Jong-term mafntersance and morsitoring is necessary, the licensee, beforetermination of atry license for byproduct material as defined in section 11 e. (2), will make available such bonding, strety, ot other finiticial arrangements as may be necessary to assure such long-term maintenance and monitor. ing.

Such standards and instructions promuigated by the Commission, pursuant to this subsection shall take into account, as determined by the Commission, so as to avoid unmecessary duplication and expense, performanee bonds or other financial arrangements which are required by other Federal agencies or State agencies and/or other local governing bodies for such decommissioning, decontamination, and reclamation and long-term maintenance and monitoring except that nothing in this paragraph shall be construed to require that the Commission accept stuch bonds or arrangements. ff the Commission determines that such bonds or arrangements are not adequate to carry out subparagraphs (1) and (2) of this subsection.".

\section{COOPERATION WTTH STATES}

Sec. 204. (a) Section 274 b. of the Atomite Enery Act of 1954, is antended by adding "as defined in section 11 e. (1)" after the words" byproduct materials" in paragraph (1) by remumbering paragrapks (2) and (3) as paragraph (3) and (4), and by inserting the following new paragraph immediately after paragraph(1): 
“(2) byproduct materials as defined in section 11 e. (2):-

(b) Section $274 \mathrm{~d}$ (2) of such Act is amended by inserting the following before the word "compatible": "in accordance with the requirements of sulbsection 0 , and in all other respects".

"Agreement" (c) Section $274 \mathrm{n}$. of such Act is amended by adding the following new sentence at the end thereof: As used in this section, the term "agreement' includes any amendment to any agrement.".

(d) Section $274 \mathrm{j}$. of such Act is amended-

(I) by inserting "all or part of" after "stispend";

Review.

(2) by inserting "(1)" after "finds that"; and

(3) by adding at the end before the period the following: ", or (2)

the State has not complied with one or more of the requiremepls of this section. The Commission shall periodically review such agreements and actions taken by the States under the agreements to ensure compliance with the provistons of this section.".

(c)(1) Section 274 of such Act is amended by adding the following new subsection at the end thereos.

"o. In the licensing and regulation of byproduct material, as defined in section 11 e. (2) of this Act, or of any activity which results in the production of byproduct material as so defined under an agreement entered into pursuant to subsection $b_{\text {, }}$ a State shall require-

(1) compliance with the requirements of subsection b. of section 83 (respecting owmership of byproduct material and land), and

"(2) compliance with standards which shall be adopted by the State for the protection of the public health, safety, and the environment from hazards associated with such material which are equivalent, to the extent practicable, or more stijggent than, standarts adopted and enforced by the Commission for the seme perrpose, including requirements and standards promulgated by the

Ante, p. 3033.

Post, p. 3039. Commission and the Admiristrator of the Environmental Protec. tion Agency pursuant to section 83,84 , and 275 , and

“(3) procedures which-

"(A) in the case of licenses, provide procedures under State law which includ:-

(i) an opportunity, after public notice, for written comments and a public hearing, with a transcript,

"(ii) an opportusity for cross examination, and

(iii) a written determination which is based upon findings included in such determination and upon the evidence presented during the public comment period and which is subject to judicial review;

"(B) in the cass of rulenalking, provide an opportunity for public participation through written comments or a public hearing and provide for judicial review of the rule;

"(C) requine for each license which has a significant impact on the humas environment a written anajysis (which shall be availabte to the public before the commencentent of any such proceedings) of the impact of such licenses, induding any ac- 
tivities conducted pursuant thereto, on the envitonment, which analysis sball include -

"(i) an assessment of the radiological and nonradiolog. ical impacts to the public bealth of the activities to be con. ducted pursuant to such ticense;

"(ii) an assessment of any impact on any waterway and groundwater Fesulting from such activities;

"(iji) consideration of alternatives, incluxing altermetive sites and engineering methods, to the activities to be conducted pursuiant to such license; and

"(iv) consideration of the long-term impacts, including decommissioning, decontamination, and reclamation inpacts, associated with activities to be conducted pursuant to such license, including the management of any byproduct uaterial, as defined by section $11 \mathrm{e}$. (2); and

"(D) probibit any major constrútion activities with respect to such material prior to complying trith the provisions of subparagraph (C).

If any State under such agreement imposes upon any ticensee any requirement for the payment of funds to stich State for the reclamation or long-terta maintenance and monitoring of such material and if transfer

Anie, p. 3033 . to the United States of such material is required in accordance with section $83 \mathrm{~b}$. of this Act, such agreement shall be amended by the Comnission to provide that such State shall transfor to the United States upon tertaination of the license issued to such licensee the total amourt collected by such $\$$ tate from such licensee for such porpose. If such payments are required, they dust be sufficient to ensure compliance with the standards established by the Contuission purstant to section $161 \mathrm{x}$. of this Act No State shall be required under paragraph (3) to conduct proceedings concerning any ticense or regutation whicti would duplicate proceedings conducted by the Commission".

\$2 Stot. 3037

42 USC. 202? nots.

42 USC 2021.

42 USC 3014.

"(2) The provisions of the amendment made by paragraph (1) of this subsection (which adds a new subsection o. to section 274 of the Atomic Energy Act of 1954) shall apply only to the maximum extent practicable during the three-year period beginnirg on the date of the enactment of this Act."4

(f) Section $274 \mathrm{c}$ of such Act is antended by inserting the following new sentence after paragraph (4) thereof: "The Comnission shall also retain authírity todter any such agreement to make a determination that all applicabie standards and requirentents bave been met prior to termuination of a license for byproduct material, as defined in section 11 e. (2).".

42 USC 2021

note.

(g) Nothing in any amendment made by this section shalt preclude any State frorn exercising any other authority permitted under the Atomic Energy Act of 1954 respecting any byptoduct material, as defined in section $11 \mathrm{e}$. (2) of the Atomic Energy Act of $19 \$ 4$.

"(h)(1) During the three-year period beginning on the date of the enactment of this Act, notwithstanding any other provision of this title, any State may exercise any authority under State law (ircluding autbor-

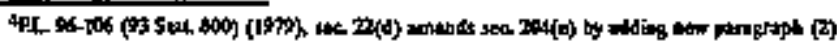


42 USC 2021. 92 Sta1. 3033. $42 \mathrm{USC} 2014$.

92 Stal, 3036. 42 USC 204

92 STAT.3039. 42 USC 2022

42 USC 2021.

92 Stat. 3003. 42 USC 2014.

42 USC 2021 ity exercised pursuant to an agreement entered into pursuant to section 274 of the Atomic Energy Act of 1954) respecting (A) byproduct material, as defined in section 1$\}$ e. (2) of the Atomic Energy Act of 1954, or (B) any activity which results it the production of byproduct material as so deñned, in the sarne matuner and to the same extent as perratitted before the date of the enactment of this Act, except that suck State authority shall be exercised in a manner which, to the extent practicable, is consistent with the requirements of section $274 \mathrm{o}$. of the Atomic Entrgy Ast of 1954 (as added by sectron 204(e) of this Act). The Commission shall bave the authority to ensure that such section 2740 . is implemented by any such State to the extent practicable during the threeyear period beginning on the date of the enactment of this Act. Nothing in this section shall be construed to preclude the Commission or the Administrator of the Environmental Protection Agency from

taking such action under section 275 of the Atomic Energy Act of 1954 as may be necessary to implement title I of this Act."."

(2) An agrement entered into with any State as permitted under section 274 of the Atomic Energy Act of 1954 with respect to byproduct material as defined in section 11 e (2) of such Act, may be entered into at any time after the date of the enactenent of this Act but no such agreentent maty take effect before the date three years after the date of the enactonent of this Act.

"(3) Notwithstanding any other provision of this title, where a State assumes or bas assumed, pursuant to an agreement entered into under section 274 b. of the Atomic Energy Act of 1954, au* thority over any actistty which results in the production of byproduct materizl, as defined in section 1l e. (2) of such Act, the Commission shall not until the end of three-year period beginning on the date of the enactment of this Act, have licensing authority over such byproduct material produced in any activity covered by such agreement, unless the agreement is terminated, suspended, or amended to provide for such Federal licensing. If, at the end of such threeyear period, a State bas not entered into such an agreenent with respect to byproduct material, as defined in section $11 \mathrm{e}$. (2) of the Atonic Energy Act of 1954, the

Commission shall have authoxtly over such byproduct material.". 6 Provided, however, That, in the case of a State which has exercised any authority under \$tate law pursuant to an agrement entered foto under section 274 of the Atomic Energy Act of 1954, the State authority over such byproduct material may be terminated, and the Commission authority over such material may be exercised, onty after compliance by the Commission with the same proce. dtures are applicable in the case of termination of agreements under section $274 \mathrm{j}$. of the Atomic Energy Act of $1954 . " 7$

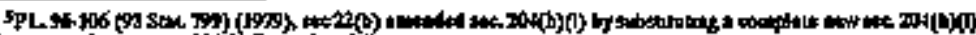

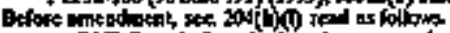

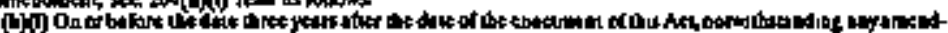

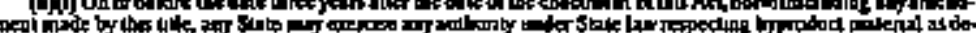

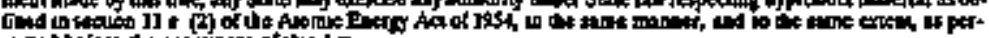

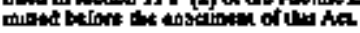

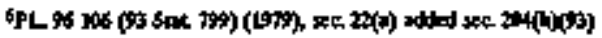

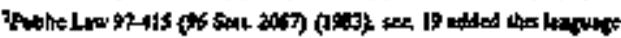


42 USC 2111

te seg.

42 U\$C 2114.

42 USC 2114.

Infra.

\section{USC 6091.}

Role, regulation or order.

42 Usc 2111.

Civil penalty.

Ante, p. 3033.

42 USC2282.

42 USC 2111

42 USC 2112 Supro

\section{AUTHOTIIES OF COAMISSION RESFECTNG CXRTANN BYPRODUCT MATERIAL}

Sec. 205. (a) Chapter 8 of the Atomic Energy Act of 1954, is amended by adding the following new section at the end tuereof:

"Sec. 84, Authoritios Of Commission Respecting Certain Byproduct Material-

"a. The Commission shall insure that the management of any byprod. uct material, as defined in section $11 \mathrm{e}$. (2), is carried out to such manner gs-

"(1) the Commission deems appropriate to protect the public health and safety and the emironment from radiological and nonradiological hazards associated with the processing and with the possession and transfer of such material,

"(2) confortus with applicable general standards promulgated by the Administrator of the Exwironmental Psotection Agency under section 275 , and

"(3) conforms to general requirements established by the Commission, with the concurrertice of the Administrator, which are, to the maxtmum extept practicatble, at least comparable to require. ments applicable to the possession, transfer, and disposal of similar hazardous material regulated by the Administrator under the Solid Waste Disposal Act, as amended.

"b. In carrying ont ifts authority under this section, the Commission is authorized to-

'(1) by rule, regulation, or orcer require persons, officers, or in. strumentalities exempted from licensing under section $\mathbf{8 1}$ of this Act to contuct monitoring, perform remedjal work, and to comply with stach other measures as it may deem necessary or desirable to protect beatt or to mirimize danger to life or propety, and in connection with the gisposal or storage of such byproduct material; and

"(2) make sucli studies and inspectionis and to contuct such monitoring as may be necessary.

Any violation by any person other than the United States or any officer or employee of,the United States or a State of any rule, regulation, or order or licensing provision, of the Commission established under this section or section 83 shall be subject to a civil penalty is the same manner and in the same amount as violations subject to a civil penalty under section 234. Nothing in this section affects any authority of the Commission under arry other provision of this Act.".

(b) The first sentence of section 81 of the Atomic Energy Act of 1954, is amended to read as follows: "No person may transfer or receive in interstate commerce, manufacture, proctuce, transfer, acquire, own, possess, import, or expont any byproduct juaterial, except to the extent authorized by this section, section 82 or section 84. .

(c) The table of content for such chapter 8 is amended by inserting the following new item after the item relating to section B3:

"Sec 84. Authorities of Comunission respecting certain byproduct material.". 
42 USC 2021.

42 USC 2022.

Ruke.

42 USC 6901

noit.

Rule.

42 USC 2014.

42 USC 2021.

Publication in

Federal

Regieter.

\section{AUTHORTY OF BNYIRONMEATAX PROTECTION AGENCY RESPECTING} CGRTAN HYPRODUCT MATERIAL

Sec. 206. (a) Chapter 19 of the Atomic Energy Act of 1954, is amended by inserting after section 274 the following new section:

"Sec. 275. Health And Environmental Standards For Uranium Mill Tailings.-

"a. As soon as practicable, but not later than one year after the date of enactment of this section, the Administrator of the Envinonmented Protection Agency (hereinafter referred to in this section as the Administrator') shall, by rule, promulgate standards of general application (including standards applicable to licenses tuder section 104(h) of the Uranium Mill Tailings Radiation Control Act of 1978) for the protection of the public health, safety, and the enviromment from radiological and nonradiological hazards associated with residual radioactive materials (as defined in section 101 of the Uranium Mil] Taillings Radiation Control Act of 1978) located at inactive uranium mill tailings sites and depository sites for such materials selected by the Secretary of Energy, pursuant to title I of the Uranium Mill Talings Radiation Control Act of 1978. Standards promulgated pursuant to this subsection shall, to the maximum extent practicable, be consistent with the requirements of the Solid Waste Disposal Act, as amended. The Administrator may periodically revise any standard promulgated pursuant to this subsection.

"b. (1) As soon as practicable, but not later than ejghteen months after the epactment of this sectoon, the Adnatnistrator shall, by rolle, promulgate standards of general application for the protection of the public health, safety, and the environment from radiological and nonradiological hazards associated with the processing and with the passession, transfer, and disposal of byproduct material, as definted in section 11 e. (2) of this Act, at sites at which ores are processed primarily for their source material content or which are used for the disposal of such bypoduct material.

"(2) Such generally applicable standards promulgated pursuant to this subsection for nontradiological hazards shall provide for the protection of human health and the environnent consistent with the standards requited under subtitle Cof the Solid Waste Disposal Act, as amended, which are applicable to such hazards: Provided, however, That no permit issued by the Administrator is requited under this Act or the Solid Waste Disposal Act, as amended, for the processing, possession, transfer, or disposal of byproduct materiaj, as defined in section 11 e. (2) of this Act. The Administrator may periodically revise any standard promulgated pursuant to this subsection. Within three years after such revision of any such standard, the Commission and any State permitted to exercise authority under section $274 \mathrm{~b}$. (2) shall apply such revised standard in the cese of any license for byproduct material as defined in section 11 e. (2) or any revision thereof.

"c. (1) Before the promulgation of any rule pursuant to this section, the Administrator shial] publish, the proposed rule in the Federal Register, together with a statement of the research, anklysis, and other avail- 
Notice, hearing opportentity.

Consultation.

Juditial

Review.

5 USC 701

etser.

42 USC 2021.

42 USC 2014 42 USC 7401 note.

33 USC 125t

note.

42 USC 2018

etsect able information in support of such proposed rule, and provide a period of public comment of at least thitty days for written couments thereom and an opportunity, after such comnent period and after public notice, for any interested person to present oral data, viexss, and argundents at a public hearing. There shall be a transcript of any such bearigg. The Administrator shall consult with the Commission and the Secretary of Energy before promulgation of any such rule.

"(2) Judicial review of any rule promulgated under this gection may be obtained by any interested person only upon such person filing a petition for review within sixty days after such promulgation in the United States court of appeals for the Federal judicial circuit in which sucis person resides or has his principal place of business. A copy of the petition shall be fortitwith trarsmitted by the clerk of court to the Administrator. The Administrator thereupon shalt file in the court the written submissions to, and transerjpt of, the wijten or oral proceediogs on which such rule was based as prowided in section 2112 of title 28 , United States Code. The court shall have juristiction to review the rule in accordance with chapter 7 of title 5, United States Code, and to grant appropriate relief as provided in such chapter. The.judgment of the court afirming, modifying, or setting aside, in whole or in part, any stuch rule shall be final, subject to judicial review by the supreme Court of the United States upon certiorari or certification as provided in section 1254 of title 28, United States Code.

(3) Any rule promiligated under this section shall not take ef. fect earlier than sixty calendar days after such promulgation.

"d. Implementation and enforcement of the standards promulgated pursuagt to subsection $b$, of this section sizall be the responsibitity of the Comnission in the conduct of its licensing activities, under this 'Act. States exercising authority pursuant to section $274 \mathrm{~b}$. (2) of this Act shall implement and enforce such standards in accordance with subsection 0 . of such section

ce. Nothing in this Act applicable to byproduct material, as defined in section 11 e. (92) of this Act, shall affect the authotity of the Administra* tor under the Clean Air Act of 1970, as amended, of the Federal Water Pollution Control Act as amended.".

(b) The table of contents for chapter 19 of the Atomic Energy Axt is amended by inserting the following new iten after the item relating to section 274:

"Sec. 275. Health and environmental standards for uranium tailings.".

\section{AUTHORIZATION OF APPROPRATION FOR GRANTS}

Sec. 207. There is herety asthorized to be appropriated for iseal year 1980 to the Nuclear Regilatory Commission not to exceed $\$ 500,000$ to be used for making grants to States which have entered into agreenents with the Commissian under section 274 of the Atomic Eneroy Act of 1954, to aid in the development of State regulatory programs under such section which implement the provisions of this Act. 
42 USC 2014

note.

42 USC 2113

thote.

42 USC 2011

note.

42 Usc 7941.

42 USC 2021

Repost to

Congress.

42 USC 742.

\section{EFFXCIIFE DATE}

Sec. 208. Except as otherwise provided in this title the amendunents made by this title shall take effect on the date of the enactment of this Act.

\section{CONSOLDATION OF LCENSES AND PROCEDUAES}

Sec. 209. The Regulatory Commission stall consolidate, to the maxiInum extent practicable, licenses and licensing procedures under amendments made by this title with licenses and licensing procedures under other authorities contained in the Atomic Energy Act of 1954.

\section{TITLE III-STUDY AND DESIGNATION OF TWO MILL TAILINGS SITES IN NEW MEXICO}

\section{STUDY}

Sec 301. The Commission, in consultation with the Attormey General and the Attomey General of the State of $\mathrm{N}$ tw Mexico, shall conduct a study to determine the extent and adequacy of the authority of the Commission and the State of New Mexico to require, under the Atomic Energy Act of 1954 (as amended by title II of this Act) or under State authority as permitted under section 274 of such Act or under other provision of law, the owmers of the following active uraniun mill sites to undertake apptopriate action to regulate and control all residual radioactive materisls at such sites to protect public health, safety, and the environment: the former Homestake-New Mexico Partners site near Mjlan, New Mexico, and the Anaconda carbonate process tailing site near Blisewater, New Mexico. Such study shall be completed and a report thereof submitted to the Congress and to the Sectetary within one year after enectment of this Act, together with such recommendations as may be appropriate. If the Commission determines that such authority is not adequate to regulate and control such materials at such sites in: the manner provided in the first sentence of this section, the Commisston shall include in the report a statement of the basis for such determination Nothing in this Act shall be construed to prevent of delay action by a State as permitted under section 274 of the Atomic Entery Act of 1954 or under any other provision of law or by the Contrision to regulate such restidual radioactive materials af such sites prior to completion of such study.

\section{DESIGNATON BY SECRETARY}

Sec. 302. (a) Within ninety days from the date of his receipt of the repott and recomumendations stibmitted by the Commission under section 301 , notwithstanding the limitations contained in section 301 , notwithstanding the limitations contained in section $101(6)(A)$ and in section 115(a), if the Commisstion determines, based on such study, that such sites carnot be regulated and controlied by the State or the Commission in the manner describid in section 301 , the Sectetary may designate either or both of the sites referred to in section 301 as a processIng site for purposes of title I. Followis such designation, the Sectetary may enter into cooperative agrements with New Mexico to perform remedial action pursuant to such title concerning only the residual radiogactive materials at stich șite resulting from uramium produtoed for sale 
Submittal to congressional comrnittees. to a Federal agency prior to Japuary 1, 1971, under contract with such agency. Any such designation shall bè' submitted by the Secrettery, together with his estimate of the cost of carrying out such remedial actron at the destgnated site, to the Committee on Interior and Insular Affairs and the Committee on Interstate and Foreign Commerce of the House of Representatives and to the Conmittet on Energy and Natural Resources of the Senate.

(b)(1) No designation under subsection (a) shall take effect before the expiration of one hundred and twenty calendar days (not includipg any day in which eitter House of Congress is not in session because of an adjournment of more than three calendar days to a day certain or an adjournment sige die) after recejpt by such Committees of such designation.

(c) Except as otherwise speciffeally prowided in subsection (a), any remedial action under title I.with respect to any sites designated under this title shall be subject to the provisions of title I (incluting the authorzation of appropriations referred to in section 112(b)). Approved Novemb $8,1978$. 


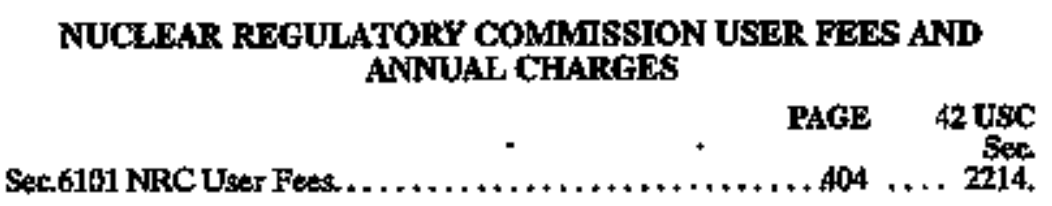

$\because$

403 
Public Law 101-508-NOW. 5, 1990

104 Stat. 1388

\title{
TIILE VI \\ ENERGY AND ENYIRONMENTAL PROGRAMS
}

\author{
Subtitle B-NRC User Fees and Anrual Charges
}

42 USC 2214

42 USC 2214
SEC 6101. NRC USER FEHS AND ANNUAL CHARGES

(a) ANNUAL ASSESSMENT, -

(1) IN GENERAL.-Fxcept as provided in paragraph (3), the Nuclear Regulatory Conmission (in this section referred to as the "Commission") shall annually assess and collect such fees and charges as are described in subsections (b) and (c).

(2) FIRST ASSESSMENT.-The first assessuent of fees under subsection (b) and annual charges under subsection (c) shall be made not later than September 30, 1991.

(3) LAST ASSESSMENT OF ANNUAL CHARGES.-The lase asstssment of anmial charges under subsection (c) stall be made not later than September 30, 1998.

(b) FEES FOR SERVICE OR THING OF VALUE.-Pursuant to secton 9701 of title 31, United States Code, asy person who receives a service or thing of value from the Conmission shall pay fees to cover the Commission's costs in providing any such service or thing of value.

(c) ANNUAL CHARGES.-

(1) PERSONS SUBJECT TO CHARGE-Except as provided in paragraph (4), any licensee of the Comunission may be required to pay, in addition to the fees set forth in subsection (b), an annual charge.

(2) AGGREGATE AMOUNT OF CHARGES.--The aggregate amount of the annual charge collected from all licensees shall equal an aphoumt that approximates 100 percent of the budget authority of the Commission in the fiscal year in which such charge is collecled, less any amount appropriated to the Commission from the Nuclear Waste fund and the antount of fees collected under subsetion (b) in such fiscal year.

(3) AMOUNT PER LJCENSEE-The Comunission shall establish, by rule, a schedule of charges fairly and equitably allocating the aggregate amount of charges described in paragraph (2) anong licensees. To the traximum extent practicable, the charges shatl have a reasonable relationship to the cost of providing regulatory services and may be based on the allocation of the Commission's resoutces among licensees or classes of licknsees.

(4) EXEMPTION-

(A) IN GENERAL.-Paragraph (1) shall not apply to the holder of any license for a federally owned research resctor used primarily for educational training and academic research purposes. 
(B) RESEARCF REACTOR-For purposes of subparagraph $(A)$, the term 'research reactort' means a nuclear reactor that-

(i) is licensed by the Nuclear Regulatory Commission under section 104c. of the Atomic Energy Act of 1954 (42 U.S.C. 2134(c)) for operation at a thermal povker level of 10 megawatts or less; and

(ii) if so licensed for operation at a thiermal power level of more than 1 megawatt, does not contain-

(I) a circulating loop through the core in which the licensee conducts fuel experiments;

(II) a liquid fuel loading; or

(III) an experimental facility in the core in excess of 16 square inches in cross-section.

(d) DEFINITION.-As used in this section, the term "Nuclear Waste Fund" means the fund established pursuant to section 302(c) of the Nuclear Waste Policy Act of 1982 (42 U.S.C. I0222(c)).

(e) CONFORMING AMENDMENT TOCOBRA-Paragraph(1)(a) of section 7601 of the Consolidated Onmibus Budget Reconciliation

42 USC 2213. Act of 1985 (Public Law 99-272) is amended by striking "except that for fiscal year of 1990 sach maximum amount shall be estimated to be equal to 45 percent of the costs incurred by the Comnission for fiscal year 1990" and tinserutog "except as otherwise provided by law".1

JUeder P1.

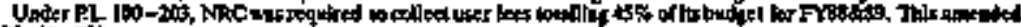
AL $99-\mathrm{T}$

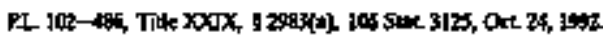

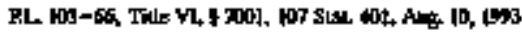




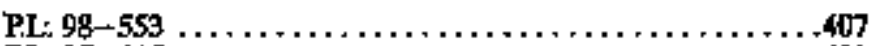

42 tusc

$407 \ldots 2017$

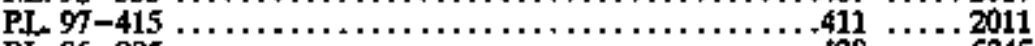

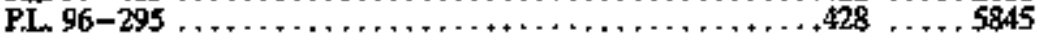

PL $95-601 \ldots \ldots \ldots \ldots+\ldots \ldots \ldots \ldots \ldots \ldots \ldots \ldots \ldots \ldots 42 \ldots \ldots+\ldots 845$

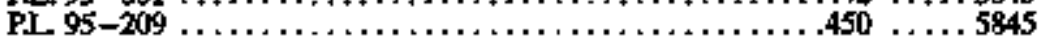

PL $94-291 \ldots \ldots \ldots \ldots \ldots \ldots \ldots \ldots+\ldots \ldots \ldots \ldots+\ldots+453 \ldots \ldots 2017$

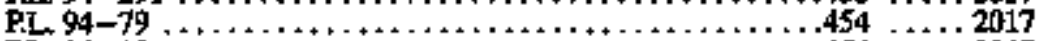

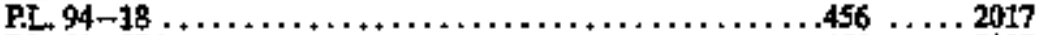

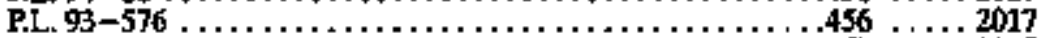

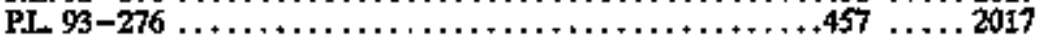

PL $93-158 \ldots+\ldots+\ldots \ldots \ldots+\ldots \ldots+\ldots \ldots \ldots+\ldots+\ldots+\ldots+462 \ldots+\ldots 2017$ 


\section{NRC AUTHORIZATION ACT FOR FISCAL YEAR 1984-1985}

\section{An Act}

Qctoher 30.1984 [S. 1291]

42 USC 2017. 42 IJSC 5875 .

Grants.
To authorize appropriations to the Nuclear Regulatory Commission in accordance with zection 261 of the Atomic Energy Act of 1954, and section 305 of the Energy Reorganization Act of 1974.

Be it enacted by the Senate and Hotse of Representattves of the United States of America in Congress assembled,

\section{TITLE I-AUTHORIZATION OF APPROPRIATIONS FOR FISCAL YEARS 1984 AND 1985}

Sec 101. There are hereby authorized to bo appropriated to the Nuclear Regulatory Commission in accordance with the provistons of section 261 of the Atomic Energy Act of 1954 and section 305 of the Energy Reorganization Act of 1974, for the fiscal years 1984 and 1985 to remain available until expended, $\$ 466,800,000$ for fiscal year 1984 and $\$ 460,000,000$ for fiscal year 1985 .

Sec. 102. (a) The sums authorized to be appropriated in this Act for fiscal years 1984 and 1985 shaill be allocated as follows:

(1) not more than $\$ 91,490,000$ for fiscal year 1984 and $\$ 87,140,000$ for fiscal year 1985, may be used for "Nuctear Reactor Regulation", of which an amount not be exceed $\$ 1,000,000$ is austhorized each such fiscal year to be used to accelerate the effort in gas-conled thermal reactor preapplication revien;

"(2) not wore than $\$ 70,910,000$ for fiscal year 1984 and $\$ 74,770,000$ for fiscal year 1985, may be used for "Inspection and Enforcesment ${ }^{n}$;

"(3) not more than $\$ 36,280,000$ for fiscal yeas 1984 and $\$ 35,710,000$ for fiscal year 1985 , may be used for "Nuclear Materiet Safety and Safeguards";

"(4) not more than $\$ 199,740,000$ for fiscal year 1984 and $\$ 193,290,000$ for fiscal year 1985 , may be used for "Nuclear Regulatory Research", of which an amount not to exceed $\$ 2,600,000$ is authorized each such fiscal year to be used to accelerate the effort in gas-cooled thermal reactor safety research;

(5) not more than $\$ 27,520,000$ for fiscal year 1984 and $\$ 27,470,000$ for fiscal year 1985, may be used for "Program Technical Support";

(6) not more than $\$ 40,860,000$ for fiscal year 1984 and $\$ 41,620,000$ for fiscal year 1985, may be used for "Program Direction and Administration ${ }^{*}$.

(b) The Nuclear Regulatory Commission Inay use not more than 1 per centum of the amounts atthorized to be appropriated under paragraph 102 (a) (4) to exercise its authority under section 31 a. of the Atomic Energy Act of 1954 (42 U.S.C. 2051(a)) to enter into grants and cocperative agreements with unipersities pursuant to such paragraph. Grants made by the Conmisston sinall be made in accordance with the Federal 
31 USC 3302.

Report. Prohíbition.
Grant and Cooperative Agreement Act of 1977 (41 U.S.C. 501 et seg.) and other applicable law.

(c) Any amount appropriated for a fiscal year to the Nuclear Regulatory Commission pursuant to any paragraph of subsection 102(a) for purposes of the program referred to in such paragraph, may be reallocated by the Commission for use in a program referted to in any otber paragraph of such subsection, or for use in any ofher activity within a program, except that the amount available from appropriations for such fiscal year for use in any program or specified activity may not, as a result of reallocations made under this subsection, be increased or reduced by more than $\$ 500,000$ uniess-

(1) a period of thirty calendar days (excluding any day in which either House of Congress is not in session because of an adjournwent of thore than three calendar days to a day certain or an adjoumment sine die) passes after the recejpt, by the Committee on Energy and Commerce and the Committee on Interior and Insulat Affairs of the House of Representatives and the Committec on Environment and Public Works of the Senate, of notice submitted by the Commission containing a full and complete statement of the reallocation proposed to be made and the facts and circurnstances relied upon in support of such proposed reallocation; or

(2) each such conmittee, before the expiration of such period, transmits to the Commission a written notingation that such committee does not object to such proposed reallocation.

Sec. 103. Moneys received by the Nuclear Regulatoty Commission for the cooperative muclear research program and the material access authorization program may be retained and used for salaries and expenses associated with such programs, notwithstanding the provisions of section 3617 of the Revised Statutes (31 U.S.C. 484), and shall remain availabłe until expendec.

Sec 104. From amounts apjupriated to the Nuclear Regulatory Contmission pursuant to this titele, the Commission may transfer to other agencies of the Federal Government sums for salaries and expenses for the performance by such agencies of activities for which such appropriations of the Commission are made. Any stums so transfermed may be merged with the appropriation of the agency to which such sums are transferred.

Sec. 105. Noturithstanding any other provisions of this Act, no authority to make payments under this Act shall be effective ezcept to such extent or in such amounts as are provided in advance in appropriation Acts.

Sec 106. (a) No funds authorized to be appropriated under this Act may be used to carry out any policy or program for the decentralization or regionalization of any Nuclear Regulatory Commission authorities regarding conmercial nuclear powerplant lioensing until sixty legislative days after the date on which the Commission submits to the Congress a report evaluating the effect of such policy or program on nuclear reactor safety. Provided, however, That the prohibition contamed in this subsection shall not apply to any personnel, assigned to the field, or to 
activities in which they were engaged, on or before September 22,1983 . The report shall include-

(1) a detailed description of the authorities to be transferted, the reason for such transfer, and an assessment of the effect of such transfer on inuclear reactor safety;

(2) an analysis of all comments submitted to the Commission regarding the effect on nticlear reactor safety which would result from carrying out the policy or programa proposed by the Conmissiont; and

(3) an evaliation of the results, including the advantages and dis. advantages, of the pilot program conducted under subsection (b).

(b) Notwithstanding the prohibition contained in subsection (a), the Commission is authorized to conduct a pilot program for the purpose of evahuating the concept of delegating anthority to regional ofirices for issuance of specifie types of operating reactor lioensing actions and for the purpose of addressing the issues identified in paragraphs (a)(1)-(3) of this section.

Sec. 107. (a) Of the amounts authorized to be appropriated under this Act for the fiscal years 1984 and 1985, sucti sums as may be necessary are authorized to be used by the Nuclear Regulatory Commission for-

(1) the acquisition (by purchase, lease, or otherwise) and insta!lation of equipment to be used for the small test prototype muclear data link program or for any other progran for the collection and transmission to the Commission of data from licensed nuclear reactors during abnormal conditions at such reactors; and

(2) a full and complete analysis of-

(A) the appropriate role of the Commission during abnormat conditions at a nuclear reactor licensed by the Commissian;

(B) the information which should be available to the Commission to enable the Commission to fulfill such role and to carry out other related functions;

(C) various alternative means of assuring that such information is available to the Commtssion in a timely manner; and

(D) any changes in existing Commission authority necessary to enhance the Commission response to abnormal conditions at a nuclear reactor licensed by the Commission:

Provided, however, That no funds shalt be available under this Act for the acquisition and installation of any equipment for the collection and transmission to the Commission of data from licensed nucleas reactors during abnormal conditions at such reactors, or for the analysis of such equipment, unjess stich acquisition and andyysis tnchudes, as one of the alteruatives considered, a fully automated electronic muclear data link. The small test prototype referred to in paragraph (1) may be used by the Commission in carrying out the stuxdy and analysis under paragraph (2). Such analysis shall jiclude a cost-benefit analysis of each alteroative examinted under subparagraph (C).

Sec. 108. Of the amounts authorized to be appropriated under this Act, the Nuclear Regulatory Commission may use such sums as may be necessary, in the absence of a State or local emergency preparedness

\begin{tabular}{ll}
\hline \\
\hline
\end{tabular}


42 Usc 2242.

42 USC 2133. 42 USC 2134. plat which has toent approved by the Federal Emergency Management Agency, to issue an operating license (including a temporary operating license under section 192 of the Atomic Energy Act of 1954, as amended) for a nuclear power reactor, if it determines that there exists a State, local, or utitty plan which provides reasonable assurance that public health and safety is not endangered by operation of the facility concerned.

Sec 109. Notwithstanding the second sentence of section $103 \mathrm{~d}$. and the second sentence of section $104 \mathrm{~d}$. of the Atomic Energy Act of 1954, as amended, the Nuclear Regulatory Commission is hereby authorized to transfér Facility Operating License numbered R-81 to a United States entity or corporation owned or controlled by a foreign corporation if the' Cónanission-

(1) finds that such transfer would not be inimical to the common defense and security or to the health and safety of the public; and (2) includes in such license, as transferred, such conditions as the Commission deems necessary to ensure that such foreign corporttion cannot direct the actions of the licensee jn ways that would be inimical to the comamon defense and security or the health and safety of the public.

Approved October 30, 1984.

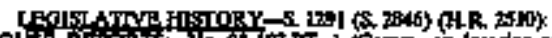

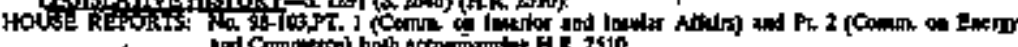

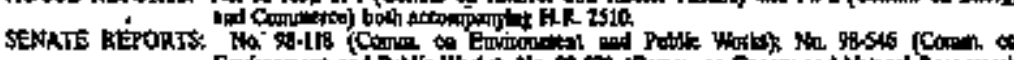

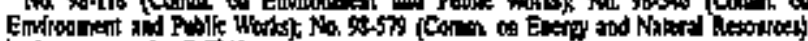

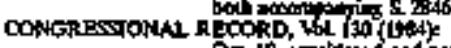

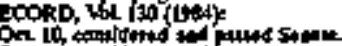

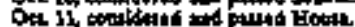

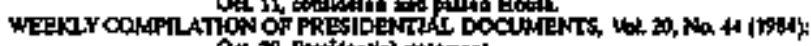

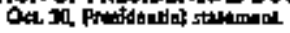


NRC AUTHORIZATION ACT FOR FISCAL YEAR 1982-1983

Jan, 4.1983

[H.R. 2330]

Nuclear

Regulatory Commission. Appropriations

\begin{abstract}
An Act
To althorize appropriations to the Nuclear Regulatory Commission fon accordance with section 261 of the Atornic Energy Act of 1954, as amended, and section 305 of the Energy Reorgatization Act of 1974, as amended, and tor other purposes.

Be ll enacied by the Senote and House of Representatives of the United States of America in Congress assembled,
\end{abstract}

\section{AUTHORIZATION OF APPROPRIATIONS}

Section 1. (a) There are hereby authorized to be appropriated to the Nuclear Regulatory Commission th accordance with the provistons of stetion 261 of the Atomic Energy Act of 1954 (42 U.S.C. 2017) and section 305 of the Energy Reorganization Act of 1974 (42 U.S.C. 5875), for the fiscal years 1982 and 1983 to remain avajlable until expended, $\$ 485,200,000$ for fiscal year 1982 and $\$ 513,100,000$ for fiscat year 1983 to be allocated as follows:

(1) Not more than $\$ 80,700,000$ for fiscai year 1982 and $\$ 77,000,000$ for fiscal year 1983 may be used for "Nuclear Reactor Regulation", of which an amount not to exceed $\$ 1,000,000$ is authorized each such fiscal year to be used to accelerate the effort in gas-cooled thermal reactor preapplication review, and an amount not to exceed $\$ 6,000,000$ is authorized each such fiseal year to be used for licensing review work for a fast bretder reactor plant project. In the event of a termination of such breeder reactor project, any unused amount appropriated pursutant to this paragraph for licensing review work for such project may be used only for safety technology activities.

(2) Not more than $\$ 62,900,000$ for fiscal year 1982 and $\$ 69,850,000$ for fiscal year 1983 may be used for "Inspection and Enforcement".

(3) Not more than $\$ 42,000,000$ for fiscal year 1982 and $\$ 47,059,600$ for fiscal year 1983 maty be used for "Nuclear Material Safety and Safeguards".

(4) Not more than $\$ 240,300,000$ for fiscal year 1982 and $\$ 257,195,600$ for fiscal year 1983 may be used for "Nuclear Regulatory Restarch", of which-

(A) an amount not to exceed $\$ 3,500,000$ for fiscal year 1982 and $\$ 4,500,000$ for tiscal year 1983 is authorized to be used to accelerate the effort in gas-cooled thernal reactor safety research;

(B) an amount not to exceed $\$ 18,000,000$ is authorized each such fiscal year to be used for fast breeder reactor safety research; and 
Grants and copperative agreerpents.

Reallocated funds.

Notification of congressional combrittees.
(C) an amount not to exceed $\$ 57,000,000$ is authorized for such two fistal year period to be used for the Loss-of-Fiuid Test Facility research prograra.

In the event of a termination of the fast breeder reactor plant project, any unused amount appropriated pursuant to this paragraph for fast breeder reactor safety research may be used generally for "Nuclear Regulatory Research".

(5) Not more than $\$ 21,900,000$ for tiscal year 1982 and $\$ 20,197,800$ for fiscal year 1983 may be used for "Program Technjcal. Support ${ }^{2}$.

(6) Not more than $\$ 37,400,000$ for fiscal year 1982 and $\$ 41,797,000$ for fiscal year 1983 may be used for "Program Direction and Admintstration."

(b) The Nuclear Regulatory Commission may use not more than 1 percent of the amounts autborized to be appropriated under subsection (a) (4) to exercise its authority under section $\mathbf{3 1} \mathrm{a}$ of the Atomic Energy Act of 1954 (42 U.S.C. 2051(a)) to enter into grants and cooperative 'agreements with universities pursuant to such section. Grants made by the Commission shall be made is accordance with the Federal Grant and Cooperative Agreement Act of 1977 (41 U.S.C. 501 et seg.) and other applicable law. In making such grants and entering jitto such co- $^{-}$ operative agreements, the Coumission shall endeavor to provide appropriate opportunitjes for universities in which the student body has bistorically been predorninantly comprised of minority groups.

(c) Any amount approptiated for a fiscal year to the Nuclear Regulatory Commission pursuant to any paragraph of subsection (a) for purposes of the program office referred to in such paragraph, or any activity that is within such program office and is specified in such paragraph, may be reallocated by the Commission for use in a program office, except that the amount available from appropriations for such fiscal year for use in any program office or specified activity may not, as a result of reallocations made under this subsection, be increased or reduced by more than $\$ 500,000$ unless-

(1) a period of 30 calendar days (excluding any day in which eitber House of Congress is not in session because of an adjournment of more than 3 calendar days to a day certain or an adjourment sine die) pesses after the receipt, by the Committee on Energy and Commerce and the Committee on Interior and Insular Affairs of the House of Representatives and the Committee on Environment and Public Works of the Senate, of notice submitted by the Commission containing a full and complete statement of the reallocation proposed to be made and the facts and circurnstances relied upon in support of such proposed reallocation; or

(2) each such oommittee, before the expiration of such period, transmits to the Commission a written notification that such com" mittee does not object to such proposed reallocation.

\section{AUTHORITY TO RETAIN CKRTATN AMOUNTS RECEYVD}

Set. 2. Moneys received by the Nuclear Regulatory Commisston for the cooperative nuclear research program and the material access au- 
Ante, p. 948 .

$31 \mathrm{USC} 3302$

Post, p. 2071 thorization program may be retained andused for stajarits and expenses associated with stuch programs, notwithstancting the provisions of section 3617 of the Revised Statutes (31 U.S.C. 484), and shall rematn available until expended.

AUTHOFIY TO TRANSFER CERTAIN AMOUNTS TO OTHER AGENCIES

Sec. 3. From amounts appropriated to the Nuclear Regulatory Commission pursuant to section 1(a), the Commission may transfer to other agencies of the Federal Government surns for salaries and expenses for the performance by such agenctes of activities for which such appropriations of the Commission are made. Any sums so transferted may be merged with the appropriation of the agency to which such sums are transferred.

\section{LDATTATION ON SPENWWE AUTHORTYY}

Sec. 4. Nowithstanding any other provision of this Act, no authority to make paytients under this Act shall be effective except to such exient. or in sach arnounts as are provided in advance in appropriation Acts.

\section{AUTHORTYY TO ISSUE LICENSES IN ABSENCE OF EMERGENCY PRERAREDNESS PLANS}

Sec 5. Of the anounts authorized to be appropriated under section 1, the Nuclear Regulatory Commission may use such sums as may be recessary, in the absence of a State or local emergency preparedness plan which hes been approwed by the Federal Emergency Management Agency, to issue an operating license (including a tomporary operating Jicense under section 192 of the Atomic Energy Act of 1954, as amended by section 11 of this Act) for a nuclear power reactor, if it determines that there exists a State, Jocal, or utility plan which provides reasonable assurance that public health and safety is not endangered by operation of the factility concensed.

\section{MUCLEAR SAFETY GOALS}

Sec 6. Funds authorized to be appropriated under this Act shall be used by the Nuclear Regulatory Commission to expedite the establishment of stafty goals for nuclear reactor regulation. The development of such safety goals, and any accompranting methodologites for the application of such safety goals, should be expedited to the maximum extent practicable to perinit establistutert of a safety goal by the ComInission not later than December 31, 1982.

\section{LOSS-OP-KLID TESY FACILTTY}

Sec. 7. Of the amounts authorized to be used for the Loss-of-Fivid Test Facility in accordance with section 1 (a) (4) for fiscal years 1982 and 1983, the Commission shell provide funding through contract with the organization responsibłe for the Lass-of-Fluid Test operations for a detajled technical review and anaiysis of research results obtained from the Loss-of-Fluid Test Facility reseasch program. The contract shall provide funding for not more than wwenty man-years in each of fiscal years 1982 and 1983 to condiact the technical review and anatysis.

\section{NUCtiak DATA bNR}

Sec. 8. (a) Of the amounts authorized to be appropriated under this Act for the fiscal years 1982 and 1983, not more than $\$ 200,000$ is autborized to be used by the Naclear Reggilatory Commission for- 
Study and analysis.

Report to Congress.

Commission action; notification of congressional committees.
(1) the acquisition (by purchase, tease, of otherwise) and installation of equipment to be used for the "snall test prototype nuclear data link" program or for any other program for the collection and transuission to the Commission of data from licensed nuclear reactors ouring abnormal condjtions at such retactors; and (2) the conduct of a full and complete study and analysis of-.

(A) the appropriate role of the Commission furing abromal conditions at a nuclear reactor licessed by the Commission;

(B) the information which should be available to the Commission to enable the Commission to fultill such role and to carry out other related functions;

(C) various alternative means of assuring that such information is available to the Comumission in a timely manner; and

(D) any changes in existing Compission autiority pecessary to enhance the Commission response to abnormal conditions at a nuclear reacto licensed by the Commission.

The suall test prototype referred to in paragraph (1) may be used by the Commission in carrying out the study and analysis under paragraph (2). Such analysis shall include a cost-benefit analysis of each altemative exarnined undes subparagraph (C).

'(b)(1) Upon completion of the study and analysis required under subsection (a)(2), the Commission shall submit to Congress a detailed report setting forth the results of such study and analysis.

(2) The Congmission may not take any action with respect to any aliernative described in subsection (a)(2)(C), uniess a period of 60 calendar days (excluding any day in which either House of Congress is not in session because of an adjournment of more than 3 calendar days to a day certain'or an adjournment sine die) passes after the re. ceipt, by the Committee on Energy and Commerce and the Committee on Interior and Insular Affairs of the House of Representatives and the Committe on Environment and Public Works of the Senate, of notice submitted by the Comumission containing a full and complete statement of the action proposed to be taken and the facts and circumstances relied upon in support of such proposed action.

\section{INTERM CONSOLIDATION OR OFHCES}

Sec: 9. (a) Of the anjounts autionized to be appropriated pursuant to paragraph 6 of section 1(a), strch sums as may be necessary shall be available for interim consolidation of Nuclear Regulatory Commission headquarters staff offices.

(b) No anount authorzed to be appropjiated under this Act nay be used, in connection with the mterim consolidation of Nuchear Regulatory 'Commission offices, to relocate the offices of members of the Commission outside the District of Columbta.

\section{TiREE MILE ULANB}

Sec 10. (a) No part of the funds authorized to be appropriated under this Act raay be used to provide assistance to the Gentral Public Utitjtites Corporation for purposes of the decontamination, cteanup, repair, or rehabilitation of facilities at Three Mile Island Unit 2 .

(b) The prohibition contained in subsection (a) shall not relate to the responsibilities of the Nuclear Regulatory Commission for monitoring 
or inspection of the decontamination, cleanup, repair, or rehabilitation activities at Three Mije Island and such prohibition shall not apply to the use of funds by the Nuclear Regulatory Commission to carry out

42 USC 2011

note.

42 USC 5877

note.

42 USC 2133, 2134,

Post, p. 2073

Initial petition.

Affldavits regulatory functions of the Commission under the Atomic Energy Act of 1954 with respect to the facilities at Three Mijle Island.

(c) The Nuclear Regulatory Commission shall include in its annual repart to the Congress under section 307(c) of the Energy Reorganization Act of 1974 (42 U.S.C. 5877 (c)) as a separate chapter a description of the collaborative efforts undertaken, or proposed to be undertaken, by the Commission and the Department of Energy with respect to the decontamination, eleanup, repair, or rebabilitation of facilities at Three Mtle lsland Unit 2.

(d) No funds authorized to be appropriated under this Act jazy be used by the Coramission to approve any willful release of "accidentgenerated water", as defined by the Commission in NUREO-0683 ("Final Programmatic Ervironmental Impact Statement" p. 1-23), from Three Mile 1sland Unit 2 into the Susquehanna River or its watershed.

\section{TEMOPORAKY OPERATHG LICENSES}

Sec. 11. Section 192 of the Atomic Energy Act of 1954 (42 U.S.C. 2242) is amended to read as follows:

"SEC. 192. TEMPORARY OPERATING LICENSE-

"a. In any proceeting upon an application for an operating license for a utilization facility required to be lieensed under section 103 or $104 \mathrm{~b}$. of this Act, in which a hearing is otherwise required pursuant to section 189 a., the applicant may petition the Commission for a temporary cperating license for such facility authorizing fuel loading, testing, and operation at a specific power level to be determined by the Commission, pending final action by the Commission on the application. The initial petition for a temporary operating license for each such facility, and any tomporary operating license issued for such factlity based upon the injtial petition, shall be limited to power levels not to exceed 5 percent of rated full thermal power. Following issuance by the Commission of the temporary operating license for each stuch facility, the licensee may file petitions with the Conmission to amend the license to ellow facility operation in staged increases at specific power levels, to be determined by the Commission, exceeding 5 percent of rated full thermal power. The tuitial petition for a temporary operating license for each such facility may be filed at any time after the filing of (I) the report of the Advisory Conarittee on Reactor Safeguards required by section 192 b; (2) the filing of the fintial Safety Evaluation Report by the Nuclear Regulatory Commission staff and the Nuclear Regulatory Commission staff's first supplement to the report prepared in response to the report of the $\mathrm{Ad}$. visory Committee on Reactor Safeguards for the facility; (3) the $\mathrm{Nu}$ clear Regulatory Commission staff's final detaled statement on the environmental impact of the facility prepared pursuant to section 102 (2)(C) of the National Environmental Policy Act of 1969 (42 U.S.C. 4332(2)(C)); and (4) a State, local, or utility emergency prepuredress plan for the facility. Petitions for the issuance of a temporary operating bicense, or for an amendment to such a license allowing operation at a 
Pubsication in

Federal

Register.

Binal order, transmiltal to congressional committees.

Judicial review,

$28 \mathrm{USC} 2341$ sect.

Post, p. 2073 ,

Hearing. specific power level gritater than that authorized in the initial temporary operating license, shall be accompanied by an affidavit or affidavits setting forth the specific facts upon which the petitioner relies tojustify issuance of the temporary operating license or the amendment thereto. The Commission shall publish notice of each such petition in the Federal Register and in such trade or news publications as the Comnission deems appropriate to give reasonkble notice to persons who mitght bave a potential interest in the grant of such temporary operating license or amendment thereto. Any person may file affidavits or statements in support of, or in opposition to, the petition within' thirty days after the publication of such notice in the Federal Register.

"b. With respect to any petition filed pussuant to subsection a. of this section, the Comnission may issue a temporary operabing license, or amend the license to authorize temaporary operation at each specific power Jevel greater than that authorized in the initial temporary operating license, as determined by the Commission, upon finding that-

"(1) in all respects otier than the conduct or completion of any secutred hearing the recuirements of law are met;

"(2) in accordance with such requirements, there is rtasonable assurance that operation of the focility during the period of the temporary operating license in accordance with its terms and conditon wil provide adequate protection to tho public health and safety and the envinonment during the penod of tomporary operationt and

"(3) denial of such temporary operating license will result in delay between the date on which construction of the facility is sufficiently completed, in the judgment of the Commission, to permit issuarce of the temporary operating license, and the date when such facility would otherwise receive a final operating license pursuant to this Act.

The temporary operating license shall become effective upon issuance and shall contain such terms and conditions as the Commission may deem secessary, incliting the duration of the license and any provisjon for the extension thereof Any inal order atuthorizing the issuance or amendment of any temporary operating license pursuant to this section stiall recite with spectifity the facts and revsons justifying the findings under this subsection, and shall be transmitted upon such issuance to the Committees on Interior and Insular Affairs and Energy and cornmerce of the Holise of Reuresentatives and the Comarittet on Environment and Public Works of the Senate. The final order of the Commission with respect to the issuance or amendment of a temporary operating license shall be subject to judicjal review pursuant to chapter 158 of title 28, United States Code. The requirements of section $189 \mathrm{a}$. of this Act with respect to the issuance or amendment of facility licenses shell not apply to the issuance or amendment of a temporary operating license under this section.

"c. Any hearing on the application for the final operating license for a facility required pursuatit to section 189 a shall be concluded as promptly as practicable. The Commission shall suspend the temporary operating license if it finds that the applicant is not prosecuting to ap- 
Infra.

Expiration date.

Notice of publication.

Regulations estabtishing standarik, ctiterita, and procedures. plication for the final operating license with due diligence. Issuarce of a temporary operating license under subsection $b$. of this section shall b: without prejudice to the right of anly party to raise any issue in a hearing required pursuant to section 189 a.; and failure to assert any ground for denial or limitation of a temporary operating license shall not bar the assertion of such ground in consection with the isstarce of a stbsequent final cperatiog license. Any party to a bearing required pursuant to section 189 a. on the final operating license for a facility for which a temporary operating license has been issued under subsection b., and any member of the Atomic Safety and Licensing Board conflucting such bearing, shall promptly notify the Commission of any information indicating that the terms and conditions of the temporary operating license are not being met, or that such terms and conditions are not sufficient to comply with the provisions of parayraph (2) of subsection b.

"d. The Commisston is authorized and directed to adopt stch admin. istrative remedies as the Commission deems appropriate to mitsintise the need for issuanoe of termporary operating licenses pursuant to this section. "e. The atuthority to isste new temporary operating licenses under this section shall expite on Decertaber 31, 1983.".

\section{OPERATINC LICENSE AMENDMLNT HEARINGS}

Sec. 12, (a) Section 189 a of the Atomic Energy Act of 1954 (42U.S.C. 2239(a)) is amended-

(1) by inserting "(I)" after the subsection designation; and

(2) by adding at the end thereof the following new paragrapb:

"(2)(A) The Commission may issue and make immediately effective any amendment to an operating license, upon a determination by the Commission that such amendment involves no signtificant hazards consideration, notwithstanding the pendency betore the Commission of a request for a hearing from any person. Such amendinent may be issued and unade immediately effective in advance of the holding and completion of any required hearing. In determining ander this section whether such amendinent involves no significant bazards consideration, the Commission shall constult with the State in which the facility involved is located. In all other respects suth anendinent shall weet the requirements of this Act.

"(B) The Commission shall periodically (but not less frequentiy thas once every thirty days) publish notice of any amendments issued, or proposed to be isstied, as provided in subparagraph (A). Each such notice shall melude all amendments sssued, or proposed to be issued, since the date of publication of the last such periodic notice. Such notice shall, with respect to each amendinent or proposed amenoment (i) identify the facitity involved; and (b) provide a brief description of such amendment. Nothing to this subsection shall be constried to delay the effective date of any amendment.

"(C) The Cormission shall, during the ninety-day period following the effective date of this paragraph, promulgate regulations establishing (i) standards for determining whether any amendment to an operating license inwolves no significant hazards consideration; (ii) criteria for providing or, in emergency situations, dispensing with prior notice and reasopable opportunity for public comment on any such determisation, 
42 USC 2239

note.

Restident intspector program. 42 USC 584 I note.

Commercial nuxlear powerptant construction, stuxty. which criteria shall take into account'the exigency of the need for the amendment involved; and (iti) procedures for consultation on any such determination with the State in which the facility involved is located.".

(b) The authority of the Nuclear Regulatory Commission, under the provisions of the amendment made.by subsection (a), to issue and to make immediately effective any amenciment to an operating license shall take effect upon the promulgation by the Commission of the regulations required in stuth provisions.

\section{QUALIT ASSURANCE}

Sec. 13. (a) The Nuclear Regulatory Commission is authorized and directed to implement and accelerate the resident inspector program so as to essure the assignment of at least one resident jnspector by the end of fiscal your 1982 at each site at which a combintercial nuclear powerplant is undert construction and construction is more than 15 percent complete. At each suct site at which corstruction is not more than 15 percent complete, the Commisston shall provide that such inspection personnel as the Conurission deems appropinate shall be phissically present at the site at such tines following issuance of the construction permit as may be necessary in. the judgment of the Commission.

(b) The Commisston shall conduct a study of existing and altemative programs for improving quality assurance and quality control in the construction of commercial nuclear potwerplants. In conducting the study, the Comtnission shall obtain. the comnuents of the public, licenstes of nuclear powreplants, the Advisory Committe on Reactor Safoguards, and organizations compitsed of professionals having expertise in approprtiate fields. The stidy shall include an analysis of the folkowing;

(1) prowiding a basis for quality asstanance and quality control, inspection, and enforcement actions through the adoption of an approach which is more prescriptive than that currently in practice for defining principal architectural and engineering criteria for the construction of commercial nuctetar powerplants;

(2) conditioning the tssuance of construction permits for commercial nuclear powerplants on a demonstration by the licensee that the licensee is capable of independently managing the effective performance of all quality assurance end quality control responsibilibes for the powerplant;

(3) evaluations, inspections, or audits of commercial nuclear powerplant constuction by organizations comprised of professionals having expertize in appropriate fields which evaiuations, inspections, or audits are more effective than those under current practice;

(4) improvement of the Commission's organization, methods, and programs for quality assurance development, review, and itispection; and

(5) conditioning the issuance of construction permits for commercial suclear powerplants on the permittee entering into contracts or other arrangements with an independent inspector to au- 
"Independent inspector."

42 USC2011 note.

Pilot program.

Sucty sesulis. subrittal to Congress.

42 USC2014. dit the quality assurance program to verify quality assurance performance.

For purposes of paragraph (5), the term "independent inspector" means a person or other entity having no responsibility for the design or construction of the plant involved. The study shal also indlide an analysis of quality assurance and quality control programs at representative sites at which such programs are operating satisfactorily and an assessment of the rasosons theretor.

(c) For purposes of-

(1) determiring the best meatus of assuring that commercial nudear powerplants are constructed in accordance with the applicable safety requirements in effect purstrant to the Atomic Energy Act of 1954; and

(2) assessing the feasibility and benefits of the various mears listed in subsection (b);

the Commiscion shall undertake a pilot program to review and evaluate programs that include one or more of the alternative corsepts identified in subsection (b) for the purposes of assessing the feasibility and benefits of their implementation. The pilot program shall include programs that use independent inspectors for auditing quality assurance responsabilities of the licinses for the construction of commercial ntwclear powarplants, as described in parageaph (5) of subsection (b). The pilot program shall include at least three sites at which commercial nuclear powerplants are under construction. The Commission shall select at least one site at which quality assurarce and quality control programs have operated satisfactorily, and at least two sites with remedial programs undenway at whtch major construction, quality assurance, or quality control deficiencies (or any combination thereof) have been identified in the past. The Commission may requite any changes in exjsting quality assurance and quality control organizations and relationships that may be necessary at the selected sites to implement the pilot program.

(d) Not later than theen months after tye date of the ensctment of this Act, the Commission shall complete the study required under subsection (b) and submit to the United States Senate and House of representatives a report setting forth the results of the study- The report shall inctude a brief summary of the information received from the public and from other persons referred to in subsection (o) and a statement of the Commisston's response to the significant comments re. ceived. The report shall also set forth in analysis of the results of the pilot program required under subsection (c). The report shall be accompanied by the recommendations of the Commission, including any legislative recommenotations, and a description of any administra. tive actions that the Commission has undertaken or intends to under* take, for tuproving quality assurance and quality control programs that are applicable diring the construction of nutlear powerplants.

\section{LDMTATION ON USE OF SPECLAL NECLEAR MATERIAL}

Sec. 14. Section 57 of the Atomic Energy Act of 1954 (42 U.S.C. 2077) is amended by adding at the end thereof the collowing new subsection: "e. Spectal nuclear material, as defined in section 11, produced in

F


42 USC 2133 , 2134.

Report to Congress.

Penalties.

95 Stat. 1169.

Juxlicial review.

Quarterly report. facilities licensed under section 103 or 104 may not be transferred, reprocessed, used, or otherwise made available by any instrumentality of the United States or any other person for auclear explosive purposes..".

\section{RESIDENT INSPECTORS}

Sec. 15. Of the amounts autherized to be appropriated under section 1. the Nuxlear Regulatory Comuntssion shall use such sums as may be necessary to conduct a study of the financial hardships incurred by resident inspectors as a result of (1) regulations of the Commission reciuiring resident inspectors to rekocate periodically from one duty station to another; and (2) the requirements of the Combission respecting the domicile of resident inspectors and respecting travel between their donicile and duty station in such manner as to avoid the appearance of a conflict of interest. Not later than 90 days after the diste of the enactment of this Act, the Commission shall submit to the Congress a report setting forth the findings of the Contrission as a result of such study, together with a legislative proposal (including any supporting date or information) relating to any assistance for resident inspectors deternined by the Commission to be appropriate.

SAB OTAGT OF NUCLRAR FACILITIES OR FUIL

Sec. 16. Section 236 of the Atomic Energy Act of 1954 (42 U.S.C. 2284) is anended to read as follows:

"SEC. 236. SABOTAGE OF NUCLEAR FACILITIES OR FUEL.

"a. Any person who intentionally and willfully desterys or causes physical damaige to, or who intentionally and willifuly attempts to destroy or cause physical damage to-

"(1) any production facility or utilization facility licensed under this Act

"(2) any nuctear waste storage facility licensed under thís Act; or

"(3) any nucltar futel for such a utilization facility, on any spent nuclear futl from such a facility:

shall be fined not more than $\$ 10,000$ or imprisoned for not more than ten years, or botit.

"b. Any person who intentionally and willfully chuses or attempts to cause an interruption of normal' operation of any such facility through the unauthorized use of or mimpering with the rachinery, components, or controls of any such facility, shall be fined not more than $\$ 10,000$ or imprisoned for not more thian ten years, or both.".

\section{DEPARTMENT OF ENERGY INEORMATION}

Sec. 17. (a) Section 148 a. (1) of the Atomic Energy Act of 1954 (42 U.S.C. $2168(a)(1)$ ) is andended by inserting after "Secretary" lownit., ", with respect to atomic energy defense programs,".

(b) Section 148 of the Atomic Energy Act of 1954 (42 U.S.C. 2168) is amended by adding at the end thereof the following new subsections:

" $d$. Any deterinination by the Secretary concerning the applicability of this section shall be subject to judicial review pursuant to section 552(a)(4)(B) of tikke 5, United States Code.

"e. The Sectetary shall prepare on a quarterly basis a report to be made available upon the request of any interested person, detailing the Secretary's application during that period of each regulation or order 
prescribed or issued under this section. In particular, such report shall-

(1) identify any information protected from disclosure pursuant to such regulation or order;

"(2) specificalfy state the Secretary's justification for determining that unauthorized dissemination of the information protected from disclostre under such regulation or order coutd reasonably be expected to have a significant adverse effect on the bealth and safety of the public or the common defense and sectirity by signiticantly increasing the likelikood of illegal production of moclear weapons, or theft, diversion, or sabotage of nuclear materials, equipment, or facilities, as specised under subsection a,; and

(3) provide justification that the Secretary has applied such reg. ulation or ordes so as to protect from disclosere only the minimum amount of information necessary to protect the health and safety of the public or the common defense and security.".

42 USC 2022.

STANDARDS AND REOUIRZMIENTS INDDER SECTION 275

Sec- 18. (a) Section 275 of the Afomic Energy Act of 1954 is amended-

(1) by striking in subsection a. "one year after the date of enact. ment of this section" and substinting "October 1, 1982" and by adding the following at the end thereof: "After October 1, 1982, if the Administrator has not promulgated standards in final form under this subsection, any action of the Secretary of Energy under title I of the Uranjum Mill tailings Radiation Control Act of 1978 which is reguired to comply with, or be taken in accordance with,

42 USC 7911. the standards proposed by the Administrator tader this subsection until such time as the Adtuinistrator promulgates such standards in final form.";

(2) by striking in subsection b. (1) *eighteen months after the enactment of this section, the Administrator shall, by nile, promulgate" and inserting in lieu thereof the following: "October 31, 1982, the Administrator shall, by rule, propose, and within 11 months thereafter profoulgate in final form,";

Promulgation (3) by adding the following at the end of subsection b. (1): "If the authority. Administrator fails to promitrlgate standards in final form under this subsection by October 1, 1983, the authority of the Administrator to promulgate such standards shall terminate, and the Conmission may take actions under this Act witllout regard to any provision of this Actrequiting such actions to comply with, or be taken in accordance with, standards promulgated by the Administrator. In any sucil case, the Conarission sball promulgate, and from time to time revise, any such standards of general application which the Commission deems necessary to carry out its responsibilities fo the conduct of its licensing activities under this Act. Requirement ts established by the Commission under this Act with respect to byproduct material as defined in section $11 \mathrm{e}$. (2) shall conforth to

42 USC 2014. such standards. Anly requirements adopted by the Commission respecting such byproduct material before promulgation by the Commission of such standards shall b amended as the Corminis-

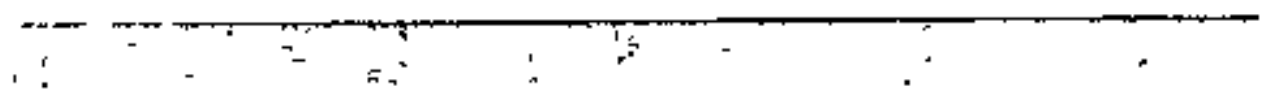


Uranìmm mil] licensting requirsmont regulations.

Implementation and enforcement.

Review, public comment, and suspension.

$42 \mathrm{USC} 2114$

Remedial action 42 UsC 7918. sion deems necessary to conform to such standards in the same manntr as provided in subsection $f$ (3). Nothing in this subsection shatl be construed to prohibit or suspend the imptementation or enforcement by the Commission of any reguirement of the Commission respecting byproctuct material as defined in section $11 \mathrm{e}$. (2) pending promulgation by the Commission of any such standard of general application.";

(4) by adding the following new stobsection at the end thereof:

uf. (1) Prior to January 1, 1983, the Commission sball not imiptement or enforce the peovisions of the Uranium Mill Licensing Requirements published as firal rules at 45 Federal Register 65521 to 65538 on Octobet 3,1980 (hereistafter referred to as the 'October 3 regulations'). After December 31, 1982, the Commission is authorized to implement and enforce the provisions of such October 3 regulations (and any subse" quent modifications or adtitions to such regulations which may be adopted by the Conmission), except as otherwise provided in paragraphs (2) and (3) of this subsection.

(2) Following the proposal by the Adritistrator of standards under subsection b., the Commission stiall review the October 3 regulations, and, not later than 90 days after the date of such proposal, suspend inplementation and enforcement of any provision of such regulations which the Commission determioes after notice aud opportunity for public comment to require a major action or major commitront by licersees which would be unnecessary if-

“(A) the standards proposed by the Administrator are promulgated in final form without modification, and

"(B) the Commisston's requirements are modified to conform to stich standards.

Such suspension sball termingate on ths earliter of April 1, 1984 or the date on which the Commission anends the October 3 segulations to conform to final standards promulgated by the Administrator under subsection b. During the period of such suspension, the Connmisston shall continue to regulate byproduct material (as defined in section 11 e. (2)) under this Act on a licensee-by-licensee basis as the Conunission deems necessary to protect public health, safety, and the environment.

"(3) Not Jater than 6 months after the date on which the Administrator promulgates final standards pursuant to subsection b. of this section, the Commission stall, after notice and opportunity for public comment, amend the October 3 regulations, and adopt such modisications, as the Commission deens necessary to conform to such final standards of the Adratinistrator.

"(4) Nothing in this subsection may be construed as affecting the atthority or responsibility of the Commission undto section 84 to promulgate regulations to protect the public health and safety and the environment."

(b) (1) Section 108(a) of the Uranitım Mill Tatlings Radiation Control Act of 1978 is amended by adding the following new paragraph at the end thereot

"(3) Notwithstandiag paragraphs (1) and (2) of this subsection, after October 31, 1982, if the Administrator has not promulgated standards 
Ante, 0. 2077; Par, p. 2080.

42 USC 2021.

42 USC 2014.

42 USC 2022.

42 USC 2021. note.

42 USC 2023.

Alternative proposals by licenseces. 42 USC 2114 ,

42 UsC 2014.

under section 275 a. of the Atomic Energy Act of 1954 in final form by strch date, remedial action taken by the Secretary under this title shall comply with the standards proposed by the Administrator under such section 275 a. intil such time as tite Administrator promulgates the standards in final form.".

(2) The second sentence of section 108(a)(2) of the Uranium Mill tailings Radiation Control Act of 1978 is reptaled,

\section{AOREEMTNT STATES}

Sec. 19. (a) Section 274 o. of the Atomic Energy Act of 1954 is amended by adding the following at the end thereof: "In adopting requirements purseant to paragraph (2) of this subsection with respect to sites at which ores are processed primarily for their source material content or which are used for the disposal of byproduct material as definted int section 11 e. (2), the State may adopt altermatives (including, where appropriate, site-specific alternatives) to the requirements adopted and enforced by the Commission for the same purpose if, after notice and opportunity for public hearing, the Commission determines that such alternatives will achieve a level of stabilization and containment of the sites concerned, and a level of piotection for public hesith, safety, and the enviconment from radiological and nonradiological hazards associated with such sites, which is equivalent to, to tho extent practicable, or more stringent than the level which would be achieved by standards and recuirements adopted and enforced by the Commission for the same pirpose and any final standards promulgated by the Admitistrator of the Environmental Protection Agency in accordance with section 275. Such alternative State requitements dray take into account local or regional conditions, including geology, topoyaphy, hydrology and meteozology.".

(b) Section 204(b)(3) of the Urantum Mil Taslings Radiation Control Act of 1978 is amended by insertis the following before the period at the end thereof: "F Provided, however, That, in the case of a State which has exercised any authority under State law pursiant to and agreement entered juto under section 274 of the Atomic Entrigy Act of 1954, the State authontcy over such byproduct material may be teruinated, and the Comurission authority over such material may be exercised, only after compliance by the Commission with the stane procedures as are applicable in the case of temination of agreements bider section $274 \mathrm{j}$. of the Atomic Energy Act of 1954.".

\section{MMENDMENT TO SECTION 8}

Sec. 20. Section 84 of the Atomic Enorgy Act of 1954 is amended by adding the following at the end thereot:

"c. In the case of sites at which ores are processed primatily for their source material content or which are used for the disposal of byproduct material as defined in section $11 \mathrm{e}$. (2), a licencee may propose altematives to specific requirements adopted and enforced by the Commission under this Act. Such alternative proposals may take into account local or regional conditions, including geology, topography, hydrolong and meteorology. The Commission may troat such alternatives as satisiying Commission requirements if the Commission determines that such at- 
42 USC 2022.

42 USC 7912

42 USC 7911 .

42 USC7917.

42 USC 2114

Ante, p. 2077. ternatives will açieve a level of stabilization and containnent of the sites cancerned, and a level of protection for public bealth, safery, and the enviroment from radiological and potmadiological hazards associated with such sites, which is equivalent to, to the extent practicable, or more stringent than the level which would be achieved by standards and requirements adopted and enforced by the Commission for the same purpose and any final standards promuitgated by the Administrator of the Environmental Protection Agency in accordance with section 275.".

\section{EDGXMONT}

Sec. 21. Section 102(e) of the Uranium Mitl Thilings Radiation Control Act of 1978 is amended by adding the following at the end thereof

"(3) the Secretary shall designate as a processing site within the mean. ing of section 101(6) any real property, or improvements thereon, in Edgemont, South Dakots, that-

"(A) is in the vicinity of the Tennessee Valley Authority uranium mill site at Edgemont (but not including such site), and

"(B) is deternined by the Secretasy to be contaminated with residual radioactive materials.

In making the designation under this paragraph, the Secretary stall consilt with the Administrator, the Comusission and the State of South Dakota. The provisions of this title shall apply to the site so designated in the same manner and to the same extent as to the sites designated under subsection (a) except that, in applying such provisions to such site, any reference in this title to the cate of tile enactment of this Act shall be treated as a reference to the date of the enactroent of this paragrapl and in determining the State share under section 107 of the costs of repiedial action, there shall be credjted to the State, expendinures made by the State prior to the date of the enactonent of this paragraph which the Secretary determines would have been made by the State or the United States in carrying out the recquirements of this title.".

\section{ADDITONAL AMENDWISNTS TO SECTIONS \&4 AND 275}

Sec. 22. (a) Section 84 a. (1) of the Atom te Energy Act of 1954 is amended by inserting before the compma at the end thereof the following: ", taking into account the risk to the public health, safety, and the envitonment, with due consideration of the economic costs and such other factors as the Commission determizes to be appropriate,".

(b) Section 275 of the Atomic Energy Aet of 1954 is amended-

(1) in subsection a, by inserting after the second sentence thereof the following new sentence: "In establishing such standards, the Adunimistrator shall consider the risk to the public health, safety, and the environment, the environmental and economic costs of applying such standards, and such other factors as the Administra. tor determines to be appropriate "; and

(2) by adding at the end of subsection b. (1) the foltowing new sentence: "In establishing such standards, the Administrator shal! consider the risk to the public bealth; safety, and the environment, the environmental and economic costs of applying such standards, 
and such other factors as the Administrator determines to be appropitate.".

\section{URANTLM SUPPLX}

Comprehentive industry styiew, submittal to Congress. 42 USC 22100 note.
Report to Congress and President. 42 USC 2210b.

42 USC 2231.

Sec. 23. (a) (1) Not later than 12 months after the date of enactment of this section, the President stall prepare and subutit to the Congress a comprebensive review of the status of the domestic uranium mining and milling industry. This review shall be made available to the appropriate connmittees of the United States Senate and the House of Representatives.

(2) The Comprehensive review prepared for submission under paragraph (1) shall include-

(A) projections of uraniun requirements and inventories of domestic utilities;

(B) present and future projected uranium production by the domestic mining and milling industry;

(C) the present and future probable pentetration of the domestic market by foreign imports;

(D) the size of domestic and foreign ore reserves;

(E) present and projected domestic uranium exploration expenditures and plans;

(F) present and projected employment and capital investment in the uranium industry;

$(G)$ an estimate of the level of domestic uranium production pecessary to ensure the viable existence of a domestic uranium industry and protection of national security interests'

(H) an estimate of the percentage of domestic uramium demand which mest be met by domestic uranitm production through the year 2000 is order to ensure the level of domestic production estimated to be necessary under subparagraph (G);

(I) a projection of domestic uraniurm production and uraninem price levels which will be in effect both under current policy and in the event that foreign import restrictions were enacted by Congress in order to guarante donestic production at the level estivated to be necessary urder subparagraph (G);

(J) the anticipated effect of spent nuclear fuel reprotessing on the demand for uranium; and

(K) other juformation relevant to the consideration of restrictions on the importation of source material and spectal nuclear material from for eipn sources.

(b)(1) Chapter 14 of the Atomic Eneriby Act of 1954 is amended by adding the following new section at the end thereof:

"SEC. 170B. URANIUM SUPPLY.-

*a. The Secretary of Enery shall monitor and for the years 1983 to 1992 report anpually to the Congress and to the President a determination of the viability of the domestic uranium mining and milling industry and shall establish by nule, after public notice and in actotdance with the requirements of section 181 of this Act, within 9 months of enactonent of this section, specific ariteria which shall be assessed in the anualal reports on the domestic uranium indistry's viability. The Secretary of 
Regułationș.

Proprietary ioformation, disclosure.

Criteria

Imported material, impact on domestic industry and national security.
Energy is authorized to issue regulation's providing for the collection of stch information as the Secretary of Energy deems necessary to carry out the monitoring and reporting requirements of this section.

tb. Upon a satisfactory showing to the Secretary of Energy by any pwison that any information, or portion thereof obtained under this section, would, if made public, divulge proptietary iuformation of such person, the Secretary shall not disclose strh information and disclosure thereof shall be punishable under section 1905 of title 18, United States Code.

"c. The sriteria referred to in subsection a. shall also include, but not be linited to-

${ }^{\text {}}(1)$ an assessment of whether exccuted contracts or options for source materíal or special nuclear material will result in greates than $37 l_{2}$ percent of actual or projected domestic uranium requirements for any two-consectitive-year period being supplied by source meterial or special muclear material from foreiws sources

"(2) projections of tuanium requirements and inventories of domestic utilities for a 10 year period;

"(3) present and probable fature use of the domestic market by foreign juports;

"(4) whether donestic economic reserves can stoply all future needs for a fiture 10 year period:

"(5) present and projected domestic uranum exploration expendiţures and plans;

*(6) present and projected employment and capital imvestment in the uranium industry,

( $(7)$ the level of domestic uranium production capacity sufficient to met projected domestic núclear power needs for a tó year peri. odj and

(B) a projection of domestic uranitum production and uranium price levels which will be in effect under various assumptions with respect to imports.

“d. The Secretary or Energy, at any time, may determine on the basis of the monitoring and annual reports required under this section that source material or special nuclear material from foreign sources is being imported in such increased quantities as to be a substantial cause of seriotus injury, or thret thereof, to the United States uranium uining and milling industry. Based on that determination, the United States Trade Representative shall request that the United States International Trade Commission initiate an investigation under section 201 of the Trade Act of 1974 (19 U.S.C. 2251).

${ }^{*}$. (1) If, during the poriod 1982 to 1992, the Secretary of Energy determines that executed contracts ot options for source material or special nuclear material trom forejgs sources for use in utilization facilities within or under the jurisdiction of the United States represent greater than 37/2 percent of actulal or projected domestic uranium requirements for any two-consecutive-year period, or if the Socretary of Enorgy shall requtest the Secretary of Commerce to initiate under section 232 of the Trade Expansion Act of 1962 (19 U.S.C. 1862) an investigation to determine the effects on the national security of imports of souree material and special nuclear material. The Secretary of 
Investigntions.

Energy shall cooperate fully with the Secretary of Commerce in cartying out such an investigation and shall make available to the Secretary of Commerce he findings that lead to this request an such other information that will assist the Secretary of Commerce in the conduct of the invertigation.

"(2) The Secretary of Commerce shall, in the conduct of arry investigation requested by the Secretary of Energy pursuant to this section, take into account any information made available by the Secretary of Energy, including information regarding the impact on nationtal security of projected or executed contracts or options for source material or special nuclear material from foreign sources or whether domestic production capacity is sufficient to supply projected national security requirements.

*(3) No sooner than 3 years following completion of any investigation by the Secretary of Comperce under parapraph (l), if no recommendation has been made pursuant to to such study for trade adjustments to assist or protect domestic tranium production, the Secretary of Energy may initiate a request for another such investigation by the secretary of Commerce.".

Approved January 4, 1983. 
NRC AUTHORIZATION ACT FOR FISCAL YEAR 1980

\section{Public Law 96-295}

94 Stat. 780

To authorize appropriations to the Nuclear'Regulatory Commission in accordence with section 261 of the Atmic Energy Act of 1954, as amended, and section 305 of the Energy Reorganization Act of 1974, as amenided, and for other purposes.

Nuclear Regulatory Commission Appropriation authorization.

Be it enacted by the Senate and House of Representatives of the United States of America in Congress assembied,

\section{TITLE 1-AUTHORIZATION OF APPROPRIATIONS FOR FISCAL YEAR 1980}

Sec 101. (a) There is hereby authorized to be appropriated to the Nuclear Regulatory Cornmission in accordance with the provisions of section 261 of the Atomic Energy Act of 1954 (42 U.S.C. 2017) and section 305 of the Energy Reorganization Act of 1974 (42 U.S.C. 5875), for the fiscal year 1980 , the sum of $\$ 426,821,000$, to remajn available until expended. Of such total amount authorized to be appropriated:

(1) not wore than $\$ 66,510,000$, may be used for "Nuclear Reactor Regulation", of which an amount not to exceed $\$ 1,000,000$ is authorized to accelerate the effort in gas-cooled thermal reactor prespplication review;

(2) not more than $\$ 42,440,000$, may be used for "Inspection and Enforcement"; of the total amount appropriated for this purpose $\$ 4,684,000$ shall be available for szpport for 146 additional inspectors for the Resident Inspector program;

(3) not more than $\$ 15,953,000$, may be used for "\$tandards Đevelopment";

(4) not more than $\$ 32,380,000$, may be used for "Nuclear Material Safety and Safeguards" this purpose-

(A) not less than $\$ 60,000$ shall be available only for the enployment by the Commission of two qualified individuals to be assigned by the Commission for implementation of the United States International Atomic Energy Agency Safeguards Treaty, following ratitication of such treaty by the Ustited States Senate:

(B) not less than $\$ 180,000$ and six additional positions shal be included in the Division of Safeguards for the regulatory improvements of material control and acsounting safeguards and the development of improwed regulatory requirements for safeguarting the transportation of spent fuel; and

(C) not less than $\$ 9,675,000$ shal] be available for Nuclear Waste Disposal and Managerment activities, including support for five additional positions in the Division of Waste Management for implementation of the Uranium Mill Talings Radiation Controt Act of 1978 (Public Law 95-604; 42 U.S.C. 7901 and following); 
(5) not mote than $\$ 213,005,000$, may be used for “Nuclear Regllatory Research", of which-

(A) an amount not to exceed $\$ 3,700,000$ shall be available to accelerate the effort in gas-coaled thermal reactor safety research;

(B) an amount not to exceed $\$ 4,400,000$ shall be available for inplementation of the Improwed Safety Systems Research plan required by section 205(f) of the Energy Reorganization Act of 1974

42 USC 5845

(C) an amount not to exceed $\$ 6,700,000$ shall be avalable for Nuclear Waste Research activities;

(6) not more than $\$ 18,125,000$, may be used for "Program Technical Support"; of the total amount appropitated for this purpose, $\$ 4,238,000$ stzall be available to the Office of State Programs, indudiug support for eight additional positons for training and assistauce to State and local goveratuents in radiological emergency response planning and operations and for review of State plans; and

(7) not more than $\$ 38,408,000$ may be used for "Program Direction and Administration"; of the total amount appropriated for this purpose, $\$ 400,000$ shall be available for support of eight additional positions in the Division of contracts, Office of Administration.

(b) No amount appropriated to the Nuclear Regulatory Commission pursuant to sulbsection (a) may be used for any' purpose in excess of the anount exptessly authonized to be appropriated therefore by paragraphs (1) through (7) of stich subsection if such excess anount is greater than $\$ \$ 00,000$, nor may the amount available fron any ap. propriation for any purpose specified in such paragraphs be reduced by more than $\$ 500,000$, uniess-

(1) a period of 45 calendar days (not including any day in whith ejther House of Congress is not in session because of an adjournment of more than 3 calendar days to a day certain or an adjourn. ment sine die) has passed after the receipt by the Coumittee on Interstate and Foreign Commerce and the Committee on Interior and Insular Affairs of the House of representatives and the Committee on Environment and Public works of the Senate of notice given by the Commission containing a full and complete statement of the action proposed to be taken and the facts and circumstances relied upos in support of stich proposed action, or

(2) each such Committee has, before the expiration of such period, transmitted to the Commission a written notification that there is no objection to the proposed action.

(c) No amount autborized to appropriated by this Act may be used by the Nuclear Regulatory Commission to enter into any contract provid. ing funds in excess of $\$ 50,000$ encomplassing research, study, or technical assistance on domestic safeguards matters except as directed by the Conmission, by majosty vote, following Iectipt by the Commission of a recommendation trom the Executive Director for Operations supporting the need for such contract. 
(d) No amount authorized to be approprated by this Act may be used by the Nuclear Regulatory Commission to-

(1) place any new work or substantial modification to existing work with another Federal agency, or

(2) contract for research services or modify such contract in an

amount greater than $\$ 500,000$ unless such placement of work, conttract or modification is approved by a Senior Contract Review Board, to be appoiated by the Commission within sixty days of the date of enactment of this Act. Such Board shall be accountable to and under the direction of the Commission. If the amount of such placement, contract, or modification is $\$ 1,000,000$ or more, approval therefof shall be by majority vote of the Contunission. Prior to-affording any approval in accordance, with the subsection, the reviewing body designated bereunder shall determine that the - placement, contract; or modification contains a detailed description of work to be performed, and that alterrative methods of obtaining performance including competitive procurement have been considered.

Sec- 102, Durting the fiscal year 1980, noneys received by the Nuclear Regulatory Commission for the cooperative nuclear research programs thay be refained and used for salaries and expenses assoctated with those programs, notwithstanding the provisions of section 3617 of the Revised Statutes (31 U.S.C. 484), Such moneys shall remain available until expended.

Transferts of

Sec. 103. During the fiscal year 1980, transfers of sums from salaries sums. and expenses of the Nuclear Regulatory Commission may be made to other agencies of the United States Government for the performance of the work for which the eppropriation is made, and in such cases of the sums to transferred may be merged with the appropriation to which transterred

Sec. 104. Notwithstanding any other provision of this Act, no authority to make payments heretunder shall be effective except to such extent or in such amourts as are provided in advance in appropriation Acts.

Sec. 105. No anount authorized to be appropriated pursuant to this Act may be used to grant any license, permit or otber authorization, or permission to any perspn for the transportation to, or the interim, long-term, or permanent storage of, spent nuclear fuel or high-level radioactive waste on any territory or insular possession of the United States ar the Trust Territory of the Pacticic Islands unless-

(1) the President subuits to the Congress a report on the transfer at least 30 days before such transfer and on a day during which-

(A) both Houses of the Congress are in session, or

(B) either or both Houses are not in session because of an adjournment of three days or liess to a day certain; or

(2) the president determines that an emergency situation exists with respect to such transfer and that it is in the national faterest to make such transfer and the President notifies the Speaker of the House of Representatives and the President of the Senate as soon as possible of sucth transfer. 
42 USO 2133, 2134.

Regulations.

Notice and hearing: "Utilization facility." 42 USC 2133, 2134.

"Accidental release."

Information ant recommendations.
The provisions of this section shall not apply to the cleanup and rehabilitation of Bikini and Eniwetok Atolls.

Sec. 106. Of the amourts authorized to be appropriated pursuant to this Act, the Nuclear Regulatory Commission is authorized and ojrected to use stuch sums as may be necessary to develop a plan for agency response to accidents at a utilization factity licensed under section 103 or section 104(b) of the Atomitc Energy Act of 1954. The plan required to be developed by this section shall be forwarded to the Congress on or before September 30, 1980 .

Sec. 107. No funds appropriated peursuant to this Act may be used for the purpose of providing for the licensing or approval of any disposal of nucletar wastes in the oceans.

Sec 108. (a) Of the amounts authorized to be appropriated pursuant to this Act, the Nuclear Regulatory Commission is authorized and directed to use such suris as may be necessary to develop ayd promulgate regulations establishing demographic requirements for the siting of utilization facilities. Such regulations skall be promulgated by the Commission after notice and opportunity for hearing in accordance with section $\mathbf{5 5 3}$ of title 5 of the United States Code. For purpases of this section, the term "utilization facility" means a facility licensed under section 103 or 104(b) of the Atomic Energy Act of 1954.

(b) The regulations promulgated pursuant to this section shall provide that no construction permit may be jssued for a utilization facility to whith this section applies after the date of such promulgation untess the facility complies with the reguirements set forth in such regulations, except that regulations promulgated under this section shall not apply to any facility for which an application for a construction permit was filed on or before October 1, 1979 .

(c) The regulations promulgated pursuant to this section shall spectify demographie criteria for facility siting, inctuding maximum population density and population distribution for zones surraunding the factity without regard to any design, engineering, or other differences among such facilities.

(d) The regulations promulgated pursuant to this section shall take into account the feasibility of all actions outside the facility whtch may" be necessary to protect public health and safety in the event of any accidental release of radioactive material from the faclity which may endanger public health or safery. For purposes of this subsection, the term "accidental relesse" jicludes, bat is not limited to, each potential accidental release of radioactive material which is required by the Cormmission to be taken into account for purposes of facility desigrt.

(e) The Commission shall provide information and recommendations to State and locat land use planning authorities having juristiction over the zones established under the regulations promulgated pursuant to this section and over areas beyond the zones which may be affected by a radiological emergency. The information and recommendations provided under this subsection shall be designed to assist such authorities in making State and local land use decisions which may affect emergency planning in relation to utilization facilities. 
(f) Nothing in this section shall be-construed to provide that the Commission shall have any authority to preempt any State requitemant relating to land use or respecting the siting of any utilization facility, except that no State or local land use or facility siting requirement relating to the same aspect of facility siting as a requirement established pursuant to this section shall bave any force and effort usless sucb State or local requirement is identical to, or more stringent than, the requirement promulgated pursuant to this section.

Ser. 109. (a) Funds authorized to be appropriated pursuant to this Act may be used by the Nuclear Regulatory Commission to conduct proceecings, and take other actions, with respect to the issuance of an operating lieense for a utilization facility only if the Commission determines that-

(1) there exists astate or local emergency preparedness plan which-

(A) provides for responding to accidents at the facility concermed, and

(B) as it applies to the facility concerned only, complies with the Commission's guidelises for such plans, or

(2) in the absence of a plan which satisfies, the requirements of paragraph (1), there exists a State, local, or utility plari which provides reasonable assurance that public health and safety is not endangered by operation of the facitity concerned.

A determination by the Commission tinder pasagraph (1) may be made only in consultation with the Director of the Federal Emergency Management Agency. If, in any proceeding for the issuance of an operating license for a utilization facility to which this subsection applies, the Commisston determines that there exists a reasoniable assurance that public bealth and safety is endangered by operation of the facility, the Conmuisston shall identify the risk to public health and safety and provide the applicant with a detailed statengent of the reasons for such

"Utilization tecility."

$420 \mathrm{UC} 2133$ 2134.

Rules. determination. ' Fớr purposes of this section, the term "utilization facility" means \& facility required to be licensed under section 103 or 104(b) of the Atomic Energy Act of 1954.

(b) Of' the amounts authorized to be appropriated under section 101 (a), such sims as may be necessary shall be used by the Nuclear Regvlatory Comunissiont to-

(1) establish by rule-

(A) standards for State radiological emergency response plans, developed is consultation with the Director of the Federal Emergency Management. Agency, and other appropriate agencies, which provide for the response to a radiological emergency involving any utilization facility,

(B) a requirement that-

(i) the Commission will issue operating licenses for utilization facilities only if the Comnussion determines that-

(t) there exists a State or local radiological entergency response plan which provides for responding to any radiological emergency at the facility con- 
cerned and which complies with the Commission's standards for such plans under subparagraph (A), or

(II) in the absence of a plan which satisfites the requirements of subclause (I), there exists a State, looll, or utility plan which provides reasonable assurance that public health and safety is not endangered by operation of the facility concemed, and

(ii) any determination by the Comnission under subclause (I) may be made onty in consultation with the Director of the Federal Euergency Management Agency and other appropriate agencies, and

(C) a mechanism to encourage and assist States to comply as expeditiously as practicable with the standards promalgated under subparagraph (A) of this paragraph,

Review of plars.

(2) reviet all plans and other proparations respecting such an emergency which have been made by each State in which there is located a utilization facility or in which construction of such a facility has been consmenced and by each State which may be affected (as determined by the Commission) by any such emergency,

Report to congressional committees.

(3) assess the adequacy of the plans and other preparations xeviewed under paragraph (2) and the ability of the States involved to cany out energency evacuations during an omergency referred to in paragraph (1) and submit a report of such assessinent to the appropriate corminittees of the Congress within 6 months of the date of the enactunent of this Act.

(4) identify which, if any, of the States described in paragraph (2) do not have adequate plans and peparations for such an emergency and notity the Governor and other appropriate authorittes in each sach State of the respects in which such plars and preperations, if any, do not conform to the guidelines pronsulgated under paragraph (1), and

(5) submit a report to Congress contajning (A) the results of its actions under preceding paragraphs and (B) its recommendations respecting any additional Federal statutory authority which the Commission deens necessary to provide that adeciuate plans and preparations for such radiological emergencies are in effect for each state described in paragraph (2).

(c) In carrying out its review and assessuent under subsection (b)(2) and (3) and in submitting its report under subsection (a)(5), the Conmission shall include a review and assessiaent, with respect to each utilization facility and each site for which a construction permit has been issued for such a facility, of the emergency response capability of State and local authorities and of the owner or operator (or proposed owner or operator) of such facility. Such review and assessment shall include a determination by the Commission of the maximum zone in the vicinity of each such facility for which evacuation of individuals is feasible at various different times corresponding to the representative warning times for various different types of accidents.

Sec. 110. (a) Of the amounts anthorized to be appropriated pursuant to section 101(a), stuch sumbs as may be necessary shall be used by the

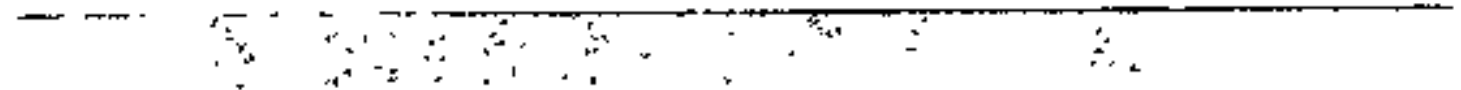


42 USC 2133, 2134.

42 USC 2133.

42 USC 2134.

42 USC 2237.

42 USC 2283.
Nuclear Regulatory Commission to develop, submit to the Congress, and implement, as scon as practicable after notice and opportarity for public comment, a comprebensive plan for the systeuatic safety evaluation of all currently operating utilization facilities requined to be licensed under section 103 or section 104(b) of the Alomic Energy Act of 1954.

(b) The plan referred to in subsection (a) shall include-

(1) the identification of each current rule and regulation corrpliance with which the Commission specifically determines to be of particular significance to the protection of the public health and safety;

(2) a determination by the Commission of the extent to which each operating facility oomplies with each nule and reguiation tdentified under parágraph.(2) of thiss subsection, including an indication of where such complfance was achieved by use of Division 1 regulatory guides and staff technitcal positions and where compliance was achueved by equivalent meanst;

(3) a tist of the generic safety issues set forth in NUREG 0410 (including categontes A, B, C, and D) for which technical solutions have been devoloped;

(4) a detemination by thie Commission of which techrical solutions for generic safery issues identified in paragraph (3) of this subsection should be incorporated into the Commission's rules and regulations; and

(5) a schedule for developing a technical solution to those generic safety issues listed in NUREO 0410 which have not yet been technically resolved.

(c) Not later than 90 days from the date of entactment of this Act, the Commission shatl report to the Congress on the status of efforts to carry out subsection (a).

\section{TITE II-AMENDMENIS TO THE ATOMIC ENERGY ACT OF 1954}

Sec. 201. (a) Section 103 of the Atomic Energy Act of 1954 is amended by adting at the end therefof the following new subsection:

"f. Each ficense issued for a utilization facility under this section or section $104 \mathrm{~b}$. shall require as a condition thereof that in case of any accident which could result in an utpplanned release of quantities of fission products in excess of allowable limits for normal operation established by the Commission, the licensee shall immediately so notify the Commission. Violation of the condition prescribed by this subsection may, in the Commission's discretion, constinute grounds for license revocation. In accordance with section 187 of this Act, the Commission shall promptly amend each license for a utilization facility issued under this section or section $104 \mathrm{~b}$. which is in effect on the date of enactment of tisis subsection to include the provisions requited under this subsections".

Sec. 202 (a) Chapter 18 of the Atoujic Energy Act of 1954 is anended by adding the following new section at the end thereof:

"Sec. 233. Protection of Nuclear Inspectors,-

"a. Whoever kills any person who performs any inspections which- 
42 UsC.2133,

2134.

42 usc 2273.

"Basic component"

42 USC 2133, 2134.
"(1) are related to any activity or facility licensed by the Commússion, and

"(2) are carried out to satisfy requirements under this Act or under any other Federal law governing the safery of utilization facilities required to be licensed under section 103 or $104 \mathrm{~b}$, or the safety of radioactive materials, shall be punished as provided under sections 1111 and 1112 of title 18, United States Code. The precediog sentence shall be applicable only if stleh person is killed while engaged in the performance of such inspection cuties or on account of the performance of sich duties.

"b. Whoever forcibly assaults, resists, opposes, inpedes, intimidates, or interferes with any person who performs inspections as described under subsection a. of this section, while such person is engaged in such inspection duties or on account of the perfornance of such duties, shall be punished as provided under section 111 of title 18, United States Code.".

(b) The table of contents for chapter 18 of the Atomic Energy Act of 1954 is amended by adding the following new item at the end thereof: "Sec. 235. Protection of nuclear tispectors.".

Sec. 203. Section 223 of the Atomic Energy Act of 1954 is amended by striksing out "Whoever" and substiknting:

"a. Whoever" and by adding at the end thereof the following;

"b. Any individual director, officer, or employee of a firm constructing, or upplying the components of any utilization facility required to be licensed under section 103 or $104 \mathrm{~b}$. of this Act who by act or omission, in connection with such construction or supply, knowingly and willfully violates or caluses to be violated, any section of this Act, any rule, regulation, or order issued thereunder, or any license condition, which violation restults, or if undetected could have resulted, in a significant impairment of a basic component of such a facility shall, upon conviction, be subject to a fine of not more than $\$ 25,000$ for tach day of violation, or to imprisonment not to exceed two years, or both. If the conviction is for a violation conpmitted after a first conviction under this subsection, ptuishment shall be a finte of not more than $\$ \$ 0,000$ per day of violation, or jemprisonment for not more than two years, or both. For the purposts of this subsection, the term 'basic component' means a facilify structure, system, component or part thereof necessary to assure-

"(1) the integrity of the reactor coolant pressure boundary,

"(2) the capability to shut-down the facility and maintain it in a safe shut-down condition, or

"(3) the capability to prevent or mitigate the consequences of accidents which coutd result in ar unplanned offisite release of quantities of fission products in excess of the linits established by the Contunission.

The provisions of this subsection sitall be prominently posted at each site where a utilization facility rexuired to be licensed under section 103 or $104 \mathrm{~b}$. of this Act is under construction and on the premises of each plent where components for such a facility are fabricated ${ }^{*}$. 
"Sec. 236. Sabotage of Nuctear Facilities or Fuel.-

Any person who intentionally and willfully destroys or causes physical damage to, or who intentionally and willfully attempts to desfroy. or cause physical, damage to--

(1) any.production facility or utilization facility ticensed under this Act

"(2) asty nucleas waste stocage facility licensed under this Act,

"(3) any nuclear fuel for such a utilization facility, or any spent nuclear fuel from such a facility,

, shall be fined not more than $\$ 10,000$ or twptisoned for not more than ten years, or both".

(b) The table of contents for such Act is amended by inserting the following new item aftor the item relating to section 234:

42 USC 2021.

"Sec, 236. Sabotage of maklear facilities or fuel.".

Sec. 205. Section 274 j. of the Atomic Enerty Axt of 1954 is amended by irserting "(1)" after " $\mathrm{j}$." and by adding the following at the end thereof:

"(2) The Connission, upon jts own motion or upon request of the Govemor of any State, may, after notifying the Governor, temporarily suspend all or part of its agreement with the State without notice or hearing if, in the fudgment of the Commission:

“(A) an emergency situation exists with respect to any mate- rial covered by such an agreentent creating danger which reguires immediate action to protect the health or safety of persous either within or outside the State, and

(B) the State has failed to take steps necessary to contain or sliminate the cause of the danger within a reasonable time after the situation arose.

A temporary suspension under this paragraph shall semain in effect only for such time as the emergency situation exists and shall authorize the Commission to exercise its authority only to the extent necessary to contain or eliminate the danger.".

Sec. 206. The ôrstsentence of section 234 a. of the Atonic Energy Act 42 USC 2282. of 1954 is amended by striking all that follows "exceed" the first time it appears and inserting it lieu thereof the following: $\alpha \$ 100,000$ for each such violation.".

Sec 207 (a)(1) The Atomic Energy Act of 1954 is amended by inserting the following new section immediately after section 146 :

42 USC 2167. "Sec. 147. Sefeguards Information-

"a. In addjition to any other authority ot tequirenent regarcing pro-

Regukations. tection fron disclosure of jifformation; and subject to subsection (o) (3) of section 552 of title 5 of the United States Code, the Commission shal] prescribe such regulations, after botice and opportunity for public cornment, or issue such orders, as necessary to prohibit tie unauthorized disclosure of safeguazds information which specifically jdentifies a bcensee's or applicant's detajled-

"(1) control and accounting procedures of secturity measures (inctuding secturity plans, procedures, and equjpment) for the 
physical protection of special nuclear material, by whomever possessed, whether in transit or at fixed sites, in quantities determined by the Commission to be signifteant to the public health and safety or the common defense and security;

"(2) securily measures (inclucing security plans, procedures, and equipment) for the physical protection of source material or byproduct material, by whomever possessed, whether in transit or at fixed sites, in quantities determined by the Commission to be significant to the public health and safety or the common defense and security; or

"(3) security measures (including security plans, procedures, and equipment) for the ptysical protection of and the location of sertain plant equipment vital to the safety of production or utilization facilities involving nuclear materials covered by paragraphs (1) and (2)

if the unauthorzed disctosure of such information could reasonably be expected to have a signtificant adverse effect on the health and safety of the public or the common defense and security by significantly increasing the likelihood of theft, diversion, or sabotage of such material or such facility. The Commission shall exercise the authority of this subsection-

"(A) so as to apply the minimum restrictions needed to protect the health and safety of the public or the common defense ond security, and

"(B) upon a determination that the unasthorzed disclosure of suchinformation could reasonably be expected to have a significant adverse effect on the heaith and safety of the public or the common defense and security by significantly increasing the likelihood of theft, diversion, or sabotage of such material or such facility.

Nothing in this Act shall authorize the Commission to prohibit the public disclosure of information pertaining to the routes and quantities of shipments of source naterial, by-product material, high-level nuclear waste, or irrradiated auclear reactor fuel. Any person, whether or not a licensee of the Commrission, who violates any regulation adopted under

42 USC 2282. this section shall be subject to the civil monetary penalties of section 234 of this Act. Notting in this section stall be construed to authorize the withbolding of thformation from the duly authorized comenittees of the Congress.

42 USC 2273. "b. For the purposes of section 223 of this Act, any regulations or or. ders prescribed or issued by the Commission under this section shall also be deemed to be prescribed or issued under section $161 \mathrm{~b}$. of this Act.

"c Any determination by the Commission concerning the applicability of this section shall be subject to judicial review purstrant to subsection (a)(4)(B) of section 552 of titie 5 of the United States Cade.

"d. Upon prescribing or issuing any regulation or order under subsection a of this section, the Commission shall submit to Congress a report that: 
42 USC 2231.

(1) specificaly identifies the type of information the Commission intends to protect from disclosure under the segulation or orcer;

"(2) specifically states the Comtrission's justification for determiming that upauthorized disclosure of the infornation to be protected from disclosure under the regulation or order could reasorably be expected to have a significant adverse effect on the health and safety of the public or the common defense and security by sig. nificantly increasing the likelihood of theft, diversion, or sabotage of such material ot such facility, as specified under subsection (a) of this section; and

"(3) provides justification, including proposed alternative regulations or orders, that the regulation or order applies only the minimum restrictions needed to protect the health and safety of the public or the common defense and security.

"e. In adtition to the reports required under subsection $d$. of this section, the Commission shall submit to Congress on a quarterly basis a report detailing the Commission's application during that period of every regulation or order prescribed or issued under this section. In particular, the report shall:

"(1) identify any information protected from disclosure pursuant to such regulation or order:

"(2) specifically state the Commission's justification for determining that unauthorized disclosure of the information protected from disclosure under such regulation or ordes could reasonably be expected to have a significant adverse effect on the health and safety of the public or the common defense and security by significantly increasing the likelibood of theft, diversion or sabotige of such material or such facility, as specified under subsection a. of this section: and

(3) provide justification that the Commission has applited such regulation or order so as to protect from disclosure only the minimutm amount of information necessary to protect the health and safety of the public or the common defense and security.".

(2) The table of contents for such Act is amended by inserting the following new item after the item telating to section 146:

"Sec. 147. Safeguards Information.".

(b) Section 181 of the Atomic Energy Act of 1954 is amended-

(I) by striking out "or defense information" the furst time it appears and substituting ",defense information, or safeguards information protected from disclosure under the authority of section 147"; and

(2) by striking out "or defense information" in each other place it appears in such section and substituting ", defense information, or such sefeguards information,".

\section{TIILE I!-OTHER PROVISIONS}

Regulations. 42 USC 5841 note.

Sec 301. (a) The Nuctear Regtilatory Commission, within 90 days of enactment of this Act, shall promulgate regulations providing for timely notification to the Governor of any State prior to the transport of nuclear waste, including spent nuclear fieel, to, through, or across the 
"Siake."

Contrast authorization.

National

1 Contingency Plan, publication.

42 USC 2133, 2134. 42 USC $5 B 42$ note

Study, tcansmittal to Congress. boundartes of such State. Such notification requirement shall not apply to nuclear waste ì such quantities and of such types as the Commission specifically determines do not pose a potentially significant hazard to the health and safety of the public.

(b) As used in this section, the term "State" jncludes the several States of the Union, the District of Columbia, the Commonwealth of Puerto Rico, the Virgir Islands, Guam, American Samoa, the Trust Territory of the Pucific Islands, and the Connononwealtit of the Northern Marjana Islands.

See. 302. The Nuclear Regtulatory Commission is authorized and directed to enter into a contract for an independent review of the Commission's management structure, processes, procedures, and operations. The review shall include an assessment of the effectiveness of all tevels of agency management in carrying out the Commission's statutory responsibitties, in developing and implementing policies and programs, and in using the personnel and funding availabie to it. The contract'shall provide for subenission of a report of the findings and recommendations of the review to the Commission not later than one year from the date of enactment of this Act, and the Commission shal pronsptly transmit such repont to the Congress.

Set 303. The Nuclear Regulatory Commission shall melude in its annual report to Congress under section 251 of the Atomic Energy Act of 1954 a statement of -

(1) the difect and indirect costs to the Commission for the issnance of any license or permit and for the juspection of any facility, and

(2) the fees paid to the Commission for the issuente of any $\mathrm{h}$ cense or permit and for the inspection of any facility.

Sec 304. On or before September 30, 1980, the President shall prepare and publish a National Contungency Plan to provide for expeditious, efficient, and coordisated action by appropriate Federal agencies to protect the pulblic health and safety in the calse of accicients at any utilization facility licensed under section 103 or $104 \mathrm{~b}$. of the Atornic Energy Act of 1954.

Sec. 305. (a) As expeditiously as practicable, the Nuclear Regutatory Commission shall establish a mechanism for instantaneous and uninterrupted verbal communication between each utilization facility licensed to operate under section 103 or section $104 \mathrm{~b}$. of the Atomic Energy Act of 1954 on the date of enactment of this Act, or thereafter, and

(1) Commission headquarters, and

(2) the appropriate Commission regional office.

(b) Withton ninety days after the date of the enactment of this Act, the Commission shall prepate and transmit to the Congress a study of alternate plans for instantaneous and otherwise timely transmission to the Commission of data indicating the status of priscipal system parameters at utilization facilities licensed to operate under section 103 or section $104 \mathrm{~b}$. of the Atomic Energy Act of 1954. For each alternative, the study shall present procedures for transmitting and analyzing steh dato 
Investigation and stuby.

Report to Congress

42 USC 2133, 2134.

Plan, devekpment. 42 U\$C 2137, note. 42 USC 2137. and a Comtrission statement regarding the advantages, disadvantages and desirability.

Sec. 306. (a) The Nuclear Regulatory Comuisston is authorized and directed to undertake a comprebensive investigation and study of the impediments to expeditious and reliable communication anong Cornmission headquarters, the Commission regional office, Commission representatives at the facility site, senior management officials and operator personnel of the licensee, and the Governor of Pennsylvania and other State oficials, in the thisty day period immediately following the accident of March 28,1979 , at unit two of the Three Mile Island Nuclear Station.in Pennsylvania, Sxch jzvestigation and study shail in. clude, but not be limited to, a determination of the need for improved communications procedures and the need for advanced communications technology.

(b) The Commission shall report to the Congress by September 30 , 1980, on the findings of the intuestigation and studfy required by subsection (a), including recommendations on administrative or legislative measures recessary to facilitate expeditious and reliable commuoications in case of an accident which could result in an unplanned release of quantities of fission products in excess of the allowable limits for normal operation estabtished by the Commission at a utilization facility licemsed under section 103 or 104b. of the Atomic Enerby Act of 1954. The Commission shall implement, as soon as practicable, each such recom. mendation not requining legistative entactrrent, and stall incorporate the recontaendation in the plan for agency response promulgated pursuant to section 304 of this Act.

Sec. 307. (a) The Commission is authorized and directed to prepare a plan for intproving the technical capability of licensee personnel to safely.operate utilization facilities licersed under section 103 or $104 \mathrm{~b}$. of the Atomic Energy Act of 1954. In proposing such plan, the Commission shall consider the feasibility of rectuing standard inandatory training programs for nuclear facility operators, including classroom study, apprenticeships at the facility, and emengency simulator training. Such plan shail include specific criteria for more intensive tráning and retraining of operator personmel licensed under section 107 of the Atomic Energy Act of 1954, and for the licensing of such personnel, to assure-

(1) conformity with all conditions and requirements of the operating license;

(2) early identification of accidents, events, or event sequencess which may significantly increase the likelihood of an accident; and (3) effective response to any such event or sequence. Surch plan shall include provision for Commission review and approval of the qualifications of personnel conducting any required training and retraining program. The plan shall also indude requirements for the renewal of operator licenses inchuding to the extent practicable, requirements that the operstor-

(A) has been activeiy and extensively engaged in the duties listed in such license, 
Plan, transmittal to Congress.

Study.

$42 \mathrm{USC} 2137$

Report to

Congress,

42 Usc 2051

note.

42 USC 2051

note.
(B) has discharged stch duties safely to the satisfaction of the Commission,

(C) is capable of continuing such dutics, and

(D) has participated in a requalification trainting program. Such plan shall include criteria for suspending or rewoling operator licenses. In addition, the Commission shalt also oonsider the feasibjlity of requiting such licensed operator to pass a requalification test every six months including-

(i) written questions, and

(ii) emergency simulator exams.

The Commistion shail transmit to the Congress the plan required by this stubsection within six months after the date of the enactonent o this Act, and shall impiement as expeditiously as practicable each element thereof not requiring legislative entectment.

(b) The Nuclear Regulatory Commission is authorized and directed to undertake a sturiy of the fesibility and value of licenstug, under section 107 of the Atomic Energy Act of 1954, plant managers of utilization facilities and senior licensee officers responsible for operation of such facilities. The Conmission shall report to the Congress within six months of the date of enactronent of this Axt on the findlings and recommendetions of the study required by this subsection, and shall expeditiously ínplement each such recommendation not requiring Jegislative enactment

Sec 308. (a) In the conctict of the study required by section 5 (d) of the Nuclear Regulatory Commission Authorization Act for Fistal Year 1979 (Public Law 95-601\}, the Nueclear Regulatory Commission and the Environmental Protection Agency, in consultation with the Secretary of Health and Human Services, shall evaluate the feasibility of epidemiological research on the health effects of jow-level ionizing radiation exposure to licensee, contractor, and subcontractor employees as a result of-

(1) the accident of March 28, 1979, at anit two of the Three Mile Island Nuclear Station in Pennsylvania;

(2) efforts to stabilize such facility or redice or prevent radiaactive unplanned offsite releases in excess of allowable limits for normal operation establisted by the Commission; or

(3) efforts to decontaminate, decommission, or repair sileh facility.

The report required by such section 5 (d) shall include the results of the evaluation required under this subsection.

(b) Sextion 5(d) of the Nuclear Regulatory Commission Authorization Act for Fiscal Year 1979 (Public Law 95-601), is amended by striking "September 30, 1979" and jnserting in lieu thereof "September 30 , 1980 ".

Approved June 30, 1980. 
NRC AUTHORIZATION ACT FOR FISCAL YEAR 1979

Public Law 95-601

92 Stat. 2947

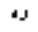

r

\author{
An Act
}

To authorize appropriations to the Nuclear Regulatory Commission for fiscal year 1979, and for other pirposes.

Nucles

Reggulatary

Cornmission.

Appropriation

autiogrimtion, 1978 .

42 USC $\$ 845$.

Sateguard research contracts; limitation.
Be it enacted by the Senate and House of Representatives of the United States of America in Congress assembled.

Section'1. (a) There is hereby althorized to be appropriated to the Nuclear Regulatory Commission in accordance with the provisions of section 261 of the Atomic Energy Act of 1954, as amended (42 U.S.C. 2017), and section 305 of the Energy Reorganization Act of 1974, as amended (42 U.S.C. 5875), for the fiscal year 1979, to remain available until experided $\$ 333,007,000$. Of such total anount authorized to be appropiated;

(1) Not more than $\$ 47,162,000$ may be used for "Nuclear Reactor Regulation"; of the total amount appropriated for this purpose, $\$ 2,0,0,000$ shall be available for Adranced Reactors;

(2) Not roore then $\$ 38,760,000$ may be used for "Inspection and Enforcement";

(3) Not more than $\$ 14,945,000$ may be used for "Standards Development"; of the total amount appropriated for this purpose, $\$ 650,000$ shall be available for Low-Level Radiation activities, in. clüting those described in section 5 of this Acx;

(4) Not mort than $\$ 27,240,000$ may be used for "Nuctear Material Safety and Safeguards"; of the total amount appropriated for this mitpose, $\$ 8,127,000$ shall be avátable for Nuclear Waste Disposal and Maragenent activit"ts;

(5) Not more tian $\$ 163,470,000$ may be tised for tNuclear Repillatory Restarch"; of the total amount appropriated for this purpose, $\$ 1,500,000$ shail be available for the inpleasentation of the Indprowed Safety Systems Research plan required by section 205(f) of the Erergy Reorganization Act of 1974, as amended, $\$ 4,448,000$ shall be available for Nuclear Waste research activities, and $\$ 18,333,000$ shail be avallable for Atvanced Reactor Rosearch, including an authorization of $\$ 3,900,000$ to accelerate the effort in gas-cooled thermal reactor stifety research.

(6) Not more than $\$ 13,480,000$ may be used for "Program Technical Suppost";

(7) Not more than $\$ 27,950,000$ may bo used for "Program Direction and Administration"; of the total anount appropriated for this purpose, \$225,000 shall be available for equal employment opportunity activities, including stupport of four positions in the Office of Equal Emptoyment Opportunity.

(c) (1) Not more than $\$ 14,285,000$ of the ategregate amount anthorized to be appropriated under paragraphs (1) tirough ( 7 ) of subsection (a) Inay be used for contracts encompassing iesearch, studies, and tevinical assistance on domestic safeguards matters. 
(2) Of the aggregate amount authorized to be appropriated under paragtaphs (1) throtigh (7) of subsection (a), $\$ 1,0,00,000$ shail be available for studies and antlysis of alternative fuel cycles (incluoting studies and analysis relating to licensing and safety, safeguards, and enfironmental aspects).

(c)(1) No amourt appropriated pursuant to stbsection (a) for pufposes of subparagraphs (1) through (7) of such subsection, may be used for any function of the Commission in excess of the amount expressly authorized to be appropriated for functions teferred to ju such paragraphs, if such excess amount is in excess of $\$ 500,000$, nor may the amount available from any appropration for any function referred to in sulbparagraphs be rechuced by more than $\$ 500,000$ unless

(i) a period of thirty calendar days (not jncluding any day in which either House of Congress is not in session because of at adjournment of more than three calendar days to a day certain or an adjournment sine die) has passed after the receipt by the Committee on Interstate and Foreign Commerce and the Committee on Interior and Insular Affairs of the House of Representatives and the Committee on Environment and Public Works of the Senate of notice given by the Commission containing a full and complete statement of the action proposed to be taken and the facts and circumstances relied upon in support of such proposed action, or

(i) each such committee before the expiration of such period has transmitted to the Commission, written notice stating in substance that stuch committee has no objection to the proposed action.

(2) Of the amounts authorized to be appropriated for the purposes set forth is paragraphs (1) througi (7) of subsection (a) of this section, the amounts available for Advanced Reactors, LowLevel Radiation, Nuclear Waste Disposal and Management, Improved Safety Systems, Research, and Nuclear Waste Research, or that specified in subsection (b)(2) of this section for Alternative Fuel Cycle activities shall not be reprogrammed, unless-.

(i) a period of ninety calendar days (not including any day in which either House of Congress is not in session because of an adjourmment of more than three calendar days to a day certain or an adjourmuent sine chie) has passed after the receipt by the Committee onInterior and Insular Affairs and the Comnittee on Interstate and Foreign Commerse of the House of representatives and the Committee on Environment and Public Works of the Senate of notice given by the Commission containing a full and complete statement of the action proposed to be taken and the facts and circumstances relied upon in support of such proposed action, or

(ii) each such committee before the expiration of such period has transmitted to the Commission, written notice 
Safegulatd research contracts, límitation.

Funds, transfers.

42 USC 5849.

I

Equal employment opposturity, report.

Radiation, bealth effects studies, consultation. 42 U\$C 2951 note.

Memorindum, submittal to Congress.

Reports to Contaress, consultations. stating in substance that such comsaittee has no objection ir to the proposed action.

...(d) No amonnt authorized to be appropriated by this Act may be used by the Commission to enter into any contract, providing funds in excess of $\$ 20,000$ encompassigg research, shudy, or technical assistance on domestic safeguards matters except as directed by the Commission, by majority vote, following receipt by the Cousuission of a recommendation from the Execttive Director for Operations supporting the peed for such contract.

Sec. 2. Moneys received by the Commission for the cooperative muclear tresearch programs may be retained and used for salaries and expenses assocjated with thase prograras, notwithstanding the provisions of section 3617 of the Revised Statutes (31 U.S.C. 484), and shall remain available until expended

Sec. 3. Transfers of sums from salaries and expenses may be made to other agencies of the Government for the performance of the work for which the appropriation is made, and in such cases the stums so transferred may be merged with the appropriation to which transferred.

'Sec, 4. (a) Subsection (b) of section 209 of the Energy Reorganization Act of 1974, as amended, is amended by adding at the end thereof the following sentence: "Notwithstanding the preceding sentence, each such director shall keep the Exemutive Director fully and currently informed concerning the content of all such direct comununications with the Connitssiont"

(b) Section 209 of the Energy Reorganization Act of 1974, as amiended, is amended by adding a new subsection (c) to read as follows and redesignating existing subsection (c) accordingly:

"(c) The Executive Director shall report to the Commission at semiannual public meetings on the problems, progress, and status of the

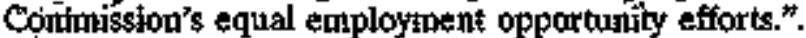

Sec. 5. (a) The Cormojission and the Environmental Protection Agency in consultation with thic Secretafy ö Health, Education, and Welfare, are anthorized aind directed to conduct prelimtotoary planuing and design studies for epidenjological research on the health effects of low-level jonizing radiation. In the conduct of such studies, the Commission and the Environmental Protection Agency shall consult with appropiriate scientific organizations and Federal and State agencies.

' (b) Within thirty days after the date of enactment of this section, the Commitission and the Environmental Protection Agency shall submit to the Congress a memorandum of understanding to delineate their responsibilities in the conduct of the planning studies authorized by subsection (a) of this section.

(c) On or before April 1, 1979, the Conmisston and the Envinonmental Protection Agency shall subnit a report to the Congress contajning an assessment of the capabilities and research meeds of such agencies in the area of health effects of low-level ionizing radiation.

(d) On or before September 30,1979, the Commission and the Environmental Protection Agency, "jin consultation with the Secretary of Health, Education, and Welfare, shall subzit a report to the Congress 
Cooperation.

Copies.

Annual status report.

Report to Congress.

Revien 42 USC 5841

note.

Report to Congress.

Disclosure rules. 42 USC 2210a. which maludes a study of options for Federal epidemiological research on the health effects of Jow-level jontizing radiations, with evaluations of the feasibility of such options. Such report shall be consistent with the findings of the assessment required by subsection (c) of this section.

(e) In carnying out the activities specified in subsections (c) and (d) such agencies shall:

(i) copperate with appropriate scientific organizations and agencies involved in related research, and

(ii) furnish copies of the reports required by those subsections to the organizations and agencies referred to in subsection (e)(i).

Sec 6. Section 209 of the Energy Reorganization Act of 1974 is anended by adding the following new subsection at the end thereof:

(d) The Exectitive Director shall prepare and forward to the Commission an annual repott (for the fiscal year 1978 and each succesding fiscal year) on the status of the Commission's programs concerring domestic stafeguards matters including an assessment of the effectiveness and adequacy of safeguards at facilities and activities licensed by the Commission. The Commission shall forward to the Congress a report under this section prior to February 1, 1979, as a separate document, and prior to Febriary 1 of ench succeeding year as a separate chapter of the Comntission's arnual report (required under section 307 (c) of the Energy Reorganization Act of 1974) following the fiscal year to which suck report appites.".

Sec. 7. The Commission is authorized and directed to undertake a comprehensive review of the existing process for selection and training of Jambers of the Atomic Safety and Licensing Boarcs, inchudirg, but not limited to, the selection criteria, including qualifications, the selection procedures, and the training programs for Board members. The Commission shall roport to the Congress on the findings of such review by Jantuary 1, 1979, and shall revise such selection and trajning process as appropriats, based on such findings.

Sec. 8 (a) Chapter 14 of the Atomic Energy Act of 1954 is amended by adding the foljowing new section at the end thereof:

"Sec, 170A. Confitets of Interest Relating to Contracts and Other Arrangements-

a. The Comunission shal, by rule, require any person proposing to enter into a contract, agreement, or oftier arsangement, whether by competitive bid of negotiation, under this Act or any otber Inw administered by it for the conduct of research, development, evaluation activities, or for technicat and management suppont services, to provide the Commission, prior to entering into any such contract, agretentent, or arrangement, with all relewant information, as determined by the Contmission, bearing on whether that person has a possible contict of jinterest with respect to-

"(1) being able to render impartial, technically sound, or objective assistance or advice in light of other activities or relationships with other persons, or

“(2) bejng given an unfair competitive advantage. Such person shall insure, in accordance with regalations prescribed by the 
Combuission, compliance with this section by any suboontractor (other than a supply subcontractor) of such persont in the case of any subcontract for more than $\$ 10,000$.

"b. The Convatssion shall not enter into any such contract agreement or arrangement unless it finds, after evaluating 'all information provided under subsection a. and any other information otherwise available to the Commission that-

"(1) it is unlikely that a conflict of interest would exist, or

"(2) such conflict has been avoided after appropriate conditions

have been included in such contract, agreement, or artangement except that if the Commission determines that such conflict of interest exists and that such conflict of interest cannot be ayoided by including appropriate conditions therein, the Commission may enter into such contract, agreement, or arrangement, if the Commission determines that it is in the best interests of the United States to do so and includes appropriate conditions in such contract, agreement, or arrangement to tijifgate steb conflict.

Publication. , - "c. The Commission shall pub hish nules for the implemeptation of this section, in accordance, with section 533 of title 5, United States Code (without regard to subsection (a) (2) thereos) as soon as practicable after the date of the enactment of this section, bat in no event later than 120 days after suct date.".

(b) The table of contents for such chapter 14, is amended by adding the following new itern at the end thereof:

Sec. 170A. Conflicts of toterest relationg to contracts axd ofher arrangements.".

Mónitoting and assistance, reports to Coperess. 42 USC 2153 note.

Sec. 9. The Commission shall monutor and assist, as requested, the International Fuel Cycje Evaluation and the studjes and evaluations of the various nuclear fuel cycle systems by the Department of Energy in progress as of the date of enactment, and report to the Congress semiannually through calendar year 1980 and annually through calendar year 1982 on the status of domestic and jaternational evalua. tions of nuclear fuel cycle, systems. This report shall include, but not be limited to, a summary of the information developed by and availabie to the Commission on the health, safety and safeguards implications of the leading fuel cycle technologies.

Sec. 10. Title II of the. Energy Reorganization Act of 1974, as amended, is amended by adding at the end thereof a new section to read as follows:

\section{"EMPLOYRE PROTECTION}

$42 \mathrm{USC} 5851$.

Sec. 210. (a) No employer, ixcluding a Commission licensee, an applicant for a Commission license, or a contractot or a subcoptractor of a Conmission licensee or applicant, nnay tischarge any employee or otherwise discriminate against any employec with respect to his compensation, terms, conditions, or privileges of entployment because the employee (or any person acting pursuant to a request of the employee)-

"(1) commenced, caused to be comutenced, or is about to commence or cause to be comunenced a proceeding under this Act or 
42 USC 2011

note.

Complaipt,

fiting and

notification.

Investigation

and

notification.

Order.

Notioe and

hearing.

Settlement.

i Relief.

i

Review. the Atomic Energy Act of 1954, as amended, or a proceeding for the administration or enforcement of any requirement jmposed under this act or the Atomic Energy Act of 1954, as amended;

"(2) testivied or is about to testify in any sach proceeding or;

“(3) assisted or participated or is about to assist or participate in any manner in such a proceceding or in anty other manter in such a procecting or in any other action to carry out the putposes of this Act or the Atomic Energy Act of 1954, as amended.

(b)(1) Any ensployee who believes that he has been discharged or otherwise discriminated against by any person in violation of subsection (a) may, within thirty days after such violation cocars, file (or have any person file on his behalf) a complaint with the Secretary of Labor (hereinafter in this subsection referred to as the 'Secretary' alleging such discharge ox discripuination. Upon receipt of sach a complaint, the Secretary shail notify the person named in the complaint of the filing of the complaint and the Commission.

"(2)(A) Upon receipt of a complaint filed under paragraph (1), the Secretary shall conduct an frvestigation of the violation alleged in the complaint. Within thitty days af the receipt of such complaint, the Secretary stals complete such investigation and shall notify in wirting the complainant (any any person acting in his behalf) and the person alleged to have comminted such violation of the resurtes of the investigation confucted pursuant to this subparagraph. Within ninety days of the recsipt of such complaint the Sectetary shal, anless the proceeding on the complaint is terminated by the Secretary on the basis of a settlement entered into by the Sectetary and the person alleged to have com. mjtted stech violation, issue an order etther providing the relief prescribed by subparagraph (B) or denytug the compiaint. An order of the Secretary stall be made on the record after notice and opportunity for pablic hearing. The Sextetary may not enter into a settlement teminating a proceeding on a complaint without the participation and consent of the complajnant

"(B) If, in response to a complaint filed tunder paragraph (1), the Secretary determines that a violation of subsection (a) has occurred, the Secretary shall order the person who committed such violation to (i) take affirmative action to abate the violation, and (ii) reinstate the complainant to his former position together with the compensation (including back pay), terms, conditions, and privileges of his employment, and the Secretaty may order such person to provide compensatory camages to the complainant. If an order is issued under this paragraph, the Secretary, at the request of the complainant shall assess against the person against whom the order is issued a sum equal to the aggregate amount of all costs and expenses (including attorneys" and expert wit. ness fees) reasonably incurred, as determined by the Secretary, by the complainant for, or in connection with, the bringing of the complaint upon which the order was issued.

"(c)(1) Any person adversely affected or aggritved by an order issued under subsection (b) may obtain review of the order in the United States court of appeals for the circuit in which the violation, with re- 
5 U.S.C. 201

et seg.

Jurisdiction.

Litigative

costs.

42 USC 2011

note.

Report to

Congress.

42 USC 2205a.

Authority extention, stady.

42 USC $5 \$ 42$

note

Cooperation. spect to which order was issued, allegedly occurred. The petition for te, view must be filed within sixty days from the issuance of the Secretary's order. Review shall conform to chapter 7 of title 5 of the United States Code. The contunencement of proceedings under this subparagraph shall not,unless ordered by the court, operate as a stay of the Secretary's order.

"(2) An order of the Stcretary with respect to which review could have been obtajned under paragraph (1) sball not be subject to judicial review in any criminal or other civil proceeding.

(d) Whenever a person has failed to comply with an order issued under subsection (b)(2), the Secretary may file a civil action in the United States district court for the district in which the violation was found to oceur to enforce such order. In actions brought under this subsection, the district courts shall have jurisdiction to grant all appropriate relief, including, but not limited to, injunctive refief, compensatory, and exemplary damages.

"(e)(1) Any person on whose, behalf an' order was issued under paragraph (2) of subsection (b) may commerse a civil action against the person to whon such order was issued to require conpliance with such order. The appropriate United States district court shall bave jurisdiction, without regard to the amount in controversy or the citizesiship of the parties, to enforce such order.

"(2) The court, in issuing any final order under this subsection, may award costs of litigation (including reasonable attorney and expert witness fees) to any party whenever the court deterninges such award is appropriate.

"(f) Any nondiscretionary duty iriposed by this section shall be enforceable in a mandamus proceeding brought under section 1361 of title 28 of the Untted States Code.

(g) Subsection (a) shall not apply with respect to any employee who, acting without direction from his or her employer (or the employer's agent), deliberately causes a violation of any requirements of this Act or of the Atomic Energy Act of 1954, as amended".

Sect 11. The Commission shall report to the Congress on Jantary 1, 1979 , and annualty thereafter on the use of contractors, consultants, and the National Laboratories by the Commission. Such report shall include, for each contract issued, in progress or completed during fiscal year 1978, information on the bidding procedure, nature of the work, amount and duration of the contract, progress of work, relation to pre+ vious contracts, and the relation between the amputt of tite contract and the amount actually spent.

Sec. 12. (a) The Commission, in cooperation with the Department of Energy, is authorized and directed to conduct a study of extending the Commission's licensing or regulatory authority to include categories of existing and future Federal radionctive waste storage and disposal activities not presently subject to such authority.

(b) Each Federal agency, subject to the provisions of existing law, shail cooperate with the Commission in the conduct of the study. Such cooperation shall include providing access to existing facilities and sites 
Report to

Congress.

Whate storage or disposal facility plantring, notifiction. 42 USC 2021a.

Srate participation, report.

Submittal with legtstative recommendations to Congress and providing ass information needed to conduct the shudy which the agency may have or be reasonably able to accuite.

(c) On or before March 1, 1979, the Commission shall stbmit a report to the Congress containing the results of the study, the Report shal] include a complete listing and inventory of all radioactive waste storage and disposal activities now being conducted or planned by Federal agencies.

Sec. 13. Notwithstanding any other provisjon of this Act, no authority to make payments under this Act shall be effective except to such extent of in suct aurounts as ase provided in advance jn approptitition Acts.

Sec. 14. (a) Ary person, agency, or other entity proposing to develop a storage or disposal factlity, including a test disposal facility, for highlevel radioactive wastes, non-high-level radionctive wastes including transuranium contaminated wastes, or inradiated nuclear reactor fuel, shall notify the Conmission as early as possible after the conmencement of planning for a particular proposed facility. The Commission shall in turn notify the Governor and the State legislature of the State of proposed sites whenever the Commission has knowledge of such proposal.

(b) The Commission is authorized and directed to prepare a report on mears for ituproving the opportunities for State partictpation in the process for siting, licemsing, and developing nucker waste stortige or disposal facilities. Such report shall include detailed consideration of a ptograra to provide grants through the Commission to any Skate, and the advisability of such a program, for the purpose of conducting an independent State review of aby proposal to develop a nuclear waste storage or disposal facility identified in subsection (a) within such State. On or before March 1, 1979, the Commission shall submit the report to the Congress including recommendiations for improving the opportunities for State participation together with any necessary legislative proposals.

Approved November 6, 1978.

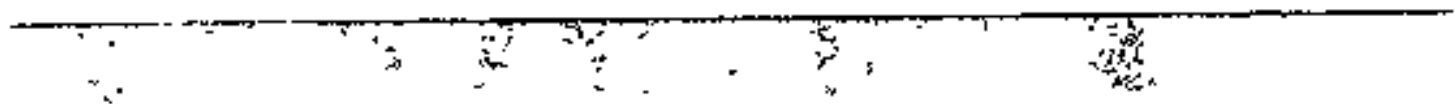


NRC AUTHORIZATION ACT FOR FISCAL YEAR 1978

Public Law 95-209

91 Stat. 1481

\begin{abstract}
Nuciear
Regulatory Comiríssion. Appropriation arthorization, 1978.
\end{abstract}

Reallocation.

Safeguard
research
contract
statement
publication.

Sateguard contract publication.

\section{An Act}

To authorize appropriations for Nuclear Regulatory Cornmission for the fiscal year 1978, and for other purposes.

Be it enacted by the Stante and Howse of Representatives of the United States of America in Congress essembled,

\section{AUTHORIZATTON}

$$
\text { ॥' }
$$

Sectlon 1. (a) There is authorized to be appropriated to the Nuclear $R \in$ gulatory Commission (hereafter is this act referred to as the "Conmission") to carry out its functions and authorties under the Atomic Energy Act of 1954 (42 U.S.C 2017) and the, Energy Reorganization Act of 1974 (42 U.S.C. 5875 ) for the fiscal year 1978 to remain avijlable until expended $\$ 297,740,000$ to be allocated as follows:

(I) For "Nucterar Reactor Regulation", not more than: $\$ 41,480,000$;

(2) For "Stàndards Developiaent", not more than $\$ 12,130,000$;

(3) For "Inspection and Enforcement", not more than $\$ 33,050,000$;

(4) For "Nucleas Materials Safety and \$afeguards", not more than $\$ 22,090,000$ :

(5) For "Nuclear Regulatory Research", \$148,900,000;

(6) Fot "Progrant Techyical Support", 10,180,000; of which an amount not to exceed $\$ 600,000$ is authorized for a fellowship programp pursuant to section 5 of this Act.

(7) For "Program Direction and Administration", not more than $\$ 29,910,000$.

(b) Of the total amount authorized under section 1(a), the Commissioners may, by majority vote, reallocate among program activities spectified in subsection (a) or pursuant to the authorty granted in subsection (d) an amount not exceeding $\$ 10,000,000$ except that the amount transferred from any of the major program activities specified in sub. section (a) shall not exceed 15 per centum of the amount so specified. Prior to any reallocation of an amount in accordance with the provisions of this subsection, where such amount is in excess of $\$ 500,000$, the Commission shall inform the appropriate congressional committees. Such reallocation may be made notwithstanding the limitations of sub. section (a).

(c) No amount authorized to be appropriated for contracts for research, studies, and technical assistance on domestic safeguard matters under subsection (a) including any amount reallocated under subsection (b) may be used for such contracts and no anount authorized to be a propriated under this subsection may be used by the Office of Nuclear Regulatory Research for such contracts until a statement supporting 
Quartarly report to Congress. 42 USC 5841.

42 USC 20000

42 USC 5850.

Submittal to Congress. Projeress reparts. the need for such research, study, or technical assistance has been prepared and published by the Commission.

(d) No amount authorized to be appropriated for contracts for regulatory research yelated to advanced reactor safety under this Act may be used for such contracts except as directed by the Commission, following consideration by the Conmission of ary recommendation that may be rade by the ACRS regarding the proposed research.

(e) In the event that the license application is withdrawn or funding for the continuation of the Clinch River Breeder Reactor project is not authorized or appropriated, the total authorization in subsection (a) shall be reduced by $\$ 2,700,000$.

(f) In the event that further construction of the facility at Barnwell, South Carolina, for the purpose of providing plutonium to be used as fuel is canceled or deferred, the total authorization in stbsection (a) sball be reduced by $\$ 2,100,000$.

\section{COMMISSION PERSONNEX}

Sec. 2 Section 201 of title II of the Energy Reorganization'Act of 1974 is arlended by adiding the following new subsection at the end thereof:

"(b) The Cormmission shall prepare and submit to the Congress a quarterly report which documents, for grades GS-11 or above:

"(1) the mumber of minority and women candidates hired, by grade level;

"(2) the number of minority and women employees promoted, by grade level;

"(3) the procedures followed by the Commission in preparing job descriptions, informing potential applicants, and selectiri from candidates the persons to be employed in positions at grade OS-11 or above; and

f "(4) other steps taken to meet provisions of the Equal Employment Act.

The first quarterly report shall be submitted to the Congress not later than January 31, 1978, and subsequent reports shall be subinitted prior to the end of one calendar month after the end of each calendar quarter thereafter.".

\section{UNRESOLVED SAFETY ISSUES}

Sec. 3. Title II of the Energy Reorganization Act of 1974, is anended by adding the following new section at the end thereof:

\section{"UNRESOLVED SAFETY ISSUES PLAN}

"Sec. 210. The Commission shall develop a phan providing for the specification and analysis of unresolved safety issues relating to muclear reactors and shall take such action as may be necessary to implement corrective measures with respect to such issues. Such plan shall be submitted to the Congress on or before January 1, 1978 and progress reports shall be included in the annual report of the Conmission thereafter.". 
Long-torm plan dewelopment. 42 USC 5845.

Animual report 10 Congress. 42 USC 2139.

Establshment. 42 USC 2010.

Guidelines. 42 USC 2201 note.

Sabarits and experists.

\section{IMPROVED SAFETY SYSTEMS RESEARCH}

Sec. 4. (a) Section 205 of the Energy Reorganization Act of 1974 is amended by adding the folloxing new subsection at the end thereof:

"(f) The Commission shall develop a long-term plan for projects for the development of new or improved safety systems for nuclear power plants.".

\section{REACTOR SAFETY RESEARCH STUDY}

Siec 5. Section 29 of the Atomic Enetgy Act of 1954 is amended by adding the following at the end thereof: "In addition to its other duties under this section, the committee, making use of all available sources, shall undertake a study of reactor safety research and prepare and submit annually to the Congress a report cortaining the results of such study. The first such report shal] be rubmitted to the Congress not later than December 31, 1977.

\section{ACRS FELLOWSHIP PROGRAM}

Sec. 6. To assist the Advisory Committee on Reactor Safeguards in carrying out its function, the conmittee shall establish a fellowshtip program under which persons having appropriate engineering or scientific expertise are assigned particular tasks relating to the functions of the committee. Such fellowship shall be for 2-year periods and the recipients of such feltowships shall be seiected pursuant to such criteria as may be established by the committee.

\section{ORGA'NZZATIONAL CONFLUCTS OF INTEREST}

Sec. 7. The Commission shall by December 31, 1977, promulgate guidelines to be applied by the Commission in determining whether an organization proposing to enter into a contractual arrargement with the Conmission bas a conflict of interest which might inpair the contractor's judgunent or otherwise give the contractor an unfair cornpetitive advantage.

\section{COOPERATIVE RESEARCH FUNDING}

Bec. 8. Moneys recetved by the Combitssion for the cooperative nuclear safety researcti programs tnay be retained and used for salaries and expenses associated with those programs, notwithstanding the provisions of section 3617 of the Revised Statutes (31 U.S.C. 484), and shal] remain available until expended. Funds may be obligated for purposes stated in this section only to the extent provided in appropriation Acts.

\section{TRANSFER OF FUNDS}

Sec. 9. Transfers of sums from salaries and expenses may be made to other agencies of the Goverrment for the pertormance of the work for which the appropriation is made, and in such cases the sums so transferred may be merged with the appropriations to which transferred,

\section{APPROPRIATIONS}

Sec. 10. Notwithstanding any other provision of this Act, no authorizy to make payments under this Act shall be effective except to such extent or in such amcunts as are provided in advance in appropriations Acts.

Approved December 13, 1977. 


\section{NRC AUTHORIZATION ACT FOR FISCAL YEAR 1977}

\section{All Act}

To authorize appropriations to the Nuclear Regulatory Commission in acoordance with section 261 of the Atomic Entrgy Act of 1954, as amended, and section 305 of the Energy Reorganization Act of 1974, as aruended, and for other purposes.

Nuclear

Regulatory

Commission.

Appropristion authorization. 42 USC 2017. 42 USC 5875.

Montys for resesch programs, use.

Transfer of sums.

89 Stat, 413
Be it enacted by the Senate and Fouse of Representatives of the United Siates of America in Congress asiembled,

Sec. 101. There is hereby authorized to be appropriated to the Nuclear Regulatory Commission in accordance with the provisions of section 261 of the Atomic Energy Act of 1954, as amended, and section 305 of the Energy Reorganization Act of 1974, as amended; for salaries and expenses, $\$ 274,300,000$ to remain available until expended.

Sec. 102. Moneys received by the Commission for the cooperative nudear safety research programs may be retained and used for salaries and experses associzted with those programs, nowwithstanding the provisions of section 3617 of the Revised Statutes (31 U.S.C. 484), and shall remain avallable unti] expended. Funds may be obligated for purposes stated in this section only to the extent provided in appropriation Acts.

Sec. 103. Transfers of sums from salaties and expenses nay be made to other agencies of the Governmept for the performante of the work for which the appropriation is made, and in such cases the sums so transferred may be metged with the appropitation to which transferred.

\section{AMENDMENTS TO PRIOR YRAR ACT}

Sec. 104. (a) Titte I of Public Law 94-79 is amended by adding section 102 to read as follows: "Moneys received by the Commission for the c0operative nuclear research program may be retained and used for salaries and expenses associated with that program, notwithstanding the provisions of section 3617 of the Revised Statutes (31 U.S.C 484), and shatl remain available until oxpended. Funds may be obligated for purposes stated in this section only to the extent provided in appropriation Acts.".

(b) Section 101 of Pablic Law 94-79 is anended by adding the phase "and shall remain available until expended" after the words "September 30, 1976". 
NRC AUTHORIZATION ACT FOR FISCAZ YTAR 1976

Public Law 94-79

89 Stat. 413

\section{An Act}

To authorize appropriations to the Nuclestr Regulatory Commission in accordance with section 261 of the Atomic Energy Act of 1954, as amended, and section 305 of the Energy Reorganization Act of 1974, and for other purposes.

Be it enocted by the Senate and House of Representatues of the United States of America in Corngress assembled,

\section{TITLE I}

Nuclea:

Regrlatory

Commission.

Appropriation authorization.

42 USC 2017

42 USC 5875

42 USC $\$ 841$

Cormmission

chaiman,

functions.

42 USC 5801 note.

Sex, 101. There is authorized to be approptated to the Nuclear Regulatory Commission to carry out the provisions of section 261 of the Atomic Energy Act of 1954, as anended, and section 305 of the Energy Reorganization Act of 1974: \$222,935,000 for fiscal year 1976 and $\$ 52,750,000$ for the period from July 1, 1976 through September 30, 1976 and-shall remain available until expended. ${ }^{3}$

Sec. 102. Moneys received by the Commission for the cooperative nu' dear research progran may be retained and used for salartes and expenses associated with that prograrn, frotwithstending the furovisions of section 3617 of the Revised Statutes (31 U.S.C. 484), and shall remain avalable until expended. Funds mat be obligated for perroses stated in this section only to the extent provided $\mathrm{m}$ appropriations Acts.".

\section{TITLE II}

Sec- 201. Section 201(a) of the Energy Reorganization Act of 1974 is amended-

(I) by inserting “(I)" immediately after "Stec. 201.(a)"; and

(2) The Chairman of the Commission shall be the principal executive officer of the Commission, and be shalt exercise all of the executive and administrative functions of the Commission, including functions of the Commission with respect to (a) the appointment and supervision of personisel employed under the commission (other than personnel ensployed regularly and ful] time in the immediate offices of commissioners other than the Chairman, and except as otherwise provided in the Energy Reorganization Act of 1974), (b) the fistribution of business among such persomnel and among administrative units of the Commission, and (c) the use and expenditure of funds.

"(3) In carrying out ary of his functions under the provisions of this section the Chairman shall be governed by general policies of the Conmission and by such regulatory decisions, findings, and determinations as the Commission may by law be authorized to make.

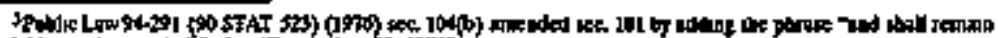

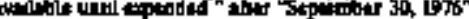

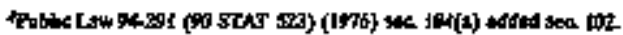


Pletonium shipments, restrictions, 42 USC 5841

note.

Term of office. 42 USC 584I
“(4) The appointment by tre Chairmant of the heads of rajor administrative units under the Commission shall be subject to the approwal of the Commisstion.

“(5) There are hereby reserved to the Commission its functions with respect to revising budget estimates and with respect to determining upon the distritution of approptrated funds according to major programs and purposes.",

The Nuclear Regulatory Commission shall not license any shipments by ait transport of plutonium in any form, whether exports, imports or domestic shipments. Provided, however, That any plutomium in any forcu contained in a medical device designed for incivioual human applcation is not subject to this restriction. This restriction shall be in force until the Nuclear Regulatoty Commission has certified ta the Joint Committee on Atomie Energy of the Congress that a safe container has been developed and tested whith will not rupture undet crash and blasttesting equivalent to the crash and explosion of a high-flying aircraft.

Sec. 202. Subsection 201(c) of the Enerigy Reorganization Act of 1974 is amended by deleting the pertod at the end of the subsection and adding the following text: ${ }^{*}$; and except that any member appointed to fill a vacancy occurring prior to the expiration of the term for which his predecessor was appointed, shall be appointed for the remainder of such term.".

Sec. 203. Section 201(c) is amended to include the following: "For the purpose of deterninuing the expiration date of the terras of office of the five members first appointed to the Nuclear Regulatory Commission, each such term shall be deemed to have began July 1 , 1973.".

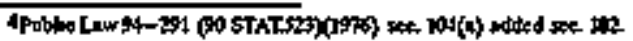




\section{An Act}

To authorize supplemental appropriations to the Nuclear Regulatory Commission for 1 iscal year 1975.

Be it enacted by the Senate and House of Representatives of the United States of America in Congress assembted,

Nuclear

Regulatory

Commission

Appropriation

Authorization.

42 USC 2017.

42 USC 5875 .

Atc Energy

Commission.

Appropriation increase.

Anite, p. 116.

Safeguands prograrn.
That there is anthorized to be appropriated to the Nuclear Regulatory Commission to carry out the provisions of section 261 of the Atomic Enerzy Act of 1954, as amended, and section 305 of the Energy Reorganization Act of $1974, \$ 50,200,000$ for fiscal year 1975 .

\section{AEC FISCAL YEAR 1975 SUPPLEMENTAL AUTHORIZATION ACT}

Public Law 93-576

88 Stat. 1878

\section{An Act}

To amend Public Law 93-276 to increase the authorization for appropriations to the Atomic Energy Commission in apcordance with section 261 of the Atomite Energy Act of 1954, as antended, and for other purposes.

Be it enacted by the Senate and House of Representatives of the United States of America in Congress arsembled,

That section 101(a) of Public Law 93-276 is hereby amended by striking therefrom the figure " $\$ 2,551,533,000 "$ and substituting the figure "\$2,580,733,000".

Sec. 2. Section 101(b) of Public Law 93-276 is hereby amended by striking trom subsection (11) capital equipment the figure $\$ 208,850,000^{*}$ and substituting the figure "\$224,900,000".

Sec. 3. From the increase of the sums authorized to be appropriated by this Act $\$ 23,000,000$ shall be allotted to, and made atrailable only for the Safeguards Program, with regard to the safeguarding of special nuclear materials from diversion frots its intended uses, and for research and development of safeguards techniques and related activities in. volved in handling nuclear material.

Approved December 31, 1974. 


\section{AEC AUTHORIZATION ACT FOR FISCAL YEAR 1975}

Public Law 93-276

77 Stat. 88

Atomic Energy

I Commission. Approprietion authorizution. 77 Stat. 88 442 USC 2017 88 Stat. 115 BB Stat. 116

\section{An Act}

To authorize appropriations to the Atomic Energy Commission in accordance with section 261 of the Atomic Energy Act of 1954, as amended, and for otber purposes.

Be it enacted by the Senate and House of Representatives of the United States of Amertica in Congress assentbled,

Sec 101. There is hereby authorized to be appropriated to the Atomic Energy Commission in accordance with the provisions of section 261 of the Atonic Energy Act of 1954 , as amended:

(a) For "Operating expenses", $\$ 2,580,733,000^{1}$ not to exceed $\$ 132,200,000$ in operating costs for the high energy physics program category.

(b) For "Plant and capital equipment", ineluding construction, axpussition, or modification of facilities, incluting land acquisition; and acquisition and fabrication of capital equipment not related to constructon, a sum of dollars equal to the total of the following:

\section{(1) NUCLLEAR MATERIALS-}

Project 75-1a, additional facilities, high-lewel waste handling and storage, Savamah River, South Carolina, \$0,000,000.

Project 75-1•b, replacement ventilation air filter, $\mathrm{H}$ chemical separations area, Savannah River, South Carolina, \$6,000,000.

Project 75-1-c, new waste calcining facility, Idaho Chemical Processing Plant, National Reactor Testing Station, Idaho, $\$ 20,000,000$.

Project 75-I-d, waste management effluent control, Richland, Washington, $\$ 3,500,000$.

Project 75-1 e, retooling of comporent preparation laboratories, multiple sites, $\$ 4,500,000$.

Project 75-1-f, atmospheric pollution control facilities, stoker fired boilers, Savannah River, South Carolina, \$7,500,000.

(2) NUCLEAR MATERIALS.-

Project 75-2-a, additional cooling tower capacity, gaseous difirston plant, Portsinouth, Ohio, $\$ 2,200,000$.

(3) WEAPONS-

Project 75-3-a, weapons production, development, and tost installations, $\$ 10,000,000$.

Project 75-3-b, high energy laser facilíty, Los Alamos Scientific Laboratory, New Mesico, $\$ 22,600,000$.

Project 75-3-c, TRIDENT production facilities, various locations, $\$ 22,200,000$.

Project $75+3+i$, consolidation of final assembly plants, Pantex, Amarillo, Texas, $\$ 4,500,000$.

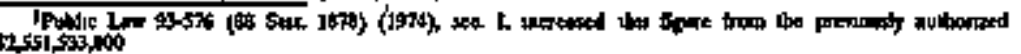


Project 75-3-e, addition 60 building 350 for safegtards analytical laboratory, Argonne National Labotatory, Illinois, \$3,500,000.

(4) WEAPONS.-

Project 75-4-a, technical support relocation, Los Alamos Scientific Laboratory, New Mexico, \$2,\$00,000.

(5) CIVILIAN REACTOR RESEARCH AND DEVELOPMENT.-

Project 75-5-ä, transient test facility, Sapta Susana, California, $\$ 4,000,000$.

Project 75-5-b, advanced test reactor control system upgrading, Nationel Reactor Testing Station, Idaho, $\$ 2,400,000$.

Froject 75-5-c, test reactor area water recycle and pollution contool facilities, National Reactor Testing Station, Idabo, $\$ 1,000,000$.

Project 75-5-d, modifications to reactors, $\$ 4,000,000$.

Project 75-5-t, high tempierature gas reactor fuel re-processing facility, National Reactor Testing Station, Idabo, $\$ 10,100,000$.

-Project 75-5-f, high temperature gas reactor futel refabrication pilot plant, Oak Ridge National Laboratory, Tennessee, $\$ 3,000,000$.

Project 75-5-g, molten salt breder reactor (prelíminary planging preparatory to possible future demonstration project), $\$ 1, \$ 00,000$.

(6) PHYSICAI RESEARCH-

Project 75-6-a, accelerator andreactor improvements and modifications, $\$ 3,000,000$.

Project 75-6-b, heavy ion research facilities, various locations, $\$ 19,200,000$.

Project 75-6-c, positron-electron jónt project, Lawence Berkeley Laboratory and \$tanford Linear Accelerator Center, $\$ 900,000$.

(7) BIOMEDICAL AND ENVIRONMENTAL RESEARCH AND SAFETY.-

Project 75-7 a, upgrading of laboratory facilitits, Oak Ridge Natoual Laboratory, Tervessee, \$2,100,000.

Project 75-7-b, environmental research laboratory, Savarutah

River, South Carolina, $\$ 2,000,000$.

Project 75-7-c, intermediate-level waste management facilities, Oak Ridge National Laboratory, Ténnessee, $\$ 9,500,000$.

Project 75-7-d, modifications and additions to biomedieal and environutental research facilities, $\$ 2,850,000$.

(8) BIOMEDICAL AND ENVIRONMENTAL RESEARCH AND SAFETY.-

Project 75-8-a, environmental sciences laboratory, Oak Ridge National Laboratory, Tenpessee, $\$ 8,800,000$.

(9) .GENERAL PLANT PROJECTS. $\$ 55,650,000$.

(10) CONSTRUCTION PLANNING AND DESIGN$\$ 2,000,000$. 
(11) CAPITALEQUIPMENT.-Acquisition and fabrication of capital equipment not related to construction, $\$ 224,900,000.2$

(12) REACTOR SAFETY RESEARCH.-

Project 75-12-a, reactor safety facilities modifications, $\$ 1,000,000$.

(13) APRLIED ENERGY TECHNOLOGY.-

Project 75-13-a, bydrothermal pilot plant, \$1,000,000.

Sec. 102. Limitations. - (a) The Commission is authotized to start any project set forth in subsection 101(b)(1), (3), (5), (6), (7), (12), and (13) only if the currentiy estimated cost of that project does not exceed by more than 25 per centum the estimated cost set forth for that project.

(b) The Commission is authorized to start any project set forth in subsection 101(b) (2), (4), (8), and (10) only if the currently estimated cost of that project does not exceed by more than 10 per centum the estimated cost set forth for that project.

(c) The Commission is authorized to start any projest under subsectoon 101(b) (9) only if it is in accordance with the following:

(1) The maximum currently estimated cost of any project shal] be $\$ 500,000$ and the maximum currently estimated cose of any , building included in such project sball be $\$ 100,000$ : Provided, That the building cost limitation may be exceeded if the Comnisstion determines that it is necessary in the interest of efficiency and economy.

(2) The total cost of all projects undertaken under subsection 101(b)(9) shall not exceed the estimated cost set forth in that subsection by more than 10 per centum.

(d) The total cost of any project undertaken under subsection 101(b) (1), (3), (5), (6), (7), (12), and (13) shall not exceed the estimated cost set forth for that project by more than 25 per centum, unless and until

7 Stat. 88 42 USC 2017. 98 Stat. 118

77 Stot. 88 42 USC 2017.

Construction desigo services.

69 Stal, 471 additional appropriations are authorized under section 261 of the Atomic Energy Act of 1954, as amended, prowided that this subsection will not apply to any project with an $\$$ stimated cost less than $\$ 5,000,000$.

(e) The total cost of any project indertaken under subsection 101(b) (2), (4), (8), (9), and (10) shall not exceed the estimated cost set forth for that project by more than 10 per centur, unless and until additional appropriations are authorized under section 261 of the Atomic Energy Aet of 1954, as amended, provided that this subsection will not apply to any project with an estimated cost less than $\$ 5,000,000$.

Sec. 109. The Contnission is authorized to perform construction design services for any Commission construction project whenever (1) such construction project has been ineluded in a proposed authorization bill transmitted to the Congress by the Commission, and (2) the Connission determines that the project is of such urgency that construction of the project should be jnitiated promptly upon enactment of legislation appropriating funds for its construction.

Sec. 104. Any moneys recejved by the Commission (except stums received Grom the disposal of property under the Atomic Energy Community Act of 1955, as amended (42U.S.C. 2301)), may be tetajned by the

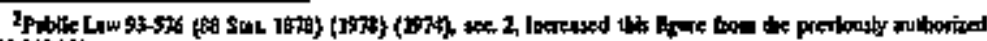
satsod00. 
Transferer of sums

Transter of amounts.

80 Stat. 163

BI Staf. 126.

87 Stat. 145

S\& Stat. 300. 97 Stat, I45.

31 USC 665.

86 Stat. 223.

88 Suth 119. 87 Seal. 143.
Commission and credited to its "Operating expenses" approppriation notwitustanding the provisions of section 3617 of the Revised Statutes (31 U.S.C. 484),

Sec 105. Transfers of stoms from the "Operating expenses" appropriation may be made to to other agencies of the Government for the perfosmance of the work for which the appropitation is made, and in such cases the sums so transferted may be merged with the appropitation to which transferred.

Sec. 106. Whien so specified to ath appropriation Act, transfers of aurounts between "Operatting expenses" and "Plant and capital equipment" may be made as provided in such appropriation Ast.

Sex, 107. AMENDMENT OF PRIOR YEAR ACTS. (a) Section 101 of Public Law 89-428, as amended, if furticer amended by striking from subsection (b)(3) project 67-3-a, fast flux test facility, the figure "\$87,500,000", and substituting therefor the figure "\$420,000,000".

(b) Section 101 of Public Law 91-273, as annended, is further armended by strikfug from stbsection (b)(1), project 71-1-f, protess equipment modifications, gaseous diffusion plants, the figure " $\$ 172,100,000$ " and substituting therefor the figure $" \$ 295,100,000^{\prime \prime}$.

(c) Section 106 of Public Law 91-273, as amended, is further amended by striking from subsection (a) the figure $\$ \$ 2,000,0,00$ and substituting therefor the figure " $3,000,000^{\prime \prime}$, and by adiding thotreto the following new subsection (c):

"(c) The Commission is hereby authorized to agree, by modification to the definitive cooperative arrangement teflecting sucb changes therein as it deenrs appropriate for such purpose, to the following (1) to execute and deliver to the other parties to the AEC defintitive contract, the special undertaking of indemnification specified in said con'tract, which undertakings shall be subject to availability of appropriations to the Atomic Energy Commission (or any other Federal agency to which the Commissjon's pertinent functions might be transferred at some futhre time) and to the provisions of section 3679 of the Revised Statntes, as amended; and (z) to acquire ownership and custody of the property constituting the Iiquidd Metal Fast Breeder Reactor powerplant or parts thereof, and to use, décommission, and dispose of sajd property, as provided for in the AEC definitive contract. ${ }^{\text {n }}$

(d) Section 101 of Public Law 92-314, as amended, is amended by striloug frora sibsection (b) (4), project 73-4-b, land acquisition, Rocky Flats, Colorado, the figure " $\$ 8,000,000^{\circ}$ and substituting therefor the figure $\$ 11,400,0000^{\prime \prime}$.

(c) Section 101 of Public Law 93-60 is amended by (1) striking froin subusection (b)(1), project 74-1-a, additional facilities, high level twaste storage, Savanuah River, South Carolina, the figure " $\$ 14,000,000^{t}$ and substituting therefor the figure " $\$ 17,500,000$ ", (2) striking from subsec. ton (b)(1), project 74-1- g, cascade uprating program, gaseous diffusion plants, the words "(partial AE and limited component procurement only) ${ }^{\prime}$ and further striking the figure ${ }^{\prime} \times \$, 000,000^{\prime \prime}$ and stbstituting therefore the tigure " $\$ 183,100,000^{n}$, and (3) striking from subsection (b)(2), project 74-2-d, national security and resources study center, the words "(AE only), site undesignated" and substituting therefor the 
words "Los Alamos Scientific Laboratory, New Mexico" and further striking the figure " $\$ 350,000$ " and stibstituting therefor the figure " $\$ 4,600,000 \%$.

83 Stat. $46 ;$

966 Stac. 225.

Sec. 108. RESCISSION, - (a) Public Laur \$1-44, as amended, is further amended by rescinding therefiom authorization for a project, except for furtis heretofore oblighted, as follows:

Project $70-1-b$, bedrock waste storage (AE and site selection drilling only), Savannah River, South Carolina, \$4,300,000.

85 Stat. 304. (b) Public Law $92-84$, as amended, is further amended by rescinding therefrom authorization for a project, except for finds beretofore obligated, as forlows:

Project 72-3-b, national radioactive waste repository, site undetermined, $\$ 3,500,000$.

86 \$tal. 224. (c) Public Law 92-314, as amended, is further amended by rescinding therefrom authorization for a project, except for funds heretofore obljgated, as follows:

Project 73-6-c, accelerator inprovements, Cambridge Electron Accelerator, Massachusetts, $\$ 75,000$.

\section{TITLE II}

69 Stal, 947. 42 USC 2187.

Sec. 201. Section 157b. (3) of the Atomic Energy Act of 1954, as amended, is amended by striking out "upon the recommendation of" and inserting in lieut thereof "after consultationt with".

Approved May 10, 1974. 


\section{An Act}

To amend Public Law $93-60$ to increase the'authorization for appropriations to the Atomic Energy Commission in accordance with section 261 of the Atonic Energy Act of 1954, as amended, and for other purposes.

$B e$ it enactad by the Senate and House of Representatives of the United Sintes of America in Congress assembled.

That section 101(a) of Public Law 93-60 is hereby amended by striking therefrom the figure $\$ 1,740,750,000^{*}$ and substibuting the figure " $\$ 1,751,450,000 "$.

Sec. 2. Section 101(b) of Public Law 93-60 is hereby amended by adding to subsection (b)(1) the following words: "Project 74-1-i, additional waste concentration and salt cake storage facilities, Richland, Washington, \$30,000,000.".

Approved Novenaber 26, 1973. 


\section{INSPECTOR GENERAL ACT OF 1978, AS AMENDED}

Public Law 95-452

PAGE USC

Ser.

Sea 1. Short Title. $\ldots \ldots+\ldots, \ldots, \ldots, \ldots+\ldots, \ldots, \ldots \ldots+464 \ldots \ldots$ app.

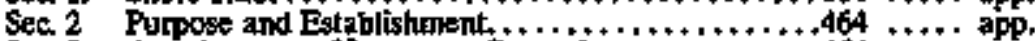

Sec 3. Appointment of Inspector Geosal .............464 ..... app.

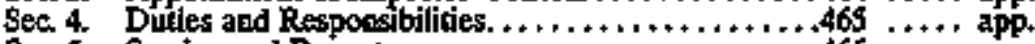

Sec 5 Semtannual Reoorts. ...................... A66 ..... app.

Sec. 6. Authority of Inspector Geperal $\ldots+\ldots \ldots+\ldots \ldots \ldots+471, \ldots$ app.

Sec. 7 Compiaints by Enployees...................

Sec. 8. Additional Frowtions with Respect

to the Inspector General. $\ldots \ldots \ldots \ldots \ldots \ldots \ldots, 473 \ldots \ldots$ app.

Sec. 8A. Special Prowisions Relating to the

Azency for Intemational Deveiopinent. . . . . . . $475, \ldots$ app.

Sec 8B. Spectial Provistoos Concening the

Nuslear Regulatony Commission . .........476 .... app.

Sea 8C. Special Prowsions Concerning the

Federal Deposit Insurance Corporation $\ldots \ldots \ldots \ldots 476 \ldots \ldots$ app.

Sec 8D. Spectal Provisions Concerning

the Department of Treasury $\ldots \ldots \ldots \ldots \ldots \ldots \ldots 476 \ldots \ldots$ app.

Sec. 8E Spectal Provistons Concerning the

Department of Iustice $\ldots \ldots+\ldots \ldots \ldots \ldots \ldots \ldots+\ldots 479 \ldots \ldots$ app.

Sec. 8F. Special Provisions Conceining the Corporation for Nationat and Community

Service $. \ldots \ldots \ldots \ldots \ldots \ldots \ldots \ldots \ldots \ldots \ldots \ldots, 480 \ldots \ldots$ app.

Sec. \$G. Requtrements for Federal Entities

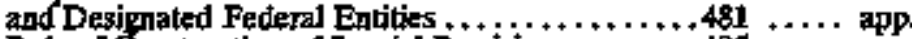

Sec. 8E Rule of Construction of Spectal Provitions. . . . . 485 $\ldots \ldots$ app.

Sec 9. Transfer of Functions. . . .................4B6 $\ldots \ldots+$ app.

Sec. 10. Conforming and Technical Amendments , . . . . . 489 .... app.

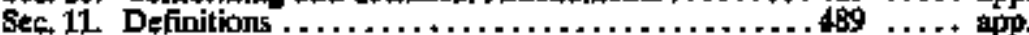

Sec 12. Effective Date $\ldots \ldots+\ldots+\ldots+\ldots+\ldots+\ldots+\ldots$ \$90 $\ldots \ldots$ app

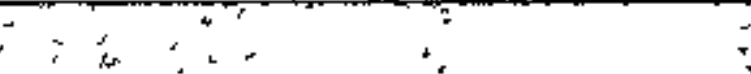


WSPECTOR GENERAL ACT OF 1978, AS AMENDED

Public Law-95-452

92 STAT. 1101

Gowemment orgarization and employees.

5 Ùśs app.

\author{
Sec. 1. SHORT TITLE
}

Sec. 2. PURPOSE AND ESTABLISHMENT OF OFFICES OF INSPECTOR GENERAL: DEPARTMENTS AND AGENCIES INVOLVED

In order to create independent and objective units-

(1) to conduct and supervise audits and investigations relating to the progrants and operations of the establishments listed in section 11(2). 1-

(2) to provide leadership and coordination and recommend policies for activities designed (A) to promote economy, efficiency, and effectipeness in the adrainistration of, and (B) to prevent and detect fraud and abuse in, such progozants and operations; and

(3) to provide a totans for keeping the head of the establishment and the Congress fully and curreptly informed about problems and deficisncies relating to the adrinistration of such programs and operations and the necessity for and progress of corrective action; there is herety established in each of such establistiments an $O F$ fice of Inspector Genteral.

Sec 3. APPOINTMENT OF INSPECTO SION: REMOVAL: POLITICAL ACTIVITIES: APPOINTMENT OF ASSISTANT INSPECTOR GENERAL FOR AUDITING AND ASSISTANT INSPECTOR GENERAL FOR INVESTIGATIONS

(a) There shall be at the head of each Office an Inspector General who stall be appointed by the President, by and with the advice and consent of the Senate, without regard to political affilitation and solely on the basis of integrity and denonstrated ability in accounting, auditing, firtantiaj analysis, Jaw, management analysis, public administation, or investigations. Each Inspector General shall report to and be under the gener. al supervision of the head of the establishment involved or, to the extent suxch authority is delegated, the officer next in rank below such head, but shall not report to, or be subject to supervision by, any othex offices of such establishment Neither the head of the establishment nor the officer next in rank below such head shall prevent or prohibit the Inspector General from initiating,carrying out, or completing any audit or investigation, or from issuing any subpoens during the course of any audit or investigation.

(b) An Inspector General may be renoved from office by the President. The President shall conmunicate the reasons for any such remowal to both Houses of Congress.

(c) For the purposes of section 7324 of title 5, United States Code, no Inspector General shatl be considered to be an emplogee who determines policies to be pursued by the United States in the nationuride adiministration of Federal laws.

(d) Each Inspector General sha!l, in aocordance with appticable laws and regutations govening the sivil service- 
(1) appoint an Assistant Inspector General for Anditing who shall have the responsibility for supervising the performance of atuditing activities relating to prograrns and operations of the establishment, and

(2) appoint an Assistant Inspector General for Investigations who shall have the responsibility for supervising the performance of iovestigative activities relating to such programs and operations.

SE. 4. DUTIES AND RESPONSIBILITIES REPORT OF CRIMINAL VIOLATIONS TO ATTORNEY GENERAL

(a) It shall be the duty and responsibility of each Inspector General, with respect to the estabjishment within which his Office is established-

(1) to provide policy directom for and toconduct, supervise, and coordinate audits and investigations relating to the programs and operations of such establishment;

(2) to review existing and proposed legislation and regulations relating to prograuns and operations of such establishment and to make recommendations in the seniznnual reports required by section 5(a) concerning the impact of such legislation or regulation on the economy and efficiency in the administration of programs and operations admizistered or fizanced by such establishment or the prevention and detection of fraud and abuse in stuch programs and optrations;

(3) to recommend policies for, and to conduct, supervise, or coordinate other activities carried out or financed by such estab. lishment for the purpase of promoting economy and efficiency in the administration of, or preventing and detecting fratud and abuse in, its programs and operations;

(4) to recommend policies for, and to conduct, supervise, or coordinate relationships between such establishment and other Federal agencies, state and local governmental agencies, and nongovermment entities with respect to $(A)$ all matters relating to the prevention and detection of fraud and abuse in, programs and operations adininistered or financed by such establishment, or (B) the identification and prosecution of participants in such fraud or abuse; and

(5) to keep the head of such establishment and the Congress fulyy and currently thormed, by means of the reports required by section 5 and otherwise, concerning frated and other serious problems, abuses, and deficiencies relating to the administration of programs and operations administered or financed by such estabfishment, to recommend corrective action concerning such problems, atbuses, and deficiencies, and to report on the progress arade in implementing stich corrective action.

"(b)(1) in carrying out the responsibilities specitied in subsection (a)(1), each Inspector General shall-

(A) comply with stardards established by the Comptooler General of the United States for audits of Federal

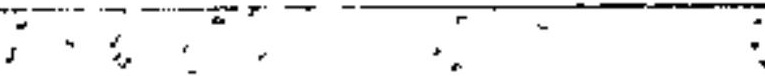


establishments, organizations, programs, activities, and functions;

(B) establish guidelines for determining when it shall be appropriate to use non-Federal auditors; and

(C) take appropriate steps to assure that any work performed by non-Federal auditors complies with the standards established by the Comptroller General as de. scribed in paragraph (1).

“(2) For purposes of determining compliance with paragraph (1)(A) with respect to whether internal guality controls are in place and operating and whether established audit standards, pollcies, and procedures are being followed by Offices of Inspector Geineral of establishments defined under section 11(2), Ofices of Inspector General of designated Federal entities defined under section $8 \mathrm{E}(\mathrm{a})$ (2), and any audit office established within a Federal entity defined under section $8 \mathrm{E}$ (a)(1), reviews shall be performed exclusively by an audit entity in the Federal Gowemment, including the General Accounting Office or the Obisce of Inspeator General of each establistment defined under section 11(2), or the Office of Inspector General of each designed Federal entity defined under section 8亩(a)(2).

"(c) In carrying out the duties and responsibilities established under this Act, each Inspector General shall give particular regard to the activities of the Comptroller General of the United States with a view toward avoiojing duplication and insuring effective coordination and conperation.

"(d) In carrying out the duties and responsibilities established under this Act, each Inspector General shall report expeditionsly to the Attomey General whenever the Inspector General has reasonable grounds to believe there has been a viclation of Federal criminal law.

Sec, 5. SEMIANNUAL REPORTS; TRANSMITTAI TO CONGRESS; AVAILABILITY TO PUBLIC, IMMEDIATE REPORT ON SERIOUS OR FLAGRANT PROBLEMS; DISCLOSURE OF INFORMATION; DEFINITIONS.

(a) Each Inspector General shall, not later that Apti 30and

October 31 of oach year, prepare semiannual reports summarizing the activities of the Office during the immediately preceding six-month periods ending March 31 and September 30. Such reports shall include, but need not be limited to-

(1) a description of significant problems, abuses, and deficiencies rejating to the administration of programs and operations of such establishment cisclosed by such activities during the reporting period;

(2) a description of the recommendations for consective action made by the Office diring the reporting period with respect to sig-

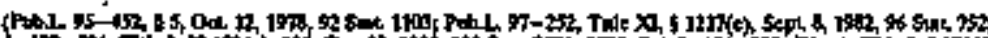

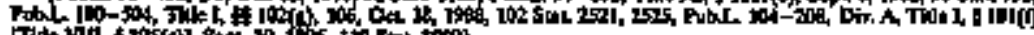

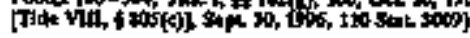


niticant problems, abuses, or deficiencies idencin̄ed pursuant to paragraph (1);

(3) an identifsestion of each significant recommendation described in previous semiannual reports on which corrective action has not been completed;

(4) a summary of matters referred to prosecutive authorities and the prosecutions and convictions which have resulted;

(5) a summary of each report made to the head of the establishment under section 6(b)(2) during the reporting perjod;

(6) a listing, subdivided according to subject matter, of each audit report issued by the Offece during the reporting period and for each audit report, where applicable, the total dollar value of questoned costs (including a separate category for the dollar value of unsupported costs) and the dollar value of recommendations that funds be put to better tes;

(7) a summary of each particularly significant report

(8) statistical tables showing the total number of atodit reports and the total dollar value of questioned costs (including a separate category for the dollar value of unsupported costs), for audit reports-

(A) for which no management decision had been made by the commencement of the reporting period;

(B) which were issued thiting the reporting periad;

(C) for which a mastagentent decistion was ulade duriag the reporting period, including

(i) the dollar value of disallowed costs; and

(ii) the dollar value of costs not disallowed; and

(D) for which no management decision has been made

by the end of the reporting period;

(9) statistical cables showing the total number of audit reponts and the dolar vajue of recommendations that funds be pet to better use by management, for audit reports-

(A) for which no management decision had been made by the commencement of the reporting period;

(B) which were issued during the reporting period;

(C) for whith a management decision was made during the reporting pertiod, jincluding-

(i) the dollar value of recommenciations that were agreed to by management; and

(ii) the dollar value of recommendations that were not agreed to by management; and

(D) for which no management decision has been made by the end of the reporting period;

(10) a surmmary of each audit report issued before the commencement of the reporting period for which no maragentent decision has been made by the end of the reporting pertod (including the date and title of each such report), an explanation of the reasois such management decision has not been made, and a statement conceming the destied timetable for achieving a management decision on each such report;

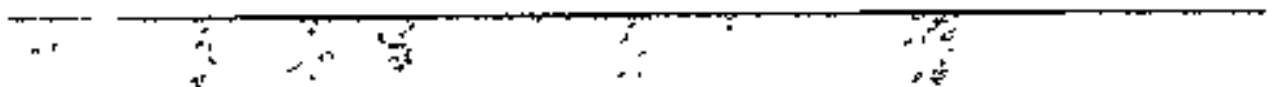


(11) a description and explanation of the reasons for any sipnificant revised management decision made during the reporting period;

(12) information concerning any significant management decision with which the Inspector General is in disagreement; and

(13) the information described under section 05(b) of the Federal Finarcial Maragement Improvement Act of 1996.

(b) Semiannual reports of each Inspector General shall be furnished to the head of the establishment involved not Jater than April 30 and October 31 of each year and shall be transmitted by such head to the appropriate committees or subcommittees of the Congress within thirly days after receipt of the report, togethes with a report by the' head of the establishment containing-

(1) any couruents such head deternines appropriate;

(2) statistical tables showing the total number of audit reports and the dollar value of disallowed costs, for audit reports-

(A) for which final action bad not been taken by the commencement of the reporting period;

(B) on which management decisions were made during the reporting period;

(C) for which final action was taken during the report* ing perood, including-

(i) the doilar value of disallowed costs that were recovered by management through collection, offset, property in lieu of cash, or otherrise; and

(ii) the dollas value of disallowed costs that were written off by management; and

(D) for which no final action has been taken by the end of the reporting period;

(3) statistical tables showing the total number of audit reports and the dollar value of recommendations that funds be put to better use by management agreed to in a management decision for audit reports-

(A) for which final action bad not been taken by the commencement of the reporting period;

(B) on which managerent decisions were made during the reporting period;

(C) for which final action was taken during the reporting period, including-

(i) the dollar value of recommendations that were actually completed; and

(ii) the dollar value of recommendations that management has subsequently concluded should not or could not be implemented or conpleted; and

(D) for which no final action has been taken by the end of the reporting period; and

(4) a statement with respect to audit reports on which management decisions have been made bat final action has not been tak- 
en, other than audit reports on which a managenent decision was made within the precesting year, containing-

(A) a list of such ardit reports and the date each such report was issued;

(B) the dollar vaiue of disallowed costs for each report;

(C) the dollar value of recommendations that funds be

put to better use agreed to by management for each report; and

(D) an explanation of the reasons final action has not been taken with respect to each such audit report, except that such statement may exclude such audit reports that are under formal administratjve or judicial appeal or upon which management of an establishment has agreed to pursue a legislative solution, but shall identify the number of reports in each category so excluded.

(c) Within sixty days of the transmission of the semiannual reports of each Inspector General to the Congress, the head of each establishment stitl make copjes of such report available to the public upon request and at a reasonable cost within 60 days after the transmission of the semiannual reports of each establishment head to the Congress, the head of each establishoment shall make copies of such report available to the public upon request and at a reasonable cost.

(d) Each Inspector General shall report immedjately to the head of the establishment involved whenever the Inspector General becomes aware of particularly seriotss or flagrane problems, abuses, or defitiencies rellating to the adninistration of programs and operations of such establishument. The head of the establishment shall transmit any such report to the appropriate committes or subcominttees of Congress within seven calendar days, together with a report by the head of the establishment confaining any comments such head deens appropriate.

(e)(1) Nothing in this section shall be construed to authorize the public disclosure of infornation which is-

(A) specifically prohibited from disclosure by any other provision of law;

(B) specifically required by Executive Order to be protected from disclosure in the interest of national defense or national security or in the conduct of foreign affairs; or

(C) a part of an ongoing criminal investigation.

(2) Notwithstanding paragraph (1)(C), any report under this section may be disclosed to the public in a forte which includes information with respect to a part of an ongoing criminal investigation if suct information has been tocluded in a publtc record.

(3) Except to the extent and in the manrer prowided under section 6103(f) of the Internal Revenue Code of 1986 [26 U.S.C.A. $\$ \$ 103(f)$, nothing in this section or in any other prowision of this Act shall be construed to euthorize or pernit the withholding of 
information from the Congress, or from any committee or subcommittee thereof.

(f) As used in this section-

(1) the term "questioned cost" means a cost that ts questioned by the Office because of -

(A) an alleged violation of a provision of a law, regulation, contrast, grant, cooperative agreement, or other agreement or doctument governing the expentiture of finds;

(B) a finding that, at the time of the audit, such cost is not supported by adequate doctumentation; or

(C) a finding that the expenditure of funds for the intended purpose is unnecessary or unreasonable;

(2) the terim "unsupported cost" means a cost that is questioned by the Ofifice because the office found that, at the time of the audit, such cost is not supported by adequate documentation;

(3) the term "disallowed cost" means a questioned cost that management, in a management decision, has sustained or agreed should not be charged to the Governiments

(4) the term "recommendation that finds be put to better use" means a recommendation by the Office that finds colukd be used mote efficiently if management of an ostablishment took actions to implement and oomplete the recommendation, inchuding--

(A) reductions in outlays:

(B) deobligation of funds from jrograms or operations;

(C) withdrawal of interest subsidy costs on loans or loan guarantees, insurance, or bonds;

(D) cosss not inicurred by implementing recommended improverients related to the operations of the establishIIent, a contractor or grantee;

(E) avoidance of unnecessary expenditures noted in pre-award reviews of contract or grant agreements; or

(F) any other savings which are specilically udentified; (5) the term "rnanagement decision" means the evaluation by the management of an establishunent of the findings and recommendations included in an audit report and the issuance of a final detistion by maragement concerring its response to such findings and recommendations, jncluding actions concluded to be necessary; and

(6) the term "final action" means-

(A) the completion of all actions that the management of asl establisbment has concluded, in its management decision, are pecessary with respect to the findings and recommendations included in an audít report; and

(B) in the event that the management of an establish. ment concludes no action is necessary, final action occurs when a Janagement decision has been made. 
Sec 6. AUTHORITY OF INSPECTOR GENERAL; INFORMATION AND ASSISTANCE FROM FEDERAL AGENCIES, UNREASONABLE REFUSAL, OFFICE SPACE AND EQUIPMENT

(a) In addition to the authority otherwise provided by this Act, each Inspector General, in carrying out the provisions of this Act, is authorizes-

(1) to have access to all records, reports, audits, reviews, doctments, papers, recommendations, or other material available to the applicable establishment which relate to programs and operations with respect to which that Inspector General has responsibtlities under this Act:

(2) to make such investigations and reports relating to the administration of the programs and operations of the applicable es. tablishment as are in the judgment of the Inspector General, necessary or desirable;

(3) to tequest such information or assistance as may be necessary for carrying out the duties and responsibilities provided by this Act from any Federal, State, or local governmental agency or unit thereof;

(4) to rexuire by subpoena the production of all information, documents, reports, answers, records, accounts, papers, and other data and documentary evidence necessary in the performance of the functions assigned by this Act, witich subpoenz, in the case of conturnacy or refusal to obey, shall be enforceable by order of ary appropriate United States district court: Provided, That procedures other than subpoenas shall be used by the Inspector General to obtain documents and information from Federal agercies;

(5) to administer to or take from any person an oath, affirmation, or affidiavit, whenever necessary in the performance of the functions assigred by this Act, wbich oath, affirmation, or affidavit when administered or taken by or before an employee of an $O$ fito of Inspector General designated by the Inspector General shall have the same force and effect as if adrninistered or taken by or before an officer having a seal;

(6) to have direct and prompt access to the head of the estabtishInent involved when necessary for any puspose pertaining to the performance of functions and responsibilities under this Act;

(7) to select, appoint, and employ such officers and employees as may be necessary for carrying out the functions, powers, and du. ties of the Ofince subject to the prowisions of title 3, United States Code, governing appointments in the competitive service, and the provisions of chapter 51 and subchapter III of chapter 53 of such title relating to classification and General Schedule pay rates;

(8) to obtain services as authorized by section 3109 of title 5 , United Stater Code, at daily rates not to exceed the equivalent rate prescribed for grade GS-18 of the General Schedule by section $\mathbf{5 3 3 2}$ of tite 5 , United States Code; and

(9) to the extent and in such amounts as may be provided in advance by appropitations Acts, to enter into contracts and other ar. rangentents for audits, studies, analyses, and other services with 
public agencies and with private persons, and to make such payments as may be necessary to carry out the provisions of this Act.

(b)(1) Upon request of an Inspector Benaral for information or assistance under subsection (a) (3), the bead of any Federal agency imvolved shall, irsofas as is practicable and not in contravention of any existing statutory restriction or regulation of the Federal agency from which the information is requested, furnish to such Inspector General, or to an authorized desig nee, strch information or assistance.

(2) Whenever information or assistance requested under subsection (a)(1) or (a)(3) is, is the judgment of an Inspector General, upreasonebly refused or not provided, the Inspector General shall report the circumstances to the bead of the establishment involved without delay.

(c) Each head of an establishment shall provide the Office within such establishment with appropriate and adequate ofEce space at central and field office locations of such establisbment, together with such equipment, office supplies, and communications facilities and services as may be necessary for the operation of such offices, and shall provide necessary mainterance services for such offices and the equipment and facilities located therein.

(d) For purposes of the provisions of title 5, United States Code, governing the Senior Execultive Service, any reference in such provisions to the 'appointing authority' for a member of the Senior Executive Service or for a Senior Executive Service position siall, if such member or position is or would be within the Office of an Inspector General, be deemed to be a reference to such Inspector General.

See 7. COMPLAINTS BY EMPLOYEES. DISCLOSURE OF IIDENTITY; REPRISALS

(a) The Inspector General may receive and investigate com. plaints or information from an enplojee of the establishment concernting the possible existence of an activity constituting a violation of Law, rules, or regulations, or mismanagement, gross waste of funds, abuse of authority or a sabstantíal and specific danger to the public health and safety.

(b) The Inspector General shall not, after receipt of a complaint or information from an employee, disclose the identity of the employee without the consent of the employee, unless the Inspector General determines such fisclosure is unavoidable during the course of the investigation.

(c) Any employee who has authority to take, direct others to take, recomotend, or approve any personnel action, shall not with respect to such authority, take or threaten to take any actions against any employee as a reprisal for making a complaint or disclosing information to an Irispector Generat, unless the complaint was made for the information disclased with the knowledge that it was false or with willful disregard for its trath or falsity. 
Sec. 8. ADDITIONAL PROVISIONS WITH RESPECT TO THE INSPECTOR GENERAL OF THE DEPARTMENT OF DEFENSE

(a) No member of the Armed Forces, active or reserve, shall be appointed Inspector Gereral of the Department of Defense.

(b) (1) Notwithstanding the last two sentences of section 3(a), the Inspector Genesal shat be under tite authority, direction, and control of the Secretary of Defense with respect to audits or juvestigations, or the issuance of subpoenas, which require access to information concerning-

(A) sensitive operational plans;

(B) Intelligence matters;

(C) cotunterintelligence matters;

(D) ongoing criminal ímestigations by other adjainistrative units of the Department of Defense related to national security; or

(E) other matters the disclosure of which would constitute a serious threat to national security.

(2) With respect to the information described in paragraph (1) the Secretary of Defense may probibit the Inspector General from initiating, carrying out, or completing any audit or jinvestigation, or from issuing any subpoena, after tie Inspector General has decided to initiate, carry out or complete such audit or investigation or to issute such sutpooens, if the Secretary determines that such prohibition is necessary to preserve the national security interests of the United States.

(3) If the Secretary of Defense exercises any povrer under paragraph (1) or (2), the Inspector Gerteral shall submit a statement concerning such exercise within thirty days to the Committees on Armed Services and Govemmental Affairs of the Senate and the Committes on Armed Services and Government Operations of the House of Representatives and to other appropriate committees or subcommittets of the Congress.

(4) The Sectetary shall, within thity days after submassion of a statement under paragraph (3), transmit a statement of the reasons for the exercise of power under paragraph (1) and (2) to the Committees on Armed Services and Govermental Affairs of the Senate and the Committees on Armed Services and Government Operations of the House of Representatives and to other appropriate convittees or subcominittees.

(c) In addition to the other duties and responsibilities speci-

fied in this Act, the Inspector General of the Department of

Defense shall-

(1) be the principal adviser to the Secretary of Defense for matters relating to the prevention and detection of fraud, waste, and abuse in the programs and operations of the Depertment;

(2) injtiate, conduct, and supervise such audits and investigatons in the Department of Defernse (including the military departments) as the Inspector General considers appropriate;

(3) provide policy direction for audits and investigations relating to fraud, waste, and abuse and program effectiveness; 
(4) investigate fraud, waste, and abuse uncovered as a result of other contract and internal endits, as the Inspector General considers appropriate;

(5) develop policy, monitor and evaluate prograno performance, and provide guidatace witt respect to all Departnent activities relating to criminal investigation programs;

(6) monitor and evaluate the adherence of Department auditors to internal audit, conteact audit, and internal review principles, policies, and procedures;

(7) develop policy, evaluate program performance, and manitor actions taken by all components of the Departantent in response to contract audits, internal andits, internal review reports, and audits conducted by the Comptroller General of the United States;

(8) request assistance as neteded from other audit, inspection, and investigative units of the Department of Defense (including military departuents); and

(9) give particular regard to the activities of the internal audit, inspection, and investigative units of the military departments with a view toward avoiding ouplication and insuring effective coordination and cooperation.

(d) Notwithstanding section 4(d), the Inspector General of the Departonent of Defense shall expeditiously report suspteted or alleged violations of chapter 47 of title 10, United States Code (Uniforn Code of Military Justice), to the Secretary of the military department concemed or the Secretary of Defense.

(e) Fur the purposes of section 7, a member of the Armed Forces shall be demaed to be an employee of the Department of Defense, except that, when the Coast Guard operates as a service of another department or agency of the Federal Government, a member of the Coast Guad shall be deemed to be an employee of such departurent or agency.

(f)(1) Each semiannual report prepared by the Inspector Generat of the Department of Defense under section S(a) shall include information concerning the numbers and types of contract audits conducted by the Department during the reporting period. Each such report shall be transuitted by the Secretary of Defense to the Committees on Armed Services and Governmental Affairs of the Senate and the Cormittees on Armed Services and Governmental Operations of the House of Representatives and to other appropriate committees or subcommittees of the Congress.

(2) Any report required to be transmitted by the Sexretary of Defense to the appropriate committees or subcommittees of the congress under section 5(d) shall also be transmitted within the seven-day period specified in such section, to the Committees on Armed Services and Governmental Affairs of the Senate and the Committes on Arried Services and Government Operations of the House of Representatives. 
(g) The provisions of section 1385 of title 18, United States Code, shail not apply to audits and investigations conducted by, ender the direction of, or at the request of the Inspector General of the Department of Defense to carry out the purposes of this Act.

Sec. 8A. SPECIAL PROVISIONS REIATING TO THE AGENCY FOR INTERNATIONAL DEVELOPMENT

(a) In addition to the other duties and responsibilities specified in this Act, the Irspector Gereral of the Agency for International Development-

(I) sinal] supervise, direct, and control all security activities retating to the programs and operations of that Agency, subject to the supervision of the Administrator of that Agency, and

(2) to the extent requested by the Director of the United States International Development Cooperation Agency (after constultaton with the Administrator of the Agency for International Development), shall supervise, direct, and control all audit, investigatwe and security activities relating to programs and operations within the United States International Development Cooperation Agency.

(b) In addition to the Assistant. Inspectar Generals provided for in section 3(d), of this Act, the Inspector General of the Agency for International Developtinent shall, in accordance with applicable laws and regulations gowerning the civil service, appoint an Assistant Inspector General for Security who shall have the responsibility for supervising the performance of se. curity activities relating to programs and operations of the Agency for Intereational Developinent.

(c) The semiansual reports requited to be subritted to the Administrator of the Agency for International Development pursuant to section 5(b) of this Act shall also be submitted to the Director of the United States International Development Cooperation Agency.

(d) In addition to the officers and employees provided for in section 6(a) (6) of this Act, members of the Foreign Service may, at the request of the Inspector General of the Agency for Intermationad Devejopment, be assigned as employees of the Inspector General. Members of the Forejer Service so assigned shall be responsible solely to the Inspector General, and the Inspector General (or his or her desiguee) shall prepare the performance evaluation reports for such members.

(e) In establishing and staffing field offices pursuant to section 6(c) of this Act, the Adsninistrator of the Agency for International Development shall not be bound by overseas person. nel cetlings established under the monitoring Overseas Direct Einployment policy.

(f) The reference in section 7(a) of this Act to an employee of the Establishment shail, with respect to the Inspector General

- of the Agenxy for International Developnent, be construed to 
include an employee of or under the United States International Development Cooperation Agency.

(g) The Inspector General of the Agency for International Development shall be in addition to the officers provided for in section 624(a) of the Foreign Assistance Act of 1961 [22 U.S.C. 2384(a)].

(h) As used in this Act, the term "Agency for International Developutent" includes any successor agency primarily re. sponsible for admintstering part I of the Foreign Assistance Act of 1961 [22 U.S.C. 2151 et seg.]

Sec- 8B. SPECIAL PROVISIONS CONCERNING THE NUCLEAR REGULATORY COMMISSION

(a) The Chairnan of the Commistion may delegate the authority specified it the second sentence of section 3 (a) to another member of the Nuclear Regulatory Commission, but shall not delegate sucti' authority to any other oficicer or employee of the Commission.

(b) Notwithstancing sections $6(a)(7)$ and $(8)$, the Inspector Genteral of the Nucsear Regulatory Commission is authorized to select, appoint, and employ such officers and employees as may be necessary for carrying out the funetions, powers and duties of the Office of Inspector General and to obtain the temporary or intermittent services of experts or consultants or an organization thereof, stbject to the applicable laws and regulations that govern such selections, appointments and employment, and the obtaining of such services, within the $\mathrm{Nu}-$ clear Regulatory Commission.

"SEC SC- SPECIAL PROVISIONS CONCERNING THE FEDERAL DEPOSIT INSURANCE CORPORATION.

"(a) DELEGATION.-The Chairperson of the Federal Deposit Insurance Corporation may delegate the authority specified in the second sentence of section 3(a) to the Vice Chairperson of the Board of Directors of the Federal Depasit Insurance Corporation, but may not delegate such authonty to any other officer of employee of the Corporation.

"(b) PERSONNEL-Notwithstanding paragraphs (7) and (8) of section 6(a), the Inspector General of the Federal Deposit Insurance Corporation may select, appoint, and employ such officers and employees as may be necessary for canrying out the functions, powers, and duties of the Office of Inspector General and to obtain the temporary or interntittent services of experts or consultants of an organization of experts ox consultants, subject to the applicable laws and regulations that govern such selections, appotatments, and eaployment, and the obtaining of stch services, witkin the Federal Deposit Insuranco Corporation.";

Sec. 8D. SPECIAL PROVISIONS CONCERNING THE DEPART. MENT OF THE TREASURY

(a)(1) Notwithstanding the last two sentences of section 3(a), the Inspector General shall be under the authority, direction, and control of the Secretary of the Treastry with respect to at:- 
dits or investigation, or the issuance of subpoenas, which require access to sensitive information concerning-

(A) ongoing criminal imwestigations or proceedings;

(B) undercover operations;

(C) the identity of confidential sources, including protected witnesses;

(D) deliberations and decisions on policy matters, including documented information used as a basis for making policy dectsions, the disclosure of which could reasonably be expected to have a signisteant influence on the economy or market behavior;

(E) inteligence or counterinteligence matters; or

(F) other usatters the disclosure of which would constitute a serious threat to national security or to the protection of any person or property authorized protection by section 3056 of title 18, United States Code, section 202 of title 3, United \$tates Code, of any provision of the Presidential Protection Assistance Act of 1976 (18 U.S.C 3056 note; Public Law 94-524),

(2) With respect to the information described under paragraph (1), the Secretary of the Treasury may prohibit the Inspector General fronl carrying out or completing any audit or irvestigation, or from issuing any subpoena, atter such Inspector General has decided to initiate, carry out, or complete such audit or inwestigation or to issue such subpoena, if the Secretary determines that such probibition is necessary to prevent the disclosure of any information described under paragraph (1) or to prevent significant impairment to the national interests of the United States.

(3) If the Secretary of the Treasury exercise any power under paragraph (1) or (2), the Secretary of the Treasury shall notify the Inspector General in writing stating the reasons for such exercise. Within 30 days after receipt of any such notice, the Inspector General shal! transmit a copy of such notice to the Committees on Governmental Affairs and Finance of the Senate and the Conmittees on Government Operations and Ways and Means of the House of Representatives, and to other appropriate committees or sulbommittees of the Congress.

(b) In carrying out the duties and responsibilities speciñed in this Act, the Inspector General of the Depertment of Treastury shall have oversight responsibility for the internal investigations performed by the Office of Internal Affatrs of the Bureau of Alcohol, Tobacco and Firearms, the Office of Internal Affaits of the United States Custops Service, and the Office of Inspections of the United States Seczet Service, and the internal audits and internal investigations perforred by the Office of Assistant Commissioner (Inspection) of the Internat Revemue Service. The head of each such office shall promptly report to the Inspector General the sigaificant activities being carried out by such office. 
(c) Notwithstanding subsection (b), the Inspector General foay initiate, conduct and superivise such audits and investigations in the Department of the Treasury (inchuding the bureaus and services referred to in subsection (b) as the Inspector General considers appropriate.

(d) If the Inspector General initiates an audit or investigation under subsection (c) concerning a bureau or service teferred to in subsection' (b), the Inspector General may provide the head of the office of such bureau or service referred to in subsection (b) with written notice that the Inspector General has initiated such an audit or investigation. If the Inspector General issues a notice under the preceding sentence, noother audit or investigation shall be initiated into the matter under audit or investigation by the Inspector General and any other audit or twvestigation of such matter shall cease.

(e)(I) The Inspector General shall have access to returns and return information, as defined in section 6103(b) of the Internal Revenue, Code of 1986, only it accordance with the provisions of section 6103 of such Code and this Act.

(2) Access by the Inspector Geperal to returns and rehurn information under section 6103(b)(1) of such Code shall be sutbject to the following additional sequirements:

(A) In order to maintain internal controls over access to returns and return infortuation, the Inspector General, or in the absence of the Inspector General, the Acting Inspector General, The Deputy Inspector General, the As. sistant Inspector General for Andits, or the Assistant Inspector General for Investigations, shall provide to the Assistant Commissioner (Inspection) of the Internal Revenue Service wiritten notice of the Inspector General's intent to access returns and return information. If the Inspector General determines that the Inspection Service of the Internal Revenue Service should not be made aware of a notice of access to returns and return information, such notice shall be provided to the Senior Deputy Commission of Internal Reventic.

(B) Such notice shall clearly indicate the specific renurns or returat information being accessed, contatin a certification by the Inspector General, or in the absence of the Inspector General, the Acting Inspector General, the Deputy Inspector General, the Assistant Inspector General for Audits, or the Assistant Inspector General for Investigations, that the reaurns or return information being accessed are needed for a purpose described under section 6103(b)(1) of the Internal Revenue Code of 1986, and identify those employees of the Office of Inspector General of the Department of Treasury who may receive such returns or return information.

(C) The Internal Revenue Service shath maintain the same system of standardized records or accounts of all re- 
quests from the Inspector General for inspection of disclosure of returns and return information (motuding the reasons for and dates of suct requests), and of returns and return information inspected or disclosed pursuant to such requests, as described under section 6103(p)(3)(A) of the Internal Revenue Code of 1986. Such system of standardized records or accountings shall also be available for examinalion in the same manner as provided under section 6103(p) (3) of the Internal Revenue Code of 1986.

(D) The Inspector General shall be subject to the same safeguards and conditions for receiving returns and teturn information as are described under section $6103(p)(4)$ of the Internal Revenue Code of 1986.

(I) An andit or investigation conducted by the Inspector General shall not affect a final decision of the Secretary of the Treasury or his delegate under section 6404 of the Internal Revente Code of 1986.

(g) Notwithstanding section 4(d), in manters involving chapter 75 of the Internal Revenue Code of 1986, the Inspector General sball report expeditously to the Attorney Geperal only offenses under section 7214 of such Code, unless the Inspector General obtains the consent of the Commissiener of Intermal Revenue to exercise additional reporting authority with respect to such chapter.

(b) Any report required to be transmitted by the Secretary of the Treasury to the appropriate committees or subcommittees of the Congress under section 5(d) shall also be trassinitted, within the seven-day period specified under such section, to the Committees on Governmental Affairs and Finance of the Senate and the Committees on Govermment Operations and Ways and Means of the House of Representatives.

SEe 8E. SPECIAL PROVISIONS CONCERNING THE DEPARTMENT OF JUSTICE

(a)(1) Notwithstanding the last two sentences of section 3(a), the Inspector General shall be under the authonity, direction, and control of the Attorney General with respect to audits or investigations, or the issuance of subpoenas, which require access to sensitive information concerning-

(A) ongoing civil or criminal investigations or proceedings;

(B) undercover operations;

(C) the identity of confidential sources, including protected witnesses;

(D) intelligence or counterintelligence matters; or

(E) other matters the disclasure of which woold constitute a serious threat to national security.

(2) With respect to the information described under paragraph (1), the Attoney General may probibit the Inspector Gereral from carrying out or completing any audit or investigation, of from 
issutng any subpoena, after such Inspector Gentral has decided to initiate, carry out, or complete such audit or investigation or to issue such subpoena, if the Attorney Genemal determines that such prohibition is necessary to prevent the disclosure of any information described ungier paragrap̧h (1) or to prevent the significant impairment to the mationa! interests of the United States.

(3) If the Attorney General exercises any power under paragraph (1) or (2), the Attomey Genteral stall notify the Inspector General in writing stating the reasons for such exercise. Within 30 days after receipt of any such notice, the Inspector General shall transmit a copy of such notice to the Committees on Boverntmentol Affairs and Judiciary of the Senate and the Conncittees on Government Operations and Judiciary of the House of Representatives, and to other appropriate committees or subcommittees of the Congress.

(b) In carrying out the duties and responsitilities specified in this Act, the Inspector General of the Department of Justice(1) may initiate, conduct and suptsvise such atudits and investigations in the Department of Justice as the Inspector General considers appropriate;

(2) shall give particular regard to the activities of the Counsel, Office of Professional Responsibility of the Department and the audit, internal investigative, and inspection units outside the $O f-$ fice of Inspector General with a view toward avoiding duplication and insuring offective coordination and cooperation; and

(3) shall refer to the Counsel, Office of Professional Responsibility of the Department for investigation, informstion or altegations relating to the conduct of an officer or exployee of the Department of Justice employed in an attorney, criminal investigation of law, regulation, or order of the Department or any other applicable standard of conduct, except that no such referral shall be made if the officer or employee is employed in the Office of Professional Responsibitity of the Department.

(c) Any report required to be transmitted by the Attorney General to the appropriate committees or subcommittes of the Congress under sectioi 5(d) shall also be transmitted, within the seven-day period specified under such section, to the Committees on the Judiciary and Gowernmental Affairs of the Senate and the Committees on the Jucticiary and Government Operations of the House of Representatives.

"Sec. 8R. SPECIAL PROVISIONS CONCERNING THE CORPORATION FOR NATIONAL AND COMMUNITX SERVICE

(a) Notwitbstanding the provistons of paragraphs (7) and (8) of section 6(a), it is within the exclusive jurisdiction of the Inspector General of the Corporation for National and Community Service to-

"(1) appoint and determine the compensation of such oftcers and employees in accordance with section 195(b) of the National and Community Service Trust Act of 1993; and 
1 "(2) procure the temporary and intermittent services of and compensate such experts and consultants, in accordance with section 3109(b) of title 5, United States Code, as may be necessary to carry out the functions, powers, and duties of the In. spector General.

"(b) No Jater than the date on which the Chief Executive Officer of the Corporation for National and Community Service transinits any report to the Congress under stibsection (a) or (b) of section 5 , the Chief Executive Officer shall thantmit such report to the Board of Directors of such Corporation.

"(c) No later than the date on which the Chief Executive Officer of the Corporation for National and Commanity Service transmits a report described under section 5 (b) to the Board of Directors as provicled under subsection (b) of this section, the Chief Executive Officer shall also transmit any audit report which is deseribed in the statement required under section 5(b)(4) to the Board of Dtrectors. All such audit reports shall be placed on the agenda for review at the next scheduled meeting of the Board of Directors following such transmittal. The Chief Executive Officer of the Corporation shall be present at stech meeting to provide any information relating to such audit reports.

"(d) No Jater than the date on which the Inspector General of the Corporation for National and Conamunity Service reports a problem, abouse, or deficiency under section 5(d) to the Chief Executive Officer of the Corporation, the Chief Executive Officer shall report such problem, abuse, or deficiency to the Board of Directors.".

Set 8G. REQUIREMENTS FOR FEDERAL ENTITIES AND DESIGNATED FEDERAL ENTITIES

(a) Notwithstanding section 11 of this Act, as used in this section-

(1) the term "Federal entity" means any Government corporation (within the meaning of sectson 103(1) of title 5, United States Code), any Government controlled corporation (within the mearing of section 103.2) of such title), or any other entity in the Executive brarch of the Govertusent, or any ixdependent regulatory agentcy, but does not include-

(A) an establishment (as defined under section 11(2) of this Act) or part of an establishment;

(B) a designated Federal entity (as defined under paragraph (2) of this subsection) or part of a designated Federal entity;

(C) the Executive Office of the President;

(D) the Central Intelligerce Agency;

(E) the General Accounting Office; or

(F) any entity in the judicial or legislative branches of the Government, including the Adninistrative Office of the United States Courts and the Architect of the Capitol and any activities tunder the direction of the Architect of the Capitol; 
(2) the term "designated Federal entity" means Amtrak, the Appalachian Regional Commission, the Board of Governors of the Federal Reserve System, the Board for International Broadcasting, the Commodity Futures Trading Commission, the Consumer Product Safety Commission, the Corporation for Public Broadcasting, the Equal Emplojment Opportunity Commission, the Farm Credit Administration, the Federal Communications Corsmission, the Federal Election Commission, the Federal Housing Fisance Board, the Federal Labor Relations Authority, the Federal Maritime Commission, the Federal Trade Commission, the Legal Services Corporation, the National Archives and Records Administration, the National Credit Union Administration, the National Endowsent for the Arts, the National Endowment for the Humanities, the National Labor Rejations Board, the National Science Foundation, the Pantatra Canal Connuission, the Peace Corps, the Pension Benegit Guaranty Comporation, the Securities and Exchange Commission, the Sinithsonian Institution, the Tenressete Valley Authority, the United States International Trade Commission, and the United States Postaj Service.

(3) the term "head of the Federal entity" means any person or persons designated by statute as the head of a Federal entity, and if no such designation exists, the chief policymaking officer or board of a Federal entity as jdentified in the list published pursuant to stubsection (h)(1) of this section;

(4) the term "head of the designated Federal entity" means any person or persons designated by statute as the head of a designated Federal entity and if no such designation exists, the chief po. licymaking officer or board of a desigrated Federal entity as jidentified in the list published pursuant to sabsection (b)(i) of this section, except tolat-

(A) with respect to the National Science Foundation, such term means the-National Science Board; and

(B) with respect to the United States Postal Strvices, stich term means the Governors (withis the meaning of section 102(3) of title 39, United States Code);

(5) the term "Office of Inspector General" means an Office of Inspector General of a designated Federal entity; and

(6) the term "Inspector General" means an Inspector General of a designated Federal entity.

(b) No later than 180 days after the date of the enactment of this section [Oct. 18, 1988], there shall be established and maintained in each designated Federal entity an Office of Inspector General. The head of the designated Federal entity shalt tranisfer to such office the offices, units, or other components, and the functions,' powers, or ditties thereof, that such head determines are properly related to the functions of the Office.of Inspector General and would, if so transferred to sthch office any program operating responsibilities.

(c) Except as provided under subsection (f) of this section, the Inspector General shall be appointed by the head of the 
designated Federal entity in accordance with the applicable laws and regulations govening appointments within the designated Federal eatity.

(d) Each Inspector Geperal shall report to and be under the general supervision of the hegd of the designated Federal ent. ty, but sball not report to, or be stoject to supervision by, any other officer or employee of such designated Federal entify. The head of the designated Federal entity shall not prevent or prohibit the Inspector General frotn initiating, carrying out, or completing any audit or irvestigation, or from issuing any subpoena during the course of any audit or investigation.

(e) If an Inspeotor General is removed from office or is tyansferred to another position or location within a designated Federal entity, the head of the designated Federal entity shall promptly communicate in writing the reasons for any such removal or trankfer to both Houses of the Congress.

(f) (1) For purposes of carrying out subsection (c) with respect to the United States Postal Service, the appointment provisions of section $202(e)$ of title 39, United States Code, shall be applitec.

(2) In carrying out the duties and responsibilities specified in this Act, the Inspector General of the United States Postal Service (hereinafter in this subsection referred to as the "Inspector General") shall have oversight resporsibility for all activities of the Postal Inspection Strvice, including any internal investigation per. formed by the Postal Inspection Service. The Chief Postal Inspector shall promptly report the significant activities being carried out by the Postal Inspection Service to such Inspector General.

(3)(A)(i) Notwittstanding subsection (d), the Inspector Gener* al stiall be under the atthority, direction, and control of the Govemors with respect to audits or investigations, or the issuance of subpoenas, which require access to sensitive information concerning-

(I) ongoing civil or criminal investigations or proceedings:

(II) undercover operations;

(III) the identity of confidential sources, irchinding protected witnesses;

(IV) intelligence or counterintelligence matters; or (V) other matters the disclasure of which would constitute a serious threat to national security.

(ii) with respect to the infornation described under clause (i), the Governors may prohibit the Inspector General from carrying out or completing ang audit or investigation, or from issuing anly subpoena, after such Inspector Generad has decided to initiate, carry out, or complete such aucit or investigation or to issue such subpoena, if the Governors determine that such prohibition is necessary to prevent the disclasure of any information de-

$\because \quad \quad-$


scribed urider clause (i) or to prevent the significant impairment to the national interests of the Unted States.

(iii) If the' Governors exercise any power under clause (i) ot (ii), the Governors shall notify the Inspector General in writing stating the reasons for such exercise. Within 30 days after receipt of any such notice, the Inspector General shall trajsmit a copy of such notice to the Contimitte on Govisgimenteal Affairs of the Senate and the Committec on Government Reform and Oversight of the House of Representatives, and to other appropriate committees or stbcommittees of the Congress.

(B) In carrying out the duties and responsibilities spectified in this Act, the Inspector 'Genera\}-

(i) Hay initiatt, conduct and supervise such audits and investigations in the United States Postal Service as the Inspector General considers appropriate; and

(ii) shall give particular regard to the activitios of the Postal Inspection Service with a view toward avoiding duplication and insurtig effective coprdination and cooperation.

(C) Any report required to be transmitted by the Governors to, the, appropriate committees or suboommittees of the Congress under section 5 (d) shall also be transmitted, within the seven-day period specified under such section, to the Conmittee on Governmental Affairs of the Senate and the Comnittee on Governnent Roform and Oversight of the House of Representatives.

(3) Nothing in this Act skall restrict, eliminate, or otherwise adversely affect any of the rights, privileges, or benefits of either $\mathrm{em}$ ployees of the United States Postal Service, or labor organizations representing employees of the United States Postal Service, under chapter 12 of title 39, United Stares Code, the National Labor Relations Act, any handbook or mantal affecting employee labor relations with the Untted States Postal Service, or any collective bärgaining agreement.

(4) As used in this subsection, the term "Governors" has the méaning given such term by section 102 (3) of title 39, United States Code.

(g)(1) Sections 4,5,6 (other than subsections (a)(7) and (a)(B) thereof, and 7 of this Act shall apply to each Inspector General and Office of Inspector General of a designated Fedtral entity and sucil sections shall be applied to each designated Federal entity and head of the designated Federal entity (as defined under subsection (a)) by substítuting-

(A) "designated Federal entity" for "establishment"; and

(B) "head of the designated Federal entity" for "head of the esfablishment".

(2) In addition to the other authorites specified in this Act, an Inspector General is authorized to select, appoint, and employ sucti officers and employees as may be necessary for carrying out 
the functions, powers, and duties of the Office of Inspector General and to obtain the temporary or intermittent services of experts or consultants or an organization thereof, subject to the applicable laws and regulations that govem such selections, appointments, and employment, and the obtaining of suci services, within the destignated Federal entity.

(3) Notwithstanding the last sentence of subsection (d) of this section, the provisions of subsection (a) of section $\mathrm{BC}$ (other than the provisions of subparagrapls (A), (B), (C), and (E) of subsection (a)(1)) shall apply to the Inspector General of the Board of Gowernors of the Federal Reserve System and the Chajrman of the Board of Governors of the Federal Reserve System in the same manner as such provistons apply to the Inspector General of the Departinent of the Treasury and the Secretary of the Treasury, respectively.

(h)(1) No later than April 30, 1989, and anusually thereafter, the Director of the Office of Management and Budget, after consultation with the Comptroller General of the United States, shall publish in the Federal Register a list of the Federal entities and designated Foderal entities and the head of each such entity (as defoned under subsection (a) of this section).

(2) Beginning on October 31,1989, and on Oetober 31 of each succeeding calendar year, the head of each Federal entity (as defined under subsection (a) of this section) shall prepate and transmit to the Director of the Office of Management asd Budget and to each House of the Congress a report which-

(A) states whether there has been established in the Federal entity an office that meets the requirements of this section;

(B) specifies the actions taken by the Federal entity otherwise to ensurte that andits are conducted of its programs and operations tim accordance with the standard for audit of goversmental organizations, programs, activities, and functions issued by the Comptroller General of the United States, and includes a list of each andit report completed by a Federal or non-Federal auditor during the reporting period and a summary of any particularly signif. jcant findings; and

(C) summarizes aby matters relating to the personenel, programs, and operations of the Federal entity referred to prosecutive authorities, including a summary description of any preliminary investigation conducted by or at the request of the Federal entity concerning these matters, and the prosecutions and convictions which have resulted.

Sec. 8H. RULE OF CONSTRUCTION OF SPECIAL PROVISIONS

Sec. 8h. The special provisions unter section 8, 8A, 8B, 8C, 8D, or 8E of this Act relate only to the establishment named in such section and no inferente shatl be drawn from the presence or absence of a provision

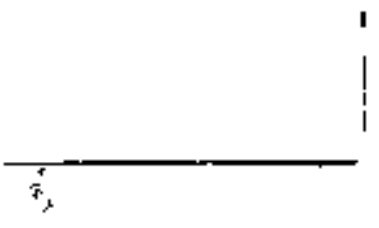


in any such section with respect to an establishment not named ta such section or with respect to a designated Federal entity as defined under section $8 \mathrm{~F}(\mathrm{a})$.

Sec. 9. TRANSFER OF FUNCTIONS

(a) There shall be transferned-

(1) to the Office of Inspector General-

(A) of the Department of Agriculture, the offices of that departutent referred to as the "Office of Investigation" and the "Office of Audit";

(B) of the Department of Commerce, the offices of that department referred to as the "Office of Audits" and the "Investigations and Inspections Staff" and that portion of the office referred to as the "Office of Investigations and 'Securtity" which has responsibility for juvestigation of alIeged criminal violations and program abuse;

(C) of the Department of Defense, the offices of that department referred to as the "Defense Aludt Service" and the "Office of Inspector General, Defense Logistics Agency", and that portion of the office of that department referred to as the "Defense Isvestigative Service" which has responsibility for the investigation of alleged crininal violations;

(D) of the Departentent of Education, all functions of the Inspector Geveral of Health, Edtcation, and Welfare or of the Office of Inspector General of Health, Education,' and Welfare relating to functions transferred by section 301 of the Department of Education Organization Act [20 U.S.C.A. \& 3441];

(E) of the Department of Energy, the Office of Inspector General (as establisłed by section 208 of the Departmient of Energy Organization Act);

(F) of the Department of Health and Human Services, the Office of Inspector General (as established by title II

- of Public Law 94-505);

(G) of the Department of Housing and Urban Development, the otisce of that department referred to as the "Office of Inspector ' 'General";

(H) of the Department of the Interior, the office of that department referred to as the "Office of Altit and Investigation";

(I) of the Department of Justice, the offices of that Department referred to as (i) the "Audit Staff, Justice Management Division", (ii) the "Policy and Procedures Branch, Ofice of the Comptroller, Immigration and Naturalization Service", the "Office of Professional Respon. sibility, Immigration and Naturalization Service", and

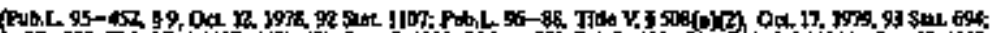

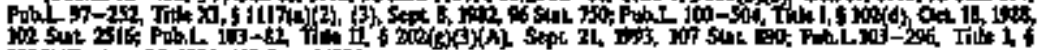
I0: 
the "Office of Program Inspections, Immigration and Naturalization Service", (iii) the "Office of Internal Inspection, United States Marsbals Service", (iv) the "Financial Audjt Section, Office of Financial Management, Bureau of Prisons" and the "Office of Inspections, Bureau of Prisons", and (v) from the Drug Enforcement Administration, that portion of the "Office of Inspections" which is engaged in internal audit activities, and that portion of the "Office of Planning and Evaluation" which is engaged in prograso review activities;

(J) of the Department of Labor, the office of that department referred to as the "Office of Special Investigatoons;

(K) of the Departinent of Transportation, the offices of that department referred to as the "Office of Imvertigations and Secunty" and the "Office of Audit" of the Department, the "Offices of Investigations and Security, Federal Avjation Administration" ${ }^{n}$, and "External Audit Divisions, Federal Aviation Administration", the "Investigations Division and the External Audit Division of the Office of Program Revitew and Investigation, Federal Highway Admiristration", and the "Oftice of Program Audits, Urban Mass Transportation Administration";

(L) of the Department of the Treasury, the office of that department referred to as the "Office of Inspector General", and, notwithstanding any other provision of lat, that portion of each of the offices of that department referred to as the "Office of Internal Affairs, Bureau of Alcohol, Tobacco, and Firearms", the "Office of Internal Affairs, United States Customs Service", and the "Office of Inspections, United States Secret Service" which is engaged in fotemal audit activities:

(M) of the Environumental Protection Agency, the offces of that agency referred to as the "OfFe of Audit" and the "Security and Inspection Division";

(N) of the Federal Emergency Management Agency, the office of that agency referred to as the "Office of $\mathrm{ln}$ spector Gexeral";

(O) of the General Services Administration, the offices of that agency referred to as the "Office of Audits" and the "Office of Investigations";

(P) of the National Aeronatutics and Space Administration, the offices of that agency referred to as the "Management Audit Office" and the "Office of Inspections and Security";

(Q) of the Nictear Regulatory Commission, the office of that commission referred to as the "Office of Inspector and Auditor";

(R) of the Office of Personnel Management, the offices of that agency referted to as tie "Office of Inspector Gen- 
eral", the "Insurance Audits Division, Retirement and Insurance Group", and the "Analysis and Evaluation Divsion, Administration Group";

(S) of the Railroad Retirement Board, the Office of Inspector General (as established by section 23 of the Railroad Reairement Act of 1974);

(T) of the Small Business Admintstration, the office of that agency seferred to as the "Ofice of Audits and Investigations

(U) of the Veterans' Admixistration, the offices of that agency referred to as the "Office of Audits" and the "Office of Imvestigations";

(V) of the Corporation for National and Community Service, the Office of Inspector General of ACTION; and

(W) of the Social Security Administration, the functions of the Inspector General of the Department of Health and Human Services which are transferred to the Socta! Security Administration by the Sociat Security Indepen+ dence and Prograsn Improvernents Act of 1994 (other than functions performed pursuant to section 105(a)(2) of such Act), except that such transfers shall be made in accordance with the provisions of such Act and shall not be subject to subsections (b) through (d) of this section: and

(2) such other offices or agencies, or functions, powers, or duties thereof, as the head of the establishonent tovolved may determine are properly related to the functions of the Office and would, if so transferred, furthin the purposes of this Act, except that there shail not be transforted to an Inspector General under paragraph (2) program operating responsibalities.

(b) The personnel, assets, liabilities, contracts, property, recortls, and unexpended balances of appropriations, authorizations, allocations, and other funds employed, held, used, arising from, available or to be made available, of any office or agency the functions, powers, and duties of which are transferred under subsection (a) ate hereby transfersed to the applicable Office of Inspector General.

(c) Personnel transferted pursuant to subsection (b) shall be transferred in accordance with applicable laws and regulations re. lating to the transfer of functions except that the classfication and compensation of such personnel shall not be reduced for one year after such transfer.

(d) In asy case where all the functions, powers, and duties of any office or agency are transferred pursuant to this subsection, such office or agency sball lapse. Any person who, on the effective date of this Act [Oct. 1, 1978], he]d a position conpensated in accordance with the General Schedule, and who, without a break in service, is appointed is an Office of Inspector General to a position having duties comparable to those performed immediately preceding such appointment shall continue to be compensated in the 
new position at not less than the rate provided for the previous position, for the duration of service in the new position.

Sec. 10. CONFORMING AND TECHNICAL AMENDMENTS

[Section amended sections 5315 and 5316 of Title S, Government Organization and Empkoyees, and section 3522 of Title 42, The Public Health and Welfare, which amendments have been executed to text.]

Sec. 11. DEFINITIONS

As used in this Act - ${ }^{-1}$

(I) the term "head of the establishment" means the Secretary of Agrialture, Conmerce, Defense, Eơucation, Energy, Health and Human Services, Housing and Urban Development, the Intertor, Labor, State, Transpostation, or the Treasury; the Attorney General; the Administrator of the Agency for Internationil Developenent, Environmental Protection, General Services, National Aeronautics and Space, Small Business, or Veterans' Affairs; the Director of the Federal Emergency Management Agency, the Office of Personnel Management of the United States Information Agercy; the Chairman of the Nuclear Regulatory Commission or the Railroad Retirement Board; the Chairperson of the Thrift Depositor Protection Oversight Board; the Chief Executive Officer of the Corporation for National and Comumunity Service; the Administrator of the Community Development Financial Institurtions Fund; and the chief executive officer of the Resolution Trust Corporation; and the chaitperson of the Federal Deposit Insurance Corporation; or the Commissioner of Soctal Securtty, Social Sectrity Administration; as the case may be;

(2) the term "establishiment" means the Departinent of Agriculture, Commerce, Defense, Education, Energy, Health and Human Services, Housing asd Urban Development, the Interor, Justice, Labor, State, Transportation, or the Treasury; the Agency for International Development, the Community Development Financial Institutions Fund, the Environmental Protection Agency, the Federal Emergency Managentent Agency, the General Services Administration, the National Aeronallties and Space Adruinistration, the Nuclear Regulatory Commission, the Office of Personnel Managenaent, the Railroad Retirement Board, the Resolution Trust Corporation, the Federal Deposit Insturance Corporation, the Small Business Administration, the United States Information Agency, the Corporation for National and Community Service, or the Veterans ${ }^{7}$ Aduninistration, or the Social Security Admisistration; as the case may be;

(3) the term "Inspector General" means the Inspector Gereral of an establishonent;

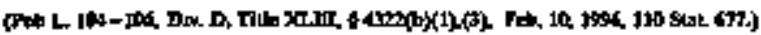


(4) the term "Office" neans the Office of Inspector General of an establishments and

(5) the term "Federal agemcy" means an agency as defined in section 552(e) of Title 5 (including an tstablishment as defined in paragraph, (2)\}, United States Code, but shall not be construed to;include the General Accounting Office.

Sec 12. EFFECTIVE DATE

The [original] provisions of this Act and the amendments [to other laws] made by.this Act [see section 10 of this Act] shel] take effect October 1, 1978 .

\section{PERTINENT POKTIONS OF INSPECTOR GENERAL ACT AMENDWIENT \\ of 1988 whilch did not anend Inspector General Att of 1978 .}

\section{UNIFORM SALARIES FOR INSPECTORS GENERAL.}

(a) UNIFORM SALARIES - Section 5315 of titie 5, United States Code, is antenced by adding at the end thereof the following new para. eraphs

"Irspector'General, Department of Commerce.

"Inspector General, Department of the Interior.

"Inspector General, Department of Justice.

Inspector General, Department of the Treasury.

"Inspector General, Agency for Intemational Development.

"Inspector General, Ertvironmental Protection Agency.

“Inspector General, Federal Estergency Mankigennent Agency.

Inspector General, Gemeral Services Administrator. tion.

"Inspector General, National Aeronautics and Space Administra-

tInspector General, Nuclear Regulatory Commission.

tInspector General, Office of Personnel Management.

"Inspector General, Raiłroad Retirement Board.

"Inspector General, Smal Business Administration.".

\section{APPROPRLATION ACCOUNTS.}

Section $1105(a)(25)$ of title 31, United States code, is amended to read as follows:

(a) Duting the first 15 days of each regular session of Congress, the President sball submit a budget of the United States Government for the following fiscal year. Each budget shall intlude a budget message and summary and supporting jifformation. The President shall include in each budget the following:

(25) a separate appropriation account for appropriations for each Office of Inspector Gerieral of an establishment deftned under section 11(2) of the Inspector General Act of 1978 .

\section{PAYMENT AUTHORITY BURJECT TO APPROPRIATIONS.}

Any authority to make payments under this title (Inspector General Act Amendments) shall be effective only to such extent as provided in approptiations Acts. 


\section{EFHDCTIV DATE.}

This title and the amendments made by this title shall take effect 180 days after the date of the enactment of this titie, except that section $5(a)(6)$ through (12) of the Inspector Genteral Act of 1978 (as amended by section 106 (a) of this title) and section (5)(b)(1) through (4) of the Inspector General Act of 1978 (as amended by section 106(O) of this title) shall take effect 1 year after the date of the enactment of tiris title. 


\section{ADMINISTRATIVE PROCEDURR ACT}

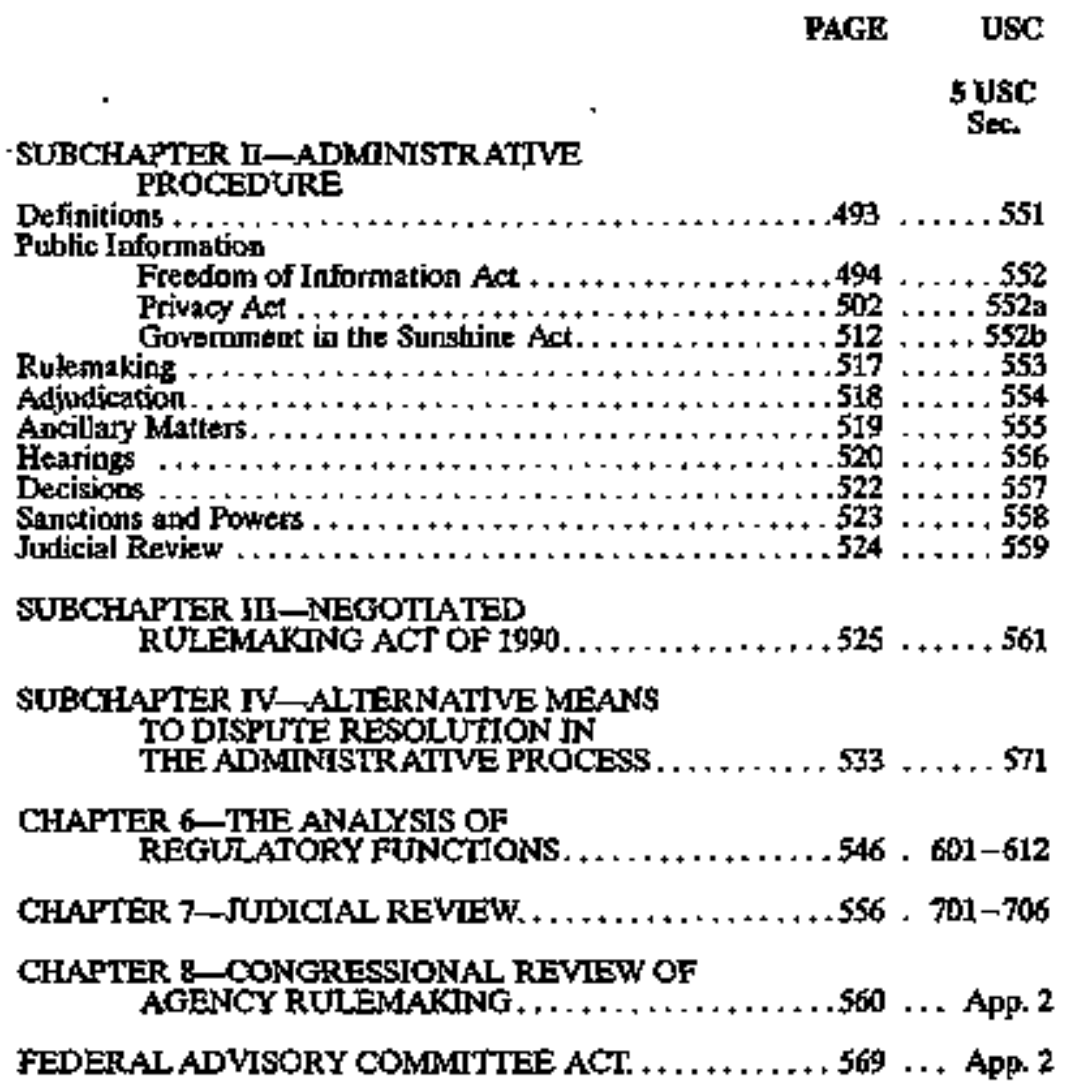




\section{SECIONS OF TIMLE S UNTTED STATES CODE}

\section{SUBCEAPTER II-ADMINISTRATIVE PROCEDURES SECTIONS 55I-559;}

Sec. 551. Definitions.

For the purpose of this subchapter-

(1) "agency " means each autbority of the Gowemment of the United States, whether ot not it is within or subject to review by another agency, but does not include-

(A) the Congress;

(B) the pourts of the United States;

(C) the governments of the territories or possessions of the United States;

(D) the Government of the District of Columbia; or except as to the requirements of section $\mathbf{5 5 2}$ of thj title

(E) agencies composed of representatives of the parties or of representatives of arganizations of the parties to the disputes deteruined by them;

(F) courts martial and military commissions;

(G) military authority exercised in the field in time of war or in occupied teritory; or

(H) function's conferred by sections 1738, 1739, 1743, and 1744 of title 12; chapter 2 of title 41 ; subchapter II of chapter 471 of title 49; or sections $1884,1891-1902$, and former section 1641(b)(2), of title 50, appendix;

(2) "person" includes an indiwidual, partnership, corporation, association, or perblic or private organization other than a agency,

(3) "party" includes a person or agency named or admitted as a party, or property secking and entitled as of right to be admitted as a party, in an agency proceeding, and a person or agency admitted by an agency as a party for limited puposes;

(4) "rule" means the whole or a part of an agency statement of general or particular applicability and future effect designed to implement, taterpret, or presctibe law or policy or describing the organization, procedure, or practice reculuremepts of an agency and includes the approwal or prescription for the future of rates, wages, corporate or finarcial structures or reorganizations thereof, prices, facilites, appliances, services or allowances therefor or of valuations, casts, or accounting, or practices bearing on any of the foregoing;

(5) "rule making" means agency process for formulating, amending, or trepeating a rule;

(6)" "order" means the whole or part of a final disposition whether affirmative, negative, injunctive, or dexlaratory in fonto, of an agency in a matter other than rule making but incluoijis licensing;

(7) "adjudication" means agency process for the formulation of as order;

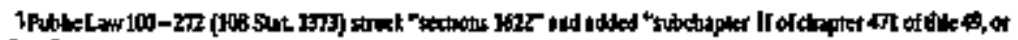
settons" 
(8) "license" includes the whole or a part of an agency pernit, certitscate, approval, registration, chaster, mentership, statutory exemption or other form of permission;

(9) "licensing" inchudes agency process respecting the grant, renewal, denial, rewocation, suspension, astulment, withdrawal, limitation, amendments, modification, or conditioning of a license;

(10) "sanction" includes the whole or a part of an agency.

(A) prohibition requirement, limitations, or other condition affecting the fretiom of a person;

(B) withholding of relief;

(C) imposition of penalty or line;

(D) destruction, taking seizate, ot with holding of property;

(E) Assessment of damages, reimbursement, restitution, compensation, costs, charges, or fees;

(F) requirement, revocation, or suspension of a lisense; or

(G) taking other compulsory or restrictive action;

(11) "relief" includes the whote or a part of an agencr-

(A) grant of money, assistance, license, authority, exemption, exception, privilege, or remedy;

(B) recogrition of a claim, right, immunity, privilege, excmption, or exception; or

(C) taking of other action on the application or petition of, and beneficial to, a person;

(12) "agency proceedings" means an "gency process as defimed by paragraphs (5), (7), and (9) of this section;

(13) "agency action" includes the whole or a'part of an agency rule, order, license, sanction, relief, or the equivaltnt or denial thereof, or failure to act; and

(14) "ex parte communication" means an oral or written communication not on the public record with respect to which reasonable pxior notice to all parties is not given, but it shall not include requests for status reports on any matter or proceeding covered by this subchapter;

(Pub. L. 89-554, Sept. 6, 1966, 80 Stat. 381; amended Pub. L. 94-409, Sept 13, 1976, 90 Stat, 1247.)

Sec. 552. Public Information; Agency Rales, Opinions, Orders, Records, and Proceeding? ${ }^{2}$

(a) Each agency shall make available to the public information as follows:

(1) Each agency shafl separately state and currently publish in the Federal Register for the guidance of the public-

(A) descriptions of its central'and field organization and the established places at which, the employees (and in the case of a uniformed service, the members) from whom, and the methods whereby, the public may obtain tofortuation, make submittals or requests, or obtain decisions;

(B) statements of the general course and method by whith sts functions are channeled and determined, including the nature

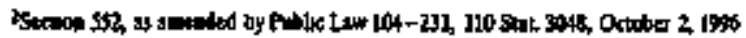


and requirements of all formal and informal procedures availab]e;

(C) rules of procedure, descriptions of forms available or the places at which forms may be obtained, and instructions as to the scope and contents of all papers, reports, or examinations;

(D) substentive rules of general applicablity adopted as authorized by law, and statements of general policy or interpseta. tions of general appliceability formulated and adopted by the agency; and

(E) each amendment, revision, or repeal of the foregoing. Except to the extent that a person bas actual and timely notice of the terms thereof, a person may not in any manner be required to Iesort to, or be adversely affected by, a matter required to be pub. lished in the Federal Register and not so published. For the purpose of this paragraph, matter reasonably avallable to the ctass of persons affected thereby is deemed published in the Federal Register when incorporated by reference therein with the approwal of the Director of the Federal Register.

(2)Each agency, in accordanice with published niles, shall make avallable for public inspection and copying-

(A) fonal opimions, theluding coneturing and dissenting opinjons, as well as orders, made in the adjucication of cases;

(B) those statements of policy and interpretations which have been adopted by the agency and are not published in the Federal Register;

(C) administrative staff manuals and instructions to staff that affect a member of the public;

(D) copies of all records, regardless of form or format, which have been released to any person under paragraph (3) and which, because of the nahure of their subject matter, the agency determines have become or are likely to become the subject of subsequent requess for substantially the same records; and

(E) a gentral index of the records referred to under rubparagraph (D); unless the matertats are protaptly published and copies offered for sale. For records created on or after November 1, 1996, wittin one year after such date, each agency shall make such records avajlable, jncluding by connputer teleconmunications or, if computer teleconamunications means have not beer established by the agency, by other electronic means. To the extent required to prevent a cleariy unwarranted invasion of personal privacy, as agency may delete identifying details when it makes avadable or publishes an opinion, statement of policy, interpretation, staff manual, instruction, or copies of records referred to in subparagraph (D). However, in each case the fustification for the deletion shall be explained fully in writing, and the extent of such deletion shall be indjcated on the portion of the record which is made avatable or published, unless including that indication would harm an in. terest protected by the exemption in sulusection (b) under which the deletion is made. If technically feasible, the extent of

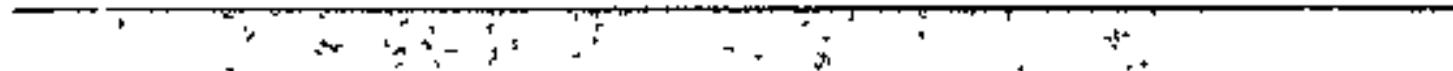


the deletion shall be indicated at the place in the record where the deletion was made. Each agency shall also maineain and make available for public ìspection and copying current indexes providing identifying information for the public as to any matter issued, adopted, or promulgated after July 4, 1967, and Iequired by this paragraph to be made availabte or pubtished. Each agency shall promptly publish, quarterly or more frequently, and distribute (by sale or otherwise) copies of each index or supplements thereto unless it determines by order published in the Federal Register that the publication tould bo unnecessery and impracticable, in which case the agency shall nonetheless provide copies of such index on request at a cost not to exceed the direct cost of duplication. Each agency shall make the index referred to in subparagraph (E) available by computer telecommurieations by December 31, 1999. A final order, opinion, statement of policy, interpretation, or staff manual or instruction,that affects a member of the public may be relied on, used, or ctted as precedent by ar agency against a - party other than an agency only it-

(i) it has been indexed and eltber made arailable or published as provided by this paragraph; or of.

(ii) the party has actual and timely notice of the terms there-

(3)(A) Except with respect to the records made available under paragraphs (1) and (2) of this subsection, each agency, upon any request for records which (i) reasonably describes such records and (ii) is made in accordance with published rules stating the time, place, fees (if any), and procedures to be followed, shall make the records promptly avaílable to any person.

(B) In making any record available to a person under this paragraph, an agency shall provide the record in any form or format Iequested by the person if the record is readily reproducible by the agency in that form or format. Each agency shall make, reasonable eftorts to majutain its records in forms or formats that are.reproditucible for purposes of this section.

(C) In responding under this paragraph to a request for Iecords, an agency shall make reasonable efforts to search for the records in electronic form or format, except when such efforts would significantly interfere with the operation of the agency's automated information system.

(D) For purposes of this paragraph, the term "search" means - to review, manually or by atutomated means, agency records for the purpose of locating those records which are responsive to a request.

(4)(A)(i) In onder to cany out the provisions of this section, each agency shall promulgate regulations, pursuant to notioe and recejpt of public comments, specifying a uniform schedule of fees applicable to all constituent units of such agency. Such fees shalt be limited to reasontable standard charges for doeuntent search and duplication and provide for recovery of only the direct costs of 
stxh search and duplication. Documents shall be fumished without charge or at a reduced charge where the agency deterenines that waiver or reduction of the fee is in the public tnterest because furnishing the information can be considered as prutuarily benefiting the general public.

(B) On complaint, the district court of the United States in the district in which the complainant resides, or has his principal place of business, or in which the agency secords are sinuated, or in the District of Columbia, has jurisdiction to enjoin the agency from withtrolding agency records and to order the production of any agency records improperly withheld from the complainant. In such a case the court shall determine the matter de nowo, and may examine the contents of such agency records in camera to determine whether such records or any part there of shall be withintdd under any of the exemptions set forth in subsection (b) of this section, and the burden is on the agency to sustain its action. In addition to any other matters to which a court accords substantial weight, a court shall accord substantial weight to an affidavit of as agency concerning the agency's deternination as to tecturical fea. sibility under paragraph (2XC) and stlbsection (b) and reproduc. ibility under paragraph (3XB).

(C) Notwithstaxding any other provision of law, the defendant shall serve an answer or otherwise plead to any contplaint made usder this subsection within thisty days after service upon the defendant of the pleading in which such complaint is made, unless the court otherwise directs for good cause shown.

(D) Repealed. Public Law 98-620, Title IV, S 402(2), Nov. 8, 1984,98 Stat. 3357.

(E) The court may assess against the United States reasonable attoiney fees and other litigation costs reasonably incurred in any case under this section fow which the complainant has substantially prevailed.

(F) Whenever the court orders the production of any agency records inaproperly withheld from the complainart and assesses against the United States reasonable attormey fees and otber litigation costs, and the court additionally issues a written finding that the circumstarces surrounding the withholding raise ques. tions whether asency personnel acting abittarity or caprictously with respect to the withholding, the Spectal Coursel shal promptby initiate a proceeding to determine whether disciplinary action is warranted against the officer or enployee who was primarity responsible for the withholding. The Special Counsel, after investigation and consideration of the evidence subonitted, shatl submit his indings and recommendations to the adininistrative authority of the agency concerned and shall send copjes of the findings and recommendaticns to the officer or employee of his representative. The administrative authority shall take the corrective attion that the Special Counsel recommends.

(G) In the event of noncompliance with the order of the court, the district court may punish for contempt the responsible em- 
ployee, and in the case of a uniformed service, the responsible member.

(5) Each agency having more than one member shall maintain and make available for public inspection arecord of the final votes of each member in every agency proceeding.

(6)(A) Each agency, upon any request for records made under paragraph (1), (2), or (3) of this subsection shall-

(t) determine within 20 days (excepting Saturdays, sundays, and legal public holidays) after the receipt of ary such request whether to comply with such request and shall immediately notify the person making such request of such determination and the reasons therefor, and of the right of suct person to appeal to the head of the agency any adverse determination; and

(ii) make a determination with respect to any appeal within twenty days (excepting Saturdays, Sundays and legal public bolidays) after the receipt of such ippeal. If on appeal the denial of the request for records is in whote or in part tpheld, the agency shall notify the person making such reguest of the provisions for judicial review of that determination under paragraph (4) of this subsection.

(B) In unusual circumstances as specified in this subparagraph, ,the time limits prescribed in either clause (i) or clanse(fi) of sabparagraph (A) may be extended by written notice to the person making such request settling forth the reasons for such extension and the date on which a determination is expected to be dispatched. No such notioc shall specify a date that woukd result in an extenston for more than tetk working days. As used in thís subparagraph, "unusual circumstances" means, but only to the extent rea.sonable necessary to the proper processing of the particular request:-

(i) the need to search for and collect the requested records from field facilities or other establishunent that are separate from the office processing the request;

(ii) the need to seasch for, collect, and appropriately examine a wolumirous amount of separate and distint records which are demanded in a single request; or

(iij) the need for consultation, which shall be conducted with all practicable speed, with another agency having a substantial interest in the determination of the request or amons two or more components of the agency having substantial subjectmatter interest therein.

(C) Anty person making a request to any agency for recorcis under paragraph (1), (2), or (3) of this subsection shall be deented to have exhausted his administrative remedies trith respect to such request if the agency fails to comply with the applicable time limit provisions of thits paragraph: If the Government can show exceptional circumstances exist and that the agency is exercising due ditigence in responding to the request, the court may tetain jurisctiction and allow the agency additional time to complete its review of the records. Upon any determination by an agency to comply with 
a request for records, the records shall be made promptly availab]e to such person making such request. Any notification of denial of any request for records under this subsection shall set forth the names and titles or positions of each person responsible for the denial of such request.

(b) This section does not apply to matters that are-

(I)(A) specifically authotized ander criteria established by an Executive order to be kept secret in the interest of national defense or foreign policy and (B) are in fact properly classified pursuant to susch Executive order;

(2) related solely to the internal personnel rules and practices of an agency.

(3) specificaly exempted from disclosure by statute (other thas section 5526 of this title), prowided that such statute (A) requires that the matters be withheld from the public in stuch a manner as to leave no discretion on the issue, or (B) establishes particular criteria for withholding or refers to particular types of matters to be withlheld;

(4) trade secrets and commercial or financial information obtained from a person and privileged or confidential;

(5) inter-agency or intra-agency memorandums or letters which would not be available by law to a party other than an agency in litigation with the agency;

(6) persoanel and medical files and similar files the disclosure of which would constitute a clearly untwarranted infasion of personal ptvacy:

(7) investigatory records compiled for law enforcement purposes, but only to the extent that the production of such records would (A) interfere with enforcement proceedings, (B) deprive a person of a right to a fair trial or an impartial adjudication, (C) constitute an unwarranted invasion of personal privacy, (D) disclose the jidentity of a confidential sources and, in the case of a record compiled by a criminal law enforcement authority in the course of a criminal investigation, or by an agency conducting a lawful national security intelligence insestigation, confidential isl. formation furnished onty by the confidential source, $(E)$ disclose investigative technigues and procedures, or (F) endanget the life or physical safecy of taw enforcement persomet;

(8) contained in or related to examination, operating, or conxtition reports prepared by, on behalf of, or for the use of an agency responsible for the regulation or supervision of 5nancial institutions; or

(9) geological and geophysical information and tata, incluting maps, concerning we]ls.

Any reasonably segregable portion of a record sball be provided to any persor requesting such record after deletion of the portions which are exempt under this subsection. The amount of information deleted shalt be indicated on the released portion of the record, unless including that indication would harm an interest protected by the exemption in this subsection under which the detetion is made. If technicalty feasible, the 
ampunt of the information deleted shall be irclicated at the place in the record where such deletion is made.

(c)(1) Whentever a request is made which involves access to records described in subsection (b)( 7$)(A)$ and- .

(A) the investigation of proceeding involves a possible violstion of criminal law, and .

(B) there is reason to believe that (i) the subject of the investigation or proceeting is not aware of 3 is pendency, and (ii) disclasure of the existence of the records could Itasonably be expected to interfere with enforcement procetdings, the agency may, duristg only stach time as that incurmstance continues, treat the records as not subject to the requirements of this section.

(2) Whenever informant records maintained by a criminal law enforcement agency under an informant's name or personal ideptifier are requested by a third party according to the informant's name or personal identifier, the agency may treat the records as not subject to the requirements of this section unless the informart's status as an informant has, been officially confirmed.

(3) Whenever a rexilest is made which involves access to records maintaised by the Federal Bureau of Investigation pertaining to foreign intelligence or counterintelitence, or international terrorism, and the existence of the records is classified information as provided in stubsection (b)(1), the Bureat1 may, as long as the existence of the records remains classified information, treat the records as not subject to the requirements of this section.

(d) This section does nat autborize withlolding of information or limit the availability of records to the public, except as specifically stated in this section. This section is not authority to withhold information from Congress.

(e)(1) On or before February 1 of each year, tach agency shall submit to the Attorney General of the United ștates a report which shall cover the preeeding fiscal year and which shall include-

(A) the number of detenminations made by the agency not to comply with requests for records mads to such agenoy under subsection (a) and the reasons for each such deternination;

(B)(i) the number of appeals made by persons under subsection (a) (6), the result of such appeals, and the reason for the action upon each appeat that resuls in a denial of information; and

(ii) a complete list of all statutes that the agency relies upon to authorize the agency to withhold infomation under subsection (b)(3), a description of whether a coust has upheld the decision of the agercy to withbold infor. mation under each such statute, and a concise description of the scope of any information witheld;

(C) the number of requests for jecords pending before the agency as of September 30 of the preceding ytar, and the median number of days that such requests had beer pending before the agency as of that date; 
(D) the number of requests for records received by the agency and the number of requests which the agency processed;

(E) the median number of days taken by the agency to process different types of requests;

(F) the toksl amount of fees collected by the agency for processing requests; and

(O) the number of full-time staff of the agency devoted to processing requests for records under this section, and the total amount expended by the agency for processing such Iequests.

(2) Each agency shall make each such report available to the public including by computer telecommumications, or if computtr relecommunications means have not been established by the agency, by other electronic means.

(3) The Aftomey General of the United States shall make each report which has been mads avaitable by electronic means avaitable at a single electronic access point. The Attorney General of the United States shall notify the Chairman and ranking minority nember of the Committee on Government Reform and Oversight of the House of Repressentatives and the Chairman and ranking minotity member of the Conmitites on Governmental Aftatrs and the Judiciary of the Senate, no later than April 1 of the year in which each such report is issued, that such reponts are available by electrontc mears.

(4) The Attorney General of the United States, in consultation with the Director of the Ofisce of Management and Budget, shall develop reporting and performance guidelines in connection with reports required by this subsection by October 1, 1997, and may establish additional requirements for such reports as the Attorney General determines may be useful.

(5) The Attorney General of the United States shall submit an annual report on or before Aprt 1 of each calendar year which shall inchude for the prior calendar year a listing of the number of cases arising under this section, the exemption involved in each case, the disposition of such case, and the cost, fees, and penalties assessed under subparagraphs (E), (F), and (G) of subsection (a)(4). Such report shall also include a description of the efforts uadertaken by the Department of Justice to encourage agency compliance with this section.

(f) For purposes of this section, the term-

(1) "agency" as defined in section 551(I) of this title jucludes any executive department, military department, Government corporation, Government controfled oxporation, or other establishment in the executive branch of the Government (including the Executive Office of the President), or any independent regulatory agency; and

(2) "record" and any other term used in this section in reference to information includes any information that would be an agenty 
record subject to the requirements of this section when maintained by ar agency in any format, including an electronic format.

(g) The head of each agency shall prepare and make pubticly available upon request, reference material or a guike for requesting records or information from the agency, subject to the exemptions in subsection (b), incluđitug-

(1) an incex of all major information systems of the agency;

(2) a description of major information and record locator systems maintaitied by the agency; and.

(3) a hanilbook for obtaining.various types and categoties of public information from the agency pursuant to chapter 35 of title 44 , and under this section.

Sec. 552 a. Records Maintained On Individuals.

(a) DEFINITIÓNS.-For purposes of this section-

(1) the term "agency" means agency as defmed in section 552(e) of this title;

(2) the' term "inifividual" means a citizen of the United States or an alieri lawfully admitíted for permanént residence;

(3) the term "riaintain" includes maintein, collect, use, or dis"serininate:

(4) the term "record" means any item, collection, or grouping of information about an' individual that is maintained by an agency. 'jncluding, but not limited to, hís education, firancial transactions, medical history, and criminal or employment history and that contains his name, or the identifying number, symbol, or other identifying particular assigned to the individual, such as a finger or voice print or a photograph;

(5) the term "system of tecords" means a group of any records under the control of any agency from which information is Ietrieved by the name of the inofvidual or by some identifying number, symbol, or other identifying particular assigned to the individual;

(6) the term "statistical record" means a record in a systems of records maintained for statistical research or reporting purposes only and not used in whole or in part in making any determination about an identifiable individual, except as provided by section 8 of title 13; and

(7) the term "routine use" means, with respect to the disclosure of a record, the use of such record for a purpose which is compatible with the purpase for which it was collected.

(b) CONDITIONS OF DISCLOSURE-No agency sball disclobe any record which is contained in a system of records by any means of communication to any person, or to another agency, except pursuant to a written reguest by, or with the prior written consent of, the individual to whom the record pertains, anless disclosure of the record wotald be-

(1) to those officers and employees of the agency which main. tains the record who have a reed for the record in the performance of their duties;

(2) required under section 552 of this title; 
(3) for a routine us as deffned in subsection (a)(7) of this section and described under subsection (e)(4)(D) of this section;

(4) to the Bureau of the Census for purposes of planning or carrying out a census or survey or related activity purstant to the provisions of titke13;

(5) to a recipient who has provided the agency with advance adequate witten assurance that the record will be used solely as a statistical research or reporting record, and the record is to be transferred in a form that is not individually identifiable;

(6) to the National Archives of the United States as a record which has sufficient historical or other value to warrmant its continued preservation by the United States Government, or for evaluation by the Administrator of General Services or bis designee to determine whether the record bas such value;

(7) to another agency or to an instrumentality of any governmental jurisdiction within or under the control of the United States for a civil or criminal law enforcement activity if the activity is authorized by law, and if the bead of the agency or instrumentality has made a written sequest to the agency which maintajns the record specifying the particular portion desired and law enforcement activity for which the record is sought;

(8) to a person pursuant to a showing of compelling circum. stances affecting the health or safety of an individual if upon stech disclosure notification is transmitted to the last known address of such indjuicual;

(9) to either House of Congress, or, to the extent of matter within its jurisdiction, any committee or subcomutitte thereof, ang joint committee of Congress or subcommittee of any such joint committee;

(10) to the Comptroller General, or any of his authorized representatives, in the course of the performance of the daties of the General Axcounting Office;

(11) pursuant to the order of a court of competent jurtsciction; or

(12) to a consumper reporting agency in accordance with section $3711(f)$ of title 31 .

(c) ACCOUNTING OFCERTAINDISCLOSURES,-Each agency, with respect to each system of records under its control, shall-

(i) except for disclosures made under subsections (b)(1) or (b)(2) of this section, keep an accurate accounting of-

(A) the date, nature, and purpose of each disclosure of a record to any person or to another agency made under subsection (b) of this section; and

(B) the name and address of the person or agency to whom the fisclosure is made;

(2) retain the accounting made ander paragraph (1) of this subsection for at least five years or the life of the record, whichever is longer, after the disclosure for which the accounting is made;

(3) except for disclosures made under subsection (b)(7) of this section, make the accounting made under paragraph (1) of this 
subsection available to the individual named in the secord at his request; and

(4) inform any person or otter ahout any correction or notation of dispute made by the agency in accordance with subsection (d) of this section of any record that has been disclosed to the person or agency if an acounting of the disclosite was made.

(d) ACCESS TO RECORDS.-Each agenty that maintains a syztem of records shall-

(1) upon request by any individual to gain access to his record on any information pertaining to him which is contained in the system, permit him and upon his request, a person of his own choosi ing to accompany him, to review the record and have a copy made of all or any portion thereof in a form comprehensible to him, except that the agency may requite the indivioutual to furnish a written statement authonizing discussion of that individual's record in the accompanying person's presence;

(2) permit the individual to request amendment of a record pertaining to him and-

(A) not later than 10 days (excluding Saturdays, Sundays, and logal public holidays) after the date of receipt of such request, ackmowiledge in writing such recejpt; and-

(B) pronptly, either-

(i) inake any conrection of any portion there of whith the individual believes is not accurate, relevant, thitely, or complete; or

(ii) inform the individual of its refusal to amend the record in acoordance with his request, the reason for the refusal, the procedures established by the agency for the individual to request a review of that refusal by the head of the agency or an offices designated by the hiead of the agency, and the name and besiness address of that ofitcal;

(3) permit the individual who disagrees with the refusal of the agency to amend his record to request a review of such refusal, and not tater than 30 days (excluding Saturdays, Sundays, and legal public holidays) from the date on which the individual requests such review, complete such review and make a final determination unless, for good cause shown, the head of the agency extends such 30-day period; and, if after his review, the reviewing official also refuses to arrend the record in accordance with the request, permit the individual to fle with the agency a concise statement setting forth the reasons for his disagretergent with the refusal of the agency, and notify the individual of the provisions for judicial review of the reviewing official's determination under subsection (g)(1)(A) of this section;

(A) in any disclosure, containing information about which the individual has filed a statement of disagreement, occurring after the fling of the statement under paragraph (3) of this subsection, clearly note any portion of the record which is disputed and pro* vide copies of the statement and, if the agency desms it appropri- 
ate, copies of a concise statement of the reasons of the agency for aot making the amendments requested, to persons or other agencies to whom the disputed record has been disclosed; and

(5) nothing in thits section shall allow an individual access to any information compiled in reasonable anticipation of a civil action or proceeding.

(e) AOENCY REQUIREMENTS-Each agency that maintains a system of records shall-

(1) majptzin in its recotds only such information about an individual as is relevant and necessary to accomplish a purpose of the agency reguired to be accomplished by statute or by executive ofder of the President;

(2) collect irformation to the greatest extent practicable directly from the subject individual when the information may result in adverse determintations about an mdividual's 渵 próvileges under Federal programs;

(3) inform each indivictual whotn it asks to supply information, or the form which it uses to collect the information or on a sepa. rate form that can be retained by the individual-

(A) the authority (whother granted by status, or by executive order of the President) which authorizes the solicitation of the information and whether disclosure of such information is mandatory or voluntary;

(B) the principal purpose or purposes for which the information is intended to be used;

(C) the routine uses which may be made of the information, as published pursuant to paragraph (4)(D) of this subsection; and

(D) the effects on him, if any, of not providing all or any part of the requested infommations

(4) subject to the provisions of paragraph (11) of this subsection, publish in the Federal Register upon establistinent or revision a notice of the existence and character of the system of records, which notice shall include-

(A) the uane and location of the system;

(B) the categories of individuals on whom records are maintained in the system;

(C) the categories of records maintained in the system;

(D) each routine use of the records containted in the system, including the categories of users and the purpose of such use;

(E) the policies and practices of the agency regarding storage, retrievability, access controls, retention, and disposal of the records;

(F) the title and business address of the agency official who is responsible for the system of records;

(G) the agency procedures whereby an individual can be notified at his request it the system of records contains a record pertaining to him;

(H) the agency procedures whereby an individual can be notified at his request how he can gain acoess to any record per- 
taining to htul contained in the system of records, and how he can contest its content; and

(I) the categories of sources of records in the system;

(5) maintain all records which are used by the agency in making any determination about any indivichul with such accuracy, relevance, tineless, and completeness as is reasonably necessary to assure fairness to the individual in the deteruination;

(6) prior to disseminating any record about an individual to any person otlier than an agency, uriless the dissemination is made pursuant to subsection (b)(2) of this section, make reasonable efforts to assure'that such records are accturare, complete, timely, and relevant for agency purposes;

(7) maintain no record describing how any individual exercises rights guaranteed by the First Anendment unless expressly authorized by statute or by the individual about whom the record is maintamed or unless pertinent to and within the scope of an authorized law enforcement activity;

(8) make reasonabte efforts to serve notice on an individual when any record on such individual is inade available to any person thder comipulsory legal pociess when such provess becomes a matter of liblic record;

(9) establish rules of conduct for persons inrolved in the design, developrnent, operation, or maintenance of any system of records, or is majutaining any record, and instruct each such person with respect to such rules and the requirements of this section, including any other rules and proceddures adopted pursuant to this section and the penalties for nomiompliance;

(10) establish appropriate administrative, technical, and physical safeguards to Insture the security and confidentiality of records and to protect against any anticipated threats or hazards to their secenrity or integrity which could restut in substantial barm, embarrassment, incomveniente, or unfairness to any indivicual on whon information is maintained; and

(11) at least 30 days prion to publication of information under paragraph (4)(D) of this subsection, publish in the Federal Register notice of any new use or intended use of the information in the system, and provide an opportunity for interested persons to subinit written data, vietws, or argunents to the agency.

(f) AGENCY RULES-In order to carry out the provisions of this section, each agency that majntains a system of records shall promulgate rules, in accordance with the requirement (including general notice) of section 553 of this title, which shall-

(1) establish procedures whereby an individual can be notified in response to his request if any system of records named by the individual contains a record pertaining to him;

(2) define reasonable times, places, and requirements for identifying an indivictual who requests his record or information pertaining to him before the agency shall make the record or information available to the individual; 
(3) establish procedures for the disclasure to an individual upon his request of his record ot information pertaintong to hin, including special procedures, if deened aecessary, for the disclosure to an individual of medical records, includiog psychological records pertaining to him;

(4) establish procedures for reviewing a request from an individual concerning the amendment to any record or information pertainting to the individual, for maloing a determination on the request, for an appeal within the agency of an initial adverse agenty deterusination, and for whatever additional means nony be necessary for each indivioual to be able to exercise fully his rights under this section; and .

(5) establish fees to be charged, if any, to any individual for making copies of his recorc, excluding the cost of ary search for and review of the record.

The Office of the Federal Register shall annually comptle and publish the rules promulgated under thiss subsection and agency notices ptblished under stubection (e)(4) of this section in a form avallable to the public at low cost.

(g)(1) CIVIL REMEDIES. - Whenever any agency-

(A) makes a determination under subsection (a)(3) of this section not to amend an individual's record in accortance with his request, or fails to make such review in conformity with that subsection;

(B) refuses to comply with an individual request under subsection (d)(1) of this section;

(C) falls to maintain any record concerting any individual with such accuracy, relevance, brieliness, and completeness as is neces. sary to assure fairmess in any determination relating to the qualifcation, character, rights, or opportunities of, or benefits to the individual that may be made on the basis of such record, and consequently a determination is made which is adverse to the individual; or

(D) fails to comply with any other provisions of this section, or any rule promulgated thereurder, in such a way as to have an adverse effect on an individual,

the individual may bring a civil action against the agency, and the dis. triet courts of the United States shall have jurtisdiction in the matters under the provisions of this subsection.

(2)(A) In any sutt brought under the provisions of subsection (g)(1)(A) of this section, the court may order the agency to amend the individual's record in accordance with his request or in such other way as the court may direct. In such case the court shall determine the matter de novo.

(B) The court may assess against the United States Ieasonable attorney fees and other litigation costs reasonably ircurred in any case under this paragraph in which the complainant has substantially prevailed.

(3)(A) In any suit brought under the provisions of subsection (B)(1)(B) of this section, the court may enjoin the agency from with. holding the records and order the production to the complainant of any 
agency records improperly withheld from him. In such a case the court shall determithe the matter de novo, and may examine the contents of any agency records in camera to deternitne whether the records or any portion thereof riay be withineld under any of the exeraptions set forth in subsection (k) of this section, and the burden is on the agency to sus - tain jes action:

(B) The covirt may assess against the United States reasonable attorney fees and other bitigation costs reasonably incurred in any case under this paragraph in which the complajuant hes stustantially prevailed.

(4) In any suit brought under the provisions of subsection $(g)(1)$ (C) or (D) of this section in which the court determines that the agenty acted in a manner which was intentional or willful, the United States shall be liable to the individual in an amount exual to the sum of-

(A) actual damages sustained by the individual as a result of the retusal or failute, but in no case shall a person entitled to recovery receive less than the sum of $\$ 1,000$; and

(B) the costs of the action together with reasonable attornty fees as determined by the coutt.

(5) An action to enforce any liability created under this section may be brought in the district court of the United States in the district in which the complainant restdes, or has his principal place of business, or in which the agency records are situated, or in the District of Columbia, without regard to the amount in controversy, within two years from the date on which the cause of action arises, except that where an agency -bas matertally and willfully misrepresented any isformation required under this section to be disclosed to an individual and the information so misrepresented is material to establishment of the liability of the agency to the individual und th this section, the action may be brought at any time gitsin two years after discovery by the individual of the mis. representation. Nothing in this section shall be construed to authorize any civil action by reason of any injury sustained as the result of a disctosuse of a record prior to September 27, 1975.

(h) RIGHTS OF LEGAL GUARDIANS.-For the purpase of this section, the parent of any minos, or the legal guardian of any indivichual who bas been declared to be incompetent due to physical or mental incapacity or age by a court of competent jutisclictiont, mady act on behalf of the individual.

(i)(1) CRIMINAL PENALTIES-Any officer or moployet of an agency, who by virtue of his employment or official position, bas possession of, or access to, agency records which contain individualby identifiatble information the disclosure of which is probtibited by this section or by rules or regulations established thereunder, and who knowing that disclosure of the specific material is so prohibited, willfully discloses the material in any manner to any person or agency not entitled to receive it, shall be guilty of a misdeneanor and fined not more than $\$ 5,000$.

(2) Any officer or employee of any agency who willfully maintains a system of records without meeting the potice requirements of subsection (e)(4) of this section shall be guilty of a misdemeanor or fined not more than $\$ \$, 000$. 
(3) Any person who knowingly and willfully requests ot obtains any record concerning an individual from an agency under false pretenses shall be guitly of a misdemeanor and fined not more than \$5,0010.

(j) GENERAL EXEMPTIONS,-The head of any agency may promulgate rules, in accordamce with the requirements (ineluding general notice) of sections 553 (b) (1), (2) and (3), (c), and (e) of this title, to exempt any system of records within the ogency from any part of this section except subsections (b), (c) (1) and (2), (c) (4) (A) through (F), (e) (6), (7), (9), (10) and (11), and (i) if the system of secords is-

(1) maintained by the Central Intelligence Agency; or

(2) Inaintained by an agency or component thereof which performs as its principal function any activity pertaining to the enforcement of criminal laws, including police efforts to prevent, control, or rectuce crime or to apprehend criminals, and the activities of prosecultors, courts, comectional, probation, pardon, or patole authorities, and which consitsts of (A) information compiled for the purpose of identifying individual criminal offenders and atleged offenders and consisting only of identifying data and notations of arrests, the nature and disposition of criminal charges, sentencing, confinement, release, and parole and probation status; (B) information compiled for the purpose of a criminal investigation, focluding reports of informants and investigators, and associated with an identifiable indivioual; or (C) reports identifiable to an irdividual compiled at any stage of the process of enforcement of the crituinal laws from arrest or indictment through re. Jease from supervision,

At the time rules are adopted under this subsection, the agency sball inctude in the statement required under section 553(c) of this title, the reasons wity the system of records is to be exempted from a provision of this section.

(k) SPECIFIC EXEMPTIONS.-The bead of any agency may promulgate rules, in accordance with the requirements (inctuding generat notice) of sections 553(b) (1), (2), and (3), (c), and (e) of this title, to exempt any system of records within the agency from subsections (c) (3), (d), (e) (l), (e) (4) (G), (H), and (I) and (f) of this section if the system of records is-

(1) subject to the provisions of section 552(b) (1) of this title;

(2) investigatory material compiled for law enforcement purposes, other than matertal within the scope of subsection (j)(2) of this section: Provided, however, That if any individual is denied any right, privilege, or benefit that he would otherwise be entitled by Federal law, or for which be would otherwise be eljgible, as a zesult of the maintenance of suci material, such material siall be provided to such individual, except to the extent that the disclosure of such material would reveal the jidentity of a source who furnished information to the Government under an express promise that the jdentity of the source would be held in confidence, or, pritor to the effective date of this section, under an implied promise that the identity of the source would be held in confidence; 
(3) maintained in contrection with providing protective services to the President of the United States or other individuals pursuant to section 3056 of title 18 ;

(4) required by statute to be maintained and used solely as statistical records;

(5) intestigatory material compiled solely for the purpose of determination suitability, eligibility, or qualisications for Federal civilian employment, militany service,Federal contracts, or access to classified information, but only to the extent that the disclosire of such material would reveal the identity of a source who furrished information to the Governenent under an express promise that the identity of the source would be held in confidence, or, prior to the effective date of this section, under an implied promise that the jdentity of the source would be held in confidence;

(6) testing or examination material uged solely to determine individual qualifications for appointment or promotion in the Fedtral service the disclosure of which would compromise the objectivity or fairuess of the testing or examination process; or

(7) evaluation material used to determine potential for promo, tion in the armed services, but only to the extent that the disctostire of such tiaterial would reveal the identicy of a source who furnished information to the Government under an express promise that the identity of the source would be held in confidence, or, prior to the effective date of this section, under an inplied prontise that the identity of the source would be held in confidence.

At the time rules are adopted under this subsection, the agency shall include in the statement required under section 553(c) of this title the reasons why the system of records is to be exeripted from a prowision of this section.

(I)(1) ARCHIVAL RECORDS.-Each agency record which is accepted by the Adsoinistrator of General Services for storage, processing, and servictiog in accordante with section 3103 of title 44 shall, for the purposes of this section, be corrsidered to be maintained by the "agency which deposited the record and shali be subject to the provisions of this section. The Administratos of General Services shall not disctose the record except to the agency which maintains the record, or under rules established by that agency which are not inconsistent with the provisions of this section.

(2) Each agency record pertaining to an identifiable individual which was transferred to the National 'Archives of the United States as a record which has sifficient historical of other value to warrant its continued preservation by the United States'Goverminent, prior to the effective date of this section, shall, for the purposes of this section, be considered to be maintained by the National Archives and shall not be subject to the provisions of this section, except that a statement generally describing such records (modeled after the requirement relating to records subject 'to subsections (e)(4)(A) through (G) of this section) shall be published' in the Federal Register.

(3) Each agency record pertaining to an identifiable individual which is transferred to the National Arcivives of the United States as a record 
whtch has sufficient histotical or other value to warrant its continued preservation by the United States Government, on or after the effective date of this section, shail, for the purposes of this section, be considered to be maintained by the National Archives and sball be exempt from the requirements of this section except subsections (e)(4)(A) through(G) and (c) (9) of this section.

(m) (1) GOVERNMENT CONTRACTORS,-When an agency provides by a contract for the operation by or on behalf of the agency of a system of records to accomplish an agency function, the agency shall, consistent with its authority, cause the requirements of this section to be applied to such system. For purposes of subsection (i) of this section any such contractor and any employes of such contrattor, if such contract is agreed to on or after the effective date of this section, shall be considered to be an emptoyee of an agency.

(2) A consumer reporting ageney to which a record is disclosed under section 371 (f) of title 31 shall not be considered a contractor for the purposes of this section,

(n) MAILING LISTS.-An individual's name and address may not be sold or rented by an agency unless such action is specifically authorized by law. This provision shall not be construed to require the withholding of names and addresses otherwise permitted to be made public.

(o) REPORTING NEW SYSTEM.-Each agency shall provide adeguate advance notice to Congress and the Office of Management and Budget of ary proposal to establish or alter any system of records in ofder to permit an evaluation of the probable or potential effect to such proposal on the privacy and other personal of property rights of fodlviduals or the disclosure of information relating to such individuals, andits effect on the preservation of the constitutional principles of federalism and separation of powers.

(p) ANNUAL REPORT-The Pesident shall arnually submit to the Speaker of the House of Representatives and the President pro tempore of the Senate a report-

(1) describing the actions of twe Director of the Office of Management and Budget pursuatt to section 6 of the Privacy Act of 1974 during the preceding year;

(2) describing the exercise of individual rights of access and armendment under this section during such year;

(3) identifying changes in or additions to systems of record;

(4) containing such other information concerning administration of this section as Jaly be nectessary or usefiul to the Congress in reviewing the effectiveness of this section in carrying out the purposes of the Privacy Act of 1974.

(q) EFFORT OF OTHER LAWS. -No agency shall rejy on any exemption contained in section 552 of this title to withhold from an individual any record which is otherwise ascessible to such individual under the provisions of this section. (Pub. L. 93-479, Sec. 3, Dec. 31, 1974, 88 Stat. 1897, amended Pub. L. 94183, Sec. 2(2), Dea. 31, 1975, 89 Stat.1057; Pab. L. 97-365, OCT. 25, 1982, 96 STAT. 1749; PUB. L. 97-452, Jan 3, 1983, 96 Stat. 2478; Pub. L 97-375, Dec. 21, 1982, 965tat. 1821.)

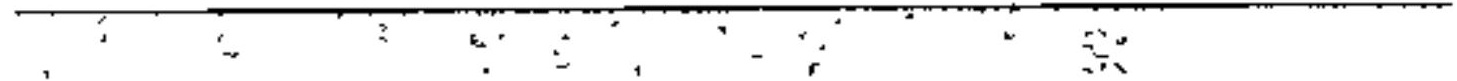


Sec, 552b. Open Meetiugs.

(a) For purposes of this section-

(1) the term "agency" means any agency, as defined in section 552(e) of this title, headed by a collegial body composed of two or more sndividual members, a majority of whom are appointed to such position by the President with the advice and consent of the Senate, and any subdivision thereof authorized to ast op behalf of the agency"

(2) the term "meeting" means the deliberations of at least the number of individual agency members requised to take action on behalf of the agency where such deliberations determine or result in the joint conduct or disposition of official agency business, but does not include deliberation reguired or permitted by subsection (d) or (c); and

(3) the term "menibers" motans an judividual who belongs to a collegial body heading an ageacy.

(b) Members shall not jointly conduct of dispose of agency business other than in accordance with thits section. Except as prowided in subsection (c), every portion of every meeting of anl agency shall be open to public observation.

(c) Except in a case where the agency finds that the public interest requites otherwise, the second sentence of subsection (b) shall not apply any portion of ary agency ureeting, and the requirentents of subsections (d) and (e) shall not apply to any information pertaining to such meting otherwise required by this section to be disclosed to the public, where the agency properly determines that such portion or portions of its meeting or the disclosire of such information is likely to-

(1) disclose matters that are (A) specifically authorized under criteria established by an Executive Order to be kept secret in the interest of national defense or foreign policy and (B) in fact properly classified pursuant to such Executive Order;

(2) relate solely to the internal personnel niles an practices of an agency;

(3) disclose matters specifically exempted from disclosure by statute (other than stction 552, of this title), provided that such statute (A) requires that the matters be withlyeld from the public in such a manner as to leave no discretion on the issue, or

(B) establishes particular criteria for withholding or refers to particular types of matters to be withbeld;

(4) disclose trade secrets and commertial on financial information obtatned from a person and prtvileged or confidential;

(5) anvolve accusing any person of a crime, or formally censuring any person;

(6) disclose information of a personal nature where disclosure would constintte a clearly tuwarranted invasion of personal privacy;

(7) disclose investigatory records compiled for law enforcement purposes, or information which if written would be contained in strch records, but only to the extent that the production of such retcords or information would (A) interfere with enforcentent pro- 
ceedings, (B) deprive a person of a right to a fair trial or an impartial adjudication, (C) constints an unwarranted imvasjon of personal privacy, (D) disclose the identity of a confidential source and, in the case of a record compiled by criminal law enforcement authority in the cotrse of a criminal investigation, or by an agency conducting a lawfil national security intelligence investigation, confidential information furnished only by the confidential source, (E) disclose invertigative techniques and procedures, or (F) endangex the life or physical safety of law enforcement personrel;

(8) disclose information contajned to or related to examination, operating, or condition reports prepared by, on behaif of, or for the use of an agency responsible for the regulation or supervision of financial institutions;

(9) disclose information the premature disclosure of which would-

(A) in the case of an agenty which regulates currencies, sectirities, commodities, of financjal institutions, be likely to (i) lead to significant financial speculation in currencies, securities, or commodities, or (ii) significantly endanger the stability of any financial institutions; or

(B) in the case of any agency, be likely to significantly frustrate implementation of a proposed agency action,

except that stbparagraph (B) shall not apply in any instance where the agency has already disclosed to the public the content or nature of its proposed action, or where the agency is required by law to make such disclosure on its orn initiative prior to taking final agency action on such proposal; or

(10) specifically concern the agency's issuance of a subpena, or the agency's participation in a civil action or proceesting, an action in a foreign court or intemectine tribunal, or an arbitration, or the initiation, conduct, or disposition by the agency of a particular case of formal agency adjudication pursuant to the procertures in section 554 of this title or otherwise involving a determination on the record after opportunity for a leating.

(d)(1) Action under subsection (c) shall be taken only when a majority of the entire membership of the agency (as defined in subsection (a)(1) votes to take such action. A separate vote of the agency members shail be taken with respect to each agency meeting a portion or portions of which are proposed to be closed to the public pursust to subsection (c), or with respect to any information which is proposed to be withheld under subsection (c). A single vote may be taken with respect to a sertes of meetings, a portion or portions of which are proposed to be closed to the public, or with respect to any information concerning such series of meetings, so long as each meeting in such series involves the same particular matters and is scheduled to be held no more than thirty days after the initial meeting in such series. The vote of each agency member participating in such vote shall be recorded and no proxies shall be allowed. 
(2) Whenever any person whose interests may be directly affected by a portion of a meeting requests that the agency close such portion to the public for any of the Jeasons referred to in paragraph (5), (6), or (7) of subsection (c), the agency, upon regiest of any one of its members, shal] vote by recorded wote whether to close such meeting.

(3) Withiz one day of ary vote baken pursuant to pasagraph (1) or (2), the agency shall make publicly available a written copy of such vote reflecting the vote of each member on the question. If a portion of a meeting is to be closed to the public, the agency shall, within one day of the vote taken pursuant to paragraph (1) or (2) of this subsection, make publicly available a full written explanation of its action closing tie portion together with a list of all persons expected to atrend the meeting and their affiliation.

(4) Any agency, a majority of whose meetings may properly be closed to the public purstant to paragraph (4), (8), (9)(A), or (10) of subsection (c), or any combination thereof, may provide by regulation for the clasing of such meetings or portions thereof in the event that a pajority of the members of the ageny votes by recorded vote at the beginining of such meeting, or portion thereof, to close the exempt portion or portions of the meeting, and a copy of such vote, reflecting the vote of each member on the question, is made available to the public. The provisions of paragraphs (1), (2), and (3) of this subsection and subsections (e) shall not apply to any portion of a meeting to whjch such regulations apply: Provided, That the agency shall, except to the extent that such Information is exempt from discjosure under the provisions of subsection (c), provide the public with public amouncement of the time, place, and subject natter of the meeting and of each portion thereof at the earliest practicable time.

(e)(1) In the case of each meeting, the agency shall make public announcement, at least one week before the meeting, of the time, place, and subject matter of the meeting, whether it is to be open or closed to the public, and the name and phone' number of the official designated by the agency to respond to request's for information about the meeting. Such announcement shall be made unless a majority of the members of the agency deternines by a recorded vots that agency buriness requires that such meeting be called at an earlier date, in which case the agency shail make public anjouncement of the time, place, and subject matter of such meeting, and whether open or closed to the public at the earliest practicable time.

(2) The time or place of a meeting may be changed following the public announcement required by paragraph (1) only if the agency publicly atnounces such change at the earliest practicable time. The subject matter of a meeting or the determination of the agency to open or close a meeting, or portion of a meeting, to the public, may be changed following the public announcement required by this subsection only if (A) a majority of the entire membership of the agency determines by a recorded vote tiat agency business so requires and that no earlier an. nouncement of the chance was posistble, and (B) the agency publicly annountes such change and the vote of each metnber upon such change at the earliest practicable time. 
(3) Intuediately following each public annoutocment required by this subsection, notice of the time, place, and subject matter of a meeting, whether the meeting is open or closed, any change in one of the preceding, and the name and phone number of the official designated by the agency to respond to requests for information about the meeting, shall also be submitted for publication in the Federal Register.

(f)(1) For every treeting closed purstuant to paragraphs (1) through (10) of subsection (c), the General Counsel or chief legal officer of the agency shall publiely certify that, in this or her opinion, the meeting may be ctosed to the public and shali state each relevant exemptive provision. A copy of stch certification, together with a staternent from the presiding officer of the meeting setting forth the time and place of the meeting, and the persons present, shall be retained by the agengy. The agency shall maintain' a complete transcript or electronsc recording adequate to record fully the proceedings of each meeting or portion of a meeting, closed to the public, except timat in the case of a meeting, or portion of a meting closed to the ptrblic pursuant to paragraph (8), (9)(A), or (10) of subsection (C), the agency shall majntain either such a transcript or recording, or a set of mintutes. Such mintes shall fully and clearly describe all matters discussed and shall provide a full and accurate summary of any actions taker, and the reasons therefor, including a description of each of the views expressed on any item asd the record of any rollcall' vote (reflecting the vote of exch member on the question). All documents considered in connection with any action shall be identified in such minutes.

(2) The agency shall make promptly availabte to the publis, in a place easily accessible to the public, the transcript, electronic recarding, or minutes (as required by paragraph (1)) of the disenssion of any item on the agenda, or of any item of the testimony of any witress received at the meeting, except for sucti item or itens of such discussian or testimo$n y$ as the agency determines to contain information which may be withheld under subsection (c). Copies of such transeript, or minutes, or a transcription of such recording disclosing the identity of each speaker, shall be furnished to any person at the achual cost of duplication or transcription. The agency shall maintain a complete veroatim copy of the transcript, a complete copy of the mintutes, or a complete electronic recording of each meeting, or portion of a meeting, dosed to the public, for a period of at least two years after such meeting, or until one year after the conclusion of any agency proceeding with respect to which the meeting or portion was held, whictiever occurs later.

(g) Each agency subject to the requirements of this section shall, within 180 days after the date of enactment of this section, following con. sultation with the Office of the Chairmar of the Administrative Con. ference of the United States and published uotice in the FederaI Register of at least thirty days and an opportunity for witten comments by any persor, proraulgate regulations to implement the requirements of subsections (b) through (f) of this section. Any person may bring a proceeding in the United States District Court for the District of CoJumbia to reguire an agency to promulgate such regulations if such agercy has not promulgated such regulations within the time pertod 
specified herein. Subject to any limitations of time provided by law, any person may bring a proceeding in the United States Court of Appeals for the District of Columbia to set aside agency regalations issued pursuant to this subsection that are not in accord with the requirements of subsections (b) through (t) of this section and to requine the promulgation of regulations that are in accord with such subsections.

(h)(1) The district courts of the United States shall have jurisdiction to enforce the requirements of subsections (b) through (f) of this section by declaratory judgment, injunctive relief, or other relief as may be appropriate. Such actions may be brought by any person against an agency prion to, or within sixty days after, the metting out of which the violation of this section arises, except that if public announcement of such'meeting is not initially provided by the agency in accordance with the requirements of this section, such action may be instituted pursuant to this section at any time prior to sixty days after any piblic announcement of such meeting. Such actions may be brought in the district court of the United States for the district in which the agency meeting is held of in which the agency in question has jts headquarters, or in the District Court for the District of Columbia. In such actions a defendant shalt serve his answer within thinty days after the service of the complaint. The beurden is on the defendant to sustajn his action. In deciding such cases the court may exarnine in carmera any portion of thie transcript, electrontic tecording or minutes of a meeting closed to the public, and may take sucti additional evidence as it deenls necessary. The court, having due regard for orderly administration and the public interest, as well as the interests of the parties, may grant such equitable relief as it deems appropriate, including grantìng an injunction agalnst future violations of this section 0 r ordering the agency to make available to the publie such portion of the transetipt, reoording, or minutes of a meeting as is not authorized to be withineld under subsection (c) of this section.

(2) Any Federal court otherwise authorized by law to review agency action may, at the application of any person properly participating fin the proceeding pursuant to other applicable law, inquire into violations by the agency of the requirements of this stction and afford such relief as it deems appropriate. Nothing in this section authorizes any Federal court baving jurisciction solely on the basis of paragraph (1) to set aside, enjoin, or invalidate any agency action (other than an action to close a meeting or to withhold information under this section) taken or discussed at any agency meeting out of which the violation of this sec. tion arose.

(i) The court may assess against any party reasonable attorney fees and other litigation costs reasonably incuured by any other party who substartially prevails in any action brought in accordance with the pro. visions of stibsections (g) or (h) of this section, except that costs may be assessed against the plaintiff only where the court finds that the suit was initiated by the plaintiff primarily for givolous or dilatory putposes. ln the case of assessment of costs against an agency, the costs may be as sessed by the court against the United States. 
(0) Each agency subject to the reguirements of this section shall annually report to Congress regarding its compliance with such requirements, including a tabulation of the total number of agency meetings open to the publis, the total number of meetings closed to the public, the reasons for closing such meetings, and a description of any litigation brought against the agency under this section, including any costs as. sessed against the agency in such litigation (whether or not paid by the agency).

(k) Nothing herein expands or limits the present rights of any person under section 552 of this title, except that the exemptions set forth in subsection (c) of this section shall gowern in the case of any request made pursuant to section 552 to copy or inspect the transcripts, recordings, of minutes described in subsection (f) of this section. The requirements of elsapter 33 of title 44, United States Code, shall not apply to the traitscripts, recordings, and minutes described in subsection (f) of this section.

(I) This section does not constitute authority to withhold any inforenation from Congress, and does not authorize the closing of any agency. meeting or portion there of required by any other provision of law to be open,

(II) Nothing in this section authorizes any agency to withloold from any frdividual any record, induding transeripts, recordings, or minutes reguired by this section, which is otherwise aecessible to such individual under section 532a of this title. (Pub. L. 94-409, Sec. 3(a), Sept. 13, 1976, 90 Stat. 1241.)

Sec, 553. Rulemaking.

(a) This section applies, according to the provisions there of, except to the extent that there is ifvolved-

(1) a military or foreign affairs function of the United States; or

(2) a matter relating to agency management or personnel or to public property, loans, grants, benesits, or contracts.

(b) General notice of proposed rule making shall be publistied in the Federal Register, unless persons stibject thereto are named and either personally served or otherwise have actual notice thereof in accordance with law. The notice sball include-

(1) a statement of the time, place, and nature of public rule mak. ing proceedings;

(2) reference to the legal authority under which the rulk is proposed; and

(3) either the terms or substance of the proposed nule or a description of the subjects and issues involved.

Except when notice or hearing is required by statute, this subsection does not apply-

(A) to interpretative rtles, general statements of poligy, or rules of agency organjzation, procediure, or practice; or

(B) when the agency for good cause finds (and incorporates the finding and a brief statement of reasons therefor in the rules issurd) that notice and public procedure thereon are impracticable, unnecessary, or contrary to the public interest.

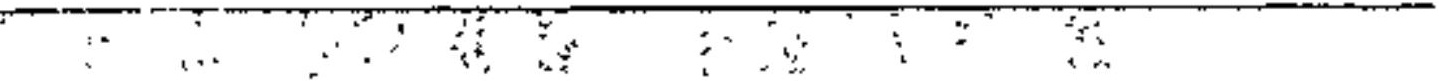


(c) After notice required by this section, the agency shall give interested persons an opportunity to particjpate in the rule making through subrission of written data, views, of arguments with or without opportunity for oral presentation. After consideration of the retevant matter presented, the agency shall incomporate in the rules adopted a concise perjerat statement of their basis and purpost. When rules are required by statute to be made on the record after opportunity for an agency hearing, sections 556 and 557 of this title apply instead of this subsection.

(d) The required publication or service of a substantive rule shall be made not less than 30 days before its effective date, except-

(1) asubstantive rule which grants or recognizes an txemption or relieves a restriction;

(2) interpretative rules and statements of policy; or

(3) as otherwise provided by the agentcy for gond cause found and published with the rule.

(c) Each agency shall give an interested pierson the right to petition for the issuance, amendment, or repeal of a nule. (Pub. L. 89-554, Sept. 6, 1966, 80 Stat. 383.)

Sec. 554. Adjudications

(a) This section applies, according to the provisions thereof, tm every case of adjudication required by statute to be determined on the record after opportunity for an agency hearing, except to the extent that there is involved-

(1) a matter subject to a subsequent trial of the law and the facts de noro in a court;

(2) the selection or tenture of an esnployee, except an admúnistrative law judge appointed under section 3105 of this title;

(3) proceedings in which decisions test solely on inspections, tests, or elections;

(4) the conduct of military or foreign affairs functions

(5) cases in which ar agency is acting as an ageat for a court; or

(6) the certification of worker representatives.

(b) Persons entitled to notice of an agency hearing shall be timely informed of-

(I) the time, place, and nature of the bearing;

(2) the legal authority and jurisciction under which the hearing

is to be held; and

(3) the matters of fact and law asserted.

When private persons are the moving parties, other parties to the proceedirg shall give prompt notice of issues controverted in faet or law; and in other instances agencies may by rule require responsive pleading. In fixing the time and place for hearings, due regard shall be had for the convenience and necessity of the parties of their representatives.

(c) The agency shall give all interested parties opportunity for-

(1) the submission and consideration of facts, argoments, offers of settlement, or propasals of adjustment when time, the nature of the proceeding, and the public interest pernit; and 
(2) to the extent that the parties are unable so to detertmine a controversy by consent, hearing and decision on notice and in accordanite with sections 556 and 557 of this title.

(d) The employee who presides at the reception of evidence pursuant to section 556 of this title shall make the recommended decision or injtal decision required by section 557 of this title, unless he becomes unabte to the agency. Except to the extent required for the disposition of ex parte matters as authorized by law, such an employee may not-

(1) consult a person or party on a fact in issue, untess on notice and opportunity for all parties to participate; or

(2) be responsible to or subject to the stpervision or direction of ar enployes or agent engaged in the performance of investigative or prosecuting functions for an agency.

An employet or agent engaged in the performance of investigative or prosecuting functions for an agency in a case may not, th that or a factually related case, participate or advise in the decision, recommended dectision, or ageticy review pursuant to section 557 of this title, except as withess or counsel in public proceedings. This subsection does not apply-

(A) in determining applications for initial licenses;

(B) to proceedings involving the validity or application of rates, facilities, or practices of public utilities or carriers; or

(C) to the agency or a member or members of the body compris. ing the agency.

(e) The agency, with jike effect as in the case of other orders, and in its sound discretion, may issue a declaratory order to terminate a controversy or remove uncertainty. (Pub. L. 89-554, Sept. 6, 1966, 80 Stat. 384; amended Publ. L. 95-251, Mar. 27, 1978, 92 Stat. 183.)

Sec, 555. Ancillary Matters.

(a) This section applies, according to the provisions thereof, exeept as otherwise provided by this subchapter.

(b) A person compelled to appear in person before an agency or representative thereof is entitled to be accompanied, represented, and advised by counsel or, if permitted by the agency, by other qualified represeptative. A perty is entitled to appear in person or by or with counsel or other duby qualified representative in an agency proceeding. So far as the orderly conduct of public basiness permits, an interested person may appear before an agency or its responsible employees for the presentation, adjustment, or determination of an issue, request, or controversy in a propeteding, whether interlocutory, sumudary, or otherwise, or in connection with at agency function. With due regard for the convenience and necessity of the parties or their representatives and within a reasonable tiuse, each agency shall proceed to conclude a matter presented to it. This subsection does not grant or deny a person whe is not a lawyer the right to appear for or represent others before an agency or in an agency proceeding.

(c) Process, requirement of a report, inspection, or other investigative act or demand nnay not be issued, made, or enforced except as authorized by law. A person compelled to submit data or evidenoe is ertitleo to retain or, on payment of lawfully prescribed to submit data or 
evidence is entitled to retain or, on payment of lewwlly prescribed costs, procure a copy or transcript thereof, except that in a nonpublic inestigatory proceeding the witness may for good cause be limited to inspection of the official transcript of his testimony.

(d) Agency subpoenas authorized by law shall be issued to a party on request and, when required by rules of procedure on a statement or showing of general relevance and reasonable scope of the evidence sought. On contest, the court shall sustain the subpena or similar process or demand to the extent that it is found to be in accordance with law. In a proceeding tor enforcement, the court shall issue an order reguiring the appearance of the witness or the production of the evidence or data within a reasonable time under penalty of punishment for contempt in case of contumacious failare to comply.

(e) Prompt notice shall be given of the denial in whole or in part of a written application, petition, or other request of an interested person made in connection with any agenoy proceedings. Except in affirming a prior demial or, when the denial is self-explanatory, the notice shall be accompanied by a brief statement of the groumds for dental. (Pub. L. 89-554, Sept. 6, 1966, 80 Stat. 385.)

Sec 556. Hearings; Presiding Emp'oyees; Powers and Daties; Burden of Proof, Evidence; Record as Basis of Derision.

(a) This section applies, according to the provisions thereof, to heasings required by section 553 or 554 of this title to be conducted in accordance with this section.

(b) There shall preside at the taking of evidence-

(1) the agency;

(2) ont or more members of the body which comprises the agency; or

(3) one or mowe admintistrative law judges appointed under section 3105 of this title,

This subchapter does not supersede the conduct of specified classes of proceedings, in whole or in part, by or before boards or other employees spectally provided for by or designated under statute. The functions of presiding employees and of employees participating to decisions in accordance with section 557 of this title shall be conducted in an impartial mannor. A presiding or participating employee may at any tíme disqualify himself. On the filing in good faith of a tintely and sufficient affidavit of personal bias or other disqualification of a presiding or partici. pating employee, the agency shall deternitio the matrer as a part of the tecord and dectision in the case.

(c) Subject to published rules of the agency and within its powers, enployees presiding at hearings may-

(1) atminister oaths and affirmations;

(2) issue subopoenas authorized by law;

(3) nule on offers of proof and receive relevant evidence;

(4) take depositions or have depositions taken when the ends of justice would be served;

(5) regulate the course of the hearing; 
(6) hold conferences for the settlement of simplification of the issues by consent of the parties; or by the use of alternative means of dispute resolution as provided in subchapter IV of this chapter;

(7) inform the parties as to the availajity of one or nore altemative means of dispute resolution, and encourage use of such methods;

(8) require the attendance at ary conference held pursuant to paragrtaph (6) of at least one representative of each party who has authority to negotiate concerring resolution of issues fin controversy. 1

(9) dispose of procedural requests or similar matters;

(10) make or recommend decisions in accordance with section 557 of this title; and

(11) take other action authorized by agency rule consistent with this stubchapter.

(d) Except as otherwise provided by statute, the proponents of a rule or order bas the burden of proot. Asy oral or documentary evidence may be received, but the agency as a nuatter of policy sball provide for the exchusion of irtelevant, iramaterial, or unduly repetitious evidence. A sartction may not be impossed or rule or order issued except on consideration of the whole record or those parts thereof cited by a party and supported by and in accordance with the reliable, probative, and substantial evidence. The agency may, to the extent consistent with the interests of justice and the policy of the underlying statutes adrinistered by the agensy, conssider a violation of section 557(d) of this title suffi. cient grounds for a decision adverse to a party who has knowingly conmitted such violation or knowingly caused such violation to occur. A party is entitled to present his case or defense by ortal or documentary evidence, to submit rebuttal evidence, and to conduct such crossexamination as may be requited for a full and tone disclosure of the facts. In rule making or determining claims for money or benefits or applications for inital licenses an agency may, when a party will not be prejudiced thereby, adopt procectures for the submission of all or part of the evidence in written form.

(t) The transcript of testimony and exhibits, togetiter with all papers and requests filed in the proceedings, constitutes the exchusive recard for decision in accordance with section 557 of this title and, on payraent of lawfully prescribed costs, shall be niade available to the partites. When an agency decision rests on official notice of a natterial fact not appearing in the evidence in the record, a party is entitled, on timely request, to an opportunity to show the contrary. (Pub. L. 89-554, Sept. 6, 1966, 80 Stat. 386; antended Pub. Ln 94-409, Sept. 13, 1976, 90 Stat. 1247; Pub. L. 95-251, Mar. 27, 1978, 92 Stat. 183.)

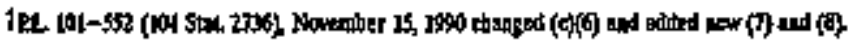


Sec. 557. Initial Decisions; Conclusiveness; Review by Agency; Sulmissions by Parties; Contents of Decisions; Record.

(a) This section applies, according to the provisions thereof, when a herang is reciuired to be conducted in acoordante with section 556 of this title.

(b) When the agency did not preside at the reception of the evidence, the presiding employee or, in cases not subject to section 554(d) of this title, an employee qualified to preside at hearings pursuant to section 556 of this title, shall initially decice the case unless the agency requires, either in specific cases or by general relle, the entire record to be certified to it for dectsion. When the presiding employes makes an tnitial decision, that decistion then becames the dectision of the agency without further proseedings unless there is an appeal to, or review on mation of, the agency within time provided by ruk. On appeal from or review of the inittal decision, the agency has all the powers which it would have in making the initial decision except as it may limit the issues on notice or by rule. When the agency makes the decision without having presided at the reception of the evidence, the presiding employee or as employee qualified to preside at hearings pursuant to section 556 of this title shall first recommeǹd a decision, except that in rule making or determining applications for initial licenses-

(1) instead thereof the agency may issue a tentative decision os one of its responsible employees may recommend a decision; or

(2) this procedure may be omitted in a case in wilich the agency finds on the record that die and timely execution of its functions imperatively and unawoidably so requires.

(c) Before a recommended, initial, or tentative decision, or a decision on agency review of the decision of subordinate employees, the parties are entitled to a reasonable opportunity to subrnit for the consideration of the employees participeting in the decisions-

(1) proposed findings and conelusions; or

(2) exceptions to the decisions or recommended decisions of subordinate employees or to téntative agency decistons; and

(3) supporting reasons for the exception of proposed fincings or conchusions.

The record shall show the ruling on each fincing, conchusion, or exception presented. All decisions, including initial, recommended, and tentative decistons, are a part of the record and shall include a statement of-

(A) findings and conclusions and the reasons or basis therefor, on all the matertal issuts of fact, latw, or disctetion prestented on the record; and of.

(B) the approptiate rtle, order, sanction, telief, or denial there-

(d)(1) In an agesscy proceeding which is subject to subsection (a) of this section, except to the extent required for the disposition of ex parte matters as authorized by law-

(A) no interested person outside the agency shall make or knowingly cause to be made to any member of the body comprising the agency, administrative law judge, or other employee who is or may 
reasonably be expected to be involved in the decisional process of the proceeding an ex parte communication relevant to the merits of the proceeding;

(B) no member of the body comprising the agency, administrative law judge, or other employes who is or may reasonalby' be expected to be involved in the decisional process of the proceeding, shall make or knowingly cause to be made to amy toterested person outside the agency an ex parte commustication relevant to the merits of the proceeding;

(C) a member of the body somprising the agency, administrative law judge, or other employee who is or may reasonably be ex. pected to be infolved in the decsional process of such proceeding who receives, or who makes or knoxingly causes to be made, a communication prohibied by this subsection shall place on the public record of the proceeding:

(i) all such written commumications;

(ii) memoranda stating the substance of all such oral commu. nications; and

(iii) all written responses, and memoranda stating the substance of all oral responses, to the materials deseribed in clauses (i) and (i) of this subparagrapb;

(D) upon receipt of a communication knowingly made or knowingly caused to be made by a party in violation of this subsection, the agency, adminigkrative law judge, or other employee presiding at the hearing may, to the extent consistent with the interests of justice and the policy of the underlying statutes, require the party to show cause why his claim or interest in the proceedings should not be dismissed, denied, disregarded, or otherwise adversely affected on account of such violation; and

(E) the prohibitions of this subsection siall apply beginning at such time as the agency may designate, but in no case shall they begin to apply later than the time at which a procseding is noticed for hearing unless the person responstble for the communication has klowledge that is will be noticed, in which case the prohibjfons shall apply beginning at the time of hts acquisition of such krowiedge.

(2) This subsection does not constitute authority to withlold information from Congress. (Pub. L. 89-554, Sept. 6, 1966, 80 Stat. 837; amended Pub. L. 94-409, Sept. 13, 1976, 90 Stat. 1246.)

Sec. 558. Imposition of Sanctions; Determination of Applications For Licenses; Suspension, Revocation, and Expiration of Licenses.

(a) This section applies, according to the provistions thereof, to the exercise of a power or autsiority.

(b) A sanction may not be imposed or a substantive rule or order issued except within jurisdiction delegated to the agency and as authorized by law.

(c) When application is made for a license reguired by law, the agency, with due regard for the rights and privileges of all the interested parties or adversely affected persons and within a reasonable time, shall set and complete proceedings required to be conducted in accordance with 
sections $\$ 56$ and $\$ 57$ of this title or other proceedings reguired by law and sball make itr decision. Except in casts of willfulness or those in which public heatth, interest, or safety requires otherwise, the withdrawal, suspension, revocation, or annulment of a license is lawful only if, before the institution of ageacy proctedings therefor, the licensee has been given-

(1) notice by the agency in writing of the facts or conduct which may warrant the action; and

(2) opportunity to demonstrate or achieve compliance with all lawnil requirements.

When the licensee has made timely and sufficient application for a renewal or a new license in accordance with agency rules, a license with reference to an activity of a continuing nature does not expire until the application has been finally determined by the agency. (Pub. L. 89-554, Sept. 6, 1966, 80 Stat. 38B.)

Sec. 559. Elitect on Other Laws; Efrect of Subsequent Statute.

This subchapter, chapter 7 , and sections 1305, 3105, 3344, 4301(2)(E), 5372 , and 7521 of this title, and the provisions of section 5335(a)(B) of this tithe that relate to administrative law judges, do not limit or reptel additional réquirentents imposed by statute or otherwise recognized by law. Except as otherwise required by law, recuirements or pivileges solating to evidence or procedure apply equally to agencies and persons. Each agency is granted the authority necessary to conply with the requirements of this stubchapter through the issuance of nules or otherwise. Subseguent statute may not be held to supersede or modify this stibchapter, chapter 7, sections $1305,3105,3344,4301$ (2)(E), 5372, or 7521 of this title, or the provisions of section 5335(a)(B) of this title that relate to administrative law judges, except to the extent that it does so expressly. (Pub L. 89-554, Sept 6, 1966, 80 Stat. 388; amended Pub. L. 90-623, \$1(1), Oct 22, 1968, 82 \$tat. 1312; Pub. L. 95-251, Mar. 27, 1978, 92 Stat. 183; Pub. L. 95-454, Oct 13, 1978, 92 Stat. 1221.) 


\section{All Act}

Noy 29.1980

[S. 303$]$

Negotiated Rulemaktng Act of 1990 .

5 USC 561

5 USC 561
To establish a framework for the conduct of negotiated rulemaking by Federal agencies.

Be it enacted by the Senate and Houst of Representatives of the United States of America in Congress assembled,

\section{SECIION 1. SHORT TIKL}

This Act may be cited as the "Negotiated Rulemaking Act of 1990 ".

\section{SEC. 2. FINDINGS.}

The Congress makes the following fincings:

(1) Government regulation has increased substantially since the enactment of the Adrninistrative Procechure Act.

(2) Agencies currently use rulemaking propedures that may discourage the affected parties from meting and communtcating with each other, and may caluse parties with different interests to assume conflicting arta antagonistic positions and to engage in expensive and time-cortsuming litigation over agency rules.

(3) Adversarial rulenaking deprives the affected parties and the public of the benefits of face-to-face negotiations and co-operation in developing and reaching agreement of a rule. It also deprives them of the benefits of shared infonmation, kmowledge, expertise, and technical abilities possessed by the affected parties.

(4) Negotiated rulemalking, in whtich the parties who will be significantly affected by a rule partictpate in the development of the rule, can provide significant advantages over adversarial rulemaking.

(5) Negotiated rulemaking can increase the acceptability and improve the substance of rules, making it less likely that the affected parties will resist enforcenent or challenge such rules in court. It maty aiso shorten the amount of tine needed to issue final rules.

(0) Agencies have the authority to establish negotiated rule making committees under the liws establishing suct agencies and their activities and under the Federal Advisory Committee Act (5 U.S.C. APp.). Several agencies have successfilly used negotiated rulemaking. The process has not been widely used by other agencies, however, in part because such agencies are unfamiliar with the process or uncertain as to the authority for such rulemaking.

SEC. 3. NEGOTLATED RULEMAKJNG PROCEDURE.

(a) IN GENERAL.-Chapter 5 of title 5, United States Code, is amended by adding at the ond the following new stibchapter: 
"The purpose of this subchapter is to establish a framework for the conduct of negattated tulemaking, consistent with section 553 of this title, to encourage agencies to use the process when it enhances the informal rulemaking process. Nothing in this subthapter sthotuld be construed as an attempt to limit innoration and experimentation with the negotiated rulenlaking process or with other tunovative rikemaking procedures otherwise authorized by law.

"For the purposes of this stubchapter, the term-

"(1) 'agency" has the same meaning as in section 551(1) of this title;

"(2) consensus' metaris unamimous concurtence among the intefests represented on a negotiated ruleutaking committee established upder this stibchapter, usless such combuittece-

(A) agrees to define such term to mean a gentral but not unanimous condurrence; or .

"(B) agrees upon another spexified definition;

"(3) 'convener" means a person who.fmpartially assists an agency in ,determining whether establishment of a negotiated rujemaking committee is feasible and appropriats in a particular rulemaking:

"(4) 'facilitator' means a person who impartially aids in the discussions and regotiations among the members of a regotiated rulentaling committee to develop a proposed rule;

“(5) 'interest' meens, with respect to an issue or matter, multipke parties which have,a similar point of view or which are likely to be affected jin a sivilar manner;

“(6) 'negotiated rulemaking' mears rukemaking through the use of a negotiared rulemalking committee;

"(7) 'negotiated rulentaling conruittee' or 'committee' means an advisory committes established by an agency jin accordance with this subchapter and the Federal Advisory Committee Act to consider and discuss issues for the purpose of reaching a consensus in the development of a proposed rule;

"(8) 'party' has the same meaning as in stection 551(3) of this title;

"(9) person' has the same meaning as in section 551(2) of this title;

"(10) 'rule' has the same meaning as in section 551(4) of this title; and

“(11) 'rulemaking' means 'ruleraaking' as that term is defined in section 551(5) of this title.

usssí. Determination of need for negotbated rulemaking comnittee

"(a)- DETERMINATION OF NEED BYY THE AGENCY,-An agenty may establish a negotiated rulerraking conmittee to negotiate and develop a proposed rule, if the head of the agency determines that the use of the negotiated rulemaking procedure is in the public interest. In making such a determination, the head of the agency shall consider whether-

"(1) there is a noed for a rule;

"(2) there are a limited number of identifiable fnterests that will be significantly affected by the rule; 
“(3) there is a reasonable likelihood that a committee can be convened with a balanced representation of persons who-

"(A) an adequately represent the foterests identified under paragraph (2); and

"(B) are willing to negotiate in good faith to reach a consensus on the propased rule;

"(4) there is a reasonable likelihood that a committee will reach a consensus on the proposed rule within a fixed period of time;

"(5) the negotiated rulemaking procedure will not unreasonably delay the notice of proposed rulemaking and the issuance of the final rule;

(6) the agency has adequate resources and is willing to commit such resources, including technical assistance, to the committee; and

" $(7)$ the agency, to the maximum extent possible consistent with the legal obligations of the agency, will vse the consensus of the committee with respect to the proposed rule as the basis for the rule proposed by the agescy for notice and comment.

“(b) USE OF CONVENERS.-

(1) PURPOSES OF CONVENERS.-An agency may use the ser. vices of a convener to assist the agency in-

"(A) identifying petson who will be significantly affected by a proposed rule, including residents of rural aress; and

"(B) conducting discassions with such persons to identify the issues of concern to such persons, and to ascertain whether the establishment of a negotiated rulemaking committee is feasible and appropriate in the particular rukmaking.

(2) DUTIES OF CONVENERS. - The convener shall report findings and may make recommendations to the agency. Upon request of the agency, the convener shall ascertatin the names of persons who are willing and qualified to represent interests that will be significantly affected by the proposed rule, including residents of rural areas. The report and any recommendations of the convener shall be made available to the public upon request.

\section{u\$ 564. Publication of notice, applications for membership on commiltees}

"(a) PUBLICATION OF NOTICE.-If, after considering the report of a conventer or conducting its own assessment, an agency decides to estabjish a negotiated rulemaking committee, the agency shall publish in the Federal Register and, as appropriate, in trade or other specialjzed publications, a notice which shall include-

(1) an annouxcement that the agency jitends to establish a negotiated rulemalking committee to negotiate and develop a proposed rule;

"(2) a description of the subject and scope of the nule to be developed, and the issues to be considered;

“(3) a list of the interests which are likely to be significantly affected by the rule;

"(4) a list of the persons proposed to represent such interests and the person or persons proposed to represent the agency;

$\therefore,+4,5, \ldots$


"(5) a proposed agenda and schedule for conspleting the work of the committes including a target date for publication by the agency of a proposed rale for notice and comment;

"(6) a description of administrative support for the comsittee to be provided by the agency, includiog technical assistance;

"(7) a solicitation for comments on the proposal to establish the committee, and the proposed membership of the negotiated rulemlaking compitter; and

“(8) an explanation of how a person may apply or nominate another person for membership on the contrnittee, as prowided under subsection (b),

(b) APPLICATIONS FOR MEMBERSHIP OR COMMITTEE - Persons who will be significantly affected by a proposed rule and who believe that their interests will not be adtequately $\mathrm{F}$ epresented by any person specifited in a notice tuder subsection (a)(4) may apply for, or nominate another person for, membership or the negotiated rulemaking committee to represent such interests with respect to the proposed rok. Each application or nomination shall include-m

"(1) the name of the applicant or nominee and a description of the tuterests stuch person shall represent;

"(2) evidence that the applicant of nominec is authoized to represent parties related to the interests the person proposes to ropresent;

"(3) a written commitment that the applicant or nomines shall actively participate in good faith in the development of the rule under consideration; and

" (4) the reasons that the persons specified in the notice under subsection (a) (4) do not adequately represent the interests of the person submitting the application or nomination.

4(c) PERIOD FOR SUBMISSION OF COMMENTS AND APPLICATIONS. - The agency stall provide for a period of at least 30 calendar days for the subjission of comments and applications urider this section.

46S 565. Establishment of committe

5 USC 565

(a) ESTABUSHIMENT:-

(1) DETERMINATION TO ESTABLISH COMMITTEE.If after considering comments and applications submitted under section 564, the agency deternines that a negotiated rulentaking comnittee can adequately represent the interests that will be sigrificantly affected by a proposed rule and that it is feasible and appropriate in the particular rulemaking, the agency may establish a negotiated rulemaking committee. In establishing and administering such a committee, the agency shall comply with the Federal Advisory Committee Act with respect to such committee, except as otherwise provided in this subethapter.

"(2) DETERMINATION NOT TO ESTABLISH COMMITTEE.-If after considering such conments and applications, the agency decides not to establish a megotiated rulemaking columit- 
tee, the agency shall promptly publish natice of such decision and the reasons therefor in the Federal Register and, as appropriate, in trade or other specialized publications, a copy of which shall be sent to any person who applied for, or nominated another person for membership on the negotiating rulemaking committee to represent stch interests with respect to the proposed rule.

"(b) MEMBERSHIP-The agency shall litait membership on a negotated rulentaking comernittee to 25 ulembers, unless the agency bead determines that a greater number of members is necessary for the functooting of the comimittee or to achiteve balanced membership. Each committee shall include at least one person representing the agency.

"(c) ADMINISTRATIVE SUPPORT.-The agency shall provide appropriate administrative support to the negotiated rulemaking conmittee, including technical assistance.

\section{"6s 566. Conduct of committee activity}

"(a) DUTIES OF COMMITTER.-Each negotiated rulemaking conjuittee established under this subchapter shall consider the matter proposed by the agency for consideration and shalt atteript to reach a consensus concerning a proposed rule with respect to such matter and any other matter the committee determines is relevant to the proposed rule.

“(b) REPRESENTATIVES OF AGENCY ON COMMITTEEThe person or persons representing the agency on a negotiated rulemaking committee shall participate in the deliberations and activities of the committee with the same rights and responsibjitities as other merabers of the committee, and shall be authorized to fully represent the agency in the discussions and negotiations of the committee.

"(c) SEILECTING FACILITATOR.--Notwithstanding section 10(e) of the Federal Advisory Committee Act, an agency may nominate either a person from the Federal Governutent or a person from outside the Federal Government to serve as a facilitator for the negotiations of the committee, subject to the approval of the committee by consensus. If the committee does not approve the pominee of the agency for facilitator, the agency shall submit a substitute nomination. If a committee does not approve any nominee of the agency for facilitator, the committee stiall select by cousensus a person to serve as facilitator. A person designated to represent the agency in substantive issues may not serve as facilitator or otherwise chair the conimittee.

“(d) DUTIES OF FACILITATOR, - A facilitator approved or selected by a negotiate $d$ rulemaking committee siall-

"(1) chair the meetings of the committee in an impartid manner;

"(2) impartially assist the members of the committee in conducting discussions and negotiations; and

"(3) manage the keeping of minutes and records as required under section 10 (b) and (c) of the Federal Advisory Comuittee Act, except that any personal notes and materials of the facilitator or of the members of a committee shall not be strbject to section 552 of this title.

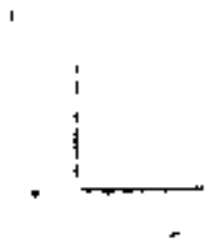


"(e) COMMITTEE PROCEDURES-A negotiated rulemaking committee established under this subchapter may adopt proceotures for the operation of the committee. No provision of section 553 of this title shall apply to the procedures of a negotiated rulemaking committee.

"(f) REPORT OF COMMITTEE.-If a committee reaches a i consensus on a proposed rule, at the conclusion of negotiations the committec shall transmit to the agency that established the comnittee a report containing the propased rule, If the committee does not reach a consensus on a proposed rule, the committee

4. Imay transmit to the abency a report specifying any areas in which the comunittee reached a consensus. The committee may include in a report any other informstion, recommendations, or materials that the comunittee considers appropriate. Any committee member may include as an addendum to the report additional information, recommendations, or materials.

(g) RECORDS OF COMMTTTEE.-In addition to the report required by subsection (f), a committee shall submit to the agency the records required under section 10 (b) and (c) of the Federal Advisory Committet Aet.

SUSC 567 "A negotiated rulemaking committee shall terminate upon promulgatron of the final rule tunder consideration, unless the committee's charter contaiss an earlier termination date or the agency, after consulting the committee, of the committee itself specifies an earlier tenmination date.

4ç 568. Services, facilities, and payment of committee member expenses

"(a) SERVICES OF CONVENERS AND FACILITATORS.-

"(1) IN GENERAL-An agency may employ or entor into contracts for the services of an individual or organization to serve as a convener or facilitator for a negotiated rulemaking combittee under this subchapter, or may use the services of a Government emplojee to act as a convener or a facilitator for such a combittee.

"(2) DETERMINATION OF 'CONFLICTING INTERESTS. - An agency shall determine whether a person under consideration to serve as a convener or facilitator of a committee under paragraph (1) has any financial or other interest that would preciude such person from serving in as impartial and independent manner.

"(b) SERVICES AND FACIEITIES OF OTHER ENTITIES. - For purposes of this subchapter, an agency may use the services and facilitites of other Federal agencies and public and private agencies and instruarentalties with the consent of such agencies and instrumentafities, and with or without reirabursenent to such agencies and instrumentalities, and may acoept volutntary and uncompensated services without regard to the pro visions of secton 1342 of titie 31. The Federal Mediation and Conciliation Ser- 
vice may provide services and facilities, with or without reimbursement, to assist agencies under this subctrapter, including furnishing conveners, facilitators, and training in negotiated rule. making.

"(c) EXPENSES OF COMMITEE MEMBERS.-Members of a negotiated rulemaking committee shall be respontible for their own expenses of participation in such committee, except that an agency may, in accordance with section 7(d) of the Federal Advisory Committee Act, pay for a member's reasonable travel and per diem expenses, expenses to obtain technical assistance, and a reasonable rate of compensation, if-

"(1) such member certifies a lack of adequate financial resources to participate in the committee; and

(2) the agency determines that such member's particjpation in the committee is recessary to assure an adequate representalion of the member's interest.

“(d) STATUS OF MEMBER AS FEDERAL EMPLOYEE.-A member's receipt of fands under this section or section 569 shall not conclusively deter mine for purposes of sections 202 through 209 of title 18 whether that mentrer is an employee of the Unted States Government.

\section{4\$ 569. Enconaraging negotiated rulemaking}

(a) The President shall designate an agency or designate or establish an interagency committee to facilitate and encourage agency use of negotiated rulemaking. Ar agency that is considering, planting, or con * ducting a regotiated rulemaking may consult with such agency or com. mittee for information and assistance.

(b) To cany out the purposes of this subchapter, an agency planning or conducting a negotiated rulemaking may accept, hold, administer, and utilize gifts, devises, and bequests of property, both real and persopal if that agency's acceptance and use of such gifts, devises, or beciuests do not create a conflitt of interest. Gifts and bequests of money and proceeds from sales of other propesty rectived as gifts, devises, or bequests shall be deposited in the Treasury and shall be disbursed upon the order of the head of wich agency. Property accepted pursuant to this section, and the proceseds thereof, shatl be used as nearly as possible in accordance with the terms of the gifts, devises, or bequests."

\section{"\$ 570. Judicial review}

5 Usc 570

"Any agency action relating to establishing, assistirg, or terminating a negotiated ruiemaking committee under this subchapter shall not be subject to judicial review. Nothing in this section shall bar judicial revieur of a nule if such judicial review is otherwise provided by law. A rule which is the product of negotiated nulemaking and is subject to judicial review shall not be accorded any greater deference by a court than a rule which is the product of other rulengking procedures.".

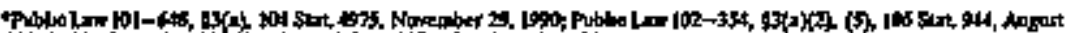

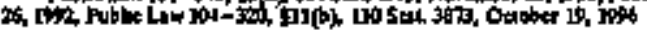


" $5570 a$. Authorization of approprtations

- There are authorized to be appropriated such suras as may be necessary to carry out the purposes of this subchapter:*

SUSC 561 note. SEC. 4, AUTHORZATION OR APPROPRIATIONS.

In order to carry out this Act and the amendments made by this Act, there are authorized to be appropriated to the Administrative Conference of the United States, in addition to amounts authorized by section 596 of title 5, United \$tates Code, not in excess of $\$ \$ 00,000$ for each of the fiscal years 1991, 1992, and 1993.

5 USC 561 note. SEC. 5. SUNSET AND SAVINGS PROVISIONS.

Subchapter III of chapter 5, United States Code, (enacted as subT chapter IV of chapter 5 of title 3, United States Code, by section 3 of this Act and redesignated as subchapter'II of such chapter 5 by section (3)(a) of the Adruinistrative Procejure Technical Amendments Act of 1991); and that portion of the table of sections at the beginning of chapter 5 of title 5, United States Code, relating to subchapter III, are repealed, effective 6 years after the date of the enactment of this Act, except that the provisions of such subchapter shall continue to apply after the date of thie repeal with respect to then pending negotiated rulemak. ing proceedings initiated before the date of repeal which, in the judgment of the agencies which are convening os have convened such proceedings, require such continuation, until such negotiated rulemaking st proceedings terminate pursuant to such stbchapter. 


\section{ADMINISTRATIVE DISPUTE RESOLUTION ACT}

Public Low 101-552

November 15, 1990

\section{An Act}

Nox.15.1990 [H.R. 2497]

Administrative Dispute

Resolution Adt. 5 USC 571 note.

5 USC 571 note.

To authorize and encourage Federal agencies to use mediation, conciliation, arbitration, and other techniques for the prompt and informal resolution of disputes, and for other purposes.

Be it enacted by the Senate and House of Represensatives of the United States of America in Congress assembled,

\section{SECTION 1. SHORT TIRLE*} Act."

This Act may be cited as the "Administrative Dispute Resolution SEC. 2. FINDINGS.

The Congress finds that-

(1) administrative procedure, as embodied in chapter 5 of title 5 , United States Cade, and other statutes, is intended to affer a prompt, expert, and inexpensive means of resolving disputes as an alternative to litigation is the Federal courts;

(2) administrative proceedings have become increasingly formal, costly, and lengthy resulting in unnecessary expendinures of time and in a decreased likelibopd of achieving consensisal resolution of disputes;

(3) alternative means of dispute resolution have been used in the private sector for many years and, in appropriate circumstances, have yielded decisions that are faster, less expensive, and less conttentious;

(4) such alternatjve means can lead to more creattve, efficient, and strusible outcoutes;

(5) sich altertative means may be used advantageousiy in a wide variety of adninistrative programs;

(6) explint authorization of the wse of well-tested dispute resolution techniques will eliminate ambiguity of agency authority under existing law;

(7) Federal agencies may not only receive the benefit of techniques that were developed in the private sector, butmay also take the lead in the further development and refipement of such techniques; and

(8) the availability of a wide range of dispute resolution procedures, and an increased understanding of the most effective use of such procedures, will enhance the operation of the Government and better serve the public.

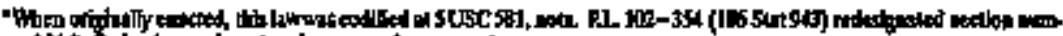

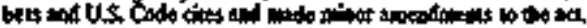


(a) PROMULGATION OF AGENCY POLICY.-Each agency shal] adopt a policy that addresses the vose of alternative means of dispute resolution and case management. In developing such a policy, each agency shall-

(1) constlt with the Administrative Conference of the United States and the Federal Mediation and Coneiliation Service; and

(2) examine alternative means of resolving disputes in contection with-
(A) formal and informal adjudications;
(B) rulemakings;
(C) enforcement actions;
(D) issuing and revoking lieenses or permits;
(E) contract administration;
(F) litigation brought by or against the agency; and
(G) other agency actions.

(b) DISPUTE RESOLUTION SPECIALISTS.-The head of each agency shall cesignate a serior offictal to be the dispute resolution specialist of the agency. Such official shall be responsible for the implementation of-

(1) the provisions of this Act and the amendments made by this Act and

(2) the agency policy developed under subsection (a).

(c) TRAINING.-Each agency shall provide for training on a regular basis for the dispute tesolution specialist of the agency and other em'ployees involved in implementiong the policy of the agency developed under subsection (a). Such training should encompass the theory and practice of negotiation, mediation, arbitration, or related techniques. The dispute resolution specialist shall periodically recommend to the agency head agency employees who would benefit from similar trainings.

(d) PROCEDURES FOR GRANTS AND CONTRACTS-

(I) Each agency shall review each of its standard agreements for contracts, grants, and other assistance and shall determine whether to anend any such standard agreements to authorize and encoufage the use of alternative means of dispute resolution.

(2) (A) Within I year after the date of the enactment of this Act, the Federal Acquisition Regulation shall be anended, as necessary, to carry out this Act ad the amendments made by this Act.

(B) For purposes of this section, the term "Federal Acquisition Regulation" means the single syster of Gowernment-wide procurement regulation referred to in section $6(a)$ of the Ofince of Federal Procurement Policy Act (41 U.S.C. 405(a)).

SEC. 4. ADMINISTRATIVE PROCEDURES.

(a) ADMINISTRATIVE HEARINGS,-Section 556(c) of title 5, United States Code, is amended- 
(1) in paragraph (6) by inserting before the semicoion at the end thereof the following: "or by the use of alternative means of dispute resolution as provided in subchapter IV of this chapter"; and (2) by redesignating paragraphs (7) through (9) as paragraphs (9) througit (11), respectively, and inserting after paragraph (6) the following new paragraphs:

"7) inform the parties as to the availability of one or more alter. natrve means of dispute resolution, and encourage use of such methods;

"(8) require the attendance at any confereace beld pursuant to paragraph (6) of at least one representative of each party who has authority to negotiate concerning resolution of issues in controversy".

(b) ALTERNATIVE MEANS OF DISPUTE RESOLUTION,Chapter 5 of title 5, United States Code, is amended by adding at the end the following new subchapter:

"SUBCHAPTER IV-ALTERNATIVE MEANS OF DISPUTE

RESOLUTION IN THE ADMINISTRATTVE PROCESS

\section{"Ss71. Dwínitions*}

For the purposes of this subchapter, the term-

(1) "ugency" bas the same meaning as in section 551(1) of this title

(2) "administrative program" jncludes a Federal function which fovolves protection of the publicinterest and the determination of rights, pivileges, and obligations of private persons through nile making, adjudication, licensing, or investigation, as those terms are used in stibchiapter 11 of this chapter;

(3) "alternative means of dispute resolution" means any prece. dure that is used to resolve issues in controversy, including but not limited to, conciliation, facilitation, mexiation, fact-finding minitrials, arbitratjon, and use of ombuds, or any combination thereof;

(4) "uward" means any decision by an arbitrator resolving the issues in controversy;

(5) "dispute Iesolution communication" means any oral or written communication prepared for the purposes of a dispute resolution proceeding, including any memoranda, notes or work product of the neutral, parties or nomparty participant; except that a written agreement to enter into a dispute resolution proceeding, or tinal written agreenent or arbitral award reached as a result of a dispute resolution proceeding is not a dispute resolution communication;

(6) "ditspute resolution proceeding" means any process in which an altemative mears of dispute resolution is used to resolve an issue in controversy in which a neutral is appointed axd specified parties participate;

(7) "in confidence" meass, with respect to information, that the information is provided-

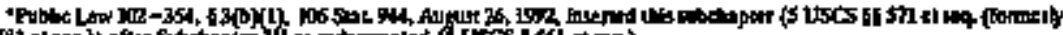

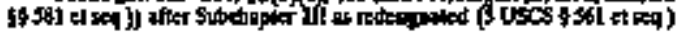


(A) with the expressed intent of the source that it not be disclosed; or

(B) under citcumstances that would create the reasonable exr. pectation on behalf of the source that the information will not be disclosed;

(8) "issue in controversy" means an issue whicht is material to a decision concerning an administrative program of an agency, and with which there is disagreentent-

(A) between an agency and persons who would be substantially affected by the decision; or

(B) between persons who would be substantially affected by the decision;

(9) "neutral" means an individual who, with respect to an issue in controversy, functions specifically to aid the parties in resolving the controversy;

(10) "party" means-

(A) for a proceeding with named pasties, the same as in section \$51(3) of this title; and

(B) for a proceeding without named parties, a person who will be significantly affected by the decision in the proceeding and who participates in the procesting;

(11) "person" has the same meanting as in section $551(2)$ of this title; and

(12) "roster" means a list of persons qualified to provide services as neutrals."

\$572. General authorlty

(a) An agency may use a dispute resolution praceeding for the resolution of an issue in coptrowersy that relates to an administrative program, if the parties agree to such proceteding.

(b) An agency shall consider not using a dispute resolution proceeding

(l) a definitive or authoritative resolution of the matter is required for precedential value, and suct a proceeding is not likely to be accepted generally as as authoritative precedent;

(2) the matter involves or may bear upon significant questions of Government policy that require additional procectures before a fnal resolution may be made, and such a proceeding would not likeby serve to dovelop a recommended policy for the agency;

(3) maintaining estabfished polictes is of special jmportance, so that varjations among individual dectsion are not mereased and such a proceeding would not likely reach consistent results among individual decisions;

(4) the matter sigutickantly affects persons ot organizations who are not parties to the proceeding;

(\$) a full public record of the proceeding is important, and a dispute resolution proceeding cannot provide such a record; and

(6) the agency must maintain continuing jurisdiction over the matter with authority to alter the disposition of the matter in the

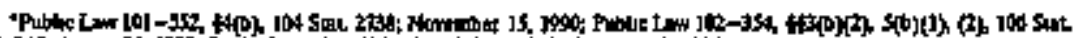

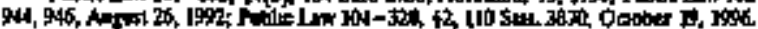


light of changed circamustances, and a dispute resolution proceeding would interfere with the agency's fulfilling that requirement.

(c) Alternative means of dispite resolution authorized under this subchapter are voltutary procechures which supplement rather than lisnit other available agency dispute resolution techniques.

\$573. Nentrals

(a) A neutral may be a permanent or temporary officer or employee of the Federal Government or any other indridual who is acceptable to the parties to a dispute resolution proceeding. A nentral shall bave no official, financial, or personal conflict of interest with respect to the issues in controwersy, unless such interest is fully disclosed in writing to all parties and all parties agree that the neutral may serve.

(b) A neutral who serves as a conciliator, facilitator, or meciator serves at the will of the parties.

(c) The Presjident shall designate an agency or designate or establish an interagency committee to facilitate and encourage agency use of dispute resolation under this subctuapter. Such agency or interagency committee, in consultation with other appropriate Federal agencies and professional organizations experienced in matters concerritug dispute resolttion, shall-

(1) encolerage and facilitate agency use of alternative means of dispute resolution; and

(2) develop procedures that permit agencies to obtain the services of neutrals on an expedited basis.

(d) An agency may use the services or one or more employees of other agencies to serve as neutrals in dispute resolution proceedings. The agencies may enter into an interagency agreement that provides for the reimbursement by the user agency or the parties of the futl or partial cost of the services of such an employee.

(e) Any agency taay enter into a contract with any person for services as a neutral, or for training in connection wjth alternative means of dispute resolution. The parties in a dispute resolution proceeding shall agree on compensation for the nentral that is fair and reasonable to the Government,"

\section{Contidentiality}

(a) Except as provided in subsections (d) and (e), a neutral in a dispute resolution proceeding shall not voluntarily disclose or through discovery or compulsory process be required to disclose any dispute tesolution communication or any commurication provided in confidence to the neutrai, unless-

(1) all parsies to the dispute resolution proceeding and the nelltrat consent in writing, and, if the dispute resolution communication was provided by a nonparty participant, that participant also consents in writing;

(2) the dispute resolution communication has already been made ptublis;

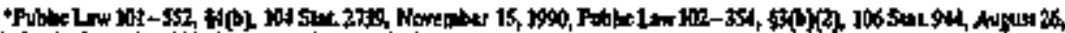

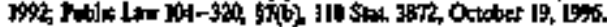


(3) the dispute resplution comminication is required by statute to be made public, but a neutral should make suci communication public oniy if no other person is reasonably available to disclose the commensication; or

(4) a court determines that such testimony or disclosure is neces. sary tom

(A) prevent a narifest injustice;

(B) belp establish a violation of law; or

" . (C) prevent harm to the public healtit or safety, of sulficient

magnitude in the particular case to outweigh the integrity of

dispute resolution proceedings in general by reduciuts the confidence of parties in future cases that their communications will remain conjidential.

(b) A party to a dispute resolution proceeding shatl not voluntarily disclose or through discowery ar compulsory process be required to fisclose any dispute resolution communications unless-

(1) the communication was prepared by the party seeking disclostirt;

(2) all parties to the dispute resolution proceeding consent in writing;

(3) the dispute resolution communication has already been made public;

(4) the dispute resolution communication is required by statute to be made public;

(5) a court deterurines that such testimony or disclosure is necessary to-
(A) prevent a manifest injustice;
(B) help establish a violation of law; or
(C) prevent harm to the public health and safety, of sufficient magnitude in the particular case to outweigh the integrity of dispute resolution proceecings in general by reducing the confidence of parties in future cases that their communications will remajn confidential;

(6) the dispute resolution comanunication is relevant to determining the existence or meating of an abresment or award that tesulted from the dispute resolution communication of to the enforcement of such an agreement or award; on

(7) except for dispute resolution comanupications generated by the neutrat, the dispute resolution contrnutication was provided to or was available to all parties to the dispute resolution proceeding.

(c) Any dispute resolution comutioujcation that is disclosed in violation of subsection (a) orr (b) shall not te adraissible in ary proceeding relating to the issues in controversy with respect to which the comsuvication was made.

(d)(1) The parties may agree to alternative confidential procediures for disclosures by a neutral. Upon such agreentent the parties shall in-

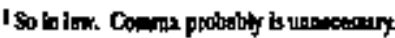


form the neutral before the commencement of the dispute resolution proceeding of any modifications to the provisions of subsection (a) that will govern the confidentiality of the dispute resolution proceeding. If the parties do not so inform the neutral, sabsection (a) shall apply.

(2) To qualify for the exemption established under subsection (j), an alternative confidential procedure under this subsection may not provide for less disclosure than the confidential procendures otherwise provided under this section.

(e) If a demand of disclosure, by way of discovery request or other legal process is made upon a meutral regarding a dispute resolution communication, the neutral shall make reasontable efforts to notify the parties and any affected nonperty participants of the demand. Any perby or affected nomparty participant who receives such notice and within 15 calendar days does not offer to defend a refasal of the neutral to disclose the requested information shall have waived any objection to such disclosure.

(f) Nothing in this section shall prevent the discovery or admissibility of any evidence that is otherwise discoverable, merely because the evidence was presented in the course of a dispute resolution proceeding.

(B) Subsections (a) and (b) shall have no effect on the information and data that are necessary to document an agreement reached or order issued pursuant to a dispute resolution proseeding.

(h) Subsections (a) and (b) shall not prevent the gathering of information for research or educational purposes, in cooperation with other agencies, governmental entities, or dispute resolution programs, so long as the parties and the specific issues fo controversy are not identiftable.

(i) Subsections (a) and (b) shall not prevent use of a dispute resolution communication to resolve a dispute between the neutral in a dispute resolution proceeding and a party to or participant in such proceeding so long as such dispute resolution communication is disclosed only to the extent necessary to resolve such dispute.

(j) A dispute resolution communication which is between a neutral and a party and which may not be disclosed under this section shall also be exempt from disclosure under section 552(b)(3).*

\section{\$575. Anthorization of arbitratlon}

(a)(1) Arbitration maybe used as an alternative means of disputs resolution whenever al] parties consent. Consent may be obtained either before or after an issise in controwersy has atisen. A party may agree to-

(A) submit only certain issues in controversy to arbitration;

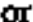

(B) arbitration on the condition that the award nust be within a range of possible cutcoines.

(2) The arbitration agreement that sets forth the subject matter subrnitting to the arbitration shall be in writing. Each such arbitration agreement shall specify a maximum award that may be issued

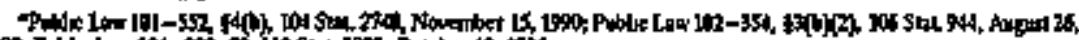

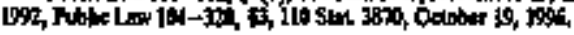


by the arbitrator and may specify other conditions limiting the range of possible cutcomes.

(3) An agency may not require any person to consent to arbitra- tion as a condition of entering into a contract or obtaining a benefit.

(b) An oficer or employee of an agency sball not offer to use arbitrafion for the resolution of issues in controversy usless such ofticter or enployee-

(1) would otherwise have authority to enter into a settlement concering the matter; or

(2) is otherwise specifically authorized by the agency to consent to the use of arbitration.

(c) Prior to using binding arbitration under this subchapter, the head of an agency, in consultation with the Atrorney General and after taking into account the factors in section.572(b), shall issue guidance on the appropriate use of binding arbitration and when an officer or enployee of the agency has authority to settle an issue in controversy through binding arbitration. *

\$576. Enforcement of arbitration agreements

An agreement to arbitrate a matter to which this subchapter applies is enforcement pursuant to section 4 of title 9 , and no action brought to onforce such an agreement shall be dismissed nor shall relief therein be deried on the grounds that it is against the United States or that the United States is an indispensable party.

\section{\$ 577. Arbitritiors}

(a) The parties to an arbitration proceeding shal be entithed to participate in the selection of the arbitrator.

(b) The arbitrator shall be a netutral who meets the criteria of section 573 of this title.

\section{\$378. Authority of the arbitrator}

An arbitrator to whon a dispute is referred under this subchapter may-

(1) regulate the course of and cònduct arbitral hearings;

(2) Administer oaths and affirmations;

(3) compel the attendance of witnesses and production of evidence at the hearing under the provisions of section 7 of title 9 only to the extent the agency involved is otherwise authorized by law to do so; and

(4) make awards.

\$579. Aroitration proceedings

(a) The arbitrator shall set $a$ time and place for the hearing on the dispute and shall notify the parties not less than 5 days before the hearing.

(b) Any party wishing a record of the hearing shall-

(1) be responsible for the preparation of stch record;

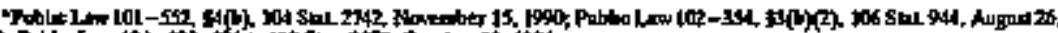

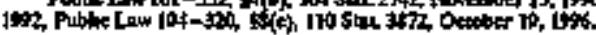


(2) notify the other parties and the arbitrator of the preparation of such record;

(3) furnish copies to all identified parties and the arbitrator; and

(4) pay all costs for stich record, unless the parties agree otherwise or the arbitrator determines that the costs should be apportioned.

(c)(1) The parties to the arbitration are entitled to be heard, to present evidence material to the controversy, and to cross-examine witnesses appearing at the hearing.

(2) The arbitrator may, with the consent of the parties, condact all or pert of the hearing by telephone, televistion, computer, or other electromic means, if each party has an opporkunity to participate.

(3) The hearing shall be conducted expeditiously and in an infor mal manner.

(4) The arbitrator may recelve any oral or documentary evtdence, except that irrelevant, immaterial, unduly repetitious, or privileged evidence may be exctuded by the arbitrator.

(5) The arbitrator shall interpret and apply relevant statutory and regulatory requirements, iegal precedents, and policy direc. tives.

(d) No fnterested person shall make or knowingly cause to be made to the arbitrator an unauthorized exparte communtikation relevant to the mertits of the proceeding, unless the parties agree otherwise. If a communication is madlo in violation of this subsection, the asbittator shall ensure that a memorandum of the communication is prepared and made a part of the record, and that an opportunity for rebuttal is atlowed. Upos receipt of a communication made in violation of this subsection, the arbitrator may, to the extent consistent with the interests of justice and the politcies underiying this subchapter, require the offending party to show calise why the claim of such party should not be tosolved against stoch party as a result of the improper conduct.

(e) The arbitrator shall make the award within 30 days after the close of the hearing, or the date of the filing of any briefs authorized by the arbitrator, whichever date is later, unjess-

(1) the parties agree to some other time limit; or

(2) the agency provides by rule for some other time limit.

\section{\$590. Arbitration awards}

(a)(1) Untess the agency provides otherwise by rule, the award in an abitration proceeding under this subdzapter shall include a brief, informal discussion of the factual and legal basis for the award, but formal findings of fact or conclusions of kaw shall not be requised.

(2) The prevailing parties shail file the award with all relewant agencies, along with proof of service on all parties.

(b) The award in an atbittation proceeding shall beconte final 30 days after it is served on all parties. Any agency that is a party to the proceedIng may extend this 30-day period for an additional 30-day period by serving a notice of such extension on all other parties before the end of the first 30-day period. 
(c) A final axard is bindtog on the parties to the arbitration procesding, and may be enforced pursuant to sections 9 through 13 of title 9 . No action brought to enforee such an award sball be dismissed nor shall relief therein be denite on the Grounds that it is against the United States or that the United States is an indispensable party.

(d) An award entered under this subchapter in an arbitration proceeding may not serve as an estoppel in any other proceedmg for any issue that was resolved in the proceeding. Such an award also may not be used as precedent or otherwise be considered in any factually unrelated proceeding, whether conducted under this subchapter, by an agency, or is a court, or in any other arbitration proceeding.*

\$s\$1. Jadicial review

(a) Notwithstanofing any other provistion of law, any person adversely affected or aggrieved by an award made in an arbitration proceeding conducted under this subchapter may bring an action for review of such award only pursuant to the provisions of sections 9 through 13 of title 9 .

(b)(1) Adecision by an agency to use or not to use a dispute resolution proceeding under this subchapter shall be committed to the discretion of the agency and shall not be subject to judicjal review, except that arbitration shall be subject to judicial review under section 10(b) of title 9 .

(2) A decision by the head of an agency under section 580 to terjisate an arbitration proceeding or vacate an arbitral award shal] be committed to the discretion of the agency and shall not be subject to judicial review.**

[\$5\$2. Repealed. Pub. L. 104-320, § 4(b)(1), Oct 19, 1996, 110 Stat. 3871.]

\section{\$583. Support services}

For the purposes of this subchapter, an agency may use (with or without teimbursement) the services and facifities of other federal agencies, state, local, and tribal governments, public and private or gan nizations and agencies, and individuals with the consent of such agenties, organizations, and ind tiduals. An agency may accept voluntary and uncompensated services for purposes of this subchapter without regard to the provisions of section 1342 of title 31 .

\section{\$584. Authorization of appropriations}

There are authorized to be appropriated such sums as may be necessary to carry out the purposes of this subchapter.

\section{SEC, 5. JUDICLAL REVIEW OF ARBITRATJON AWARDS.}

Section 10 of title 9, United States Code, is amended-

(1) by redesignating subsections (a) through (e) as paragraphs (1) through (\$), respectively;

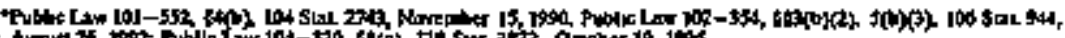

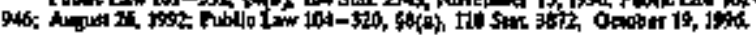

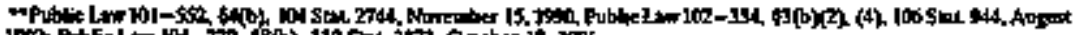

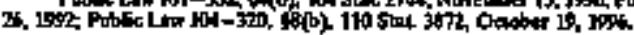


(2) by strilking out "In either" and inserting in lieu thereof "(a)In any"; and

(3) by adding at the end thereof the following:

(b) The United States district court for the district wherein an award was made that was issued pursuant to section 590 of title 5 may make an order vacating the award upon the application of a person, other than a party to the arbitration, who is adversely affected or aggrieved by the award, if the use of arbitration or the award is clearly inconsistent with the factors set forth in section 582 of title $5 . "$

\section{SEC. 6. GOVERNMENT CONTRACT CLAIMS.}

(a)ALTERNATTVEMEANSOF DISPUTE RESOLUTION.-Sec. tion 6 of the Contract Disputes Act of 1978 (41 U.S.C. 606) is amended by adding at the end the following new subsections:

"(d) Notwithstanding any ather provision of this Act, a contractor and a contracting officer may use any alternative means of dispute resolution urder subchapter IV of chapter 5 of title 5, United States Code, or other mutually agreeable procectures, for resolving claims. In a case in which such alternative means of dispute resolution or other mutually agreeable procedures are used, the contractor shall certity that the daim is made in good faith, that the supporting data are accurate and complete to the best of his or ber knowledge and betief, and that the amount requested accurately ieflects the contract adjustment for which the contractor believes the Government is tiable. All provisions of subchapter IV of chapter 5 of title 5 , Uatited States Code, shall apply to such alternative means of dispute resolution.

(e) The autbority of agencies to engage in alternative means of dispute resolution proceedings under stbsection (d) sball cease to be effective on October 1, 1995, except that stech authotity shatl continese in effect with respect to then pending dispute resolution proseedings which, in the judgment of the agencies that are parties to slich proceedings, require such continuation, until stuch proceedings terminate.".

(b) JUDICLAL REVIEW OF ARBITRAL AWARDS.-Sectión \&(g) of the Contract Disputes Act of 1978 (41 U.S.C. 607(g)) is amended by adding at the end the following new paragraph:

“(3) An award by an arbitrator under this Act shall be reviewed pursuant to sections 9 through 13 of title 9, United States Code, except that the court may set aside of limit any award that is found to violate limitations imposed by Federal statue.".

\section{SEC. 7. FEDERAL MEDIATION AND CONCIMATION SERVICE}

Section 203 of the Labor Management Relations Act, 1947 (29 U.S.C. 173) is amended by adding at the end the following new subsection:

(f) The Service may make its services avallable to Federal agencies to aid in the resolution of disputes unfer the provisions of subchapter $\Gamma V$ of chapter 5 of titie 5, United States Code. Fonctions performed by the Service may mitlude assisting parties to disputes related to administrative programs, training persons in skils and procedures employed in alternative means of dispute resolution, and furnishing officers and emplogees of the Service to act as neutrals. Only officers and employees 
who are qualjified in actordance with section 583 of title 5 , United States Code, may be assigned to act as neutrals. The Service shall consult with the Administrative Conference of the United States and other agencies in maintaining rosters of neutrals and abitrators, and to adopt such procechures and nules as are necessary to cary out the services authorized in this subsection.".

\section{SEC. 8. GOVERNMHEN TORT AND OTHER CLAIMS.}

(a) FEDERAL TORT ClAIMS.-Section 2672 of tite 28, United States Cock, is annended by adding at the end of the first paragraph the following: "Notwithstanding the proviso contatued in the preceding sentence, any award, compromise, or settlement may be effected with. out the prior written approval of the Attoney General or his or her designee, to the extent that the Attorney General delegates to the bead of tho agency the authority to make such award, compromise, or settiement. Such delegations may not exceed the authority delegated by the Artorpey General to the United States attorneys to settle claims for money damages against the United States. Each Federal agency may use arbitration, or other alternative means of dispute resolution under the provisions of subchapter IV of chapter 5 of title 5 , to settle any tort claim against the United States, to the extent of the agency's authority to award, compromise, or settie such claim without the prior written approval of the Attorney General or his ot het desippes.".

(b) CLAIMS OF THE GOVERNMENT-Section 3711(a)(2) of titie 31, United States Code, is amended by striking out $\$ 20,000$ (excluding inter̦est)" and inserting in lieu thereof $\$ \$ 100,000$ (excluding interest) or such higher amount as the Attoney General may from time to time prescribe".

5 USC 57,

\section{SEC.9. USE OF NONATTORNEYS.}

note.

(a) R'EPRESÉNTATION OF PARTIES.-Each agency, in developing a policy on the use of alternative means of dispute resolution toder this Aet,'shall develop a policy with regard to the representation by persons other than attorneys of parties in alternative dispute resolution proceedings and shall jdentify any of its administrative programs with numerous claims or disputes before the agency and deternine-

(1) the extent to which individuals are represented or assisted by attorntys or by persons who are not attormeys; and

(2) whether the subject areas of the applicable proceedings or the procectures are so complex or specialized that onty attorneys Imay adequately provide such representation or assistance.

(b) REPRESENTATION AND ASSISTANCE BY NONATTORNEYS,-A person who is not an attorney may provide representation or assistance to any individual in a claim or dispate with ar agency, if-

(1) such claim or dispute concerns an administrative program identified under subsection (a);

(2) such agency determines that the proceeding or procedure does not necessitate represemtation or assistance by an attomey under subsection (a)(2); and 
5 USC 57, note.

SUSC $\$ 71$, note.
(3) such person meets any requirement of the agency to prowide representation or assistance in such a clain or dispute.

(c) DISQUALIFICATION OF REPRESENTATION OR ASSISTANCE.-Any agency that adopts regulations under stbchapter IV of chapter 5 of title 5. United States Code, to permit representation or assistance by persons who are not attorneys shall review the nules of prac. tice belore such agency to-

(1) ensure that any rules pertaining to disquelification of attorneys from practicing before the agency shall also apply, as appropriate, to other persons who provide representation or assistance; and

(2) establish effective ageacy procedures for enforcing such rules of practice and for receiving complaints from affected persons.

\section{SEC. 10. DEFINITSONS.}

As used th this Act, the terms "agency", "atministrative program", and "altermative means of dispute resolution" have the mearings given such terms in section 581 of tifle 5, United States Code, as added by section $4($ b) of this Act.

\section{SAC. 11. SUNSET PROVISION.}

The authority of agencies to use dispute resolution proceedings under this Act and the anendments made by this Act shall terminate on October 1,1995 , except that such authority shall continue in effect with respect to then pending proceedings which, in the judgment of the agencies that are parties to the dispute resolution proceectings, require such continttation, until such proceedings terminate. 


\section{CHAPTER 6 - THE ANALYSIS OF REGULATORY FUNCTIONS}

\begin{tabular}{|c|c|}
\hline PAGE & $\ldots .5 \mathbf{U}$ \\
\hline 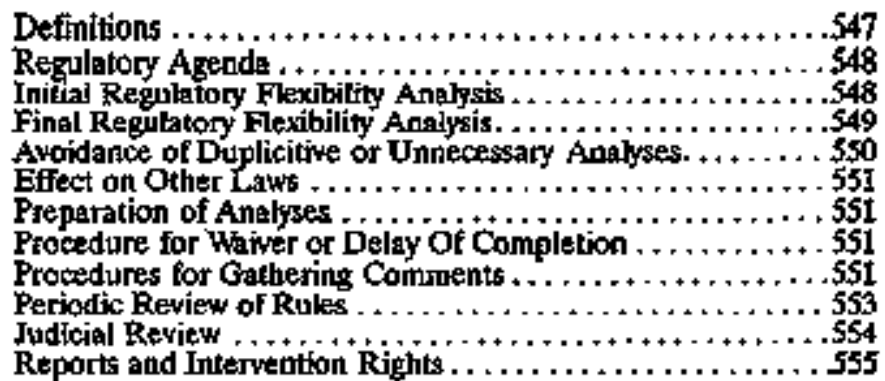 & $\begin{array}{l}502 \\
503 \\
504 \\
505 \\
500 \\
509 \\
510\end{array}$ \\
\hline
\end{tabular}


CHAPTER 6-THE ANALYSIS OF RBGULATORY EUNCTIONS

Sec. 601. Definitions.

For purposes of this chapter-

(1) the term "agenç", means asl agency as defined in section 551 of this title;

(2) The term "ruie" means any rule for which the agency publishes a general notice of proposed rulemaksing pursuant to section 553(b) of this title, or any other law, inchuding any nule of general applicability governing Federal grants to State and local govermments for which the agency provides an opportunity for notice and public comment, except that the term "rule" does not include a rule of particular applicability relating to rates, wages, corporate or finaneial structures or reorganizations thereof, prices, facilities, appliances, services, or allowances therefor or to valuations, costs or accounting, or practices rejating to such rates, wages, structures, prices, appliances, services, or allowances;

(3) the term "small business" bas the same meaning as the term "small bxsiness concern" voder section 3 of the Small Business Act, unless an agency, after consultation with the Office of Advocacy of the Small Business Administration and after opportunity for public comment, establishes one or more definitions of such torm which are approptiate to the activities of the agency and pub. lisbes such definitions(s) in the Federal Register;

(4) the term "small organization" means any not-for-profit enterprise which is independently owned and operated and is not dominant in its field, unless an agency establishes, after opportunity for public comment, one or more definitions of such terms which are appropriate to the activities of the agency and publishes such definition(\$) in the Federal Register;

(5) the term "small governmental jurisdiction" means govern. ments of cities, counties, towns, townships, viltages, school districts, or special districts, with a population of less than infty thotsand, unless an agency establishes, after opportunity for publtc comment, one or more definitions of such term which are appropriate to the activities of the agency and which are based on such factors as location in rural or sparsely populated areas or lin?ited reverulues due to the population of such jurisdiction, and publishes definition(s) in the Federal Register; and

(6) the term "small entity" shall have the same meaning as the temos "small business," "smal organization" and "small governmental jurisdiction" defined in paragraphs (3), (4) and (5) of this section.

(7) the term "collection of information"-

(A) means the obtaining, causing to be obtained, soliciting, or requiring the disclosure to third parties or the public, of facts or opinions by or for an agency, regardless of form or format, calling for either $\rightarrow$

(1) answers to identical questions posed to, or identical reporting or recordiketping requirements injposed on, 10 
or more persons, other than agencies, instrumentalities, or employees of the United States; or

(ii) answers to questions posed to agencies, instrumenthities, or employees of the United States which are to be used for general statistical purposes; and

(B) shall not include a collection of information described under section 3518(c) (1) of titlo 44, United States Code.

(B) Recordkeeping Requirement.-The term "tecordkeeping requirement" means a requirement imposed by an agency on persons to maintán specified records.*

Sec 602. Regulatory Agenda.

(a) During the months of October and April of each year, each agency shall publish ín the Federal Register a regulatory Dexability agenda which shall contasto-...

(1) a brief desctiption of the subject area of any nule which the agency expects to proposed or promulgate which is tikely to bave a significant economic impact on a substantial number of snali entities;

(2) a summary of the nature of any such rule under consideration for each subject area listed in the agenda pursuant to paragraph (1), the objectives and legal basis for the issuance of the rale, and an approximate schedule for completing action on any rule for which the agency bas issued a general notice of proposed rulemaking, and

(3) the name and telephone number of an agency official knowledgeable concerning the items kisted in paragraph (1).

(b) Each regulatory flexibijity agenda shall be transuitted to the Chief Coumsel for Advocacy of the Small Business Administration for comment, if any.

(c) Each agency shall endeavor to provide notice of each regulatory flexibility agenda to small entities or their representatives through direct notification of publication of the agenda in publications likely to be obtained by such small entities and sball invite comments upon each subject area on the agenda.

(d) Nothing in this section precludes an agency from considering or acting on any matter, not included in a regulatory flexibjlity agenda, or requires an agency to consider or act on any matter listed in such agenda. (Added Pub. L. 96-354, Sept. 19, 1980, 94 Stat. 1166.)

\section{Sec. 603. Inittal Regulatary Flevibility Analysis.}

(a) Whenever an agency is required by section 553 of this title, or any other law, to publish general rotice of proposed rulemaling for any proposed rule, or publishes a notice of proposed rulemaking for an interpretative rule involving the internal tevenue laws of the United States, the agency shall prepare and make available for public comment an initial regulatory flexibility analysis. Such analysis shall describe the impact of the proposed rule on small entities. The initial regulatory flexibility analysis or a summary stalt be published in the Federal Regis-

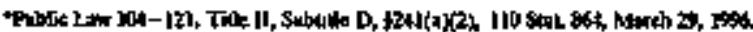


ter at the time of the publication of genetal notice of proposed rulenalking for the rule. The agency shall transmit a copy of the intial regulatory flexibitity analysis to the Chief Counsel for Advocaty of the Small Business Administration. In the case of an interpretative rule involving the internal revenue laws of the United States, this chapter applies to interpretative rules published in the Federal Register for codjfication in the Code of Federal Regulations, but only to the extent that such interpre. tative rules impose on small entities a collection of information requirement.

(b) Each initial regulatory flexibitity analysis required under thits section shall contain-

(1) a description of the reasons why action by the agency is being considered;

(2) a succinct statement of the objectives of, and legal basis for, the proposed rule;

(3) a description of and, where feasible, an estimate of the number of small entities to which the proposed rule wilt apply;

(4) a description of the projected reporting, recordkeeping and other compliance requirements of the proposed rule, including an estimate of the classes of small entities whtoch will be subject to the requirement and the type of professional skills necessary for preparation of the report or record;

(5) an identification, to the extent practicable, of all relevant Federal rules which may duplisate, overlap or conflice with the proposed rule.

(c) Each initial regulatory flexibility analysis shall also contain a description of any significant alternatives to the proposed juite which accomiplish the stated objectives of applicable statutes and witch minimize any signiftcant economic impact of the ptoposed rule on small entities. Consistent with the stated objectives of applicable statutes, the analysis shall discuss significant alternatives such as-

(1) the establishment of differing compliance or reporting requfrements or timetables that take into account the resources available to small entities;

(2) the clarification, consolidation, or simplification of compliance and reporting requirements under the rule for such small entities;

(3) the use of performance rather than design standards; and

(4) an exemption from coverage of the nule, or any part thercof, for such snal] entities.".

\section{Sec. 604. Ftral Regulatory Flexibility Analysis.}

(a) When an agency promulgates a final rule under section 553 of this tite, after being required by that section or any other law to publish a general notice of proposed rulemaking, or promulgates a ninal interpretative iule involving the internal revenue laws of the United States as described in section 609(a), the agency shall prepare a final regulatory

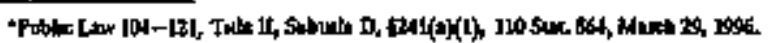


flexibility analysis. Each final regutatory flexibility analysis shall contain-

(1) a succinct statement of the need for, and objectives of, the rule;

(2) a summary of the significant issues raised by the public comments in response to the initial regulatory flexibility analysis, a stimmary of the assessment of the agency of such issties, and a statement of any changes made in the proposed rule as a result of such comments;

(3) a description of and an estimate of the number of small entities to which the rule will apply or an explanation of why no such estimate is available;

(4) a description of the projected reporting, recordkeeping and other compliance requirements of the rule, incluoing an estimate of the classes of small entities which will be subject to the requirement and the type of professional skills necessary for preparation of the report or recort; apd

(5) a description of the steps the agoncy has taken to minimize the significant econornic impact on smanl eititites consistent with the stated objectives of applicable statutes, including a statement of the factual, policy, and legal reasons for selecting the alternative adopted in the final rule and why each one of the other significant alternatives to the rule considered by the agency whish affect the impact on sulall entities was rejected.

(b) The agency shall malke copies of the final regulatory flexibility analysis avalabue to members of the public and shalj publish in the Federal Register such anabysis or a sumumary thereof."

Sec. 605. Avoldance of Duplticative or Unnecessary Analyses.

(a) Any Federal agency may perform the analyses required by sections 602,603 , and 604 of this title in conjunction withor as a part of any other agenda or analysis required by any other law if such other analysis satisfies the provisions of such sections.

(b) Sections 603 and 604 of this title stall not apply to any proposed or final culc if the head of the, agency certises that the rule will not, if promulgated, have a signtificant economic impact on a substantial nuniber of smalt entities. If the head of the agency makes a certification under the preceding sentence, the agency shall peublish such certititation in the Federal Register at the time of publication of general notice of proposed rulemaking for the rule or at the tione of publication of the final rule, along with a statement providing the factual basis for such certifcation. The agensy shall provide such certification and statement to the Chief Counsel for Advocacy of the Small Business Aduinistration.

(c) In order to avoid duplicative action, an agency may consider a series of closety related rules as one rule for the purposes of sections 602 , 603,604 and 610 of this title.**

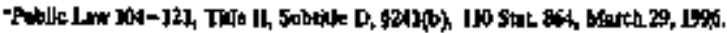

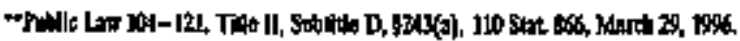


Sec. 696. Effect on Other Law.

The requirements of sections 603 and 604 of this title do not alter in any manner standards othervise applicable by law to agency action.

Sec. 607. Preparation of Analyses.

In complying with the provisions of sections 603 and 604 of this title, an agency may provide either a quantifiable or numerical description of the effects of a proposed rule or alternatives to the proposed rule, or more general descriptive statements if quantification is not practimable or relizble.

Sec. 608. Procedure for Waiver or Delay of Completion.

(a) An agency head may waive or delay the completion of some or all of the reguirements of section 603 of this title by publishing in the Federad Register, not later than the Jate of publication of the final rule, a witten finding, with reasons therefor, that the final rule is being promulgated in response to ar emergency that makes compliance or timely compliance with the provisions of section 603 of this title impracticable.

(b) Except as provided in section $605(b)$, an agency head toay not waive the requirements of section 604 of this titte An agency head may delay the completion of the requitrements of section 604 of this title for a period of not more than one hundred and eighty days after the date of publication in the Federal Register of a final nule by publishing in the Federal Revister, not later than sucis date of publication, a written firding, with reasons therefor, that the inal rule is being promulgated to response to an emergency that makes timely compliance with the provisions af section 604 of this title impracticable. If the agency has not prepared a final regulatory analysis pursuant to section 604 of this title within one hundred and eighty days from the date of publication of the fintal rule, stech rule shall lapse and have no effect. Such rule shall not be repromulgated until a ñnal regulatory flexibility analysis has been com. pleted by the agency. (Added Pub. L. 96-354, Sept. 19, 1980, 94 Stat. 1168.)

Sec 609. Procedures for Gathering Comments.

(a) When any rule is promulgated which will bave a significant economic impact on a substartial mumber of small entities, the head of the agency promulgating the rule or the official of the agency with stanutory responsibility for the promulgation of the rule shall assure that sinal entities have been given an opportunity to participste in the nulemaking for the rule through the reasonable use of techuigues ${ }^{2}$ such as-

(1) the inclusion in an adranced notice of proposed rtultmaking, if issued, of a statement that the proposed rule may have a significant economic effect on a substantial number of sinall entities;

(2) the perblication of general notice of proposed rulenaling in publications likely to be obtained by small entities;

(3) the direct notification of interested small entities;

(4) the corduct of open conferences or public hesings concerning the rule for small entities incluaing soliciting and receiving comments over computer networks; and 
(5) the adoption or modification of agency procednral rules to reduce the cost or complexity of participation in the rulemaking by sall] entities.

(b) Prior to publication of an initial regulatory flexibility anajysis which a covered agency is required to consalact by this chapter--

(1) a covered agency shall notify the Chief Counsel for Advocacy of the \$mall Busjiness Administration and provide the Chief Counsel with information on the potential impacts of the proposed rule on small entities and the type of small entities that might be affected;

(2) not later than 15 days after the date of receipt of the materiats described in paragraph (1), the Chief Counsel shall identify indi. viduals representative of affecied sinall entities for the purpose of obtatning advice and recommendations from those individuals about the potential impacts of the proposed zute;

(3) the agency shall convene a review panel for such rule consisting wholly of full time Federal employees of the office within the agency responsible for carying out the proppsed rule, the Office of Information and Regulatory Affairs within the Office of Management and Budget, and the Chitef Counsel;

(4) the panel shall review any material the agency has prepared in connection with this chapter, including any draft proposed rule, collect advice and recommendations of each individual small entity representative identified by the agency after consultation with the Chief Counsel, on issues related to subsections 603 (b), paragraphs (3), (4) and (5) and 603(c); ${ }^{3}$

(5) not later than 60 days after the date a cowered agency convenes a review panel pursuant to paragraph (3), the review panel shall report on the conments of the small entity representatives and its findings as to issues related to subsections $603(\mathrm{~b})$, paragraphs (3), (4) and (5) and 603 (c), ${ }^{4}$ provided totat such report shal! be made public as part of the rulemaking record; and

(6) where appropriate, the agency shall modify the proposed rule, the initial regulatory flexibility analysis or the decision on whether an initial regulatory flexibility analysis is required.

(c) An agency may in its discretion apply subsection (b) to rules that the agency iutends to certify under subsection 605 (b), but the agency believes may have a greater thas de roinimis impact on a substantial number of small entities.

(d) Fo* purposes of this section, the term "eovered agency" means the Environmental Protection Agency and the Occupational Safety and Healtit Administration of the Department of Labor.

(e) The Chief Counsel of Advocacy, in consultation with the individuals identified in subsection (b)(2), and with the Administrator of the Office of Information and Regulatory Affairs within the Office of Management and Bodget, may waive the sequirements of subsections (b) (3), (b) (4), and (b)(5) by induding in the rilemaking record a writ-

$n$, ten fincing, with reasons therefor, that those requirenients would not advance the effective participation of small entities in the rulemaking 
process. For purposes of this subsection, the factors to be considered in making such a finding ate as folkows.

(I) In developing a proposed rule, the extent to which the covered agency consulted with individuals representative of affected small entities with respect to the potential impacts of the rule and took suci concerns into consideration.

(2) Special circumstances requiring prompt issuance of the rule.

(3) Whether the requirements of subsection (b) would provide the individuals identitied in subsection (b)(2) with a competitive advantage relative to other strall entities."

Sec 610. Perloglic Review of Rules.

(a) Within one hundred and eighty days after the effective date of this chapter, each agency shall publish in the Federal Register a plan for the periodic review of the rules issued by the agency which have or will bave a significant economic impact upon a substantial number of small entities. Such plan may be amended by the agency at any time by publishing the revision in the Federal Register. The purpose of the review slall be to determine whether such niles should be continued without change, or shotld be amended or rescinded, consistent with the stated objectives of applicable statutes, to mftuinize any significant economic impact of the rules upon a substantial number of such smatl entities. The plan shall provide for the review of al such agency rules existing on the effective date of this chapter within ten years of that date and for the review of such rules adopted atter the effective date of this chapter within ten years of the publication of such rul tes as the final rule. If the head of the agency determines that comptetion of the review of existing niles is not feasible by the established date, he shall so certify in a statement published in the Federal Register and may extend the completion date by one year at a time for a total of not more than five years.

(b) In reviewing rules to minimize any significant economic impact of the rufe on a substantial mumber of small entities in a mamer consistent with the stated objectives of applicable statutes, the agency shall consider the following factors-

(1) the contimued need for the nule;

(2) the nature of complaints or comments received concerning the rale from the public;

(3) the complexity of the rule;

(4) the extent to which the rule overlaps, duplicates or conflicts with other federal rules, and, to the extent feasible, with State and local governmental rules; and

(5) the length of time since the sule has been evaluated or the degree to which technology, economic conditions, or other factors have changed in the area affected by the rule.

(c) Each year, each agengy shall publish in the Federal Register a list of the nules which bave a significant economic impact on a sutbstantial number of small entities, which are to be reviewed pursuant to this section during the sureceding twetve months. The list shall itclude a brief

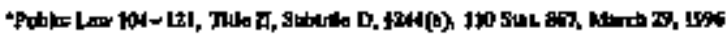

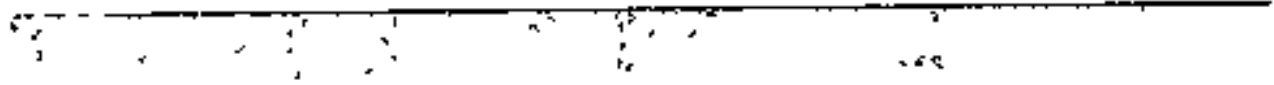


description of each rule and the need for and legal basis of srich rule and shall invite public comment upon the rule. (Added Pub. L. 96-354, Sept. 19, 1980, 94 Stat. 1168.)

\section{Sec. 611. Júdiclal Review.}

(a)(1) For any rule subject to this chapter, a small entity that is adversely affected or aggrieved by final agency action is entitled to judicial review of agency compliarice with the requirements of sections 601,604 , 605(b), 608(b), and 610 in accordance with chapter 7. Agency compliance vith sections 607 and 609(a) shall be juticially revitwalble in connection with judicial reviev of section 604.

(2) Each court having juristiction to review such rule for compliance with section 553 , or under any other provision of law, shall have jurisdiction to review any claims of nonconpliance with sections $601,604,605$ (b), 608(b), and 610 in acsordance with chapter 7. Agency coimpliance with sections 607 and 609(a) shall be judicially reviewable in consection with judicial review of section 604 .

(3) (A) A small entity may seek such review during the period beginning on the date of final agency action and ending one year later, except that where a provision of law reguires that an action challenging a nnal agency action be commenced before the expitation of one year, stech lesser period shall apply to an action for judicial revitw under this section.

(B) In the case where an agency delays the issuance of a final regulatory flextivility analysis pursuant to section 608(b) of this chapter, an action for judicial review under thís section shall be filed not later than-

(i) one year after the date the analysis is made available to the public, or

(ii) where a provision of law requires that an action chafenging a final agency regulation be commenced before the expiration of the 1-year period, the number of days specified in such provision of law that is after the date the analysis is made avajlable to the public.

(4) In granting any relief in an action under this section, the court shall order the agency to take corrective action consistent with this chapter and chapter 7 , including, but not limited to-

(A) remanding the rule to the agenxy, and

(B) deferring the enforcement of the rule against small entities unless the court finds that continued enforcement of the fule is in the public interest.

(5) Nothing in this subsection shall be construed to limit the au. thority of any court to stay the effective date of any rule or provision thiereof under any other provision of law or to grant any other relief in addition to the requirements of this section.

(b) In an action for the judiciat review of a rule, the regulatory flexibility analysis for such rule, including an analysis prepared or corrected purstant to paragraph (a)(4), shall constitute part of the entire record of agency action in connection with such review. 
(c) Compliance or nomcompliance by an agency with the provisions of this chapter shall be stbject to judicial review only in accordance with this section.

(d) Nothing in this section bars judicial review of any other impact statement or similar analysis required by any other law if judicial review of such statement or analysis is otherwise permitted by law.*

Sex. 612. Reports and Intervention Rights.

(a) The Chief Counsel for Advocacy of the Small Business Administration shall monitor agency compliance with thiss chapter and shall report at least anmaily thereon to the President and to the Committees on the Judiciary and Small Business of the Senate and House of Representatives.

(b) The Chief Counsel for Atwocacy of the Small Business Administration is authorized to appear as amicus curiae in any action brought in a court of the United States to review a rult. In any such action, the Chief counsel is authorized to present his or her views with respect to compliance of this chapter, the adequacy of the rulemaking record with respect to small entities." "w

(c) A court of the United States shall grant the application of the Chief Counsel for Adrocacy of the \$roill Business Administration to appear in any such action for the purposes described in subsection (b). (Added Pub. L. 96-354, Sept 19, 1980, 94 Stat. 1170.)

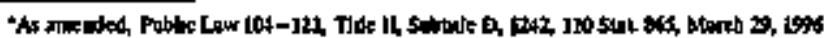

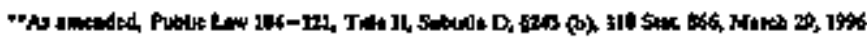


CHAPTER 7 - JUDICIAL REVIEW

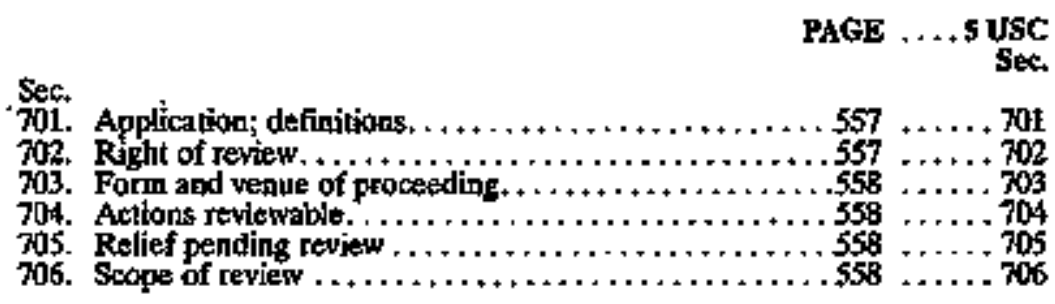


Sec. 701. Application; Definitions,

(a) This chapter applies, according to the provisions thereof, except to the extent that-

(1) statutes prechude judicial review; or

(2) agency action is committed to agency discretion by law.

(b) For the purpose of this chapter-

(1) "agency" means each authority of the Govermment of the United States, whether or not it is within or subject to review by another agency, but does not include-

(A) the Congress;

(B) the courts of the United States:

(C) the governilents of the territontes or possessions of the United States;

(D) the government of the District of Columbia;

(E) agencies composed of representatives of the parties or of representatives of organizations of the parties to the disputes deterritined by tijem;

(F) courts martial and military commissions;

(G) military authority exercised in the field in time of war or in occuptied territory; or

(H) functions conferred by sections $1738,1739,1743$, and 1744 of title 12; chapter 2 of title 41 ; subchapter II of chapter 471 of title 49 ; or sections $1884,1891-1902$, and former section 1641(b)(2), of title 50, appendix; and

(2) "person", "rule", "order", "license", "sanction", "relief", and "agency action" have the meanings given them by section 551 of this title.

\section{Sec 702, Right of Review.}

A person suffering legal wrong because of agency action, or adversely affected or aggrieved by agency action within the meaning of a relevant statute, is entitled to judicial review there of. An action in a court of the United States seeking relief other than money damages and stating a chaim that an agency or an officer or employee thereof acted or faited to act in an official capacity or under color of Jegal authontty shatl not be dismissed not relief therein be denied on the ground that it is against the United States or that the United States is an indispensable party. The United States may be named as a defendant in any such action, and a judgment or decree may be entered against the United States: Pro. vided, That any mandatory or injunctive decree shall specify the Federal officer or officers (by name or by title), and their successors in office, personally responsible for compliance. Nothing herein (1) affects other limitations on judicial review or the powrer or duty of the court to dismiss any action or deny relief on any other appropriate legal or equitable ground; or (2) confers authority to grant relief if any other statute that grants consent to suit expressly or impliedly forbids the relief which is sought. 
Sec. 703. Form and Yenue of Proceeding.

The form of proceeding for judicial review is the special statutory review proceeding relevant to the stbject matter in a court spectified by stante or, in the absence or inadequacy thereof, any applicable form of legal action, including actions for declaratory judgments or writs of probibitory or mandatory injunction or habeas corpus, in a court of competent juristiction. If no special statutory review proceeding is applicable, the action for judicial review may be brought against the United States, the agency by its offscial title, or the appropriate officer. Except to the extent that prior, adequate, and exclusive opportunity for jucicial review is provided by law, agency action is subject to judicial review in civil or criminal proceedings for judicial enforcement.

Sec. 704. Actions Reviowable.

Agency action made reviewable by statute and final agency action for which there is no other adequate rempedy in a conrt are subject to judicial review. A preliminary, procedural, or intermediate agency action or ruling not directly reviewable is subject to review on the review of the Enal agency action. Except as otherwise expressly required by statute. agency action otherwise final is final for the purposes of tiris section whether or not there has been presented or determined an application for a deciaratory order, for any form of reconsideration, or, urless the agency otherwise requires by nule and provides that the action meanwhile is inoperative, for an appeal to superior agency authority.

Sec. 705. Relief Pending Review.

When an agency finds that justice sorequires, it may postpone the effective date of action taken by it, pending judicial revew. On such conditions as may be required and to the extent necessary to prevent irseparable injury, the reviewing court, including the court to which a case Imay be taker on appeal from or on application for certiorari or other Writ to a reviewing court, may issue all necessary and appropriate process to postpone the effective date of an agency action or to preserve status or rights pending conclusion of the review proceedings.

Sec. 706. Scope of Review.

To the extent necessary to decision and when presented, the reviewing court shall decide all relevant questions of law, interpret constitutional and statutory provisions, and determine the meaning or applicability of the terms of an agency action. The reviewing court shall-

(1) compel agency action unlawfully withheld or unreasonably delayed; and

(2) hold unlawful and set aside agency action, findings, and conclusionts found to be-

(A) arbitrary, capricious, an abuse of disctetion, or otherwise not in accordance with law;

(B) contrary to constitutional right, power, privilege, or immunity;

(C) in excess of statutory jurisdiction, authority, ot limitations, or short of statutory right;

(D) without observance of procecture requited by law; 
(E) unsupported by substantial evidence in a case subject to sections 556 and 557 of this title or otherwise reviewed on the record of an agency hearing provided by statute; or

(F) unwarranted by the facts to the extent that the facts are subject to tral de noro by the reviewing court.

In making the foregoing determinations, the court shall review the whole record or those parts of it cited by a party, and due account shall be taken of the rule of prejudicial error. 


\section{CHAPTKR 8 - CONGRESSIONALE REVIEW OF AGENCY}

RJLEMAKING*

$-b$

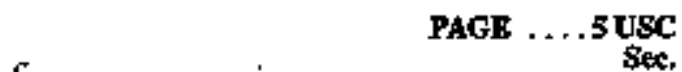

$\sec$

80t. Congressionial review. $\ldots \ldots \ldots \ldots \ldots \ldots \ldots \ldots \ldots \ldots \ldots, 561$

802 . Congressionsal disapprowal procedute ............563

803. Specing rule on statulory, regulatory, and judicial

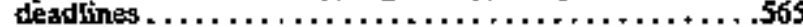

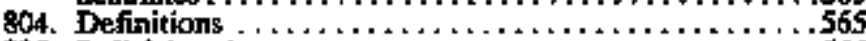

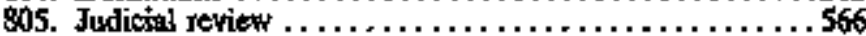

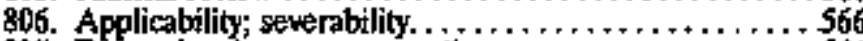

807. Extmption for moretary policy.................... s66

808. Effective date of certain mles. . . . . . . . . . . . . . . 566

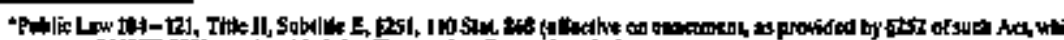

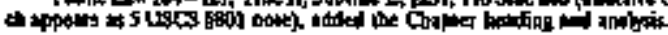




\section{\$801. Congressinnal review}

(a)(1)(A) Before a tule can take effect, the Federal agency promulgating stuch tule shall submit to each House of the Congress and to the Comptroller Genemal a report containing-

(i) a copy of the rule;

(ii) a concise general statement relating to the ruie, including whettier it is a major rule; and

(iii) the proposed effective date of the ruite.

(B) On the date of the submission of the report under subparagraph (A), the Federal agency promulgating the rule shalt submit to the Comptroller General and make available to each House of Congress-

(i) a complete copy of the cost-benefit analysis of the rule, if any;

(iI) the agency's actions relevant to sections 603,604 , 605, 607, and 609;

(iii) the agency's actions relevant to sections 202,203, 204, and 205 of the Unfunded Mandates Refors Act of 1995; and

(iv) any ather relevant information or requirements under any other Act and any relevant Executive ofders.

(C) Upon receipt of a repont submitted under subparagraph (A), eact House shall prowide copies of the report to the chairman and ranking member of each standing committee with jurisdiction under the rules of the House of Representatives or the Sentate to report a bill to anend the provision of law under which the rule is issued.

2(A) The Comptroller General shall provide a report on each major rule to the committees of jurisdiction in each House of the Congress by the end of 15 calendar days after the submission or publication date as provided in section $802(b)(2)$. The report of the Comptroller General shall include an assessment of the agency's compliance with procedural steps required by paragraph (1)(B).

(B) Federal agenties shall cooperate with the Comptroller General by providing information relevant to the Comptroller Geperal's report inder subparagraph (A).

(3) A major rule relating to a report submitted under paragraph (1) shall take effect on the latest of-

(A) the later of the date occurring 60 days after the date on which-

(i) the Congress receives the report submitted under paragraph (1); or

(ii) the nule is published in the Federal Resister, if so published;

(B) if the Congress passes a joint resolution of disapproval described in section 802 relating to the rule, and the President signs a veto of such resolution, the earlier date-

(i) on which either House of Congress votes and fails to override the veto of the President; or

$i$ is ${ }^{2} i$


(ii) occurring 30 session days after the date on which the Congress received the veto and objections of the Presidents or

- (C) the date the nile would have otherwise taken effect, not for this section (unless a joint resohation of disapprowad under section 802 is enacted).

(4) Except for a major rule, a rule shali take effect as oftrerwise provided by law after submission to Congress under paragraph (1).

(5) Notwithstanding paragraph (3), the effective date of a rule shall not be delayed by operation of this chapter beyond the date on which either House of Congress wates to reject a joint resolution of disapproval under section 802.

(b)(1) A. rule shall not take effect (or continue), if the Congress enacts a joint resolution of disapproral, described under section 802, of the rute.

(2) A rule that does not take effect (or does not continue) under paragraph (1) may not be reissued in substantially the same form, and a new rule that is stubstartially the same as such a rule may not be issued, unless the reissued or new nule is specifically authorized by a law enacted after the date of the foint resolution disapproving the original rule.

(c)(1) Notwithstanding any other prowision of this section (except subject to paragraph (3)), a rule that wotuld not take effect by teason of subsection (a) (3)' ualay take effect, if the President makes a determination under paragaph (2) and submits writren notice of such determination to the Congress.

(2) Paragraph (1) applies to a defermination made by the President by Executive order that the rule should take effect because such rule is-

(A) necessary becaluse of an imminent threat to health or safety or other emergency;

(B) necessary for the enforcement of criminal laws;

(C) necessary for national security; or

(D) issued purșuant to any stante implomentitg an international trade agreement.

(3) An exercise by the President of the authority under this subsection shall bave no effect on the procedures under section 802 or the effect of a joint resolution of disapproval under this section.

(d)(1) In addition to the opportunity for review otherwise provided under this chapter, in the case of any rule for which a report was submitted in accordance with subsection (a)(1)(A) during the period beginting on the date occurring-

(A) In the case of the Senate, 60 sessions days, or

(B) in the case of the House of Representatives, 60 legislative

days, before the date the Congress adjourns a session of Congress through the date on which the stame or sucoeding Congress first convenes its next session, section 802 shall apply to such rule in the succeeding session of Congress. 
(2)(A) In applying section 802 for purposes of stich additional review, a rule described under poragraph (1) shal! be treated as though-

(i) such rule were published in the Foderal Register (as a role that shall take effect) on-

or

(I) in the case of the Senate, the 15th session day,

(II) in the case of the Fouse of Represertatives, the 15th legislative day, after the succecting session of Congress first convenes; and

(it) a report on such rute were submitted to Congress under sutosection (a)(1) on such date.

(B) Nothing in this paragraph stall be conserued to affect the requirement under subsection (a) (1) that a report shalt be submitted to Congress before a rule can take effect.

(3) A rule described under paragraph (1) shall take effect as otherwise provided by law (tucluding other sibsections of this secion).

(e)(1) For purposes of this subsection, section 802 stiall also apply to any major rule promulgated between March 1, 1996, and the date of the enactment of this chapter.

(2) In applytug section 802 for pirposes of Congressional review, a rale described under paragraph (1) shall be treated as though-

(A) such rule were published in the Federal Register on the date of enactment of this chapter; and

(B) a report on such rule were subritted to Congress under subsection (a)(1) on such date.

(3) The effectiveness of a rule described under paragraph (1) shall be as otherwise provided by lew, unless the rule is made of no force or effect under section 802 .

(f) Any rule that takes effect and later is made of no force or effect by enactment of a joint resolution under section 802 shall be treated as though sach rule had never taken effect.

(g) If the Congress does not enact a joint resolution of disapproval under section 802 respecting a rule, no court or agency may infer any intent of the Congress from any action or inaction of the Congress with regard to such rule, related statute, or joint resolution of disapproval.

\section{\$ 802. Congressłonal djsepproval procedure}

(a) For purposes of this section, the term "joint resolution" means only a jojnt resolution introduced in the period beginning on the date on which the report referred to in section 801(a)(1)(A) is received by Congress and ending 50 days thereafter (excluding days either House of Congress is adjourned for more than 3 days during a session of Congress , the matter after the resolving chause of which is as follows: "That Congress disapproves the rule submitted by the relating to

and such rule shall have no force or effect." (The blank spaces being appropriately filled in.) 
(b)(1) A joint resolution described in subsection (a) shall be referred to the committees in each House of Congress with jurisdic tion.

(2) For purposes of this section, the term "gubinission or pubtica. tion date" means the later of the date on which-

(A) the Congress receives the report submitted under section 801(a)(1); or

(B) the rule is published in the Federal Register, if so published.

(c) In the Senate, if the conmittee to which is referred a joint resolu. tion described in subsection (a) have not reported such joint resolution (or an identical joint resolution) at the end of 20 calendas days after the submission or publication date detiped under subsection (b)(2), such comsnittee may be discharged from further consideration of such joint resolution upon a petition supported in writing by 30 Members of the Senate, and such joint resolution shall be placed on the calendar.

(d)(1) In the Senate, when the committee to which a joint resolution is referred has reported, or when a cormitte is discharged (under subsection (c)) fron further consideration of a joint resolution described in subsection (a), it is at any time thereafter in order (even though a previous motion to the same effect has been disagreed to) for a motion to proceed to the consideration of the joint resolution, and all points of order ageinst the joint resolution (and against consideration of the joint resolution) are waived. The motion is not subject to amendment, or to a motion to post. pove, or to a motion to proceed to the consideration of other business. A motion to reconsider the vote by which the motion is agreed to or disagreed to shall not be to order. If a motion to proceed to the consideration of the joint resolution is agreed to, the joint Jesolution shall remain the unfinished business of the Senate until dispased of

(2) In the Senate, debate on the joint resolution, and on all debatable motions and appeals in connection therewith, shall be limited to not more than 10 hours, which shall be divided equally between those favoring and those opposing the joint resolution. A mottion further to limit debate is in order and not debatable. Ar amendiment to or a motion to postpone, or a motion to proceed to the consideration of other business, or a motion to recommit the joint resolution is not in orcter.

(3) In the Senate, jumperiately following the conclusion of the debate on a joint resolution described in subsection (a), and a single quorum call at the conclusion of the debate if requested in accordance with the rules of the Senate, the viote on fingl passage of the joint resolution shall occur.

(4) Appeals from the decisions of the Chair relating to the application of the rules of the Senate to the procechure relatiog to a joint resolution described in subsection (a) shafl be decided without debate.

(e) In the Senate the provedure specified in subsection (c) or (d) shall not apply to the consideration of a joint resohution respecting a rule- 
(1) after the expiration of the 60 session days beginming with the applicable submission or publication date, ot

(2) if the report under section 801(a)(1)(A) was submitted during the period referred to in section 801(d) (1), after the expiration of the 60 session days beginning on the 15th session day after the sueceeding session of Congress first convenes.

(f) If, before the passage by owe House of a joint resolution of that House described in subsection (a), that House receives from the other House a joint resolution described in subsection (a), then the following procedures shall apply;

(1) The joint resolution of the other House shall not be referred to a committee.

(2) With respect to a joint resolution described in subsection (a) of the House receiving the joint resotution-

(A) the procedure in that House shall be the same as if no joint resolution had been received from the other House; but

(B) the vote on final passage shall be on the joint resolution of the other Howse.

(g) This section is enacted by Congress-

(1) as an exercise of the rulemaking power of the Senate and House of Representatives, respectively, and as such it is deemed a part of the nules of each House, respectively, but applicable only with respect to the procechure to be followed in that House in the case of a jotnt resolution described in subsection (a), and it supersedes other rules only to the extent that it is inconsistent with such rules; and

(2) with full recognition of the constitutional right of either House to change the rules (so far as relating to the procedure of that House) at any time, in the same manner, and to the same extent as in the case of any other rule of that House.

\section{803. Special rule on statutors regulatory, and judictal deadines}

(a) In the case of any deadline for, relating to, or involving any rule which does not take effect (or the effectiveness of which is teruinated) because of enactment of ajoint resolution under section 802, that deadline is extended until the date 1 year after the date of enactment of the joint resolution. Nothing in this subsection shall be construed to affect a deadline merely by reason of the postponement of a rule's effective date under stction 801 (a).

(b) The term "deadtine" means any date certain for fulfiljing any obligation or exercising any authority established by or under any Federal statute or regulation, or by or under any court order implementing any Federal statute or regulation.

\section{804. Definitions}

For purposes of this chapter-

(1) The term "Federal agency" mears ary agency as that term is defired in section 551(1).

(2) The term "major rule" means any rule that the Adrainistrator of the Office of Information and Regulatory Affairs of the Office

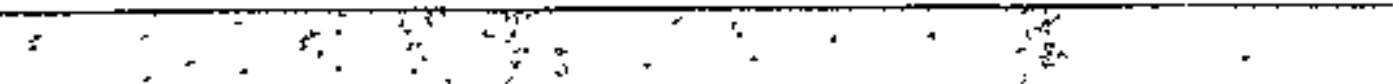




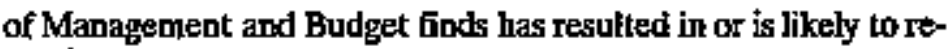
sult in-

. (A) at annual effect on the economy of $\$ 100,000,000$ or more;

(B) a major increase in costs or prices for consumers, individual industries, Federal, State, or local government agencies, or geographic regions; or

(C) significant adverse effects on competition, employment, investment, productivity, innovation, or on the ability of United States-based enterprises to compete with foreignbased enterprises in domestic and export markets. The terin does not include any rule promulgated under the Teleconumunications Act of 1996 and the amendments made by that Act.

(3) The texm "rule" has the meaning given such term in section 551, except that such term does not include-

(A) aty rule of particular applicability, including a rute that approves or prescribes for the futture rates, wages, prices, services, or allowances therefor, corporate or financial structures, reorgarizations, mergers, of acquisitions thereof, or accounting practices or disclosures bearing on any of the foregoing:

(B) any rule relating to agency management or personnel; or

(C) any rule of agency organization, procedure, or practice that does not substantially affect the rights or abtigations of non-agency parties.

\section{\$ 805. Judicial review}

No determination, finding, action, or omission under this chaptes shall be sulfject to judicial review.

\section{\$ 806. Applicability; sererability}

(a) This chaptet shall apply notwithstanding any other provision of law.

(b) If any provision of this chaptes or the application of any provision of this chapter to any person or cireumstance, is held invalid, the application of such provision to other persons or pircimstances, and the remainder of this chapter, shall not be affected thereby.

\section{807. Exemaption tor monetary policy}

Nothing in this chapter shall apply to roles that concern monetary policy proposed or implenented by the Board of Governors of the Federal Reserve System or the Federal Open Market Committee.

\section{'\$ \$08. Effective date of certain rule}

\section{Notwithstanding section 801-}

(1) any rule that establishes, modifies, opens, closes, or conducts a regulatory program for a commercial, recreational, or subsis. tenoe activity related to husting, fishing, or canping, or

(2) any rule which an agency for good cause finds (and incorporates the finding and a brief statement of reasons therefor in the rule issued) that notice and public procedure thereon are imprac. 


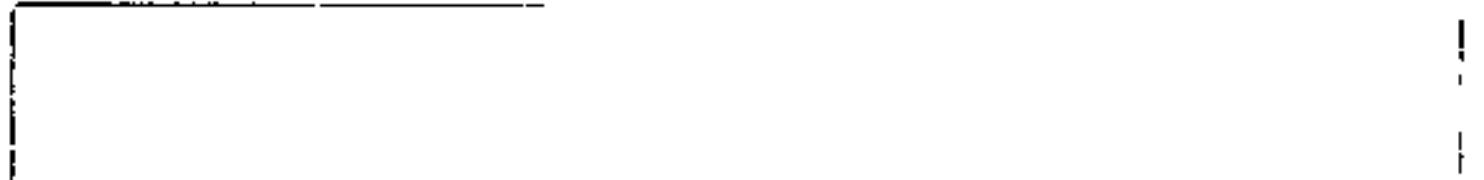

ticable, unnecessary, or contrary to the public interest, shall take effect at such time as the Federal agency promulgating the rule determines.

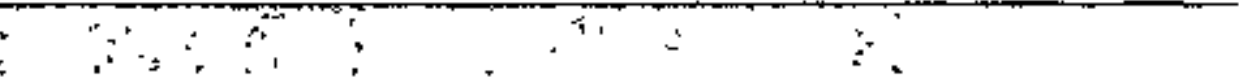




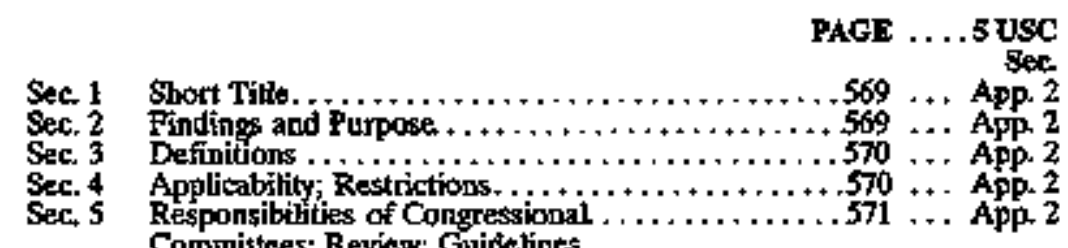

Comnittees; Revicw; Guideline

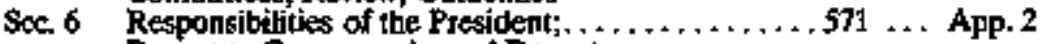
Report to Congress; Anmual Report to Congress; Exclusion.

Sec. 7 Retponsibjities of the Director $\ldots \ldots \ldots+\ldots+\ldots+572 \ldots$ App. 2 Office of Managenkent and Budget;

Committes Management Secretarial

Establishment; Review; Recommendations

to President and Congress; Agency

Copperation; Perfomance Guldelines;

Uniform Pay Guidelines; Travel Expenses;

Expense Recomunoradations.

Sec 8 Responsibilities of Agency Hieads;........... $574 \ldots$ App. 2 Asvisory Coramittee Management

Officer, Designation.

\$ec. 9 Establishment and Porpose of , .$\$ 74 \ldots$ App. 2 Adrisory Committess; Publication in Federal Register;Charter; Filing Contents Copy.

Sec 10 Adtison Committee Procedures $.575 \ldots$ App. 2 Moelinas; Nolice; Publication in Federa Register; Regulations; Minutes; Cstification; Annual Report; Federal Officer or Employee, Altendance.

Sec. 11 Availability of Transcripts; "agency proceeding". ... \$76 ... App. 2

Sec 12 Fiscal and Administrative Prơvisions; recordkeepins; Audit; A gency Support Services. . . . . $576 \ldots$ A.p. 2

Sec. 13 Responsibilities of Library of Congress; reports and background papers; Depository. ..... 576 ... App. 2

Sec. 14 Termination of Advisory Cominittess; Renewal; Continugtion . . . . . . . . Ap. 2

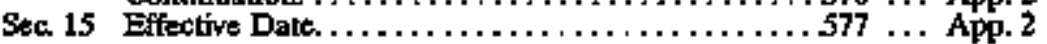


TITLE 5 USC-APPENDIX 2

\section{FEDERAL ADVSORY COMMITTEE ACT}

Public Law 92-463

86 STAT. 770

Sec.

1. Short title.

2. Findings and purpose.

3. Definitions.

4. Applicability; restrictions.

5. Responsibitities of Congressiontal comentites review, guidelines

6. Responsibilities of the President; report to Congress; annual report to Congress; exclusion.

7. Responsibilities of the Director, Office of Management and Budget Commiltee Management Secretariat, establishment; review; recommendations to President and Congress; agenty cooperation; performance guidelines; unjform pay guidelines; travel expenses; erpense recommendations.

8. Responsibilities of agency heads, Acvisony Committee
Management Officer, designation.

Sec.

9. Establishuent and propose of advisory contuittees; publication in Federal Register. charter, filing contents; copy.

10. Advisony committes proxeChres, meetings notice, publication in Foderal Register; regulations; minutes; crrtification; anmelal neport; Federal offtor or employee, attendaroe.

11. Avalability of trasscripts; "agency proceeding".

12. Fiscal and administrative provistons record-k pirus audif agency suppott services.

13. Responsibilities of Library of Congress; reports and backgrourd papers; depository.

14. Termination of advisory committees, renewal; continuation

15. Effective date.

Sec 1. Short Title.

This Act may be cited as the "Foderal Advisory Committee Act".

Sec. 2. Findings and Purpose.

(a) The Congress finds that there are numerous committees, boards, comnuissions, councils, and similar groups which have been established to advise officers and agencies in the executive branch of the Federal Government and that they are frequently a useful and beneficial means of furrishing expert advice, ideas, and diverse opinions to the Federal Government.

(b) The Congress further finds and declares that-

(1) the need for many existing advisory committees has notbeen adequately reviewed;

(2) new advisory committees should be established only when they are determined to be essential and their number should be kept to the minimum necessary; 
(3) atvisory committees should be terminated when they are no longer carrying out the purposes for which they were established;

(4) standards and uniform procedures should govern the establishment, operation, administration, and duration of advisory conlmittees;

(5) the Congress and the public should be kept informed with respect to the number, purpose, membership, activities, and cost of advisoty committees; and

(6) the fumction of actvisory comntities should be advisary only, and that all matters under their consideration should be determined, in acoordance with law, by the official, agency, or afficer involved.

Sec. 3. Defindtlons.

For the purpose of this Act-

(1) The term "Administrator" means the Administrator of General Services.

(2) The term "advisory committe" means any committee, board, commission, councal, conference, panel, task force, or other sirnilar group, or any subcommittee or other subgroup thereof (hereafter in this paragraph referred to as "comonitte"), which is-

(A) established by statute or recorganization plan, or

(B) established or utilized by the President, or

(C) established of utilizad by one or more agencies, in the interest of obtajning advice or recommendations for the President or ofle or more agencies or officters of the Federal Government, except that such term excludes (i) the Advisory Commission on Intergoveramental Relations, (ii) the Commission on Government Procorement, and (iii) any committee which is conposed wholly of full-time officers or employees of the Federal Goverrunent.

(3) The term "agency" has the same meaning as in section 551 (1) of Title 5, United States Code.

(4) The term "Presidential advisory committee" means an advisory committee which advises the President.

\section{Sec 4. Applicabilits; Restrictions.}

(a) The provisions of this Act or of any rule, ordier, or regulation promulgated under this Act shall apply to each advisory committee except to the extent that any Act of Congress establtshing any such advisory cormittee speciffeally provides otherwise.

(b) Nothing in this Act shall be construed to apply to any advisory committe established or utilized by-

(1) the Central Intelligence Agency, or

(2) The Federal Reserve System.

(c) Nothing in this Act shall be construed to apply to any local civic group whose primary function is that of rendering a public service with respect to a Federal program, or any State or local comunittee, councith, board, commission, or similar group established to advise or unake recommendations to State or local officials or agencies. 
Sec 5. Responsifilities of Congressional Committees; Review; Gutdelines.

(a) In the exercise of its kegislative review function, each standing committes of the Senate and the House of Representatives shall make a conttouing review of the activities of each advisory committee under its jurisdiction to determine whether such advisory committee should be abolished or merged with any other advisory committee, whether the responsibitities of such advisocy committee should be revised, and whether such advisory committee performs a necessary function rot already being perfortued. Each sucin stanoing committee shall take appropriate action to obtain the enactment of legislation nexssary to carry out the purpose of this stubsection.

(b) In considering Jegislation establishing, or autborizing the establishment of any advisory committee, each standing committee of the Senate and of the House of Representatives shall determine, and report such determination to the Senate or to the House of Representatives, as the case may be, whether the fumctions of the proposed advisory committee are being or conld be performed by ons or more agencies ot by an advisory conmittee atready in existence, or by enlarging the mandate of ab existing advisory committee. Any such tegislation shall-

(1) contain a clearly defined purpose for the advisory committee;

(2) require the membership of the advisory committee to be fairly balanced in terms of the points of view represented and the functions to be performed by the advisory committes;

(3) contain appropriate provisions to assure that the advice and recommendations of the advisory comsnittee will not be inappropriately influenced by the appointing authority or by any special interest, but will instead be the result of the advisory committee's independent judgarent;

(4) contain provisions dealing wrth authorization of approprtations, the date for submission of reports (if any), the curation of the advisory committee, and the publication of reports and other materials, to the extent that the standing committee determines the provisions of section 10 of this Act to be inadequate; and

(5) contain provisions which will assure that the advisory com+ mitte will have adequate staff (either supplied by an agency or entuployed by it), will be provided adequate guarters, and witl have funds avatlable to meet its other necessary expenses.

(c) To the extent they are applicable, the guidelines set out in subsection (b) of this section shall be followed by the President, agency heads, or other Federal officials in creating an advisory committee.

Sec. 6. Responslbilities of the President; Report to Congress; Annual Repart to Congress; Exclusion.

(a) The President may delegate responsibility for evaluating and taking action, where appropriate, with respect to all public reconmendations made to him by Presidential advisory committees.

(b) Within one year after a Presidential advisory committee has submitted a public report to the President, the President or his delegate 
shall make a report to the Congress stating either his proposais for ac tion or hits reasons for toraction, with respect to the recommendations contained in the public report.

(c) The President shall, not later than' December 31 of each year, make an annual report to the Congress on the activities, status, and changes in the composition of advisory cornmittees in existence during the preceding fiscal year. The report shall contain the name of every ad. visory committes, the date of and authority for its creation, its terningtion date or the date it is to make a report, its functions, a reference to 'the reports it has submitted, a statenent of whether it is an ad boc or continuing body, the dates of its metimgs, the names and ocetpations of its current members, and the total estimated atnual cost to the United States to fund, service, supply, and maintain such committee. Such report shall include a list of those acivisory committees abolished by the President, and in the case of advisory committees established by statute, a list of trose advisory committees which the President recommends be abolished together with his reasons therefor. The President shall exclude from this report any information which, in his judgment, should be withheld for reasons of national security, and he shall include in such report a statement that such information is excluded.

Sec. 7. Responsibilities of the Admintstrator of General Services; Contmittee Maragement Secretaritat, Establishment; Review; Recominelldations to President and Cangress; Agency Cooperation; Performance Guidelines; Uriform Pay Gudelines; Trarel Expenses; Erpense Reconmentations.

(a) The Adninistrator shall establish and maintain within the Genera Services Administration a Connitter Managenent Secretariat, which shall be responsible for all matters relating to advisory committees.

(b) The Administrator shall, immediately after October 6, 1972, irstituite a comprehenstive review of the activities and resporisibilities of each atuisory committee to determine-

(1) whether such committee is carrying out its purpose;

(2) whether, consistent with the provisions of applicable stat-

utes, the responsibilities assigned to it shoukd be revised;

(3) whether it should be merged with other advisory committees; or

(4) whether is 1 should be abolished.

The Administrator may from time to time request such information as he deems necessary to carry out his functions under this subsection. Upon the completion of the Administrator's review be shall make recommendations to the President and to either the agency head or the Congress with respect to action he believes should be taken. Thereafter, the Adtointstrator shall carry out a similar review amzuslly. Agency heads shall cooperate with the Admizistrator in making the reviews required by this subsection.

(c) The Administrator shall prescribe administrative guidelínes and managenent controls applicable to actisory contrittets, and to the

\footnotetext{
I so la wopdogh
} 
maximum extent feasible, provide advice, assistance, and guidance to advisory committees to inprove their performance. In carrying out his functions under this subsection, the Adiministrator shall consider the recommendations of each agency head with respect to means of improving the performance of advisony committees whose duties are related to such agency.

(d)(1) The Administrator, after study and consultation witt the Director of the Office of Personnel Management, shall establish guidelines with respect to uniform fair rates of pay for comparable services of members, staffs, and consultants of advisory committees in a mannier which gives appropriate recogrition to the responsibilitíes and qualifications required and other relevant fac. tors. Such regulations shall provide that -

(A) no member of any advisory committee or of the staft of any advisory committee shall receive compensation at a rate in excess of the rate specified for GS-18 of the General Scheodule under section 5332 of Title 5, United States Code;

(B) such members, winile engaged in the performance of their duties away from their homes or regular places of business, may be allowed travel expenses, inctuding per diem in lieu of subsistence, as authorized by section 5703 of Title 5, United States Code, for persons employed intermittently in the Goverminent service; and

(C) stuch members-

(j) who are blind or deaf or who otherwise qualify as handicapped individuals (within the motaning of section 501 of the Rebabilitation Act of 1973 (29 U.S.C. 794)), and

(ii) who do not otherwise qualify for assistance under section 3102 of Title 5, United States Code, by reason of being an employee of an agency (within the meaning of section 3102 (a)(1) of such Title 5), may be provided services pursuant to section 3102 of stch Titie 5 while in pefornlanes of thetr advisory conmittee duties.

(2) Nothing in this sulbsection sbail prevent-

(A) an jndividual who (without regard to his service with an advisory comtnittee) is a full-time employee of the United States; or

(B) an individuat who immediately before his service with an advisory committee was such an employee.

from receiving compensation at the rate at which he otherwise would be compensated (or was compensated) as a fill-time employee of the United States.

(e) The Administrator shall include in budget recommendations a summary of the amokuts he deens necessary for the expenses of advisory committees, including the expenses for publication of reports where appropriate. 
Sec 8. Responsibilities of Agency Heads; Advisory Committee Management Offictr, Designgtion.

(a) Each agency head shall establish laniform administrative guidelines and manggenvent controis for advisory committees established by that agency, which stall be conststent with directives of the Administrator under section 7 and section 10 . Each agency shall maintain systematic information on the nature, functions, and operations of each adviscry compinittee within its jurisdiction.

(b) Tho head of each agency whith has an advisory committec shall designate an Advisory Counnittee Mantagement Ofticer who shall-

(1) exarcise control and supiervision over the establishment, procedures, and gcomplishments of advisory committees esbablished by that agency;

(2) assemble and maintain the reports, records, and other papers of any such committee during its existence; and

(3) carry out, on behaif of that agency, the provisions of section 552 of Title 5, United States Code, with respect to such reports, records, and other papers.

Sec. 9. Estoblthment and purpose of ad visory committees publication in Federal Register, Charter; Filing; Contents; Cops.

(a) No advisory committes shall be established unless such establishInent is-

(1) spectifically authorized by statute or by the President or

(2) deterwined as a natter of formal record, by the head of the agency involved after consultation with the Administrator with timely notice published in the Federal Register, to be in the public interest in comection with the performanoe of duties imposed on that ageacy by lay.

(b) Untess otherwise specifically provided by statute or Prestikential directive, advisory committees shall be utilized soleby for advisory functions. Determinations of actoon to be taken and policy to be expressed with respect to matters upon whịch an advisory committee reports or makes reconumendations shall be made solely by the Presiklent or an officer of the Federal Governument.

(c) No advisory committee shall meet or take any action until an advisory committee charter has been filed with (1) the Administrator, in the case of Presidential advisory committees, or (2) with the head of the agency to whom any advisory conmittee reports and with the standing committees of the Senate and of the House of Representatives having legislativs juriscliction of suxch agency. Such charter shall contain the following information:

(A) the committee's official designation;

(B) the committee's objectives and the scope of its activity;

(C) the period of time necessary for the committee to carry out its purposes;

(D) the agency or official to whom the committes reports;

(E) the agency responsibje for providing the necessary support for the committee; 
(F) a description of the duties for which the cornmittes is responsibie, and, if such duties are not solely advisory, a specification of the authority for such functions;

(G) the estimated annual operating costs in dollars and unanyears for such committee;

(H) the estimated number and frequency of committee meetings;

(I) the cosmmittee's termination 'date, if less than two years from the date of the committes's establishment; and

(J) the date the charter is filed.

A copy of any such charter sthall also be furnished to the Library of Congress.

Sec. 10. Advisory Committee Procedures; Metijags; Notice, Publicar tion In Federal Register; Reculations; Minutes; Certification; Annual Report; Federal Oficer or Employee; Atterdanace.

(a)(1) Each advisory conlmittee meeting shall be open to the public.

(2) Except when the President determines otherwise for reasons of national security, timety notice of each such meeting shall be published In the Federal Register, and the Administrator shall prescribe regulations to prowide for other types of public notice to insure that all interested persons are notified of such meeting prior thereto.

(3) Interested persons sball be perratitted to attend, appear before, or file statements with any advisory committee, subject to such reasonable rules or regalations as the Adritinistrator may prescribe.

(b) Subject to section 552 of Title 5 Utited States Code, the records, reports, transcripts, minutes, appendixes, wotking papers, drafts, studies, agenda, or other documents which were made available to or prepared for or by each advisory committee shall be available for public inspection and copying at a single location in the offices of the advisoty committes or the agency to which the advisory committee reports until the advisory committee ceases to exist.

(c) Detailed minutes of each meeting of each advisory committee shall be kept and shall contain a record of the persons present, a complete and accurate description of matters discussed and conclusions reached, and copies of all reports receited, tssued, or approved by the advisory committee. The accuracy of all minutes shall be certified to by the chairman of the advisory conomittee.

(d) Subsections (a)(1) and (a)(3) of this section shall not apply to any portion of an advisory committee meeting where the President, or the head of the agency to which the advisory committee reports, determines that such portion of such meeting may be closed to the public in accordance witb subsection (c) of section 552b of Title 5, United States Code. Any such determination shall be in writing and shall contain the reasons for such determination. If such a determination is made, the advisory committee shall issue a report at least infually sttting forth a sumingary of its activities and such rejated matters as would be informative to the public consistent with the policy of section 552(b) of Title 5 United States Code. 
. (e) There slall be designated an officer or employee of the Federal Goverment to chais or attend each meeting of each advisory committee. The officer or employee os designated is autiorized, whenever be determitues it to be in the public interest, to adjoum any such meeting. No advisory committee shall conduct any meeting in the absence of that officer or eraployet.

(f) Advisory comutittees shal not hold any meetings except at the call of, or with the advanee approval of, a designated officer or employee of the Federal Government, and in the case of advisory committees (other than Presidential advisory committees) with an agenda approved by such officer or employee.

Sec. 11. Arailability of Transcrlpts; "Agency Proceeding"

(a) Except where prohibited by contractual agreements entered into prior to the effective date of this Act, agencies and advisory committees shall make available to auy person, at acnual cost of duplication, copies of trapscripts of agency proceedings or advisory committee meetings.

(b) As used in this section "agency proceeding", means any proceeding as deñned in section 551(12) of Titte 5, Unutted States Code.

Sect 12. Fiseal and Admipistrative Provisions; Recordlkeping; Audlt; Agency Sipport Services.

(a) Each agengy shall keep records as will futly disclose the disposition of any funds which may be at the disposal of its actisory conmittetes and the nature and extent of their activities. The General Services Administration, or stuch other agency as the President may designate, shalt maintain financial records with respect' to Prtsidential advisory cornmittees. 'The Comptrolter General of the United States, or any of his authorized representatives, shall have access, for the purpose of audit and examination, to any such records.

(b) Each agency shall be responsible for providing support services for each advisory committee established by or reporting to it unless the establishing authority provides otherwise. Where any such advisory committee reports to more than one agersey, only one agency shall to responsible for support services at anry one time. In the case of Presidential advisory committees, such services may be provided by the General Services Adenfnistration.

Sec. 13. Responsibilitles of Lbrary of Conpress; Reports and Background Papers; Depository.

Subject to section 552 of Title 5, United States Code, the Administrator shill provide for the filing with the Library of Congress of at least eight copies of each report made by every advisory committe and, where appropriate, background papers prepared by consultants. The Librarian of Congress shall establish a depostrory for stuch reports and papers where they shall be available to public inspection and use.

Sec. 14. Termination of Advisory Committees; Renewal; Continuation.

(a)(1) Each advisory committee which is in exrstence on the effective date of this Act shall terminate not later than the expiration of the two. year perjod following such effective date unless- 
(A) in the case of an advisory committee established by the President or an officer of the Federal Government, such advisory com. mittee is renewed by the President or that officer by appropriate action prior to the expiration of such two-year pertios; or

(B) in the case of ant advisory committee established by an Act of Congress, its duration is otherwise provided for by law.

(2) Each advisory committee established after such effective date shall terminate not later than the expiration of the two-year period beginning on the date of its establisitment unless-

(A) in the case of an advisory committee established by the President or an officer of the Federal Government sach afvisory committee is renewed by the President or such officer by ap. propriate action prior to the end of such period; or

(B) in the case of an advisory connmittee establisbed by an Act of Congress, its duration is otherwise provided for by law. (b)(1) Upon the renewal of any advisory committes, such advisory comusittee shall file a charter in accordance with section 9(c).

(2) Any advisory committe established by an Axt of Congress shal file a charter in accordance with stuch section upon the expitation of each successive two-year period following the date of enactment of the Act establisising such advisory committee.

(3) No advisory committee requted under this subsection to file a charter shall take any action (other than preparation and filing of such charter) prior to the date on which such charter is fled.

(c) Anty advisory committee which is renewed by the President or any officer of the Federal Government may be continued only for succes. sive two-year periods by appropriate action taken by the President or such officer prior to the date on which strch advisory committee would otherwise termitales.

Sec. 15. Bffective Date.

Except as provided in section 7(b), this Act shall become effective upon the expiration of nizety days following October 6,1972 . 


\begin{tabular}{|c|c|}
\hline 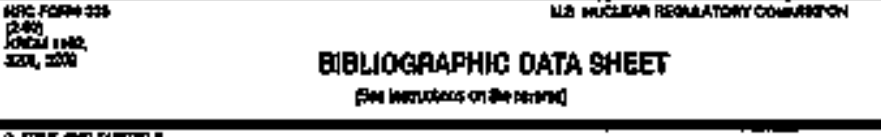 & 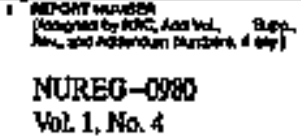 \\
\hline \multirow{3}{*}{ 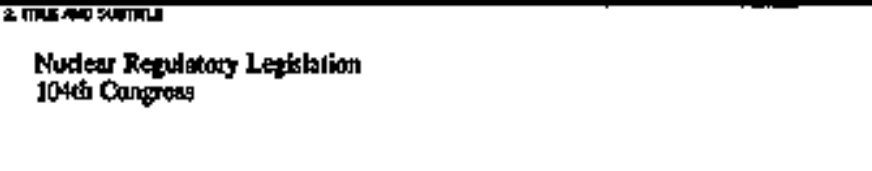 } & 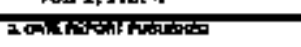 \\
\hline & 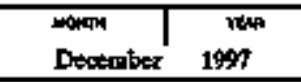 \\
\hline & 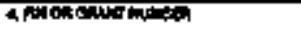 \\
\hline 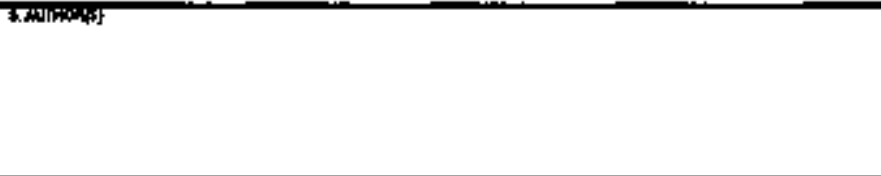 & 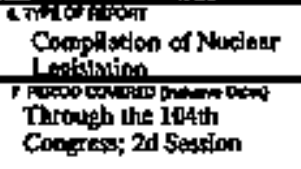 \\
\hline \multicolumn{2}{|c|}{ 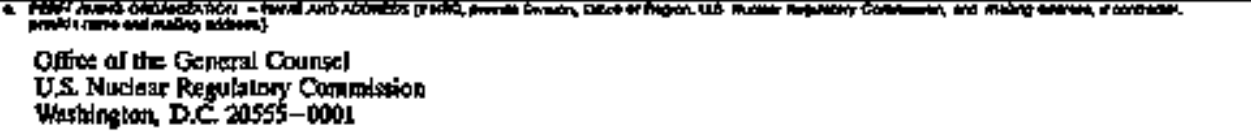 } \\
\hline \multirow{2}{*}{\multicolumn{2}{|c|}{ 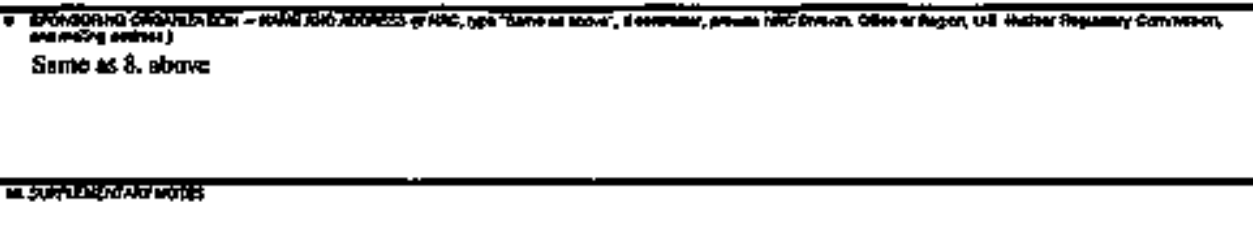 }} \\
\hline & \\
\hline \multicolumn{2}{|l|}{ 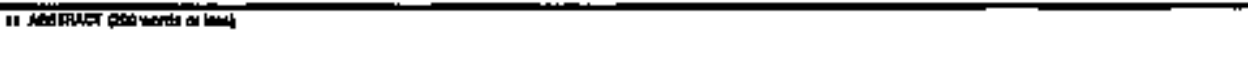 } \\
\hline \multicolumn{2}{|c|}{ 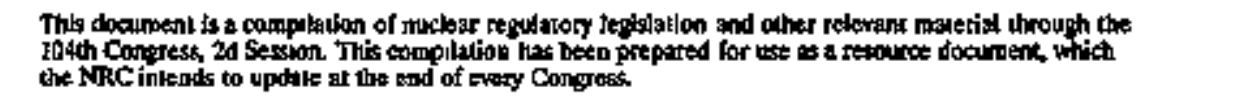 } \\
\hline \multicolumn{2}{|c|}{ 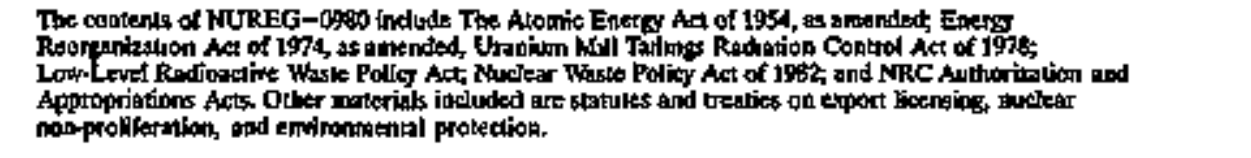 } \\
\hline \multirow{3}{*}{ 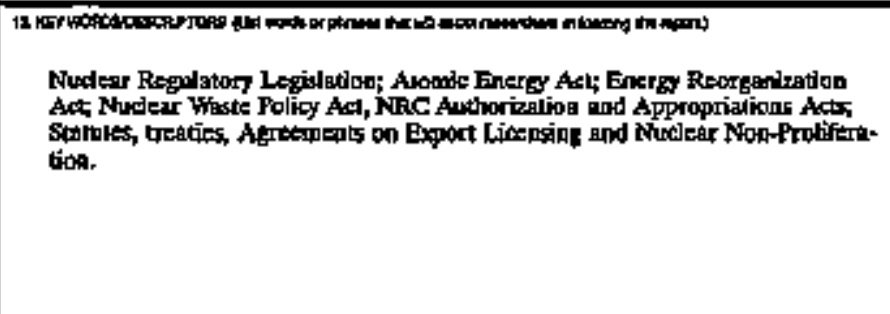 } & 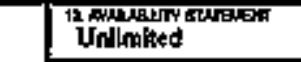 \\
\hline & 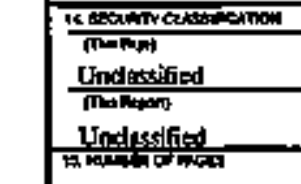 \\
\hline & 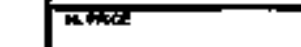 \\
\hline
\end{tabular}

